UNIVERSIDADE DE SÃO PAULO

FACULDADE DE FILOSOFIA, LETRAS E CIÊNCIAS HUMANAS

DEPARTAMENTO DE LETRAS CLÁSSICAS E VERNÁCULAS

PROGRAMA DE PÓS-GRADUAÇÃO EM ESTUDOS COMPARADOS DE LITERATURAS

DE LÍNGUA PORTUGUESA

\title{
História em Quadrinhos: gênese, estrutura e sociedade
}

Márcia de Souza Ravaglio

São Paulo

2018 


\section{Márcia de Souza Ravaglio}

História em Quadrinhos: gênese, estrutura e sociedade

Dissertação apresentada ao Programa de Pós-Graduação em Estudos Comparados de Literaturas de Língua Portuguesa do Departamento de Letras Clássicas e Vernáculas da Faculdade de Filosofia, Letras e Ciências Humanas da Universidade de São Paulo para obtenção do título de Mestre em Letras.

Orientador: Prof. Dr. José Nicolau Gregorin Filho. 
Autorizo a reprodução e divulgação total ou parcial deste trabalho, por qualquer meio convencional ou eletrônico, para fins de estudo e pesquisa, desde que citada a fonte.

Catalogação na Publicação

Serviço de Biblioteca e Documentação

Faculdade de Filosofia, Letras e Ciências Humanas da Universidade de São Paulo

R252h

Ravaglio, Márcia de Souza

História em quadrinhos: gênese, estrutura e sociedade / Márcia de Souza Ravaglio ; orientador José Nicolau Gregorin Filho. - São Paulo, 2018. $310 \mathrm{f}$.

Dissertação (Mestrado) - Faculdade de Filosofia, Letras e Ciências Humanas da Universidade de São Paulo. Departamento de Letras Clássicas e

Vernáculas. Área de concentração: Estudos Comparados de Literaturas de Língua Portuguesa.

1. HISTÓRIA EM OUADRINHOS 2 2. LITERATURA INFANTOJUVENIL . 3. COMUNICAÇÃO. 4. IMAGEM . 5. LINGUAGEM. I. Gregorin Filho, José Nicolau, orient. II. Título. 
AGRADECIMENTOS

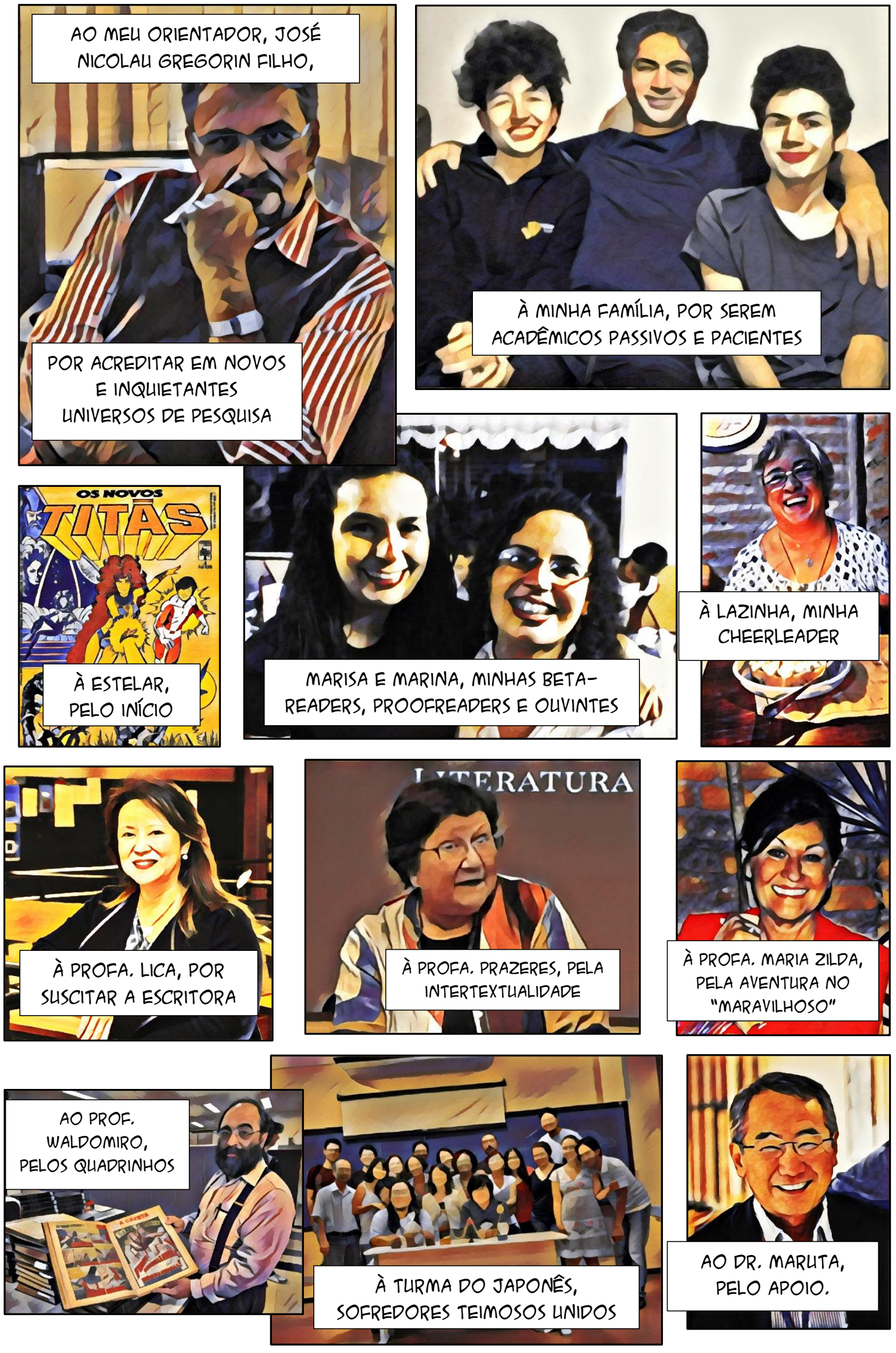


Um dia, a mãe da menina the disse: "Chapeuzinho Vermelho, aqui estão alguns bolinhos e uma garrafa de vinho. Leve-os para a sua avó. Ela está doente, sentindo-se fraquinha, e estas coisas vão revigora-la. Trate de sair agora mesmo, antes que o sol fique quente demais, e quando estiver na floresta olhe para a frente como uma boa menina e não se desvie do caminho..."

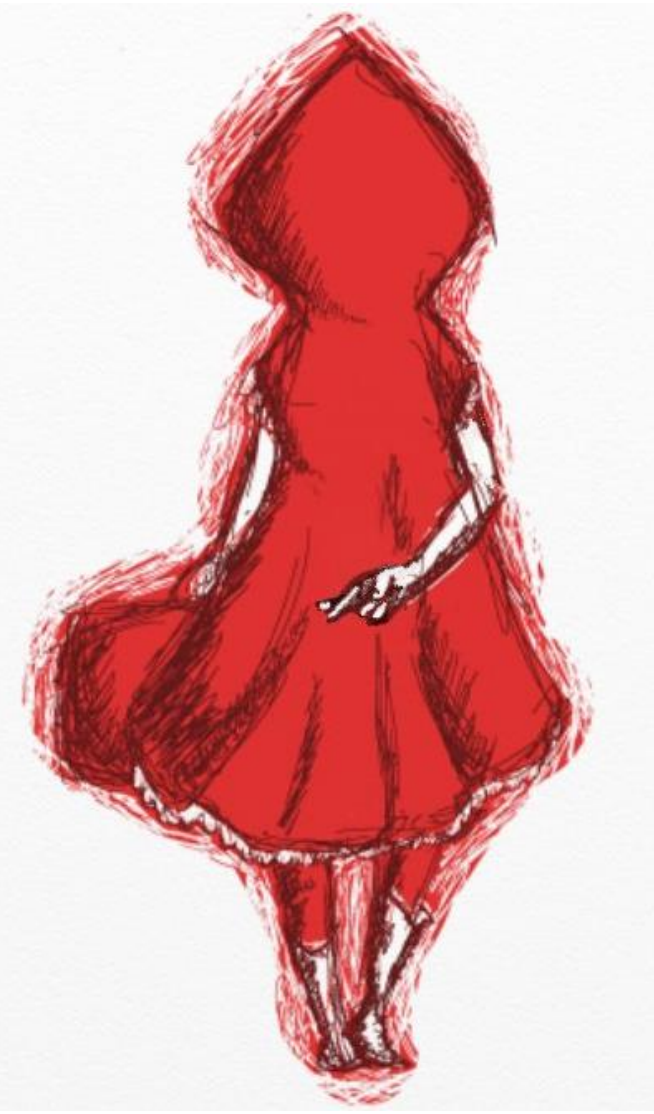

"Farei tudo o que está dizendo..." 


\section{RESUMO}

RAVAGLIO, Marcia de Souza. História em Quadrinhos: gênese e estrutura - um estudo em perspectiva comparada. 2018....f. Dissertação (Mestrado) - Faculdade de Filosofia, Letras e Ciências Humanas, Universidade de São Paulo, São Paulo, 2018.

A presente dissertação está inserida na área de Estudos Comparados de Literaturas de Língua Portuguesa em razão de dialogar com a produção artística de várias culturas e tem o objetivo de analisar a manifestação cultural, histórica e comunicativa, chamada de "História em Quadrinhos" (HQ), principalmente no que concerne a leitura da imagem e sua relação com diferentes sociedades. Para tanto, realizou-se um levantamento em diferentes linhas de pesquisa das diversas concepções a respeito da História em Quadrinhos, suas distintas nomenclaturas em cada país, bem como de seus limiares e estruturas heterogêneos.

A HQ se utiliza tanto de ícones figurativos quanto linguísticos para transmissão de ideias, pensamentos e sentimentos, que pode ocorrer entre uma ou mais pessoas, e utilizar-se de uma ou mais imagens em vários suportes, temáticas e estéticas, na forma de texto para uma ampla gama de intencionalidades. Para um objeto de estudo tão atual e peculiar permitiu-se que ele próprio, o objeto, fosse apontando a metodologia para a pesquisa.

A princípio, foi elaborado um perfil espaço-temporal para ressaltar que os fatores que consolidaram os elementos da $\mathrm{HQ}$ (como sua linguagem e temática, por exemplo) em dado contexto se deveu mais a fatores externos, mercadológicos ou censores, do que a limitações linguísticas, estéticas ou relativas a necessidade de suportes específicos. Acompanhando a história da História em Quadrinhos é possível perceber sua elasticidade, pois suas relações fundamentais foram construídas de formas tão diversas que poderiam parecer antagônicas. Isso nos levou à segunda parte, um estudo da estrutura da História em Quadrinhos em suas aplicações práticas. Com base em teóricos que estudaram as características da linguagem dos quadrinhos, empregamos suas concepções nas diversas manifestações encontradas, sem traçar fronteiras restritivas nas potencialidades do meio.

Palavras-chave: História em Quadrinhos. Literatura Infantil. Comparatismo midiático. Leitura da imagem. Ícone figurativo e linguístico. 


\section{ABSTRACT}

RAVAGLIO, Marcia de Souza. Comics: genesis and structure - a study in comparative perspective. 2018 ... .f. Dissertation (Master degree) - Faculty of Philosophy, Letters and Human Sciences, University of São Paulo, São Paulo, 2018.

The present dissertation is inserted in the area of Comparative Studies of Portuguese Language Literature in order of a dialogue with the artistic production of various cultures and has the objective of analyzing the cultural, historical and communicative manifestation called "Comics", mainly in what concerns the reading of the image and its relation with different societies. Therefore, it was realized a survey of the diverse conceptions regarding Comics, its distinctive nomenclatures in each country, as well as of its thresholds and heterogeneous structures.

Comics uses both figurative and linguistic icons to transmit ideas, thoughts and feelings, between one or more people, with one or more images in various supports, thematic and aesthetic, in textual form for a wide range of intentions. For an object of study so current and peculiar, it was allowed that the object itself indicated the methodology for the research.

At first, a space-time profile was elaborated to emphasize that the factors that consolidated the elements of the $\mathrm{HQ}$ (such as their language and thematic, for example) in a given context were due more to external factors, marketing or censors, than to linguistic limitations, aesthetic or relating to the need for specific supports. Accompanying the history of comics is possible to perceive its elasticity, since their fundamental relations were constructed of forms so diverse that could appear antagonistic. This led us to the second part, a study of the structure of comics in its practical applications. Based on theorists who studied the characteristics of Comics language, we used their conceptions in the various manifestations found, without drawing restrictive boundaries in the potentialities of the medium.

Keywords: Comics. Children's Literature. Midiatic Comparatism. Reading the image. Figurative and linguistic icon. 


\section{ÍNDICE DE FIGURAS}

FIGURA 1 - CARTA MANUSCRITA DO CONDE DE MEURS - BIBLIOTECA DE ZUTPHEN .....................................25

FIGURA 2 - A HISTÓRIA DO MARTÍRIO DE SANTO ERASMO, DATANDO DE CERDA DE 1460 - LAMBIEK...............25

FIGURA 3 - CENTSPRENT - DE KOOPMAN EN DE KNECHT (O COMERCIANTE E O SERVO) - EDITORA NACHF DE

C. BURCKARDT.

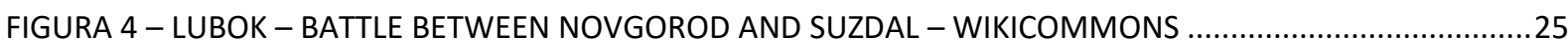

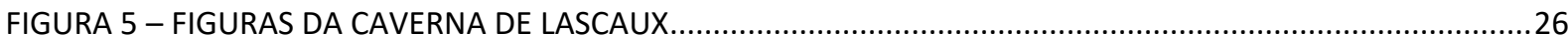

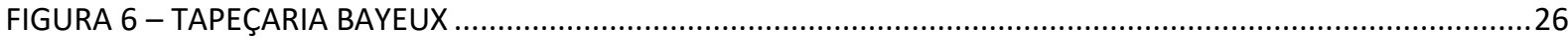

FIGURA 7 - EMAKIMONO - "THE ILLUSTRATED SUTRA OF PAST AND PRESENT KARMA" - ARTISTA

DESCONHECIDO DO FINAL DO SÉCULO XIII - METROPOLITAN MUSEUM OF ART - NOVA YORK...............26

FIGURA 8 - ESCRITA DOS OSSOS DO ORÁCULO - CARACTERES CHINESES DA DINASTIA SHANG - (XVI A XI A.C.).26

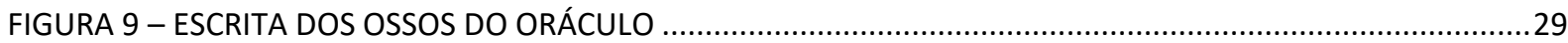

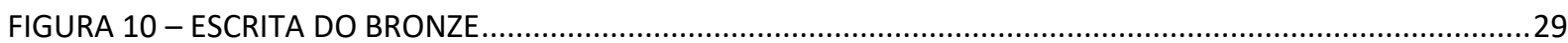

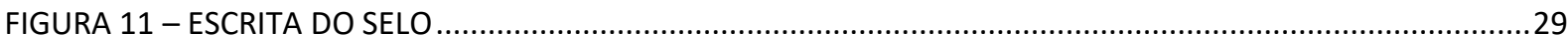

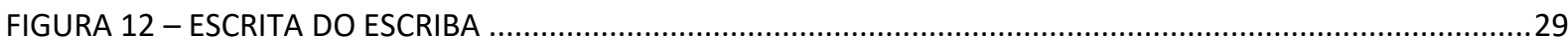

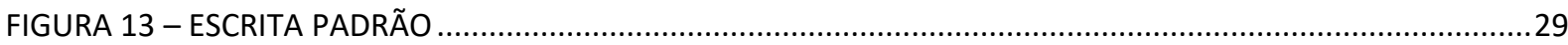

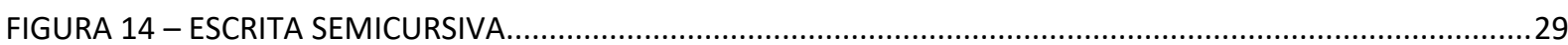

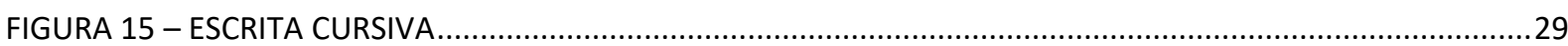

FIGURA 16 - CARACTERE 安 - “QUIETO” OU “SEGURO” - ESCRITA DOS OSSOS DO ORÁCULO ............................31

FIGURA 17 - FIGURAÇÃO E TRANSFORMAÇÃO DO CARACTERE 女- MULHER - NORIKO K. WILLIAMS..................31

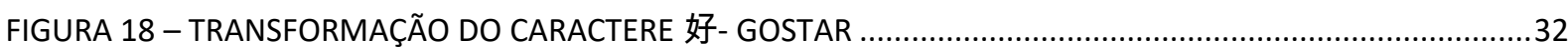

FIGURA 19 - WILLIAM HOGARTH - 1762 - CHARGE POLÍTICA EM QUE O REI HENRIQUE III TENTA APAGAR AS

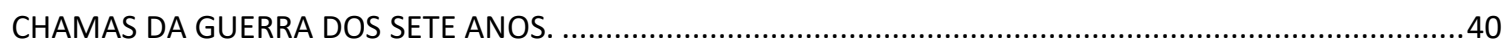

FIGURA 20 - MON LIVRE D'HEURES - 1919 - FRANS MASEREEL …..............................................................40

FIGURA 21 - OTTO NÜBKEL - DESTINY - 1930 - NOVA YORK- REPÚBLICAÇÃO POR DOVER PUBLICATIONS 2007

FIGURA 22 - LE CAHRIVARI - 1832

FIGURA 23 - DAUMIER - MAIS PIS QUE J'VOUS DIS QU'C'EST DES AMIS.....(MAS DEIXE-ME DIZER-LHE QUE SÃO AMIGOS...) LITOGRAFIA - PUBLICADA EM LE CHARIVARI EM 08, 18, E 23 DE AGOSTO DE1845 ...............47 FIGURA 24 - DAUMIER - UNE DISCUSSION LITTÉRAIRE DANS LE DEUXIÈME BALCON (UMA DISCUSSÃO

LITERÁRIA NO SEGUNDO BALCÃO). LITOGRAFIA - PUBLICADA EM LE CHARIVARI, PARIS, $1864 \ldots \ldots \ldots \ldots . . . . .47$

FIGURA 25 - CHARLES-JOSEPH TRAVIÈS DE VILLERS - STUDIO OF LA CARICTURE AND LE CHARIVARI $1834 \ldots . . . . .48$

FIGURA 26 - DAUMIER - RUE TRANSNONAIN - LITOGRAFIA - PUBLICADA EM LA CARICATURE - 1834 -

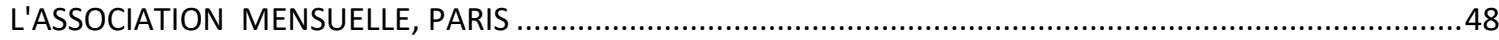

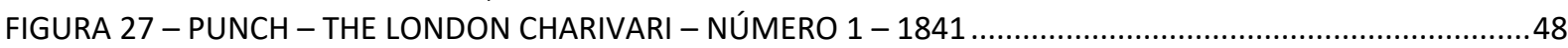

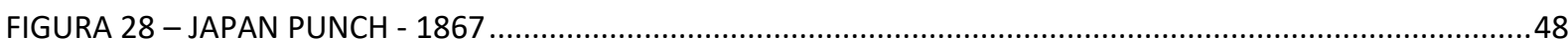

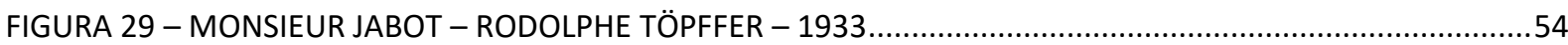

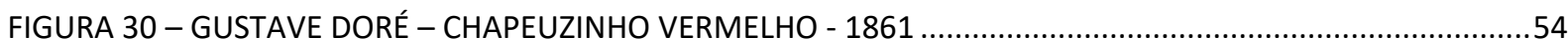

FIGURA 31 - GUSTAVE DORÉ - LA VIE EN PROVINCE, HISTOIRE D'UNE INVITATION À LA CAMPAGNE (VIDA NA

PROVÍNCIA, HISTÓRIA DE UM CONVITE AO INTERIOR) - JOURNAL POUR RIRE - 1849 ............................54

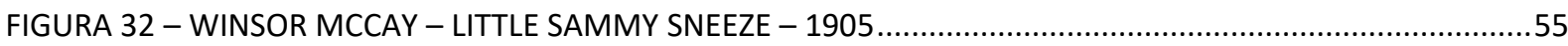

FIGURA 33 - GUSTAVE DORÉ - DES-AGRÉMENTS D'UN VOYAGE D'AGRÉMENT - 1851..................................55

FIGURA 34 - THE STRANGE ADVENTURES OF BACHELOR BUTTERFLY - 1846 - WILSON \& CO ..........................56

FIGURA 35 - JOURNEY TO THE GOLD DIGGINS BY JEREMIAH SADDLEBAGS - JAMES A. E DONALD F. READ - 1849

FIGURA 36 - AS AVENTURAS DE NHÔ-QUIM JANEIRO DE 1869 - JORNAL VIDA FLUMINENSE ...........................56

FIGURA 37 - CARICATURA DE HERMES DA FONSECA POR RIAN (NAIR DE TEFFÉ) .........................................71

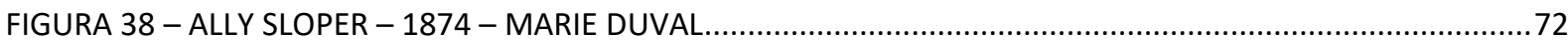

FIGURA 39 - CHRISTOPHE (GEORGES COLOMB), UN ARROSEUR PUBLIC, LE PETIT FRANÇAIS ILLUSTRÉ, 1889....81

FIGURA 40 - RICHARD F. OUTCAULT, HOGAN'S ALLEY, NEW YORK WORLD - 1896......................................82

FIGURA 41 - REVISTA TICO-TICO, № 1 - 11/10/1905 - EXTRAÍDO DO SITE EFEMÉRIDES ESCOTEIRAS, EM SEU TÓPICO DATANDO O NASCIMENTO DA REVISTA TICO-TICO QUE MAIS TARDE DIVULGARIA O ESCOTISMO BRASILEIRO 
FIGURA 42 - PROPAGANDA DOS COLLETES DE MME. GARNIER NA REVISTA TICO-TICO № 15 DE 17/01/1906 ..84

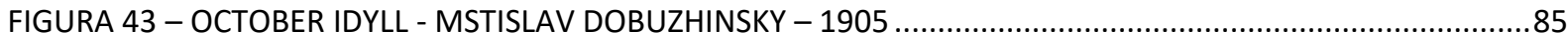

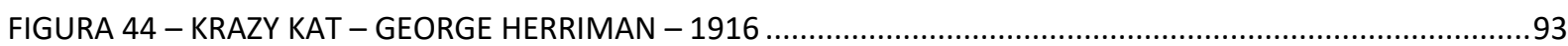

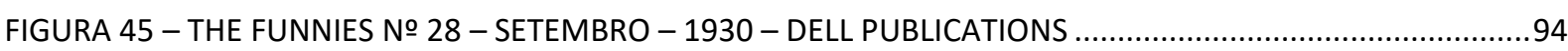

FIGURA 46 - TINTIN NO PAÍS DOS SOVIETES - 1929 - LE PETIT VINGTIÈME ….................................................

FIGURA 47 - SUPLEMENTO IL BALILLA - № 7 - 23/02/1928 (FALTA LOCALIZAÇÃO) ..........................................94

FIGURA 48 - NOTENKRAKER, SUPLEMENTO SOCIALISTA DO JORNAL HET VOLK (FALTA LOCALIZAÇÃO) .............94

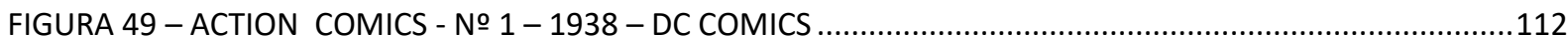

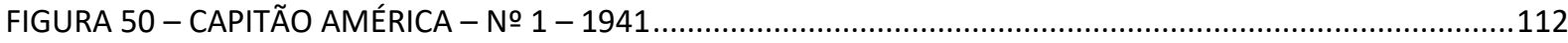

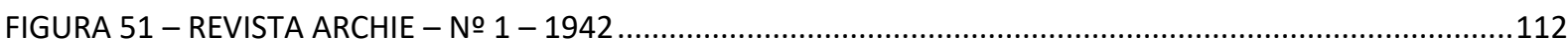

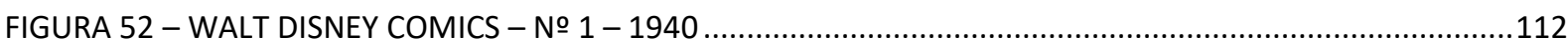

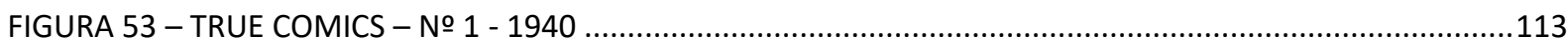

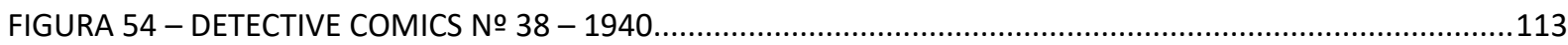

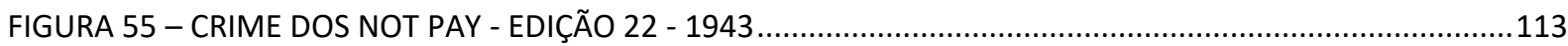

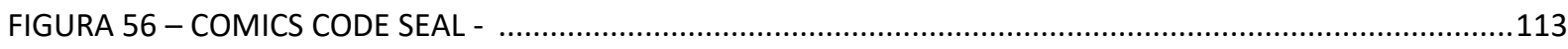

FIGURA 57 - BACIO SOTTO LE STELLE - WALTER MOLINO SOB O PSEUDÔNIMO DE J. W. SYMES ....................114

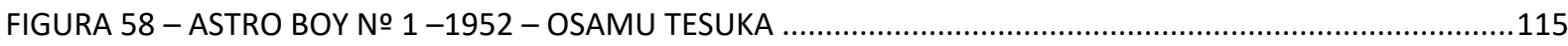

FIGURA 59 - RIBON NO KISHI (A PRINCESA E O CAVALEIRO) - 1953 - OSAMU TESUKA...................................115

FIGURA 60 - PÔSTER ORIGINAL JAPONÊS DO FILME BRANCA DE NEVE E OS SETE ANÕES DE WALT DISNEY ....115

FIGURA 61 - MASAHIKO MATSUMOTO - THE MAN NEXT DOOR (HINOMARU BUNKO - 1957) .......................115

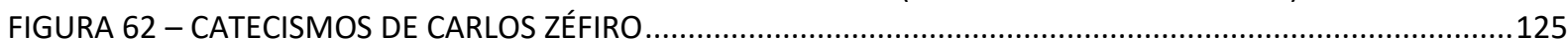

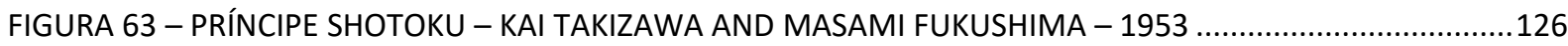

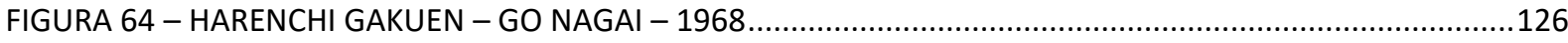

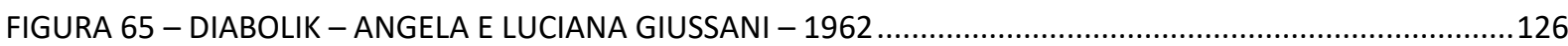

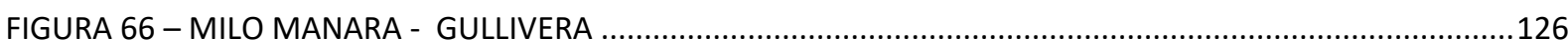

FIGURA 67 - HUGO PRATT - CORTO MALTESE - UNA BALLATA DEL MARE SALATO .........................................127

FIGURA 68 - DINO BATTAGLIA - MAMMA SAUVAGE - ADAPTAÇÃO DO CONTO DE GUY DE MAUPASSANT ......127

FIGURA 69 - MAUS - ART SPIEGELMAN - ENTRE 1980 E 1991 NA REVISTA RAW ..........................................127

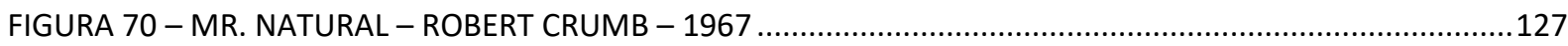

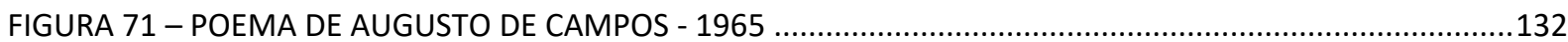

FIGURA 72 - A TRAIÇÃO DAS IMAGENS, 1928-9, ÓLEO SOBRE TELA, 60 CM X 81 CM, RENÉ MAGRITE, LACMA -

LOS ANGELES COUNTY MUSEUM OF ART, LOS ANGELES ............................................................... 136

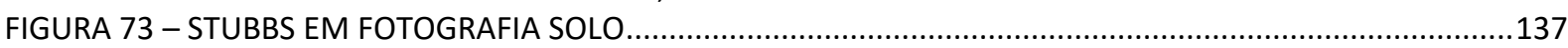

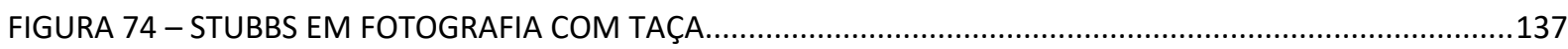

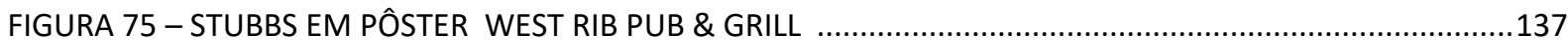

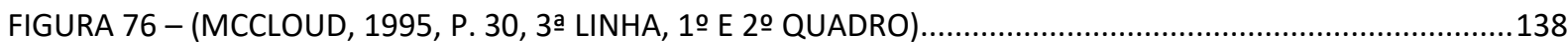

FIGURA 77 - KATRIN - MENSILE DI ATTUALITA VARIETA E FOTOROMANZI - № 46, 1978 - PÁGINA 54..............141

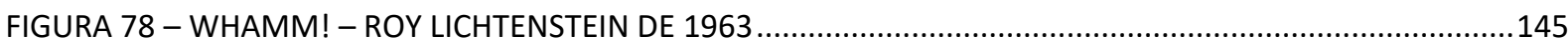

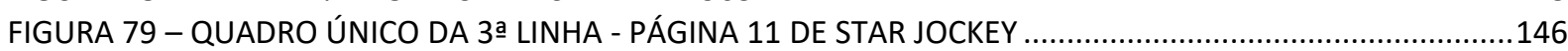

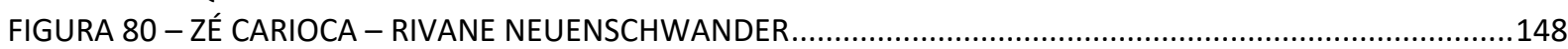

FIGURA 81 - ZÉ CARIOCA - RIVANE NEUENSCHWANDER - INTERVENÇÃO DOS VISITANTES............................149

FIGURA 82 - EXPOSIÇÃO LOUVRE № 9 - MORI GALLERY - TÓQUIO - FOTOS DE KEISUKE TANIGAWA ..............150

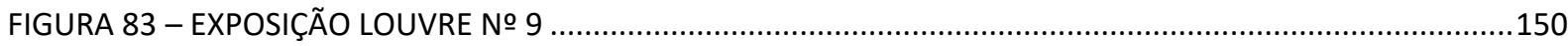

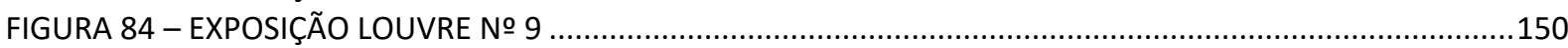

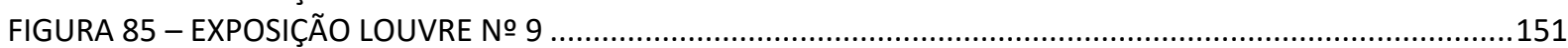

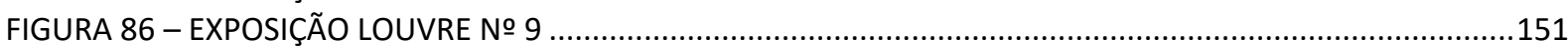

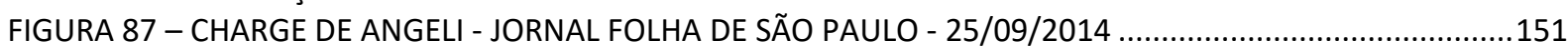

FIGURA 88 - CALVIN AND HOBBES (CALVIN E HAROLDO) - BILL WATERSON ...............................................152

FIGURA 89 - NUDE DESCENDING A STAIRCASE, NO. 2 - MARCEL DUCHAMP - 1912 .....................................152

FIGURA 90 - THE RUDE DESCENDING A STAIRCASE (RUSH-HOUR AT THE SUBWAY) - 1913...........................152

FIGURA 91 - ABSTRACT COMICS - GARY PANTER - SEM TÍTULO - 2000 ...................................................157

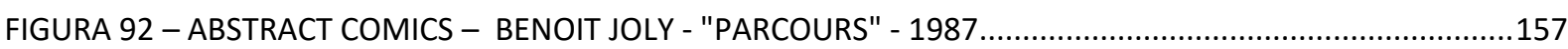

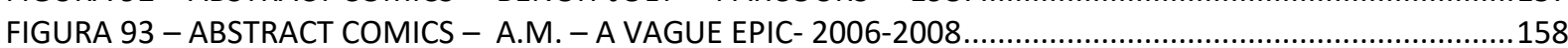

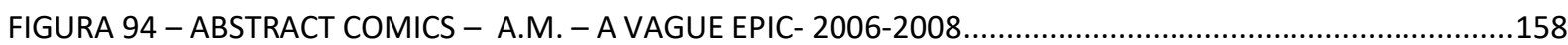

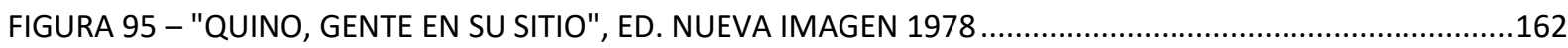

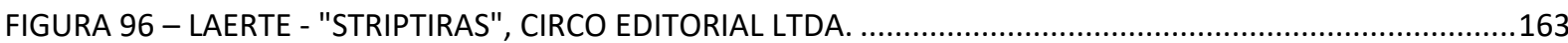

FIGURA 97 - PROJETO DE BENTHAM - PANÓPTICO - DESENHO DO ARQUITETO INGLÊS WILLEY REVELEY, 1791 
FIGURA 98 - VINHETAS

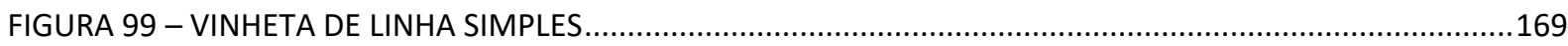

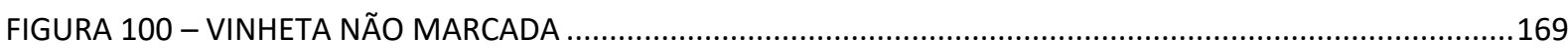

FIGURA 101 - VINHETA PELO AMBIENTE

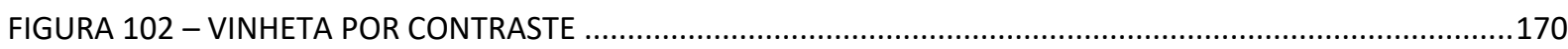

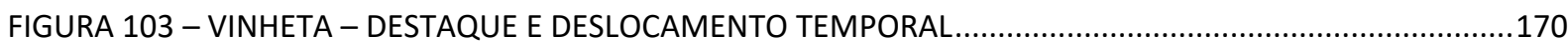

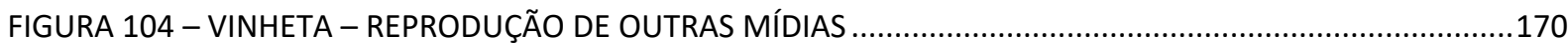

FIGURA 105 - VINHETA METALINGUÍSTICA ............................................................................................170

FIGURA 106 - MCCLOUD - DESVENDANDO OS QUADRINHOS, 1995, PÁGINA 68, 2a E 3a LINHAS .....................171

FIGURA 107 - LES YEUX DU CHAT. JODOROWSKY E MOEBIUS. (1991, P. 4), PÁGINA INTEIRA ............................173

FIGURA 108 - LES YEUX DU CHAT. JODOROWSKY E MOEBIUS. (1991, P. 5), PÁGINA INTEIRA ...........................174

FIGURA 109 - LES YEUX DU CHAT. JODOROWSKY E MOEBIUS. (1991, P. 6-7) VISÃO DO LEITOR (VERSO E ANVERSO)....

FIGURA 110 - LES YEUX DU CHAT. JODOROWSKY E MOEBIUS. (1991, P. 8-9) VISÃO DO LEITOR (VERSO E

ANVERSO) ……................................................................................................................ 176

FIGURA 111 - LES YEUX DU CHAT. JODOROWSKY E MOEBIUS. (1991, P. 12-13) VISÃO DO LEITOR (VERSO E

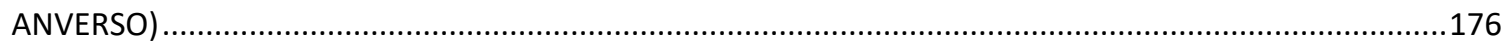

FIGURA 112 - LOBO NEGRO - ANTOINE GUILLOPPÉ (2006, P. 4 - 5) ...........................................................177

FIGURA 113 - LOBO NEGRO - ANTOINE GUILLOPPÉ (2006, P. 6 - 7) ........................................................177

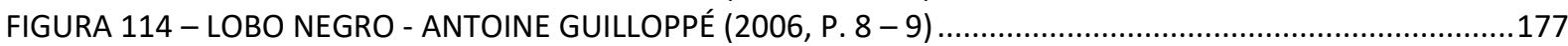

FIGURA 115 - LOBO NEGRO - ANTOINE GUILLOPPÉ (2006, P. 12 - 13) ............................................................177

FIGURA 116 - WILL EISNER - QUADRINHOS E ARTE SEQUENCIAL 2010, P. 25 ..............................................178

FIGURA 117 - QUADRINHOS E ARTE SEQUENCIAL - WILL EISNER, 2010, P. 25............................................178

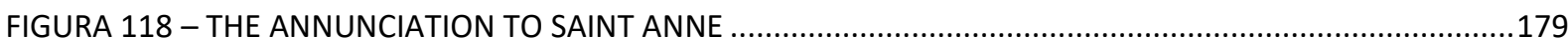

FIGURA 119 - DETALHE DE: THE ANNUNCIATION TO SAINT ANNE, 1505 - 1510 - BERNHARD STRIGEL - MUSEO

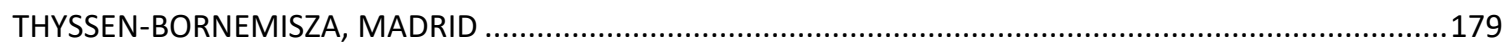

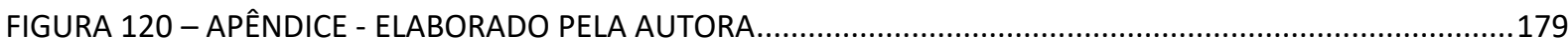

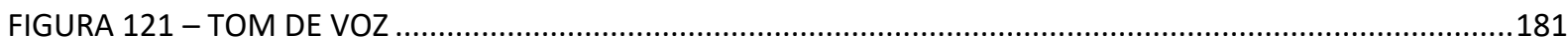

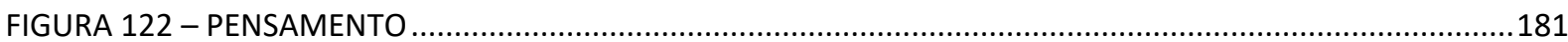

FIGURA 123 - VOZ DE PERSONAGEM AUSENTE E VOZ INDIVIDUALIZADA PELO FORMATO ...............................181

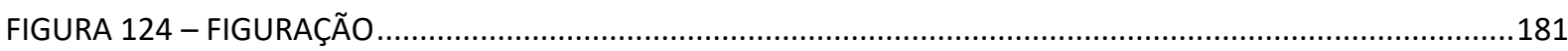

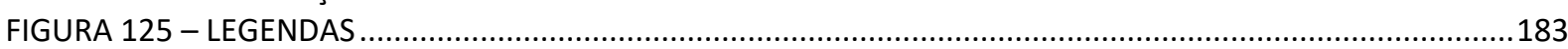

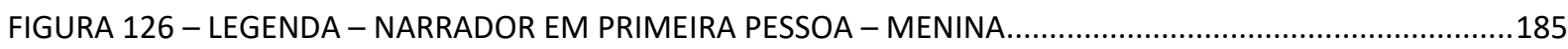

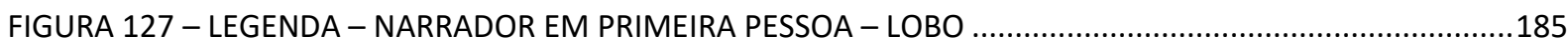

FIGURA 128 - LEGENDA - NARRAÇÃO PARALELA - TEMPO / LEGENDA NÃO MARCADA ……………................185

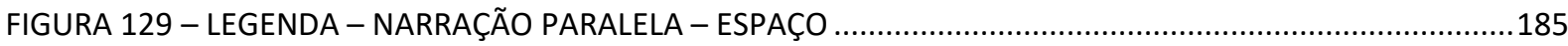

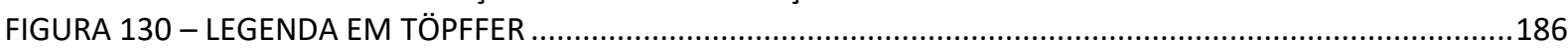

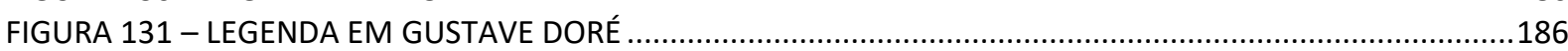

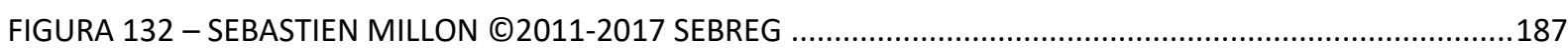

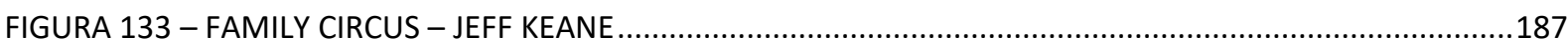

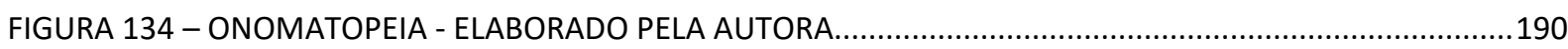

FIGURA 135 - CHOBITS - CLAMP, 2000, ED. KODENSHA, TÓQUIO, PG 92, TERCEIRO QUADRO. ........................191

FIGURA 136 - CHOBITS - CLAMP, 2000 - ED. JBC, SÃO PAULO, PÁG. 98, TERCEIRO QUADRO ………...............191

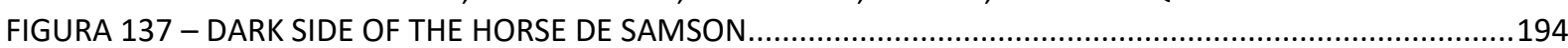

FIGURA 138 - (EISNER, 2010, P. 40) - ENQUADRAMENTO ……………………………………………......196

FIGURA 139 - (MCCLOUD, 2008, P. 12), QUADRO ÚNICO, PRIMEIRA LINHA …………….............................197

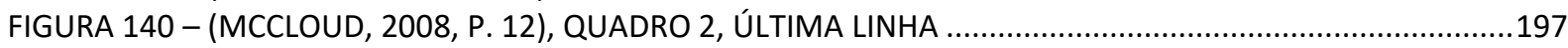

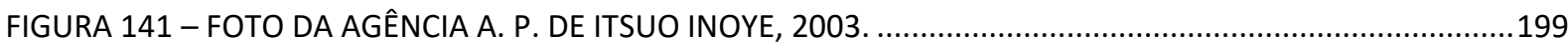

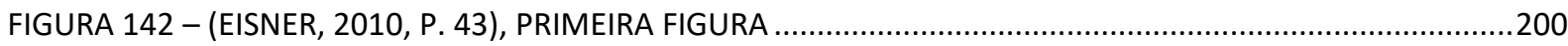

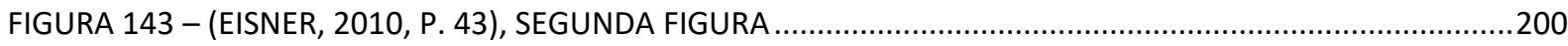

FIGURA 144 - MONTAGEM USANDO DECALQUE DE MCCLOUD COMO BASE ……........................................201

FIGURA 145 - UMA CHAPEUZINHO VERMELHO, MARJOLAINE LERAY - FOLHA DE GUARDA (ESQUERDA) PAGINA

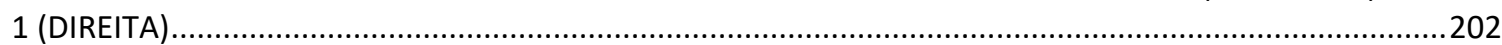

FIGURA 146 - UMA CHAPEUZINHO VERMELHO, MARJOLAINE LERAY - PÁGINA 2 (ESQUERDA) PAGINA 3 (DIREITA)...

FIGURA 147 - UMA CHAPEUZINHO VERMELHO, MARJOLAINE LERAY - PÁGINA 4 (ESQUERDA) PAGINA 5 


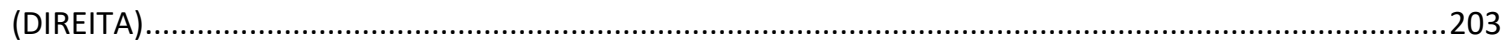
FIGURA 148 - NÍQUEL NAUSEA - FERNANDO GONZALES - JORNAL FOLHA DE SÃO PAULO, 22/07/11 P.E11....203 FIGURA 149 - (MCCLOUD, 2008, P. 14), QUADRO 1, ÚLTIMA LINHA - EXTRAÍDOS SOMENTE OS QUADROS DE EXEMPLO

FIGURA 150 - (MCCLOUD, 2008, P. 14), QUADRO 2, ÚLTIMA LINHA - EXTRAÍDOS SOMENTE OS QUADROS DE EXEMPLO

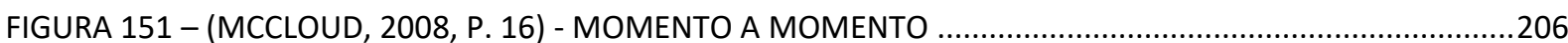

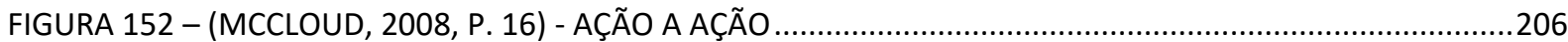

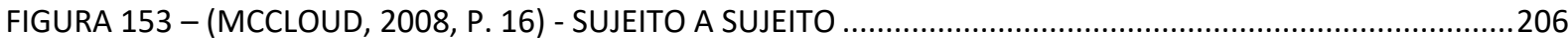

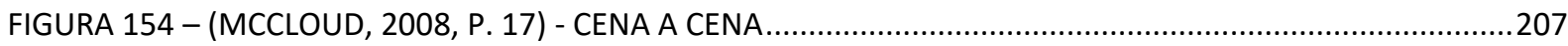

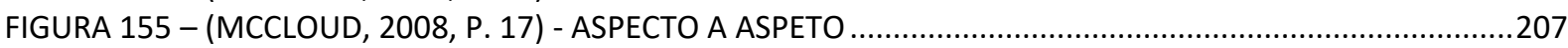

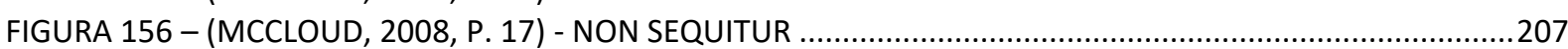

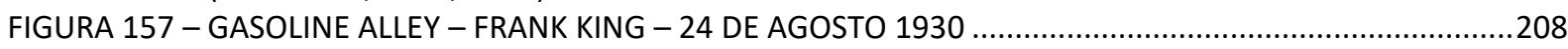

FIGURA 158 - DRUCE, ARDEN. BRUXA, BRUXA VENHA A MINHA FESTA, PÁG. 4 E 5 .....................................209

FIGURA 159 - DRUCE, ARDEN. BRUXA, BRUXA VENHA A MINHA FESTA, PÁG. 32 E 33 ..................................209

FIGURA 160 - (MCCLOUD, 2008, P. 32), FLUXO DE PÁGINA E DENTRO DO QUADRO ......................................210

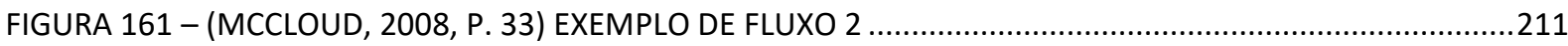

FIGURA 162 - (EISNER, 2013, P. 65) SIMULAÇÃO DE ENTONAÇÃO ...............................................................214

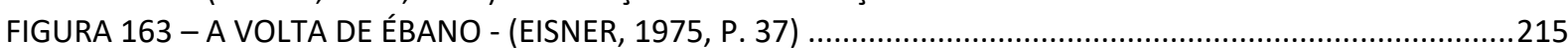

FIGURA 164 - GAIMAN, N. SANDMAN: PRELUDIO - VOL 2, PÁG. 12-13 (PÁGINA DUPLA) ...............................216

FIGURA 165 - DESTAQUE DE GAIMAN, N. SANDMAN: PRELUDIO - VOL 2, PG 13, 2a E 3a LINHAS, ED. PANINI .216

FIGURA 166 - BLACK BUTLER - YANA TOBOSO, VOL. 17 PG. 154 - EDITORA PANINI COMICS, SÃO PAULO ......219

FIGURA 167 - KUROSHITSUJI - YANA TOBOSO, VOL. 17 PG. 154 - EDITORA SQUARE ENIX, TÓQUIO ...............219

FIGURA 168 - BLACK BUTLER - YANA TOBOSO, VOL. 17 PG. 154 - EDITORA YEN PRESS, NOVA YORK .............219

FIGURA 169 - BLACK BUTLER - YANA TOBOSO, VOL. 17 PG. 154 - EDITORA TONG LI COMICS - TAIWAN ........219

FIGURA 170 - CHAPEUZINHO PELA ESTÉTICA EUROPEIA, DECALQUE DA AUTORA DE MILO MANARA E DINO BATTAGLIA.

FIGURA 171 - CHAPEUZINHO PELA ESTÉTICA AMERICANA, DECALQUE DA AUTORA DE PATRICK GLEASON E THOMAS GIORELLO

FIGURA 172 - RECORTE DE GEKKAN SHOUJO NOZAKI-KUN, IZUMI TSUBAKI, CAPÍTULO 1, PÁG. 1. EDITORA

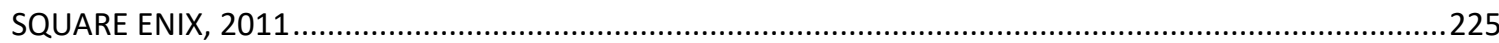

FIGURA 173 - RECORRTE DE TAKANE TO HANA, YUKI SHIWASU, CAPITULO 1, PÁG. 16, EDITORA HAKUSENSHA,

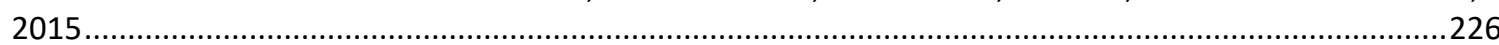

FIGURA 174 - CHARGE DE CAU GOMEZ, PUBLICADA 18/11/2015, NO JORNAL A TARDE................................230

FIGURA 175 - CHARGE DE CAU GOMEZ PUBLICADA EM DIA 05/06/2015 - JORNAL A TARDE..........................230

FIGURA 176 - CHARGE DE SIGNE WILKISON, PUBLICADA EM 01/12/2017 ...............................................230

FIGURA 177 - CHARGE DE ANDY MARLETTE

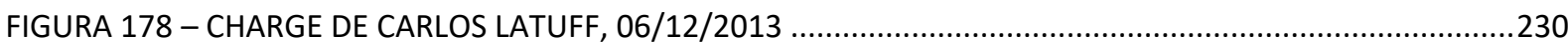

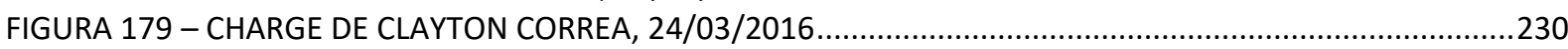

FIGURA 180 - CARTUM DE MIKE PETERS, 25-01-2014 (VOCÊ ACHA QUE ESTE ME FAZ PARECER GORDA?) [TRADUÇÃO DA AUTORA]

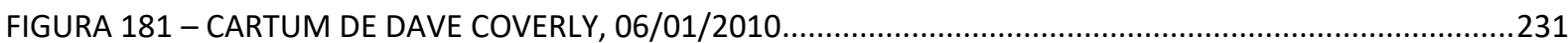

FIGURA 182 - RECORTE DA PÁGINA DO JORNAL FOLHA DE SÃO PAULO DE 24/09/2017..............................234

FIGURA 183 - ARMANDINHO - ALEXANDRE BECK - FACEBOOK - 09/03/2018 ….......................................235

FIGURA 184 - ARMANDINHO - ALEXANDRE BECK - FACEBOOK 20/05/2016 .................................................235

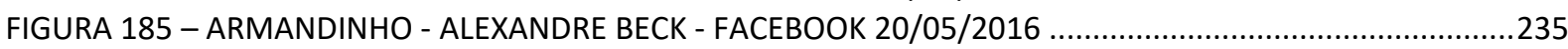

FIGURA 186 - ARMANDINHO - ALEXANDRE BECK - FACEBOOK 20/05/2016 …............................................235

FIGURA 187 - PÔSTER DA PEÇA COUPS DE FEU RUE SAINT-ROCH, COM ACRÉSCIMO DE TARJA COLOCADA PELA

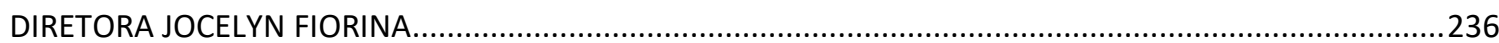

FIGURA 188 - MUSEU DE HISTÓRIA NATURAL DE VIENA, VÊNUS DE WILLENDORF .....................................236

FIGURA 189 - CHARGE DE IVAN CABRAL, ORIGINAL (ESQUERDA) E ADULTERADA (DIREITA) .........................239

FIGURA 190 - WORLD'S FINEST COMICS, NÚMERO 153, DC COMICS, PÁGINA 5, LINHA 2, 1ㅇ E 2ㅇ QUADROS..239

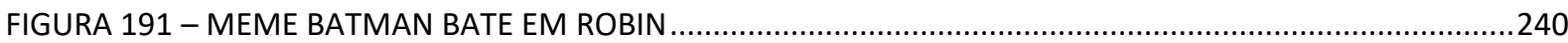

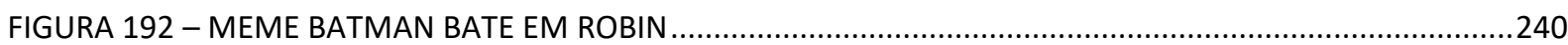

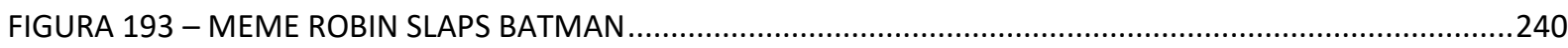

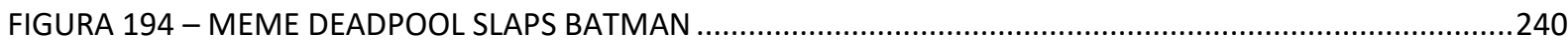

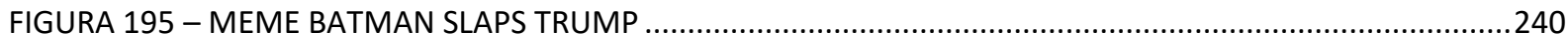


FIGURA 196 - MEME BATMAN BATE EM ROBIN - PANO DE PRATO....

FIGURA 197 - SANDMAN - OS CAÇADORES DE SONHOS, 2000 - ED. CONRAD, PG. 28 E 29 ............................244

FIGURA 198 - SANDMAN - THE DREAM HUNTERS - ED. DC COMICS 1999, PG. 28 E 29..................................244

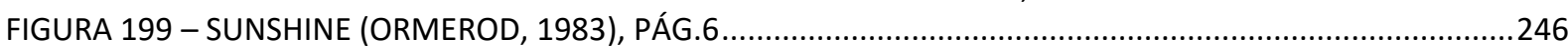

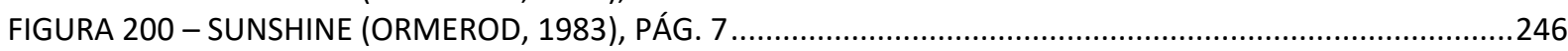

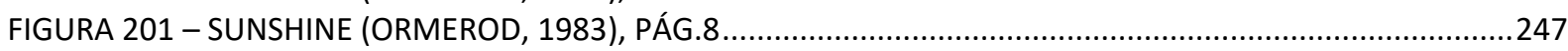

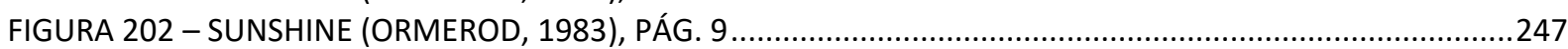

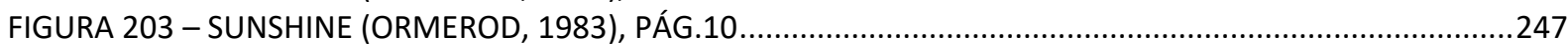

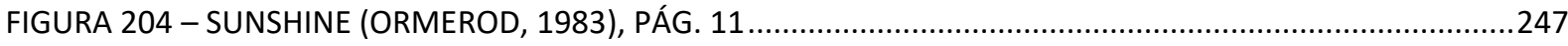

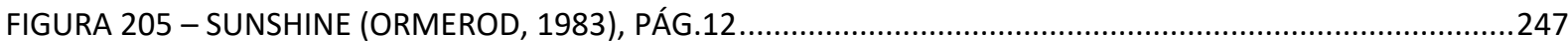

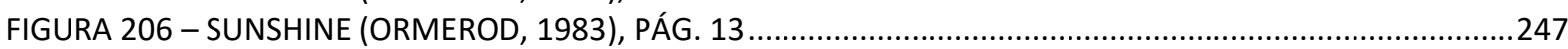

FIGURA 207 - SOLDADO G.U.I. LAMBERT, B2ND BATTALION ROYAL 22E REGIMENT, LENDO UMA REVISTA EM QUADRINHOS, CORÉIA, 28 DE MAIO DE 1951, ROYAL 22ND REGIMENT. FOTOGRÁFO: PAUL E. TOMELIN

FIGURA 208 - KUROSHITSUJI (BLACK BUTLER), YANA TOBOSO, VERSÕES JAPONESA, BRASILEIRA, AMERICANA E CHINESA. 251 FIGURA 209 - KUROSHITSUJI, YANA TOBOSO, PÁGINAS 2 E 3 DAS VERSÃO JAPONESA IMPRESSA EM PAPEL ..251 FIGURA 210 - KUROSHITSUJI (BLACK BUTLER), YANA TOBOSO, PÁGINAS 2 E 3 DAS VERSÃO BRASILEIRA IMPRESSA EM PAPEL....

FIGURA 211 - BLACK BUTLER PÁGINA VERSÃO EBOOK 2\% KINDLE (4 DE 183) ..............................................252

FIGURA 212 - KUROSHITSUJI - PÁGINA 5 VERSÃO CHINESA, PRIMEIRA ROLAGEM .........................................252

FIGURA 213 - FIGURA 143 - KUROSHITSUJI - PÁGINA 5 VERSÃO CHINESA, SEGUNDA ROLAGEM......................252

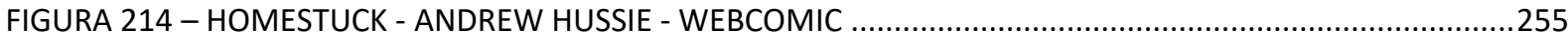

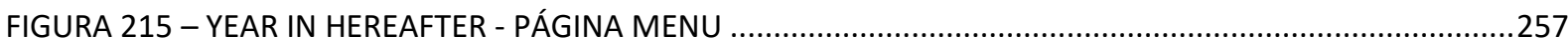

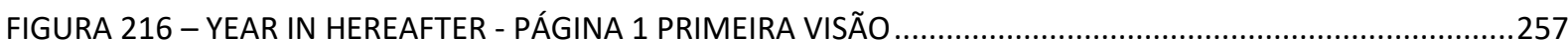

FIGURA 217 - YEAR IN HEREAFTER - PÁGINA 1 ROLAGEM ATÉ O FINAL DA IMAGEM ....................................257

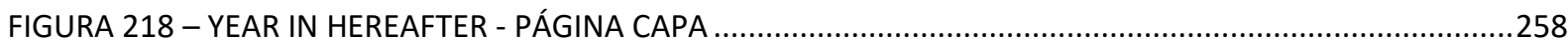

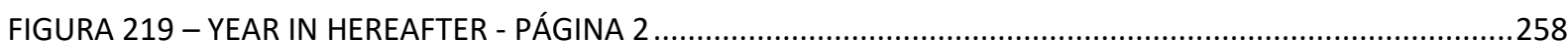

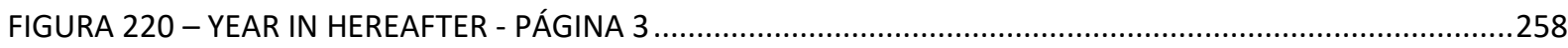

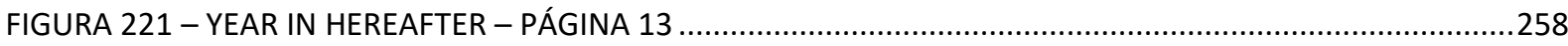

FIGURA 222 - CORTE DE QUADRO DA WEBTOON YUN T'AEHO'S P'AIN, EPISÓDIO 53....................................259

FIGURA 223 - EXEMPLO DE IMAGEM DE ALONGAMENTO VERTICAL DA WEBTOON ......................................260

FIGURA 224 - "ROMANCE DE BANCA" - COLEÇÕES SABRINA, BIANCA, JULIA, ECT .........................................265

FIGURA 225 - TINTIM NA ÁFRICA - HERGE - EDIÇÃO BRASILEIRA DE 1970 - EDITORA RECORD, PÁGINA 22, 1a E 2a LINHAS

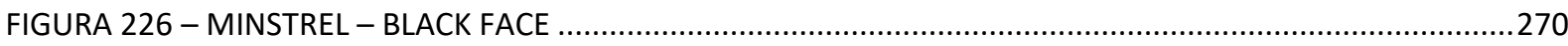

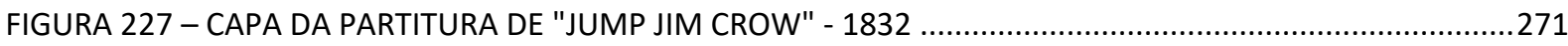

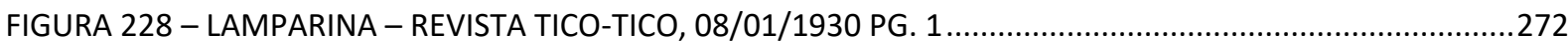

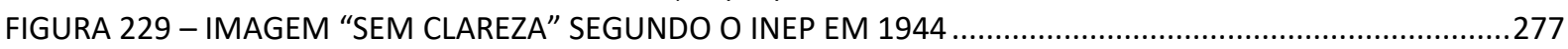

FIGURA 230 - ILUSTRAÇÃO DE ETTORE BOTTINI PARA A CAPA DO LIVRO "A GUERRA DOS GIBIS" DE GONÇALO JUNIOR, 2004... 


\section{LISTA DE TABELAS}

TABELA 1 - EVOLUÇÃO DOS CARACTERES CHINESES - ADAPTAÇÃO DA AUTORA DO ORIGINAL DE THOMAS O. HÖLLMANN

TABELA 2 - FIGURA E SIGNIFICADO EM CARACTERES CHINESES ANTIGOS - ADAPTAÇÃO DA AUTORA DO ORIGINAL DE THOMAS O. HÖLLMANN

TABELA 3 - FRASES POSSÍVEIS PARA DESCREVER UMA TIRA DE QUADRINHOS ……..........................................183

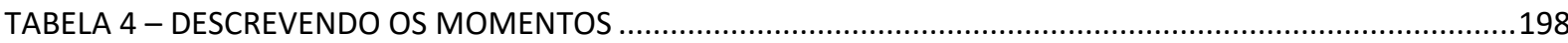

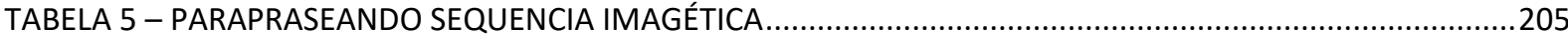

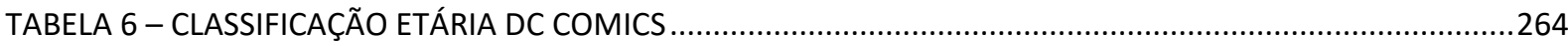




\section{LISTA DE ANEXOS}

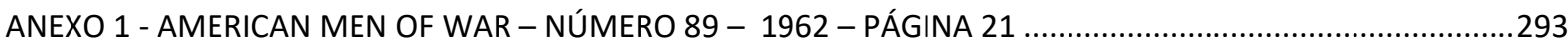

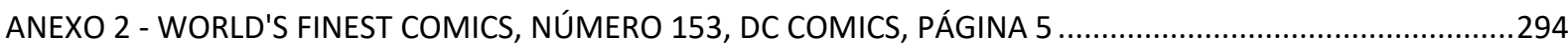

ANEXO 3 - MILO MANARA - EROTIC TAROT E ILUSTRAÇÃO LITOGRÁFICA .....................................................295

ANEXO 4 - BIANCO, NERO E GRIGIO: L'UNICITÀ DELLO STILE DI DINO BATTAGLIA..........................................296

ANEXO 5 - ILUSTRAÇÃO DE DINO BATAGLIA PARA “IL RACCONTO” DE ITALO CALVINO....................................297

ANEXO 6 - UTILIZADA PARA DECALQUE, A FIGURA ÚNICA DA QUARTA LINHA DA REVISTA BATMAN E ROBIN, №

13 PÁGINA 16, DC COMICS 201,

298

ANEXO 7 - UTILIZADA PARA DECALQUE A FIGURA PANORÂMICA FUNDO LINHA 1 MESCLADO COM LINHA 2,

REVISTA BATMAN E ROBIN, № 3 PÁGINA 9 DC COMICS 2011 ..............................................................299

ANEXO 8 - UTILIZDA PARA DECALQUE A FIGURA ÚNICA DA SEGUNDA LINHA DA REVISTA BATMAN E ROBIN, №

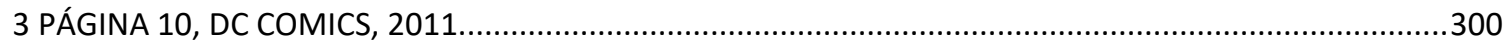

ANEXO 9 - UTILIZADA PARA DECALQUE A FIGURA ÚNICA DA TERCEIRA LINHA DA REVISTA BATMAN E ROBIN,

№ 3 PÁGINA 12 DC COMICS 2011.

301 


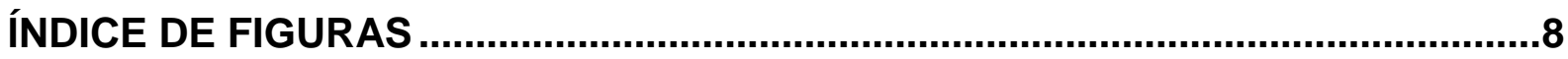

LISTA DE TABELAS

LISTA DE ANEXOS

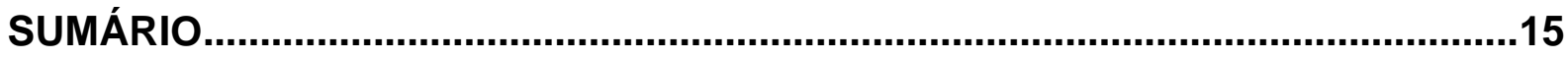

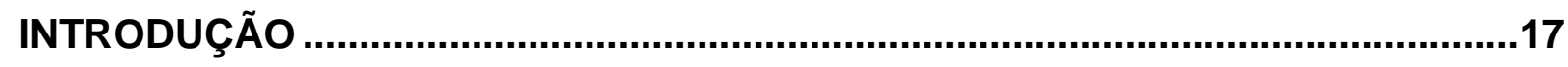

I. GÊNESE

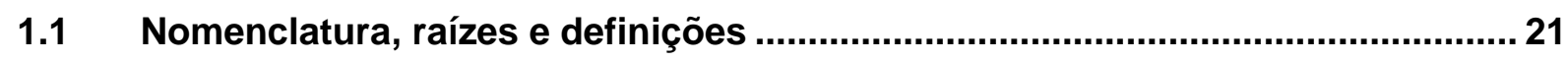

1.2 Le Charivari e Punch - o humor gráfico político................................................ 44

1.3 Töpffer $\mathrm{e} o$ início dos quadrinhos na cultura de massa ......................................51

1.4 Raízes da oposição à narrativa imagética ..........................................................58

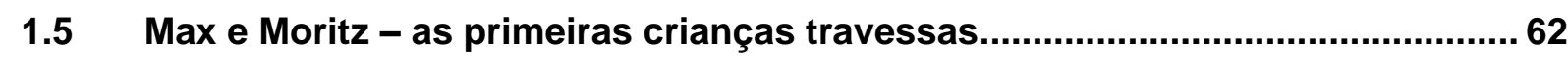

1.6 Marie Duval e Rian - o bastidor feminino dos quadrinhos .................................67

1.7 Revistas ilustradas, tiras cômicas e merchandising …........................................73

1.8 Engraçados, mas nem tanto, Tintin e os soviéticos ............................................ 86

1.9 Super-homem e a sedução americana ou quase ................................................ 95

$1.10 \mathrm{O}$ underground - sexo, drogas e samurais ..................................................... 116

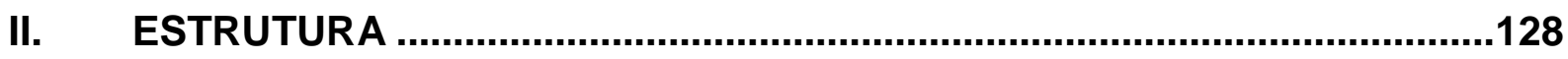

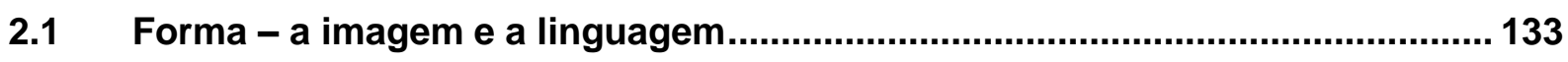

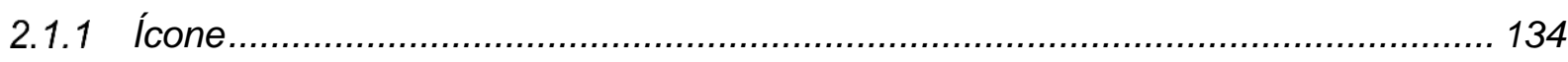

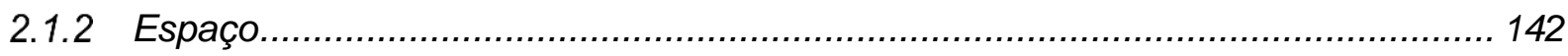

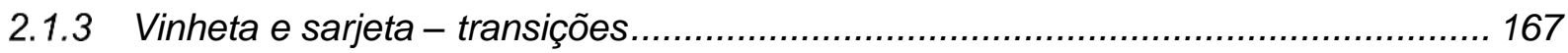

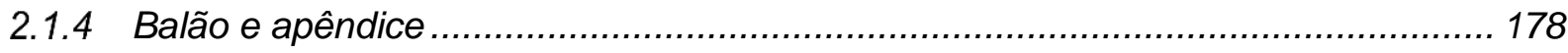

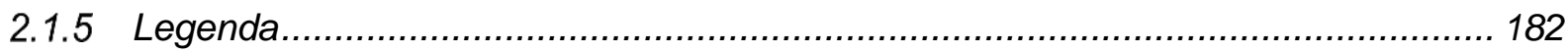

2.1.6 Onomatopeia

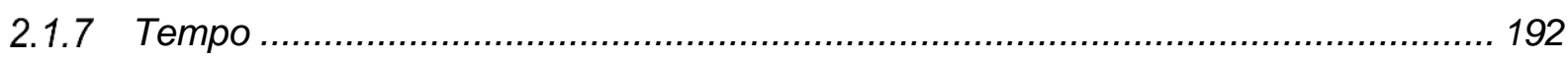

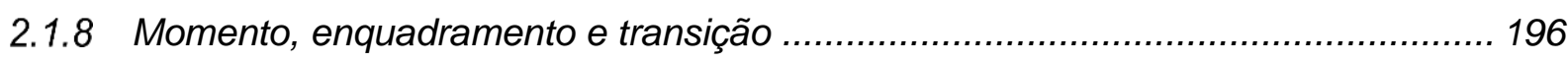

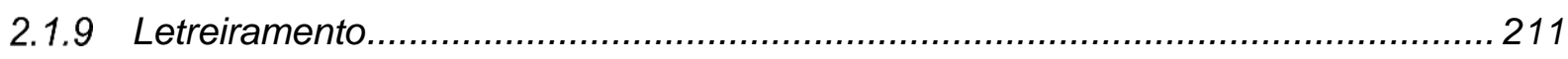

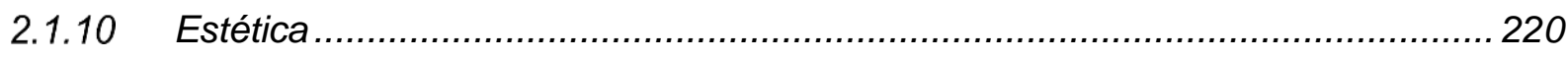

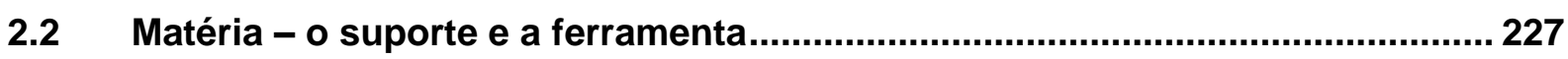

2.2.1 Do jornal para a web - cartum, charge e tira de quadrinhos ................................. 228 
2.2.2 Revistas, livros e Web - Narrativas sequenciais.

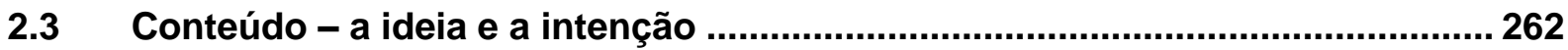

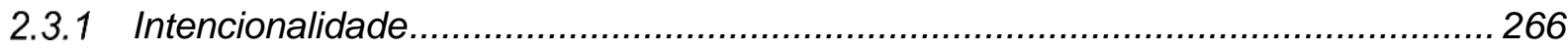

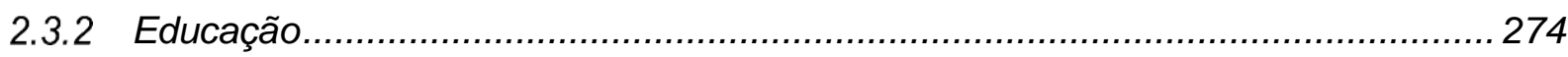

III. CONSIDERAÇÕES FINAIS ............................................................280

REFERÊNCIAS BIBLIOGRÁFICAS ..........................................................283

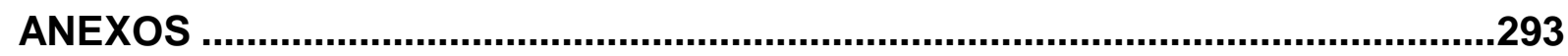

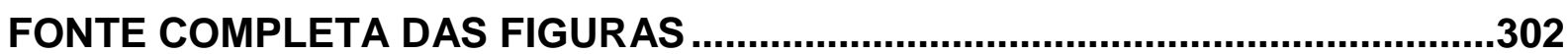




\section{INTRODUÇÃO}

Como a maioria das crianças da minha geração comecei a "ler" histórias em quadrinhos muito cedo, antes mesmo de ser alfabetizada, já que a "leitura" de um gibi não era diferente de assistir desenhos animados na televisão, completar álbuns de figurinhas, montar modelos de aviões e navios recorte-cole e vestir bonecas de papel, ou seja, mais uma atividade de criança que não tinha relação com as atividades escolares.

Quando aos quinze anos, Aldous Huxley, George Orwell, Jorge Amado, Stendall, Kiss, AC/DC, Camisa de Vênus, a expectativa do holocausto nuclear (estávamos nos anos 80 ) e o primeiro emprego já tinham suprimido em mim a fada e a princesa da Carochinha e da Disney, em um momento de tédio, caiu em minhas mãos um gibi de super-herói, uma coisa de "menino" que peguei para ler apenas pensando em rir da imaturidade dos rapazes. Mas me deparei com uma linda garota dourada de sorriso meigo e grandes olhos verdes sem pupilas, voando com seu imenso cabelo crespo e soltando raios com mãos na capa do no 3 da revista Novos Titãs da editora Abril.

Ela era uma poderosa princesa alienígena adolescente, engraçada, romântica e dramática, que havia sido sacrificada em prol do seu mundo, enviada para uma vida de escravidão, humilhada e torturada e que, sem deixar de ser doce e sexy (sim, as duas coisas eram possíveis juntas!), lutou, venceu seus inimigos, escapou e chegou à Terra onde se juntou a uma equipe de coadjuvantes de herói, os sidekicks ${ }^{1}$ Robin, Kid Flash, Moça Maravilha, que cresciam, questionavam e se rebelavam nas relações com seus mentores e seus papeis como heróis. Foi uma experiência impactante, pelo menos, naquele meu momento, idade e contexto, pois os dilemas morais e as questões humanas tratadas nas páginas de quadrados coloridos estavam perto da minha realidade em uma linguagem ainda muito familiar: a fantasia. $O$ realismo adulto era em minha jornada juvenil um terreno inóspito e muitas vezes árido, e por isso as obras literárias mais marcantes dessa fase de transição foram as ficções

1 Sidekick é uma gíria da língua inglesa que designa um companheiro(a) com certo grau de subordinação de um herói, exemplos na literatura são Sancho Pança de Dom Quixote e Dr. Watson de Sherlock Holmes. A presença de sidekicks nos quadrinhos americanos foi muito forte em determinado período, sendo Robin, de "Batman e Robin", o mais famoso. O termo é traduzido no português com "ajudante", mas como isoladamente ela perde o teor pejorativo da subordinação implícita, muitos tradutores preferem manter sidekick quando o intuito é remeter ao contexto do ajudante do herói, geralmente submisso, alienado e cegamente fiel. 
distópicas "1984" e o "Admirável Mundo Novo", que criavam imagens maravilhosas em metáforas do real, e imagens reais travestidas de maravilhoso.

Essa ironia, esse engodo, essa metáfora do real, com uma crítica dissimulada e sentidos escondidos, incoerências e incógnitas que a fantasia e a imagem criavam, me atraíram para as Histórias em Quadrinhos (HQs) onde, arte, filosofia, feminismo, religião, drogas, sexualidade, as relações do indivíduo e a sociedade, desfilaram perguntas e respostas em páginas de textos e traços em diversos estilos e tendências, criando cânones, obras primas, consumo e lixo. Os super-heróis, as novelas gráficas, as obras bibliográficas, as eróticas, me levaram a explorar o mundo com uma linguagem, mais do que familiar, cúmplice. Presenciei quando a década de 80 convulsionou os conteúdos das HQs ampliando seus limites, apesar de ainda permanecer restrita aos aficionados e a uns poucos simpatizantes, pois no geral a $\mathrm{HQ}$ era considerada um entretenimento de massa sem valor artístico e/ou um vício que deixava o jovem alienado e improdutivo, e por isso internalizei esse aspecto de mim sob o rótulo de hobby.

Hoje os leitores de $\mathrm{HQ}$ podem começar com os quadrinhos infantis da Turma da Mônica ou super-heróis, pelos mangás japoneses, pelos livros de luxo adultos, ou pelas tradicionais páginas de jornais, pelas webtoons ou simplesmente pelas redes sociais, pois há uma infinidade de percursos em que as obras se manifestam dentro da linguagem da chamada $9^{a}$ arte. Mas ainda há certo estranhamento e preconceito que rotula toda obra de $\mathrm{HQ}$ como uma coisa única, mesmo que ninguém saiba dizer categoricamente o que é essa coisa.

Durante a graduação, a Semiótica traduziu o percurso do herói de HQ, nas Literaturas Clássicas a mitologia e a epopeia singraram o espaço em collants coloridos e armaduras robóticas, as Teorias e Críticas Literárias descortinaram sentido em olhares, sorrisos e silêncios, a Língua Japonesa revelou a cultura e identidade de um povo escondida nas onomatopeias e arquétipos. Enfim, durante o curso de Letras percebi que a $\mathrm{HQ}$ e a Literatura se equivaliam na minha biblioteca interna de referência. E quis descobrir por que o hobby e o acadêmico se encontravam tão integrados na formulação de sentido e por que $\mathrm{HQ}$ parecia tão integrada com a Literatura, mesmo sendo algo diferente.

A investigação começou na literatura infantil, ainda na graduação, para compreender a relação do lúdico e do imaginário ao ir do brinquedo ao livro, ou do brincar de ler. Esse se mostrou ser o caminho certo, pois a $\mathrm{HQ}$ funciona ainda hoje 
para a criança antes da alfabetização como um brinquedo, um objeto repleto de imagens e formas em que ela vai construindo um sentido. Já na pós-graduação os estudos caminharam para a intertextualidade, para o maravilhoso e o fantástico, para a comunicação visual, para a forma e a estrutura, o cânone e a sociedade.

Polêmicas ou polemizadas, críticas ou criticadas, infantis ou infantilizadas, as Histórias em Quadrinhos são um tipo de manifestação única, que combina elementos de outras formas de arte e linguagem para narrar o mundo, a sociedade e o indivíduo. Vestidas das roupagens mais singelas nos baratos papeis de baixa qualidade de gibis descartáveis, convertidos em bits em telas de computadores e telefones celulares ou encadernadas em livros de luxo, elas podem contar épicas lendas em aquarela ou salpicar livros didáticos ensinando Gramática e Álgebra. Lidas no ponto de ônibus, no intervalo do almoço ou debaixo dos lençóis furtivamente iluminadas por lanternas, histórias engraçadas, tristes, românticas, intrigantes, apavorantes ou eróticas acompanham gerações crescerem e ideologias mudarem.

As Histórias em Quadrinhos possuem um universo ilimitado de possibilidades, perspectivas, funcionalidades e objetivos, tão intrincados quanto o imaginário humano. Navegando esse vasto cosmo, que permeia a cultura e a sociedade, este projeto vai olhar a imagem como mensagem encontrando a palavra como figura e esse amálgama se tornar linguagem e contar as histórias de heróis e de patifes, narrar épicos, dramas e a intimidade lírica do ser, educar crianças e desvirtuar inocências e, (por que não?) fazer rir. 


\section{GÊNESE}

"Comics are a strange beast.
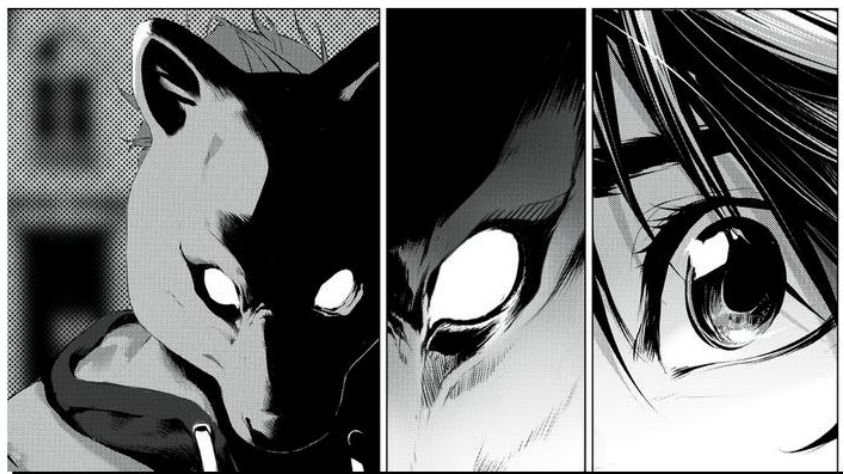

It's a strange attractor of an artform, and almost everything that sticks to it is a source of continual argument, including the term "comics." From one perspective, comics take things from all other artforms and sew them together into a weird hybrid animal. Comics compriseillustration and prose and theatre and sloganeering and graphic design and any other damn thing you want to sling into the pot. From another, it's the first and simplest way we did visual narrative. Cave paintings are sequential art. So is the Bayeux Tapestry. Someone once argued that the Stations Of The Cross constitute a comic strip."

Warren Ellis e Z-Pico ${ }^{2}$

${ }^{2}$ Epígrafe Tradução e fonte: Quadrinhos são um estranho monstro. Um estranho magneto para formas de arte, e tudo que gruda nele é uma fonte contínua de discussão, incluindo o termo "História em Quadrinhos". Por uma perspectiva, os quadrinhos pegam elementos de todas as outras formas de arte e costura todos juntos em um estranho animal híbrido. Quadrinhos são compostos de ilustrações, prosa, teatro, slogan e design gráfico e qualquer outra bobagem que você quiser colocar dentro do caldeirão. Por outra, é a primeira e mais simples forma que fizemos narrativas visuais. Pinturas das cavernas são arte sequencial. Assim como a Tapeçaria Baeux. Alguém uma vez argumentou que a Via Crucis constitui uma história em quadrinhos. (ELLIS, 2012, p. 12) [Tradução da autora] e Z-PICO. The Boy and the Wolf. Tapas, 2016. Disponível em: <https://tapas.io/episode/500166>. Acesso em: 06 Abr. 2018. 


\subsection{Nomenclatura, raízes e definições}
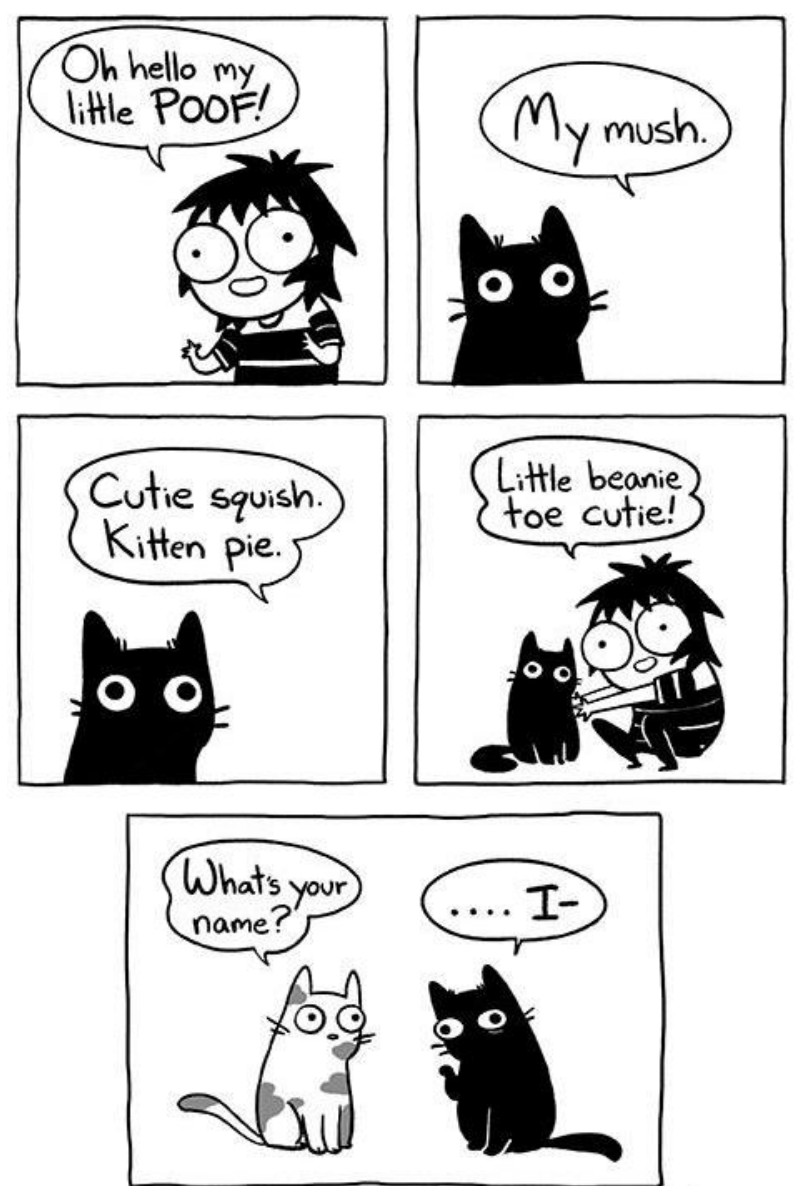

Sarah Andersen ${ }^{3}$

Histórias em quadrinhos são tão integradas ao cotidiano que muitas vezes se tem a impressão de que qualquer criança pode apontar o dedo e mostrar o que é uma $\mathrm{HQ}$, mas mesmo sua nomenclatura não é um consenso universal. Uma vez que, em cada país, ou melhor, em cada contexto cultural, foi adotado uma terminologia com sentido diferente para designar sua manifestação. Também a forma ao longo do tempo e do espaço se distanciou em experiências quase antagônicas, e ainda assim, reconhecíveis como parte da mesma manifestação.

A definição de "História em quadrinhos" no dicionário Aurélio é uma "sequência de desenhos (geralmente limitada por bordas regulares) com ou sem legendas, que contam uma história.” (FERREIRA, 2004, p. 454), já no dicionário Houaiss é uma "história narrada por meio de desenhos contido em pequenos

3 Epígrafe - fonte: ANDERSEN, S. Sarah's Scribbles. Tapas, 2017. Disponivel em: <https://tapas.io/series/Doodle-Time>. Acesso em: 18 Maio 2018. 
quadrados, com diálogos inseridos em balões ou com texto narrativo sob forma de legenda." (HOUAISS e VILAR, 2009, p. 1029). Francis Lacassim (1931-2008), jornalista, escritor e crítico especialista em cultura pop, aponta a definição do Larousse para Bande dessinée como:

Story in images serialized in the press before collection in periodical booklets or albums sold in bookstores. 'Band dessinée' in the singular, designates the means of expression; in the plural, the term designates the objective creation ${ }^{4}$. (LACASSIN, 2014, p. 39)

Tanto as definições brasileiras do verbete quanto a francesa ressaltada por Lacassin não são consensuais entre si e destoam, também, das diversas concepções dos estudiosos sobre o assunto, contudo a abordagem francesa, aqui utilizada, colabora com uma reflexão sobre a diferença na nomenclatura entre a área e o objeto de estudo, assim por associação se pode dizer que HQ é a abreviação de História em Quadrinhos, que no singular se refere à manifestação cultural, e histórias em quadrinhos, no plural, referem-se aos objetos de criação, ou seja, às obras produzidas.

A História em Quadrinhos é um fenômeno global e em cada país o termo escolhido para designá-lo ressaltou um ou mais aspectos, como o desenho, a narrativa ou a junção de ambos, outros ressaltaram ainda a mídia, a forma ou a temática. O professor de cultura americana da universidade de Bordeaux na França, Jean-Paul Gabilliet chama atenção para o fato de que as traduções do termo História em Quadrinhos em várias línguas demostram a imprecisão da correlação entre a nomenclatura e o meio,

Where the English usage retains the older humorous nature of its content
(funnies, then comics), and even emphasizes its most common visual layout
in newspapers (comic strip), the German speaks of "stories in images"
(Bildergeschichte); the Dutch have several terms but the most common is
strip; the Italian alludes to the speech balloons (fumetti); the Spanish talks
about little stories (historietas) or, even more frequently in Spain, calls them
tebeos (a reference to Tebeo, one of the country's first illustrated magazines),
although the anglicized term cómics is now often used. The French term
"bande dessinée" is relatively recent: [...] "Bande dessinée" did not become
common usage until the 1950s; before that, albums and magazines were
known as "revues illustrés" or "illustrés"s. (GABILLIET, 2010, p. 12)

${ }^{4}$ História em imagens serializadas na imprensa antes de reunidos em brochura ou álbuns vendidos em livrarias. 'História em quadrinhos' no singular, designa os meios de expressão; no plural, o termo designa a criação objetiva (LACASSIN, 2014, p. 39) [Tradução da autora].

${ }^{5}$ Onde 0 uso em inglês retém a natureza humorística mais antiga do seu conteúdo (funnies [engraçados], depois comics [cômicos]), e enfatiza seu layout visual mais comum nos jornais (comic strip [tira cômica]), o alemão fala de "histórias em imagens" (Bildergeschichte); os holandeses têm vários termos, mas o mais comum é strip [tira]; O italiano alude aos balões de fala (fumetti); O espanhol fala sobre pequenas histórias (historietas) ou, ainda mais frequentemente na Espanha, os chama de tebeos (uma referência a Tebeo, uma das primeiras revistas ilustradas do país), embora o termo 
$\mathrm{Na}$ França, histórias em quadrinhos são chamadas de Bande Dessinée (BD), literalmente, tira desenhada. Essa nomenclatura surgiu nos escritórios da Opera Mundi, uma agência especializada na distribuição de quadrinhos na França fundada em 1928 pelo jornalista e editor judeu-húngaro Paul Winkler (1898-1982) e foi consagrada nos contratos da agência tanto com os artistas quanto com as editoras (GLASSER, 2014, p. 21). Para o público, no entanto, essa terminologia demorou a se fixar partilhando também as nomenclaturas: série dessinée (série desenhada), bande illustrée (tira ilustrada), bandes imagées (tiras em imagens), etc. Contudo, segundo o historiador francês Jean-Claude Glasser (1941-2005), artigos críticos geralmente empregavam a nomenclatura Bande Dessinée e, com a fundação do Le Club des Bandes Dessinée (o clube das histórias em quadrinhos) em 1962, essa terminologia se tornou popularmente aceita (GLASSER, 2014, p. 22).

Apesar do nome Bande Dessinée ser relativamente recente, a produção de algo similar as histórias em quadrinhos já era uma tradição antiga, tanto na França, como em outras partes da Europa. Na Holanda, onde os quadrinhos são chamados "Stripverhalen" (tira narrativa), segundo a Comiclopedia Lambiek, editada pelo tradutor e escritor de revistas infantis Bas Schuddeboom (1980), a tradição da linguagem de quadrinhos na Holanda pode ser traçada desde os manuscritos medievais ilustrados (Figura 1, pág. 25) que já usavam imagens sequênciais nas narrativas e por vezes o "balão de diálogo"6 e também dos centsprent ou mannekesprent (Figura 3, pág. 25), folhas impressas em papel de baixa qualidade, vendidas a preços módicos (um cent, por exemplo), geralmente retratando a vida dos santos (Figura 2, pág. 25), anedotas e fábulas (SCHUDDEBOOM e KNUDDE, 1994-2017).

O Japão, país reconhecido como possuidor do maior mercado interno de História em Quadrinhos, produz ampla variedade de gêneros e temáticas de HQ, que abarcam desde a infância até o público adulto. É tanto uma mídia reconhecida como meio de informação e educação, como uma forma de arte valorizada. A HQ no Japão é chamada de mangá (漫画), os caracteres que compõe o nome são 画 (ga): pintura, desenho; e 漫 (man): algo involuntário, livre, corrompido ou a despeito de si mesmo, ou como frequentemente traduzido para outras línguas: irresponsável ou

anglicano cómics seja usado frequentemente. O termo francês "bande dessinée" [tira desenhada] seja relativamente recente: [...] "Bande dessinée" não se tornou uso comum até a década de 1950; Antes disso, álbuns e revistas eram conhecidos como "revues illustrés" [revistas ilustradas] ou "illustrés" [ilustradas] (GABILLIET, 2010, p. 12) [tradução da autora]

${ }^{6}$ Balão de diálogo: espaço específico para representação da fala oral, será trato em capítulo específico. 
inconsequente. O termo surgiu no Japão, muito antes da popularização do gênero, a estudiosa de cultura japonesa Helen McCarthy relata que o primeiro registro de seu uso, de acordo com o estudioso Adam Kern, data de 1798 pelo poeta escritor e desenhista Santo Kyoden e que em 1814 Aikawa Minwa publicou o Manga Hyakujo (manga das cem meninas) (MCCARTHY, 2014, p. 7-8).

No Brasil a HQ - História em Quadrinhos ou simplesmente "quadrinhos" também é conhecida como "Gibi". Segundo o jornalista, escritor e pesquisador de cinema, imprensa, música e histórias em quadrinhos, Gonçalo Junior, "gibi" que no início do século XX queria dizer "moleque", "garoto" ou "negrinho", foi o título de uma das revistas de maior circulação dos anos 40 aos 60, lançada pelo jornalista Roberto Marinho, editor do jornal "O Globo" (GONÇALO JUNIOR, 2004, p. 69). A palavra "gibi" se tornou uma espécie de sinônimo de $H Q$, mas carregava um teor pejorativo, decorrente da crítica negativa da sociedade da época, que acreditava que a leitura de histórias em quadrinhos aumentava a delinquência juvenil e, por isso, se referiam a todas as revistas de histórias em quadrinhos como "aquelas revistinhas tipo gibi..." (GONÇALO JUNIOR, 2004, p. 11).

Na Itália a HQ é conhecida como Fumetti, o termo, literalmente "fumacinha" tem origem no formato do balão de fala dos personagens e ganhou notoriedade em um artigo do crítico Antonio Rubino em 1938 (BOSCHI, 2010). Fora da Itália o termo também é usado para designar fotonovelas, que na Itália são chamadas fotoromanzo, um tipo de $\mathrm{HQ}$ com narrativas românticas e dramáticas, muito popular na Itália e exportado para o resto do mundo (ABELL, 2012, p. 67). As publicações anteriores à importação do material americano não continham balões, apesar de imagens sequenciais e personagens fixos, o texto era mantido fora dos quadros, por isso até o artigo de Rubino as histórias em quadrinhos tiveram várias nomenclaturas como: "caricature" (caricaturas), "satire figuratte" (sátiras figuradas), "pupazzetti" (fantoches), e com o sucesso de Corriere dei Piccoli em 1908 foi introduzido o termo "storie a quadretti” (histórias aos quadradinhos) (GROENSTEEN, 2014, p. 95).

Gérard Blanchard, gravurista, tipógrafo, historiador e acadêmico francês, em seu livro Historie de la bande dessinée (1969), ressalta que apesar do cristianismo repudiar a imagem e privilegiar a palavra durante seus primeiros séculos, pelo fato de Jesus ter atestado que "ele" era a palavra de Deus encarnada, a imagem foi crescendo junto aos povos onde Arte era um modo efetivo de reforçar a religião (BLANCHARD, 2014, p. 26). 


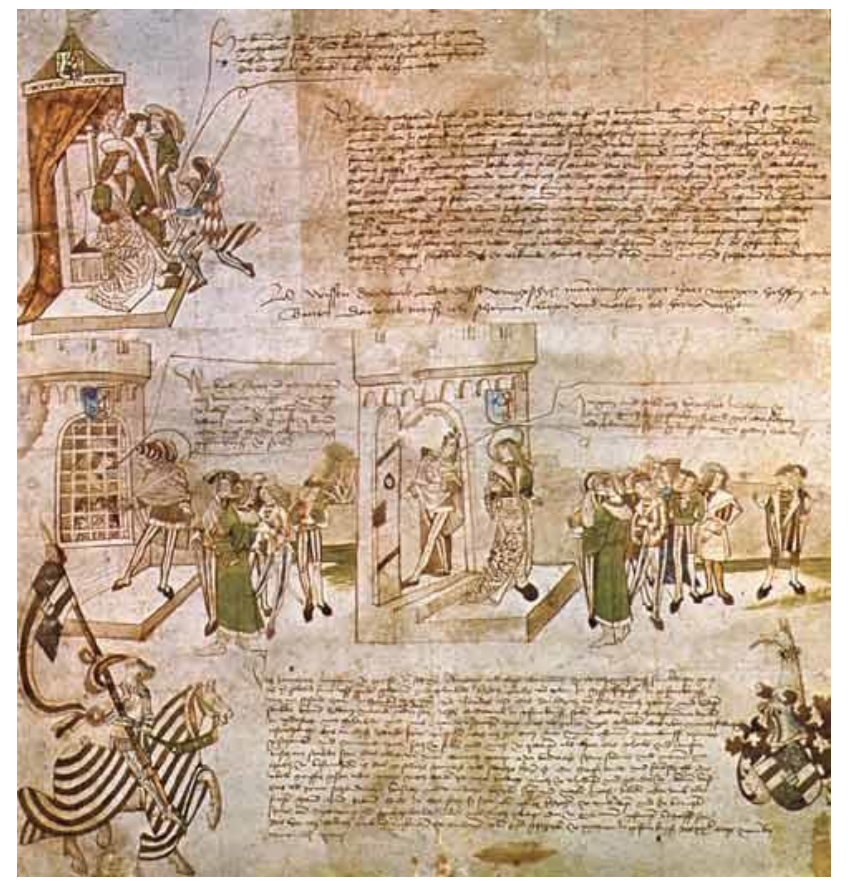

Figura 1 - Carta manuscrita do Conde de Meurs Biblioteca de Zutphen'

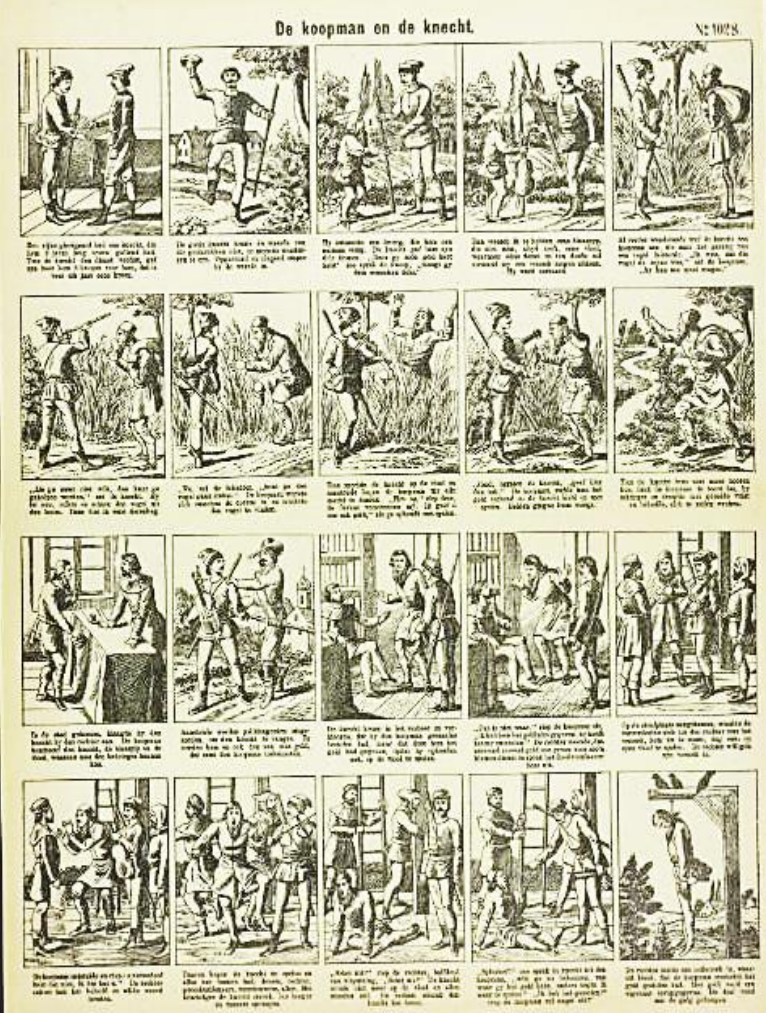

Figura 3 - Centsprent - De koopman en de knecht (o comerciante e o servo) - editora Nachf de C. Burckardti

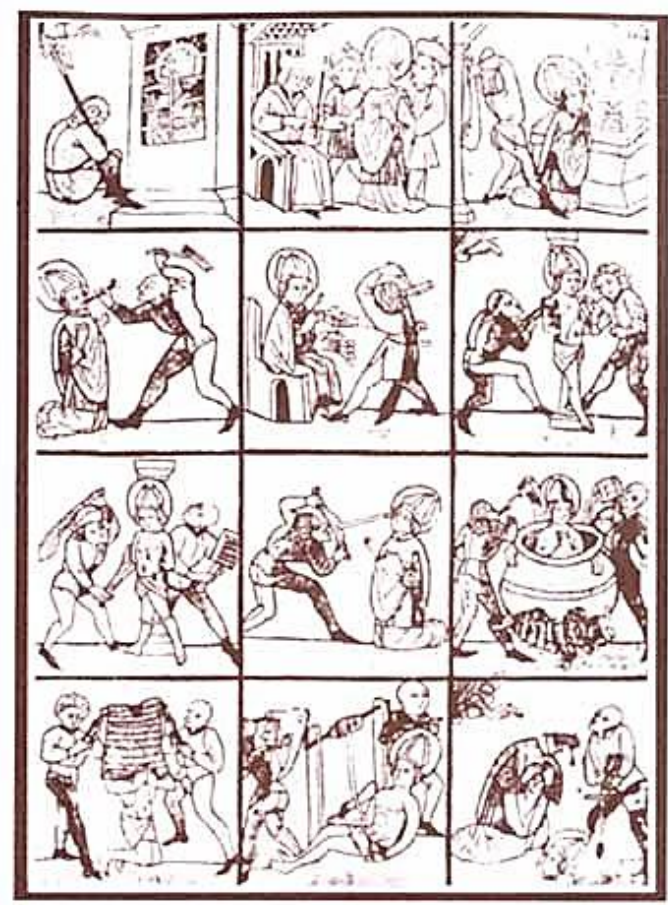

Figura 2 - A história do martírio de Santo Erasmo, datando de cerda de 1460 - Lambiek

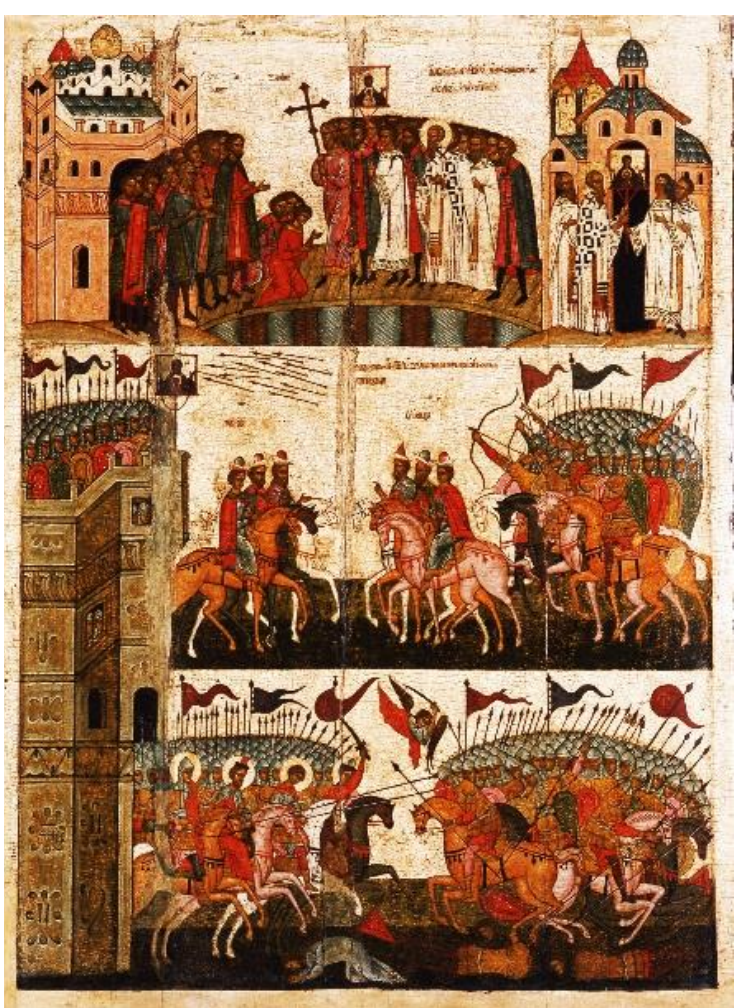

Figura 4 - Lubok - Battle between Novgorod and Suzdal - Wikicommons 


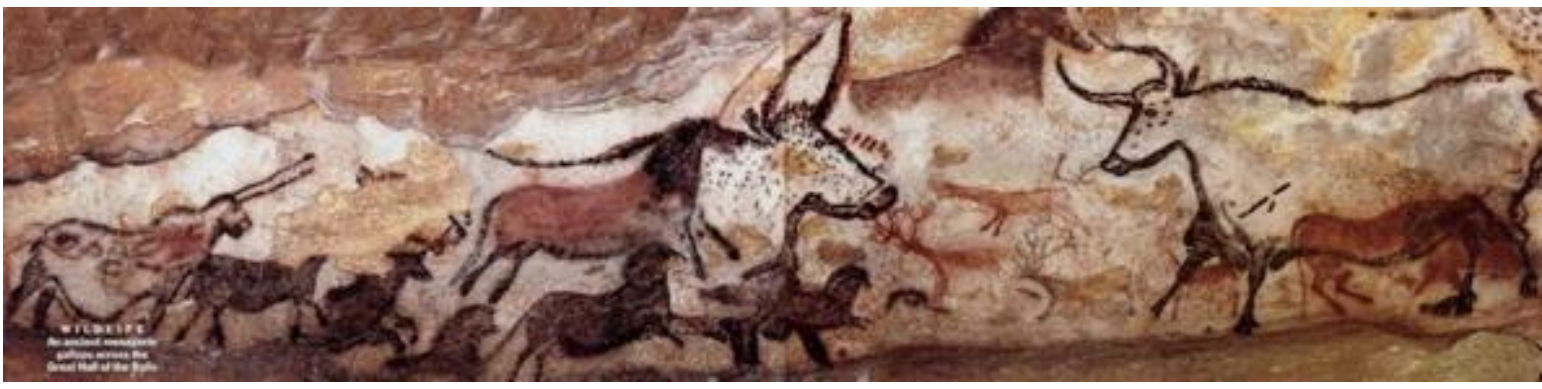

Figura 5 - Figuras da caverna de Lascaux ${ }^{\mathrm{iii}}$

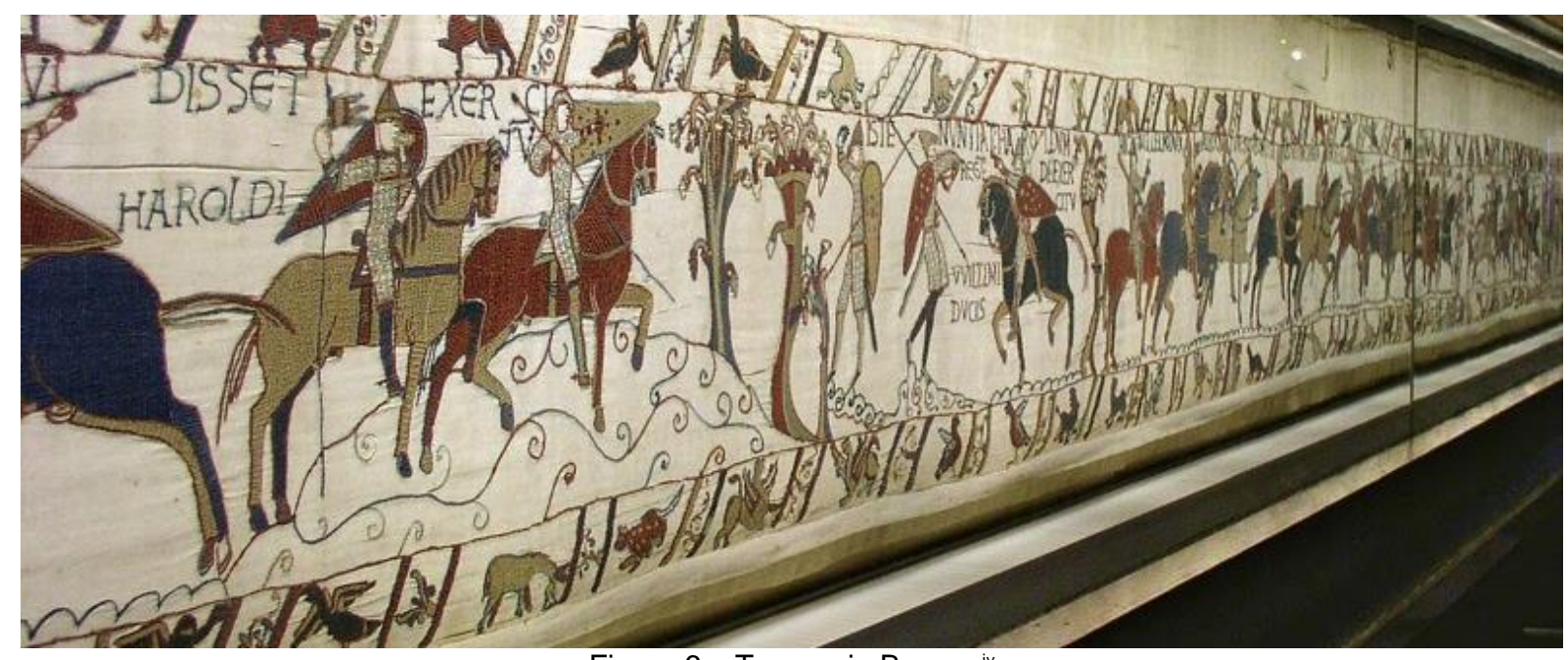

Figura 6 - Tapeçaria Bayeuxiv

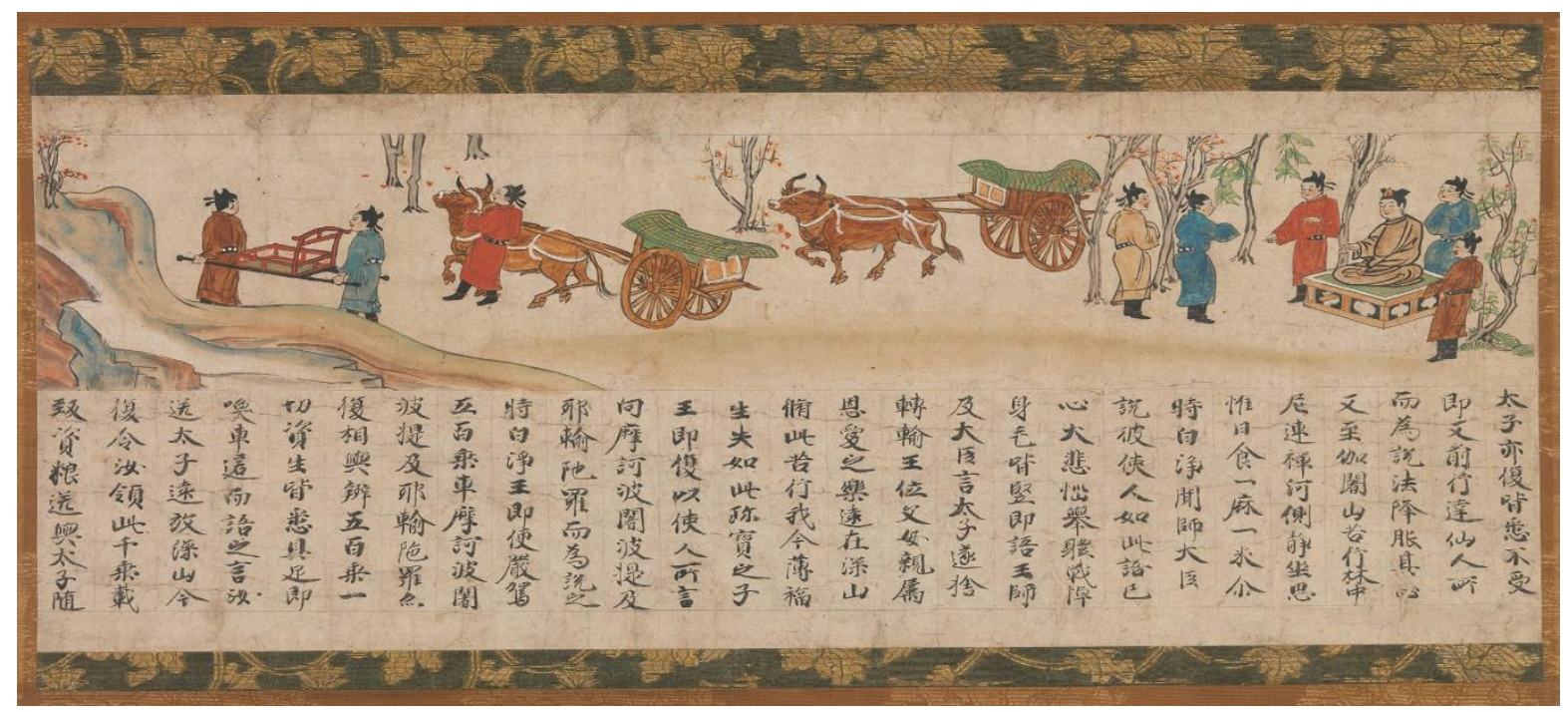

Figura 7 - Emakimono - "The Illustrated Sutra of Past and Present Karma" - artista desconhecido do final do século XIII - Metropolitan Museum of Art - Nova Yorkv

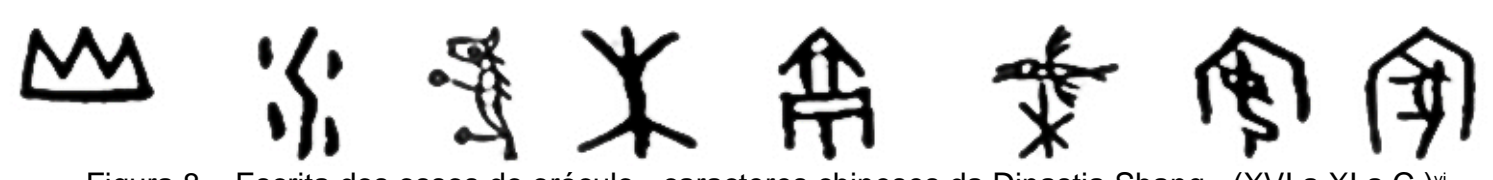

Figura 8 - Escrita dos ossos do oráculo - caracteres chineses da Dinastia Shang - (XVI a XI a.C. $)^{\text {vi }}$ 
José Alaniz, professor do departamento de línguas e literaturas eslavas da universidade de Washington, em seu livro Komiks: Comic Art in Russia de 2010, expõe que apesar de hoje ser usado o termo Komiks, derivado da palavra inglesa Comics (os quadrinistas chamados de "Komiksmen" ou "Komiksist," "Komiksistka" (feminino) e "Komiks-meiker" para o editor de quadrinhos) (ALANIZ, 2010, p. 7), alguns estudiosos russos ainda tentam uma definição do termo, como G. Ananov, citado por Alaniz, que usa a nomenclatura "livro de cinema" ou "livros cinematográficos" (khizhnoe kino ili kinoshnye knizhki), pois, para esses estudiosos, a cultura imagéticonarrativa russa é anterior aos quadrinhos da Europa ocidental e América, com raízes antigas conjuntamente com início da religião cristã, através do ícone religioso trazido pelos bizantinos no século $X$ para os antigos povos que formariam a Rússia.

A imagem foi a ferramenta de conversão e era utilizada como objetos de adoração, criando na Rússia uma inclinação especial com o visual (ALANIZ, 2010, p. 13). As narrativas sequênciais religiosas contadas nos vitrais e mosaicos das capelas e igrejas, eram impressos nos Lubok ou Lubki (Figura 4 pág. 25), com ou sem texto, e as pessoas comuns compravam para decorar suas paredes. Mais tarde lendas, fábulas e contos de fadas além de anedotas cômicas também passaram a ser impressos nos Lubok. Com o passar do tempo também foram impressos almanaques e calendários, sempre mantendo a estética tradicional (ALANIZ, 2010, p. 16).

In both form and content, lubok was a unique hybrid art. First, its interaction
of word and image, notes the literary critic/semiotician Yurii Lotman", was not
simply that of an illustration and explanatory caption, but more like a theme
and its elaboration (razvertyvanie): "It is as if the caption 'plays up'
(razygrivaet) the drawing, compelling the viewer to perceive it not as
something static, but as an action"8. (ALANIZ, 2010, p. 19)

Para o quadrinista e teórico americano, Scott McCloud, autor de "Desvendando os Quadrinhos" (Understanding Comics: The Invisible Art), de 1993, "Reinventando os Quadrinhos" (Reinventing Comics: How Imagination and Technology Are Revolutionizing an Art Form), de 2000 e "Desenhando Quadrinhos" (Making Comics: Storytelling Secrets of Comics, Manga and Graphic Novels), livros teóricos no formato $\mathrm{HQ}$, as histórias em quadrinhos são: "Imagens pictóricas e outras

\footnotetext{
${ }^{7}$ Lotman, lurii. Ob iskusstve. St. Petersburg: Iskusstvo SPB, 1998.

${ }^{8}$ Tanto em forma quanto em conteúdo, lubok era uma única arte hibrida. Primeiro, sua interação de palavra e imagem, nota o crítico literário / semioticista Yurii Lotman, não era de uma simples ilustração e uma legenda explicativa, mas mais como um tema e sua elaboração (razvertyvanie): "Era como se a legenda 'animasse' (razygrivaet) o desenho, instigando o espectador a perceber isso não como algo estático, mas como ação" (ALANIZ, 2010, p. 19) [tradução da autora]
} 
justapostas em sequência deliberada destinadas a transmitir informações e/ou produzir uma resposta no espectador." (MCCLOUD, 1995). Ele ressalta que a narrativa sequencial das histórias em quadrinhos vai além daquilo que é atualmente popularmente reconhecido como História em Quadrinhos e aponta para a sua linguagem já presente não só na tapeçaria de Bayeux, uma das mais importantes obras de arte e história, (Figura 6, pág. 26) que detalha em imagens sequenciais e texto a conquista da Normandia pela Inglaterra em 1066, como também no manuscrito de história épica pré-colombiano "Garras de Tigre" de 1519, além dos hieróglifos egípcios, da coluna de Trajano, da pintura grega e dos arabescos japoneses (MCCLOUD, 1995, p. 15).

A tapeçaria Bayeux também é citada por Blanchard, que ressalta a união entre o sacro e o profano no período medieval e, principalmente, a propaganda expressa na forma como a narrativa é composta. Encomendada pelo meio irmão do rei Guilherme, Otto de Conteville, bispo de Bayeux, a versão da conquista pela perspectiva dos "vencedores" enaltece a vitória de Guilherme II, com seu exército normando e francês sobre a Inglaterra (BLANCHARD, 2014, p. 27).

Essa ancestralidade da História em Quadrinhos também é apontada pelo quadrinista e crítico Dan Mazur e o pesquisador, quadrinista e escritor, Alexander Danner no livro "Quadrinhos - história moderna de uma arte global”:

A propensão de contar histórias com figuras, combinando imagem e texto,
parece universal: a Coluna de Trajano, pergaminhos asiáticos, tapeçarias
medievais e retábulos, os jornais broadsheet do século XVIII e as gravuras
japonesas feitas a partir de pranchas de madeira podem sem sombra de
dúvida ser identificados como "pré-história" dos quadrinhos. (MAZUR e
DANNER, 2014, p. 7)

Também no Japão a tradição dos emakimono 絵巻物 - rolo de pintura (Figura 7, pág. 26) serviriam de base estética e narrativa para, em conjunto com a tradição da imprensa ocidental, dar origem ao mangá, a História em Quadrinhos japonesa. Anna Willmann, do departamente de arte asiática do MET (The Metropolitan Museum of Art) de Nova York, aponta as narrativas ilustradas em rolo, emakimono, como importantes documentos religiosos e oficiais. Compostas por folhas de papel ou seda unidas horizontalmente e enroladas em torno de uma cavilha, as seções de cerca de 60 centímetros que são desdobradas um segmento por vez, eram direcionadas à elite política e religiosa. Segundo Willmann, como um livro, os emakimonos, eram objetos íntimos para serem lidos por uma ou poucas pessoas de cada vez (WILLMANN, 2002). Willmann explica que os arqueólogos e pesquisadores da área 
acreditam que as narrativas ilustradas em rolos tenham se originado na Índia, por volta do século IV a.C. sendo levadas à China no século I d.C. e posteriormete ao Japão no século VI d.C. por meio do budismo (WILLMANN, 2002).

Por volta do ano 1100 d.C. o alto sacerdote budista japonês Toba Sojo produziu uma série de cartuns em rolo mostrando animais antropomorfizados como sapos, macacos, ratos entre outros, para satirizar os monges menos devotados. Conforme Helen McCarthy, as pinturas eram usadas para ensinamentos religiosos, mas se tornaram tão populares que qualquer pintura cômica vendida para o público era chamada de Toba-e (pinturas de Toba).

Fusanosuke Natsume (1950) colunista, cartunista e crítico de quadrinhos, filho do renomado novelista Natsume Sōseki, acredita que a popularidade e aceitabilidade do mangá no Japão se devam ao fato de as culturas asiáticas terem uma relação muito próxima entre imagem e linguagem. Para ele,

East Asian cultures have had a relatively close picture-to-language
relationshtip. In cultures with Kanji (Chinese characters), it seems easier to
develop a mode of expression in which letters are combined with illustrations
and are treated as a picture. Emakimono, rolls of illustrations that accompany
a story, developed in 12 th century Japan as a means to tell a story. There has
also been a tradition in popular culture of storytelling with both pictures and
words. Kibyoshi, in the Edo period, is one such example. ${ }^{9}$ (NATSUME, 2003,
p. 2 - 3)

Os caracteres chineses apontados por Natsume são mais conhecidos no ocidente como ideogramas, por serem símbolos que representam um conceito abstrato. Em sua origem (Figura 8 pág. 25) o kanji tentava ser uma representação do objeto. Acompanhando a evolução do kanji ao longo do tempo a relação entre imagem e conceito presente na escrita, como, por exemplo, na palavra cavalo, 馬 (mă em chinês, uma em japonês):

Tabela 1 - Evolução dos caracteres chineses - adaptação da autora do original de Thomas O. Höllmannvii

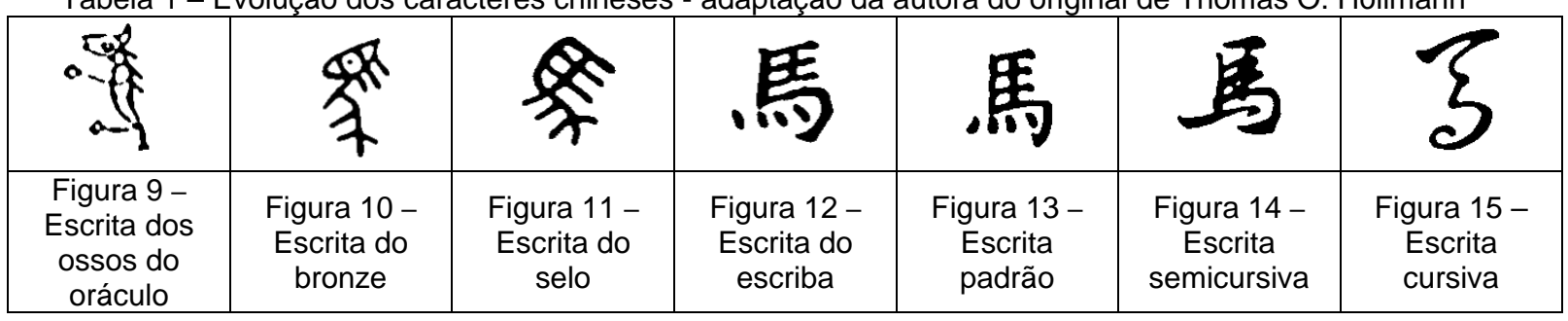

9 Culturas do leste asiático tiveram um relacionamento relativamente próximo de imagem-paralinguagem. Em culturas com o Kanji (caractere chinês), pareceu fácil desenvolver um modo de expressão no qual as letras são combinadas com ilustrações e tratadas como uma imagem. Emakimono, rolos de ilustrações que acompanham uma história, se desenvolveram no século 12 no Japão como uma forma de contar uma história. Havia também a tradição na cultura popular de contação de história com imagem e palavras. Kibyoshi, na era Edo é um exemplo do tipo. 
Segundo o sinólogo ${ }^{10}$ e antropólogo alemão Thomas O. Höllmann, presidente da Academia de Ciências da Baviera e membro do Instituto Arqueológico Alemão e do Instituto de Antropologia Histórica, os símbolos pertencentes à classificação "Escrita dos ossos do oráculo" datam do início da Dinastia Shang (XVI a $\mathrm{XI}$ a.C.), e foram encontrados gravados em ossos de animais ou cascos de tartarugas, em sítios de escavações das antigas câmaras dos oráculos reais, em geral se referindo à questões de sacrifício, causas de doenças, datas de gestação, fundação de assentamentos, guerras, tributos, previsão do tempo e interpretação de sonhos (HÖLLMANN, 2017).

Ainda de acordo com Höllmann, a "Escrita do bronze" foi surgindo ao longo da Dinastia Shang, ainda muito ligada à função divina, aparecendo em itens usados em cerimônias, mas ao final da dinastia com o poder ampliado das elites, esse tipo de escrita se firma em objetos de bronze com funções de designações, contratos e registros oficiais, que com a Dinastia Zhou (XI a 771 a.C.) são aprimorados se tornando a "Escrita do selo" (primeiro grande selo e posteriormente selo pequeno) menos pictórica e com regras mais rígidas sobre o design de cada elemento do caractere.

Devido à dificuldade no desenho dos traços, mesmo escribas oficiais acabaram adotando uma forma mais cursiva, mais prática e rápida de desenhar, a "escrita do escriba", com apogeu na Dinastia Qin (221 a 207 a.C.), que por fim se consolidaria na Dinastia Tang (618 a 907 d.C.) na escrita regular ou formal, utilizada até hoje (HÖLLMANN, 2017).

O estudo de Höllmann sobre a ancestralidade da escrita iconográfica chinesa e, por adoção, japonesa aponta para a relação cultural entre imagem e a linguagem, pois se torna possível vislumbrar que além do significado absoluto de uma palavra, existe nesta outra nuance semântica, apontada pela escolha das imagens usadas em sua representação, conforme apontado no quadro a seguir.

\footnotetext{
${ }^{10}$ Sinólogo - especialista no estudo da China ou seus habitantes (língua, escrita, civilização, história, etc.)
} 
Tabela 2 - Figura e significado em caracteres chineses antigos - adaptação da autora do original de Thomas 0. Höllmann:

\begin{tabular}{|c|c|c|c|}
\hline $\begin{array}{c}\text { Escrita do osso do } \\
\text { oráculo }\end{array}$ & Kanji atual & Significado & Elementos na figura \\
\hline & & Montanha & Montanha \\
\hline & & Água & Curso de água \\
\hline & & Cavalo & Cavalo \\
\hline & & Árvore & Árvore \\
\hline & & Celeiro, capital & Um prédio grande e alto \\
\hline & & Coletar & Um pássaro sobre uma árvore \\
\hline & & Quieto, seguro & Uma mulher dentro de casa \\
\hline & & Lar, família & Um porco dentro de casa \\
\hline
\end{tabular}

Para exemplificar a agregação de outra nuance semântica a uma palavra, pode-se destacar o caso do caractere usado para o sentido de "quieto" ou "seguro": [安] (an em chinês, yasu em japonês), cuja representação é uma mulher sentada dentro de casa.

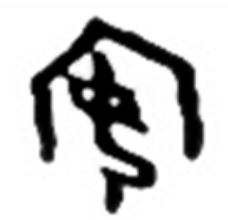

Figura 16 - caractere 安 - “quieto" ou "seguro" - escrita dos ossos do oráculo

Segundo a professora de Línguas e Culturas Mundiais, Noriko K. Williams, há vários caracteres que possuem como radical o kanji [女] (mulher), partindo da escrita dos ossos do oráculo, representava uma pessoa ajoelhada com os braços cruzados na frente:
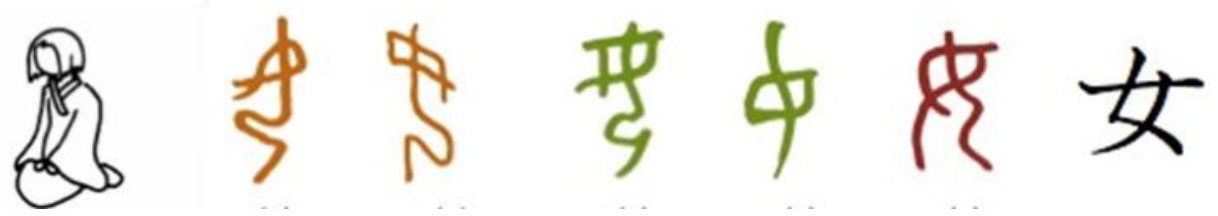

Figura 17 - figuração e transformação do caractere 女- mulher - Noriko k. Williams viii 
A postura flexionada indica que a pessoa é uma mulher, o kanji agrega o sentido de fêmea, feminino. Por ele, infere-se o comportamento "normal" ou "esperado" para a mulher. Esse kanji será o radical, a imagem base, para construção de inúmeras outras palavras, como [好] (gostar), composto pelos kanjis [女] (mulher) e [子] (criança).

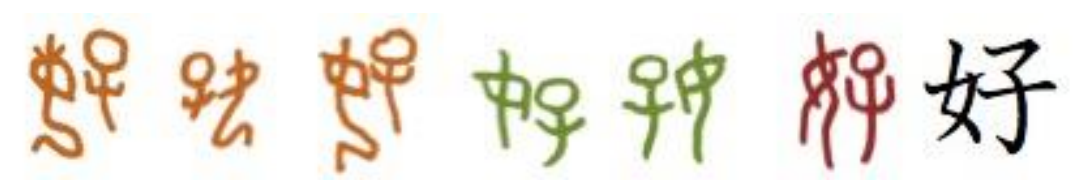

Figura 18 - transformação do caractere 好- gostarix

Em sua forma ancestral, o caractere representava uma mulher com uma criança no colo. A profa. Williams nota que é pela postura terna com que a mulher trata a criança que o significado se tornou "gostar", "ter afeição por" e também "bom", "desejável" (WILLIANS, 2010, p. 116).

A diferença entre a imagem usada como figuras ou palavras é apontada por Blanchard na relação de figuras concretas e abstratas nas pinturas ruprestes (Figura 5, pág. 26),

From the beginning, figuration tended either towards what we call Art (drawing) or towards the Sign. The animal figures in Lascaux are concrete in comparison with the more abstract, more schematic signs that overlap then or cover certain other parts of the cave, in patterns that can be found at other prehistoric sites. The mixture of concrete and abstract, promoting a double reading, recurs as a constant throughout the history of stories in pictures. The drawing is the description of events and action (and things), while the sign, in carefully constructed combinations, can provide a detailed account of words, thoughts or feelings. Two of the main means of communication complement each other in this way ${ }^{11}$ (BLANCHARD, 2014, p. 26).

Em seu ensaio "The origins of Stories in Images", Blanchard ressalta a conexão da espécie humana com a importância da leitura de imagens desde as mais primitivas e simples manifestações. Desde o princípio o homem precisou interpretar as "pistas" deixadas pelo seu entorno para sobreviver. Foi preciso reconhecer as pegadas, marcas e rastros de predadores e presas. Segundo Blanchard, essas marcas perpetuam a presença deixada pela ausência do sujeito: seguir esses rastros

\footnotetext{
${ }^{11}$ Desde o início, a figuração tendia para o que chamamos de Arte (desenho) ou para o Signo. As figuras de animais em Lascaux são concretas em comparação com os signos mais abstratos, mais esquemáticos que se sobrepõem, ou cobrem certas outras partes da caverna, em padrões que podem ser encontrados em outros sites pré-históricos. A mistura de concreto e abstrato, promovendo uma leitura dupla, repete-se como uma constante ao longo da história das histórias em imagens. O desenho é a descrição de eventos e ações (e coisas), enquanto o signo, em combinações cuidadosamente construídas, pode fornecer uma descrição detalhada de palavras, pensamentos ou sentimentos. Dois dos principais meios de comunicação se complementam deste modo." (BLANCHARD, 2014, p. 26) [tradução da autora]
} 
são como contar a si mesmo uma história, a história do ser que está sendo seguido, a história do espaço onde habita, das coisas e eventos que existiram ou aconteceram sem que fossem presenciadas (BLANCHARD, 2014, p. 25). Não é possível saber se foi a linguagem falada ou a representação de símbolos que surgiu primeiro como exposição do pensamento, mas é possível inferir que a leitura e interpretação de imagens e sons aconteceu na aurora da humanidade por uma necessidade de sobrevivência.

Para o professor Antonio Luiz Cagnin, professor no Departamento de Cinema, Rádio e TV da USP, autor do livro Os quadrinhos (1975), uma referência aos pesquisadores brasileiros,

\begin{abstract}
A imagem não é aquilo que representa, não tem a transparência da palavra nem a opacidade do objeto; o meio do caminho do real e do imaginário, do documento e da ficção, ela fascina e também amedronta. Com a palavra, ou antes dela, a imagem acompanhou o homem em todas as suas necessidades, para se comunicar, para ensinar, para criticar os erros, para elevar, para destruir. (CAGNIN, 2014)
\end{abstract}

A palavra "imagem" deriva do latim Imāgo, Ǐnis e significa: retrato, semelhança; imagem; aspecto; ideia; aparência; eco (BUSARELLO, 2007, p. 133). A palavra imago na Roma clássica era usada para a "máscara mortuária", um molde em cera do rosto da pessoa morta. As primeiras máscaras mortuárias cobriam o rosto do morto, porém mais tarde começaram a ser usadas por atores para representar personalidades do passado (DIAS, 2017). José A. F. Dias, antropólogo, curador, programador e professor da Faculdade de Belas Artes da Universidade de Lisboa (FBAUL), nota que curiosamente a palavra latina imago adquiriu vários sentidos ao longo dos séculos, na teologia cristã, a criação do homem à semelhança de Deus é chamada imago Dei e a expressão imago mundi remete para a ideia religiosa de uma ordem cósmica (DIAS, 2017), sendo o nome de uma série de livros, incluindo um texto de cosmografia de 1410 do teólogo francês Pierre d'Ailly. No século XX, Jung insere o termo na psicanálise como o protótipo inconsciente de personagens, formado a partir das primeiras relações intersubjetivas. Segundo a informação do Centro de Medicina Psicossomática e Psicologia Médica do Hospital Geral da Santa Casa de Misericórdia do Rio de Janeiro,

As imagos funcionam como verdadeiros clichês mentais de personagens da vida afetiva da pessoa, e orientam a maneira com que a pessoa percebe a outra. Dizem respeito às figuras do pai (imago paterna), da mãe (imago materna) e dos irmãos (imagos fraternas) e não precisam ser reflexos das figuras originais. (CMPPM, 2017) 
Posteriormente, Jung evolui o conceito de imago para seu conceito de arquétipo, que será muito adotado na caracterização figurativa de personagens nos quadrinhos.

Imago no sentido de máscara é o ato de esconder, de disfarçar, mas também de revelar e de dar presença ao que está ausente. A imagem, principalmente nos quadrinhos, tem o efeito da máscara, descrita por Dias, "apresenta um poder ambíguo, tendo sobre nós um efeito de surpresa, ameaça ou medo, que por sua vez pode conduzir ao riso" (DIAS, 2017).

Pois assim como as máscaras, a imagem, revive a presença daquilo que está ausente e, por conseguinte, do inalcançável, do irreal e do mítico. Para Platão a imagem era uma imitação de uma imitação, pois para ele o mundo percebido pelos sentidos humanos (tato, audição, visão e olfato) já era uma fração do real limitada pela capacidade interpretativa humana. Já para Aristóteles a imagem era a representação mental do objeto real, sendo adquirida através dos sentidos. A oposição dos dois filósofos iniciou uma ruptura conceitual entre idealismo e realismo.

A discussão sobre a veracidade ou farsa da imagem em sua relação com a personificação do ausente ou inalcançável (o sagrado, o mítico, o mágico), conforme Margarida Medeiros, culminou na Guerra entre Iconoclastas e Iconófilos no período Bizantino (séc. VIII), e similares como o iconoclasma protestante na Holanda no século XVI e a destruição das gigantescas estátuas dos Budas de Bamyan pelos Taliban em 2001 (MEDEIROS, 2017). Este estudo de Medeiros sobre a imagem em geral reforça a informação prévia de Blanchard acerca da relação conflituosa e contraditória da cultura cristã que mesmo centralizada na palavra como porta voz do sagrado em detrimento da imagem, mantinha estreitos laços com o visual como forma de propagação (propaganda) da fé.

Ao mesmo tempo em que a imagem é uma justaposição contraditória entre o real e a farsa no que tange a representação do mundo, sua materialização (em qualquer suporte) é uma asserção, um recorte no tempo e espaço - aqui e agora onde imperam os verbos "ser" e "estar", algo é e está. Portanto, toda imagem insere uma proposição assertiva a respeito de algo (mesmo que essa asserção seja uma inverdade, um questionamento ou uma possibilidade). Como aponta Margarida Medeiros a imagem é produzida e desejada pelo Homem em determinados contextos (MEDEIROS, 2017), 
Considerando imagem num sentido lato, ela envolve formas de representação visual de diferentes materialidades e suportes, mas que remetem, todas elas, para a necessidade de construir, no espaço bidimensional ou tridimensional, objectos cujo significado é partilhado no interior de um certo grupo e ao qual este atribui determinadas propriedades simbólicas. No centro da produção das imagens está o Homem, como agente de trocas simbólicas e como seu destinatário. (MEDEIROS, 2017, p. Imagem)

Hans Belting (1935), historiador alemão, especializado em história da arte medieval, renascentista e contemporânea, em seu livro "An antropoly of images" de 2001 (versão inglesa 2011) traz um viés antropológico do estudo de imagens, ressaltando as diversas acepções da palavra imagem. Ele nota que em alemão a palavra "bild" é usada tanto para imagem quanto para figura, apesar das pessoas estarem se referindo a coisas diferentes. Ele aponta que alguns autores criam a impressão que imagens circulam em uma forma desencarnada (etérea), o que não seria verdade nem com as imagens imaginadas ou de memória pois, segundo ele, estas imagens habitam nossos corpos. Belting indica que outros autores associam a imagem com o plano visual, sugerindo que tudo que é visual é uma imagem (BELTING, 2011, p. 9).

The "image", however, is defined not by its mere visibility but is being invested, by the beholder, with a symbolic meaning and a kind of mental "frame" 12 (BELTING, 2011, p. 9).

Hans Belting nota ainda que há aqueles que identificam imagens como signos e ícones, ignorando, como ele ressalta, "a diferença entre o semiótico e o icônico", e uma escola de pensamento que busca proteger a "arte" de ser contaminada por imagens de meios de comunicação de massa e outras fontes. Belting acredita que, como resultado dessa diversidade de interpretações do conceito de imagem, "we not only speak in the same way about very different images, but also apply very different modes of discourse to the same kind of images"13 (BELTING, 2011)

Um dos maiores nomes da História em Quadrinhos, Will Eisner, artista, editor e crítico com mais de 70 anos de carreira, autor dos livros Os Quadrinhos e a Arte Sequencial (Comics and Sequential Art) (1985) e Narrativas Gráficas (Graphic Storytelling and Visual Narrative) (1996), quando fala da junção nas Histórias em Quadrinhos de dois importantes dispositivos de comunicação, a palavra e a imagem,

12 A "imagem", no entanto, é definida não por sua mera visibilidade, mas por ser investida, pelo observador, com um significado simbólico e uma espécie de "quadro" mental (BELTING, 2011, p. 9) [tradução da autora].

${ }^{13}$ Não só falamos da mesma maneira sobre imagens diferentes, mas também aplicamos modos de discurso muito diferentes para o mesmo tipo de imagens (BELTING, 2011) [tradução da autora]. 
ressalta que mesmo que sejam tratados separadamente, na verdade, derivam de uma mesma origem (EISNER, 2013, p. 7). Essa origem comum, notada por Cagnin, é o fato de os códigos, palavra escrita e imagem, serem ambos visuais (CAGNIN, 2014, p. 41).

Para a professora Lucrécia D’Alessio Ferrara, líder do Grupo de Pesquisa Espaço-Visualidade/Comunicação-Cultura (ESPACC) e autora do livro "Leitura sem palavras" (1993), tanto a fala, quanto à escrita e a imagem são sistemas de comunicação, como prática humana são uma representação do real,

Toda representação é uma imagem, um simulacro do mundo a partir de um sistema de signos, ou seja, em última ou em primeira instância, toda representação é gesto que codifica o universo, daí se infere que o objeto mais presente e, ao mesmo tempo, mais exigente de todo processo de comunicação é o próprio universo, o próprio real (FERRARA, 1986, p. 7).

Corroborando essa acepção está a afirmação de Thierry Groensteen, pesquisador de História em Quadrinhos e diretor do Musée de la Bande Dessinée, em Angoulême, cidade sede do Festival Internacional de Quadrinhos de Angoulême, o mais importante evento europeu da área, de que "toda representação (pode ser) codificada e que toda contemplação de uma representação é uma leitura" (GROENSTEEN, 2015, p. 17). Ele propõe um estudo dos "Quadrinhos como fenômeno semiológico - linguagem - primazia da imagem como 'códigos visuais'”, e em seu livro O sistema dos quadrinhos de 2015 aponta:

Os quadrinhos [...] são uma combinação original de uma (ou duas, junto com a escrita) matéria(s) da expressão e de um conjunto de códigos. É a razão pela qual podem ser descritos apenas em termos de sistema. O problema que se põe em análise, portanto, não é favorecer um código; é encontrar uma via de acesso ao interior do sistema que permita explorá-lo na sua totalidade e mostrar sua coerência. (GROENSTEEN, 2015, p. 14-15)

Contudo, a professora Ferrara lembra que "todo processo de comunicação é, se não imperfeito, certamente parcial” (FERRARA, 1986, p. 7), e ressalta que

[...] toda codificação é representação parcial do universo, embora conserve sempre, no horizonte da sua expectativa, o desejo de esgotá-lo. É dessa parcialidade e dessa expectativa que brotam o interesse e a pertinência da ação interpretante do receptor: uma ação interpretante sobre o modo de representação de uma linguagem é, necessariamente, uma relação entre a face do objeto realmente representada, a expectativa não exaurida dessa representação e os demais e eventuais modos ou possibilidades de representação (FERRARA, 1986, p. 7).

As reflexões de Ferrara ressaltam a participação do leitor na construção do sentido do real, uma vez que ela afirma que o significado de uma linguagem é o resultado de uma relação entre uma representação presente e outras representações 
possíveis, eventuais e virtuais (FERRARA, 1986).

Em outra linha de pesquisa, Jean-Paul Gabilliet, professor de estudos Americanos na Universidade de Bordeaux na França, a despeito de todo debate sobre a ancestralidade das narrativas imagéticas, considera importante não simplesmente identificar possíveis limites formais da História em Quadrinhos, incluindo aquilo que apresente determinados critérios ou excluir aquilo que não os possua. Ele demostra que vários estudos que seguem essa conduta (como McCloud, Eisner, Groensteen, Cagnin, entre outros, que priorizam a sequência de imagens como um parâmetro delimitador) acabam categorizando os livros ilustrados como História em Quadrinhos e deixando de fora as charges e cartuns. Gabilliet acredita em realizar os estudos a respeito de quadrinhos tanto sincrônicos quanto diacrônicos e pensar: "When and where were comics "born"? When did the notion of "comics" become pertinent, historically and culturally?"14 (GABILLIET, 2010, p. 12).

Por isso Gabilliet acredita em quadrinhos como,

a medium of expression should not be analyzed as an ahistoric, transcendent object. It is the result of a multiplicity of endogenic and exogenic factors. Thus comic art is not a medium of expression in the absolute sense (in the manner of painting, sculpture, and cinema) but a category comprising means of expression that are more or less proximate. The category of "comics"-for want of a better term-applies to all narratives constructed with images (whether they be drawn, engraved, photographed, painted, or by other means). ${ }^{15}$ (GABILLIET, 2010, p. 16)

Mesmo assim, na busca pelos limites formais da História em Quadrinhos, Gabilliet ressalta que reluta em considerar obras como as novelas em xilogravuras produzidas pelo artista belga Frans Masereel em 1919 (Figura 20 pág. 40), pelo artista alemão Otto Nückel em 1926 (Figura 21, pág. 40) ou do americano Lynd Ward em 1929, ou ainda History of Holy Russia de Gustave Doré de 1854 ou as séries de desenhos dos caricaturistas ingleses Hogarth (Figura 19, pág. 40), Woodward, Gillray do século XVIII, como História em Quadrinhos.

Gabilliet argumenta que os xilogravuristas como Lynd Ward que estudou Artes Plásticas na Universidade de Columbia em Nova York, por exemplo, receberam

\footnotetext{
${ }^{14}$ Quando e onde os Quadrinhos nasceram? Quando a noção de "quadrinhos" se tornou pertinente, histórica e culturalmente? (GABILLIET, 2010, p. 12) [Tradução da autora]

${ }^{15}$ uma mídia de expressão não deveria ser analisada como um transcendente objeto de fora da história. $\mathrm{HQ}$ é o resultado da multiplicidade de fatores endogênicos [estrutural, estético] e exógenos [tecnológico econômico e cultural]. Além disso, a arte dos quadrinhos não é uma mídia de expressão no sentido absoluto (da maneira da pintura, da escultura e cinema), mas uma categoria compreendendo meios de expressão mais ou menos próximos. A categoria "quadrinhos" - por falta de um termo melhor - se aplica a todas as narrativas construídas com imagens (sejam elas desenhadas, gravadas, fotografadas, pintadas ou qualquer outro meio). (GABILLIET, 2010, p. 16) [tradução da autora]
} 
treinamento plástico clássico e, portanto, sua estética é diferente da $\mathrm{HQ}$, dessa forma, os livros com sequencias de imagens em xilogravura, para Gabilliet, fazem parte de um conjunto maior de "narrativa em imagem" na qual quadrinhos está inserido (GABILLIET, 2010, p. 14-18).

$\mathrm{Na}$ Espanha, Santiago Garcia, escritor de quadrinhos, jornalista, tradutor e pesquisador de Histórias em Quadrinhos, colabora com a seção de Quadrinhos do $A B C D$ las artes y las letras, o suplemento do jornal espanhol $A B C$, tem uma visão similar à de Gabilliet de que o estudo da HQ não pode se basear apenas no aspecto estrutural, sem levar em conta o aspecto cultural. Ele considera a HQ como uma "Forma artística com entidade própria, e não um subgênero da literatura." (GARCIA, 2012, p. 14). Seu livro $A$ novela gráfica de 2010 procura abordar a História em Quadrinhos de um ponto de vista histórico-cultural explicando o objeto, segundo o autor,

através de cada momento de sua existência, e não em um plano puramente abstrato, ideal e teórico. O que aconteceu, aconteceu em um lugar e em um momento concretos, em circunstâncias determinadas, e é esse relato que temos que reconstruir para chegar ao capitulo que estamos escrevendo neste momento, hoje, amanhã. (GARCIA, 2012, p. 14)

Para Eisner, quadrinhos são uma forma de leitura na qual a "linguagem se vale da experiência visual comum ao criador e ao público" (EISNER, 2010, p. 1), essa experiência diz respeito a decodificação de imagem e texto, pois ele aponta que "o tratamento visual das palavras como forma de arte gráfica faz parte do vocabulário" (EISNER, 2010, p. 2).

Os livros de Eisner, baseados no curso que ministrou na School of Visual Arts de Nova York, são fundamentais para a compreensão artística da linguagem dos quadrinhos. Sua contribuição é tão importante que a maior premiação do gênero nos EUA leva seu nome, o Eisners ou Eisner Award é conferido anualmente na ComicCon em San Diego, a maior convenção de quadrinhos da América (GROPPER, 2018). Já o americano Bill Blackbeard, escritor, editor e estudioso de histórias em quadrinhos, fundador e diretor da Academia de Artes Cômicas de San Francisco, uma coleção de tiras de jornal e arte em cartoons dos jornais dos Estados Unidos da América, com um acervo por volta de 2,5 milhões de recortes de jornais que abrangem os anos de 1894 a 1996 disponibilizados para pesquisadores, tem sobre HQs uma definição bem definida, contestada por Groensteen, 
Uma narrativa dramática ou uma série de anedotas correlacionadas sobre personagens recorrentes e identificáveis, publicada regularmente, em episódios e sem final determinado, narrada na forma de desenhos sucessivos, contendo frequentemente diálogos dispostos em balões ou equivalentes, com texto geralmente mínimo. (BLACKBEARD apud GROENSTEEN 2015)

Também contestado por Groensteen, está a definição do britânico David Kunzle, professor de história da arte na UCLA (Universidade da Califórnia em Los Angeles), pesquisador de história em quadrinhos, autor de The Early Comic Strip, 1973.

Segundo minha definição, uma "história em quadrinhos", seja de qualquer período ou país, precisa cumprir as seguintes condições para ser tratada como tal: 1. Que seja uma sequência de imagens separadas; 2. Que exista preponderância de imagens em relação a texto; 3 . A história em quadrinhos precisa ser concebida para reprodução e aparecer em suporte impresso, ou seja, um suporte que predisponha à difusão massiva; 4. A sequência deve contar uma história que tanto tenha sentido moral quanto seja atual. (KUNZLE apud GROENSTEEN 2015)

Para o historiador francês, Pierre Couperie, chefe de equipe do Centro de Investigação Histórica da Escola de Altos Estudos em Ciências Sociais, em Paris, e vice-presidência do Clube das Bandas Desenhadas - o primeiro na Europa.

As histórias em quadrinhos seriam uma narrativa (mas não obrigatóriamente uma narrativa...) constituída pelas imagens criadas pela mão de um ou de mais artistas (a fim de eliminar o cinema e a fotonovela), imagens fixas (diferente dos desenhos animados), múltiplas (ao contrário dos cartuns) e justapostas (diferente da ilustração e dos romances em gravura). Mas essa definição ainda se aplica muito bem à Coluna de Trajano e à Tapeçaria de Bayeux... (COUPERIE apud GROENSTEEN 2015)

No Brasil, Cagnin, pioneiro da pesquisa semiótica de quadrinhos, considera que $\mathrm{HQ}$ é um sistema narrativo iconográfico e nele,

A imagem e a escrita pertencem a sistemas diversos, ao código iconográfico e ao código linguístico da escrita, enquanto modalidade de fala. Notar que ambos são igualmente visuais. Os dois códigos que juntos formam as histórias em quadrinhos são opostos quanto a natureza do signo utilizado, analógico um, digital o outro. O código linguístico da escrita é um sistema de signos discretos, também chamados digitais (contados nos dedos), isto é, composto de um conjunto definido de unidades autônomas e contáveis, as letras e as palavras que se articulam [...] e não conservam nenhuma semelhança com o objeto representado [...] é na maioria dos casos imotivada. [...] A imagem desenhada dos quadrinhos, ao contrário, é um signo analógico e contínuo, mantém uma relação estreita de semelhança com o objeto representado, a sua forma física é, por isso, motivada (CAGNIN, 2014, p. 4142).

Segundo Cagnin, nas histórias em quadrinhos se o verbal tem amplo poder de representação no vasto campo das ideias e dos conceitos universais, a imagem está revestida da imensa riqueza da representação do real (CAGNIN, 2014, p. 42). 


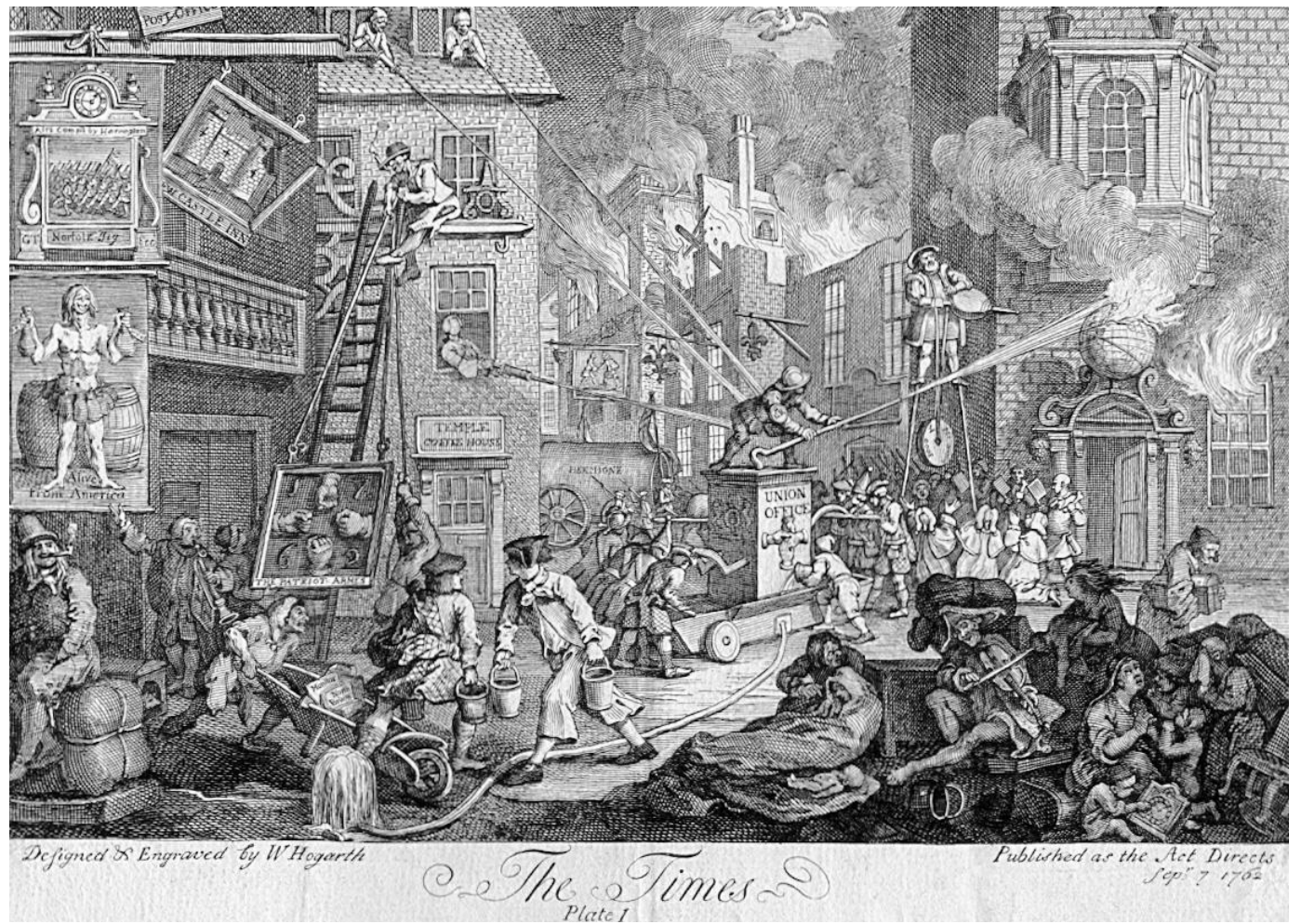

Figura 19 - William Hogarth - 1762 - charge política em que o Rei Henrique III tenta apagar as chamas da guerra dos Sete Anos. ${ }^{x}$
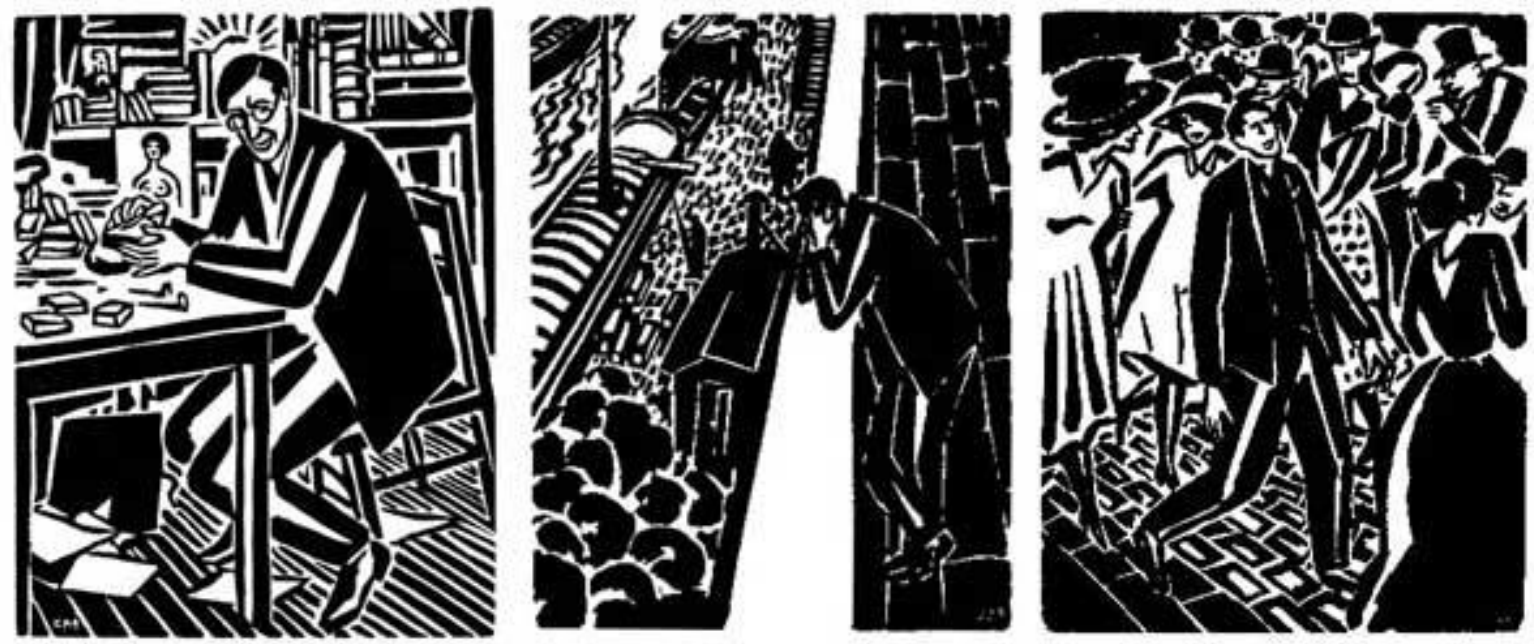

Figura 20 - Mon livre d'heures - 1919 - Frans Maseree ${ }^{\mathrm{xi}}$
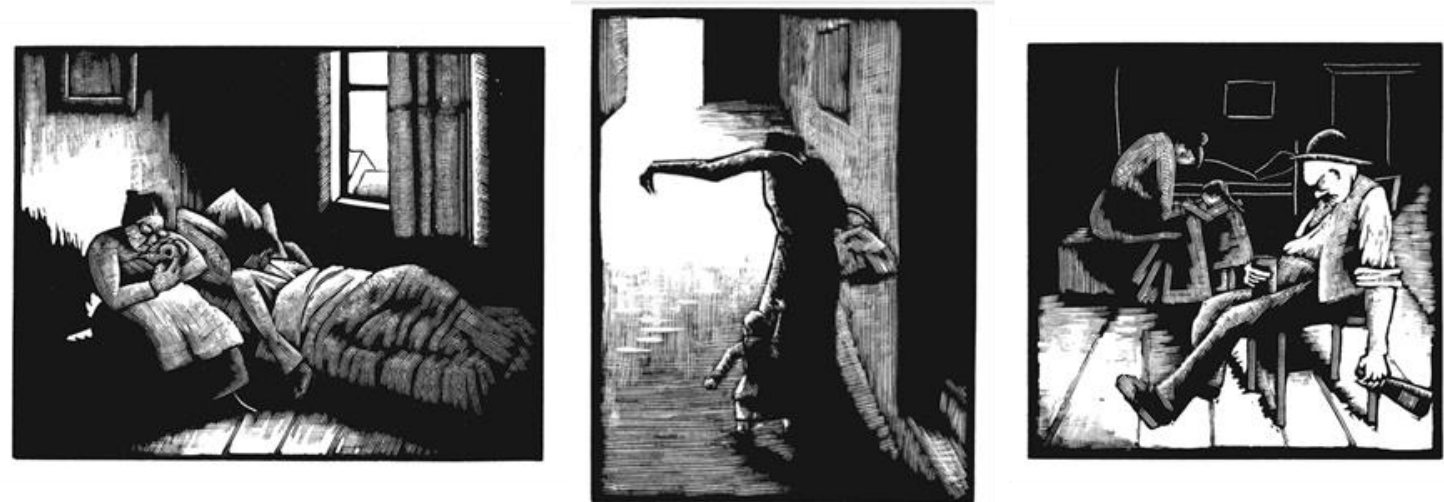

Figura 21 - Otto Nübkel - Destiny - 1930 - Nova York- repúblicação por Dover Publications 2007i 
O brasileiro Moacy Cirne, professor aposentado do Departamento de Comunicação Social da Universidade Federal Fluminense que, como poeta, participou do movimento de lançamento do Poema-Processo, em 1967, foi editor da Revista de Cultura Vozes, de 1971 a 1980, e autor dos livros $A$ explosão criativa dos quadrinhos (1970), Para ler os Quadrinhos (1972), Uma introdução política aos Quadrinhos e Quadrinhos (1982), Quadrinhos, sedução e paixão (2000) todos pela Editora Vozes e de História e Crítica dos Quadrinhos Brasileiros (1990) pela Funarte e A escrita dos Quadrinhos (2006) pela Sebo Vermelho (VERGUEIRO, RAMOS e CHINEN, 2013, p. 38), propõe um novo olhar para as HQs. Uma percepção com mecanismos próprios que levem em conta a sua especificidade: "Quando pensamos uma prática estética, devemos pensar uma nova modalidade de leitura" (CIRNE, 1975, p. 10) pois, segundo ele, há na leitura de uma manifestação estética, três etapas informacionais:

A primeira compreenderia a leitura simbólica, de predomínio conteudístico; a
segunda, a leitura estrutural, de fundo orgânico; a terceira, a leitura criativa,
baseada no processo de cada produto. Esta leitura criativa, formulada a partir
do poema/processo, pode ser aplicada a qualquer objeto estético, em uma
operação que se realize da estrutura ao projeto, separando a leitura da escrita.
(CIRNE, 1975, p. 11)

Recentemente, o pesquisador brasileiro Paulo Ramos, jornalista, doutor em Letras pela USP, participante do Núcleo de Pesquisas em Histórias em Quadrinhos da USP e consultor de língua portuguesa da Folha de S. Paulo e do UOL, escreveu no livro A leitura dos quadrinhos (2010) que,

Quadrinhos são quadrinhos. E, como tais, gozam de linguagem autônoma, que usa mecanismos próprios para representar elementos narrativos. Há muitos pontos comuns com a literatura, evidentemente. Assim como há também com o cinema, o teatro e tantas outras linguagens. (RAMOS, 2010)

Nesse mesmo livro ele especificou alguns conceitos básicos da $H Q$, que são:

1. Diferentes gêneros utilizam a linguagem dos quadrinhos; 2 . Predomina nas histórias em quadrinhos a sequência ou tipo textual narrativo; 3 . As histórias podem ter personagens fixos ou não; 4 . A narrativa pode ocorrer em um ou mais quadrinhos, conforme o formato do gênero; 5 . Em muitos casos, o rótulo, o formato, o suporte e o veículo de publicação constituem elementos que agregam informações ao leitor, de modo a orientar a percepção do gênero em questão; 6 . A tendência nos quadrinhos é a de uso de imagens desenhadas, mas ocorrem casos de utilização de fotografias para compor histórias. (RAMOS, 2010, p. 19)

Álvaro de Moya, professor aposentado do Departamento de Cinema, Televisão e Rádio da Escola de Comunicações e Artes da Universidade de São Paulo, foi diretor da TV Excelsior de São Paulo. Organizou a I Conferência Internacional de 
Histórias em Quadrinhos, em 1951 em São Paulo. Foi organizador da Gibitecas Henfil e Gibiteca do SESI também em São Paulo. Lançou os livros Shazam! (1970) pela editora Perspectiva, História da história em quadrinhos (1993) pela Melhoramentos, Vapt-Vupt (2002) pela Clemente \& Gramani, O mundo de Walt Disney (1996) pela Geração Editorial, Gloria in Excelsior: Ascensão, apogeu e queda do maior sucesso da televisão brasileira (2004) pela IMESP e A Reinvenção dos Quadrinhos (2012) pela Criativo. Foi também quadrinista, chargista e ilustrador do jornal O Tempo, de São Paulo, a partir de julho de 1950. Também desenhou as adaptações para os quadrinhos de A Marcha, baseado na obra de Afonso Schmidt, para a revista Edição Maravilhosa da Ebal, Zumbi, sobre a vida do Rei dos Palmares, e Macbeth, de Shakespeare, para a revista Seleções de Terror, editada por Jayme Cortez. (UCHA, 2011)

Sua experiência como artista que, junto com um grupo de amigos, se aventura em uma arte sem mestre, criando os próprios métodos, demostra a transcendência do artesão ao artista, e daqueles que partem da experimentação à conjectura.

Um colega de um grupo que alguns de nós formávamos, Syllas Roberg, era
escritor, mas trabalhava em um banco. Quando chegava o seu dia de
pagamento, nós estávamos na porta do banco e gastávamos todo o salário
dele comprando livros: Steinbeck, Faulkner, Hemingway, London, Stevenson,
Balzac, Stendhal, Sartre, Conrad, Gogol etc. Nós sabíamos que, a fim de
fazer quadrinhos, nós tínhamos que ler porque nós estávamos trabalhando
com a escrita. E nós íamos ao cinema para assistir filmes com legenda [...].
Nós íamos à Cinemateca para ver os clássicos. Nós entramos em contato
com os críticos de cinema dos jornais. Nós sabíamos que os quadrinhos eram
literatura e que eles tinham as mesmas tomadas como o cinema. Mas os
quadrinhos tinham alguma coisa especial, intermediária. Naqueles dias, não
havia qualquer teoria de comunicação de massa, assim nós chamávamos
aquilo de "expressão", um conceito retirado dos filmes expressionistas
alemães, especialmente porque nós víamos alguma semelhança entre os
filmes de Fritz Lang e o "Spirtit" de Will Eisner. (MOYA, 2013)

Essa "expressão", essa "alguma coisa especial", para o professor Antonio Luiz Cagnin, é o "código imagético e narrativo" ou, dentro de uma visão semiológica, o "sistema narrativo iconográfico dos quadrinhos" (CAGNIN, 2014, p. 28-29).

Já em uma vertente de pesquisa das relações dos quadrinhos com 0 mundo está José Marques de Melo, professor emérito da USP, fundador dos cursos de Jornalismo e de Editoração, diretor da Cátedra UNESCO de Comunicação da Universidade Metodista de São Paulo, autor dos livros: Vestígios da Travessia - da impressa à internet (2009), Os caminhos cruzados da Comunicação: economia, política e cultura (2010), História do Jornalismo (2012) pela editora Paulus, O campo da comunicação no Brasil (2008) editora Vozes e História política das ciências da 
comunicação (2008) editora Mauad (VERGUEIRO, RAMOS e CHINEN, 2013, p. 11), que em seu foco de pesquisa vai priorizar a relação dos quadrinhos e a sociedade, no âmbito da comunicação.

Entre o usuário do produto e o observador do fenômeno existe uma sintonia inequívoca, que vale a pena explícitar, porque tal conjunto enfrenta o contingente dos que nutrem atitudes de recusa ao gênero e seus formatos, bem como aos tipos. (MELO, 2013).

José Marques de Melo viveu um período que ele define como "Quadrinhofobia”, com a perseguição e preconceito aos quadrinhos, com campanhas de difamação em artigos de jornais e revistas, sermões nas igrejas, discursos políticos e conselhos educacionais, que ele acredita que tenha causado mais o efeito oposto, pois afirma que os leitores mirins se sentiam muito mais atraídos pelos personagens e aventuras que os adultos detratavam (MELO, 2013, p. 14).

Como ressalta a epígrafe de Paul Dawson no livro de James Chapman:

Comics have not yet arrived in the way that films and television have, accepted as a rational amusement for adults and a proper subect for academic study. Comics are still liable to be dismissed wholesale as trash, appropriate for weak or underveloped minds, and probably detrimental. Criously enough much the same was said of the drama in Shakespeare's day and of the novel in Jane Austen's time. ${ }^{16}$ Paul Dawson (DAWSON apud CHAPMAN, 2011, p. Introdução)

Há inúmeros outros pesquisadores de várias partes do mundo não citados, ou que serão citados posteriormente ao longo desse trabalho, com visões corroborantes ou contrárias sobre o que é História em Quadrinhos. Pesquisadores que seguem uma linha estrutural, seja ela semiótica ou estética, e outros que procuram uma abordagem histórica. Há aqueles que pensam a HQ como uma arte independente que abrangem vários gêneros (por exemplo revistas, livros ilustrados e fotonovelas) e aqueles que consideram haver uma literatura em imagens que possui os gêneros: $\mathrm{HQ}$, fotonovela, livro ilustrado, poema concreto entre outros. Este estudo não tem a pretensão de determinar uma categoria definitiva, pois a cada categorização surgem imediatamente obras que a contradizem, mas ainda assim, segue certas premissas determinadas pela leitura dos vários estudos diferentes.

Foram consideradas pertinentes, as perpectivas dos estudiosos que traçam

${ }^{16}$ Os quadrinhos não chegaram ainda, do modo como filmes e televisão chegaram, a aceitação como um divertimento racional para adultos e um objeto válido para estudos acadêmicos. Quadrinhos ainda são passíveis de serem descartados como lixo, próprios para mentes fracas ou subdesenvolvidas, e, provavelmente, prejudiciais. Curiosamente, muito do mesmo foi dito sobre o teatro nos dias de Shakespeare e sobre os romances na época de Jane Austen (CHAPMAN, 2011, p. Introdução) [tradução da autora]. 
a origem dos quadrinhos com a origem da própria imagem, entendendo a $\mathrm{HQ}$ como uma forma de se comunicar por imagens, um fenômeno mundial, com imensas possibilidades de manifestação, cuja forma atual foi moldada por fatores culturais, políticos, econômicos e, finalmente, estéticos.

Contudo, para uma posição melhor fundamentada, se faz necessário uma ampliação desse estudo a respeito das manifestações de quadrinhos do mundo árabe e indiano, africano, latino, da Oceania e ilhas havaianas, tanto de suas obras quanto de seus estudiosos, pois em todos esses locais também existem HQs.

\subsection{Le Charivari e Punch - o humor gráfico político}

"Where will you stop?... If you will condemn a man for two years for drawing a pear, then you must condemn all caricatures in which a head is narrow at the top and large at the bottom..."

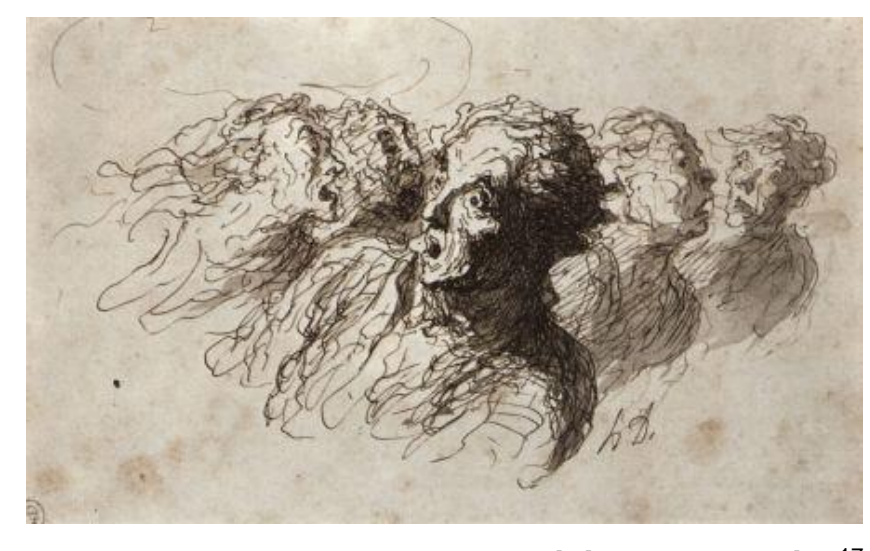

Phillipon e Daumier ${ }^{17}$

Há, sem dúvida, momentos marcantes para o desenvolvimento da História em Quadrinhos. Acontecimentos que estimularam uma ruptura com o paradigma anterior de comunicação por imagens e proporcionaram o desenvolvimento dos

\footnotetext{
${ }^{17}$ Epígrafe - tradução e fonte: "Onde você vai parar? Se você condena um homem a dois anos por desenhar uma pera, então você tem que condenar todas as caricaturas em que a cabeça é estreita em cima e larga na base...", frase de Charles Philipon argumentando em seu processo que não havia confirmação de que a caricatura que ele havia feito era realmente do rei ou de qualquer outra pessoa cujo formato da cabeça lembrasse uma pera. [tradução da autora] fonte: Charles Phillipon em: ROSE, C. The Power of the Pear: When Caricature Met Poster Art. The Comics journal, 2016. Disponivel em: $<$ http://www.tcj.com/the-power-of-the-pear-when-caricature-met-poster-art/>. Acesso em: 17 Maio 2018. Honoré Daumier disponível em: https://frankzumbach.files.wordpress.com/2015/03/honorc3a9daumier-tek-1.jpg?w=450\&h=272.
} 
quadrinhos da forma como são conhecidos hoje, como, por exemplo, a publicação em 1832 da revista francesa Le Charivarie, por sua inspiração, a inglesa Punch em 1841.

Contrariando a ressalva de Gabilliet sobre a formação plástica clássica dos xilogravuristas os afastarem dos quadrinhos é importante ressaltar que, assim como muitos dos quadrinistas modernos, os mais renomados caricaturistas e cartunistas do século XIX possuíam esse tipo de formação, como Charles Philipon (1800 - 1861), litógrafo, caricaturista e jornalista francês, que estudou na École Impériale des Beauxarts de Lyon (Escola Imperial de Belas Artes de Lyon) e foi o fundador das revistas La caricature (1830) e Le Charivari (1832) (GABILLIET, 2010).

Foi em uma França pós derrota napoleônica com o restauro de uma monarquia absolutista, a de Carlos $\mathrm{X}$, com consequente acirramento da censura da imprensa, crise econômica para a burguesia e desemprego ao proletariado que, segundo David Kunzle, a revolução de 1830: Les Trois Glorieuses (três gloriosas), foi responsável pelo nascimento de La caricature e Le Charivari,

Every true democratic revolution promises a rebirth, a renaissance, and new cultural and political freedoms. The Revolution of July 1830 gave birth to La Caricature and then the daily Charivari magazine, the virulent political caricature of Daumier and his many graphic allies, as well as the "bourgeois monarchy" of Louis Philippe, with its own distinctive culture of corruption, encapsulated in the writings of Balzac. ${ }^{18}$ (KUNZLE, 2015, p. 10)

Sobre a origem do nome da Le Charivari, de acordo com Lilian e Dieter Noack, curadores da Galeria Noak, especializada na obra de Honoré Daumier (1808 - 1879), renomado caricaturista, chargista, pintor e ilustrador francês, e responsáveis pelos sites: "THE DAUMIER REGISTER", contendo um catálogo completo das obras de Daumier com 4.000 litografias, 1.000 xilogravuras em madeira, 550 pinturas à óleo, 100 esculturas e 1.900 desenhos; e "DAUMIER'S LIFE AND WORK" , contendo biografia, exibições, ilustrações, cartas e guia de colecionadores,

\footnotetext{
18 Toda verdadeira revolução democrática promete um reinicio, um renascimento, e novas liberdades culturais e políticas. A revolução de julho de 1830 deu origem à La Caricature e posteriormente a revista diária Charivari, à virulenta caricatura política de Daumier e seus muitos aliados gráficos, bem como a "monarquia burguesa" de Luís Felipe, com sua própria distinta cultura de corrupção, encapsulado na escrita de Balzac (KUNZLE, 2015, p. 10) [tradução da autora].
} 
The word CHARIVARI can be traced back to the 17th century, when Italian artist A. CARACCI drew so-called "ritratti caricati", absurd portraits and figures, literally translated: overloaded portraits. The Italian word "caricare" has its counterpart in the French word "charger" (engl. "load"). We can assume that the name CHARIVARI is based on these roots. Later, the word became part of the French language and had the meaning of loud and unmelodious cacophony. ${ }^{19}$ (NOAK e NOAK, 2017)

Le Charivari foi uma ampliação da revista La Caricature, visando a uma tiragem maior que cobrisse os riscos de La Caricature (NOAK e NOAK, 2017). Sobre o grande mote de ambas, a caricatura, A. Hyatt Mayor (1901-1980), historiador de arte e curador emérito do Metropolitan Museum of Art de Nova York, em seu estudo acerca da história da impressão de imagens cita a fala de Sir Thomas Browne, filósofo e escritor do século XVII: "When men's faces are drawn with resemblance to some other animals, the Italians call it, to be drawn in caricature"20 (BROWNE apud MAYOR, 1972, p. 137).

Segundo Mayor, de acordo com os seguidores de Aristóteles, caricare significa carregar algumas características visando trazer à tona o animal latente cuja natureza forma a personalidade de determinada pessoa. Ainda segundo esse autor, era prática comum grega, ridicularizar escravos e estrangeiros com caricaturas, sendo o italiano Bernini (Gian Lorenzo Bernini 1598 - 1680), artista barroco, pintor, escultor e arquiteto, o primeiro a criar caricaturas de nobres, que por sua influência, passaram a achar graça na piada (MAYOR, 1972, p. 137). De acordo com Mayor, foi após 1820 com o triunfo burguês que a França dominou a caricatura até se tornar praticamente uma arte francesa,

Daumier and his editor Philipon followed English precedent by using caricature as the most dreaded political attack. The supreme caricaturists have been masters of the grand manner, like some of the late Greek sculptors and moderns such as Leonardo, Michelangelo, Bernini, and Daumier - all artists who explored the pitfalls that they must avoid if they were to make men look noble ${ }^{21}$ (MAYOR, 1972, p. 137).

\footnotetext{
${ }^{19}$ A palavra Charivari pode ser rastreada de volta ao século 17 , quando o artista italiano A. Caracci desenhou o assim chamado "ritratti caricati", figuras e retratos absurdos, traduzidos literalmente: retratos sobrecarregados. A palavra italiana "caricare" tinha sua contraparte na palavra francesa "charger" (inglês "load" - português "carga"). Podemos assumir que o nome CHARIVARI é baseado nessas raízes. Mais tarde, a palavra se tornou parte da língua francesa e adquiriu o sentido de uma cacofonia alta e sem melodia. (NOAK e NOAK, 2017) [tradução da autora]

${ }^{20}$ Quando as faces humanas são desenhadas relembrando algum outro animal, os italianos chamam isso de ser desenhado em caricatura. (BROWNE apud MAYOR, 1972, p. 137) [tradução da autora]

${ }^{21}$ Daumier e seu editor Philipon seguiram o precedente inglês usando a caricatura como a maior forma de ataque político. Os supremos caricaturistas têm sido mestres de um modo grandioso, como os antigos escultores gregos e modernos como Leonardo, Michelangelo, Bernini e Daumier - todos artistas que exploraram as armadilhas que eles deveriam evitar se fosse para o homem parecer nobre. (MAYOR, 1972, p. 137) [tradução da autora]
} 


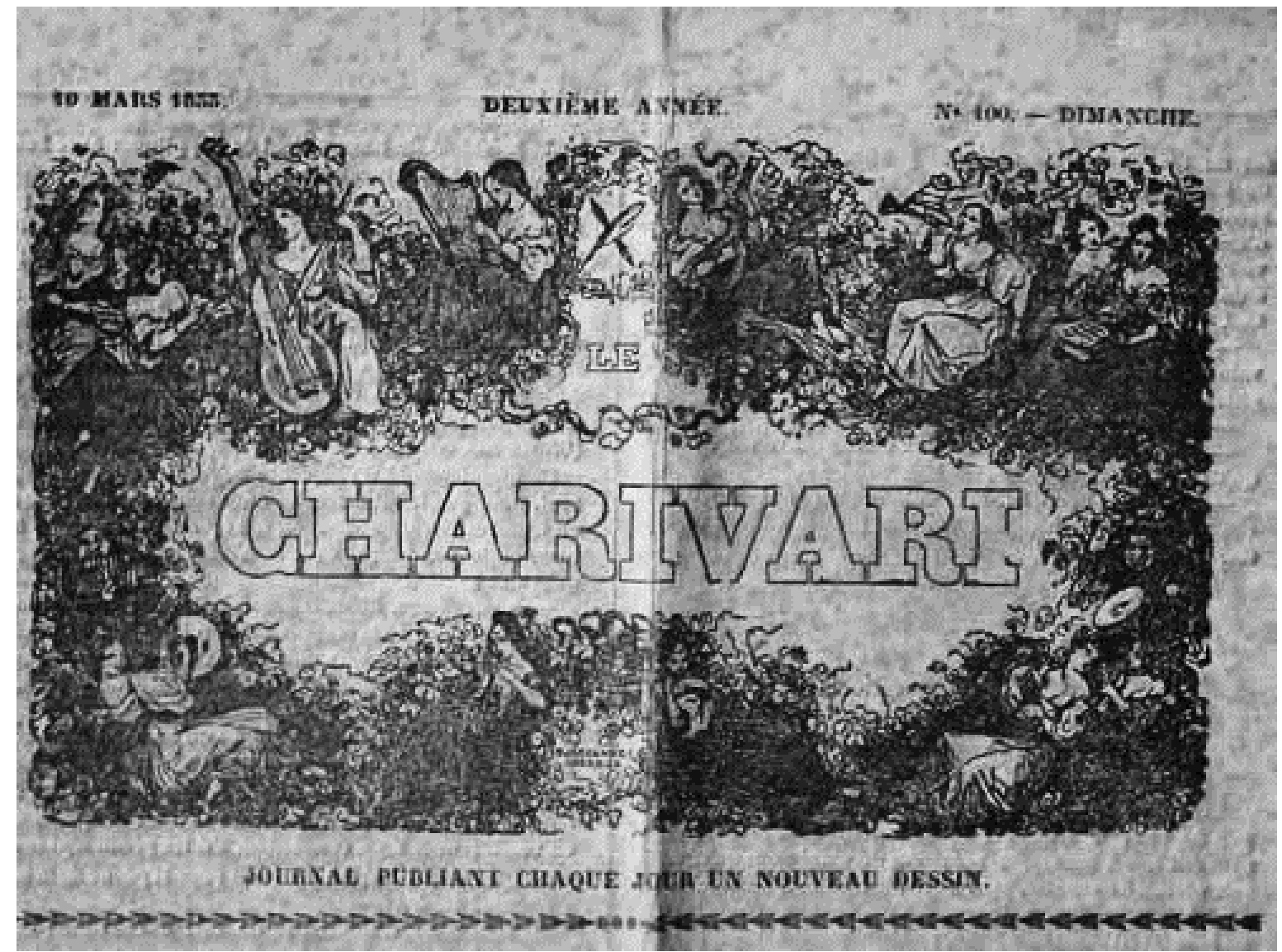

Figura 22 - Le Cahrivari - 1832

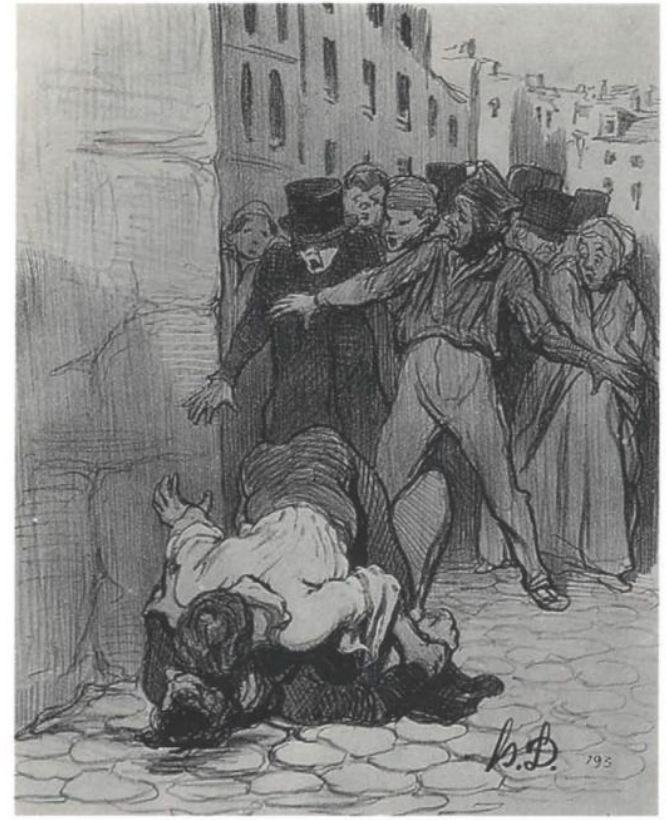

Figura 23 - Daumier - Mais pis que j'vous dis qu'c'est des amis....(Mas deixe-me dizer-lhe que são amigos...) litografia - publicada em $L e$ Charivari em 08, 18, e 23 de agosto de $1845^{\text {xiv }}$

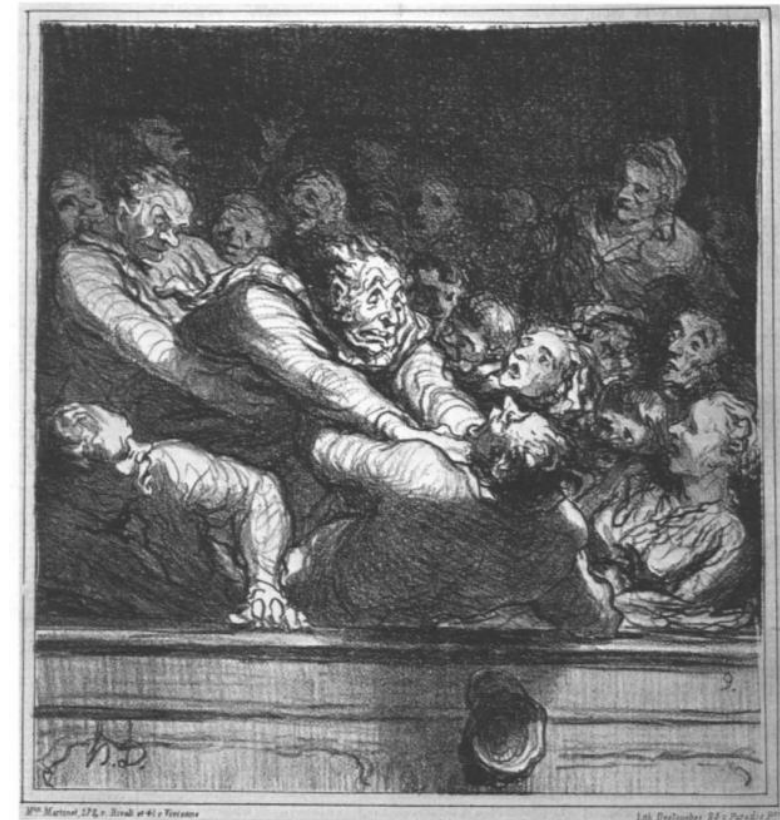

Figura 24 - Daumier - Une discussion littéraire dans le deuxième balcon (uma discussão literária no Segundo balcão). Litografia - publicada em Le Charivari, Paris, $1864^{\mathrm{xv}}$ 


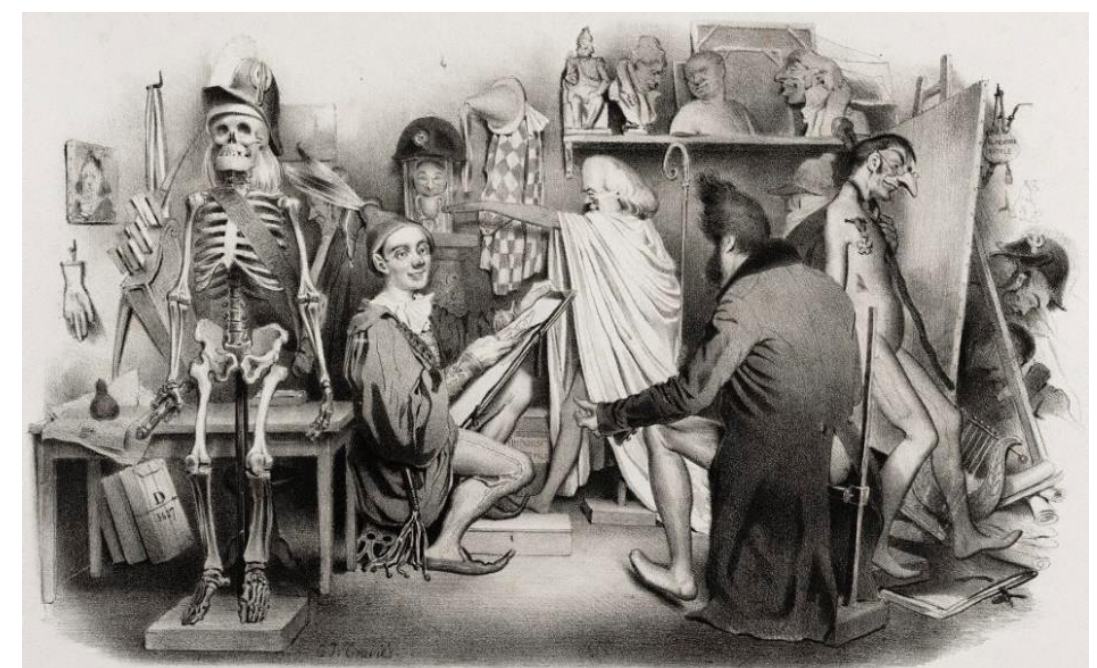

Figura 25 - Charles-Joseph Traviès de Villers - Studio of La Caricture and Le Charivari 1834xvi

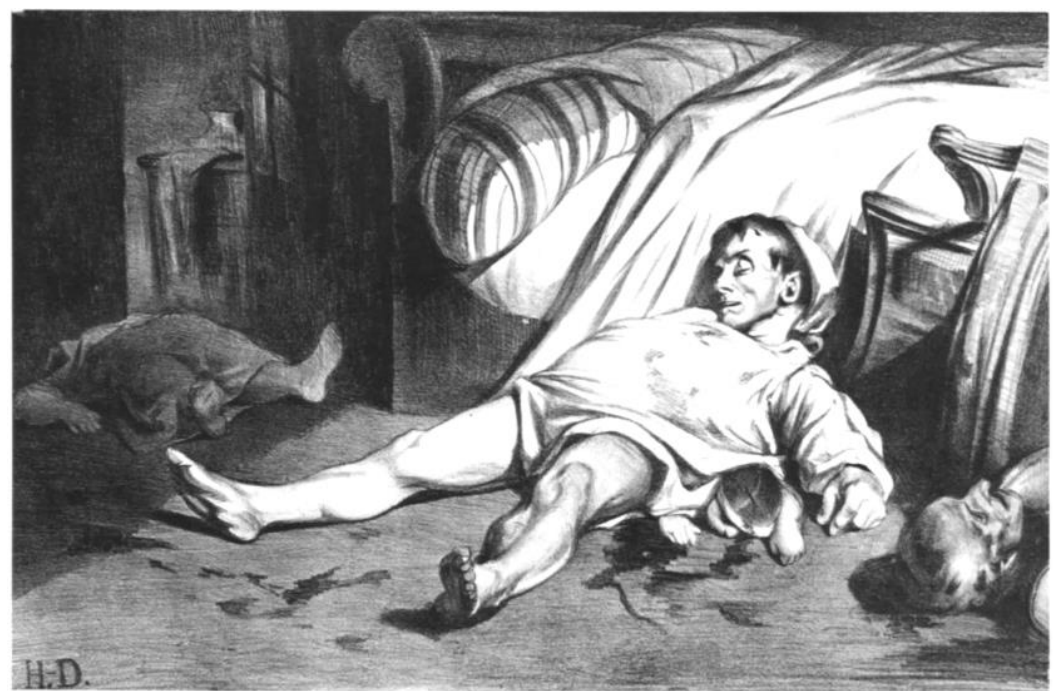

Figura 26 - Daumier - Rue Transnonain - litografia - publicada em La Caricature - 1834 - L'Association Mensuelle, Paris

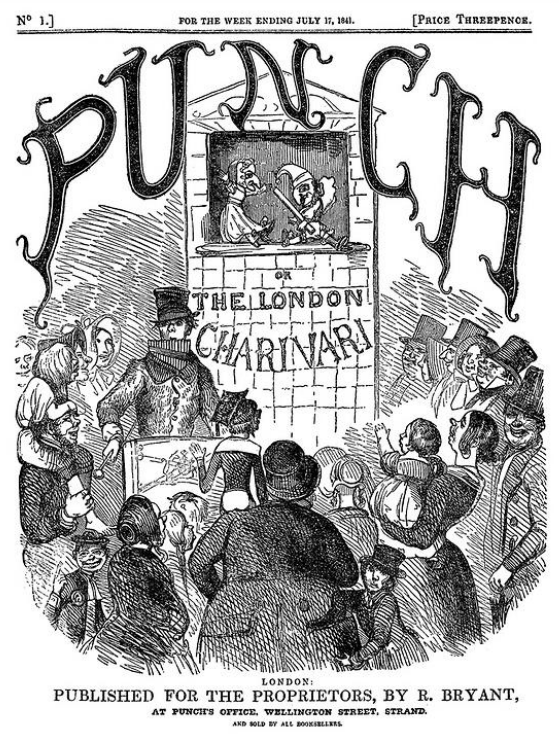

Figura 27 - Punch - The London Charivari - número $1-1841 \times v i i i$

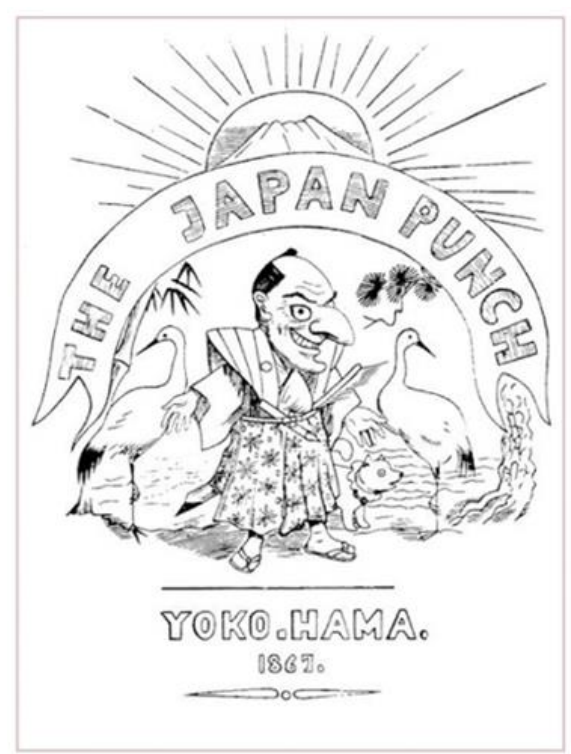

Figura 28 - Japan Punch - 1867xix 
Os artistas contribuindo com litografias, xilogravuras e, depois de 1870, com zincografias foram Honoré Daumier (1808 - 1879), Paul Gavarni, pseudônimo de Guillaume Chevalier (1804 - 1866), Henry-Bonaventure Monnier (1799 - 1877), Jean Ignace Isidore Gérard Grandville (1803 - 1847), Charles-Joseph Traviès de Villers (1804 - 1859), Alexandre-Gabriel Decamps (1803 - 1860), Cham, pseudônimo de Charles Amédée de Noé (1818 -1879), Gustave Doré (1832 - 1883) entre outros (NOAK e NOAK, 2017).

Mayor aponta que Charles Philipon, travou o que ele chamava de "A guerra de Philipon contra o Rei Luís Felipe" organizando a primeira ofensiva sistemática de sátira verbal e imagética (as imagens eram ainda mais mordazes), dirigida à França, (MAYOR, 1972, p. 423). Philipon incumbiu seu artista de maior expoente Honoré Daumier, a fazer as caricaturas de todos os deputados reacionários, e, sendo Daumier já um cartunista conhecido não lhe era permitido entrar na assembleia com seu bloco de esboços, então ele memorizava seus rostos e os esculpia em casa, depois disso usava o busto esculpido como base das caricaturas (MAYOR, 1972, p. 423). Por causa de suas litografias na La Caricature e Le Charivari, Daumier ficou seis meses preso, enquanto seu empregador enfrentava o risco de censura e falência.

Com a publicação da litografia “Rue Transnonain” (1834) (Figura 26, pág. 48) uma cena com o massacre sem sentido de uma família por um esquadrão antitumulto, que foi considerada por Baudelaire como uma obra prima "trivial e terrivel", as forças censoras do governo se acirraram e finalmente La Caricarute foi fechada em 1835, assim como outras 30 revistas ilustradas (MAYOR, 1972, p. 425).

De acordo com o professor e historiador John Simkin, os liberais reformistas Mark Lemon e Henry Mayhew tiveram a ideia de lançar na Inglaterra uma revista que combinasse humor e comentários políticos. Junto com Douglas Jerrold, jornalista, John Leech, um estudante de medicina cujos desenhos impressionaram Lemon, Joseph Last, impressor, Ebenezer Landells, gravador e o empresário gráfico Stirling Coyne eles a lançaram no dia 17 de julho de 1841, com o artigo entitulado "The Moral of Punch", Mark Lemon escreveu que o jornal ajudaria a "destruir o principio do mal aumentando os meios de cultivar o bem" e em seus primeiros anos adquiriu a reputação de "defensor dos oprimidos e um chicote radical em toda autoridade". Seus alvos eram a monarquia e os líderes políticos, principalmente o príncipe Albert (SIMKIN, 2014).

Segundo o site oficial da revista, Punch, que em sua primeira edição tinha 
o subtítulo "The London Charivari" (a Charivari londrina), circulou entre 1841 a 2002, sendo uma instituição internacionalmente renomada por sua inteligência e irreverência. A revista introduziu o termo "cartoon" como conhecido hoje e publicou as obras de grandes quadrinistas, poetas, jornalistas e cartunistas (PUNCH EDITORIAL, 2018).

Mesmo após a censura francesa à caricatura e humor gráfico, que levou a Le Charivari à falência, a revista Punch continuou suas atividades não só na Inglaterra, mas inspirando outras publicações no gênero em todo mundo. De acordo com a pesquisadora britânica Helen McCarthy, especialista em cultura popular japonesa, seis anos após os Estados Unidos forçarem a abertura das fronteiras japonesas para vistantes e comerciantes após 250 anos de isolação, o cartunista e correspondente do jornal Illustrated London News, Charles Wirgman se mudou para Yokohama. Além de montar um estudio fotográfico, dar aulas de inglês e artes, ele fundou a primeira revista satirica japonesa, batizada de Japan Punch (MCCARTHY, 2014, p. 9).

Modeled on the London magazine Punch, it was a gossipy account of current events, with cartoons. Although aimed at Japan's growing foreign community, it soon acquired Japanese readers, and was sold across Asia for 25 years $^{22}$ (MCCARTHY, 2014, p. 9).

Mesmo que o humor gráfico tenha prosperado na Inglaterra, os outros paises europeus não viam com bons olhos a liberdade da imprensa britânica. David Kunzle comenta que Goethe acreditava que essa liberdade tinha o propósito de servir à malícia (KUNZLE, 1985),

What have the Germans had with their charming freedom of the press, except to allow everyone to say as many bad and sordid things as they wanted? Freedom of the press is demanded only by those who want to abuse $\mathrm{it}^{23}$ (GOETHE apud KUNZLE, 1985).

Com o aval da elite intelectual para desmerecer a forma e a mídia, muitos regimes autoritários temendo a força de mobilização por reformas da carticatura e midia satírica, censuraram, coibiram ou simplesmente proibiram a circulação desse tipo de manifestação. Isso explica grosso modo porque alguns paises desenvolveram outras formas de quadrinhos ampliando a linguagem e outros não.

\footnotetext{
${ }^{22}$ Seguindo o modelo da revista londrina Punch, ela era uma narrativa de fofocas de eventos atuais, com cartuns. Embora direcionada à crescente comunidade estrangeira, logo ganhou o interesse dos leitores japoneses, e foi vendida pela Asia durante 25 anos (MCCARTHY, 2014, p. 9). [tradução da autora]

${ }^{23} \mathrm{O}$ que os alemães tiveram com a encantadora liberdade de imprensa, exceto permitir que todos dissessem quantas coisas horriveis e sórdidas quizessem? Liberdade de imprensa é exigida apenas por aqueles que desejam abusar dela (GOETHE apud KUNZLE, 1985).
} 


\title{
1.3 Töpffer e o início dos quadrinhos na cultura de massa
}

\begin{abstract}
Devolvo os curiosos livrinhos com meus agradecimentos. A pequena perenigração com rapazes é prova de que o artista sabe captar com graça seu tempo presente. Nos romances caricaturados são de admirar os variados motivos que ele consegue extrair de poucas figuras; ele faz empalidecer o mais prolífico inventor de combinações, e cabe desejar sorte ao seu talento inato, jovial e sempre de prontidão.
\end{abstract}

Goethe $^{24}$

Outro grande momento é Rodolphe Töpffer (1799 a 1846) que, conforme aponta Gabilliet, é considerado o primeiro autor de quadrinhos: "A transatlantic consensus nowadays acknowledges Töpffer as the first author of comics" 25 (GABILLIET, 2010, p. 14).

Töpffer foi um artista gráfico, cartunista, escritor e professor suíço muito conhecido pelas suas narrativas ilustradas (littérature en estampes). Seu primeiro livro “Histoire de M. Jabot”, 1833 (Figura 29, pág. 54) publicado em capa dura com 24,5 cm de largura por $15,5 \mathrm{~cm}$ de altura e 52 páginas, é considerado por muitos como a primeira história em quadrinhos moderna. O livro, recentemente lançado no Brasil (2017) pela Editora Sesi-SP por André Caramuru Aubert, conta as aventuras de um dândi de classe média tentando ascender sua posição social.

O trabalho de Töpffer é consagrado hoje como marco dos quadrinhos modernos por possuir texto integrado com a imagem, separação e variação de ângulos e enquadramento, características consideradas por muitos como singulares da HQ (LACASSIN, 2014, p. 41) e também o grande reconhecimento obtido pelos elogios de Goethe a seu trabalho por, como na literatura da época, exprimir um questionamento sobre o indivíduo e a sociedade,

\footnotetext{
${ }^{24}$ Epígrafe: Goethe a respeito de Töpffer, fonte: TÖPFFER, R. Mousieur Jabot. Tradução de Flavia Lago. São Paulo: SESI-SP, 2017. Pg. 9 Introdução, por André Caramuru Aubert.

${ }^{25} \mathrm{Um}$ consenso transatlântico hoje em dia reconhece Töpffer como o primeiro autor de quadrinhos (ainda mais com o prestígio que já lhe conferiam os elogios de Goethe aos seus trabalhos) (GABILLIET, 2010, p. 14) [tradução da autora]
} 
Deve-se admirar no mais alto grau como a força de imaginação do desenhista recria continuamente um espectro como esse, denominado $M$. Jabot, no ambiente apropriado, sob as mais variadas formas, e como sua pena espirituosa fixa do modo mais singular esse indivíduo impossível, como se fosse verdadeiro. (GOETHE apud TÖPFFER, 2017)

Gabilliet ressalta que as histórias em imagens já tinham existido por séculos, mas foi Töpffer que as adaptou para a era da produção em massa, ou como ele ressalta, a era do romance, sendo o romance a forma literária que se tornou não só a única mídia tanto da elite quanto da cultura de massa (o romance canônico e o best seller), mas também a forma de atividade literária que suplantou o teatro e a poesia (GABILLIET, 2010, p. 18). O próprio Töpffer tinha conhecimento de que estava criando algo novo, com as ferramentas de seu tempo, pois na publicação da edição de 1937 de "Histoire de M. Jabot" ele escreve:

The drawings, without this text, would have only an obscure meaning; the text, without the drawings, would mean nothing. The whole forms a kind of novel, all the more peculiar in that it no more resembles a novel than anything else. ${ }^{26}$ (TÖPFFER apud GABILLIET, 2010, p. 18)

Gustave Doré, que seria posteriormente mundialmente conhecido pela ilustração de livros clássicos infantis (Figura 30, pág. 54), começou sua carreira na revista Le Charivari onde produziu caricaturas, cartuns e, sob influência do trabalho de Töpffer, narrativas gráficas (Figura 31, pág. 54) publicadas no Journal pour Rire (jornal para rir) também criado por Charles Philipon que durou de 1848 a 1855 (KUNZLE, 2015, p. 8).

Doré viveu uma época em que as novelas seriadas e suas ilustrações eram formas de publicação revolucionárias e lucrativas amadurecendo durante 1830-1840. A llustração, ao que Baudelaire chamou de "culto das imagens", reinava absoluta em qualquer lugar. A conjunção de novela e caricatura como um todo estava bem estabelecida; os caricaturistas e novelistas sabiam, valorizavam e davam suporte um ao outro. Literatura elevou a caricatura, a caricatura popularizou (a elite dizia depreciou) a ficção. Baudelaire já havia associado a Comédia Humana de Balzac com a produção de Daumier (KUNZLE, 2015, p. 15). Kunzle nota que tanto Doré como vários outros artistas da época se aventuraram em outras mídias, como teatro e principalmente escrita, "Writers of comic strips usually tried their hand at other literary

${ }^{26}$ Os desenhos, sem o texto, teriam apenas um sentido obscuro; o texto, sem os desenhos, não significaria nada. A forma toda é um tipo de romance, e o mais peculiar é que isso parece mais um romance do que qualquer outra coisa. (TÖPFFER apud GABILLIET, 2010, p. 18) [tradução da autora] 
and visual genres."27 (KUNZLE, 2015, p. 13).

Contudo, a segunda república (1848-1851) já era opressora e, com a censura ainda mais acirrada do segundo império (1852-1870) suprimindo a liberdade jornalística, as revistas e jornais satíricos franceses foram extintos e a história em quadrinhos francesa entrou em hiato (KUNZLE, 2015, p. 11) tornando a profissão de cartunista perigosa, o que fez com que Doré, entre outros, se afastasse - até mesmo rejeitasse seu envolvimento prévio, e com qualquer questão política - das caricaturas, cartuns e quadrinhos.

Thierry Smolderen (1954), ensaísta e professor da École des Beaux-Arts de Angoulême na França, aponta que desde suas origens, as novelas gráficas de Töpffer, Cham, pseudônimo de Charles Amédée de Noé (1818-1879) e Doré demostravam a presença irônica do autor na representação realista (metalinguagem), as imagens deveriam ser lidas e não apenas vistas. Smolderen nota que Winsor McCay (1869-1934), e muitos outros cartunistas depois dele continuaram a recordar este princípio para o leitor do século XX (SMOLDEREN, 2014, p. 55).

Smolderen exemplifica com uma passagem da obra Les Dés-Agréments d'un Voyage d'Agrément (1851) de Doré,

The footprint of a Savoyard (Figura 31, pág. 54) is inadvertently imprinted on the album of Doré's Parisian traveler. This is one of the most spectacular excesses in a novel in prints that is crammed with them. By multiplying such obviously fake "effects of the real," the author underlines the artificiality of the editorial enterprise. This typically Sternian strategy, which encompasses everything right up to the paratextual system of the book - including the editor's note - is found again in his Histoire de la sainte Russie ${ }^{28}$ (SMOLDEREN, 2014, p. 58)

Artistas de vários países foram influenciados pelo trabalho de Töpffer, em 1842 a versão em inglês de sua obra de 1837, "Histoire de M. Vieux Bois" foi publicada nos Estados Unidos sob o título de The Adventures of Obadiah Oldbuck, dando origem a uma série de imitações, como The Strange Adventures of Bachelor Butterfly publicado por Wilson \& Co. em New York em 1846, um plágio de Monsieur Cryptogame de Töpffer (GABILLIET, 2010, p. 24).

\footnotetext{
${ }^{27}$ Escritores de tiras em quadrinhos geralmente tentavam suas mãos em outros gêneros literários e visuais. (KUNZLE, 2015, p. 13) [tradução da autora]

${ }^{28}$ A pegada de um savoiano é impressa inadvertidamente no álbum do viajante parisiense de Doré. Este é um dos mais espetaculares excessos em uma novela gráfica que está repleta deles. Ao multiplicar esses "efeitos do real" obviamente falsos, o autor sublinha a artificialidade da empresa editorial. Esta estratégia tipicamente Sterniana [referência ao estilo de Laurence Sterne como em "A Vida e Opiniões de Tristram Shandy" de 1759] , que abrange tudo até o sistema paratextual do livro incluindo a nota do editor - é encontrada novamente em sua Histoire de la sainte Russie (SMOLDEREN, 2014, p. 58) [tradução da autora].
} 

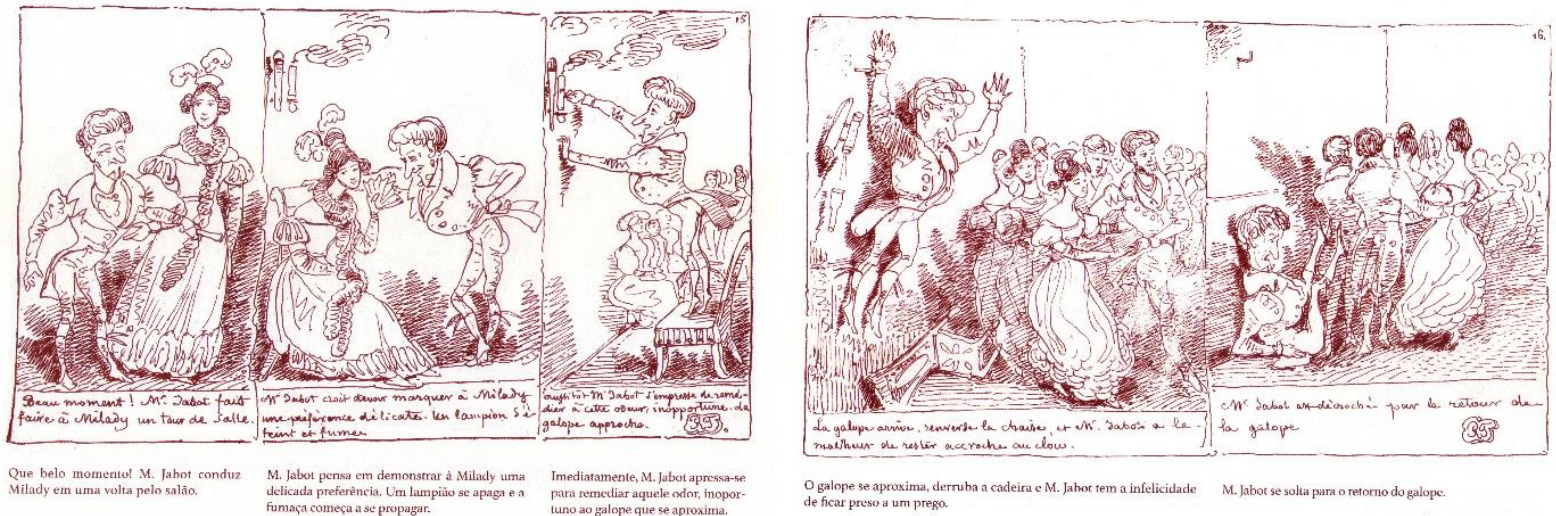

Figura 29 - Monsieur Jabot - Rodolphe Töpffer - 1933

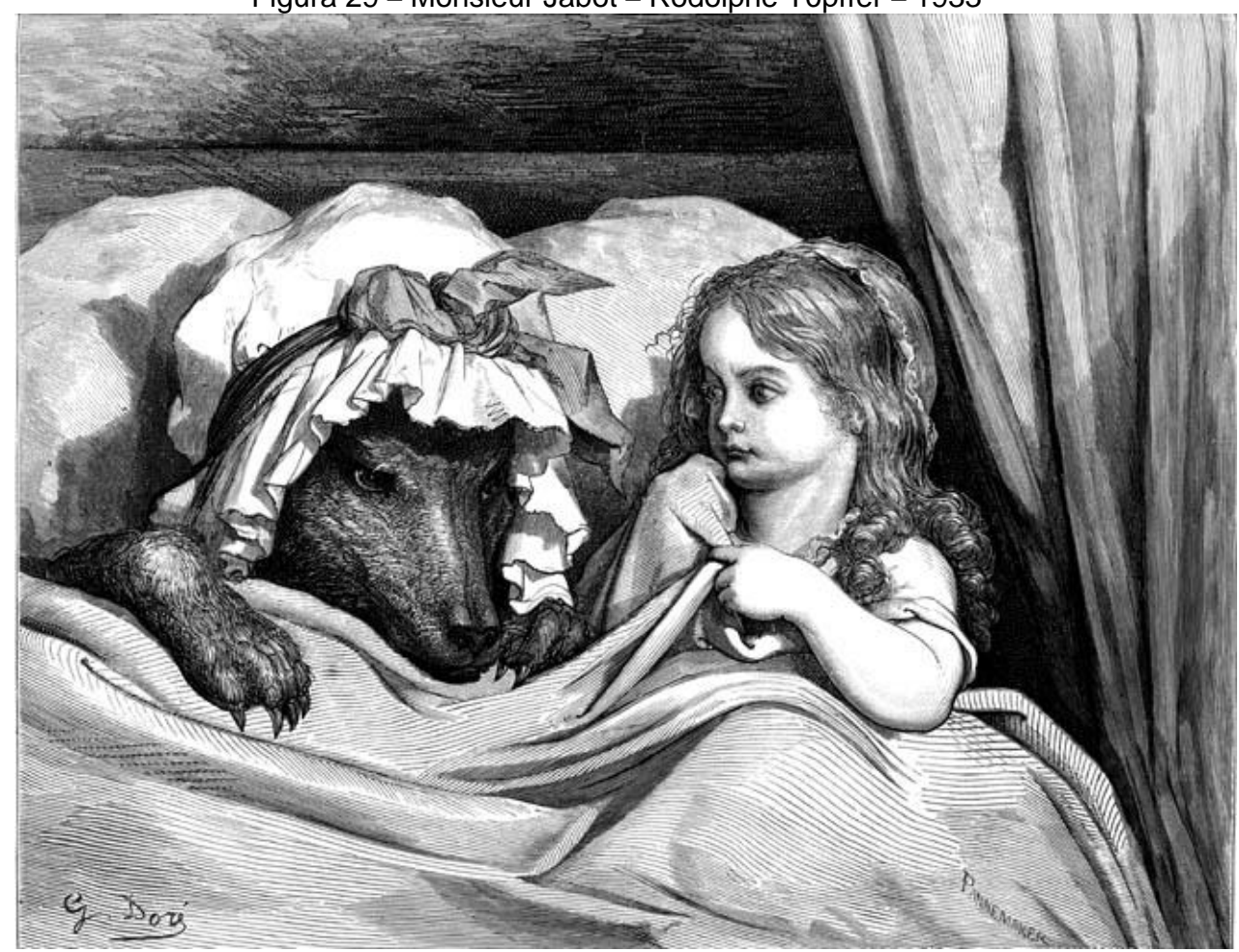

Figura 30 - Gustave Doré - Chapeuzinho vermelho - 1861 ${ }^{\text {xi }}$

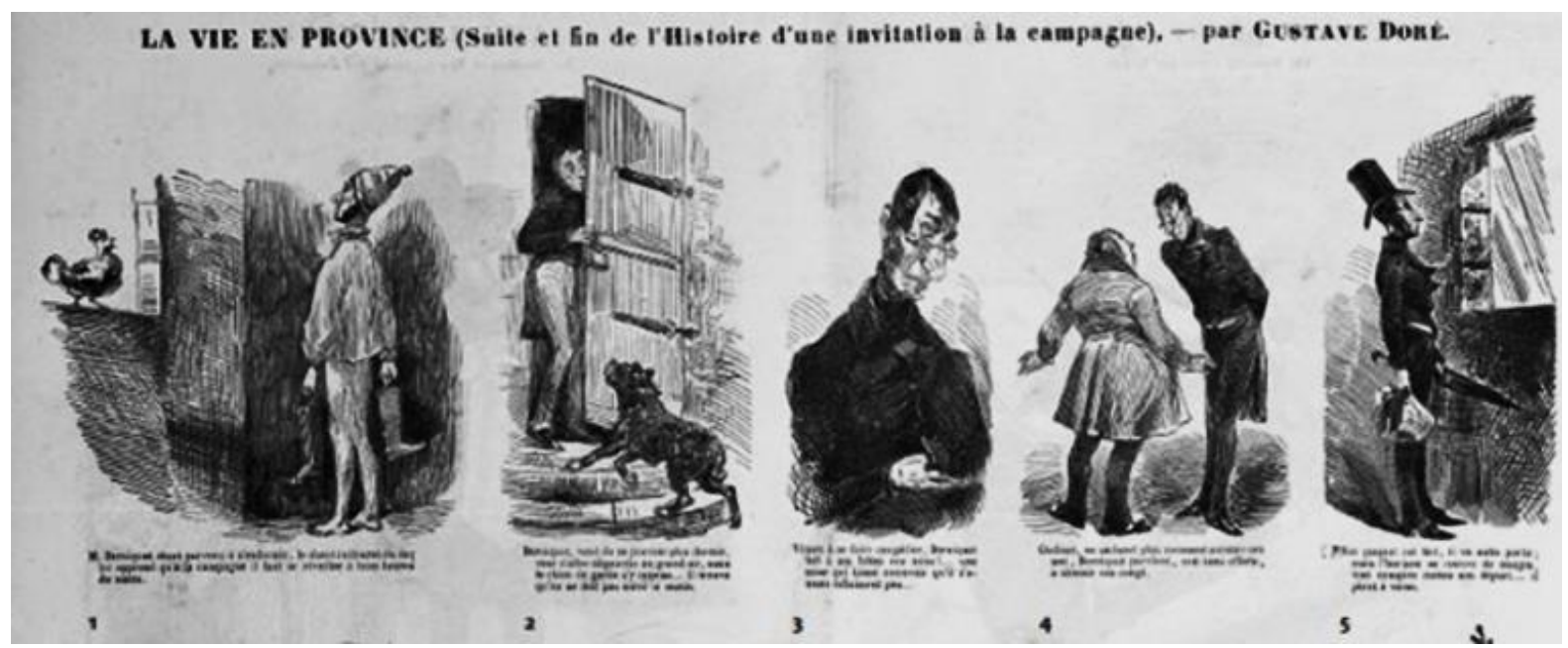

Figura 31 - Gustave Doré - La Vie en Province, Histoire d'une invitation à la campagne (Vida na província, história de um convite ao interior) - Journal pour Rire - 1849xxii 


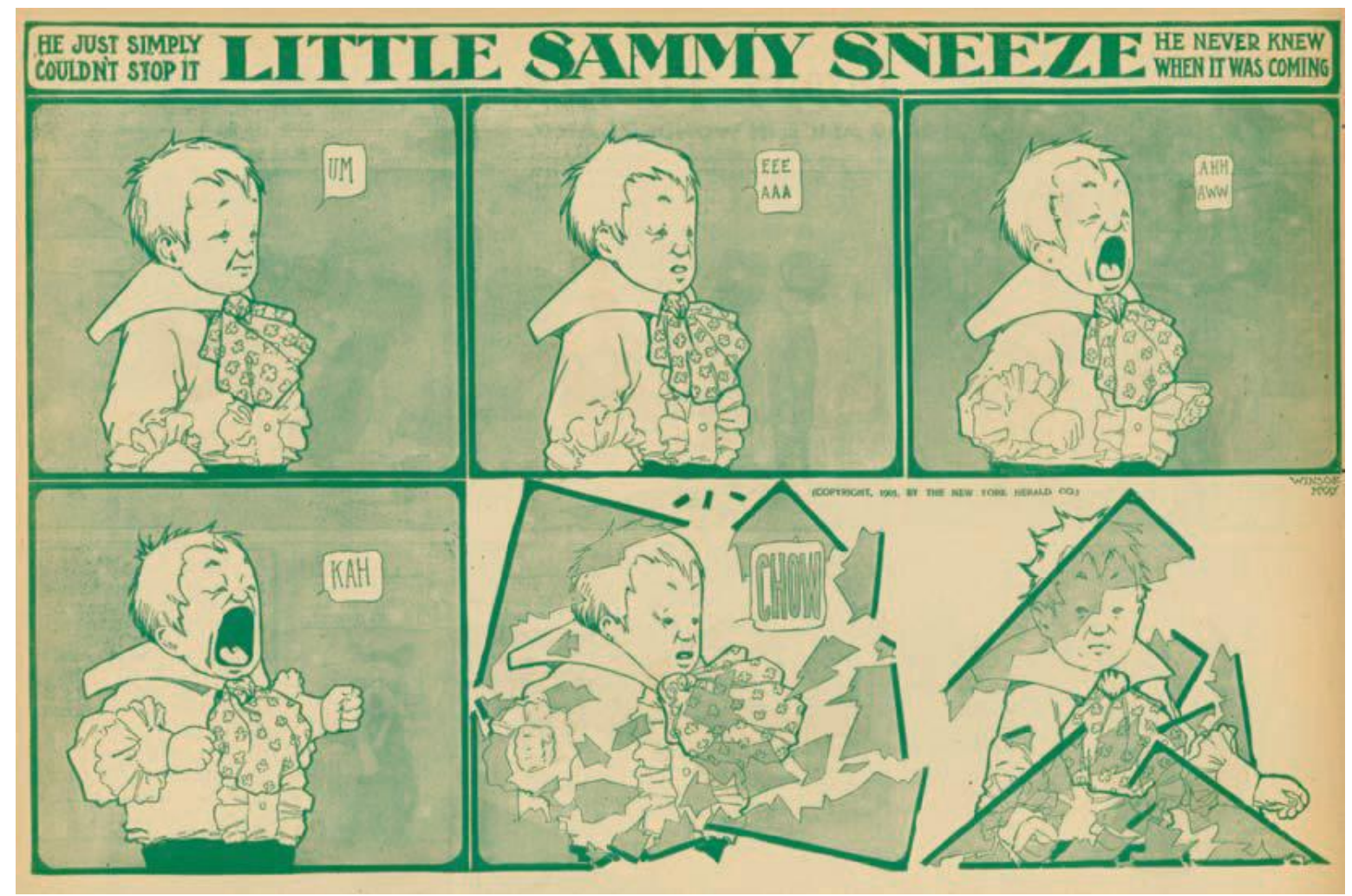

Figura 32 - Winsor McCay - Little Sammy Sneeze - 1905xxiii
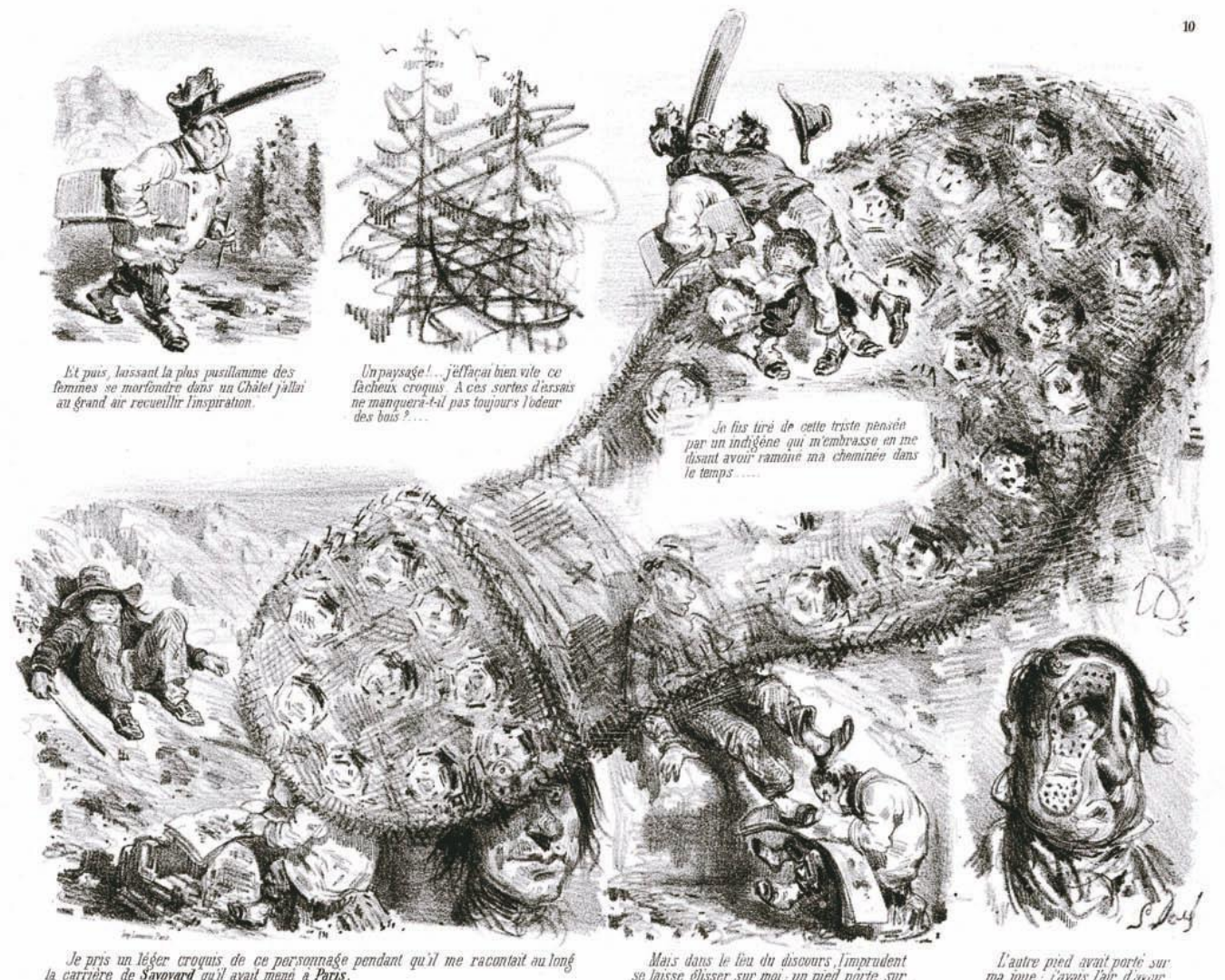

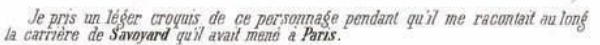

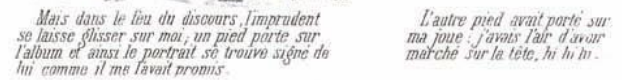

Figura 33 - Gustave Doré - Des-agréments d'un voyage d'agrément - 1851 xxiv $^{\text {iv }}$ 


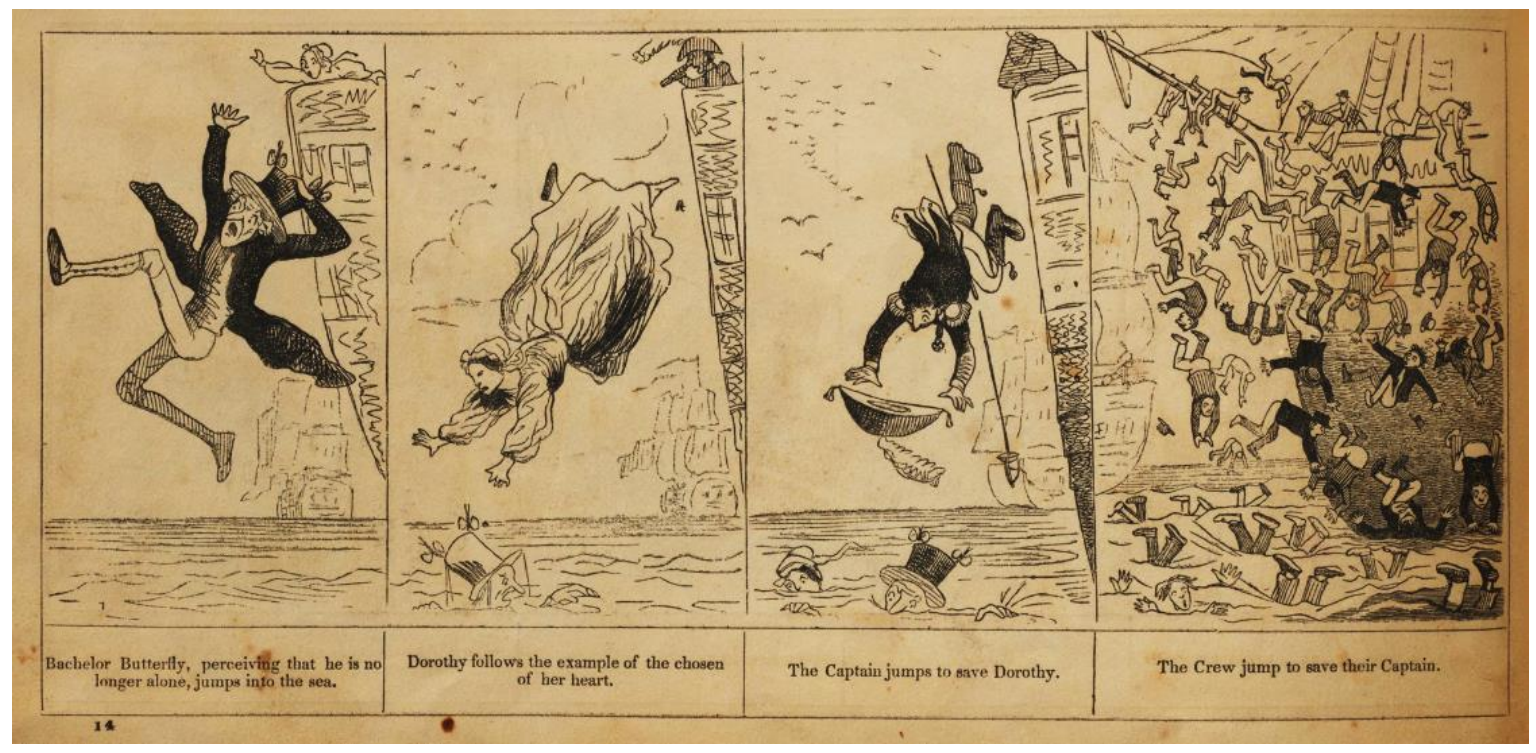

Figura 34 - The Strange Adventures of Bachelor Butterfly - 1846 - Wilson \& Co ${ }^{x \times v}$
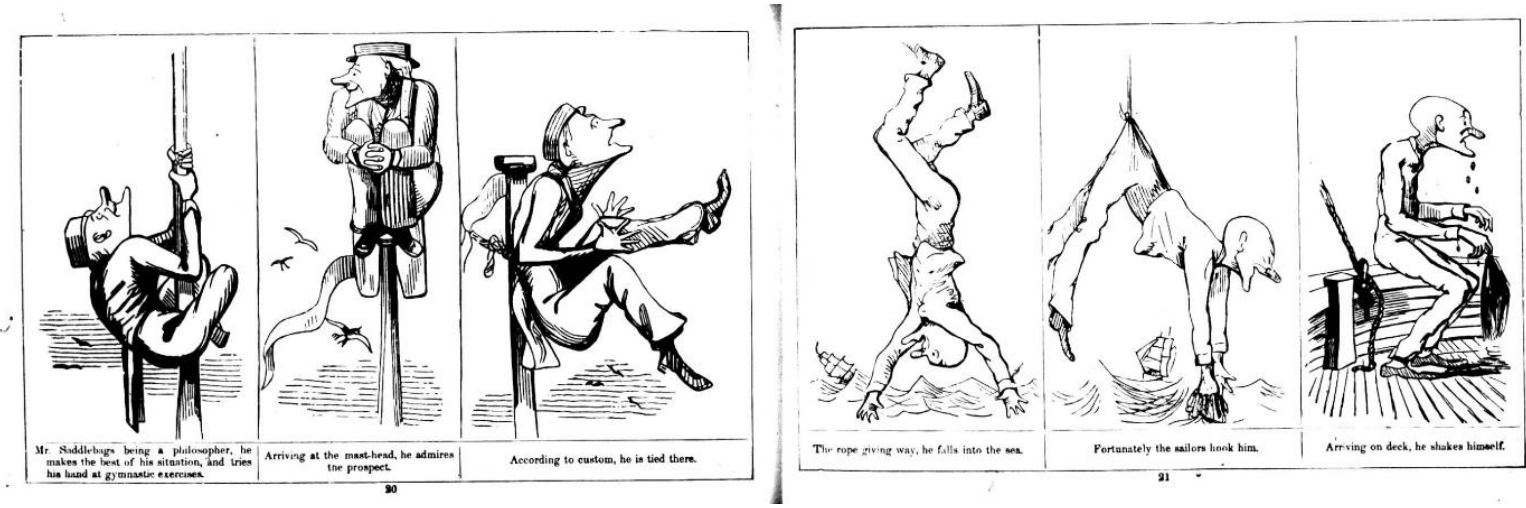

Figura 35 - Journey to the Gold Diggins by Jeremiah Saddlebags - James A. e Donald F. Read - 1849

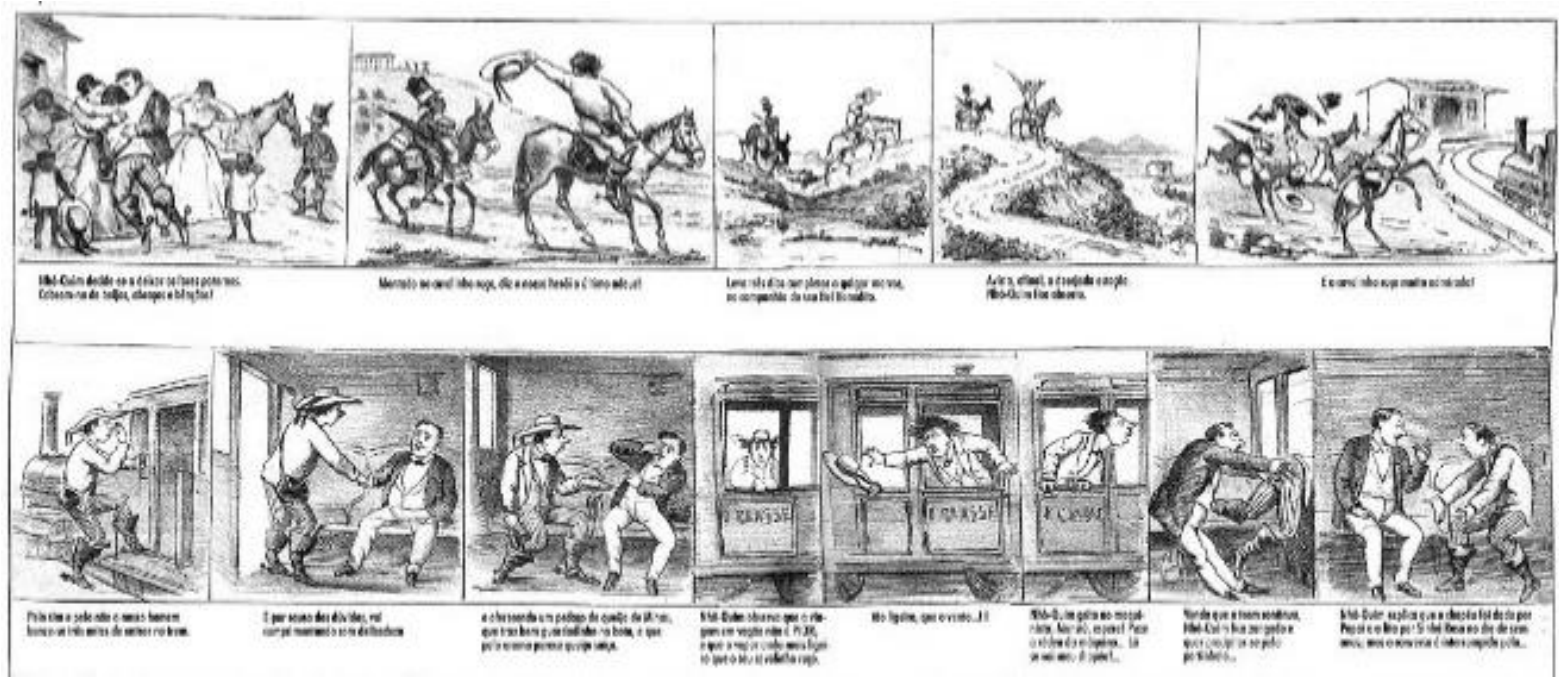

Figura 36 - As aventuras de Nhô-Quim Janeiro de 1869 - Jornal Vida Fluminense ${ }^{x \times v i}$ 
Seguindo o mesmo estilo de Töpffer, a primeira obra produzida na América foi Journey to the Gold Diggins by Jeremiah Saddlebags de James A. e Donald F. Read, publicada em Cincinnati e em New York em 1849, inspirada na corrida do ouro da Califórnia começada no ano anterior. Na mesma linha, em 1850 foi publicada The Adventures of Mr. Tom Plump por Philip Cozans em Nova York (GABILLIET, 2010, p. 25).

De acordo com a Comiclopedia Lambiek, na segunda metade do século XIX, juntamente com as publicações infantis, se popularizaram as revistas ilustradas satíricas para adultos com caricaturas, charges e histórias em quadrinhos, sendo uma das mais famosas "Het Humoristisch Album" lançada em 1856, a qual publicou em 1866 uma versão holandesa de "Monsieur Cryptogame" de Rudolf Töpffer (sem creditá-lo) como "Meneer Spillebeen" ou "Meneer Prikkebeen" (SCHUDDEBOOM e KNUDDE, 1994-2017).

Mesmo no Brasil, o estilo de Töpffer influenciou também a publicação pelo ítalo-brasileiro Angelo Agostini em 1869 de: "As aventuras de Nhô Quim" (Figura 36, pág. 56), uma narrativa cômica contando as trapalhadas de um caipira visitando a corte do Rio de Janeiro, no jornal Vida Fluminense e, posteriormente, com uma estética figurativa mais realista e uma temática de aventura dramática: "Zé Caipora", no jornal $O$ Malho em 1883. Agostini foi um renomado jornalista e cartunista, ferrenho abolicionista e grande opositor dos privilégios e regalias da monarquia imperial no Brasil que além de produzir charges e matérias políticas foi um grande analista da vida cotidiana da corte carioca (CARDOSO, 2002, p. 20).

O trabalho de Agostini ficou durante muito tempo esquecido, pois fora coleções particulares, pouco material foi conservado em virtude da mídia utilizada: jornal, que em essência é um objeto efêmero. O primeiro a investigar a obra de Angelo Agostini, foi o professor Cagnin, que conseguiu, junto aos especialistas da área, que a obra "As aventuras de Nhô-Quim" fosse reconhecida como a primeira obra de História em Quadrinhos nacional. Esse reconhecimento propiciou a instituir o dia 30 de janeiro como o dia do quadrinho nacional. Nesse dia, uma vez por ano, a Associação dos Quadrinistas e Cartunistas do Estado de São Paulo organiza o prêmio Angelo Agostini para prestigiar os profissionais brasileiros na área. Cagnin organizou também exposições sobre Angelo Agostini no Brasil e na Europa (LUYTEN, 2014, p. 20-21). Em 2002, o pesquisador de literatura de massa, história e cultura brasileira, Coronel de Reserva Athos Eichler Cardoso fez um trabalho minucioso de resgate, 
digitalização e compilação dos originais de "As aventuras de Nhô-Quim" e também de "Zé Caipora", publicando-os em um volume de capa dura pelo conselho editorial do Senado Federal.

\subsection{Raízes da oposição à narrativa imagética}

Plato's critique of the image was, however, also triggered by the desire to defend living memory against artificial forms of memory, such as writing and painting. Only living beings can remember. Left to their own devices, artifacts merely duplicate death. Plato's critique of writing in Phaedrus was intended to save living speech from lifeless written words. And the written word is analogous to painting in that painting imitates life: it imitates the speech of living beings, just as a painting imitates their bodies.

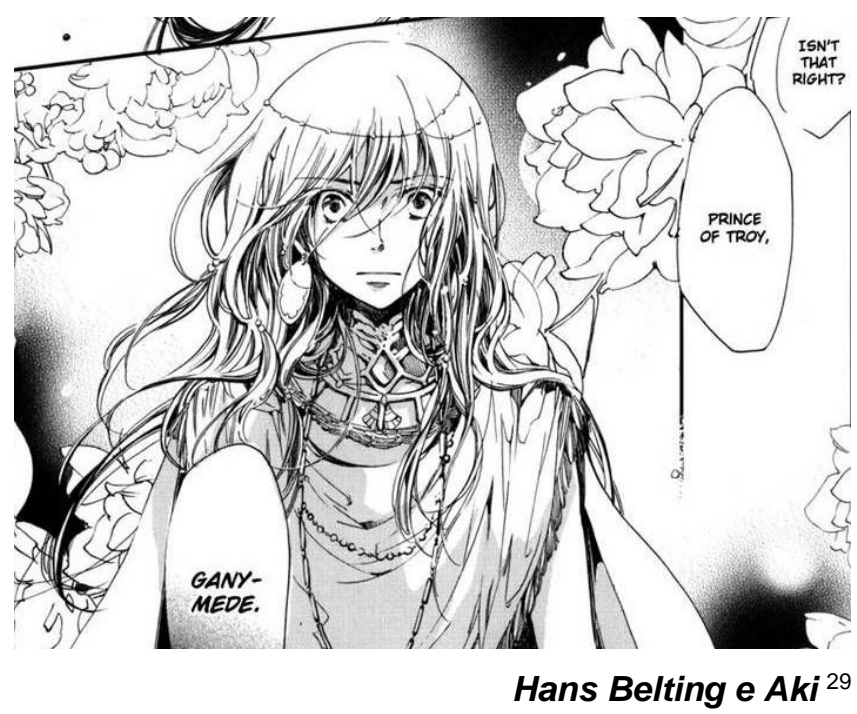

Em seu livro "Para ler o livro ilustrado", Sophie Van der Linden, jornalista, crítica literária especializada em literatura infantil e criadora da primeira Université

${ }^{29}$ Epígrafe - tradução e fonte: A crítica de Platão à imagem era, não obstante, também movida pelo desejo de defender a memória viva contra formas artificiais de memória, como a escrita e a pintura. Apenas seres vivos podem se lembrar. Deixados por sua própria conta, artefatos apenas duplicam a morte. A crítica de Platão à escrita no Phaedrs tinha a intenção de salvar o discurso vivo das escritas palavras sem vida. E a palavra escrita é análoga à pintura no fato de somente imitar a vida: ela imita o discurso dos seres vivos da mesma maneira como a pintura imita seus corpos. "Não é mesmo? Príncipe de Tróia. Ganymede." [tradução da autora] Fonte: BELTING, H. An anthropology of images. Tradução de Thomas Dunlap. Oxford: Princeton Unversity Press, 2011. Pg. 112. AKI. Olympus. Tóquio: Ichijinsha, v. 2, 2007. 
d'été de l'image pour la jeunesse (Universidade de verão sobre a imagem para a infância), reflete sobre a relação entre a imagem e o texto escrito e, também, sobre o livro ilustrado sem palavras que se utiliza apenas de imagens sequenciais para desenvolver a narrativa.

A autora afirma que os primeiros livros para crianças surgiram com 0 advento da xilogravura, que permitia compor caracteres e figuras em uma mesma página. Segundo ela, ao longo do século XVI com a popularização da técnica do talhodoce (gravura com cinzel ou ácido sobre placa de cobre) para figuras e o uso de caracteres em relevo para palavras. Naquele período, a distância entre texto e imagem se dava por uma questão de manufatura, pois eram impressos em separado, em dois ateliês diferentes e, de acordo com as legislações vigentes, duas corporações distintas (LINDEN, 2014, p. 11-12).

Linden informa que é a partir da técnica de litografia, desenvolvida por Aloysius Senefelder no final do século XVIII, que Rodolphe Töpffer consegue realizar em 1835 uma narrativa em imagens, na qual cada imagem era acompanhada de uma vinheta com o texto manuscrito abaixo (LINDEN, 2014, p. 13). Na gênese do livro ilustrado descrita por Linden não há distinção nesse período entre o livro ilustrado e a história em quadrinhos, ambos eram uma nova abordagem de comunicação, considerada de fácil leitura e por isso muito direcionada às crianças e iletrados.

A união de imagem e escrita, apesar de consagrada pelo gosto popular e festejada pelo empresariado editorial, foi coibida por muitos regimes governamentais em resposta à força de oposição e mobilização das massas que a mídia satírica começava a evocar, principalmente junto ao proletariado.

Também foi execrada pela força clerical, pela facilidade de inventividade de imaginário mítico e enlevos de desvio moral. Pois as imagens fantasiosas de seres imaginários pareciam possíveis junto as crianças (o que era considerado prejudicial para a inocência infantil) e as imagens lascivas aguçavam as libidos dos adultos, o que seria pernicioso à virtude e aos bons constumes.

$\mathrm{E}$, por fim, repudiada pelos intelectuais elitistas, que viam no fenômeno de popularização em massa, em níveis jamais vistos em outras artes até então (o cinema ainda era escasso e rádio e TV surgiriam somente mais tarde), uma ameaça à Literatura.

Dentre as manifestações de oposição à narrativa imagética está o soneto "Illustrated Books and Newspapers" de 1846 do poeta inglês William Wordsworth 
(1770 - 1850), que traduz o sentimento de aversão das Belas Letras à nova mídia:

DISCOURSE was deemed Man's noblest attribute,

And written words the glory of his hand;

Then followed Printing with enlarged command

For thought-dominion vast and absolute

For spreading truth, and making love expand.

Now prose and verse sunk into disrepute

Must lacquey a dumb Art that best can suit

The taste of this once-intellectual Land.

A backward movement surely have we here,

From manhood, -back to childhood; for the age-

Avaunt this vile abuse of pictured page!

Must eyes be all in all, the tongue and ear

Nothing? Heaven keep us from a lower stage ${ }^{30}$

(WORDSWORTH, 2013)

No poema, Wordsworth aponta a preocupação com a decadência

intelectual da sociedade que ao invés de continuar o "nobre atributo humano" do discurso (prosa e verso) e "a glória das mãos ao escrever palavras", prefere ver páginas ilustradas, associando a imagem a uma volta à infância e consequentemente à imaturidade.

Nos Estados Unidos, o movimento que o filósofo, poeta, ensaísta e romancista espanhol criado e educado nos EUA, George Santayana (1863-1952), batizou de "Genteel Tradition" (tradição gentil), formado por um refinado grupo de intelectuais - poetas, acadêmicos, editores, críticos e grandes publicadores - tentava controlar os padrões morais na literatura, manter as hierarquias sociais e encorajar uma reforma política conservadora. De acordo com a enciclopédia de Thomson Gale,

$30 \mathrm{O}$ DISCURSO foi considerado o atributo mais nobre do homem, / $\mathrm{E}$ palavras escritas a glória de sua mão; / Em seguida, seguiu a impressão com o poder ampliado / Para o domínio do pensamento vasto e absoluto / Para espalhar a verdade, e fazer expandir o amor. / Agora, a prosa e o verso se afundaram em descrédito / Devemos lisonjear uma arte estúpida que melhor se adapte / Ao gosto desta Terra uma vez intelectual. / Um movimento para trás certamente temos aqui, / Da masculinidade, do retorno à infância; para a idade - / Apresente este abuso vil da página ilustrada! / Os olhos devem ser todos, a língua e a orelha / Nada? O céu nos mantenha acima de um andar inferior. (WORDSWORTH, 2013) [tradução da autora] 
These well-bred, educated, and decorous Anglo-Saxon men asserted their cultural authority soon after the Civil War, claiming that they were the only ones capable of defining and maintaining American high culture. They criticized popular culture and censored what they considered "bad" literature, particularly literary realism. Rigidly conforming to Victorian standards of taste, they argued that "good" literature had only two functions: to transport readers from the real world to one of ideal truth and beauty and to teach "proper" manners to members of the middle and upper classes. Because the defenders of the genteel could control most of the literature written, edited, reviewed, and published at this time, they were often the only authoritative secular voice America heard on the subjects of personal conduct, intellectual thought, and artistic taste. ${ }^{31}$ (THOMSON GALE - ENCYCLOPEDIA.COM, 2006)

Já a Rússia teve uma relação ambígua com a combinação de imagem e texto, de acordo com José Alaniz o profundo apego popular com a tradição antiga dos Lubok tornou sua narrativa em imagens uma grande fonte propagandista, tanto do governo do Czar Pedro I quanto de sua oposição. Já a igreja ortodoxa russa tentou ao longo do tempo proibir através de decretos a disseminação das narrativas fora de seu controle, temendo principalmente as histórias impressas por seguidores dos "velhos crentes" (cismáticos fundamentalistas que romperam com a igreja por causa das reformas do patriarca Nikon em meados do século XVII) (ALANIZ, 2010, p. 22).

Alaniz aponta que a facilidade de criação e veiculação dos Lubok fez com que o governo tentasse, de tempos em tempos, monitorar ou censurar imagens subversivas com decretos, como o de 1839 que impunha que todas as imagens deveriam ter um selo de origem. O mais radical foi o decreto de 1851 de Dmitry Bludov, chefe da Segunda Secção da chancelaria do czar, que ordenava que todas as placas de impressão anteriores deveriam ser destruídas (ALANIZ, 2010, p. 23).

Esses não são momentos atípicos na interação das diversas formas de veiculação de usos imagéticos no ocidente ao longo do tempo, ressaltá-los se faz importante para apontar que, o preconceito e marginalização dos quais a História em Quadrinhos será alvo posteriormente, fazem parte de um quadro maior na relação cultural do homem com a imagem, com a narrativa imagética e, principalmente, com seu alcance.

\footnotetext{
${ }^{31}$ Estes bem-nascidos, educados e decorosos homens anglo-saxões afirmaram sua autoridade cultural pouco despois da Guerra Civil, alegando que eram os únicos capazes de definir e manter a alta cultura americana. Eles criticavam a cultura popular e censuravam aquilo que consideravam literatura "ruim", particularmente o realismo literário. Rigorosamente de acordo com os padrões de gosto vitoriano, eles argumentavam que "boa" literatura tem apenas duas funções: transportar os leitores do mundo real para o ideal da verdadeira beleza e ensinar "boas" maneiras para os membros das classes média e alta. Porque os defensores da gentileza podiam controlar a maior parte da literatura escrita, editada, revisada e publicada da época, frequentemente, eram a única voz secular que a América ouvia em assuntos de conduta pessoal, pensamento intelectual e gosto artístico. (THOMSON GALE ENCYCLOPEDIA.COM, 2006) [tradução da autora]
} 


\subsection{Max e Moritz - as primeiras crianças travessas}

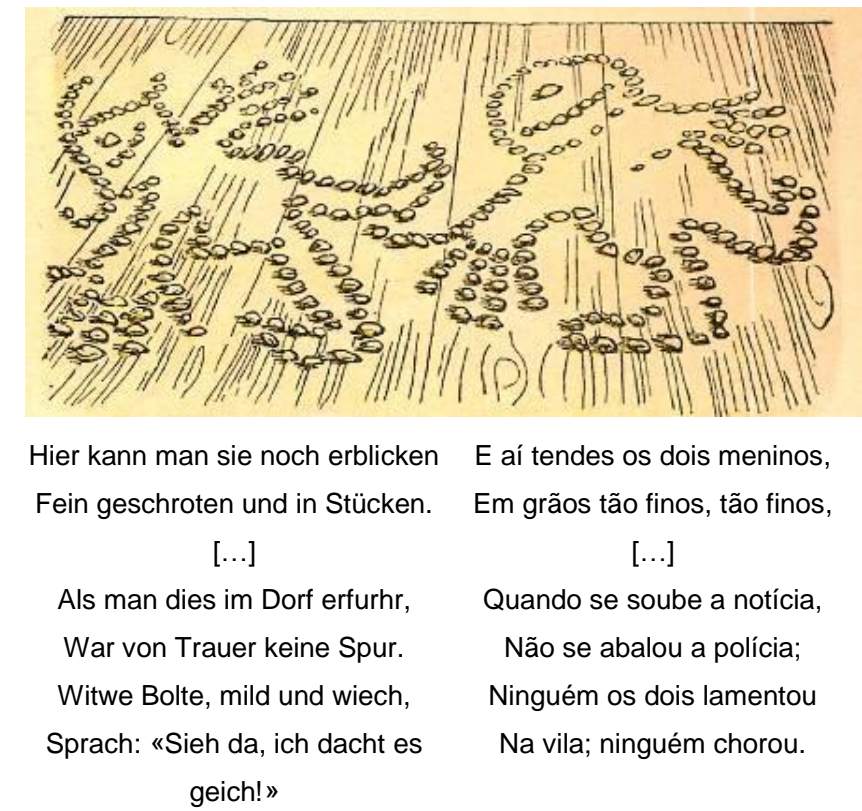

Willhem Busch ${ }^{32}$

De acordo com Thierry Smolderen, por volta de 1850 a forma original das novelas gráficas ${ }^{33}$ töpfferianas havia desaparecido, mas o gênero permaneceria vivo graças a adaptação de Cham da novela Monsieur Cryptogame (1845) de Töpffer no formato de tira para o jornal L'Illustration (SMOLDEREN, 2014, p. 67). Contudo, segundo Smolderen,

There is, however, one important exception to this general movement away from the form of the novel in prints. Wilhelm Busch (author of Max and Moritz and Pious Helen) represents an important deviation from this trend. In the last third of the century, Busch drew and wrote a number of novels in prints that were a major influence on the international community of humoristic illustrators of the period. His picture stories are typical of the stylized evocation of the old tradition of popular imagery, which he combined with the tone of nursery rhymes, legend, and folktales. Quite different from the Töpfferian canon, his mix of rustic and contemporary themes became extremely popular during this period. His well-known work should probably be seen as another genre, altogether a third form of the novel in prints, as distinctive, in its own right, as the Hogarthian and Töpfferian forms ${ }^{34}$ (SMOLDEREN, 2014, p. 69).

${ }^{32}$ Epígrafe - fontes : BUSCH, W. Max und Moritz Polyglott. München (Munique): dtv Verlagsgesellshaft $\mathrm{mbH} \&$ Co., 1982 e BUSCH, Wilhelm. Juca e Chico. História de Dois Meninos em Sete Travessuras. Tradução: BILAC, Olavo. 11aㅡ edição São Paulo: Melhoramentos, s/d.

${ }^{33}$ No original novels in prints (novelas em impressão ou impressas), considerando que as novelas somente em texto escrito também são impressas, para distinguir os trabalhos somente escritos dos trabalhos gráficos do estilo de Töpffer, optamos por adotar a tradução do termo moderno para obras do tipo: novela gráfica do inglês graphic novel.

${ }^{34}$ Houve, no entanto, uma importante exceção para esse movimento geral de distanciamento da forma 
O século XIX foi marcado pela explosão da imagem na mídia de massa, jornais, revistas ilustradas e livros infantis que foram se popularizando ao longo dos séculos anteriores. Segundo Hyatt Mayor, o inventor do livro infantil ${ }^{35}$ foi o bispo protestante tcheco exilado Jan Amos Comenius (1592 - 1670). Comenius acreditava que a educação seria a forma de dissolver diferenças e unir a humanidade. Diferentemente dos jesuítas que aplicavam uma educação rigorosa, ele acreditava em atrair a atenção dos meninos com figuras que ensinassem as coisas do mundo de forma lúdica. Para tanto, publicou em 1658 em Nuremberg, o Orbis Sensualium Pictus, um livro pequeno, voltado para as mãos infantis, contendo 304 xilogravuras que ensinavam latim para as crianças alemãs (MAYOR, 1972, p. 287).

Mayor aponta que,

His [Comenius] book started an educational revolution that is still spreading. Protestant publishers quickly discovered a market in children's books. In the early 1700s The New England Primer taught the alphabet with gloomy jingles that start "In Adam's fall we sinned all" and continue through "Xerxes did die and so must l"36 (MAYOR, 1972, p. 287)

Para Mayor, apesar de Emílio (1762) de Jean-Jacques Rousseau não conter imagens, ele redirecionou a educação infantil para um modelo de aprendizado pelo "bom exemplo", e isso teria incentivado tanto católicos como protestantes a ilustrar os livros para crianças com as recompensas de ser bom. Segundo ele, os livros que os pais compravam para distrair as crianças levaram naturalmente aos livros que as crianças queriam comprar elas mesmas (MAYOR, 1972, p. 287).

Na Alemanha, o pai dos quadrinhos é o escritor, poeta, pintor e cartunista Wilhelm Busch com a obra "Max und Moritz" publicado em 1865, que conta as travessuras de dois meninos em imagem e verso. Martha Zan, pesquisadora especializada em Historia da Arte de Colônia na Alemanha e Florença na Itália,

de novelas gráficas. Willhem Busch (autor de Max e Moritz e Piedosa Helen) representa um importante desvio dessa tendência. No último terço do século, Busch desenhou e escreveu um número de novelas gráficas que foram uma influência enorme na comunidade internacional de ilustrações humorísticas da época. Suas histórias ilustradas são a típica evocação estilizada da velha tradição de imagens populares, que ele combinou com o tom e rimas infantis, lendas e contos populares. Bem diferente do cânone töfferiano, sua mistura de temas rústicos e contemporâneos se tornaram extremamente populares durante este período. Seu bem conhecido trabalho deveria provavelmente ser visto como outro gênero, uma terceira forma de novela gráfica, como característica, a seu próprio modo, como as formas hogarthianas e töpfferianas (SMOLDEREN, 2014, p. 69) [tradução da autora].

${ }^{35}$ Considerando aqui os livros com imagens que em sua concepção tinham a criança como leitor alvo. ${ }^{36}$ Seu [de Comenius] livro começou uma revolução educacional que ainda está se espalhando. Os editores protestantes logo descobriram um mercado para os livros infantis. No começo de 1700 , o The New England Primer [cartinha da Nova Inglaterra, publicada em 1867 por Benjamin Harris] ensinou o alfabeto em rimas mórbidas que começavam com "A queda de Adão nos pôs todos no chão" e continuava por "Xerxes morreu e também devo eu" (MAYOR, 1972, p. 287) [tradução da autora]. 
assistente de produção da German Radio Station e curadora da seção de educação do Museum for Illustrations of Children's Books (Museu para ilustrações de livros infantis) em Troisdorf, Alemanha, aponta que após a marcha revolucionária de 184849, o relaxamento da censura de imprensa proporcionou o surgimento de vários jornais críticos, o que possibilitaria anos mais tarde a abertura da mídia para as publicações de Busch (ZAN, 2014, p. 48). O trabalho de Busch como caricaturista e a evolução do quadrinho alemão em geral, conforme Zan, receberam um grande impulso com a modernização da xilogravura, que permitia a publicação de mais de 100.000 cópias.

Álvaro de Moya em seu livro "História da História em Quadrinhos" de 1986, ressalta que Max e Moritz foi recusado pelo mesmo editor que já havia publicado as tiras cômicas anteriores de Busch, Die Maus oder gestorte Nachtrube (O Camundongo ou Sonho Disturbado) e Eine eurpäische Zeitgeschichte (Uma História Europeia dos Tempos). A obra, segundo a jornalista Petra Lambeck, da Deutsche Welle (DW), empresa pública de radiodifusão da Alemanha, que foi publicada na integra pelo editor e xilogravurista, Kaspar Braun, em formato de livro e não em tiras em jornal satírico como a princípio intencionava Busch (LAMBECK, 2015), sofreu, segundo Moya, a crítica pesada de pedagogos (MOYA, 1986, p. 17). Em entrevista ao repórter da DW, Toma Tasovac, Hans Joachim Neyer, diretor do Museu Wilhelm Busch aponta que,

Com seu jeito moderno, suas obras tinham algo de sensacional, algo pelo
qual muitos representantes do clero se sentiam ofendidos. O problema é que
Busch não aderia às normas estéticas clássicas, não escrevia sobre o
verdadeiro, o belo e o bom, como o fizeram Goethe ou Lessing. Ele foi na
direção diametralmente oposta ao focar o mau, o errado e o feio. E era isso
o que a nova classe média emergente em um mundo industrial e capitalista
queria ler. Eles queriam personagens novas. (NEYER apudTASOVAC, 2007).

Petra Lambeck comenta que a primeira edição do livro tornou-se um sucesso rapidamente, sendo um best-seller durante a vida de Wilhelm Busch. Em 1866 foi lançada a primeira tradução na Dinamarca e alguns anos depois na Inglaterra. Em 1887 foi lançada também uma tradução no Japão (LAMBECK, 2015). No Brasil, a obra foi publicada em 1915 com tradução de Olavo Bilac, que renomeou os garotos para Juca e Chico.

Lambeck cita a fala de Eva Weissweiler na biografia que fez do autor: "Wilhelm Busch himself was stunned by this success"37. A biógrafa acredita que a obra não teria sido escrita necessariamente para crianças, mas como uma crítica à forma

${ }^{37}$ Wilhelm Busch ficou ele próprio aturdido por este sucesso [tradução da autora]. 
da sociedade da época.

In the 1860s, people from poor, rural regions were massively migrating to America. There were many incredibly poor people working as day laborers, and they would leave their numerous children on their own. There were therefore thousands of children roaming around, and some of them would survive by stealing food, like Max and Moritz. So if there actually is a 'moral' to Max and Moritz, I believe it went in this direction. It aimed to criticize through humor - the terrible social conditions which were created by adults. (WEISSWEILER apud LAMBECK, 2015).

Martha Zan ressalta que o próprio Wilhelm Busch refutava as duras críticas que recebia principalmente de educadores a respeito da brutalidade e permissividade das suas histórias dizendo que suas figuras machucadas e mutiladas ou pulverizadas pelo moinho são apenas contornos, "Kontur wesen", que não seguem os princípios da gravidade e não sentem dor (ZAN, 2014, p. 49).

No final de Max e Moritz, a dupla de meninos é morta triturada por um moinho, deixando apenas farelos que os patos devoram, sem que nenhum adulto sinta a perda dos dois. Eva Weissweiler comenta que isso não era tão distante da realidade da época, pois crianças que eram pegas cometendo pequenos crimes podiam ficar na prisão por décadas e em caso de reincidência, até mesmo serem condenadas à morte, "Whether they ended up hanging in prison or crushed by a mill, death is death" 38 (WEISSWEILER apud LAMBECK, 2015).

Para Hans Joachim Neyer, era justamente por retratar a realidade de uma forma dura, o motivo de Busch fazer tanto sucesso com o público,

Todas as suas histórias terminam de maneira brutal, mas é exatamente isso que seus leitores mais apreciavam. Busch não era nem pastor, nem professor. Ele tinha que convencer as pessoas a comprar seus livros e o fez atendendo às suas necessidades. Estamos falando de literatura popular: seus livros eram vendidos em estações ferroviárias. As pessoas tinham que optar se compravam um livro ou uma cerveja. E muitos preferiam comprar um livro, tanto que, no fim da vida, Busch estava milionário (NEYER apud TASOVAC, 2007).

Partindo para outro formato de narrativa imagética, segundo Smolderen, a publicação da adaptação de Cham de Monsieur Cryptogame no jornal L'Illustration, em 1845, marcou um ponto decisivo para histórias em imagens. Ele acredita que Cham introduziu um gênero novo na impressa periódica, definindo seu futuro formato por mais de um século,

${ }^{38}$ Se eles acabaram enforcados na prisão ou esmagados por um moinho, a morte é a morte (WEISSWEILER apud LAMBECK, 2015) [tradução da autora]. 
In moving to another medium, Töpffer's invention also changed its raison d'être. Its artistic goals could no longer remain the same: the aim was not to produce an autonomous work - a novel in prints - but to share in the life and rhythms of a periodical and its readers. The periodical press offered rich evolutionary possibilities; it also suffered from an obvious flaw: authors could not control this complex environment in the same way that they were able to control the publication of a novel ${ }^{39}$ (SMOLDEREN, 2014, p. 75).

Apesar de Busch ter publicado no formato de livro, pode-se assumir que ele também sofreu com a popularização da imprensa periódica, pois de acordo com Petra Lambeck, conforme as tiras se tornaram populares nos Estados Unidos, em 1897, foi publicado no New York Journal, "The Katzenjammer Kids" (Os sobrinhos do Capitão, no Brasil) do cartunista alemão, criado nos EUA, Rudolph Dirks. O magnata da mídia, William Randolph Hearst, ao encomendar a série para Dirks disse que queria algo como Max e Moritz para seu jornal. Apesar da linguagem ser mais voltada para a narrativa imagética, segundo Lambeck, Dirks aplicou as instruções de Hearts literalmente ao criar os gêmeos Hanz e Fritz, que eram chamados de Max e Moritz nas versões em alemão do jornal (LAMBECK, 2015).

The Katzenjammer Kids obteve imenso sucesso, sendo traduzido para vários países ainda durante a vida de Busch, mas segundo Lambeck, ele não podia tomar qualquer medida legal quanto aos casos de plágio, pois não possuía os diretos da obra, cedidos ao editor Kaspar Braun (LAMBECK, 2015). Segundo sua biógrafa, "He was both irritated and flattered: Irritated by the very obvious plagiarism and flattered that the stories of his village got such an international reception." 40 (WEISSWEILER apud LAMBECK, 2015).

Smolderen especula que, por ter Dirks baseado The Katzenjammer Kids em Max e Moritz de Busch, geralmente se assuma que as histórias de Busch sejam uma linha direta entre Töpffer e as tiras cômicas americanas, mas indica que o cenário da ilustração cômica, no entanto, era muito complexo na época para uma associação tão direta. Segundo ele, enquanto as histórias de Töpffer ridicularizavam a rígida lógica da causa e efeito que dominava o mundo industrial, as de Busch

\footnotetext{
${ }^{39}$ Ao ser movida para outra mídia, a invenção de Töpffer também mudou sua raison d'être (razão de existir). Seus objetivos artísticos não podiam mais permanecer os mesmos: a meta não era produzir um trabalho autônomo - uma novela gráfica - mas compartilhar a vida e os ritmos de um periódico e seus leitores. A imprensa periódica ofereceu ricas possibilidade evolutivas; e também sofreu de uma falha óbvia: autores não podiam controlar este ambiente complexo do mesmo modo que eles eram capazes de controlar a publicação de uma novela (SMOLDEREN, 2014, p. 75) [tradução da autora].

${ }^{40}$ Ele estava ao mesmo tempo irritado e lisonjeado: irritado com o mais obvio plágio e lisonjeado que as histórias de sua vila alcançassem tanta acolhida internacional (WEISSWEILER apud LAMBECK, 2015) [tradução da autora].
} 
homenagearam alegremente a lógica poética da lenda e do conto popular. Seu deliberado estilo rústico tinha como referência as xilogravuras populares préindustriais, e até mesmo suas histórias em imagens sem palavras sugerem, pelo ritmo visual, a escansão e lógica do verso infantil. Smolderen ressalta que a presença virtual de um narrador popular oral era uma parte integral do charme de suas histórias (SMOLDEREN, 2014, p. 112-113).

Para Smolderen, no Katzenjammer Kids de Dirks, esse tom foi completamente perdido, nele o tema de Max e Moritz foi tratado por Dirks em um novo estilo de história sem palavras desenvolvido pela geração que seguiu Busch na revista semanal satírica não política alemã Fliegende Blätter (1845 e 1944). Nessas histórias, cartunistas alemães das décadas de 1880 e 1890 cultivaram a forma positivista da paródia mecânica que se valia inteiramente da lógica visual da causa e efeito. Suas piadas sem palavras, que muitas vezes apresentavam dispositivos mecânicos, geralmente eram desenhadas em um estilo claro e diagramático que evocava esquemas técnicos (SMOLDEREN, 2014, p. 113).

\subsection{Marie Duval e Rian - o bastidor feminino dos quadrinhos}

Pontilhei minha vida como procuradora de coisas modernas e avançadas para aquela época de educação severa, no estilo do ancient regime, o qual foi o segredo do binômio: "talento e formosura", Não ser formosa e sem talento... é triste...

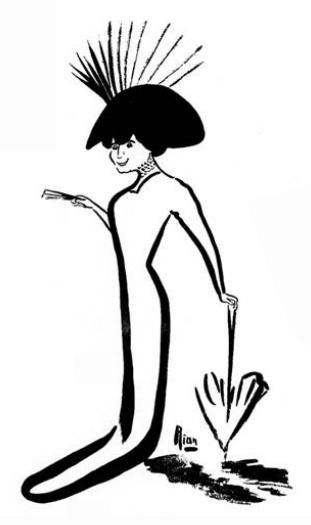

Nair de Tefé 41

${ }^{41}$ Epígrafe - fonte: CAMPOS, M. D. F. H. Nair de Teffé: artista do lápis e do riso. Curitiba: Appris, 2016. Pg. 32 e 86. 
Marie Duval é o pseudônimo de Isabelle Émilie de Tessier (1847-1890), uma atriz, escritora e cartunista francesa, coautora do popular personagem Ally Sloper, o primeiro personagem recorrente da Inglaterra, publicado na revista Judy, uma concorrente da Punch. Segundo David Kunzle, a obra de Maria Duval, muito popular em sua epóca, foi publicada entre 1869 e 1878, grande parte com sua assinatura retirada, foi creditada erroneamente ao marido, também cartunista, Charles Ross,

The various disabilities which afflicted women in the pursuit of an artistic career are compounded in the case of caricature, a more thoroughly maledominated profession even than painting. Caricature, as a major branch of magazine illustration, provided a livelihood for a large number of western Europeans artists during the $19^{\text {th }}$ century. All, with the exception of Marie Duval, seem to have been men. This is not hard to explain: "Woman's nature" was considered antithetical to the aggressive polemical and critical nature of much journalism in general and caricature in particular ${ }^{42}$ (KUNZLE, 1986, p. 26).

Ellen C. Clayton (1834-1900), cartunista, ilustradora e escritora do século XIX, em seu livro de 1876 sobre as artistas femininas inglesas do período aponta que mesmo a revista Punch já sendo "um velho idoso de barbas brancas" havia apenas uma mulher como colaboradora frequente na revista, Georgina Bowers (1835-1912), outras mulheres tiveram apenas versos curtos publicados esporadicamente, e mesmo assim, o trabalho de Georgina ficou durante um período limitado aos desenhos de caçadas e animais (CLAYTON, 1876, p. 322-323).

Segundo Clayton, o Humor é um atributo especialmente reivindicado pelo "homem", à mulher é permitido o chiste, mas com exceção de atrizes em farsas burlescas, nas quais ela simplesmente parodia as fantasias masculinas, lhe é negada qualquer percepção do Humor.

\footnotetext{
${ }^{42}$ As várias impotências que afligiram as mulheres na busca de uma carreira artística são agravadas no caso da caricatura, uma profissão completamente dominada pelos homens até mais que a pintura. A caricatura, como um ramo importante da ilustração de uma revista, proporcionou um sustento para inúmeros artistas europeus ocidentais durante o século XIX. Todos, com exceção de Marie Duval, parecem ter sido homens. Isso não é difícil de explicar: "A natureza da mulher" foi considerada uma antítese à natureza polêmica e crítica agressiva de muito do jornalismo em geral e da caricatura em particular (KUNZLE, 1986, p. 26) [tradução da autora].
} 
For the defence it may be urged that Humour is a quality scarcely coveted by the ladies. They like to be admired for wit, archness, piquancy, even sarcasm, or any similar attribute that may be slightly tinged with soupçon of comic - but Humour, as a rule, they willingly relegate to those who care to claim it. Wit is fine and elegant: wit shines and scintillates in drawing-rooms and boudoirs, but Humour may run the risk of stepping over the boundary lines of vulgarity. Thus, it may be, arises the otherwise singular fact that so few women have come forward as humorists, though many have been famous for wit and sarcasm $^{43}$ (CLAYTON, 1876, p. 321).

No livro: "The Brothers Dalziel - A record of fifty years' work in conjunction with many of the most distinguished artists of the period 1840-1890" de 1901 dos irmãos Daziel, uma companhia de impressão vitoriana muito influente do período, há uma passagem sobre o editor da Judy, Charles Ross, em que ele é apontado como um "escritor dotado de vários poderes, dramatúrgico e novelista da mais sensacional ordem. Mas acima de tudo, um grande humorista, com sua maneira peculiar", o texto aponta ainda que em suas figuras humorísticas que apareciam na Judy, ele geralmente assinava como "Marie Duval", colhido do nome de solteira de sua esposa explicando porque alguns de seus temas traziam frequentemente uma pitada de tempero francês (THE BROTHERS DAZIEL, 1901, p. 320).

Segundo Kunzle, durante muito tempo se achou que Marie Duval era um pseudônimo de Charles Ross, ele cita "A Dictionary of British Book lllustrators and Caricaturists 1800-1914" de Simon Houfe, que indica no tópico Marie Duval: veja C. H. Ross, e no tópico de Ross lê-se "generally signed 'Marie Duval”" (geralmente assina 'Marie Duval') (KUNZLE, 1986, p. 26).

Kunzle aponta que Charles Ross sempre foi categórico sobre a criação do personagem "Ally Sloper" ser somente sua e, de sua esposa, ter recebido apenas um auxílio. O filho do casal, Charles Ross Jr, que segundo Kunzle, tinha o propósito de defender a invenção do pai contra a subsequente apropriação pelos irmãos Dalziels descreve sua mãe como coautora juntamente com seu pai de "Ally Sloper", defendendo o pai como criador intelectual do personagem (mesmo que sua mãe tenha desenvolvido as narrativas), mas também afirma que ela era a única cartunista cômica

\footnotetext{
${ }^{43}$ Para a defesa, pode-se argumentar que o Humor seja uma qualidade pouco cobiçada pelas damas. Elas gostam de ser admiradas pelo chiste, malícia, picância, mesmo sarcasmo, ou qualquer atributo similar que possa ser ligeiramente tingido com uma pincelada de cômico - mas Humor, como regra, elas voluntariamente relegam para aqueles que se preocupam em reivindicá-lo. $O$ chiste é bom e elegante: o chiste brilha e cintila nas salas de desenho e boudoirs [sala de senhoras], mas Humor pode correr o risco de pisar as linhas de fronteira da vulgaridade. Assim, pode ser, surge o fato singular de que tão poucas mulheres aparecem como humoristas, embora muitas tenham sido famosas pelo chiste e sarcasmo (CLAYTON, 1876, p. 321) [tradução da autora].
} 
de seu tempo, cujo pseudônimo era Marie Duval.

Contudo, Kunzle nota que A. J. Wilson, gravurista da Punch, escreveu em 1927:

"Marie Duval, who invented Ally Sloper, was its [Judy,s] mainstay. The drawings were excruciating bad, but the legends were always amusing, and they led up to the establishment of Ally Sloper's" 44 (WILSON apud KUNZLE, 1986).

Kunzle aponta que Dalziel prontamente reafirmou a posição de que Marie

Duval não foi a inventora do personagem, mesmo que isso tenha sido impresso, reiterando que o único inventor de "Ally Sloper" foi o editor da Judy, Charles H. Ross (KUNZLE, 1986). Contudo a escritora Helen Clayton aponta em seu livro Marie Duval como criadora do personagem,

Her designs for Judy are probably the most familiar to the English public. Nothing could be more irresistibly droll than "Ally Sloper", absurdly comic, with an under-current of serious reflection, sometimes with a touch of strange pathos. "Ally" himself has become a pronounced character and familiar friend, like Micawber and a few other terrible old schemers. Austere morality of the droll old scamps, yet somehow a smile will relax the features of Justice herself, where a frown should mark displeasure and discouragement. Her figures are humorous to grotesqueness, though the "drawing" is often incorrect: but this defect has been judiciously utilized in heightening the burlesque. Mlle. De Tessier may be pardoned for not drawing in academic proportion when it is understood that she is self-taught ${ }^{45}$ (CLAYTON, 1876, p. 332).

Kunzle aponta que Marie Duval teve participação ativa na revista do marido, incluindo a direção gráfica e, analisando as obras publicadas, constata que a maioria das ilustrações estão assinadas MD, Duval ou Marie Duval, em contraste com as poucas assinadas CHR e chega à conclusão que Charles Ross teve a ideia inicial para o personagem, mas foi Marie Duval que fez a caracterização e experimentação gráfica, um século antes da estética do "primitivismo" surgir (KUNZLE, 1986, p. 30).

No Brasil em 1909, a revista ilustrada Fon Fon! publica a primeira charge do cartunista Rian, pseudônimo masculino usado por Nair de Teffé, pintora, cantora,

\footnotetext{
${ }^{44}$ Marie Duval, que inventou Ally Sloper era o mastro principal dela (da Judy), os desenhos eram excruciantemente ruins, mas as legendas eram sempre divertidas, e eles levaram ao estabelecimento de Ally Sloper (WILSON apud KUNZLE, 1986) [tradução da autora].

${ }^{45}$ Seus projetos para Judy são provavelmente os mais familiares para o público inglês. Nada poderia ser mais irresistivelmente engraçado do que "Ally Sloper", absurdamente cômico, com um nível profundo de reflexão séria, às vezes com um toque de pathos do estranho. "Ally" tornou-se um personagem marcado e um amigo familiar, como Micawber e alguns outros terríveis antigos vigaristas. Austera moralidade dos antigos escrúpulos, mas, de alguma forma, um sorriso vai relaxar a face da própria Justiça, onde um olhar franzido deveria marcar o desprezo e o desânimo. Suas figuras são bem-humoradas pendendo para o grotesco, embora o "desenho", seja muitas vezes incorreto: mas esse defeito foi utilizado judiciosamente no aumento do burlesco. Madame De Tessier pode ser perdoada por não desenhar em proporção acadêmica quando se entende que ela é autodidata (CLAYTON, 1876, p. 332) [traduzido pela autora].
} 
atriz e pianista, cartunista e primeira dama, esposa do Marechal Hermes da Fonseca, a quem retratou em uma caricatura pouco convencional.

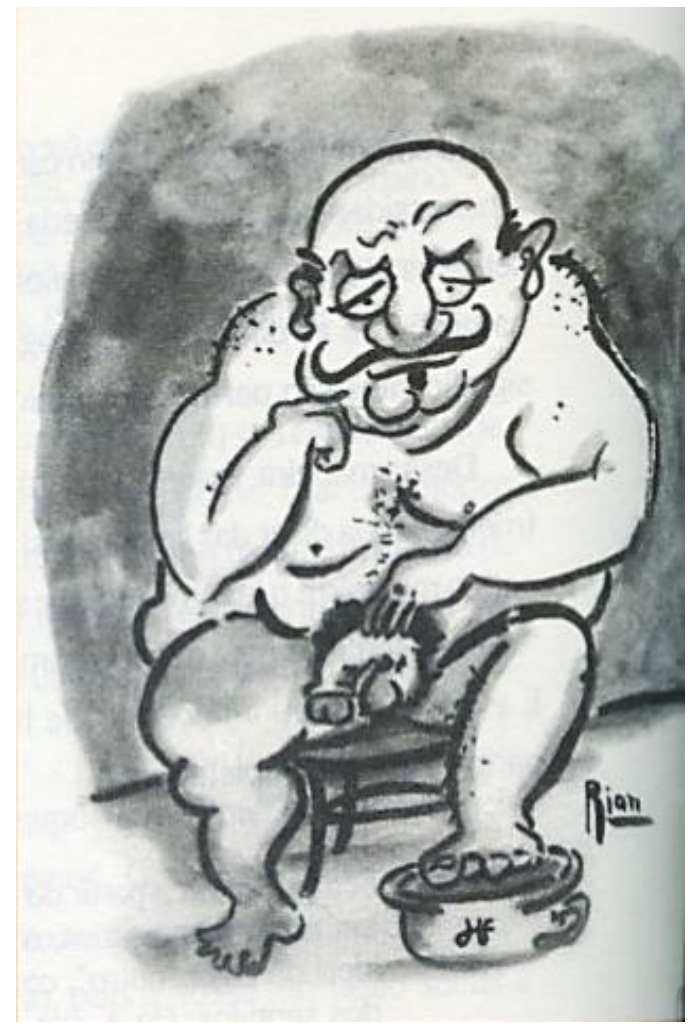

Figura 37 - Caricatura de Hermes da Fonseca por Rian (Nair de Teffé) $)^{x x i i}$

Nair de Teffé foi uma primeira dama polêmica, intelectual e artista, pertencente a uma família influente, era filha do Barão de Teffé, quebrou vários tabus incorporando a cultura popular nos salões presidenciais. Ainda assim, publicou suas caricaturas sob um pseudônimo masculino, pois a caricatura não era uma atividade bem vista socialmente.

A mulher brasileira [do início do século $X X$ ] firma-se no tripé: rainha do lar, súdita do homem e escrava da moda. Reforçada pela imprensa e propaganda, a imagem que na década de 1910 se faz do "belo sexo" ainda está associada à ideia de fragilidade física e mental. Sua atuação social se resumia às missas dominicais, demostrações de fé e caridade, às reuniões beneficentes, e boa anfitriã nos salões em que expunha seus dotes musicais. Sem direito a voto ou participação política, sobrava à mulher o papel de mãe e educadora, sua principal tarefa na sociedade patriarcal (CAMPOS, 2016, p. 28-29).

O trabalho de Rian era, na época, chamado de portrait-charge, a pesquisadora doutora em História da Arte pela Universidade do Porto (Portugal) e professora da Universidade do Estado da Bahia Maria de Fátima Hanaque Campos, explica que ele é o avesso do retrato com suas fisionomias sérias e retocadas visando a fixação das virtudes e dignidades, pois emprega-se uma fisionomia de traços carregados e os defeitos claramente apresentados (CAMPOS, 2016, p. 58). 


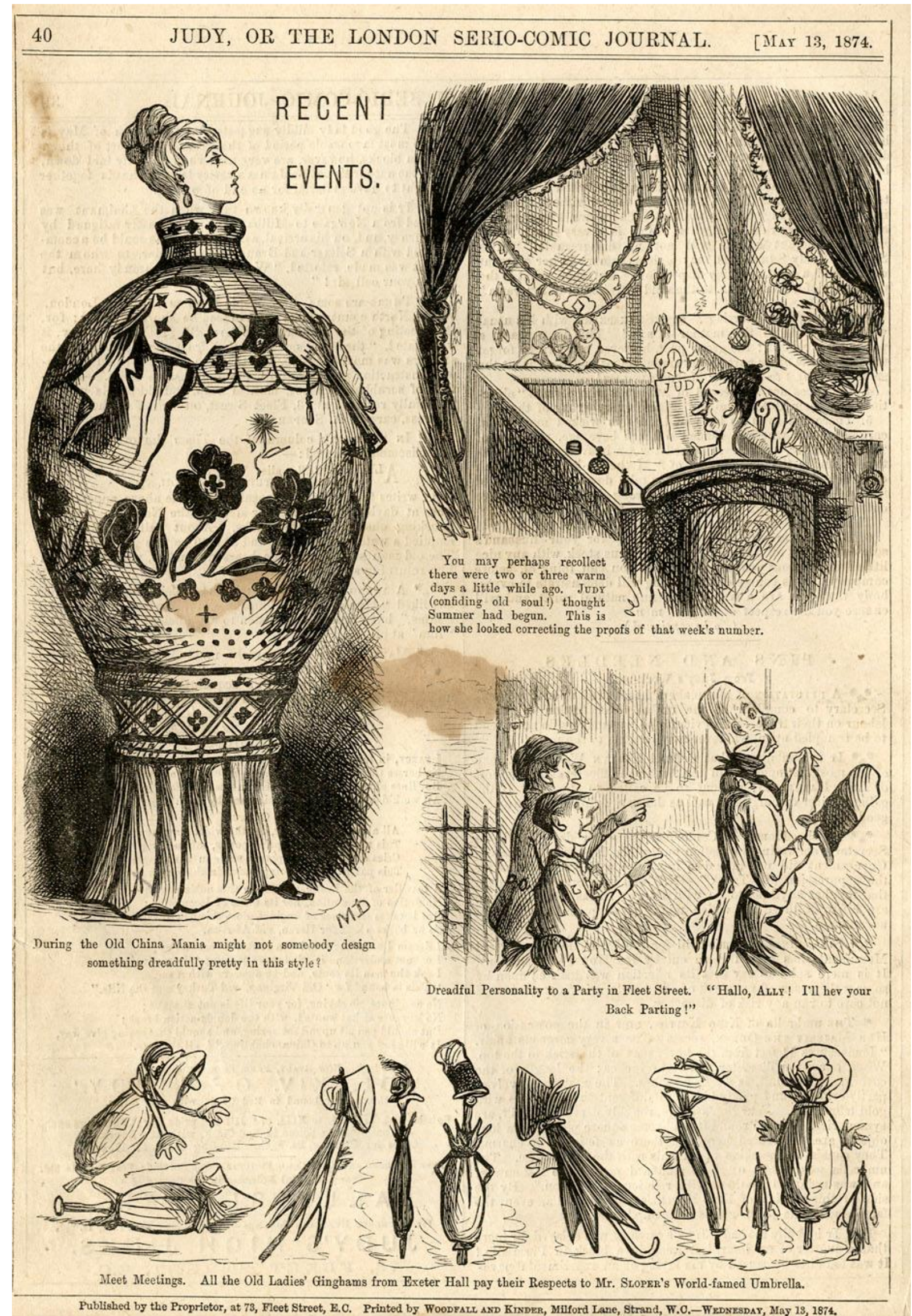

Figura 38 - Ally Sloper - 1874 - Marie Duvalxxviii 


\subsection{Revistas ilustradas, tiras cômicas e merchandising}

Comic strips aren't art, they never will be art. Comic strips are not made to last; they are made to be funny today in the paper, thrown away. And that is its purpose, to sell that edition of the newspaper.

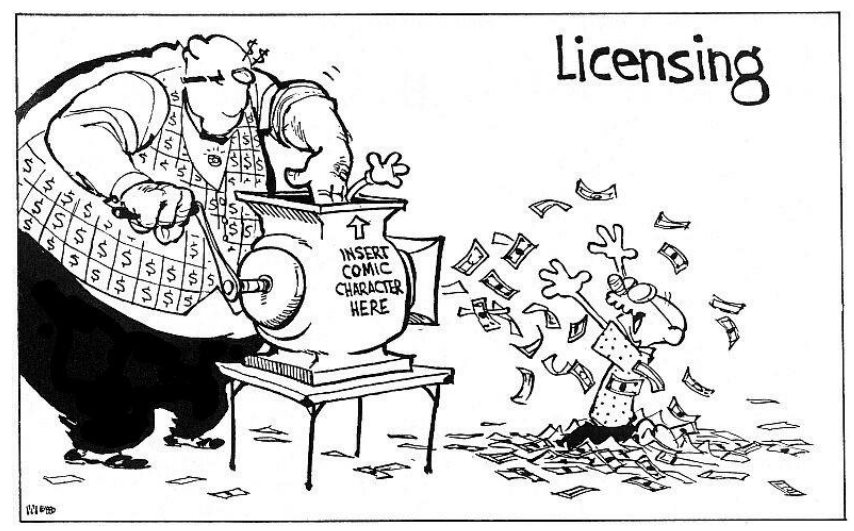

Schulz e Watterson ${ }^{46}$

Os cartunistas franceses Caran d'Ache, pseudônimo de Emmanuel Poiré (1858-1909), e Christophe, pseudônimo de Marie Louis Georges Colomb (1856-1945), sob a influência dos alemães, frequentemente adotavam um tom similar ao da revista alemã Fliegende Blätter, onde os desenhos apresentavam uma explicação perfeitamente autossuficiente em uma cadeia de ações, e o fato de que não precisavam de nenhuma paráfrase ou comentário era provavelmente a sua característica mais notável: estas "frases" puramente visuais eram claramente produtos auto propelidos da moderna era industrial (SMOLDEREN, 2014, p. 113).

${ }^{46}$ Epígrafe - tradução e fontes:Tiras de quadrinhos não são arte, elas nunca serão arte. Tiras de quadrinhos não são feitas para durar, elas são feitas para serem engraçadas hoje no jornal e jogadas fora. E seu propósito é vender aquela edição do jornal. [tradução da autora] Fontes: frase de Charles M. Schulz, criador dos Peanuts (Charlie Brown e Snoopy), cartoon de Bill Watterso, criador de Calvin and Hobbes (Calvin e Haroldo) extraído de: CHATFIELD, J. On Comic Strips, Commercialism and Selling out as an Artist. The Coffeelicius, 2015. Disponivel em: <https://thecoffeelicious.com/on-comicstrips-commercialism-and-selling-out-as-an-artist-c28e08bfea7c>. Acesso em: 18 Maio 2018. 


\begin{abstract}
A story without words is, in principle, the closest thing to a story without a narrator-a story that "reads itself "; hence the coldly diagrammatic line often used in the 1880-1890 period by the likes of Schliessmann, Christophe, Caran d'Ache, and others for depicting purely visual gags in terms of a transparently readable syntax of mechanical causes and effects. The genre is not only typical of the period's fascination for new contraptions, it also jubilantly explores the new kind of "mechanical" mode of storytelling that comic illustrators could foresee in the emerging technology of the moving picture. It is no coincidence, then, that the early cinematographers immediately adopted gags of this type as natural content for the new medium ${ }^{47}$ (SMOLDEREN, 2014, p. 117).
\end{abstract}

Em 1877, Joseph Keppler inaugura a revista satírica Puck em sua versão em língua inglesa em Nova York (a revista havia sido lançada em 1871 em alemão/inglês em St. Louis). Conforme o escritor, acadêmico e professor da Universidade de Arkansas, M. Keith Booker, a revista se tornou uma via importante para o cartum político americano (BOOKER, 2014).

De acordo com o historiador e professor da National University of Singapura, lan Gordon, a revista Puck demonstrou a influência dos prévios artistas europeus e em especial, especificamente a cultura americana de Nova York. O material gráfico que a revista publicou deve sua forma e técnica às tradições europeias, com exceção ao ocasional aceno a Wilhelm Busch, cujo conteúdo era inspirado localmente na cultura emergente das cidades, que as revistas de humor não só celebravam mas ajudavam a criar (GORDON, 1998, p. 15).

Ian Gordon aponta que em 1883, Joseph Pulitzer começou a publicação de seu recém-adquirido jornal The New York World. Com base nos sucessos da penny press (imprensa de centavos), o The World contou histórias detalhadas sobre o lado infame da vida da cidade, histórias que ajudaram a moldar as fofocas, rumores e escândalos em um gênero comercializável: a notícia. The World e outros jornais baratos foram os produtos dos desenvolvimentos em tecnologia de impressão, transporte e comunicação. A audiência deles era o novo público de leitores das cidades do Leste. Cerca de 90 por cento da classe trabalhadora urbana era alfabetizada e realizou gastos significativos com jornais (GORDON, 1998, p. 13).

\footnotetext{
47 Uma história sem palavras é, em princípio, a coisa mais próxima de uma história sem um narrador uma história que "se lê sozinha"; por isso a linha fria e esquemática usada frequentemente no período de 1880-1890 por Schliessmann, Christophe, Caran d'Ache e outros por representar piadas puramente visuais em termos de uma transparente sintaxe legível de causas e efeitos mecânicos. $O$ gênero não é apenas típico do fascínio do período por novos engenhos, mas também explora com júbilo um novo modo de contar histórias de certa forma "mecânico" que os ilustradores cômicos poderiam prever na tecnologia da imagem em movimento surgindo. Não é, portanto, coincidência, que os primeiros cineastas adotaram imediatamente piadas deste tipo como conteúdo natural para o novo meio (SMOLDEREN, 2014, p. 117) [tradução da autora].
} 
Ainda segundo lan Gordon, The World liderou o caminho para esses jornais. Uma das suas inovações importantes foi o uso regular de cartuns editoriais, que antes de meados da década de 1880 eram largamente confinados às revistas de humor ilustradas,

\begin{abstract}
The increased use of illustrated material in newspapers also contributed to the development of comic strips. The first comic strip character to enjoy widespread popularity, Richard Felton Outcault's Yellow Kid, appeared as an unnamed figure in a series of illustrations in Pulitzer's Sunday World in 1895 and 1896. Dubbed "the Yellow Kid" by the newspaper's readers because of the color of his nightshirt, the figure became the center of a craze in New York and nearby cities. The Yellow Kid craze demonstrated that comic strip characters could sell newspapers. By the end of 1895 the Sunday World circulation averaged half a million copies-almost a 100 percent increase over $1891^{48}$ (GORDON, 1998, p. 14).
\end{abstract}

Gordon aponta que Outcault, Pulitzer e seu concorrente William Randolph Hearst logo reconheceram as possibilidades comerciais que a popularidade das tiras cômicas e o aumento da circulação de jornais ofereciam. Outcault tentou assegurar, sem sucesso, os direitos autorais para seu personagem, possivelmente para licenciar os produtos Yellow Kid. Hearst obteve os serviços de Outcault sobre a objeção de Pulitzer e, em outubro de 1896, lançou um suplemento cômico para o New York Journal construído em torno do Yellow Kid. Embora o Yellow Kid tenha sido de curta duração, outros personagens de quadrinhos, como The Katzenjammer Kids e Happy Hooligan, logo o seguiram e garantiram o sucesso tanto dos jornais de Hearst como da forma dos quadrinhos (GORDON, 1998, p. 14).

Gordon explica que por volta de 1903 os jornais ao longo do país todo traziam tiras cômicas em suas edições de domingo. Esta expansão colocou os personagens de tira cômica e sua forma de arte em evidência para uma ampla audiência nacional, lançando as bases para seu uso em outros produtos. Isso também proporcionava aos leitores urbanos e rurais experiências compartilhadas semanalmente e reuniu diversas audiências nacionais como mercados de produtos de mídia de massa. Além do aumento vigoroso de circulação que os jornais de Nova

\footnotetext{
$48 \mathrm{O}$ aumento do uso de material ilustrado nos jornais também contribuiu para o desenvolvimento de tiras de quadrinhos. O primeiro personagem de tira cômica a desfrutar ampla popularidade, Yellow Kid de Richard Felton Outcault, apareceu como uma figura sem nome em uma série de ilustrações no Sunday World de Pulitzer em 1895 e 1896. Denominado "Yellow Kid" (menino amarelo) pelos leitores do jornal por causa da cor de sua camisola, a figura se tornou o centro de uma mania em Nova York e cidades próximas. A mania de Yellow Kid demonstrou que personagens de quadrinhos poderiam vender jornais. No final de 1895, a circulação do Sunday World era em média meio milhão de cópias, quase um aumento de 100\% em relação a 1891 (GORDON, 1998, p. 14) [tradução da autora].
} 
York experimentaram quando introduziram tiras cômicas, dois fatores contribuíram para a disseminação rápida da forma de arte através da nação; o crescimento da sindicalização e a consolidação do controle por cadeias de jornais. Ambos o The World e o The Journal organizaram Syndicates ${ }^{49}$ (sindicatos) para vender os clichês ${ }^{50}$ de tiras cômicas para outros jornais. Os sindicatos independentes, que começaram a fornecer material para os jornais, em particular os suplementos de domingo, na década de 1880 desenvolveram seus próprios suplementos de quadrinhos que foram vendidos para jornais em todo o país.

O Japão do período, com aumento do contato e do comércio com o exterior após a abertura forçada das fronteiras, recebeu muita influência americana e após a abertura e publicação da Japan Punch e Toba-e. Segundo McCarthy, as primeiras revistas japonesas eram em sua maioria satíricas e voltadas para o público adulto, a primeira revista ilustrada para crianças foi Shonen Sekai (O mundos dos meninos), lançado em 1895, por Sazanami Iwaya, um famoso escritor de livros infantis. A intenção de Iwaya foi criar uma revista que pudesse se conectar com os meninos de todos os níveis da sociedade. A revista continha, além de histórias em quadrinhos, artigos sobre o mundo moderno, contos da cultura japonesa e traduções de histórias infantis ocidentais. Em 1902 Iwaya lança uma versão feminina da revista, Shoujo Sekai (O mundo das meninas) com romances ilustrados, contos, poemas e artigos sobre a cultura do ocidente. Além de Iwaya, contribuíram para a revista o posteriormente ganhador do prêmio Nobel de literatura Yasunari Kawabata e a poetisa e ativista feminista Akiko Yosano, entre outros (MCCARTHY, 2014, p. 16).

Apesar do termo 漫画 “manga” - em português com acento oxitonante na partícula "ga": "mangá", que é frequentemente traduzido para outras línguas como: irresponsável ou inconsequente (por causa dos caracteres do qual é composto: 画 (ga): pintura, desenho; e 漫 (man): algo involuntário, livre, corrompido ou a despeito de si mesmo) - ter surgido no Japão, de acordo com o estudioso Adam Kern, apontado por Helen McCarthy, em 1798 pelo poeta escritor e desenhista Santo Kyoden e usado posteriormente em 1814 quando Aikawa Minwa publicou o Manga Hyakujo (mangá das cem meninas), só em 1902 ele é usado como no contexto moderno, com a publicação do suplemento dominical Jiji Manga do jornal Jiji Shinpo,

${ }^{49}$ Syndicate - empresa responsável pela distribuição de material para jornais, revistas e blogs, como artigos, crônicas, contos, passatempos, tiras de quadrinhos, charges, etc.

${ }_{50}$ Clichê - matriz gravada em placa metálica e destinada à impressão de imagens e textos. 
trazendo a história das desventuras de dois caipiras na capital, "Tagosaku e Mokube em Tóquio" (田吾作と杢兵衛の東京見物), do mangaka e cartunista político Rakuten Kitazawa, considerado pelos estudiosos o precursor do mangá moderno. É creditado também a Rakuten Kitazawa a introdução do uso de personagens de mangá como mercadoria, Chame e Dekobo (茶目と凸坊), dois garotos travessos foram usados como figurinhas colecionáveis e bonecos já nos primeiros anos de 1900 (MCCARTHY, 2014, p. 20).

No Brasil, em 1905 foi lançada em estilo europeu, com logotipo de Angelo Agostini, a revista "O Tico-Tico", que conforme aponta o professor de Comunicação e Arte da Universidade de São Paulo, fundador e coordenador do Observatório de História em Quadrinhos e editor da revista $9^{a}$ Arte Waldomiro Vergueiro, não era composta exclusivamente por histórias em quadrinhos, trazia também contos infantis, passatempos, poesias, matérias sobre datas comemorativas etc. Desde seu início, entretanto, incluiu histórias em quadrinhos em suas páginas, tornando o contato com vários personagens dos comics norte-americanos do começo do século XX possível aos leitores brasileiros. O primeiro deles foi Chiquinho, sem dúvida o mais famoso personagem da revista (VERGUEIRO, 2017, p. 32).

Durante muito tempo no Brasil se acreditou que as histórias em quadrinhos da revista Tico-Tico fossem originais, criadas por artistas brasileiros, principalmente Chiquinho, mas, segundo Álvaro de Moya, em uma exposição sobre quadrinhos realizada em 1951, foi exposto que Chiquinho na verdade era um "decalque" 51 do personagem Buster Brown, de Richard F. Outcault de 1902. O delcaque foi feito no Brasil pelos artistas Luís Gomes Loureiro, Augusto Rocha, Alfredo Storni, Paulo Affonso, Osvaldo Storni, filho de Alfredo e Miguel Hochmann (MOYA, 1986, p. 29).

Contudo, conforme ressalta o professor Waldomiro Vergueiro,

A revista O Tico-Tico também tornou possível a disseminação de vários
personagens de histórias em quadrinhos no Brasil, muitos deles produzidos
por autores da própria terra, que foram publicados durante anos,
representando uma plêiade de interessantes criações artísticas
(VERGUEIRO, 2017, p. 33).

Waldomiro Vergueiro aponta também que entre os personagens mais importantes internacionais trazidos pela revista estavam: Mickey Mouse (no início chamado de Ratinho Curioso), desenhado por Ub Iwerks (1901-1971) e

${ }^{51}$ Decalque - uma cópia do original sem autorização. 
posteriormente por Floyd Gottfredson (1905-1986); Krazy Kat (no Brasil, As Aventuras do Gato Maluco), de George Herriman (1880-1944); Little Jimmy, de James Swinnerton (1875-1974); Popeye (com o nome de Brocoió), de Elsie C. Segar (18941938); Mutt e Jeff, de Bud Fisher (1885-1954); e o Gato Félix, de Pat Sullivan (18871933) (VERGUEIRO, 2017, p. 33).

Segundo a estudiosa e professora da Universidade Anhembi-Morumbi Maria Cristina Merlo,

O Tico-Tico representou um marco na história do ensino e educação no Brasil realizado de maneira digna, fiel, divertida e com muita paixão. Foi responsável, em parte, pelo surgimento de grandes nomes de nossa literatura, artes e cultura em geral (MERLO, 2004).

De acordo com o escritor, historiador e crítico literário Leonardo Arroyo (1918-1985), O Tico-Tico seguiu a tradição da imprensa infantil internacional, como as inglesas The Liliputian Magazine (1751-1752), Infant's Magazine, The Children's Friend e Little Folk; as francesas Le Journal des Jeunes Personnes, La Femme e La Famille, Journal des Enfants e La Semaine des Enfants, etc. (ARROYO, 1990, p. 152)

Sobre a importância da revista no cenário nacional, Waldomiro Vergueiro cita seu trabalho de 2005 quando da comemoração do centenário de publicação da revista:

A revista O Tico-Tico é um marco entre os títulos regulares dirigidos à infância
no Brasil. Em primeiro lugar, por ter sido a pioneira em trazer regularmente
histórias em quadrinhos, em uma época em que a arte gráfica sequencial não
tinha absolutamente qualquer reconhecimento por parte dos intelectuais, dos
pais ou dos professores. Em segundo lugar, por se constituir, até o momento,
na mais longeva revista infantil já publicada no país, atingindo 56 anos de
vida. E, por último, mas talvez não menos importante, por ter preenchido o
inconsciente coletivo de várias gerações de jovens brasileiros, que por ela
guardaram as mais gratas e pungentes recordações (VERGUEIRO apud
VERGUEIRO, 2017).

A revista $\mathrm{O}$ Tico-Tico, como as demais revistas, jornais e suplementos que Ihe serviram de modelo, continha propagandas em vários níveis de exposição: havia a propaganda direta, em legenda simples somente de texto no cabeçalho ou rodapé com mercadorias como o "Sabonete de Reuter - para crianças" ou mais elaborados com figuras (Figura 42, pág. 84) provavelmente direcionada às mães; propagandas disfarçadas de brincadeiras como o concurso da edição número 15 do ODOL (enxaguante bucal alemão lançado em 1892 pelo empresário Dresden Karl August Lingner), que prometia às primeiras 100 crianças que resolvem um enigma um frasco do produto com um grande desconto no preço pela empresa distribuidora; e havia ainda a propaganda inserida nas histórias como a da história "As desventuras de 
Chiquinho - a corrida com Jagunço" da edição número 7, em que no primeiro quadro da quarta linha, na legenda há o texto: "Na outra sala, estava papae lendo o Malho" (em itálico no original), sutilmente indicando que o jornal que adultos liam ou deveriam ler era, naturalmente, O Malho, editado na época por Angelo Agostini, do qual a revista Tico-Tico era uma espécie de suplemento ${ }^{52}$.

Do outro lado do mundo, segundo Alaniz, devido a censura severa dos czares, a Rússia não forma um longo pedigree em caricaturas e cartuns satíricos como o resto da Europa ocidental, mas a sensibilidade política subversiva vista nos lubki contra o czar Pedro no século XVIII viveu nos trabalhos de artistas como Alexei Venetsianov (que publicou o primeiro jornal satírico russo no século XIX) e Terebenev com seus cartuns antinapoleônicos. No meio do século surgiu o jornal humorístico Eralash (confusão), mas foi logo vítima da censura despertada pela turbulência revolucionária na França. Em 1859, foi publicado o jornal satírico de maior importância do século, Iskra (faísca), que se descrevia como "a crônica dolorosa dos lados engraçados e escuros da vida russa", seguido por outro periódico político ilustrado, Gudov (apito). Um dos mais importantes caricaturistas da época, Alexander Lebedev, publicou seus trabalhos nos jornais Strekoza (libéula) de 1875, Oskolki (fragmentos) de 1891 e outros. Em 1896, a estreia do semanário alemão de Albert Langen, Simplicissimus, teve um impacto incalculável nos cartunistas russos (ALANIZ, 2010, p. 26).

The 1905 Revolution and its aftermath saw a burst of caricature and satirical journals as a result of the stark changes in the nation's political life. In the wake of the violent crackdown against protesters in St. Petersburg in January (an event known as "Bloody Sunday"), Czar Nicholas II was forced to concede some of his powers in the form of the October Manifesto, which promised greater civic rights and freedoms, including freedom of speech. Publishers seized on the reforms and new journals poured forth - 309 from 1905 to 1907, as compared to 89 for the whole of the nineteenth century. And it was not only a matter of quantity; some of the greatest works of Russian caricature appeared in this era; renowned artists such as Boris Kustodiev, Dobuzhinsky, Bilibin, and Valentin Serov vented forth their indignation at the state in morbid expressionistic works full of marauding skeletons, piles of corpses, grotesque politicians, and soldiers. In one the most striking images, "October Idyll" (1905), Dobuzhinsky showed a huge splotch of blood against a wall and sidewalk, with a child's doll, a shoe, and a pair of glasses strewn on a city street ${ }^{53}$ (ALANIZ, 2010, p. 29).

52 Informações inferidas a partir da leitura dos originais das revistas Tico-Tico, disponíveis na Hemeroteca Digital da Biblioteca Digital da Fundação Biblioteca Nacional: http://bndigital.bn.br/acervodigital/tico-tico/153079

${ }^{53}$ A Revolução de 1905 e suas consequências viram uma explosão de caricaturas e revistas satíricas como resultado de mudanças radicais na vida política da nação. Na sequência da violenta repressão 
Alaniz aponta que após a prisão Bilibin (Ivan Yakovlevich Bilibin, 18761942) e fechamento do jornal Zhupel (Bicho Papão) por causa da publicação do cartun "Donkey - Equus Asinus” (burro) em 1906 - um burro rodeado dos brasões czarianos - a imprensa satírica russa aprendeu a usar de sutileza e mensagens veladas para burlar a censura do czar. Como ressalta Alaniz, às vezes, esses artistas faziam uso da comparação "cross-gutter"54 e propriedades sequenciais de painéis justapostos já vistos nos lubok. Como a primeira capa de Zritel (espectador), que seguiu a restrição governamental e, mesmo assim, descreveu abertamente a desordem de 1905, colocando um quadro de pés de soldados marchando ao lado de outro quadro de pés de civis, fugindo. A arte sem palavras seguiu a regra da lei, mas o significado, lido "através" dos painéis, era claro. Tais estratégias de estética politizadas, acentuadas ao longo de séculos na tradição folclórica do lubok, revigoradas pelos futuristas e cartunistas satíricos, transitariam para o início da era soviética - e transformaram a herança dos quadrinhos da Rússia de maneiras novas, excitantes e trágicas.

contra manifestantes em São Petersburgo em janeiro (um evento conhecido como "Domingo Sangrento"), o czar Nicolau II foi forçado a conceder alguns dos seus poderes na forma do Manifesto de Outubro, que prometeu maiores direitos civis e liberdades, incluindo a liberdade de expressão. Os editores aproveitaram as reformas e novos jornais afloraram de 309 para 1905 a 1907, em comparação com os 89 de todo o século XIX. E não foi apenas uma questão de quantidade; algumas das maiores obras da caricatura russa apareceram nesta era; artistas renomados como Boris Kustodiev, Dobuzhinsky, Bilibin e Valentin Serov colocaram para fora sua indignação com o Estado em mórbidas obras expressionistas cheias de esqueletos arrogantes, pilhagens de cadáveres, políticos grotescos e soldados. Em uma das imagens mais impressionantes, "October Idyll" (1905), Dobuzhinsky mostrou uma grande quantidade de sangue contra uma parede e uma calçada, com uma boneca de criança, um sapato e um par de óculos espalhados por uma rua da cidade (ALANIZ, 2010, p. 29) [tradução da autora].

${ }^{54}$ Cross-gutter - pulando a sarjeta, seguindo a teoria de McCloud, de que o leitor cria o significado no espaço entre um quadro e o outro, retomaremos este conceito no capítulo linguagem. 
Histoire sans paroles. - Un Arroseur public
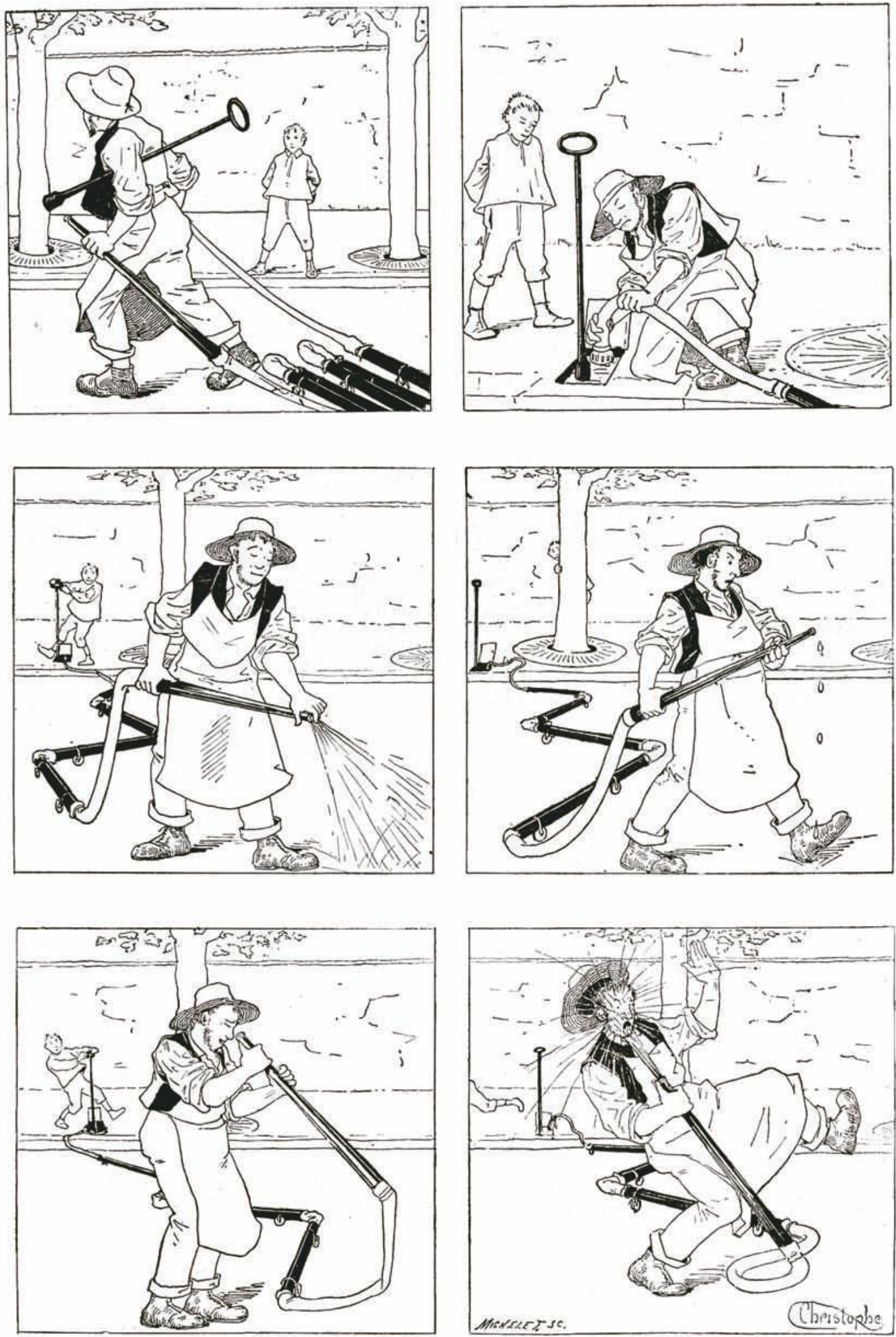

Figura 39 - Christophe (Georges Colomb), Un Arroseur Public, Le petit français illustré, 1889.xxix 


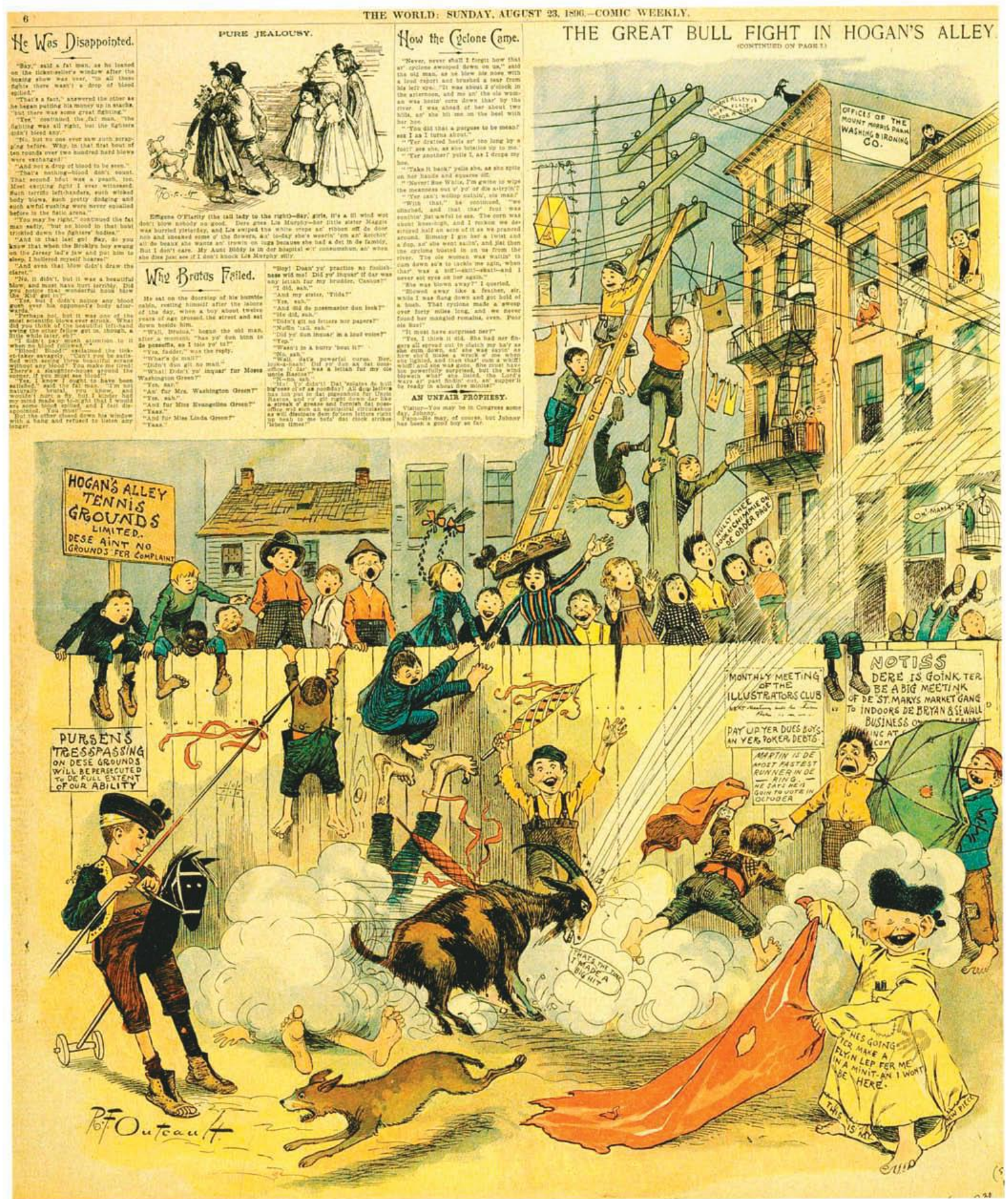

Figura 40 - Richard F. Outcault, Hogan's Alley, New York World - 1896. ${ }^{\text {xx }}$ 


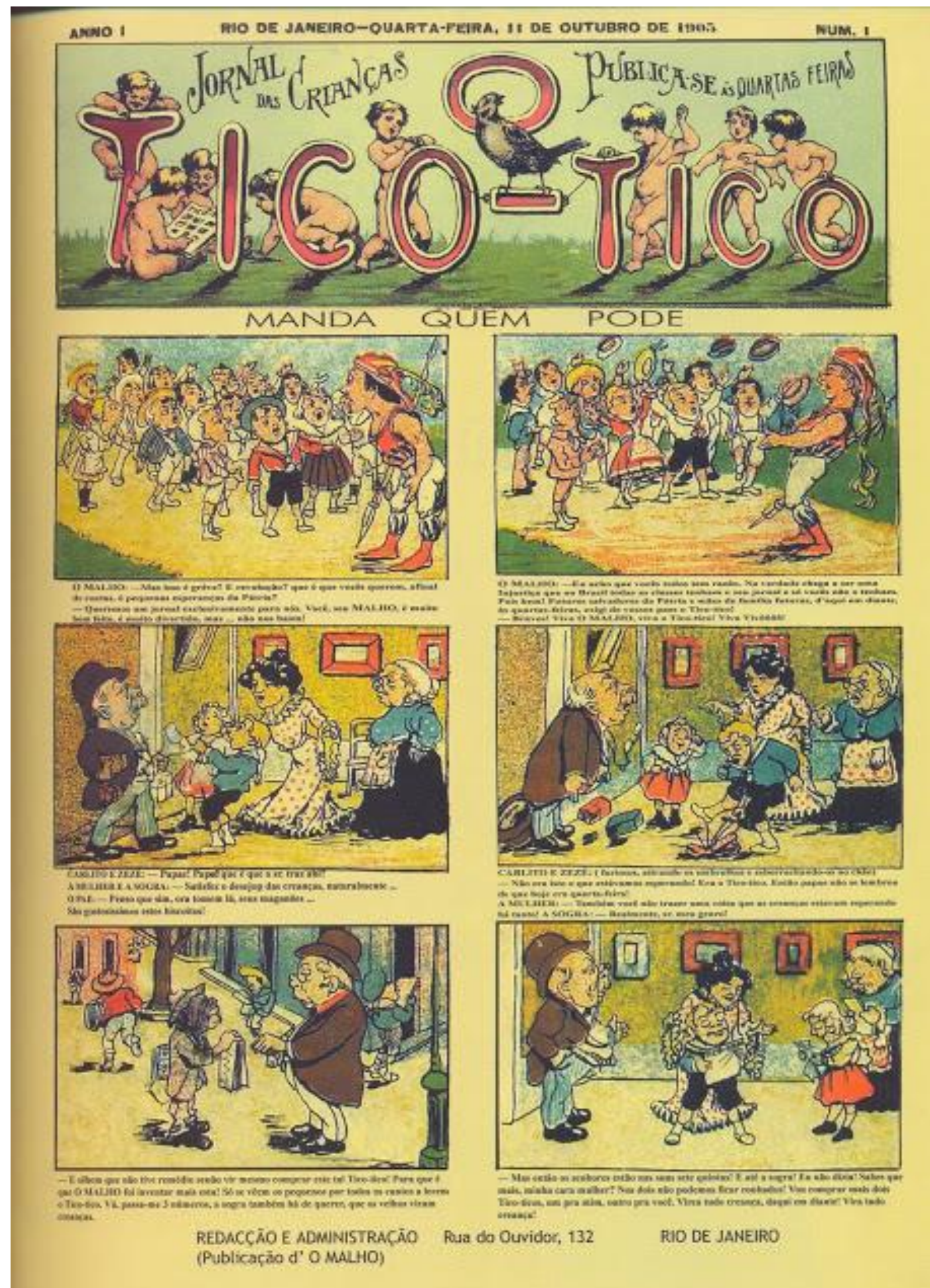

Figura 41 - Revista Tico-Tico, oㅡ 1 - 11/10/1905 - extraído do site Efemérides Escoteiras, em seu tópico datando o nascimento da revista Tico-Tico que mais tarde divulgaria o escotismo brasileiro ${ }^{x \times x i}$ 
Annunoios d'O Troo-Tioo

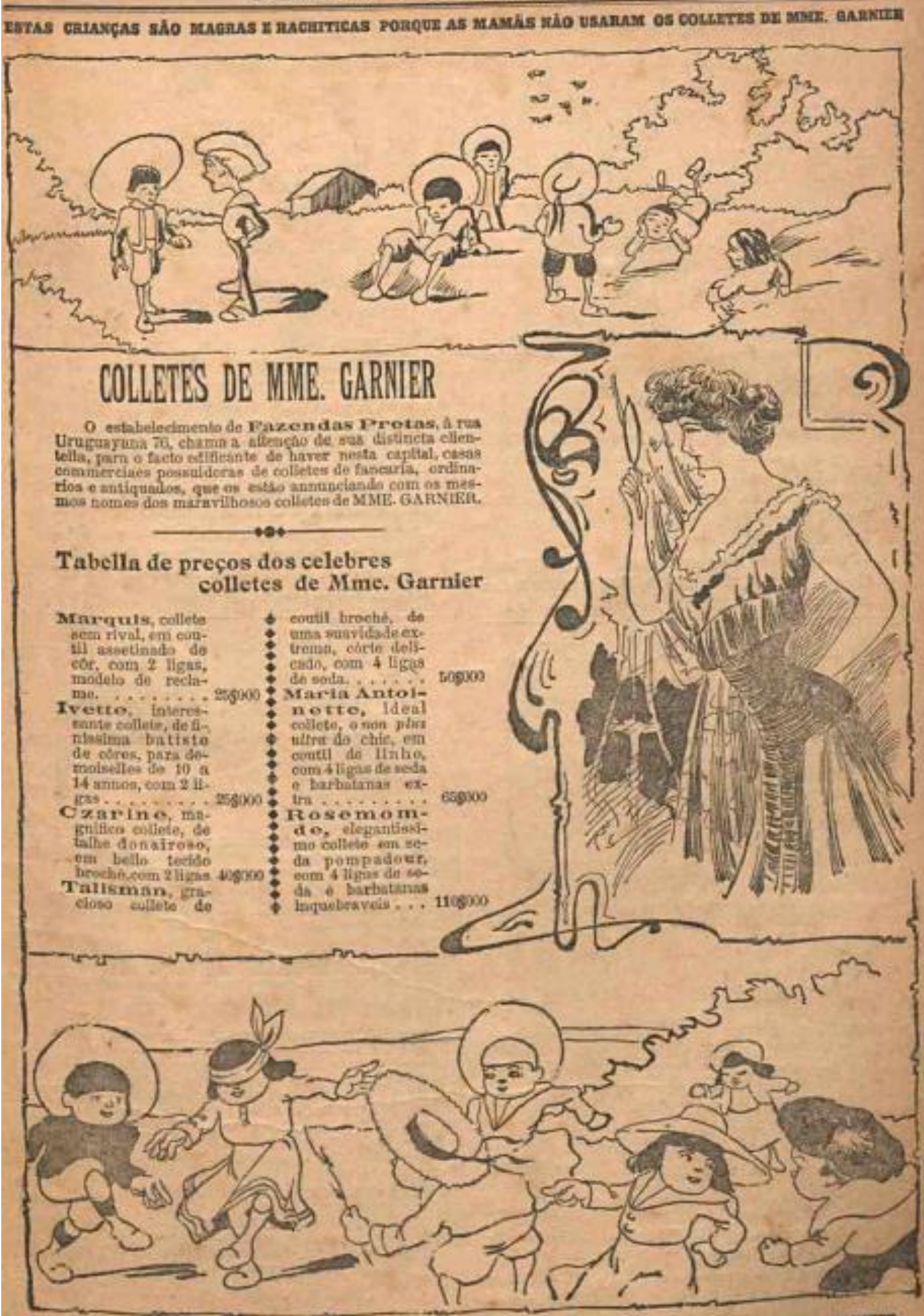

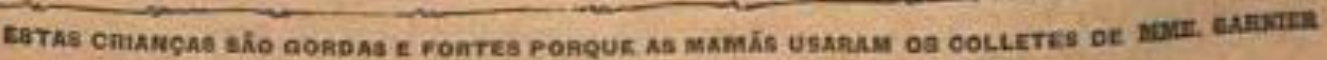

Figura 42 - Propaganda dos Colletes de Mme. Garnier na Revista Tico-Tico no 15 de 17/01/1906xxxi 


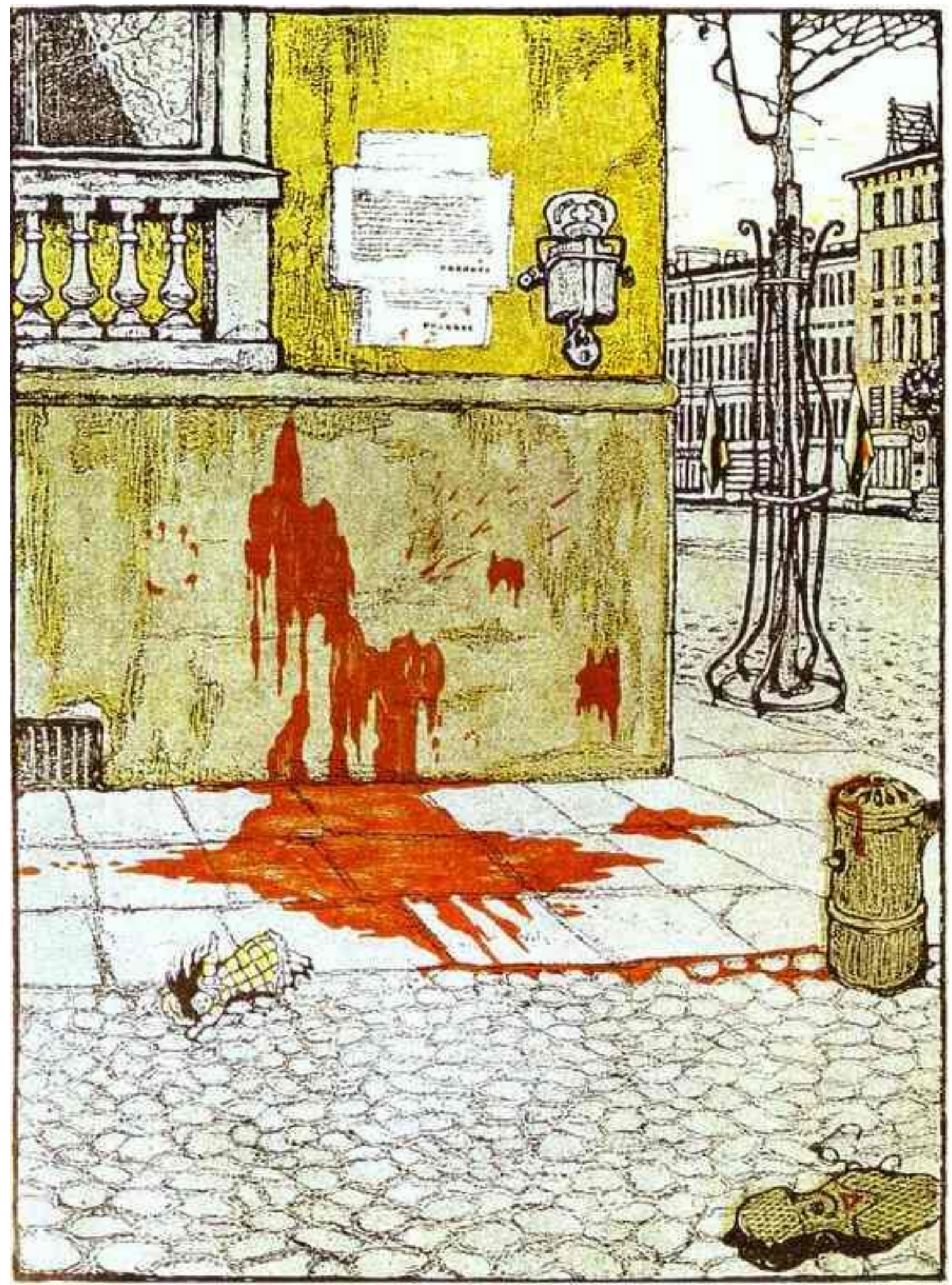

Figura 43 - October Idyll - Mstislav Dobuzhinsky - 1905xxxiii 


\subsection{Engraçados, mas nem tanto, Tintin e os soviéticos}

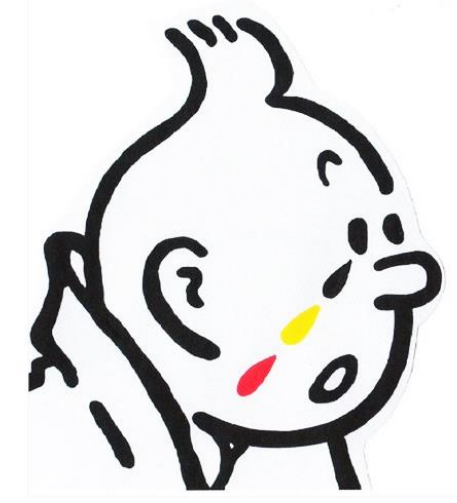

\#JesuisBruxelles \#PrayforBelgium ${ }^{55}$

No mesmo ano da primeira aparição de "Tintin", personagem de Hergé, no suplemento de do jornal franco-belga Le Petit Vingtième, 1929, era publicada nos Estados Unidos, o material que originaria as revistas em quadrinhos, a publicação semanal da editora Dell com o título de The Funnies. Esse mesmo ano marca a transição de dois personagens literários para o formato de tiras em quadrinhos, "Tarzan" de Edgar Rice Burroughs, ilustrado por Hal Foster e "Buck Rogers no século 25" de Philip Francis Nowlan ilustrado por Dick Calkins, ambos vindo das pulp magazines, revistas de literatura em fascículos consideradas de baixa qualidade. A transição de ambos personagens foi um sucesso, talvez pelo fato de, nos dois casos, os autores estarem a frente do projeto, reescrevendo suas histórias na nova linguagem. No mesmo período, no entanto, a Rússia perdia seus quadrinistas, que fugiam para o estrangeiro, principalmente para Sérvia, ou eram presos e mortos pela austeridade do regime soviético.

Ian Gordon aponta que com o sucesso das tiras de jornal fez com que seus editores compilassem o material em livros com capa de papelão (como já havia sido feito com as narrativas ilustradas no estilo de Töpfer), que eram vendidas em lojas de brinquedos e livrarias. Os preços giravam em torno de 25 a 60 cents depedendo da qualidade e tamanho do papel e da brochura. Apesar de não ter durado muito (cerca de um ano e meio), a editora Dell Comics lança a revista Funnies em formato de tabloide $(43 \times 28 \mathrm{~cm})$ contendo material de quadrinhos original a um preço mais

${ }^{55}$ Epígrafe - fonte: Meme do personagem de Hergé, Tintin, chorando acompanhado das hastag \#JesuisBruxelles ou \#PrayforBelgium, que foi criado e compartilhado por internautas nas redes sociais em campanha de apoio e solidariedade à Belgica durante a onda de atentados terroristas em 2016. 
acessível, 5 cents. Maxwell (M. C.) Gaines e Wildenberg, empregados da Eastern Color Printing Company, que editava as seções de tiras para os suplementos de domingo para os jornais da Costa Leste, persuadiram a editora Procter \& Gamble a publicar Funnies on Parade, uma revista com reimpressões de tiras cômicas, com 36 páginas, medido sete e meia polegadas por dez polegadas com capa, para ser distribuída como prêmio publicitário. Esta foi a primeira revista com as características físicas das revistas em quadrinhos americanas (GORDON, 1998, p. 129).

Gabilliet ressalta que nos primeiros dias da revista em quadrinhos, muitas relançavam no novo formato as tiras de jornais de Walt Disney. Ele acredita que o intuito era atrair leitores jovens do jornal sem perder os pais e o facilitador foi o sucesso dos desenhos animados lançados por Walt Disney, Warner Bros e 20th Century Fox desde os anos 30 (GABILLIET, 2010, p. 52).

Segundo Keith M. Booker, o artista belga Georges Prosper Remi criou seu pseudônimo Hergé a partir da pronuncia fonética francesa de "RG", suas iniciais "GR" ao contrário. Hergé é um dos grandes nomes do quadrinho mundial, mais conhecido pelos 23 livros em quadrinhos dedicados ao jovem repórter Tintin (BOOKER, 2014, p. 174).

O quadrinista, pesquisador de quadrinhos e professor na Universidade de Lancaster, Inglaterra, Benoît Peeters (1956), aponta que a chave principal do método narrativo de Hergé é a aplicação discreta de elementos importantes, que Peeters chama de "understatedness" 56 . Explicada em sua análise pela elaboração de um cenário realista e natural, cujo os elementos ganham destaque na trama através de suas repetidas aparências. Peeters explica que,

It is always possible to take things at face value in Les Bijoux de la Castafiore [em português "As Jóias da Castafiore"]: the myriad birds and flowers may pass unnoticed right up the moment where their role becomes explicit ${ }^{57}$ (PEETERS, 2014, p. 251).

Booker ressalta que duas grandes influências para Hergé foram Zig et Puce, uma história em quadrinhos franco-Belga criada por Alain Saint-Ogan em 1925 e Krazy Kat de George Herriman de 1913.

Segundo o pesquisador e curador da biblioteca da Université Bordeaux

\footnotetext{
${ }^{56}$ Understatedeness - Understate + ness $=$ qualidade daquilo que é apresentado ou expresso de um modo menor, pior ou menos importante do é realmente.

57 É sempre possível perceber as coisas em seu valor nominal em Les Bijoux de la Castafiore [em português "As Jóias da Castafiore"]: a miríade de aves e flores podem passar desapercebida até o momento em que seus papéis se tornam explícitos (PEETERS, 2014, p. 251) [tradução da autora].
} 
Montaigne, Julien Baudry, a carreira profissional de Alain Saint-Ogan como desenhista começou em torno de 1911-1913. Depois de treinar como desenhista na l'École des Arts Décoratifs, ele fez alguns desenhos sob encomenda. Naquela época, o jovem experimentou diferentes variantes das artes gráficas, incluindo a arte do cartaz e da ilustração. Nos anos anteriores à guerra, ele hesitou, especialmente entre os quadrinhos humorísticos e a ilustração infantil.

Les champs de production culturelle du dessin de presse et de la création pour enfants sont les deux pôles de sa carrière, et il participeà leurs évolutions conjointes ${ }^{58}$ (BAUDRY, 2014, p. 21).

Baudry destaca que Alain Saint-Ogan inovou tanto os quadrinhos, quanto os livros infantis franceses com experimentalismos gráficos. Multimidiático, ele se aventurou também no rádio, animação e romances. É creditado a ele o desenvolvimento da "linha clara" que será seguida e aprimorada por Hergé (BAUDRY, 2014).

Krazy Kat primeiro apareceu em 1913, de acordo com Booker, em uma tira cômica narrando o triângulo amoroso entre o gato (Krazy Kat), um rato (Ignatz) e um cachorro (Offisa Pup). O rato lança um tijolo no gato. O gato interpreta ser atingido com o tijolo como amor. O cão tenta parar o rato. Para Booker, a história é ambientada em uma interpretação surreal minimalista do Paint Desert (deserto pintado) no Arizona. Dentro deste quadro simples, o criador George Herriman fornece um modelo complexo de análise da condição humana (BOOKER, 2014, p. 152).

Ian Gordon cita vários intelectuais sobre a obra de Herriman,

George Herriman's "Krazy Kat" has long been a favorite of the intelligentsia. Jay Cantor's 1988 novel Krazy Kat figures Krazy as the key to the latter half of the twentieth century. In 1924 Gilbert Seldes described Herriman's work as "the most amusing and fantastic and satisfactory work of art produced in America today." E. E. cummings in the 1940s found Krazy Kat's capacity for love an illimitable transcending force indicative of true democracy, which is fulfilled only when "society fails to suppress the individual." Recently Kirk Varnedoe and Adam Gopnik have described Herriman as liberating "the sublime landscape from the decorum of high seriousness." Seldes found "Krazy Kat" a delicate mixture of sensitiveness, irony, and fantasy. Varnedoe and Gopnik regard the strip as "Arcadia without nostalgia" and Herriman's style as prefiguring Surrealism, which used some of his devices ${ }^{59}$ (GORDON, 1998, p. 75).

58 Os campos da produção cultural do desenho de imprensa e a criação para crianças são os dois polos de sua carreira, e ele participa conjuntamente em suas evoluções (BAUDRY, 2014, p. 21) [tradução da autora].

$59 \mathrm{O}$ "Krazy Kat" de George Herriman tem sido o favorito dos intelectuais. O romance de Jay Cantor [novelista e ensaísta] de 1988, Krazy Kat, descreve Krazy como a chave para a segunda metade do século XX. Em 1924, Gilbert Seldes [escritor e crítico cultural] descreveu o trabalho de Herriman como 
Para lan Gordon, Krazy Kat é tudo isso e muito mais. Como um dos pioneiros na temática humorística classificada como "funny animals" (animais engraçados), ele transforma em beleza aquilo que os críticos consideram a mais básica forma de piada visual. Como a famosa cena em que Krazy Kat, alheio ao intenso desafeto do rato Ignatz, considera uma prova de amor o tijolo que o rato lhe atira na cabeça. Gordon aporta que a premissa básica de "Krazy Kat" era menos violenta do que a tira de "Sambo" de Willian Marriner (1873-1914), o que a temperava seu humor era o fato dos personagens serem animais. Ele acredita que seria fácil tecer a história de Krazy Kat como uma metáfora da existência ambígua do negro na América branca, porque a constante incerteza sobre o gênero sexual, as tentativas de Herriman de representar o/a gato/a louco/a sem que ele/a pareça ser, a própria identidade racial ambivalente do autor ofereceria possibilidades nessa linha de análise (GORDON, 1998, p. 76).

De acordo com o biógrafo Michael Tisserand, somente após sua morte em um estudo sobre grandes cartunistas, foi constatado na certidão de nascimento de Herriman que ele era, de acordo com a lei americana, uma pessoa negra (sua bisavó era uma negra livre da Louisiana). Herriman, segundo consta, escondeu durante toda sua vida sua ascendência. Tendo vivido em plena era das Leis Jim Crow ${ }^{60}$, caso sua raiz negra viesse à tona, pelo segregacionismo, impossibilitaria que ele se educasse em uma escola para brancos, morasse em um bairro de branco, se casasse com uma esposa branca e trabalhasse junto aos brancos (TISSERAND, 2016).

Hergé, assim como muitos outros quadrinistas, foi muito influenciado pelo surrealismo bucólico de Herriman, e com a "recorrência de mote", uma vez que Krazy Kat fazia tanto uso da anedota recorrente, a ponto de poder brincar com a expectativa do leitor em determinado comportamento dos personagens. Essa recorrência

\footnotetext{
"a obra de arte mais divertida, fantástica e satisfatória produzida na América hoje". E. E. Cummings [poeta, pintor, ensaísta e dramaturgo] na década de 1940 achou que a capacidade de Krazy Kat de amar, uma força de transcendência ilimitada, indicativa da verdadeira democracia, que é cumprida somente quando "a sociedade não suprime o indivíduo". Recentemente, Kirk Varnedoe [historiador e professor] e Adam Gopnik [escritor e ensaísta] descreveram Herriman como libertadora "a paisagem sublime do mais sério decoro". Seldes encontrou "Krazy Kat" uma mistura delicada de sensibilidade, ironia e fantasia. Varnedoe e Gopnik consideram a tira como "Arcadia sem nostalgia" e o estilo de Herriman como prefiguração do surrealismo, que usava alguns de seus dispositivos (GORDON, 1998, p. 75) [tradução da autora].

${ }^{60}$ Leis Jim Crow, nome baseado na canção "Jim Crown" que o ator, cantor e dançarino branco, Thomas D. Rice, interpretava com o rosto pintado de negro (black face), usando roupas que imitavam escravos de plantações do Sul dos Estados Unidos. As leis adotadas em muitos estados sulistas instauravam a segregação racial, separando instituições, comércio e bairros entre brancos e negros.
} 
aprimorada se tornará a repetição de elementos de forma sutil já apontada por Peters como understatedness,

Booker ressalta que, "Tintin no País dos Sovietes" (Les Aventures de Tintin, repórter du "Petit Vingtième", au pays des Soviets) estreou na edição 11 do Le Petit Vingtième, sofreu a crítica de alguns intelectuais pela falta de pesquisa histórica e estilo cru, contudo, as aventuras do jovem jornalista, infiltrado no exército soviético, teve muito sucesso. O estilo de desenho em linha clara, o realismo das ambientações e as referências satíricas críticas à política de seu tempo (claramente anticomunistas) atraíram a atenção positiva tanto das crianças quanto dos adultos belgas.

Não é à toa que o tema dos soviéticos estava muito presente nesse período, José Alaniz aponta que pelo final da primeira década soviética, com Lenin morto, o país esgotado e a Nova Política Econômica (NEP) minando (como alguns viram) os princípios incondicionais da Guerra Comunista, o Estado começou a mitigar a liberdade de expressão, particularmente na vanguarda, que era agora acusada de "modo obtusos burguês" e "formalismo",

Starting in earnest in the 1930s, with Joseph Stalin having eliminated his rivals, consolidated power, cancelled NEP, and launched the first Five Year Plan of crash industrialization, Soviet policies on the arts looked inward, casting an intolerant gaze on anything that bore traces of Western-type mass culture and, during the cold war, America. Comics, broadly speaking, fell victim to this political outlook; no comic book industry as such ever developed in the Soviet era $^{61}$ (ALANIZ, 2010, p. 32).

Durante a era soviética os quadrinhos fizeram parte das proibições governamentais, com sua linguagem sendo rechaçada como americanismo, lixo e depravação burguesa. Mesmo assim era tolerada nas revistas educativas infantis (nunca com personagens estrangeiros). Havia ainda a produção de contravenção, mas com a crescente perda de liberdade, muitos quadrinistas russos foram presos e executados ou fugiram do regime emigrando principalmente para a Sérvia (ALANIZ, 2010, p. 58).

Não só o regime soviético mitigou seus artistas por questões políticas, na Alemanha, as revistas e jornais satíricos, com suas caricaturas e cartuns foram

61 Começando de verdade na década de 1930, com Joseph Stalin, tendo eliminado seus rivais, consolidado seu poder, cancelado a NEP e lançado o primeiro Plano Quinquenal de industrialização acelerada, as políticas soviéticas sobre as artes se votaram para dentro, lançando um olhar intolerante sobre qualquer coisa que trouxe vestígios de cultura de massa do tipo ocidental e, durante a guerra fria, a América. Os quadrinhos, em termos gerais, foram vítimas desta perspectiva política; nenhuma indústria de quadrinhos como tal chegou a se desenvolver na era soviética (ALANIZ, 2010, p. 32) [tradução da autora]. 
reprimidos, as vezes brutalmente, desde o início da aparição do Partido Nazista, fazendo com que muitos quadrinistas se voltassem para as histórias cômicas não políticas ou ilustração de livros. As tiras Vater und Sohn (pai e filho) publicadas no jornal Berliner Ilustrirte Zietung de 1933 a 1937 estavam nesse contexto, de acordo com Nina Schipper que em 2015 compilou as tiras do jornal em um livro lançado no Brasil pela Editora Octavo, depois de ser proibido de trabalhar pelo regime nazista, o cartunista político opositor do regime Erich Ohser criou o pseudônimo para E. O. Plauen para conseguir trabalho e sustentar a família (SHIPPER, 2015, p. 7-9). As tiras mudas foram um sucesso mundial tanto com crianças quanto adultos, por trazer questionamentos sobre a rigidez familiar e mostrar um modo novo de olhar a criança. Por não conter texto elas foram facilmente exportadas por toda Europa e América, contudo conforme ressalta Schipper, Ohser nunca conseguiu esconder sua dissidência em relação ao nazismo,

\begin{abstract}
Quando a guerra atinge também a população civil, o ateliê de Ohser é destruído, mas o artista permanece em Berlim. Ele e Knauf encontram alojamento temporário em uma casa na cidade bombardeada, e é ali que os dois amigos, no auge de seu desespero e desencorajamento, manifestam um ao outro opiniões implacáveis sobre Hitler, Goebbels e a guerra perdida. As conversas são entreouvidas por seus vizinhos, o capitão Bruno Schultz e sua esposa, que os denunciam. No início de 1944, Osher e Knauf são detidos e condenados à pena de morte (SHIPPER, 2015, p. 9-10).
\end{abstract}

Não há nos quadrinhos, cômicos ou não, uma tendência política específica, tanto a sátira, quanto o drama são temáticas usadas para defender ou contestar qualquer regime. A Comiclopedia Lambiek aponta que os suplementos jornalísticos, como "Notenkraker" (1907) e as revistas ilustradas como "De Neef van Prikkebeen" (1910), adquiriram um tom mais crítico e mordaz conforme se aproximava a primeira guerra mundial (1914-1919) (SCHUDDEBOOM e KNUDDE, 1994-2017). Mas da mesma forma que a narrativa imagética serviu nos primeiros séculos para propagar para igreja, além da vida de Cristo e dos santos, os interesses da elite do vaticano, os quadrinhos serviram durante o regime fascista de Benito Mussoline para educação infantil e propaganda em revistas como: II Giornale dei Balilla - 1923 e La piccola italiana - 1927, e na Holanda sucumbiram à ocupação nazista.

Toda maturidade estética e temática sócio-política dos quadrinhos holandeses foram suplantadas pelo regime nazista durante a ocupação na segunda guerra mundial. Obrigados a se filiar à Kulturkammer (Câmara de Cultura), os artistas eram obrigados a submeter seus trabalhos à severa censura, alguns foram forçados a abandonar seus projetos pois eram considerados vexatórios ao regime nazista ou 
suas personalidades, como, por exemplo, a tira cômica de Henk Backer "Adolfus" que foi cancelada para que o Fuhër Aldolf Hitler não fosse associado ao personagem e ridicularizado. Alguns artistas se recusaram a cooperar com o regime, como Alfred Mazure criador do popular "Dick Bos", que não aceitou fazer de seu personagem um oficial nazista. Contudo vários artistas se mantiveram neutros quanto à ocupação ou apoiaram abertamente o regime nazista como Peter Beekman cujo protagonista na série "Hansje, Ansje en de Meeuw" era um orgulhoso membro da Jeugdstorm equivalente holandês da Hitler Jugend, a juventude hitlerista (SCHEDDEBOOM e KNUDDE, 1994-2017).

Uma forma bastante sutil de propaganda nazista holandesa foi a revista em quadrinhos "Flits de Herder en Bull de Dog" (1943), de Matho, com a história de filhote de cão pastor alemão Flits, que tinha que assistir os ratos com "hook-noses" (nariz em gancho, um estereotipo caricato vexatório para judeus) comiam da sua tigela enquanto seu pai estava sendo acorrentado pelo bulldog inglês, o ganso francês e a mula americana. Esta revista deveria ter sido distribuída em todas as escolas holandesas, mas a maioria dos professores se recusou a fazê-lo, com a revista desaparecendo "misteriosamente" das bibliotecas escolares, o que a torna um item muito raro hoje em dia (SCHEDDEBOOM e KNUDDE, 1994-2018).

Para escapar da censura os artistas holandeses desenvolveram um discurso metafórico e oblíquo, como Hugo Lous, com a história de Witsok, um cavalo branco que tem um desejo profundo de deixar o país.

De certa forma, o fascismo foi beneficial para o desenvolvimento de uma indústria nacional do quadrinho italiano, pois nesse período houve proibição de importação de histórias em quadrinhos estrangeiras, a única exceção foi para as revistas de "Topolino" nome italiano de Mickey Mouse, pois Romano e Anna Maria Mussolini, filhos do Duce, eram grandes fãs dos personagens. Disney conseguiu a concessão para distribuição dos seus personagens durante uma visita à casa de Mussolini em 1935. O método de distribuição de Disney, consistia em, além de exportar o material feito nos EUA, empregar estúdios e artistas locais, que adaptavam seus personagens e narrativas à realidade local, ele fez isso em diversos países, mas seus estúdios na Itália foram os mais bem-sucedidos, exportando o material italiano para outros países da Europa e América do Sul (MANETTI, 2014). 


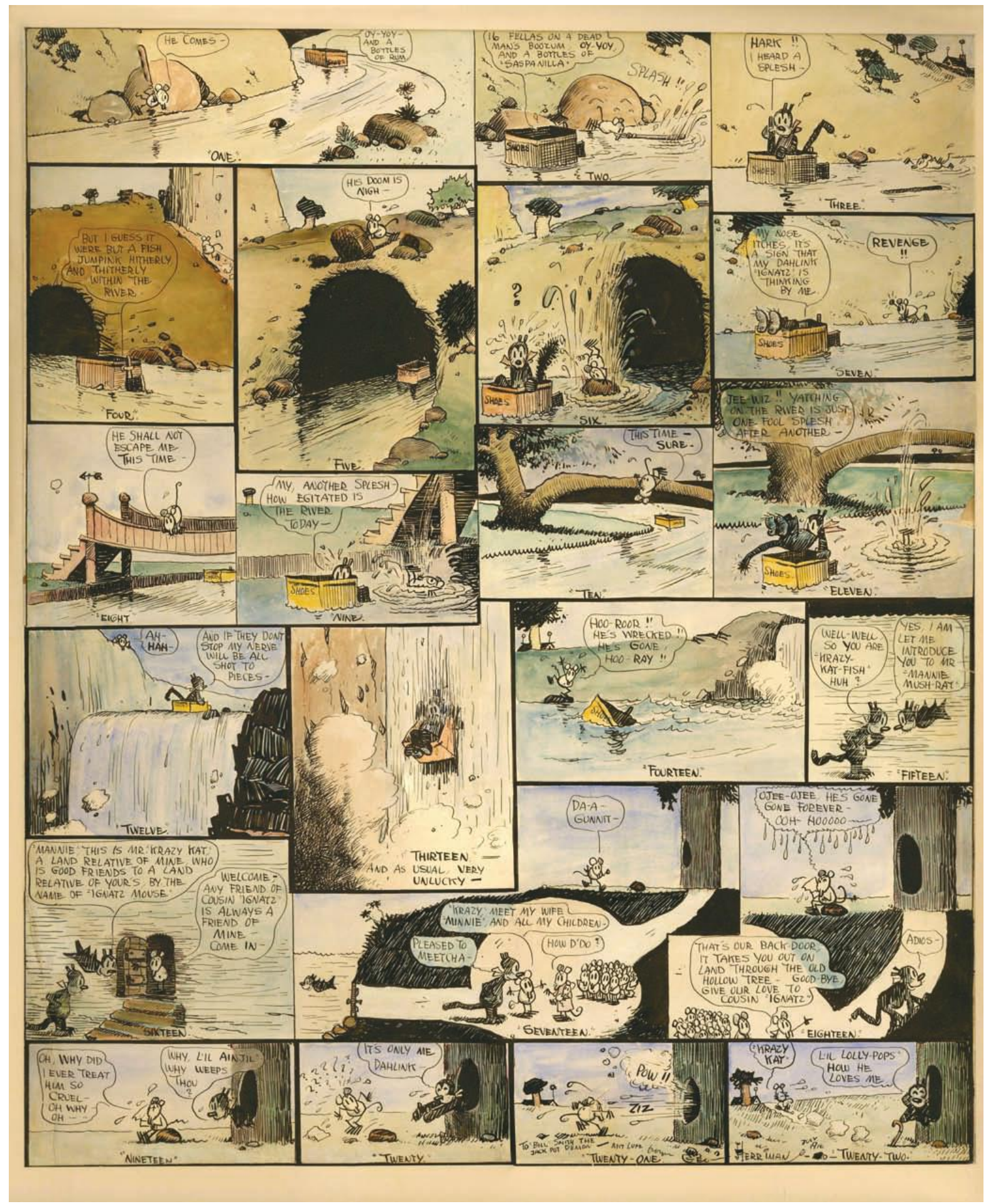

Figura 44 - Krazy Kat - George Herriman - 1916xxxiv 


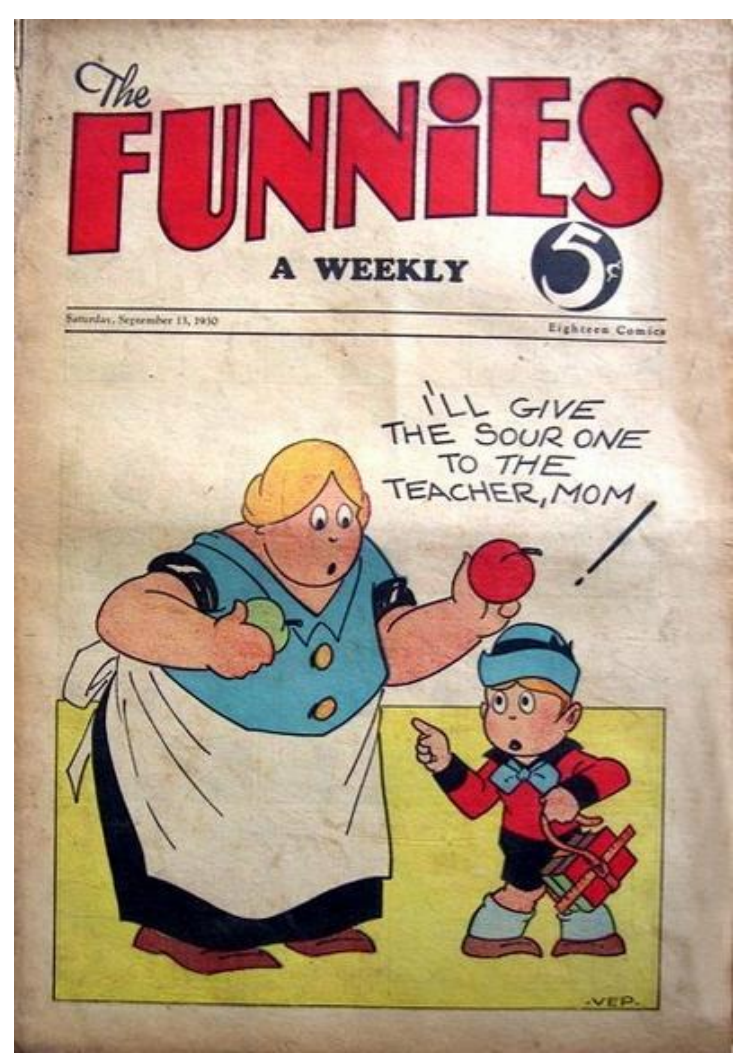

Figura 45 - The Funnies no 28 - Setembro - 1930 Dell Publications ${ }^{\mathrm{x} x \mathrm{v}}$

\section{AS AVENTURAS DE TINTIN}

REPÓRTER DO"PETIT VINGTIĖME,
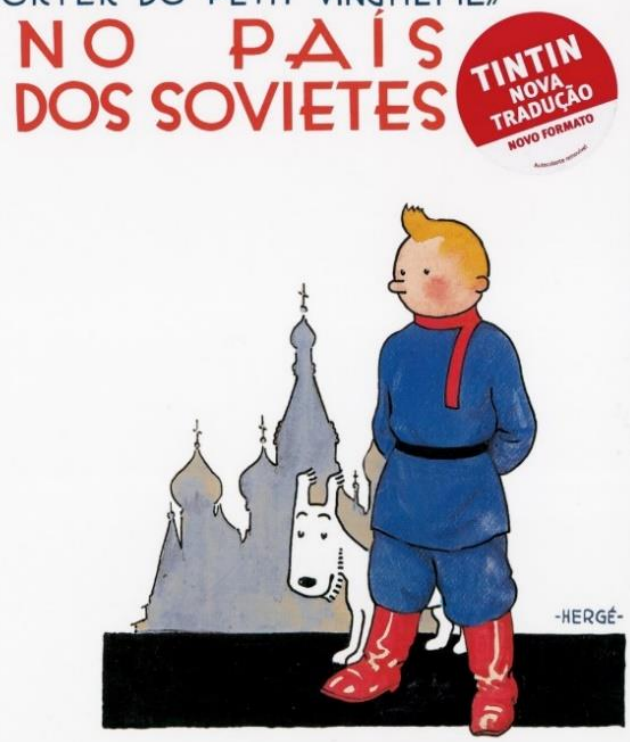

ASA

Figura 46 - Tintin no País dos Sovietes - 1929 - Le Petit Vingtième ${ }^{\mathrm{xx} x \mathrm{v}}$

\section{I1 Ba1i11a

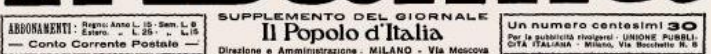

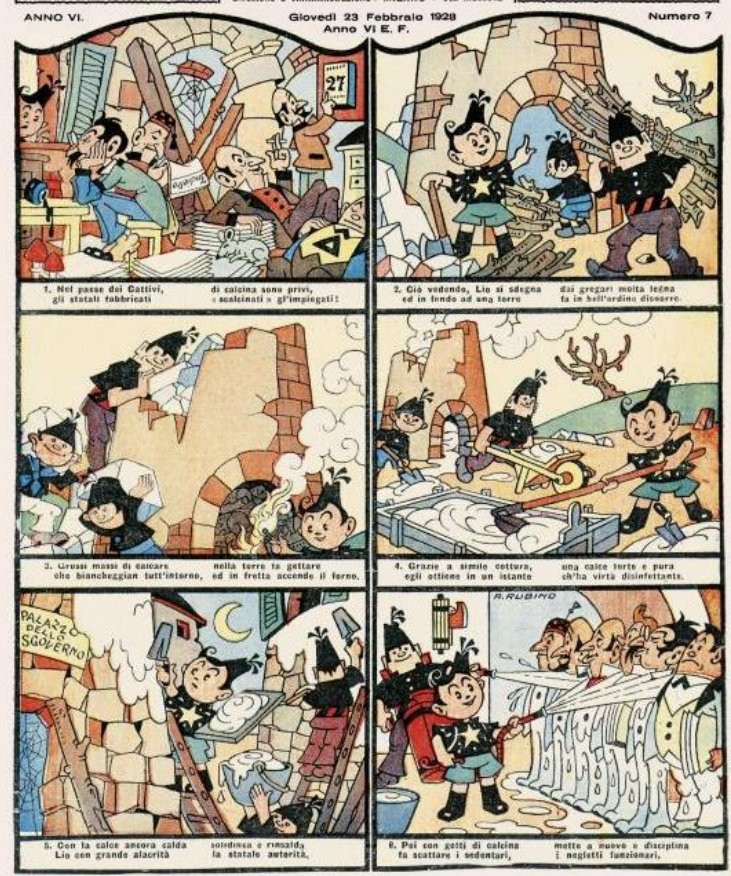

Figura 47 - Suplemento II Balilla - nº 7 - 23/02/1928 (falta localização)

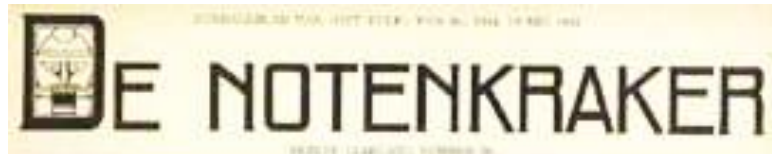

\section{E.INDHOVEN.}

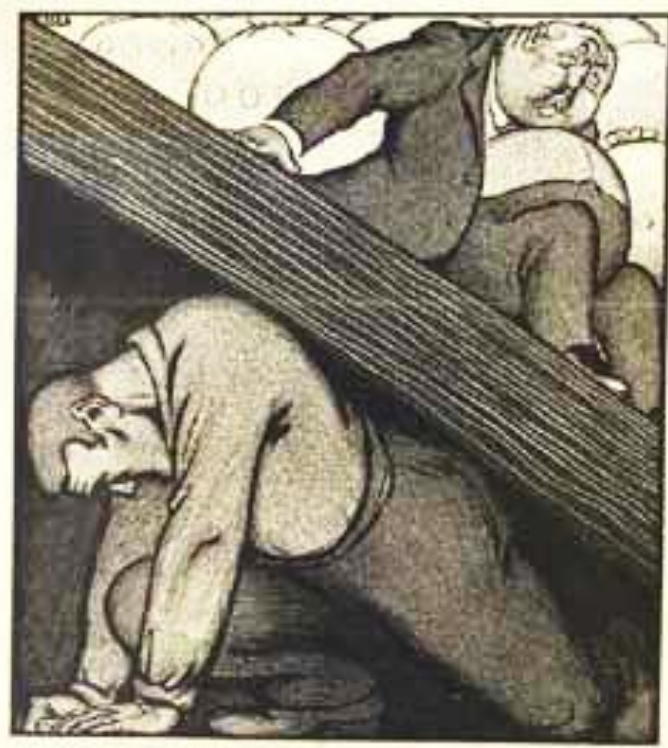

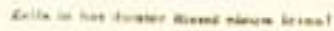

Figura 48 - Notenkraker, suplemento socialista do jornal Het Volk (falta localização) 


\subsection{Super-homem e a sedução americana ou quase}

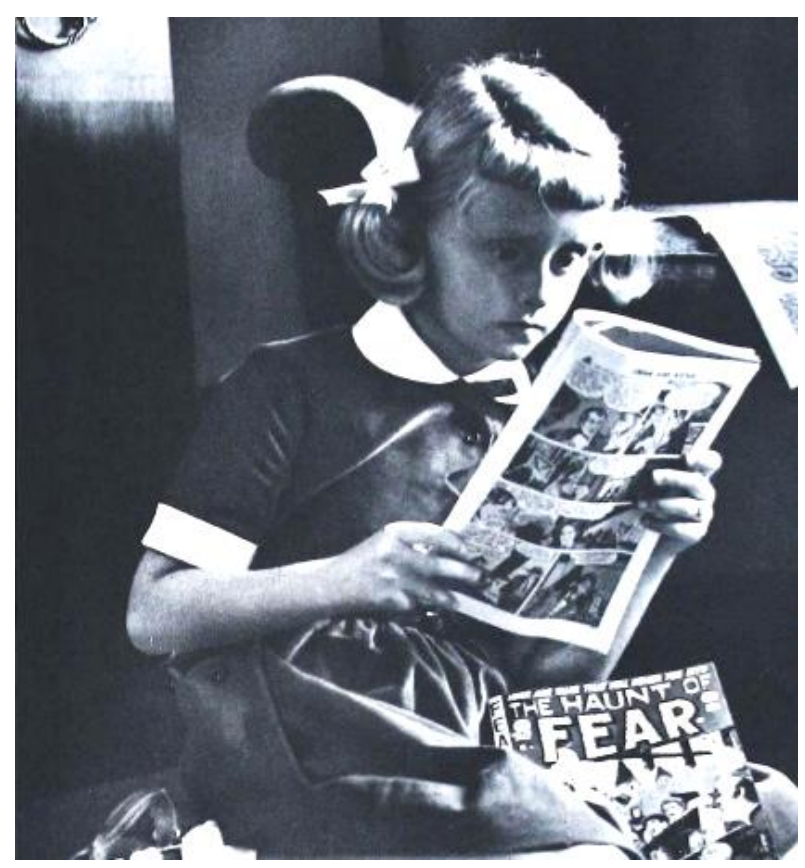

Actually, Superman (with the big $S$ on his uniform we should, I suppose, be thankful that it is not an S.S.) needs an endless stream of ever new submen, criminals and "foreign- looking" people not only to justify his existence but even to make it possible. It is this feature that engenders in children either one or the other of two attitudes: either they fantasy themselves as supermen, with the attendant prejudices against the submen, or it makes them submissive and receptive to the blandishments of strong men who will solve all their social problems for them - by force.

Fredric Wertham ${ }^{62}$

\section{“Dick Tracy" de Chester Gould já se aventurava pelas tiras do jornal Detroit}

62 Epígrafe - tradução e fonte: Na verdade, Super-homem (com o grande $\mathrm{S}$ no seu uniforme deveríamos, suponho, agradecer por não ser uma SS) precisa de um fluxo interminável de sempre novos sub-humanos, criminosos e pessoas de "aparência estrangeira" não apenas para justificar sua existência, mas até mesmo para torna-la possível. É essa característica que engendra nas crianças uma ou outra de duas atitudes: ou elas fantasiam a si mesmas como super-homens, com os preconceitos concomitantes contra o submisso, ou as torna submissas e receptivas as lijonjas de homens fortes que resolverão todos os problemas sociais para elas - pela força [tradução da autora]. Fonte da epígrafe: Citação e imagem do livro "Seduction of the Innocent" de Fredric Wertham em SERGI, J. The Amazing Adventure of The Man of Steel and the Psychiatric Censor - Superman vs. Doctor Wertham. CBLDF - Comic Book Legal Defense Fund, 2012. Disponivel em: $<$ http://cbldf.org/2012/09/the-amazing-adventure-of-the-man-of-steel-and-the-psychiatric-censorsuperman-vs-doctor-wertham/>. Acesso em: 18 Maio 2018. 
Free Press, quando, de acordo com M. Keith Booker, Harry Donenfeld e Jack Liebowitz fundaram a Independent News Co. como a maior distribuidora de pulp magazines em 1932 (BOOKER, 2014, p. xl-xli). Nesse período, Tarzan, Buck Rogers entre outros heróis de aventura, faroeste e ficção científica circulavam entre a literatura das pulps e as tiras dos jornais. Pulp (polpa) tem esse nome devido ao papel de baixa qualidade feito de polpa celulose utilizado na sua confecção, barateando o custo. As pulp magazines (revistas pulp) publicavam diversos contos e novelas seriadas de várias temáticas, com capas chamativas que os intelectuais viam com descaso por se tratar de "literatura" de massa.

Não é de se estranhar que em 1938, Harry Donenfeld, familiarizado com a temática das pulps, invista nesse conteúdo em outro formato, e lance a revista em quadrinhos Action Comics, especializada em heróis de aventura, trazendo em seu primeiro número personagens como Marco Polo, o aventureiro Tex Thompson, o cowboy Chuck Dawson, o repórter Scoop Scanlon, o lutador Pep Morgan, e o mágico Zatara. Além desses, comprou os direitos exclusivos de publicação e merchandising por 130 dólares do personagem criado pelo escritor Jerry Siegel e o desenhista Joe Shuster durante a adolescência de ambos alguns anos antes: Superman (Superhomem) (Figura 49 pág. 112). A história de um bebê alienígena sobrevivente de um planeta moribundo, encontrado e criado por um casal de meia idade sem filhos em uma fazenda do Kansas, com super força, super velocidade, e um pulo tão alto que parecia voar, que na vida adulta apesar de parecer um pacato e tímido repórter, tem outra identidade onde veste uma roupa colorida com capa esvoaçante e toma para si a justiça, punindo bandidos com suas próprias mãos, foi um sucesso imediato (BOOKER, 2014, p. 2).

Tanto que, de acordo com Donenfeld, citado no livro de lan Gordon, as três primeiras edições da Action Comics não apresentaram vendas muito marcantes, mas a quarta registrou um aumento significativo. A editora realizou uma pesquisa de banca de jornais e descobriu que as crianças pediam a revista "com o Super-homem nela". Donenfeld disse a um repórter em 1941 que ele assegurou que as edições subsequentes da Action Comics exibissem o Super-homem proeminente na capa, o que fez com que as vendas aumentassem dramaticamente. Até 1941, a Action Comics vendeu 900 revistas mil por mês, aproximadamente $10 \%$ das vendas mensais de todas as revistas em quadrinhos. Para Gordon, o Super-homem tornou-se uma figura de arte quadrinística onipresente. Em janeiro de 1939, o sindicato McClure começou 
a distribuir os quadrinhos do Super-homem para 230 jornais. No verão de 1939, a DC iniciou uma revista de quadrinhos trimestral composta unicamente de histórias do Super-homem. Quando a empresa o converteu em uma revista bimestral em setembro de 1940, o Super-homem teve uma circulação de 1.250 .000 revistas e arrecadou 950 mil dólares só naquele ano (GORDON, 1998, p. 132).

When Jerry Siegel and Joe Shuster invented Superman, they created both a character and a type, the comic book superhero, around which comic book publishers could sell a product and expand their nascent market. Superman's success inspired a plethora of costumed superhero characters. The most familiar and lasting of these characters were DC's Batman and Wonder Woman, and Timely/Marvel Comics' Sub-Mariner, the Human Torch, and Captain America. But these were just a few of several hundred costumed adventurers who first appeared in the pages of comic books in the late 1930s and early $1940 s^{63}$ (GORDON, 1998, p. 132).

Para Jean-Paul Gabilliet a instantânea popularidade do Super-homem deu início à era dos super-heróis e deu origem ao primeiro gênero ${ }^{64}$ específico de histórias em quadrinhos. Os heróis logo se expandiram para outras mídias da cultura de massa (filme, rádio e literatura pulp) ao mesmo tempo como concorrentes e complementos. Mas, Gabilliet aponta que, no entanto, justamente por sua visibilidade e seu espalhafato, os posicionou no fundo da escada cultural, um lugar onde ficaram por décadas.

Segundo lan Gordon, os editores de revistas em quadrinhos presumiram que tinham um público de leitores mais jovem do que aqueles que compram jornais, com isso o conteúdo e marketing das revistas em quadrinhos refletiram essa crença. Gordon ressalta que os criadores também eram jovens, pois muitos dos artistas e escritores de revistas em quadrinhos eram adolescentes ou por volta do começo dos vinte anos, isso porque quando o os Estados Unidos entraram na $2^{\mathrm{a}}$ Guerra Mundial, muitos dos criadores mais velhos se juntaram ao serviço militar (GORDON, 1998, p. 129).

${ }^{63}$ Quando Jerry Siegel e Joe Shuster inventaram o Super-homem, eles criaram um personagem e um tipo, a revista de quadrinhos de super-herói, em torno do qual as editoras de quadrinhos poderiam vender um produto e expandir seu mercado nascente. O sucesso de Super-homem inspirou uma infinidade de personagens de super-heróis fantasiados. Os mais conhecidos e duradouros desses personagens foram o Batman e Mulher Maravilha da DC [DC Comics editora], e o Príncipe Submarino, Tocha Humana e Capitão América da Timney / Marvel Comics [editora]. Mas estas foram apenas algumas das várias centenas de aventureiros vestidos que apareceram pela primeira vez nas páginas de quadrinhos no final da década de 1930 e início da década de 1940 (GORDON, 1998, p. 132) [tradução da autora].

${ }^{64}$ Cabe ressaltar que "gênero" é usado por Gabilliet no mesmo sentido de classificações temáticas: horror, aventura, romance, ficção científica, etc. nomenclatura convencionada também para denominar livros e filmes no meio comercial. 
According to Coulton Waugh, the number of comic book titles published in this period peaked at 160 in 1940, then fell to 100 by the summer of 1942. But sales increased slightly from 10.0 million a month in 1940 to 12.5 million a month in 1942. These sales produced $\$ 15$ million of revenue annually, of which 75 percent came from children's purchases. By the mid-1940s more than 90 percent of children aged six to eleven across the country read an average of fifteen comic books a month. Between ages twelve and eighteen, readership fell to 80 percent and the average number read fell to twelve a month ${ }^{65}$ (COULTON apud GORDON, 1998, p. 132).

Gonçalo Junior aponta no livro "A Guerra dos Gibis" de 2004, a chegada fervilhante dos super-heróis ao Brasil, trazidos dos Estados Unidos pelo jovem editor Adolfo Aizen em 1934 depois de uma estadia nos Estados Unidos.

Encantado com as possibilidades dos suplementos de jornal (um deles era o suplemento de quadrinhos) Aizen a princípio tentou convencer Roberto Marinho a financiar a empreitada no Brasil, mas este preferiu não arriscar em uma ideia tão inusitada e os suplementos foram publicados primeiramente no jornal "A Nação",

[Nos Estados Unidos] Todas as manhãs, Aizen comprava os jornais para ler a sequência de seus personagens preferidos - gostava em especial de Buck Rogers no século 25, de Philip Francis Nowlan, publicado desde 1928. Aizen se espantou ao ver que as continuações das histórias de Buck Rogers e Tarzan eram acompanhadas com ansiedade por uma legião de fãs, como se fossem folhetins. O mais curioso: os comics exerciam fascínio sobre o público de todas as idades, ao contrário do que acontecia no Brasil, onde os raros quadrinhos publicados em revistas como Tico-Tico eram dirigidos às crianças. Aquelas histórias em tiras ou páginas seriadas que ele lia nos Estados Unidos eram desconhecidas no Brasil. Muitas haviam sido criadas fazia pouco tempo e não tinham despertado o interesse dos editores brasileiros. (GONÇALO JUNIOR, 2004, p. 26).

Em pouco tempo o suplemento de quadrinhos do jornal a Nação se tornou um sucesso, segundo Gonçalo, tornando-se praticamente leitura obrigatória, principalmente entre os meninos, que compravam o jornal, pegavam o suplemento e jogavam o resto fora.

Apesar das vendas do jornal aumentarem, por ser um jornal com tendência nacionalista, seu diretor, o capitão João Alberto Lins de Barros, polêmico chefe da polícia de Getúlio Vargas, constrangido com a fama de "Nação Infantil" que o jornal estava adquirindo, ajudou Aizen a montar uma editora de distribuição de suplementos

${ }^{65}$ De acordo com Coulton Waugh [cartunista, pintor, crítico e professor de arte, publicou em 1947 um importante estudo sobre quadrinhos The Comics], o número de títulos de revistas em quadrinhos publicados neste período alcançou 160 em 1940, caiu para 100 no verão de 1942. Mas as vendas aumentaram ligeiramente de 10 milhões por mês em 1940 para 12,5 milhões por mês em 1942. Essas vendas produziram US\$15 milhões de receita anualmente, das quais $75 \%$ provêm de compras de crianças. Em meados da década de 1940, mais de $90 \%$ das crianças entre as seis e as onze do país liam uma média de quinze quadrinhos por mês. Entre as idades de doze e dezoito anos, a porcentagem de leitores caiu para $80 \%$ e o número médio de leitura caiu para doze por mês (COULTON apud GORDON, 1998, p. 132) [tradução da autora]. 
independente do jornal, o Grande Consórcio de Suplementos Nacionais (GONÇALO JUNIOR, 2004).

Aizen lança com sucesso o Suplemento Juvenil, que seria seguido após alguns anos pelo concorrente Globo Juvenil, de Roberto Marinho. Mais uma vez trazendo as novidades americanas, Aizen lança no Brasil um novo formato, as revistas em quadrinhos, a Mirim, em 1939, no mesmo ano, seguindo sua trilha Roberto Marinho publica a revista Gibi (GONÇALO JUNIOR, 2004). Foi nas páginas de Mirim que Super-homem e vários heróis chegam ao Brasil.

Ian Gordon ressalta que a DC Comics usou a Segunda Guerra Mundial para fazer do Super-homem, não só um defensor da virtude e da fortitude, mas também um sinônimo da democracia americana (GORDON, 1998, p. 137), tanto o homem de aço quanto os demais super-herói tiveram narrativas em que participavam da campanha de guerra, principalmente da Marvel Comics cujo Capitão América (Figura 50, pág. 112), criado especificamente como símbolo das forças militares americana, foi combater o terceiro Reich diretamente,

Superheroes remained dominant, often battling against Nazis or other national enemies during the war years. Indeed, one of the most famous covers in comic book history appeared when Captain America \#1, published months before the United States entered the war, sported a drawing of its title protagonist punching out none other than Adolf Hitler66 (BOOKER, 2014, p. xxxi-xxxii).

lan Gordon nota a disparidade de abordagens na época sobre o envolvimento dos personagens na guerra. Enquanto os personagens da Marvel Comics, combatiam ativamente na guerra em situações de campo de batalha, a DC Comics apesar de enfatizar propaganda antinazista e promover campanhas de arrecadação de fundos de guerra, mantinha suas narrativas em uma conduta defensiva.

\footnotetext{
${ }^{66}$ Super-heróis permaneceram dominantes, frequentemente lutando contra nazistas ou outros inimigos durante os anos de Guerra, uma das mais famosas capas da história das revistas em quadrinhos apareceu em Capitão América ํำ 1, publicado antes dos Estados Unidos entrarem para a guerra, exibiu um desenho do seu protagonista do título que esmurrava ninguém menos que Adolf Hitler (BOOKER, 2014, p. xxxi-xxxii) [tradução da autora].
} 
Except for an explanatory note in Superman, no. 25 (November-December 1943), DC avoided the issue of Superman's service. But in mid-February 1942 the comic strip version of Superman had Clark Kent fail his physical by accidentally using his X-ray vision to read the eye chart in the next office. Shortly after, on March 11, Superman told the U.S. Congress that "the American armed forces are powerful enough to smash their treacherous foes without the aid of Superman." DC kept Superman out of the war because there was no way to explain why someone with his powers could not put an end to it ${ }^{67}$ (GORDON, 1998, p. 145).

Mesmo assim, essa postura não parecia incomodar os leitores, pois como Ian Gordon expõe, as histórias da DC Comics ressalvam para o público discursos como: "a arma secreta da América está na coragem do soldado comum" e "Sua batalha, seu futuro, sua America!!!", retiradas do acervo de revistas da época que estudou ${ }^{68}$. Por isso as vendas continuavam enormes para um período de relativa escassez de recursos,

Between 1941 and 1944 sales of comic books doubled from 10 million to 20 million copies a month despite paper shortages. Much of this increase can be attributed to the reading habits of servicemen. In 1944, 41 percent of men between the ages of eighteen and thirty read comic books regularly, which researchers defined as more than six comic books a month. In military training camps, 44 percent of men read comic books regularly and 13 percent read them occasionally ${ }^{69}$ (GORDON, 1998, p. 139).

Segundo Gabilliet, a Segunda Guerra Mundial foi o pano de fundo para uma fase de crescimento contínuo para a indústria de quadrinhos, com cada vez mais revistas de temas diversos e personagens recorrentes (que se multiplicavam) utilizando esse mote. Apesar dos Estados Unidos só entrarem na guerra posteriormente, as narrativas das revistas em quadrinhos americanas já colocavam seus heróis combatendo espiões nazistas e japoneses, defendendo populações

${ }^{67}$ Com exceção de uma nota explicativa no Super-homem, no. 25 (novembro-dezembro de 1943), DC evitou a questão do serviço do Super-homem. Mas, em meados de fevereiro de 1942, uma versão em quadrinhos do Super-homem mostrou que Clark Kent tinha falhando no seu exame físico acidentalmente por usar sua visão de raios- $X$ para ler a tabela do exame de vistas do escritório seguinte [ao que ele estava]. Pouco depois, em 11 de março, Super-homem disse ao Congresso dos EUA que "as forças armadas americanas são poderosas o suficiente para esmagar seus inimigos traiçoeiros sem a ajuda de Super-homem ". DC manteve o Super-homem fora da guerra porque não havia como explicar por que alguém com seus poderes não conseguia acabar com ela (GORDON, 1998, p. 145) [tradução da autora].

68 De acordo com as notas em (GORDON, 1998), as frases foram extraídas de: Superman, no. 23 (JulyAugust 1943); Batman, no. 15 (February- March 1943). See also Superman, no. 18 (September-October 1942). And see the "For America and Democracy" cover of All Star Comics, no. 4 (March-April 1941).

69 Entre 1941 e 1944, as vendas de revistas em quadrinhos duplicaram de 10 milhões para 20 milhões de cópias por mês, apesar da escassez de papel. Grande parte desse aumento pode ser atribuído aos hábitos de leitura dos militares. Em 1944, 41\% dos homens entre as idades de dezoito e trinta liam quadrinhos regularmente, o que os pesquisadores definiram como mais de seis quadrinhos por mês. Nos campos de treinamento militar, 44 por cento dos homens liam quadrinhos regularmente e 13 por cento os liam ocasionalmente (GORDON, 1998, p. 139) [tradução da autora]. 
oprimidas por ditadores, em manifestações cada vez mais patrióticas (GABILLIET, 2010).

The US Army was the largest institutional customer of comic book publishers and the readers who stayed home, particularly the young, had comparatively little else than comic books to spend their money on as industrial production was geared toward the war effort. Several innovations specifically destined to attract preadolescent readers were introduced during the first half of the decade $^{70}$ (GABILLIET, 2010, p. 49).

Uma das inovações apontadas por Gabilliet foram as introduções de protagonistas adolescentes, ou parceiros adolescentes (sidekicks) para o herói adulto. Os heróis de quadrinhos foram inspirados nos protagonistas da literatura pulp, basicamente, adultos. O primeiro parceiro de um herói de quadrinhos, foi Jimmy Olsen, o fotografo adolescente amigo do Super-homem, contudo ele nunca deixou de ser um coadjuvante inexpressivo. O primeiro sidekick oficial foi "Robin" (Figura 54, pág. 113), de Batman, que conseguiu unir a característica trágica já conhecida da narrativa infantil, o órfão em situação dramática, assim como Bruce Wayne (alter ego de Batman) com habilidade para a ação. O conceito do jovem ajudante se expandiu por todas as editoras (GABILLIET, 2010, p. 50).

I had always thought Robin was a real pain-in-the-ass, but I now realize what a brilliant creation it was, because it really does give a human context to Batman's character. - Frank Miller on including a Robin in the apocryphal The Dark Knight Returns, Comics Interview, $1986^{71}$ (MILLER apud LANGLEY, 2012, p. 214)

Fora as razões comerciais e históricas para a criação de Robin, o Dr. Travis Langley, psiquiatra e professor de psiquiatria criminal, comportamento social e media Henderson State University, aponta que a criação de Robin por Bill Finger, escritor e roteirista de quadrinhos co-criador de Batman, seria uma resposta a uma necessidade narrativa, pois o personagem Batman quando trabalha sozinho é silencioso e também mais violento. Visto somente em ação ele é tão distante do leitor quanto dos vilões que intimida. A alternativa seria colocar suas análises, ideias e emoções em balões de pensamento, mas isso o deixa muito menos misterioso. Assim, um parceiro fornece

\footnotetext{
70 O Exército dos EUA foi o maior cliente institucional de editores de quadrinhos e os leitores que ficaram em casa, particularmente os jovens, tinham comparativamente pouca coisa além de quadrinhos para gastar seu dinheiro quando a produção industrial estava voltada para o esforço de guerra. Várias inovações especificamente destinadas a atrair leitores pré-adolescentes foram introduzidas durante a primeira metade da década (GABILLIET, 2010, p. 49) [tradução da autora].

${ }^{71}$ Eu sempre achei que Robin era um verdadeiro pé-no-saco, mas eu me dei conta da brilhante criação que ele foi, porque ele realmente dá um contexto humano para o personagem de Batman - Frank Miller quando incluiu Robin no apócrifo O Retorno do Cavaleiro das Trevas, Comics Interview [no 36], 1986 (MILLER apud LANGLEY, 2012, p. 214) [tradução da autora].
} 
um equilíbrio para revelar sua natureza, conforme necessário, enquanto mantém seu mito. Bob Kane, desenhista co-criador de Batman, propôs que o parceiro deveria ser adolescente, para que os leitores se identificassem com ele e Bill Finger concordou (LANGLEY, 2012, p. 215).

Entre os protagonistas adolescentes, o mais popular foi Archie Andrews, publicado em 1942 por John Goldwater, um dos sócios da editora MLJ, de acordo com Gabilliet, a introdução de personagens adolescentes não estava limitada à temática de ação, Goldwater teve a ideia de criar um personagem adolescente all-american ${ }^{72}$ e publicou Archie Andrews. O sucesso de Archie e seus amigos foi tão amplo que a editora MLJ mudou seu nome para Archie Comics e Archie foi a primeiro personagem de quadrinhos sem ser super-herói a ser título de uma revista de longa duração (GABILLIET, 2010, p. 51).

Além dos adolescentes, outra temática a ganhar muito destaque no período foi funny animals, com "Mickey" e o "Pato Donald" de Walt Disney como seus maiores expoentes. Para Gabilliet,

Humorous comic books for young children were among the true innovations of the 1940s. Up until then, the original characters created specifically for very young readers appeared in anthology titles where "serious" adventure strips alternated with lighter material. [...] Nevertheless, the most prevalent genre during the period of 1940-1945 was unquestionably "funny animals" comics, the common offspring of animation and comics ${ }^{73}$ (GABILLIET, 2010, p. 52).

De acordo com Booker, Disney começou a comercializar seus filmes como uma alternativa saudável às produções questionáveis produzidas pelos outros estúdios de Hollywood, e sua postura para seus quadrinhos foi torná-los mais amigáveis para as crianças, mas sem um conteúdo que pais, professores e autoridades achassem possivelmente prejudicial, como os da maioria dos outros quadrinhos. Essa estratégia funcionou muito bem, pois as revistas de Walt Disney tornaram-se as primeiras revistas sem super-heróis a vender mais de um milhão de cópias por mês e, em meados da década de 1950, o título teria mais de três milhões

\footnotetext{
72 Segundo o dicionário Oxford, all-american: "completamente americano". Curiosamente o Google Tradutor, atualmente uma das fontes de consulta mais buscadas para tradução, fornece o significado de "all-american" como "possessing qualities characteristic of American ideals, such as honesty, industriousness, and health" (possuindo qualidades características dos ideais americanos, como honestidade, industrialização e riqueza).

${ }^{73}$ Revistas humorísticas para crianças pequenas foram uma das verdadeiras inovações dos anos 40 . Até então, os personagens criados especificamente para leitores muito pequenos apareciam em antologias onde tiras de aventuras "sérias" eram alternados com material mais leve. [...] de qualquer forma, o gênero que mais prevaleceu no período entre 1940-1945 foi inquestionavelmente revistas de "funny animals", o filho comum de animação e quadrinhos (GABILLIET, 2010, p. 52) [tradução da autora].
} 
de assinantes, dando-Ihe a maior circulação que qualquer revista em quadrinhos já teve nos Estados Unidos (BOOKER, 2014, p. xxxii).

A preocupação de Disney era fundada, pois em maio de 1940, Sterling North, escritor e editor literário do jornal Chicago Daily News publicou a matéria " $A$ National Disgrace" (uma desgraça nacional), criticando as revistas de histórias em quadrinhos, que foi reimpressa em jornais por todo os Estados Unidos (BOOKER, 2014, p. xlii). Seguida pela crítica de diversos membros da sociedade americana.

Outra inovação nas revistas em quadrinhos do período foi a introdução temática educacional, com o lançamento em 1941 pela editora Parents' Magazine (revista dos pais) de George Hecht, inspirado pelas revistas Life e Reader's Digest, as revistas "True Comics" (quadrinhos verdadeiros), "Real Life Comics" (Quadrinhos da vida real), "Real Heroes" (heróis reais), "It Really Happened" (isso realmente aconteceu) e "Picture News" (notícias ilustradas), com fatos reais, eventos históricos e biografias de pessoas ilustres além de uma postura patriótica e moralista (BOOKER, 2014, p. 117). Segundo Gabilliet,

It was an immediate commercial success with three hundred thousand copies sold in ten days, although most buyers were certainly Parents Magazine readers rather than their children ${ }^{74}$ (GABILLIET, 2010, p. 55).

Seguindo a tendência educacional para agradar os pais foram criadas revistas com adaptações literárias, de acordo com Gabilliet, a ideia não era nova, pois outras revistas didáticas trouxeram seções de adaptações, mas Albert Lewis Kanter tinha outra perspectiva, como autodidata filho de imigrantes russos ele notou 0 desânimo de seus filhos em ler livros sem ilustrações em contraste com o profundo interesse em revistas de quadrinhos, por isso ele decidiu lançar a cada revista, uma revista inteira dedicada à adaptação de um clássico da literatura, o primeiro número de "Classic Comics" de Outubro de 1941, foi "The Three Musketeers" (Os Três Mosqueteiros) de Alexandre Dumas (GABILLIET, 2010, p. 56). Contudo como ressalta Booker, essas revistas literárias foram acusadas de encorajar as crianças a lerem as adaptações em detrimento do livro original (BOOKER, 2014, p. xxxii).

Também no Brasil começava a crescer uma oposição aos quadrinhos importados dos Estados Unidos, por isso durante a segunda guerra mundial, além das disputas comerciais, os editores Aizen e Marinho, se viram às voltas com as duras

\footnotetext{
${ }^{74}$ Foi um sucesso comercial imediato com trezentos mil exemplares vendidos em dez dias, embora a maioria dos compradores tenha sido certamente, leitores da Parents' Magazine, em vez de seus filhos (GABILLIET, 2010, p. 55) [tradução da autora].
} 
críticas às suas revistas. Gonçalo Junior comenta que,

os personagens de comics fascinavam cada vez mais a garotada de todo o mundo. Tanto que não demoraram a despertar a atenção de segmentos da sociedade que protestavam em nome da formação moral de crianças e adolescentes. (GONÇALO JUNIOR, 2004, p. 77)

No Brasil, segundo Gonçalo Junior, os inimigos declarados dos quadrinhos foram os padres. Muitos destes sendo descendentes italianos, adotavam a ideologia fascista difundida pelo Ministério Popular da Cultura do ditador Benito Mussolini, a qual advogava que "os quadrinhos importados do Estados Unidos escondiam mensagens subliminares bem menos inocentes do que os pais imaginavam" (GONÇALO JUNIOR, 2004, p. 77). As revistas desse período se constituíam basicamente de material importado dos Estados Unidos, pois era mais barato traduzir o material pronto distribuído pelos Syndicates americanos do que investir em pagamentos para desenhistas e roteiristas para publicação de material nacional, o que fez com que as HQs recebessem também a crítica de "americanizar" a juventude brasileira.

A crítica aos quadrinhos americanos já havia começado na Europa há algum tempo, o influente crítico de cinema francês Georges Sadoul já se posicionava contra o que ele chamava de "invasão americana" por meio de comics, em seu livro de 1936 "Ce que lisent les enfants" (o que lêem as crianças) ele frisa:

Everywere, at every page, we found exaltation of brute force, assassination, violence, war, spying, banditism, and at the same time, escape to the most stupidity irreality ${ }^{75}$ (SADOUL apud GROENSTEEN, 2004, p. 34).

$\mathrm{Na}$ França, a praticidade de distribuição de material americano pelos Syndicates suplantou muito a produção nacional francesa. Contudo após a segunda guerra mundial, a implantação de uma lei em 26 de julho de 1949, censurando e regulando publicações infantis, contribuiu para eliminar a concorrência estrangeira e, com isso, a escola Franco-Belga criada por Hergé desenvolveu uma linguagem artística e narrativa inovadora muito diferente do material vindo da América. Essa estética única conquistou tanto público como crítica, com muito da sua produção, como Tintin e Asterix, exportada para outros países.

Além da rejeição internacional, com o final da guerra, os quadrinhos de super-herói americanos enfrentam um grande desinteresse do público com essa

${ }^{75} \mathrm{Em}$ todos os lugares, em todas as páginas, encontramos a exaltação da força bruta, o assassinato, a violência, a guerra, a espionagem, o banditismo e, ao mesmo tempo, o escapismo para a mais absurda irrealidade (SADOUL apud GROENSTEEN, 2004, p. 34) [tradução da autora]. 
temática desgastada,

The other victims of the return to peacetime were the publishers. Many were quite embarrassed when the conflict ended and they still had a year or two's worth of unpublished stories. They found out that the transition to peace involved the reconversion of superheroes, whom they typically regarded as one staple of the war effort and nothing more. Nineteen forty-six was the first year since the start of that decade when no new superhero debuted. Marvel replaced its last superhero titles with romance comics in 1949 and up until 1956 , every attempt to relaunch superheroes met with bitter failure ${ }^{76}$ (GABILLIET, 2010, p. 64)

As editoras, tentando diminuir as quedas nas vendas, investiram em outras temáticas, além das já consagradas funny animals, exploram também revistas com narrativas inspiradas nas pulps, aventura, terror e ficção científica e o romance, visando especificamente ao público feminino. Segundo Booker, os quadrinhos de romance foram um sucesso imediato, tanto que em 1949, se tornaram o principal gênero de venda no setor de quadrinhos americanos. Booker afirma que eles continuaram a aumentar de popularidade por vários anos, e estima-se que uma em quatro revistas de quadrinhos nas bancas entre 1949 e meados da década de 1950 eram de romance (BOOKER, 2014).

De acordo com o poeta, crítico literário e professor de estudos culturais na Universidade de Leuven, Jan Baetens (1957), os quadrinhos românticos chegam à Europa através da Itália, em 1946, e depois na França em 1947. A nova temática é batizada de roman-fumetti (quadrinhos românticos) e depois fotoromanzo (romance em fotos), primeiramente desenhada seguindo o modelo americano é aprimorada pelos estúdios italianos (BAETENS, 2014, p. 180)

Uma das mais importantes revistas de fotoromanzo, a Grand Hotel, empregava a técnica "mezzatinta acquerellata" (Figura 57, pág. 114) aperfeiçoada especialmente para a fumetti para obter efeitos volumétricos na ausência de cor (OSSINO, 2017), também conhecida fora da Itália como “mezzo-fumetti".

Uma tendência do quadrinho romântico italiano foi usar o desenho realista, tanto que os atores e atrizes italianos e norte-americanos eram usados como modelo para as revistas, segundo Baetens,

\footnotetext{
${ }^{76}$ As outras vítimas do retorno ao tempo de paz foram as editoras. Muitos ficaram bastante envergonhados quando o conflito terminou e eles ainda tinham um ano ou dois de histórias inéditas [sobre a guerra]. Eles descobriram que a transição para a paz envolveu a reconversão de super-heróis, que tipicamente consideravam uma peça do esforço de guerra e nada mais. 1946 foi o primeiro ano desde o início dessa década quando nenhum novo super-herói estreou. Marvel substituiu seus últimos títulos de super-heróis com quadrinhos de romance em 1949 e até 1956, todas as tentativas de relançar super-heróis encontraram uma amarga falha (GABILLIET, 2010, p. 64) [tradução da autora].
} 
Dans les années cinquante il n'était pas rare de trouver dans les pages de Grand Hôtel des histoires comme La loi du Sud, reprise non dite d'Autant en emporte le vent (Victor Fleming, 1939), avec des protagonistes ressemblant beaucoup à Clark Gable et Vivienne Leigh. Comme par hasard, ces mêmes pages multipliaient aussi les sosies de James Dean, Rita Hayworth, Burt Lancaster, Montgomery Clift ou Robert Mitchum. L'image des vedet-tes reste cependant un peu en sourdine et peut même se renverser de manière surprenante. Sur les couvertures de Grand Hôtel James Dean n'est pas le personnage désespéré de La Fureur de vivre, mais plutôt un jeune homme séduisant. Ava Gardner n'est pas la belle dame sans merci, mais une jeune femme qui a soif d'aventures. Montgomery Clift n'est pas le personnage torturé qui s'apprête à tuer d'Une place au soleil, c'est plutôt unn riche égoïste $^{77}$ (BAETENS, 2014, p. 180).

Baetens explica que substituir o desenho realista pela fotografia foi um movimento natural de explorar as ferramentas da linguagem, vista pelo público como uma modernização, ainda mais pelo fato das fotoromanzo, photo-novels no inglês e fotonovelas no Brasil, trazerem uma modernização dos enredos girando em torno de novas relações entre homens e mulheres, dando mais espaço à igualdade de parceiros (BAETENS, 2014, p. 181).

Nos Estados Unidos, além das temáticas de romance, que floresceram durante a baixa dos super-heróis estava também crime e horror, visando ao público adulto, essas revistas primavam pelo conteúdo violento e sensual. Em 1942, a editora Lev Gleason Publications, lança a revista "Crime Does Not Pay" (O crime não compensa) (Figura 55, pág. 113), com relatos mórbidos, violentos e muitas vezes sensacionalistas de vários crimes, incluindo narrativas baseadas nas histórias de gangsters famosos do mundo real, como Baby Face Nelson e Machine Gun Kelly. Booker nota que a revista teoricamente era direcionada ao público adulto, contudo exercia um grande apelo ao público jovem (BOOKER, 2014, p. xxxii)

Segundo Booker, "Crime Does Not Pay" gerou críticas imediatas, embora seu editor Gleason tenha argumentado que o próprio título, que indicava o resultado da maioria das histórias, transmitiam mensagens positivas sobre o aspecto desagradável do comportamento criminoso, muitos, no entanto, sentiram que a série

\footnotetext{
${ }^{77} \mathrm{Na}$ década de cinquenta, não era incomum encontrar nas páginas de histórias do Grand Hotel, como "La loi du Sud" (A lei do Sul), espelhada em de "Autant en emporte le vent" (E o vento levou...) (Victor Fleming, 1939), com protagonistas parecidos com Clark Gable e Vivienne Leigh. Como se por acaso, essas mesmas páginas também multiplicavam as aparências de James Dean, Rita Hayworth, Burt Lancaster, Montgomery Clift ou Robert Mitchum. A imagem das estrelas, no entanto, permanece um pouco muda e pode até mudar de forma surpreendente. Nas capas do Grand Hotel James Dean não é o personagem desesperado de "La Fureur de vivre" (Juventude Transviada), mas sim um jovem atraente. Ava Gardner não é a bela dama sem piedade, mas uma jovem que deseja aventuras. Montgomery Clift não é o personagem torturado que está prestes a matar em "Une place au soleil" (Um Lugar ao Sol), ele é um homem bastante egoísta e rico (BAETENS, 2014, p. 180).
} 
glorificava o crime. Principalmente com a introdução do "Sr. Crime", um personagem de chapéu alto e uma mortalha fantasmagórica, que era uma espécie de cicerone que guiava os leitores à história dando destaque aos comportamentos e consequências. Durante os primeiros cinco anos, o Sr. Crime também apareceu dentro das próprias histórias, às vezes quebrando a quarta parede para abordar diretamente os leitores no meio da ação. Como resultado, essa figura sinistra foi a influência mais imediata na interpretação moral e emocional do leitor da ação. Nos anos subsequentes, ele costumava ser imitado, os mais famosos desses personagens-narradores de quadrinhos, foram das revistas de terror da EC Comics: The Crypt Keeper (O Zelador da Cripta), The Vault Keeper (Guardião da Câmara) e Old Old Witch (Bruxa Velha) (BOOKER, 2014, p. xxxiii).

Gabilliet nota que a EC Comics, primeiro Educational Comics, alterada depois para Entertainment Comics, experimentou um sucesso meteórico a partir de 1950, quando seu proprietário e editor William Gaines reformulou toda sua linha editorial em volta de revistas de horror (The Haunt of Fear, Tales from the Crypt, The Vault of Horror), suspense (Crime Suspenstories, Shock Suspenstories) e ficção científica (Weird Fantasy, Weird Science) e, em 1952, seu maior sucesso, a revista Mad, a primeira revista humorística focada na audiência juvenil (GABILLIET, 2010, p. 70).

As revistas de horror da EC Comics, foram o ponto central das controvérsias sobre revistas em quadrinhos que estouraram depois da Segunda Guerra Mundial. Gabilliet ressalta que o estopim que levou o Subcomitê de Delinquência Juvenil do Comitê Judiciário do Senado a agendar as audiências sobre a indústria de quadrinhos na primavera de 1954 foi a repercussão da publicação de uma paródia em quadrinhos do poema "The Night Before Christmas" de 1823 no primeiro número da revista humorista Panic, também da EC Comics (GABILLIET, 2010, p. 71). O advogado, ensaísta e quadrinista, Joe Sergi, comenta que "The Night Before Christmas", fez não só a revista Panic ser banida no estado de Massachusetts, mas também levou Bill (William) Gaines, seu associado Lyle Stuart e sua recepcionista Shirley Norris, a serem presos, por descrever o natal de maneira pagã (SERGI, 2013).

Em 1954 o psiquiatra alemão Fredric Wertham, que focava seu trabalho em causas para a delinquência juvenil, lançou o livro "Sedução dos Inocentes", condenando sumariamente as revistas em quadrinhos. Quando se fala na trajetória das histórias em quadrinhos americana Wertham é um nome de destaque, 
provavelmente, não há nenhum estudioso de $\mathrm{HQ}$ no ocidente que não tenha lido ou falado a respeito de "Sedução dos Inocentes", pelo impacto que seu livro teve e
continua tendo na opinião pública a respeito da História em Quadrinhos como um todo. Keith M. Booker, por exemplo, comenta na introdução de seu livro:

Wertham gained considerable attention for his now notorious and seemingly excessive crusade against comic books, beginning in the late 1940s and culminating the 1954 publication of his book Seduction of the Innocent, which argued that the violence that he saw as central to the content of contemporary comic books promoted a climate that tended to make young people more accepting of violence in society, leading them directly into juvenile delinquency. Wertham also criticized the sexual imagery contained in comics, which he saw as potentially promoting inappropriate sexual behavior, including homosexuality. Wertham, a progressive, insisted that he was not advocating censorship, though he argued that children's access to comics containing images of violence and sexuality should be controlled ${ }^{78}$ (BOOKER, 2014, p. xXXV).

Mais à frente, Booker dedica um tópico inteiro ao psiquiatra, apontando sua carreira e seu papel no processo movido contra a indústria dos quadrinhos no Senado americano. Também lan Gordon aponta a publicação do livro de Wertham como o ponto crucial da derrocada da chamada Era de Ouro dos quadrinhos americanos,

Fredric Wertham's Seduction of the Innocent, published in 1954, highlighted the violence of the crime and horror comic books that had sprung up after the Second World War and drew a simple causal link between comic book readership and juvenile delinquency. Ignoring the distinctions among comic books, he attacked superhero and funny animal comic books with the same ferocity as horror and crime books. Wertham's work galvanized criticism of comic books, forced publishers to establish a code of self-censorship, and energized Estes Kefauver's Senate Subcommittee to Investigate Juvenile Delinquency. Among comic book enthusiasts Wertham's efforts to ban comic books, and the publishers' establishment of a code limiting violence, are held to have destroyed a "Golden Age"79 (GORDON, 1998, p. 152).

\footnotetext{
${ }^{78}$ Wertham ganhou atenção considerável por sua, agora notória e aparentemente excessiva, cruzada contra quadrinhos, começando no final da década de 1940 e culminando a publicação de 1954 de seu livro Seduction of the Innocent, que argumentou que a violência que ele viu como o conteúdo central das revistas em quadrinhos contemporâneas promoviam um clima que tendia a fazer com que os jovens aceitassem melhor a violência da sociedade, levando-os diretamente à delinquência juvenil. Wertham também criticou as imagens sexuais contidas nos quadrinhos, que ele viu como potencialmente promovendo comportamentos sexuais inapropriados, incluindo a homossexualidade. Wertham, um progressista, insistiu que não defendia a censura, embora argumentasse que o acesso das crianças aos quadrinhos que continham imagens de violência e sexualidade devessem ser controladas (BOOKER, 2014, p. xxxv) [tradução da autora].

${ }^{79}$ A sedução dos inocentes de Fredric Wertham, publicado em 1954, destacou a violência das revistas de quadrinhos de crime e horror que surgiram após a Segunda Guerra Mundial e desenharam um vínculo simplista entre leitores de quadrinhos e a delinquência juvenil. Ignorando as distinções entre os quadrinhos, ele atacou histórias de quadrinhos de "funny animals" e super-heróis com a mesma ferocidade usada para as revistas de terror e crime. O trabalho de Wertham galvanizou a crítica aos quadrinhos, forçou as editoras a estabelecer um código de autocensura e energizou o Subcomitê do Senado de Estes Kefauver para Investigar a Delinquência Juvenil. Entre os entusiastas dos quadrinhos dos esforços de Wertham para proibir os quadrinhos, e o estabelecimento de um código que limita a violência das editoras, estão os fatores que teriam destruído a "Era de Ouro" (GORDON, 1998, p. 152) [tradução da autora].
} 
A repercussão do livro de Wertham e da criação do "Comics Code Seal of Approval" (selo de aprovação do código de quadrinhos) do Comics Code Authoriry pela CMAA - Comics Magazine Association of America (Associação das revistas em quadrinhos da América), um código de autocensura altamente restritivo, influenciou ainda mais a rejeição das revistas em quadrinhos americanas em outros países.

No Brasil, onde o quadrinho importado dos EUA já sofria várias pressões de padres, educadores e intelectuais, a discussão se acirrou como demonstrado no artigo Máquinas de corrupção da infância de Álvaro Negromonte publicado na revista católica Ecos Marianos em 1953, citado por Gonçalo Junior no livro A guerra dos gibis:

Essas revistas embrutecem a inteligência; tiram o gosto para os estudos, degradam a língua, recheiam de grosserias o vocabulário de crianças e jovens, valorizam gírias, incapacitam seus leitores para a simples narração de um fato. [...] Muitos pasmarão ao saber que as famigeradas revistas em quadrinhos, os chamados gibis, são máquinas de corromper. Talvez nunca as leram [sic]. Por isso é que as entregam aos filhos. (GONÇALO JUNIOR, 2004, p. 195)

A hostilidade com revistas em quadrinhos era tamanha que, segundo o renomado quadrinista brasileiro Maurício de Souza, algumas cidades brasileiras promoveram até mesmo campanhas de queimas de revistas em eventos escolares instigados por pais e professores,

Eu mesmo tive que dar dois ou três exemplares (que possuía em duplicata, é claro) para queimar. Os considerados maus gibis não tinham jeito: viravam cinzas. Fiz isso para não ficar mal visto na escola. Naquela época, não era nem louco de dizer que lia histórias em quadrinhos... (SOUSA apud GUSMAN, 2006, p. 16)

Uma das formas encontradas no Brasil para coibir as editoras de quadrinhos, foi um projeto de lei que taxaria duramente as empresas caso publicassem material não aprovado por um comitê de censura. Mas antes que fosse votada Aizen, Marinho e Alfredo Machado se aliaram para pressionar o Ministro Tancredo Neves e o Congresso (GONÇALO JUNIOR, 2004, p. 207). Além do lobby político, segundo Gonçalo Júnior, enquanto Roberto Marinho mantinha uma postura de combate frontal na defesa dos quadrinhos e detração dos opositores em seu jornal, Adolfo Aizen buscava um endosso intelectual às publicações em quadrinhos de sua editora a EBAL, como quando Cecilia Meireles, uma das maiores autoridades em literatura infantil na época, foi procurada por Naumim Aizen, seu filho mais velho, e Fernando Albagli, diretor industrial, 
Cecília recebeu Naumim e Albagli com simpatia. Ao saber que eram editores de quadrinhos, brincou: "Vocês cometem esse crime?" Para a poetisa, quadrinhos eram sinônimo de português errado e de histórias incompreensíveis que deformavam o aprendizado escolar das crianças. Ela disse aos visitantes, depois de folhear as revistas: "Ah, mas os quadrinhos de vocês são totalmente diferentes." (GONÇALO JUNIOR, 2004, p. 260).

A poetisa chegou a autorizar a quadrinização de um de seus poemas e participou da revisão das provas (GONÇALO JUNIOR, 2004, p. 260).

Mesmo a Holanda sentiu pressões similares, depois da segunda guerra mundial, com a escassez do papel, foram criadas revistas baratas em formato pequeno chamadas de "beeldromans" (novelas de imagens), principalmente com histórias de detetives e combate ao crime. Segundo a Comiclopedia Lambiek, é dito que quando a governanta da princesa Juliana, encontrou algumas dessas revistas nas mãos de seus pupilos, pediu que fossem tomadas medidas governamentais a respeito. Então o ministro da cultura colocou uma declaração nos jornais pedindo aos professores para parar com a distribuição desses "perigosos e corruptores quadrinhos. Estes livrinhos que contém uma série de ilustrações acompanhando texto são geralmente de caráter sensacionalista e sem nenhum outro valor." Acompanhando este fato houve a descoberta de beeldromans nos pertences de um jovem de 15 anos que assassinou a namorada de 16 anos. Isso fez com que não só os beeldromans, mas todos os quadrinhos entrassem na mira dos opositores. Mas, ainda assim, as revistas em quadrinhos consideradas "saudáveis" continuaram a ser vendidas na Holanda (SCHEDDEBOOM e KNUDDE, 1994-2018).

Segundo Mazur e Danner, o quadrinhos, principalmente infantis, prosperaram muito na Europa Ocidental, criando estéticas independentes do quadrinho americano, como os da Ecole de Bruxelles, que valorizada a ligne claire (linha clara) cujo maior expoente é Hergé, e da Ecole de Chaleroi seguido por André Franquim (MAZUR e DANNER, 2014, p. 12).

No Japão, além dos autores nacionais, também eram importados os quadrinhos estrangeiros através dos Syndicate, em especial as revistas de Walt Disney, que faziam bastante sucesso com o público infantil, influenciando muitos artistas japoneses. Os mangás também foram usados como ferramenta política, tanto pelos partidos nacionalistas quanto seus opositores socialistas nas campanhas pró e contra as campanhas de guerra contra Rússia e China, e também durante a Segunda Guerra. Por serem considerados efêmeros ou coisas de criança, os mangás escaparam da dura censura imposta pelos americanos durante a ocupação no pós- 
guerra, e tiveram um grande impacto nos jovens leitores, uma vez que sendo mais baratos e de fácil acesso do que o cinema, tornaram-se um meio possível de distração da dura realidade. Além disso, havia bibliotecas de aluguel de mangá para aqueles que não podiam comprá-los, chamadas Kashibon'ya, um lugar onde se podia ler a preços módicos (MCCARTHY, 2014, p. 38-39).

Em 1947 Osamu Tesuka publica "Shin Takarajima" (a nova ilha do tesouro) no formato tnokabon - barato, encadernado com papelão, com o tamanho de uma revista $(26 \mathrm{~cm} \times 18 \mathrm{~cm}$ ), vendido por comerciantes ambulantes e lojas de doces. Em 1952, já em Tóquio, ele lança "Tetsuwan Atom", que se tornou a franquia de êxito mundial Astro Boy (Figura 58, pág. 115), segundo Mazur e Danner,

O estilo acelerado e a narrativa e o traço dinâmicos de Tezuka, com influência do estilo Disney (Figura 60, pág. 115), definiram o tom para a estética do mangá por, pelo menos, uma década (MAZUR e DANNER, 2014, p. 12)

Além do enorme sucesso de Astro Boy, Osamu lançou em 1953 na revista Shojo Club, o mangá "Ribbon no Kishi" (Figura 59, pág. 115), no Brasil conhecida como "A princesa e o cavaleiro" por causa do desenho animado exibido pela TV Record em 1973, que se tornou extremamente popular. McCarthy aponta que, como as personagens femininas em Astro Boy eram apenas coadjuvantes, Tesuka queria criar uma personagem feminina que fosse tão heroica para as meninas quanto Astro Boy para os meninos (MCCARTHY, 2014, p. 39).

Durante os anos 50 e 60, enquanto os quadrinhos do ocidente estavam sofrendo as consequências dos movimentos conservadores influenciados pelo livro de Wertham ${ }^{80}$, o movimento estudantil japonês dava vazão às suas frustações em experimentações estéticas e narrativas cada vez mais ousadas, dando origem ao gênero gekiga (Figura 61, pág.115). Segundo Mazur e Danner,

As primeiras histórias gekiga eram principalmente de suspense e mistério e destinadas a leitores adolescentes do sexo masculino, com quadros de estilo cinematográfico e efeitos de iluminação inspirados em filmes noir franceses e norte-americanos (MAZUR e DANNER, 2014, p. 13).

McCarthy lembra que em 1952 a grande parte da força de ocupação americana após a derrota do Japão na segunda guerra mundial deixou o território japonês. A economia começou a se estabilizar e a demanda por jornais, revistas ilustradas e mangás aumentou (MCCARTHY, 2014, p. 42).

\footnotetext{
80 Sedução dos Inocentes (Seduction of the Innocent) 1954, do psiquiatra alemão Fredric Wertham.
} 


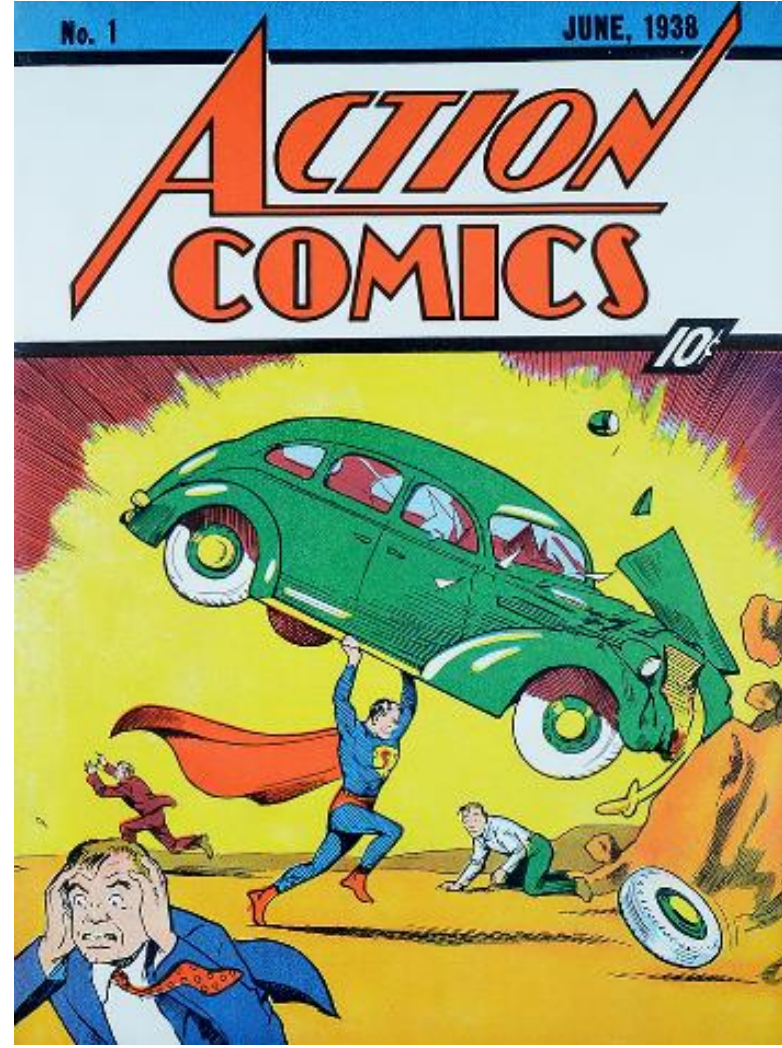

Figura 49 - Action Comics - nº 1 - 1938 - DC Comics

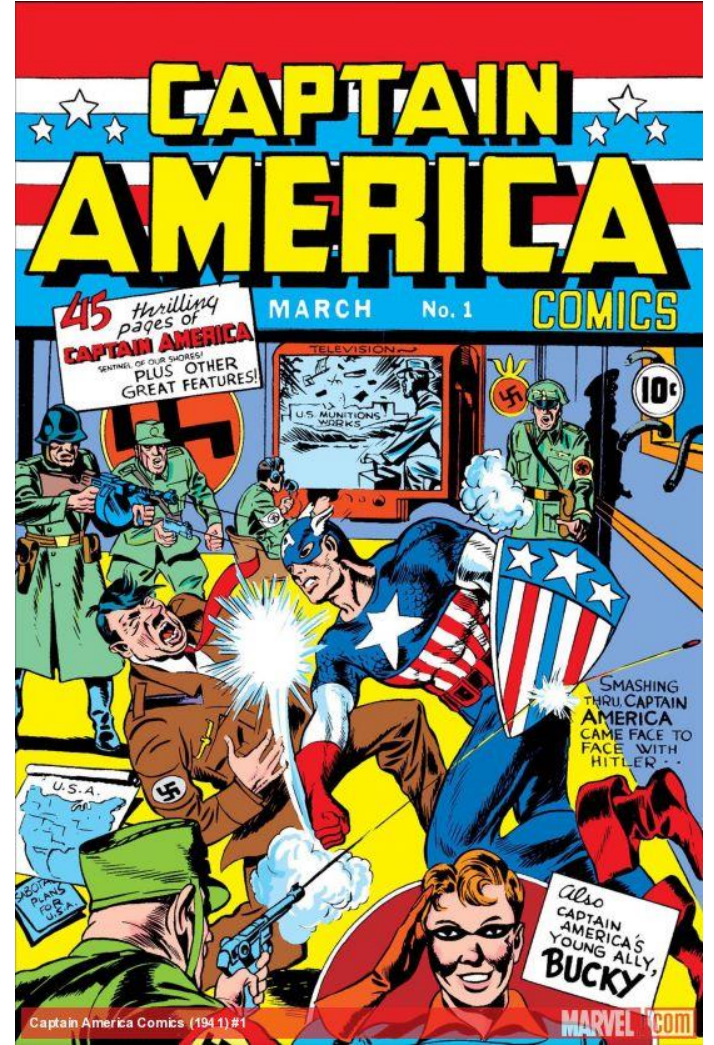

Figura 50 - Capitão América - no1 - 1941 xxxvii

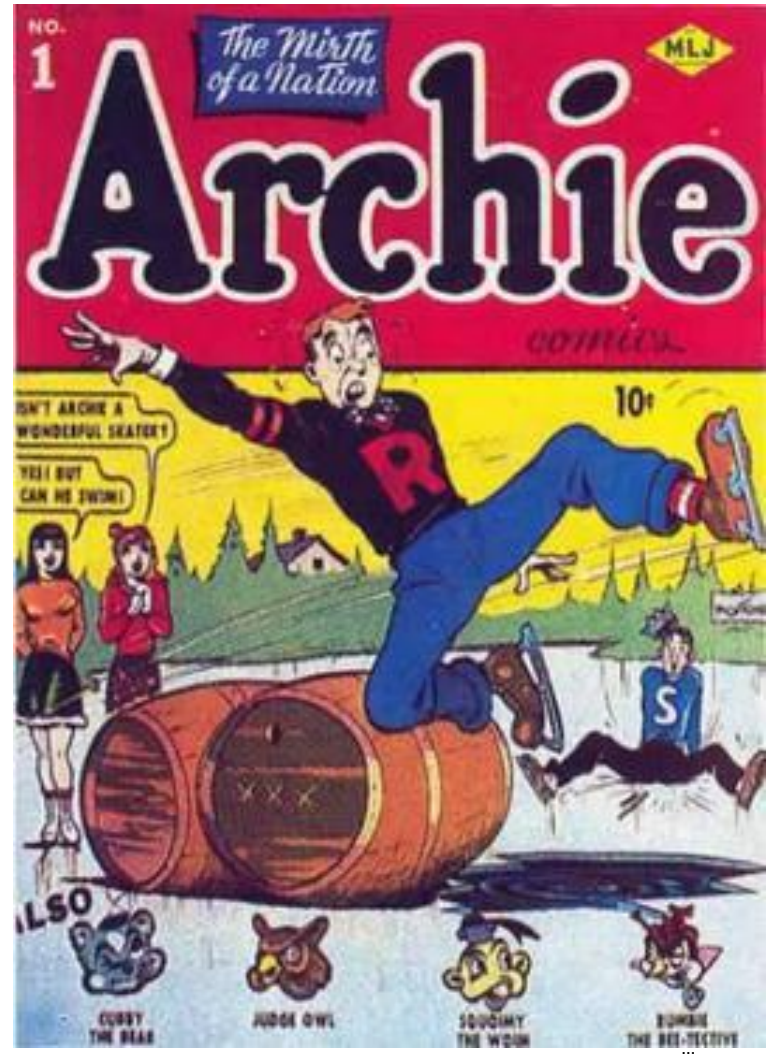

Figura 51 - Revista Archie - no $1-1942^{\text {xxxviii }}$

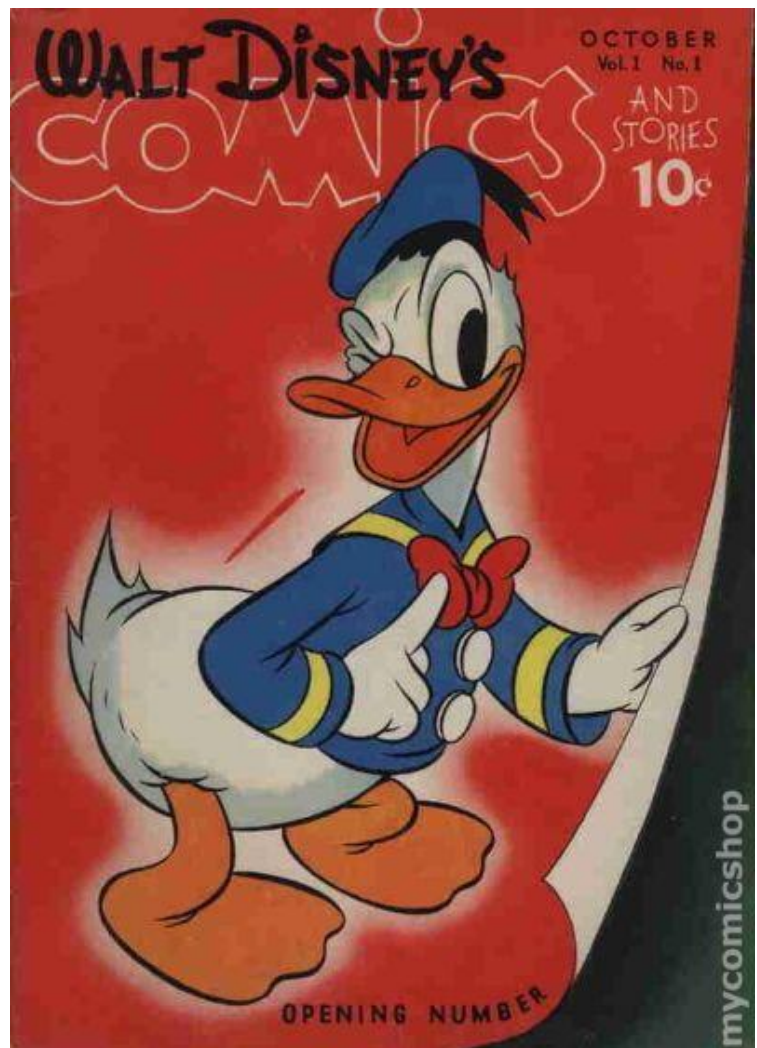

Figura 52 - Walt Disney Comics - nº 1-1940xxxix 


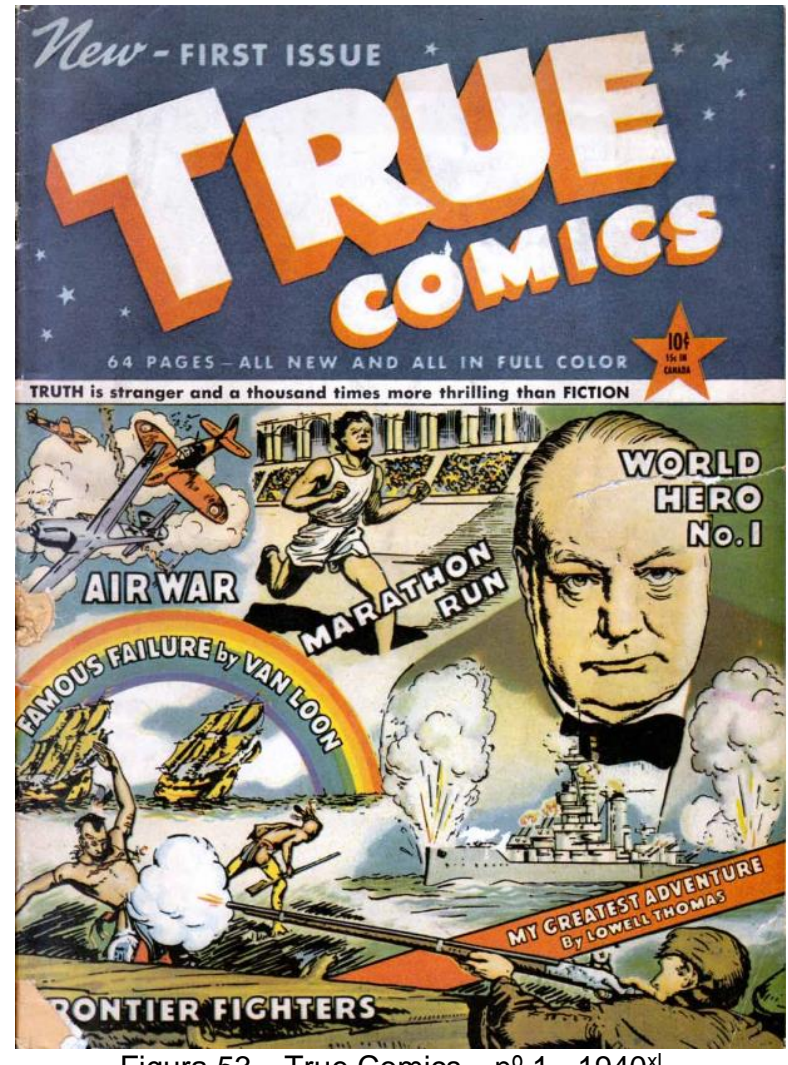

Figura 53 - True Comics - no $1-1940^{\mathrm{xl}}$

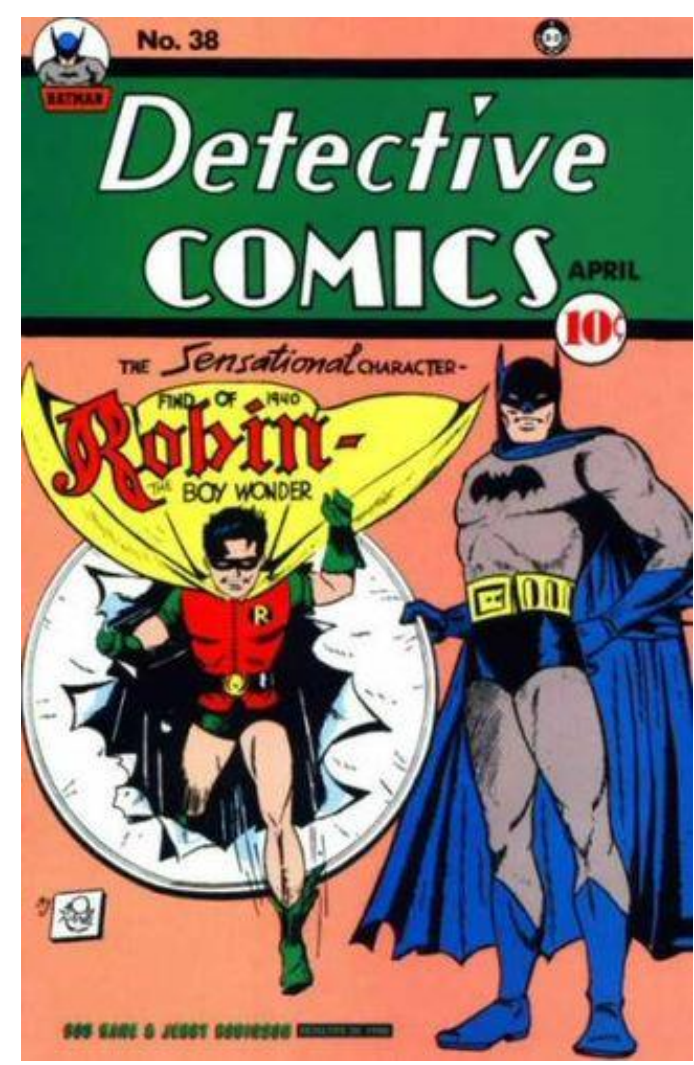

Figura 54 - Detective Comics № 38 - 1940xli

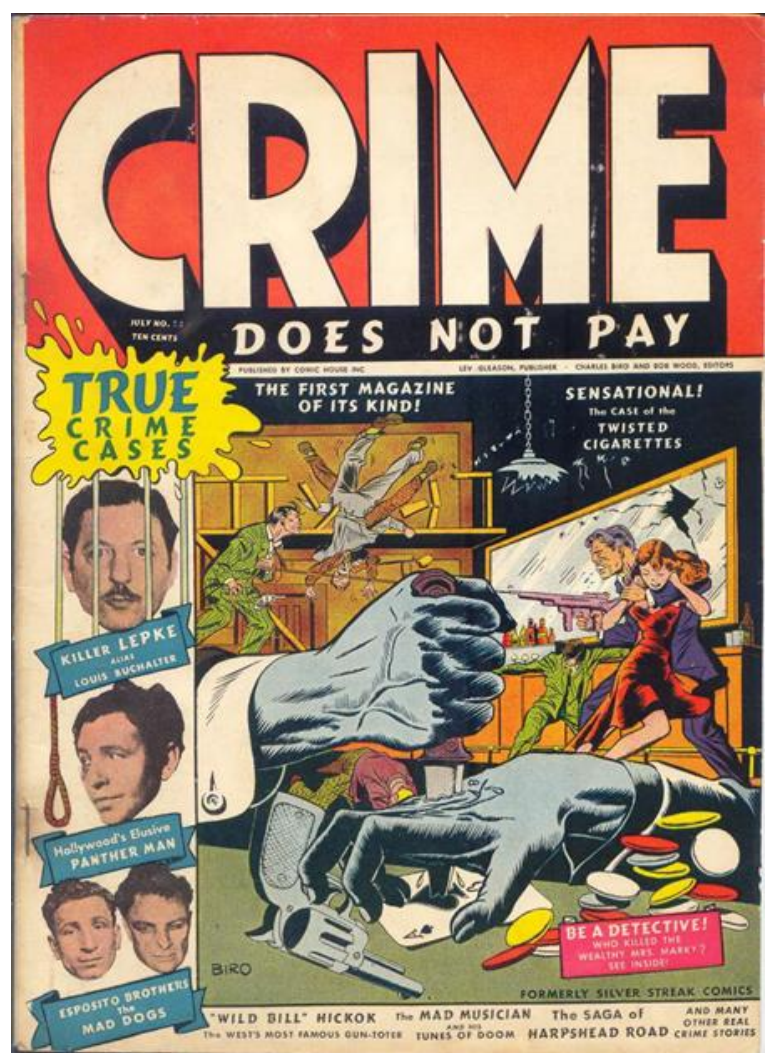

Figura 55 - Crime dos not pay - edição 22 - 1943

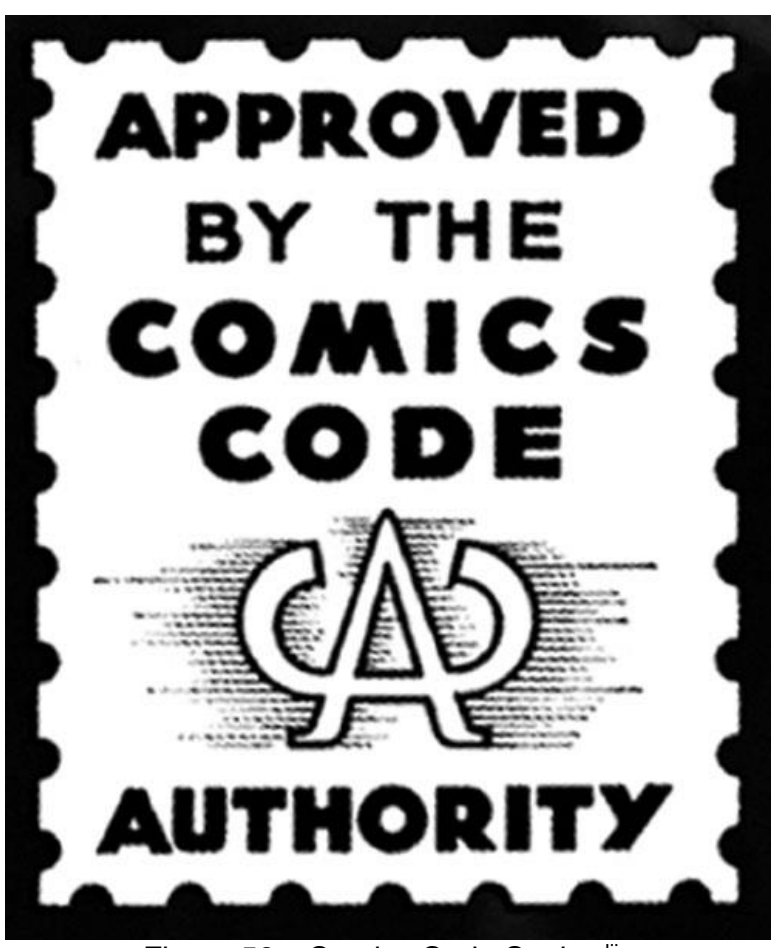

Figura 56 - Comics Code Seal - xlii 


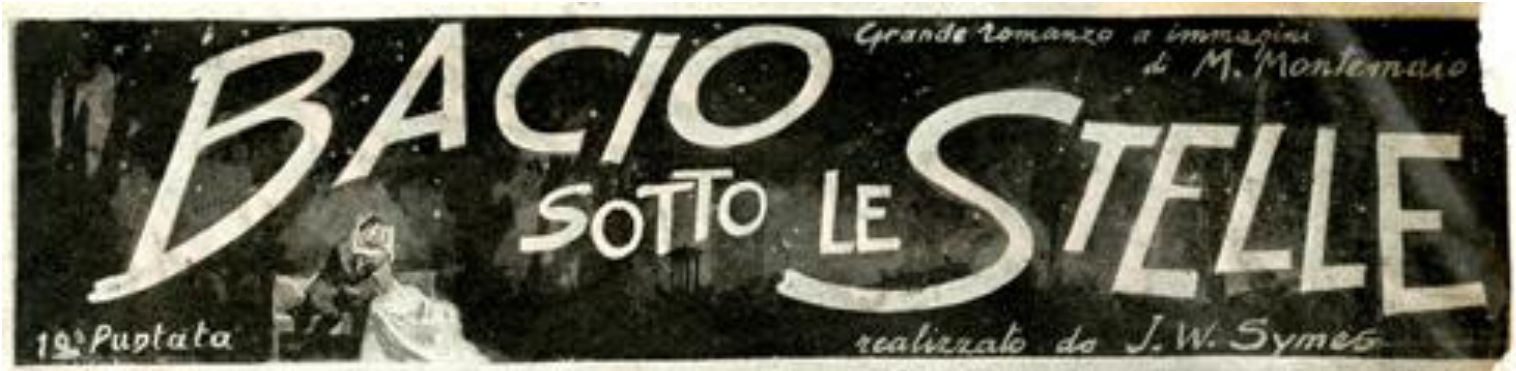

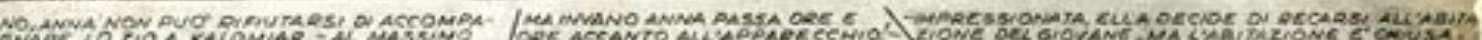

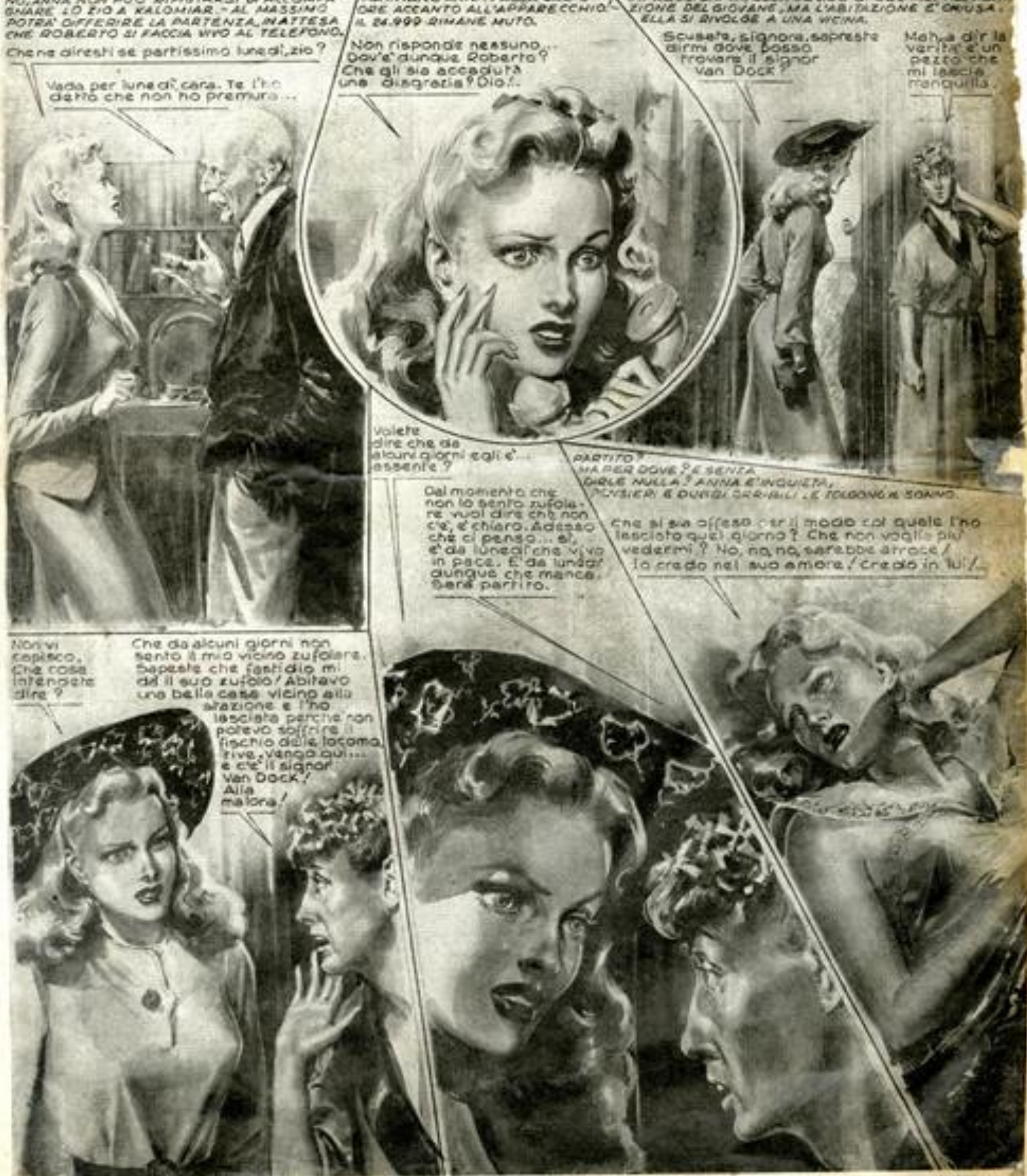

Figura 57 - Bacio Sotto le Stelle - Walter Molino sob o pseudônimo de J. W. Symes ${ }^{\text {xlii }}$ 


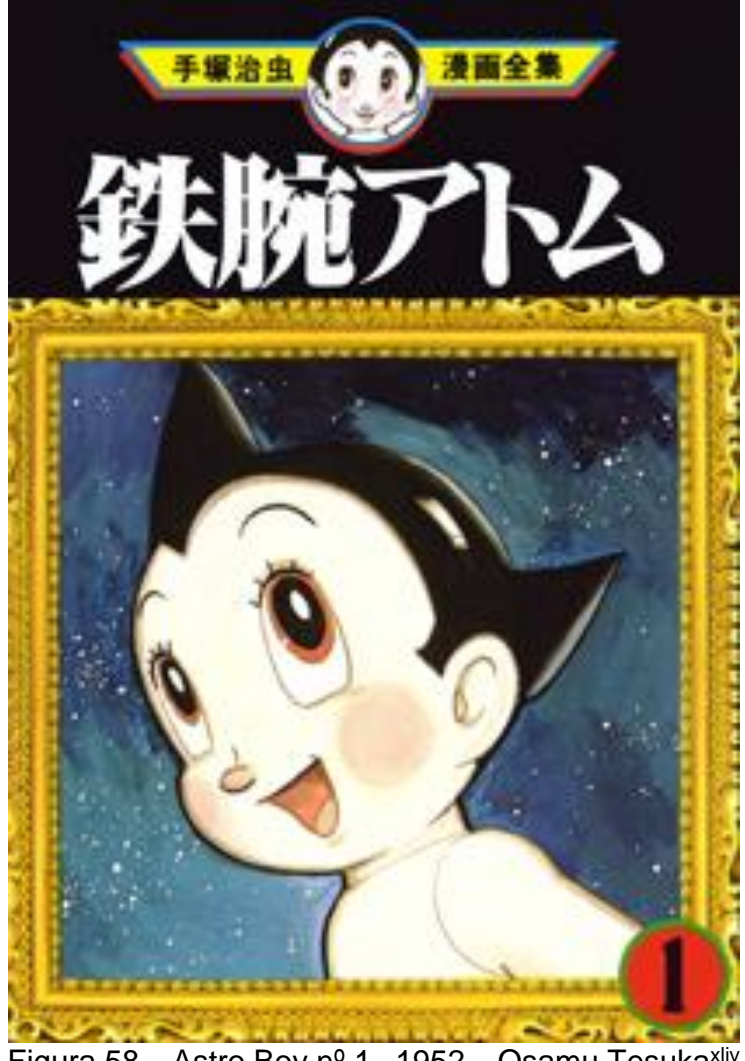

Figura 58 - Astro Boy no 1-1952 - Osamu Tesuka ${ }^{\text {xliv }}$

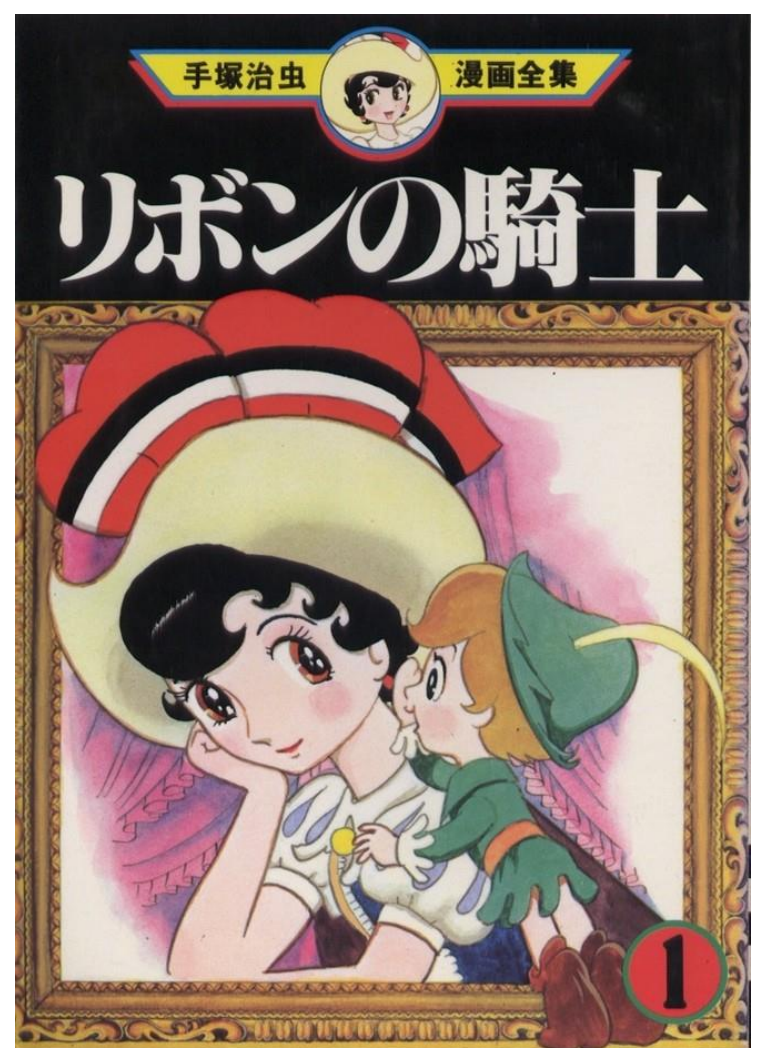

Figura 59 - Ribon no Kishi (A Princesa e o Cavaleiro) - 1953 - Osamu Tesuka ${ }^{x / v}$

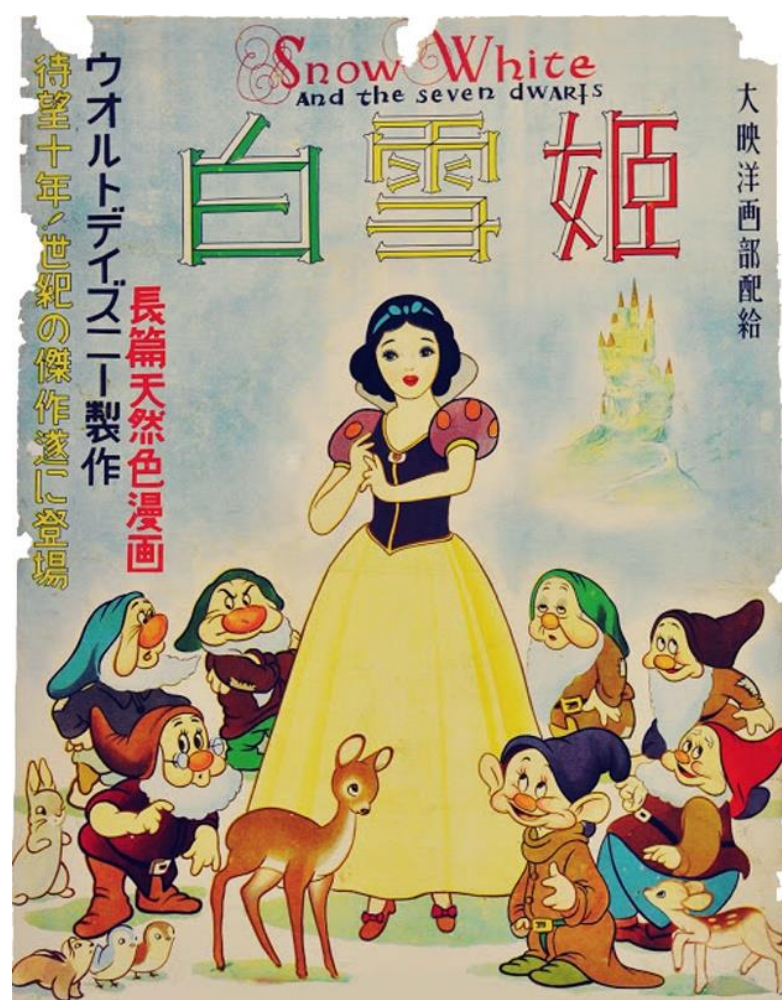

Figura 60 - Pôster original japonês do filme Branca de Neve e os Sete anões de Walt Disney ${ }^{x \mid v i}$

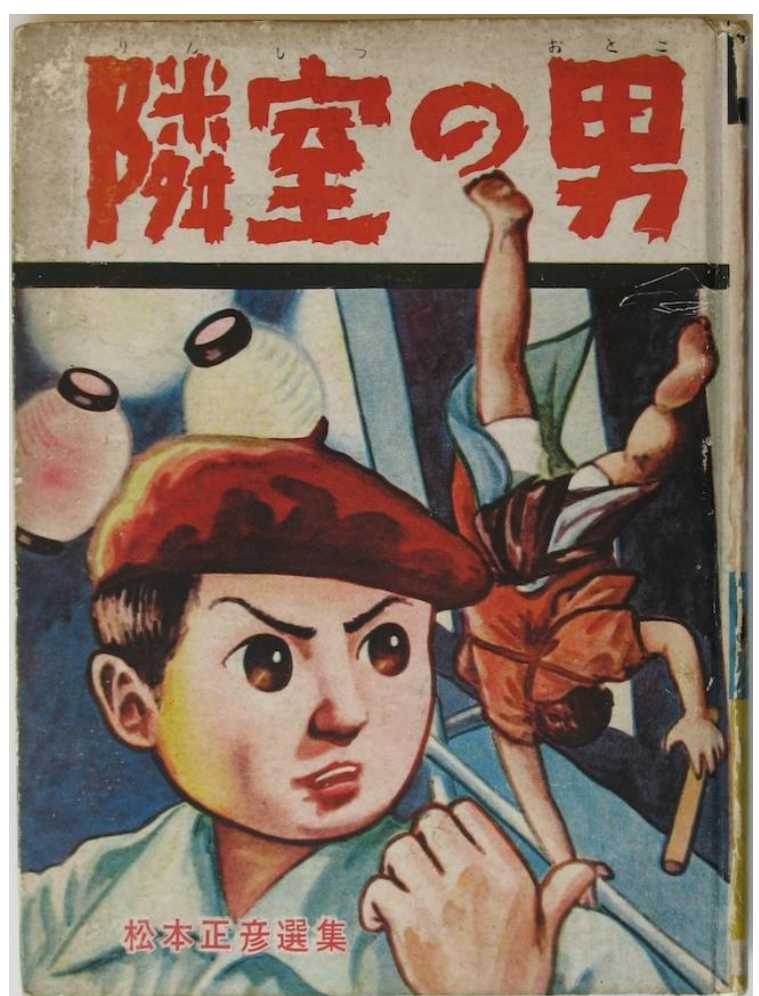

Figura 61 - Masahiko Matsumoto - The Man Next Door (Hinomaru bunko - 1957) ) xii $^{\text {van }}$ 


\subsection{O underground - sexo, drogas e samurais}

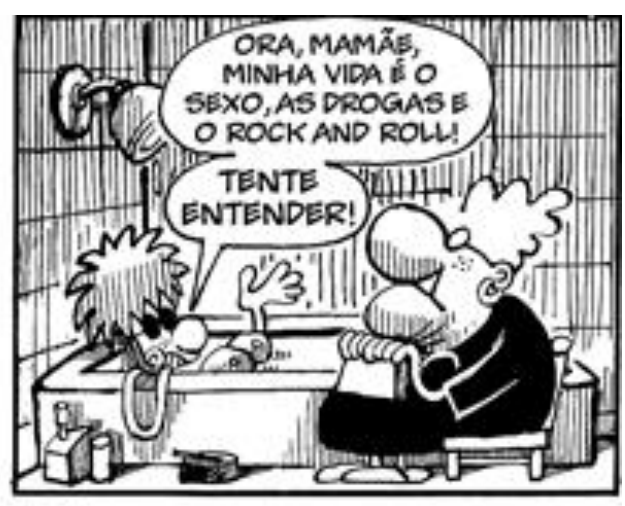

Meus heróis morreram de overdose

Eh, meus inimigos estão no poder Ideologia

Eu quero uma pra viver

Angeli e Cazuza ${ }^{81}$

Depois do fim da Segunda Guerra Mundial, o medo da invasão comunista de um lado e do imperialismo capitalista do outro, fez com que inimigos, infiltrados sorrateiramente para corromper o cidadão de desviá-lo do "bom caminho" (qualquer que fosse esse caminho), fossem vistos em todo lado. A estudiosa russa Natalia Barmina na introdução de seu artigo "Polovina schast'ia." Na revista Sobesednik, no 29 de 1989, salienta:

There were two things we didn't have in my childhood: chewing gum and comics. Someone long ago, and apparently forever, decided for us that gum was unhealthy, and comics were good-for-nothing bourgeois art ${ }^{82}$ (BARMINA apud ALANIZ, 2010, p. 81).

Em um clima de paranoia coletiva, o moralismo reinou praticamente absoluto nos anos 50 , qualquer coisa que parecesse um desvio da norma era uma ameaça em potencial e, os quadrinhos, a corrupção encarnada.

Por isso no Brasil, onde os críticos, como ressalta Gonçalo Junior, já consideravam histórias em quadrinhos subversivas em sua essência, o surgimento dos "catecismos" (Figura 62, pág. 125) de Carlos Zéfiro foi uma afronta incontestável

\footnotetext{
${ }^{81}$ Epígrafe - fonte: Angeli, disponível em: http://piaui.folha.uol.com.br/materia/re-bordosa-em-tirinhas/ e Cazuza e Frejat, albúm Ideologia, 1988 Philips Gravadora.

82 Há duas coisas que não podíamos ter em minha infância: chiclete e quadrinhos. Alguém há muito tempo e, aparentemente, para sempre, decidiu por nós que a goma era insalubre, e que os quadrinhos eram uma inútil arte burguesa (BARMINA apud ALANIZ, 2010, p. 81).
} 
as autoridades zelosas da moralidade social e, com isso, uma verdadeira caçada policial surgiu durante os anos da ditadura para descobrir a verdadeira identidade do autor.

As revistinhas, surgidas no final da década de 1950, continham desenhos e narrativas de pornografia explícita, segundo Alvaro Moya, a arte era canhestra, decalcada de outros meios, mas com roteiros que levantavam os tabus, os comportamentos sexuais e machismos da época (MOYA, 2013, p. 186). De acordo com Gonçalo Junior,

As escandalosas revistinhas pornográficas de certo desenhista misterioso que permaneceu no anonimato por mais de trinta anos - que assinava como Carlos Zéfiro. As edições - impressas em pequenas gráficas nas madrugadas -, vendidas de modo clandestino, logo transformariam seu autor, nas três décadas seguintes, no quadrinista mais combatido - e procurado pela polícia - de todos os tempos (GONÇALO JUNIOR, 2004, p. 319)

Gonçalo Junior comenta que Zéfiro, posteriormente identificado como o funcionário público aposentado Alcides Caminha na Primeira Bienal de Quadrinhos em 1991, que era odiado por juízes e inspetores de menores, foi investigado por delegados de polícia, agentes da Polícia Federal e de órgãos ligados à repressão durante a ditadura militar. Gonçalo acredita que ele só não foi descoberto, porque boa parte dos policiais eram seus leitores e, por isso, coniventes com sua produção (GONÇALO JUNIOR, 2004, p. 319).

Seu pseudônimo se tornou sinônimo de imoralidade e de falta de decência, e
seus gibis pornôs, impressos em formato de bolso, ficaram conhecidos pelo
provocativo nome de "catecismos". O termo, no fundo, tinha pertinência como
guia de aprendizado. Rapazes na puberdade buscavam ali as primeiras lições
- bem rudimentares, diga-se - sobre o sexo e não mediam esforços para
adquirir seus números com jornaleiros, livreiros e até baleiros de portas de
colégios. As revistas também eram consumidas por adultos apreciadores
desse tipo de "leitura" (GONÇALO JUNIOR, 2004, p. 322).

Gonçalo ressalta que o desenho era o que menos importava para seus leitores, ele acredita que a arte de Zéfiro era copiada dos quadrinhos americanos de romance como Rosalinda publicado pela EBAL e Gilda pela La Selva ou das fotonovelas italianas como a Grand Hotel publicada pela Vecchi e Capricho, que na época era uma revista de fotonovela e somente mais tarde alterou seu conteúdo para atualidades, e llusão Abril, que transformava as cenas em pornografia (GONÇALO JUNIOR, 2004, p. 323). 
Alguns padres as consideravam [os catecismos] um sinal do fim dos tempos, um indício de que o dia do Juízo Final estaria próximo. A Conta, claro, quem pagava era a péssima reputação dos quadrinhos de um modo geral. Zéfiro era citado como exemplo de até onde poderiam chegar os danos causados pelos gibis para a formação moral de crianças e adolescentes. Ao mesmo tempo, reforçava a ideia de uma urgente interferência dos poderes públicos para controlar a circulação de gibis no Brasil de forma indiscriminada (GONÇALO JUNIOR, 2004, p. 324).

No Japão, o final da década de cinquenta, ainda sob os destroços da derrota na Segunda Guerra Mundial, foi marcado pela procura de estéticas e temáticas pelos quadrinistas mais jovens, que representassem a identidade fragmentada tanto suas quanto do seu país. Conforme argumenta a diretora, produtora de cinema e tradutora nascida no Japão filha de missionários americanos, Linda Hoaglund, em seu ensaio "Protest Art in 1950s Japan: The Forgotten Reportage Painters" (Arte de protesto no Japão de 1950: Os esquecidos pintores repórteres) publicado pelo MIT Visualizing Cultures,

The 1950s have become something of a lost decade in historical recollections of postwar Japan. It is not difficult to understand why. The " $50 \mathrm{~s}$ " were overshadowed by the dramatic U.S. occupation that followed the country's defeat in World War II, lasting until 1952. And they were eclipsed by what followed: the "income doubling" policies initiated in 1960 that, for the first time, drew international attention to Japan's economic reconstruction. In fact, this was a tortured and tumultuous decade. Bitter memories of the recent war that ended in Hiroshima and Nagasaki folded into the spectacle of a cold-war nuclear arms race and a hot war next door in Korea (extending from 1950 to 1953). The continued post-occupation presence of a massive network of U.S. military bases provoked enormous controversy, as did the conservative government's commitment to rearm Japan under the U.S. military aegis. Former leaders of Japan's recent aggression returned to the political helmsymbolized most dramatically by the 1957 elevation to the premiership of Kishi Nobusuke, an accused (but never indicted) war criminal ${ }^{83}$ (HOAGLIND, 2012).

Em meio a uma agitação social e política, os jovens quadrinistas japoneses ligados ao Movimento Estudantil no Japão, segundo McCarthy, achavam que as linhas arredondadas e fluidas com histórias otimistas e fantásticas do mangá pós-guerra, principalmente de Tesuka, eram muito infantis e isso já não se encaixava em seu

${ }^{83}$ Os anos 50 tornaram-se uma década perdida quanto as lembranças históricas do pós-guerra do Japão. Não é difícil entender o porquê. Os "50" foram ofuscados pela dramática ocupação dos EUA que seguiu a derrota do país na Segunda Guerra Mundial, que durou até 1952. E eles foram eclipsados pelo que se seguiu: as políticas de "duplicação de renda" iniciadas em 1960 que, pela primeira vez, chamou a atenção internacional para a reconstrução econômica do Japão. Na verdade, esta foi uma década torturada e tumultuada. Amargas lembranças da recente guerra que terminou em Hiroshima e Nagasaki embrulhadas pelo espetáculo de uma corrida por armas nucleares da guerra fria e uma vizinha guerra quente na Coréia (que se estendeu de 1950 a 1953). A continuada presença pósocupação de uma rede maciça de bases militares dos EUA provocou enorme controvérsia, assim como o compromisso do governo conservador de rearmar o Japão sob a égide militar norte-americana. Os ex-líderes da recente agressão japonesa retornaram ao time político - simbolizado de forma mais dramática pela subida ao governo em 1957 de Kishi Nobusuke, um criminoso de guerra acusado (mas nunca indiciado) (HOAGLIND, 2012) [tradução da autora]. 
mundo, nem era capaz de expressar seus sentimentos. Eles queriam criar novas formas de narrativa imagética que pudessem ter apelo com os jovens de sua geração pegos entre a adolescência e a idade adulta em um mundo de rápidas mudanças (MCCARTHY, 2014).

Para isso eles evoluíram o gekiga, aumentando suas temáticas e lapidando sua estética gráfica. Uma das inovações mais marcantes foi a introdução do que ficou conhecido como "pillow shot", que alguns estudiosos, como Deborah Shamoon, professora do departamento de estudos japoneses da Faculty of Arts and Social Sciences da National University of Singapura, acreditam ser inspirados na técnica de edição de filmes japoneses, principalmente do diretor Yasujirō Ozu. Essa técnica, em uma descrição simplista, consiste em, imprimir uma sensação ou alterar o clima de uma narrativa, ao mudar a cena para um espaço, paisagem ou objeto que não parece ter função dentro da diegese (SHAMOON, 2011, p. 21-22).

Diferente da técnica de Hergé, de pausar em cenas que se mesclam dentro do ambiente, o "pillow shot" de certa forma quebra a continuidade da cena gerando uma suspensão de expectativa, criando uma pausa no ritmo de leitura. A técnica muito usada no gekiga, supunha um público adulto, pois exigia mais maturidade e sensibilidade ao ler as imagens, mas foi aos poucos incorporada a outras temáticas e classificações etárias dos mangás japoneses, se tornando um diferencial específico de sua estética.

Além do gekiga, outro gênero para adultos surgiu em 1968, com a publicação de Harenchi Gakuen (Escola do harém-pornô) de Go Nagai, mesmo não contendo sexo explícito (como os catecismos de Zéfiro) é considerado o primeiro mangá erótico publicado legalmente por uma grande editora. De acordo com McCarthy, os adolescentes japoneses amaram o mangá, mas as associações de pais e professores odiaram e moveram protestos. Contudo em 1974, Nagai criou outra comédia escolar, Kekko Kamen, com uma heroína lutando pela justiça, usando somente botas, luvas, echarpe em volta do pescoço e uma máscara com orelhas de coelho, com isso o mangá Hentai (pervertido) foi definitivamente inaugurado (MCCARTHY, 2014, p. 50).

$\mathrm{Na}$ Itália um novo tipo de quadrinhos, o fumetto nero (quadrinhos negros), é inaugurado quando as duas irmãs Angela e Luciana Giussani publicam pela Astorina de Milão em 1962, Diabolik. Uma revista de ação sobre as aventuras do personagem título, um anti-herói que era um criminoso violento e vingativo, que sempre vencia e 
nunca sendo pego. Suas ações segundo Gino Moliterno, editor da enciclopédia da cultura contemporânea italiana, eram uma declaração de auto-afirmação e individualismo anti-social diante da hipocrisia da falsa moralidade e respeitabilidade da classe média,

This genre [fumetto nero] imposed itself strongly on the market. It had a profound influence not only on the comic book world but also on society through its violent critique of middle-class myths, taboos and values. As a genre, it was well in tune with the tendency to question everything which characterized many cultural manifestations of that period ${ }^{84}$ (MOLITERNO, 2000, p. 178).

De acordo com Moliterno, as revistas Kriminal e Satanik publicadas em 1964 seguiam o mesmo estilo de Diabolik, contudo eram muito mais extremas, com novos e mais chocantes elementos. Elas adotaram desenhos expressionistas tanto na diagramação quanto nas caricaturas, com audaciosos close-ups e um ritmo rápido de narrativa. O diálogo era seco, vulgar e muitas vezes truculento. Ele ressalta que essas fumettis introduziram um poderoso conteúdo erótico e sádico juntamente com um clima tétrico e mágico (MOLITERNO, 2000, p. 178).

Outras produções adultas italianas chamadas fumetti d'autore (quadrinhos autorais), influenciaram os quadrinhos do mundo todo. Com temáticas intimistas, reflexivas e insólitas nomes como Dino Battaglia, Milo Manara, Guido Buzzelli, Hugo Pratt e Guido Crepax, pertencentes à "Escola de Veneza" (MAZUR e DANNER, 2014, p. 100-104) abriram o caminho para a recontextualização dos limites dos quadrinhos na época, com um misto de inovação e reformulação, eles desafiaram tanto a linguagem quanto a estética padronizada do período.

No Brasil, Henfil, Adão entre outros, publicaram a Revista Pasquim em oposição ao regime militar, sofrendo pressões e perseguições, e até mesmo prisões e torturas. São artistas que conquistaram o respeito para a História em Quadrinhos, ainda que com temática restrita ao humor e sátira. Ziraldo um dos grandes nomes do quadrinho infantil brasileiro se voltou mais para um encontro entre $\mathrm{HQ}$ com a literatura e direcionou-se para o material didático. Já o quadrinista de maior sucesso e renome no Brasil, Maurício de Souza, que predomina as publicações de quadrinhos nacionais, dirige seu trabalho em geral para o público infantil, o que enfrenta no Brasil, assim

\footnotetext{
${ }^{84}$ Este gênero [fumetto nero] se impôs fortemente no mercado. Tinha uma profunda influência não apenas no mundo dos quadrinhos, mas também na sociedade através da sua crítica violenta aos mitos, tabus e valores da classe média. Como gênero, estava em sintonia com a tendência de questionar tudo, o que caracterizava muitas das manifestações culturais desse período (MOLITERNO, 2000, p. 178) [tradução da autora].
} 
como a literatura infantil, o estigma de ser uma publicação pueril ou menor.

Nos Estados Unidos, as grandes indústrias de quadrinhos, conhecidas pelo nome "mainstream" - palavra que segundo o dicionário Oxford possui o sentido de: "as ideias e opiniões que se consideram normais porque são partilhadas pela maioria das pessoas; as pessoas as quais as ideias e opiniões são na maioria aceitas." e no caso dos quadrinhos americanos, e por associação na maior do mundo, usada para diferenciar a indústria de quadrinhos (editoras, gráficas e distribuidoras) em seus conglomerados que comercializam oficialmente a maioria da produção de quadrinhos, das produtoras independentes - estavam sob o jugo do Comics Code Authority, o que não coincidia com o clima de questionamento e desafio social da América do fim dos anos 50 e início dos 60 . São em pequenas agremiações de estudantes que surgem as primeiras revistas underground.

Inúmeros autores e obras fervilharam por entre lojas duvidosas ou vendidas de mão em mão, entre bebidas, drogas e rock'roll, tornando-se parte integrante de um movimento de rebeldia e afrontamento. Até que em 69, Gary Arlington funda a San Francisco Comic Book Company, a primeira loja a vender tanto material underground quanto mainstream (BOOKER, 2014, p. 837).

Alguns dos mais importantes autores do undergroud, também chamado de Comix, foram Justin Green (Binky Brown Meets the Holy Virgin Mary), Art Speigelman (Maus), Robert Crumb (Fritz the Cat, Mr. Natural, entre outros), Kim Dietch (Corn Field Comics, entre outros), Trina Robbins (Tits and Clits, entre outros), Rory Hayes (Bogeyman, entre outros), Roger Brand e Willy Murphy.

Além do underground como temática, nos Estados Unidos, Eisner introduz uma inovação conceitual, a Graphic Novel. Na verdade, o conceito não era nem inédito nem novo e, nem ao menos, americano, mas Eisner consegue pela exposição e insistência que o termo ganhasse visibilidade e distinção.

Segundo o professor Waldomiro Vergueiro, doutor em Ciências da Comunicação da ECA-USP, Eisner que já havia estabelecido o modelo para vários estúdios de quadrinhos - moldando a sistemática de produção de gibis nos EUA (VERGUEIRO, 2005), como a produção em várias etapas, em que ele rascunhava e artistas assistentes finalizavam tanto o desenho e o texto - exerceu uma grande pressão junto ao mercado editorial, fazendo com que o termo "Graphic Novel" seja adotado hoje para distinguir quadrinhos com temática ou estética adultos: 
Eu estava sentado ao telefone, conversando com este sujeito, e eu disse, "Eu tenho uma coisa nova para você, uma coisa muito nova." E ele disse: "O que é?" E eu olhei para ela e me dei conta de que se eu falasse, "Uma história em quadrinhos", ele desligaria. Ele era um sujeito muito ocupado, e aquela era uma editora de alto nível. Por isso, eu a chamei de romance gráfico (graphic nove/), e ele disse, "Oh, isto é interessante. Traga aqui!" Eu levei. Ele olhou para ela, olhou para mim por cima de seus óculos de leitura, e disse, "Você sabe, ainda é uma história em quadrinhos. Nós não podemos publicar esse tipo de coisa". (EISNER apud VERGUEIRO, 2005)

Já na Rússia, durante a Perestroika, o aumento da liberdade de expressão e, principalmente, de imprensa propiciou o surgimento de revistas em histórias em quadrinhos dos até então artistas clandestinos. Inspirados na antiga tradição dos Luboks, que muitos estudiosos consideram como precursores da linguagem das Komiks russas e pelos jornais satíricos e pôsteres sequenciais da era soviética as "janelas" ROSTA, de artistas como o poeta e cartunista Vladimir Maiakovski, os quadrinistas desse período inovaram a linguagem dando-Ihe refinamento estético, abordagem temática e narrativa relevante à realidade russa.

Artistas e estudiosos do gênero, tendo em vista as possibilidades expressivas da linguagem, estavam otimistas quanto a valorização da nova mídia como $9^{\mathrm{a}}$ arte, mas com o fim da Perestroika, a abertura generalizada das fronteiras, trouxe para o iniciante mercado editorial nacional, uma concorrência sólida e experiente do mercado estrangeiro. A crise financeira que abalou o final do regime comunista tornou os custos de publicação de material nacional inviáveis para os editores, que optaram em comprar material estrangeiro por meio dos Syndicates e redes de distribuição similares. Além disso, o meio sofreu com as críticas dos conservadores que viam nas representações de gângsteres, delinquentes e prostitutas, exemplos da decadência burguesa à que a Rússia estava se dirigindo.

Os estudiosos notaram com tristeza que apesar de quadrinhos serem vendidos abertamente, isso não queria dizer que a $\mathrm{HQ}$ estivesse finalmente aceita, como ressalta Alaniz, 
When children buy comics about Mickey Mouse, Donald Duck, and Uncle Scrooge, their parents don't give a thought to the fact that they are buying comics. Most of them could not clearly answer the question as to what made them buy the comics, because the question itself would be a revelation to them. For they didn't buy comics, they bought illustrated stories based on the plots of their child's favorite weekly cartoon series. They wanted to make the kid happy, and maybe to carve out some free time for themselves with the help of the comics. This is why the current popularity of comics is not the popularity of a genre, but of famous animated and movie characters or brands. It is no accident that all of the comics on the market today are a form of printed support for the Western film industry, and are bought only because their protagonists are so well known from films ${ }^{85}$ (ALANIZ, 2010, p. 94).

Alaniz cita a fala do crítico Ivan Kulikov, no primeiro festival de quadrinhos russos em 2002: "A situação para os quadrinhos na Rússia é, em geral, muito estranha. Em pouco tempo o país conseguiu adquirir todas as formas de cultura de massa. Exceto, quadrinhos" (KULIKOV por ALANIZ, 2010, p. 5). Quadrinistas russos, segundo Alaniz, devem trabalhar em um ambiente semi-hostil, onde quadrinhos estão longe do respeito, status social e financiamento cultural que a Bande Dessineé recebe na França.

Em 1989, o mangaka, como são chamados os quadrinistas no Japão, Shotaro Ishinomori tentou mudar semanticamente a imagem negativa do mangá imbuída pelo ideograma 漫 (man) propondo a troca para o kanji: 万 com a mesma leitura, mas cujo significado é: mil, milhares, muitos, imensidão, etc. Com isso ele esperava agregar ao mangá um conceito como mil imagens ou uma imagem com infinitas possibilidades, mas a versão mais antiga já estava tão agregada ao cotidiano e conhecimento coletivo que a inovação não foi acatada (MCCARTHY, 2014, p. 9).

Atualmente o mangá no Japão é uma indústria sólida e rentável, com subdivisões demográficas que tentam agradar diversos tipos de público: Kodomo manga - crianças pequenas; Shōjo manga - meninas de 9 a 18 anos; Shōnen manga - meninos de 9 a 18 anos; Josei manga - mulheres adultas; Seinen manga — homens adultos; Gekiga — jovens adultos (18 a 25 anos); Hentai — pornografia;

\footnotetext{
${ }^{85}$ Quando as crianças compram quadrinhos do Mickey Mouse, Pato Donald ou Tio Patinhas, seus pais não se atentam para o fato de que estão comprando quadrinhos. A maioria deles não pôde responder claramente à questão de o que os fez comprar quadrinhos, porque a própria questão foi uma revelação para eles. Porque para eles, eles não compraram quadrinhos, eles compraram histórias ilustradas baseadas nos personagens e temas favoritos dos desenhos animados que seus filhos assistem na TV. Eles queriam fazer seus filhos felizes, e talvez conseguir algum tempo livre para si mesmos com a ajuda dos gibis. É por isso que a atual popularidade dos quadrinhos [na Rússia] não é a popularidade do gênero, mas de famosos personagens de desenho animado e filmes ou marcas. Não é por acidente que os quadrinhos vendidos no mercado hoje são uma forma de apoio impresso a indústria de cinema ocidental, e são comprados apenas porque seus protagonistas são bem conhecidos dos filmes (ALANIZ, 2010, p. 94) [tradução da autora].
} 
Yuri / GL / girls love - temas homoeróticos e homoafetivos femininos; Yaoi / shonen ai / BL — temas homoeróticos e homoafetivos masculinos; Yonkoma — tiras e Dojinshi — mangás criados por fãs.

Dentre esses gêneros maiores ainda se encontram subdivisões e mesclagem de estilos, além de outros mangás sem propósito comercial. No Japão o mangá tem espaço consagrado na cultura e identidade nacional. É comum ver o uso da linguagem em panfletos explicativos institucionais, em livros didáticos escolares e empresariais, em campanhas médicas e de prevenção de desastres e acidentes.

Ao longo do tempo, os diferentes tipos de público, abordagens e experiências com o meio distanciou a estética e design tanto gráfico quanto narrativo do mangá das histórias em quadrinhos ocidentais, tornando-o uma manifestação tão díspar da europeia e americana que durante algum tempo foi tomada por algo completamente diferente. Desde a década de 80 que os quadrinhos japoneses são influenciadores na arte e expressividade de artistas ocidentais. O mangá é uma mercadoria exportada pelo mundo todo como um produto tipicamente japonês, tanto que na França, apesar do uso normal de Bande Dessinée como a nomenclatura para designar a História em Quadrinhos como um todo, para o material japonês eles utilizam o termo "mangá" e o para o americano termo "comics" (GROENSTEEN, 2014, p. 94). 


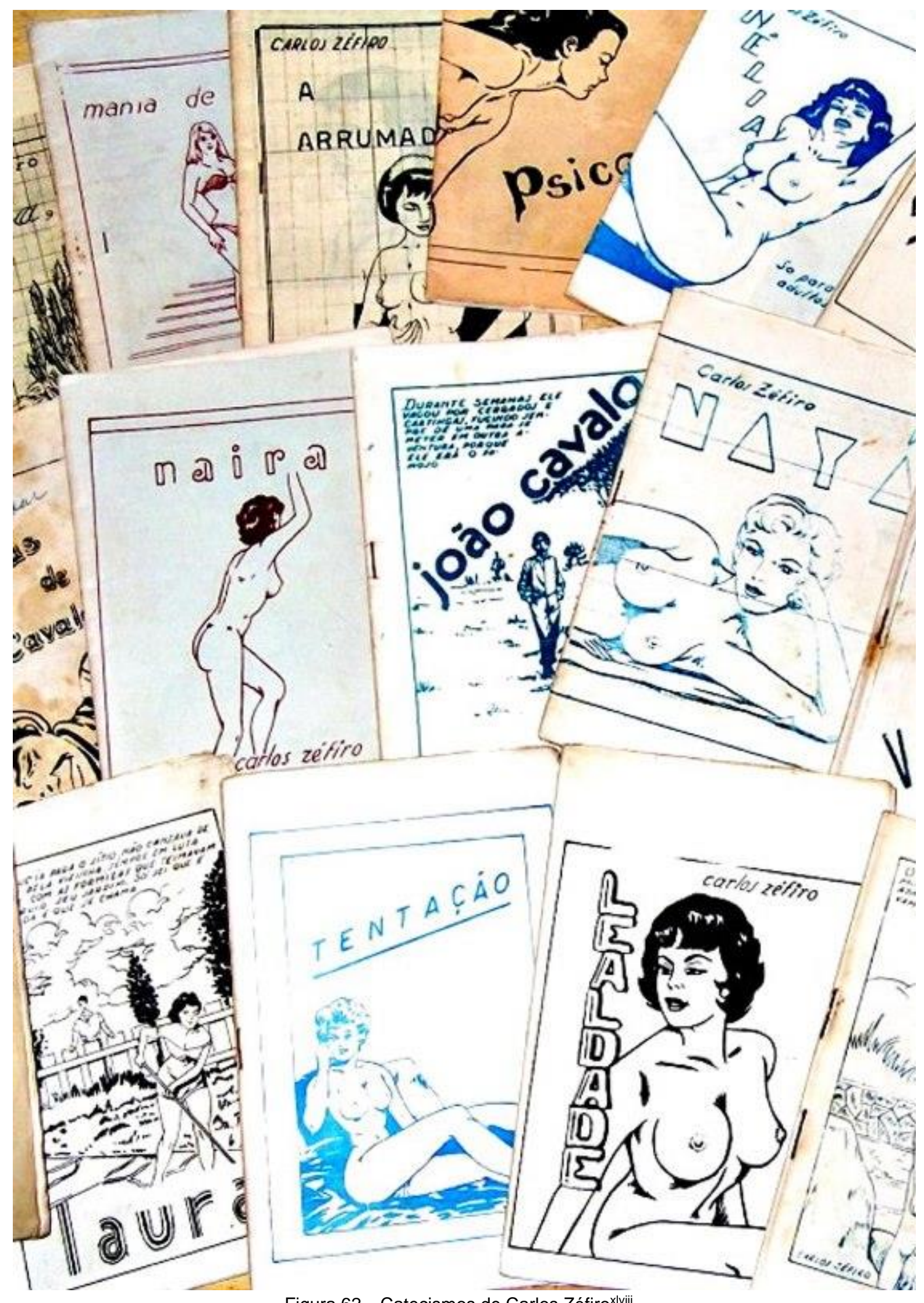

Figura 62 - Catecismos de Carlos Zéfiro ${ }^{\text {xlviii }}$ 


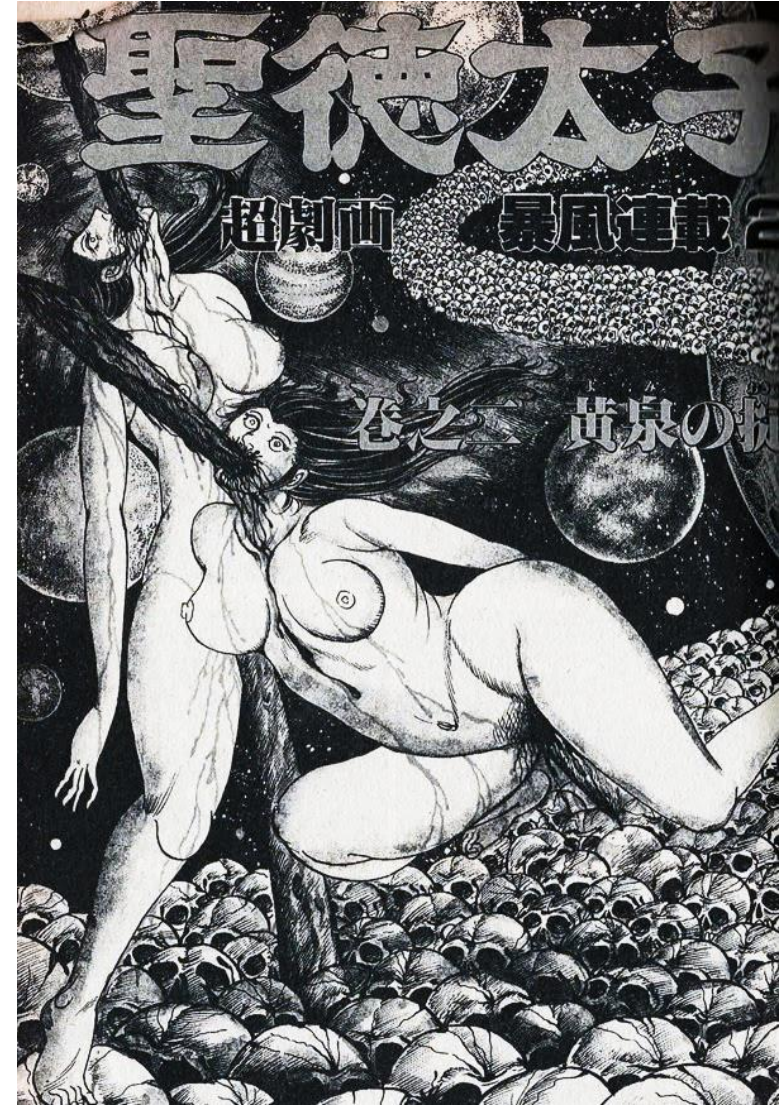

Figura 63 - Príncipe Shotoku - Kai Takizawa and

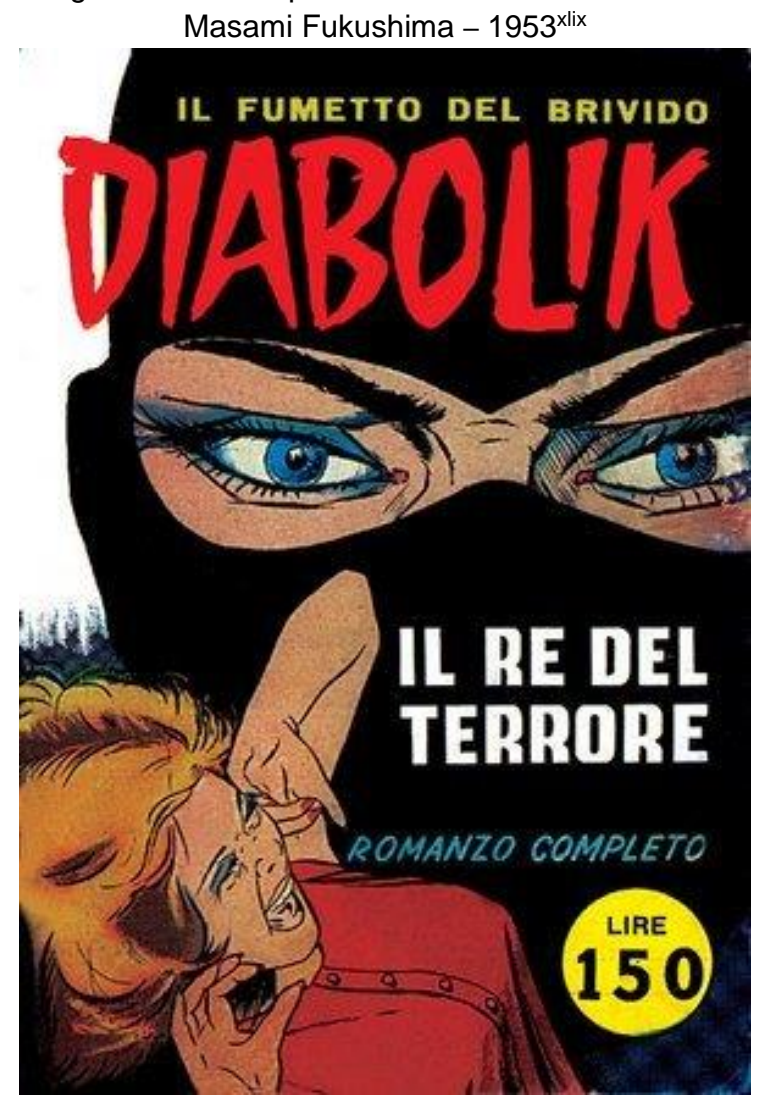

Figura 65 - Diabolik - Angela e Luciana Giussani 1962

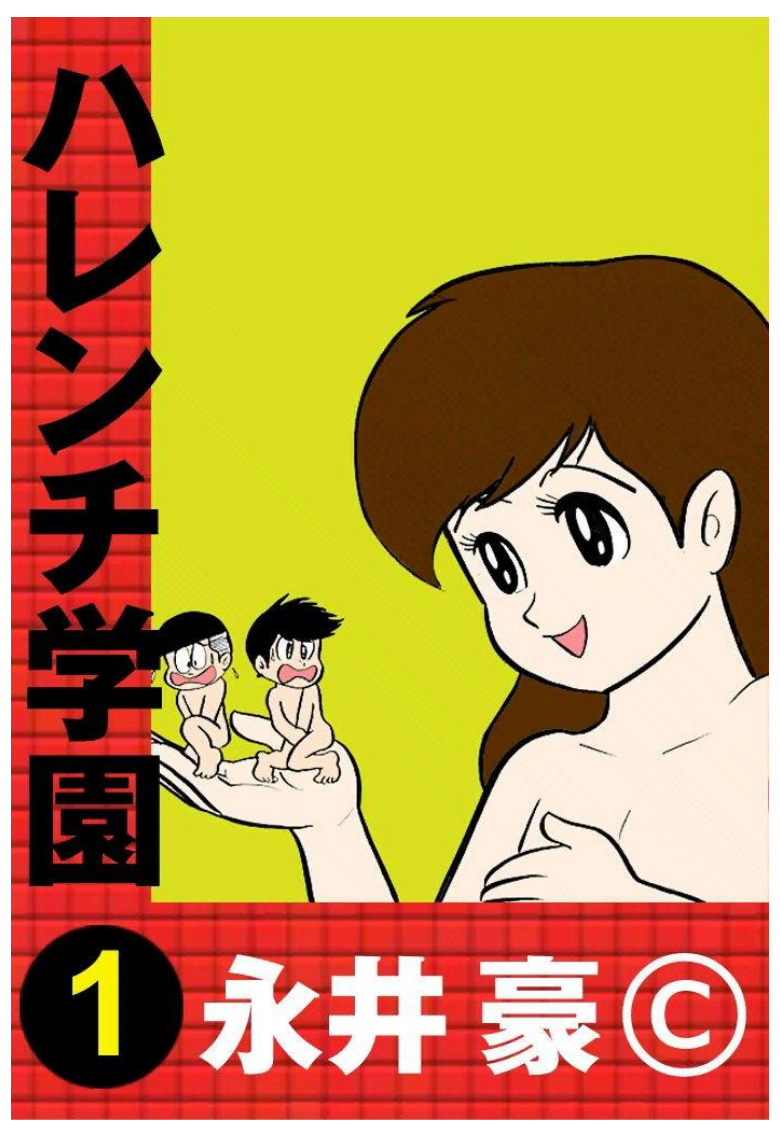

Figura 64 - Harenchi Gakuen - Go Nagai - 1968'

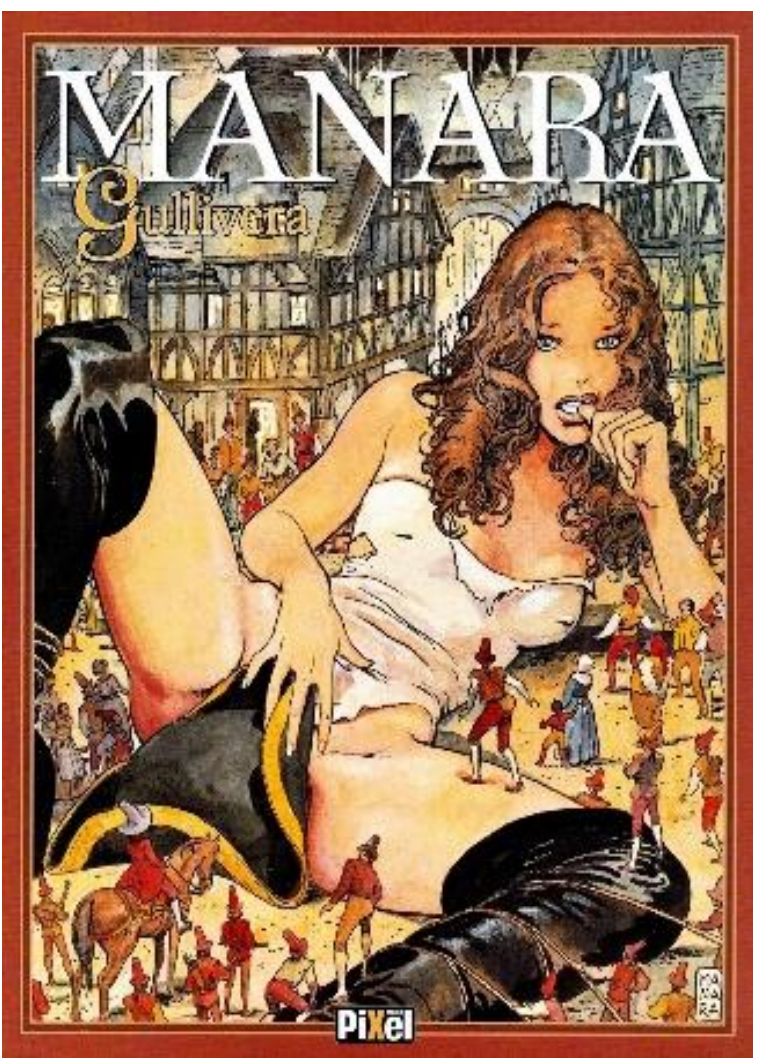

Figura 66 - Milo Manara - Gullivera 


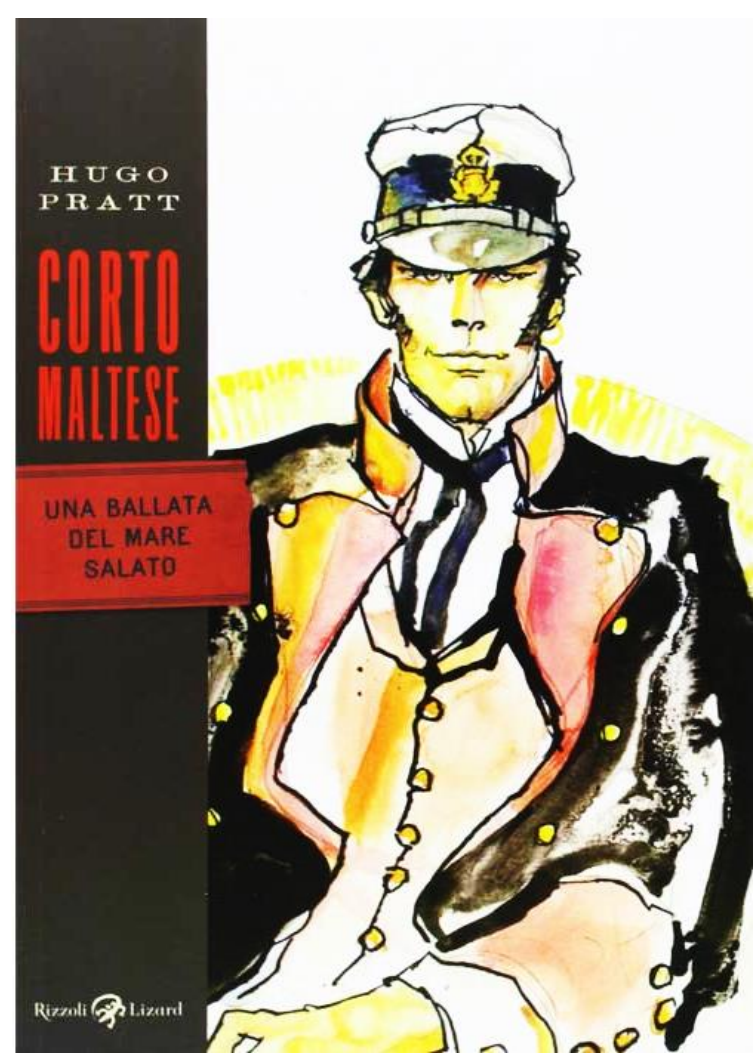

Figura 67 - Hugo Pratt - Corto Maltese - Una Ballata Del Mare Salato

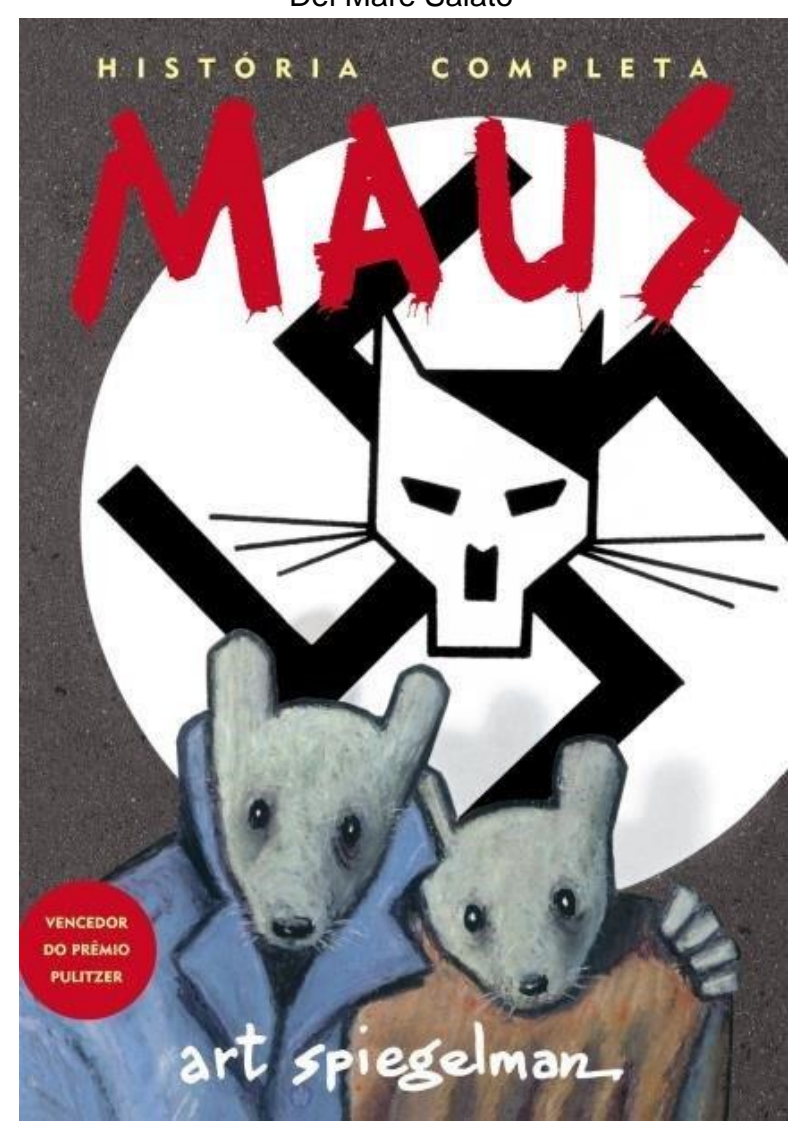

Figura 69 - Maus - Art Spiegelman - entre 1980 e 1991 na revista Raw ${ }^{\text {lii }}$
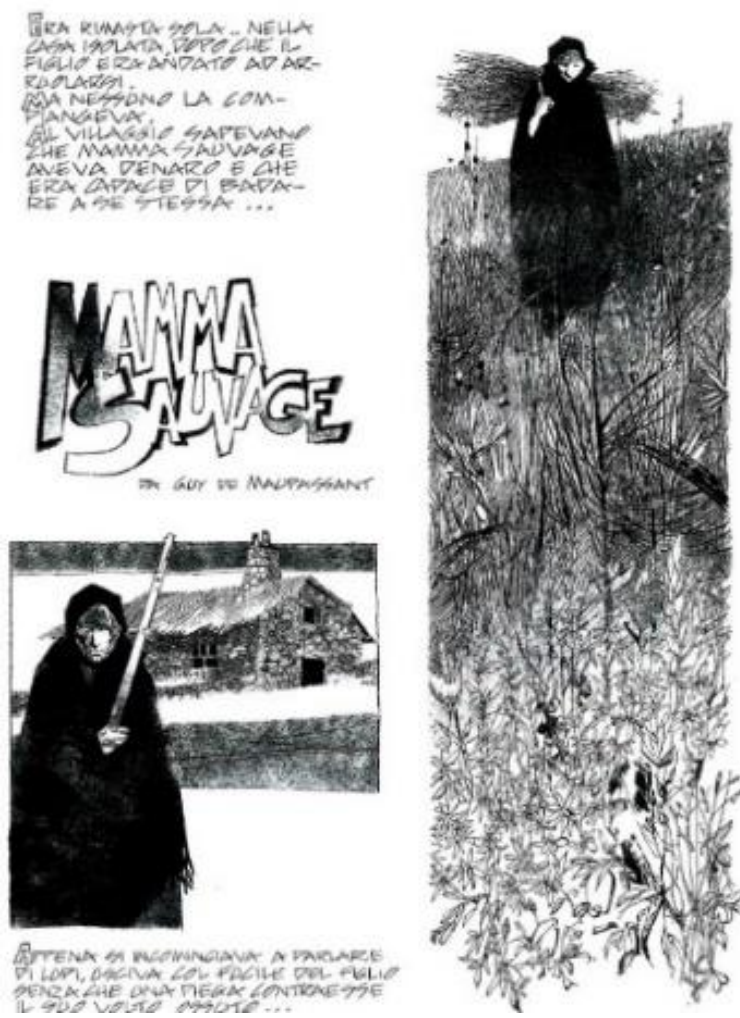

Figura 68 - Dino Battaglia - Mamma Sauvage adaptação do conto de Guy de Maupassant

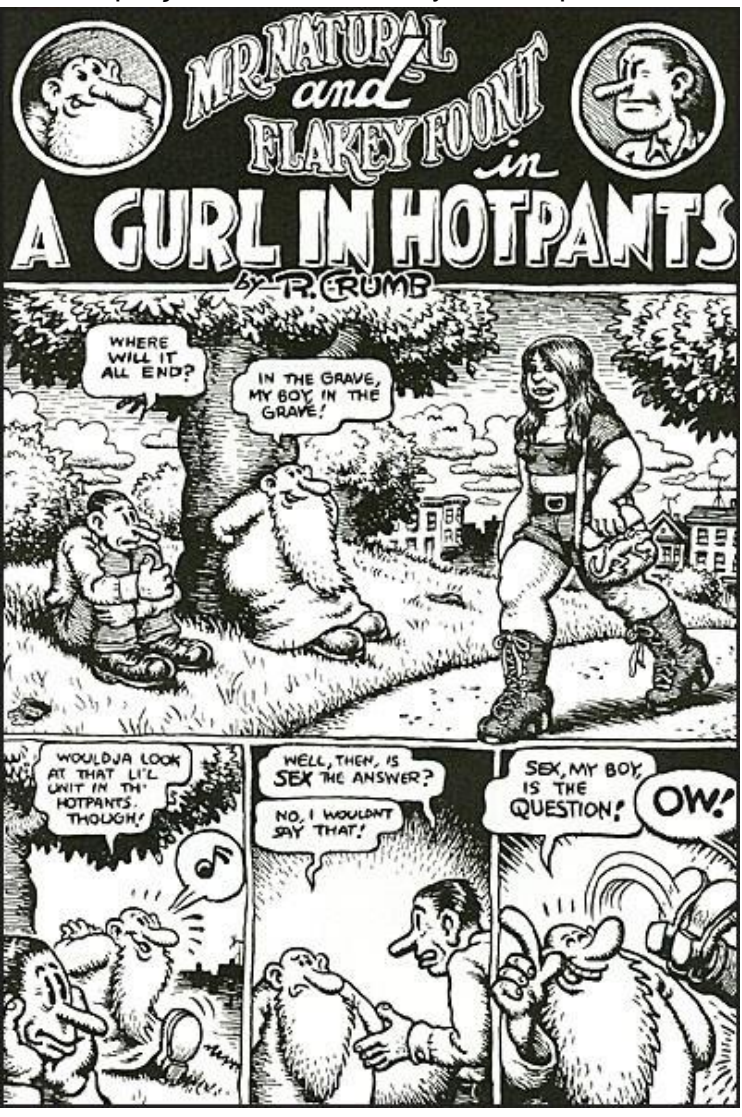

Figura 70 - Mr. Natural - Robert Crumb - 1967 $7^{\text {lii }}$ 


\section{ESTRUTURA}

$O$ que se percebe nos estudos realizados nesta perspectiva é, na sua maioria, um quase que esvaziamento do aspecto literário ou artístico presente na obra, isto é, a obra passa a ser encarada de um ponto de vista pragmático, desvinculada de seu ideal artístico.

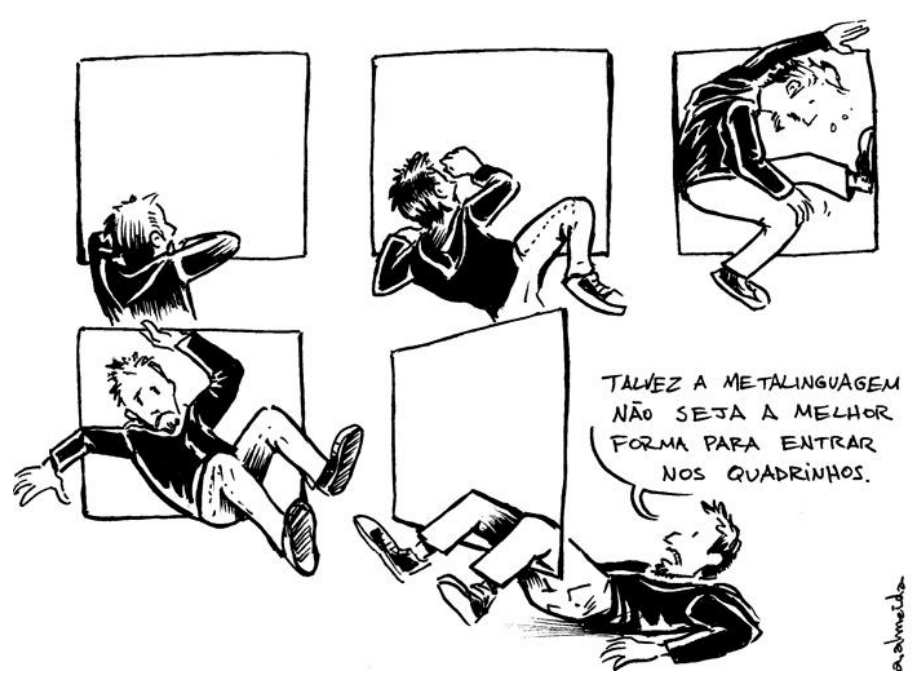

José Nicolau Gregorin Filho e André Almeida ${ }^{86}$

Analisar a estrutura dos quadrinhos é, de certa forma, dissociar a $H Q$ de seu aspecto artístico, uma vez que a manipulação artística passa a ser vista como uma ferramenta de construção de algo que pode resultar não artístico. Pois, com base nas pesquisas dos estudiosos ressaltados na primeira parte, o presente estudo entende a $\mathrm{HQ}$ como uma das muitas formas de comunicação de ideias e sentimentos entre pessoas. Um dos meios pelos quais uma ou mais pessoas se expressam para si mesmas e para outras. Uma comunicação, seja ela qual for, pode ou não resultar "artística", ou o fato de ser Arte não impede que seja outras coisas, da mesma forma que a Mona Lisa além de ser uma obra de arte é um objeto de valor e um ícone cultural.

Segundo o professor Rutger Graaf, doutor em ciência da comunicação da faculdade de Amsterdã, a Comunicação, seja ela interpessoal (entre uma ou mais pessoas) ou intrapessoal (do indivíduo consigo mesmo), é cada ato de transmitir

${ }^{86}$ Epígrafe - fonte: GREGORIN FILHO, J. N. Literatura para criancas e jovens: panorama de linhas investigativas. Via Atlântica, São Paulo, p.35-44, 2008. E ALMEIDA, A. Ainda sem título. André Almeida Quadrinhos e llustrações, 2012. Disponível em: <https://andrehq.wordpress.com/2012/08/07/aindasem-titulo/>. Acesso em: 08 Abr. 2018. 
informação, sendo informação, todos os pensamentos, ideias e emoções,

The most simple definition: Communication is each act of transmitting information. Information in the broadest sense of the word: including thoughts, ideas and emotions. Giving someone a buquet of flowers is communicating a certain message. Adding to that gift a verbal compliment, "You're pretty" is another separate act of communication. Blushing 'because you're just receive flowers and a compliment is again another form of communication ${ }^{87}$ (GRAAF, 2016).

O resultado da comunicação por meio da História em Quadrinhos é variável de acordo com a intencionalidade: arte, didática, propaganda, entretenimento, filosofia, etc. Sua realização, do ponto de vista deste estudo, envolve três conceitos principais: forma - a linguagem utilizada para expressar; matéria - a mídia, o meio ou suporte físico, em que a linguagem e o conteúdo são expressos; conteúdo - a ideia que se quer expressar.

Esses três conceitos que compõe a $\mathrm{HQ}$, forma - matéria - conteúdo, não possuem posição fixa e equivalência de importância no arranjo da obra. Pois tanto uma ideia pode apontar o tipo de linguagem e mídias mais adequadas para sua intencionalidade, quanto o suporte disponível pode estabelecer os limites tanto da linguagem quanto do conteúdo que podem ser expressos. Mesmo a linguagem, que é a ferramenta de expressão do quadrinista, pode determinar tanto o conteúdo quanto a mídia de acordo com as preferencias ou habilidade do autor.

O desenvolvimento de uma história em quadrinhos se dá pela aplicação das ideias, pensamentos e emoções sob forma de representação imagético-textual (texto escrito com imagens) pelo "quadrinista". São várias as funções exercidas pelos quadrinistas, como desenhista, roteirista, colorista, letrista, arte-finalista, fotógrafo e designer gráfico, que podem ser desempenhas por um só artista ou vários.

Cada uma dessas funções têm um impacto na construção do significado, maior ou menor de acordo com a intencionalidade da obra, sensibilidade ou espaço do artista. Há obras com roteiros complexos e desenhos simples, e obras imageticamente grandiosas para roteiros singelos.

Scott McCloud apontou para a importância de separar as concepções sobre as obras individuais de histórias em quadrinhos, das possibilidades universais da

\footnotetext{
${ }^{87} \mathrm{~A}$ mais simples definição: Comunicação é cada ato de transmitir informação. Informação no mais amplo sentido da palavra: inclui pensamentos, ideias e emoções. Dar um buquê de flores a alguém é comunicar uma certa mensagem. Adicionando ao presente um elogio verbal, "Você é bonita" é outro ato separado de comunicação. Enrubescer porque você acabou de receber flores e um elogio é, novamente, outra forma de comunicação (GRAAF, 2016) [tradução da autora].
} 
manifestação artística "História em Quadrinhos". Na primeira parte de seu livro teórico ele destaca principalmente a separação entre a forma e o conteúdo da HQ:

A forma artística - o meio - conhecido como quadrinhos é um recipiente que pode conter diversas ideias e imagens. O "conteúdo" dessas imagens e ideias depende, é lógico, dos criadores, e todos temos gostos diferentes. $O$ truque é nunca confundir a mensagem com o mensageiro. (MCCLOUD, 1995, p. 6)

Nessa mesma linha de pensamento, tentando separar a linguagem do conteúdo, Will Eisner em seu estudo emprega o termo "arte sequencial", muito adotado por outros estudiosos, mas que enfrenta o mesmo problema das nomenclaturas tradicionais: não englobar todas as manifestações dessa comunicação e por isso ser restritivo quanto a alguns aspectos, por exemplo, a linguagem pode ser usada para outras formas de expressão que não a "Arte", como a didática ou na propaganda comercial, política e religiosa, etc. E ainda, há obras compostas por apenas um quadro, sem necessidade da "sequência" nas imagens e que mesmo assim são parte das Histórias em Quadrinhos. Ainda assim, seu trabalho de pesquisa e reflexão representa um marco na mudança de percepção sobre quadrinhos quanto a sua estrutura e estética, suas características e possibilidades. Eisner reiterava a importância em:

Considerar e examinar a singular estética da arte sequencial como veículo de expressão criativa, uma disciplina distinta, uma forma artística e literária que lida com a disposição de figuras ou imagens e palavras para narrar uma história ou dramatizar uma ideia (EISNER, 2010, p. IX).

Testando a independência e autonomia da estrutura em relação à criação artística, ou seja, que uma história em quadrinhos é capaz de existir, mesmo se do processo de criação não resulte Arte, nesse estudo foi aplicada uma demonstração prática dos componentes estruturais da $\mathrm{HQ}$ em uma construção paradigmática, elaborada pela autora, empregando as ferramentas mais conhecidas da linguagem da $H Q$ visando distinguir a forma de "escrever" do conteúdo "escrito". O uso do termo escrever, neste estudo, se refere ao ato de elaborar um texto (redação original de qualquer obra escrita, segundo o Houaiss), poético, narrativo ou mesmo informativo, para um leitor. Isso não quer dizer que História em Quadrinhos seja Literatura, uma vez que a palavra literatura vem do latim "littera", que significa letra, sendo portanto, uma arte de construção de um texto exclusivamente através dos sentidos evocados por palavras escritas, já a na HQ a construção do texto se solidifica através dos sentidos evocados pela interação de vários tipos de imagens, inclusive letras.

Os Quadrinhos são lidos, e sua escrita é realizada por imagens, sejam elas 
figurativas ou simbólicas, assim, tanto o texto escrito quanto a ilustração são imagens ou, como apontado por McCloud, são ícones - qualquer imagem que represente uma pessoa, local, coisa ou ideia (MCCLOUD, 1995, p. 27). McCloud separa os ícones em duas categorias: ícones de linguagem (imagens com significado absoluto; texto escrito, seja fonético, matemático, simbólico, etc) e ícones pictóricos ou figuras (imagens com significado fluído e variável). Essa divisão um ponto de partida geral, uma vez há obras que contrariam essa acepção, onde a forma com que a letra ou palavra é desenhada altera sua interpretação, sua intensidade e até contraria seu significado absoluto.

Outro aspecto recorrente nas pesquisas sobre quadrinhos é a tentativa de classificação de manifestações similares. Em muitos estudos pesquisados o termo "gênero", as vezes emprestado da literatura, outras do cinema, é empregado de formas díspares. Por exemplo, ao tratar de tiras de jornal (comic strips), uma mídia, compara-se à uma temática como a dos super-heróis; ou uma forma de encadernação, a revista em quadrinhos, é comparada com a estética japonesa do mangá; ou mesmo obras para adultos sendo diferenciadas em Graphic Novel ou Fumetti por serem provenientes de países diferentes, mesmo que ambas tenham tratamentos estéticos, temáticos e escopo similares.

A análise da manifestação ao longo do tempo e das diversas culturas constatou que o fato de uma obra possuir determinado conteúdo, não estipula sua linguagem ou sua mídia, foi identificado que uma obra necessita da integração de três aspectos para sua realização.

Primeiro, o conteúdo: é preciso que haja uma ideia e a intenção de comunicar isso a alguém. A intencionalidade dessa comunicação pode ter por finalidade a informação, o entretenimento, a propaganda ou a didática. Dependendo do tipo de intencionalidade, o teor da comunicação pode ser mais sóbrio e formal ou mais descontraído e casual ou, ainda, irônico ou tétrico. Além disso, a intencionalidade supõe um receptor para a mensagem, no caso dos quadrinhos, um público alvo, que possuem inúmeras variações como: faixa etária, gênero, ambiente cultural, etc. Assim, a intencionalidade define a temática que a história em quadrinhos possuirá, e a tonalidade dessa temática será moldada de acordo com o público alvo intencionado.

O segundo aspecto é a matéria, ou seja, o suporte físico, o meio pelo qual essa comunicação será realizada. A HQ utiliza vários tipos de mídia para sua manifestação, como: jornal, revistas de lombada canoa e de lombada quadrada, livro, 
site de internet, aplicativo de smartphone, etc. Assim como diversas técnicas (desenho, pintura, fotografia, design gráfico, editoração, etc.) e as mais variadas ferramentas (lápis, canetas, tintas, papeis, telas, tecidos, colagens, fotografias, programas de edição de imagens virtuais, etc.). Não há uma mídia, técnica ou ferramenta específica para criar uma $\mathrm{HQ}$, mas há alguns que são usualmente mais preferidos por questões de comodidade, de costume ou de mercado.

Por fim, o aspecto da forma, do como a ideia é colocada em um suporte, ou melhor, a linguagem utilizada nessa comunicação. A linguagem, na $\mathrm{HQ}$, utiliza imagens em relações icônicas assertivo-dedutivas. Ou seja, a imagem, seja de uma palavra escrita ou uma figura, é tratada como um ícone. Os ícones são agregados à um espaço de grade de forma a induzir uma construção de sentido pelo confronto entre seus significados dispares e pelas relações de sentido complementares com o referencial do leitor. O texto resultante pode ser singular (uma imagem) ou sequencial (várias imagens em sequência).

Assim, mesmo que em muitos dos estudos pesquisados haja certo consenso em afirmar que um dos fundamentos da $\mathrm{HQ}$ é a imagem sequencial justaposta - para ser considerado História em Quadrinhos é preciso que haja um quadro (com ou sem margem) ao lado do outro que desenvolva a narrativa, podendo ou não ter texto - neste estudo não é seguida essa prerrogativa, uma vez que manifestações como charges e cartuns, que expressam uma ideia por meio de vários elementos da linguagem da $\mathrm{HQ}$ usando muitas vezes apenas um quadro, parecem se enquadrar na História em Quadrinhos, da mesma forma que um poema concreto de uma só palavra, como o de Augusto de Campos (Figura 71), na literatura.

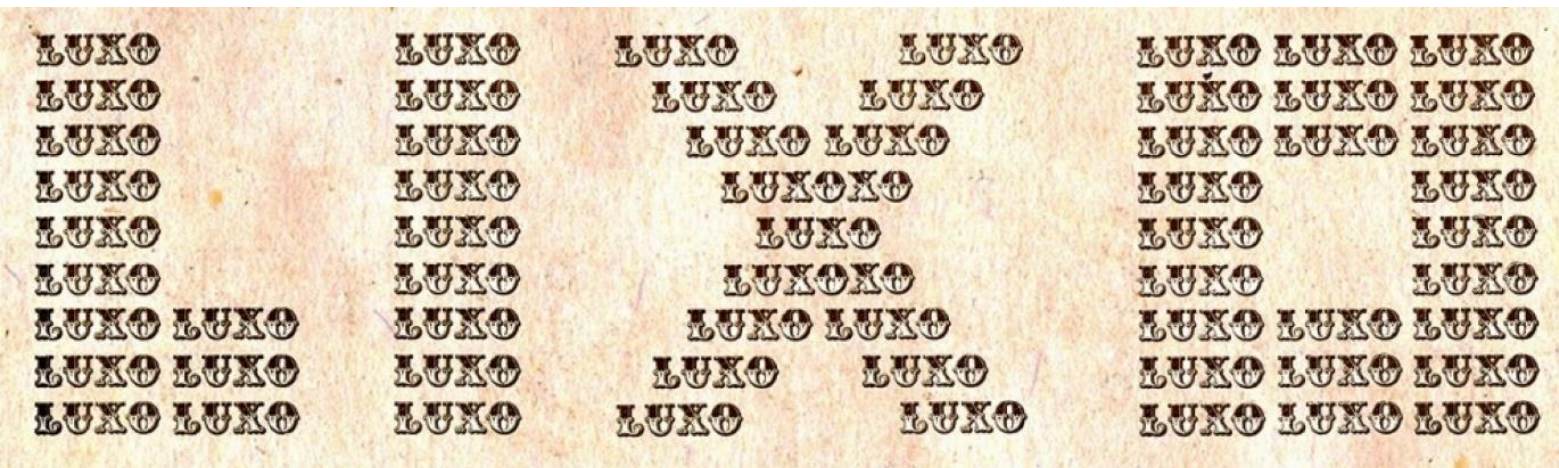

Figura 71 - Poema de Augusto de Campos - 1965 liv

Ainda cabe ressaltar que, tendo em vista a nomenclatura para História em 
Quadrinhos ser diferente em cada país, onde internamente a manifestação é tratada com seu respectivo nome e o produto estrangeiro tratado com termo usado no país de origem - principalmente no caso do mangá japonês - este estudo considera Bande Dessinée, Comics, Fumetti, Manga, etc. como a mesma coisa, com diferenças estéticas e culturais. O mesmo se aplica ao termo Graphic Novel, que hoje é cultural e mercadologicamente muito aplicado para a produção de luxo voltada para o público adulto, contudo não deixa de ser uma história em quadrinhos com editoração e intencionalidade etária diferente.

\subsection{Forma - a imagem e a linguagem}

Porém onde está e qual é o objeto de representação do texto não-verbal?

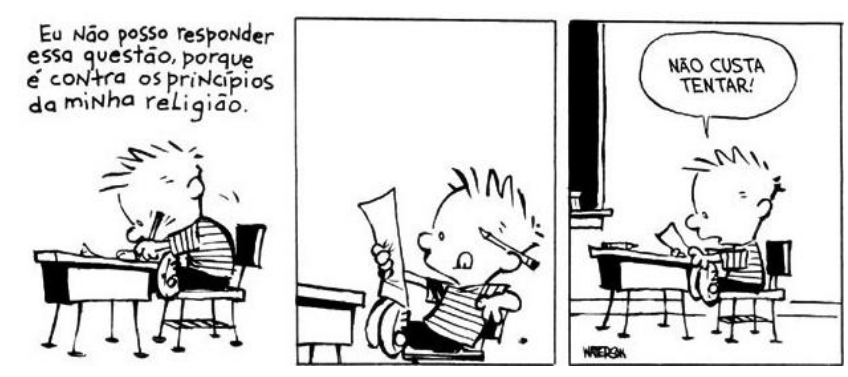

Lucrécia D'Alessio Ferrara e Calvin ${ }^{88}$

A imagem nesse estudo é tanto objeto de investigação quanto ferramenta de argumentação, portanto as figuras desenvolvidas pela autora foram consideradas parte do discurso, para serem "lidas" conjuntamente com o texto escrito. Foi considerado que uma legenda, como tratado em tópico específico, pode direcionar a interpretação na leitura da imagem, sendo assim, as figuras de cunho paradigmático não foram legendadas.

${ }^{88}$ Epígrafe - fonte: FERRARA, L. D. Leitura sem palavras. São Paulo: Ática, 1986, pag. 16. E recorte de Calvin and Hobbes (Calvin e Haroldo no Brasil) de Bill Watterson, publicada no jornal O Estado de São Paulo, caderno 2, 2 quarta-feira, 03/08/2011. http://acervo.estadao.com.br/publicados/2011/08/03/m/20110803-43023-nac-41-cd2-d4-not.jpg consultado em 13/05/2018. 


\subsection{1 ĺcone}

Ícone, em uma visão semiótica, segundo o professor Cagnin citando o linguista Charles Sanders Peirce é "um signo que se refere ao objeto que denota simplesmente por força de caracteres próprios e que ele possuiria, da mesma forma, existisse ou não existisse" e citando o linguista Ferdinand de Saussure, "signo é bifronte, composto de dois elementos psíquicos, a imagem acústica, a que deu o nome de significante, e o conceito a que deu o nome de significado. Para Cagnin, a possibilidade da imagem de formar um código e de construir mensagens the dá o estatuto de signo (CAGNIN, 2014, p. 38 e 46).

Para Scott McCloud, Ícone é qualquer imagem que represente uma pessoa, local, coisa ou ideia, divididos em dois grandes grupos.

Ícones de linguagem: imagens com significado absoluto; texto escrito, seja fonético, matemático, simbólico, etc. Por exemplo os símbolos a seguir:

$$
A-1-\text { 栄 }-\Omega-\delta-\$-q-\sqrt{ }
$$

Ícones pictóricos ou figuras: imagens com significado fluído e variável.

Como:

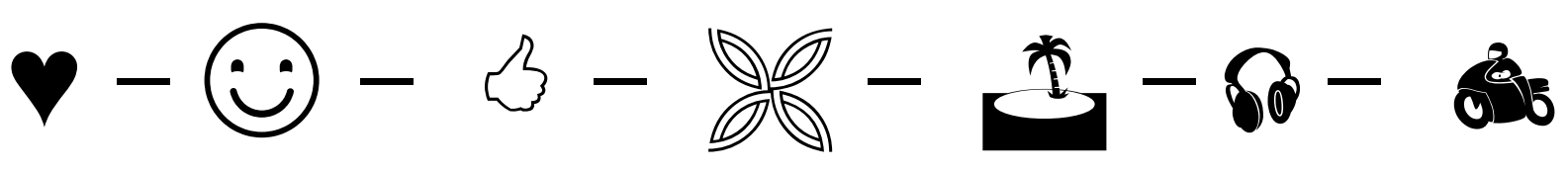

Blanchard, em uma linha de pesquisa histórico-antropológica, aponta a capacidade humana de ler imagens desde o início dos tempos preenchendo as lacunas nas marcas e rastros encontrados, reconstruindo a informação daquilo que não está mais presente, imaginando 0 antes, trazendo de volta 0 ausente (BLANCHARD, 2014). Além disso, para McCloud, os humanos são uma espécie centrada em si mesma, que vê a si própria em tudo e atribui emoção onde não existe nada, transformando o mundo à sua imagem (MCCLOUD, 1995, p. 31).

Por isso, quando são juntas algumas figuras de formas básicas, conseguese a representação de algo diferente, sem a necessidade de uma representação realista, por exemplo, triângulo, círculo e retângulo: 

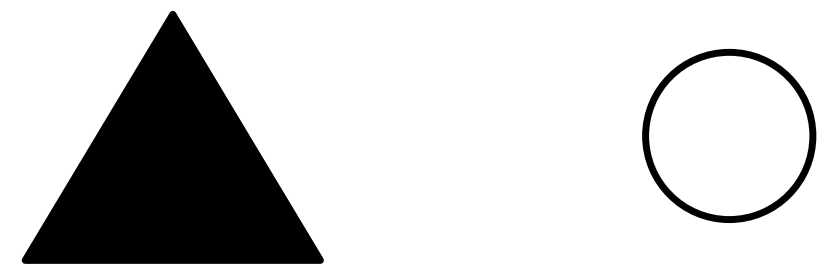

Podem, de acordo com a artiulação entre elas, serem utilizadas para criar a representação de um personagem:

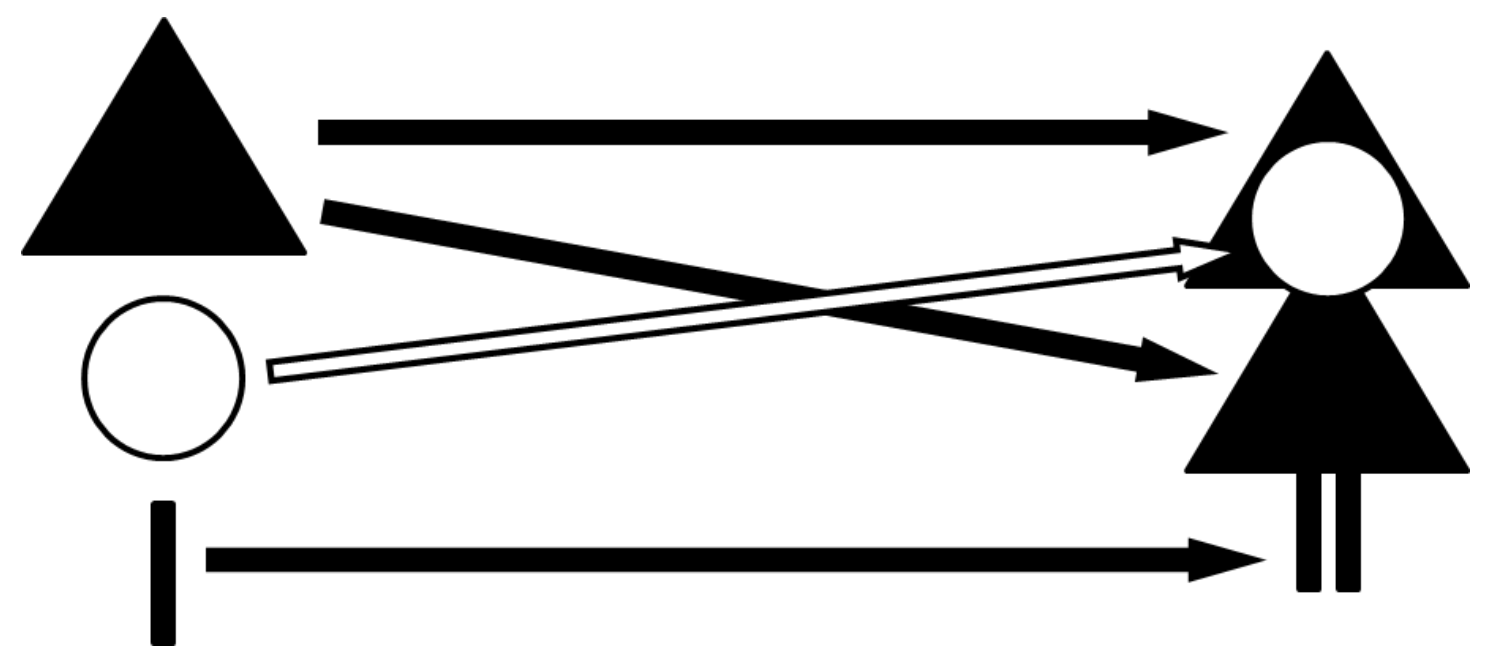

Não parece ser necessário a colocação de muitos detalhes para que o resultado dessa construção seja reconhecido, em geral, como uma figura humanoide, do gênero feminino. Extrapolando as teorias de Branchard e McCloud, o reconhecimento do resultado dessa construção não se dá pela similaridade inerente da figura com o objeto representado, e sim pela construção do referencial cultural do observador, que completa o sentido daquilo que vê com aquilo que conhece, conferindo-Ihe assertividade, ou seja, uma existência real - ou verossimilhante — em um plano ficcional. Por exemplo, reconhecer o triangulo inferior como uma vestimenta de característica feminina (saia), depende do contexto cultural de um observador, onde em geral somente mulheres usem saias e, a partir do momento que esse reconhecimento é feito, o vínculo assertivo é criado e as formas básicas (triangulo, círculo e retângulo) apesar de estarem presentes não são mais vistas como objetos independentes.

Groeensteen ressalta que o estudo de formas mínimas nos quadrinhos acaba se tornando infrutífero, justamente pela facilidade com que as formas básicas em conjunto ganham outros significados dependendo da forma de sua associação, 
ele cita Umberto Eco,

Em um sintagma icônico intervêm relações contextuais tão complexas que parece difícil distinguir entre elas as unidades pertinentes das variantes facultativas. (...) Os aspectos pertinentes variam: ora são grandes configurações reconhecíveis por convenção, ora até mesmo pequenos de linha, pontos, espaços brancos, como acontece em um desenho de perfil humano, onde um ponto representa o olho e um semicírculo, a pálpebra. Sabemos que, em outro contexto, o mesmo tipo de ponto e o mesmo semicírculo representam, pelo contrário, uma banana e um bago de uva. (ECO apud GROENSTEEN, 2004, p. 35-36).

Mostrando uma diferença conceitual entre o objeto e sua representação McCloud usa como exemplo a tela de René Magrite (Figura 72, pág. 136). Com a inscrição "Isto não é um cachimbo" abaixo da figura de um cachimbo, Magritte declara que o objeto real não pode ser confundido com sua representação, ou seja, mesmo que a pintura, desenho ou mesmo a fotografia pareçam idênticos a determinado objeto, na verdade são apenas representações que não possuem a tangibilidade do objeto em si.

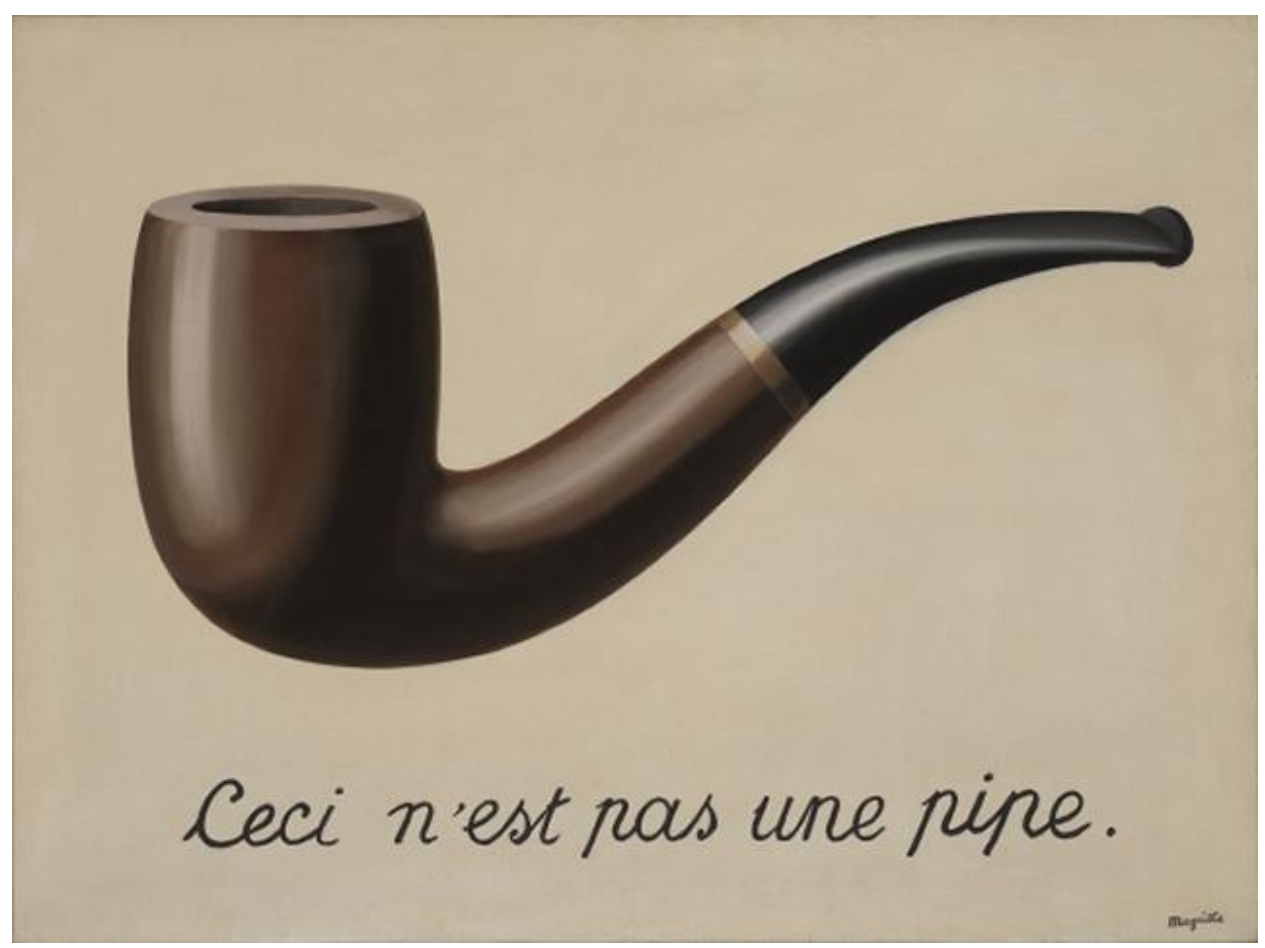

Figura 72 - A Traição das Imagens, 1928-9, óleo sobre tela, $60 \mathrm{~cm}$ x $81 \mathrm{~cm}$, René Magrite, LACMA - Los Angeles County Museum of Art, Los Angeles ${ }^{\text {lv }}$

Outro exemplo demonstra que, mesmo que a imagem seja a reprodução exata de um objeto, ainda assim pode não o representar, dependendo de mais traços ou marcas distintivas agregadas à imagem para que a assertividade seja alcançada. Apesar de Thierry Groensteen usar o conceito de "solidariedade icônica" ao nível do 
quadro, ou seja, de um quadro a outro de uma narrativa sequencial, o termo é muito apropriado para explicar a relação entre um ícone e outro para construção da assertividade da imagem.

As imagens Figura 73, Figura 74 e Figura 75, pertencem à Stubbs, o gato eleito como prefeito de Talkeetna no Alaska em julho de 1997. Como Stubbs ocupou o cargo honorariamente por aproximadamente 20 anos (até sua morte), era conhecido por todos na cidade e frequentemente visto nos pubs e cafés tomando leite, água ou uma bebida com erva de gatos (nepeta/catnip) em taças.

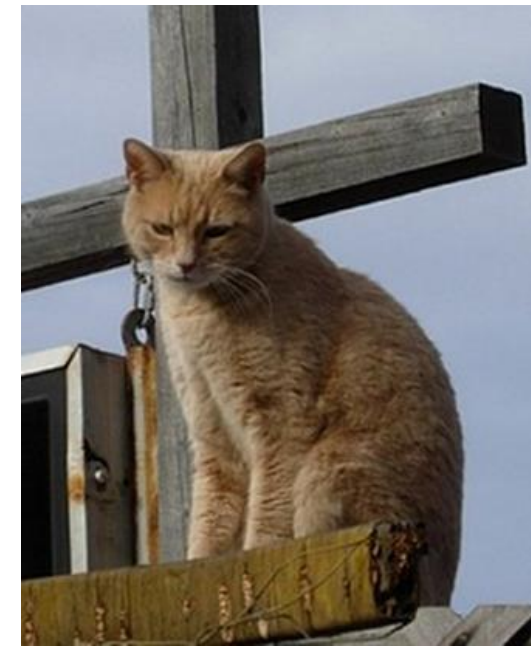

Figura 73 - Stubbs em fotografia sololvi

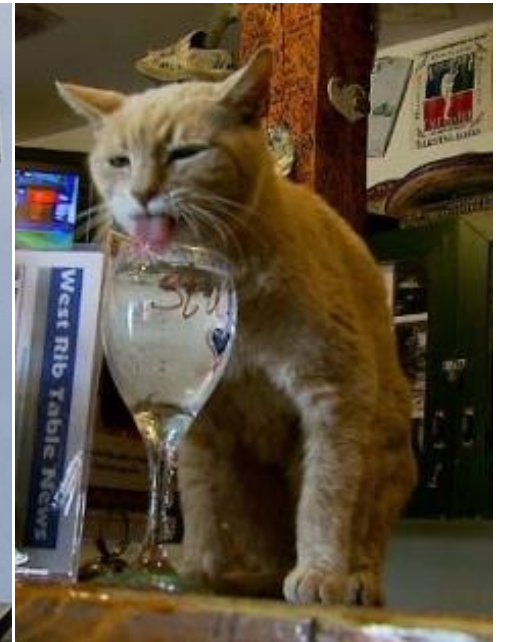

Figura 74 - Stubbs em fotografia com taçalvii

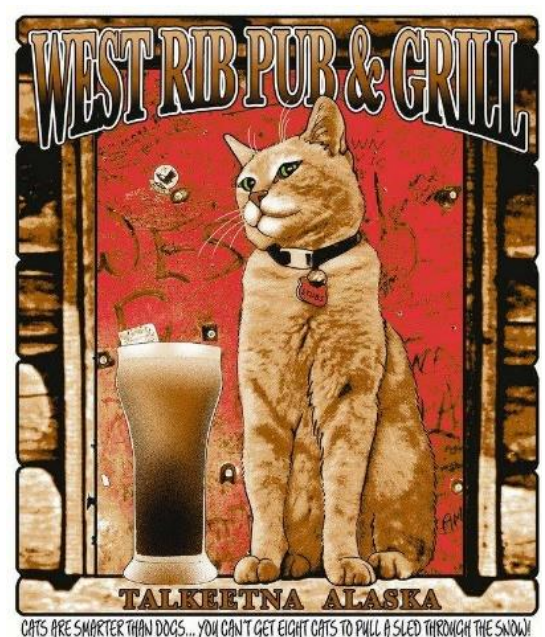

Figura 75 - Stubbs em pôster West Rib Pub \& Grill Iviii

A imagem da esquerda (Figura 73), uma reprodução fotográfica, apesar de ser a reprodução exata do indivíduo Stubbs, não o identifica para pessoas fora de sua área de conhecimento imediato, apenas pela fotografia, poderia ser um gato qualquer. A imagem do meio (Figura 74), também uma reprodução fotográfica, apresenta um elemento externo de identificação, o fotógrafo procurou retratar o gato em um de seus afazeres habituais, $\mathrm{o}$ ato de beber em taças, proporcionando alguma marca distintiva, mesmo que externa, para que seja mais facilmente reconhecido como o indivíduo Stubbs. Já na figura da direita (Figura 75), um desenho, nota-se que o desenhista, usa um traço realista, próximo à representação fotográfica, mas acrescenta elementos contextuais à imagem para identificação de Stubbs, como a coleira com seu nome e a taça ao seu lado e a postura corporal imponente.

Esta sequência de representações exemplifica a colocação de pistas, traços, marcas singulares, que realmente representem 0 indivíduo Stubbs e o diferencie de todos os outros gatos de pelagem amarelada. Isso não quer dizer que o desenho represente melhor que a fotografia, e sim que a representação não é estática 
e uniforme, ela é contextual, depende do tanto de informação que o emissor consegue agregar na imagem e do quanto dessa informação o receptor consegue inferir pelos vestígios encontrados.

Uma outra questão abordada por McCloud acerca da representatividade da imagem é a respeito dos graus de variação entre a similaridade da imagem com o objeto representado. A diferença entre um traço realista ou simplificado implicam na universalidade ou individualidade da representação, pois no primeiro caso a imagem representa um indivíduo específico, já a imagem abstrata em seu nível mais básico, a qual ele chama de "cartum", retrata qualquer indivíduo (MCCLOUD, 1995, p. 28-29).

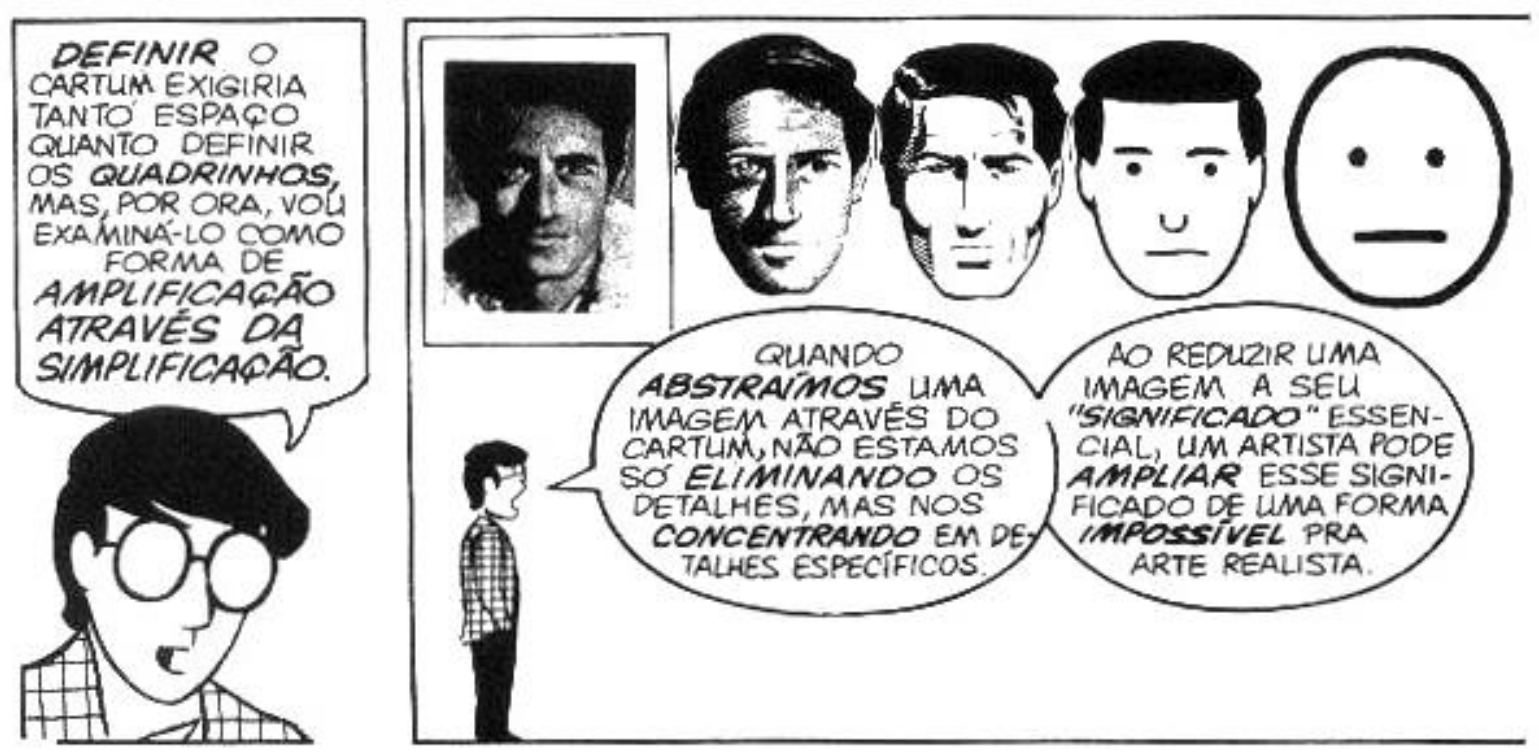

Figura 76 - (MCCLOUD, 1995, p. 30, $3^{a}$ linha, $1^{\circ}$ e $2^{\circ}$ quadro)

Isso demostra a capacidade humana de antropomorfizar as imagens recebidas conferindo um significado que faça sentido dentro das suas referências à certo conjunto de formas. Assim, mesmo apenas dois círculos e dois triângulos podem ser reconhecidos como um gato, como demostrado nessa sequência de simplificação:
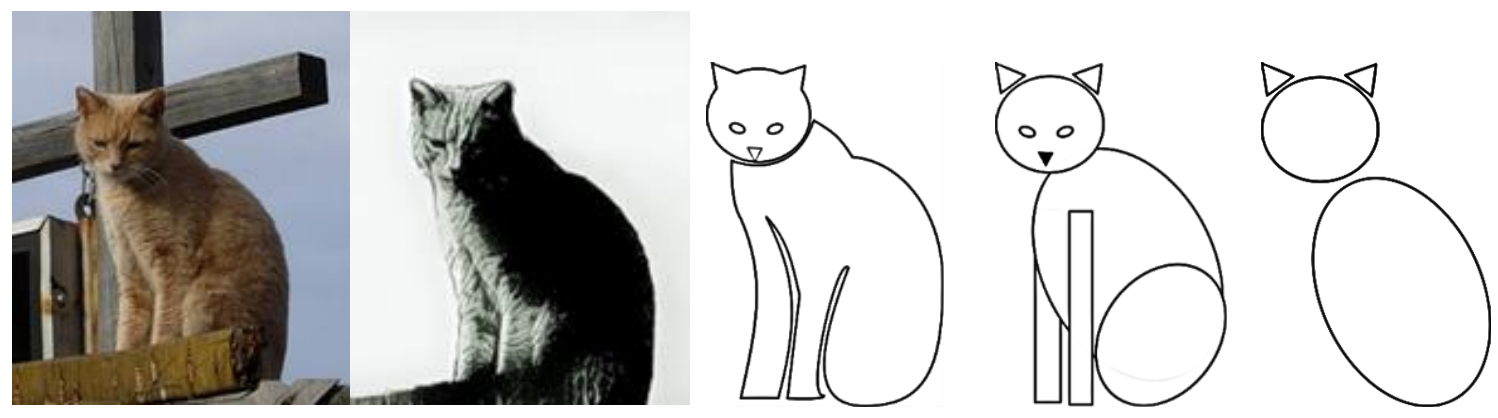

A partir da teoria de McCloud de que a simplificação da imagem em seus elementos mais básicos seria uma "cartunização", pode-se extrapolar que o uso das técnicas da caricatura, ou seja, uma "caricaturização" a partir desses elementos 
mínimos, fazendo ressaltar as características culturais e traços distintivos, podem criar um personagem ao mesmo tempo único e universal, ao colocar "marcas" que transformem esse modelo geral em um indivíduo reconhecível dentro de determinado contexto, mas que não possua contraparte no mundo físico.

Esse personagem se torna uma representação imagética de um estereótipo, de um ideal ou de uma mensagem. Para McCloud é a estilização e simplificação do da representação imagética que permite ao leitor uma identificação e empatia com o personagem de quadrinhos (MCCLOUD, 1995, p. 30-31).
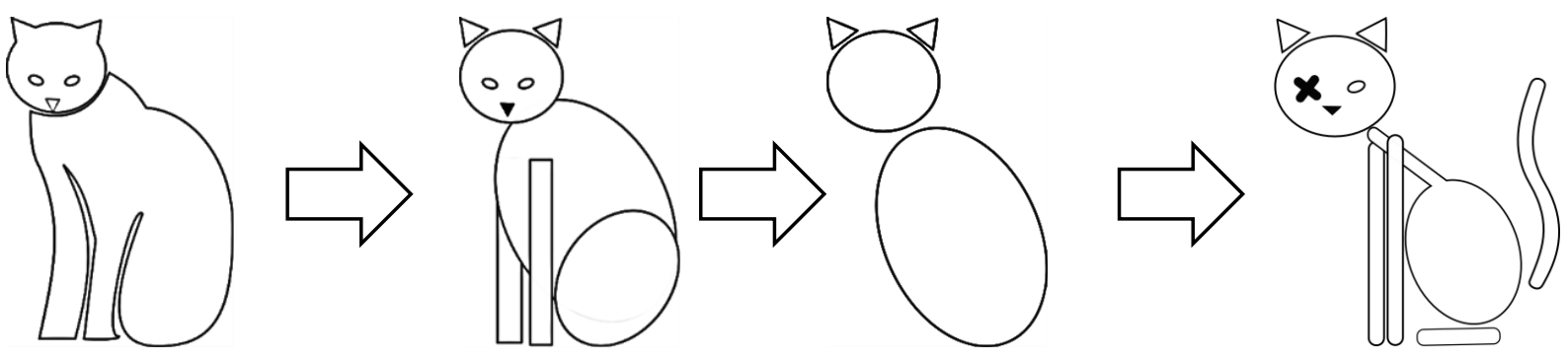

Parece, à primeira vista, uma redundância usar cartunização e caricaturização, mas tendo em vista que os propósitos na origem dos termos cartum e caricatura são diferentes, é preferível mantê-las isoladamente. A palavra cartum (do inglês cartoon) era utilizada na Inglaterra para os esboços preliminares em papel cartão que os artistas enviavam a seus patronos, utilizada pela primeira vez no âmbito dos quadrinhos pela revista Punch, para satirizar a competição de artistas para conseguir a encomenda de novas telas e murais pelo Parlamento inglês em 1843.

In a series of drawings which it ironically titled "cartoons", Punch contrasted
the sumptuousness of the Parliamentary plans with the miserable poverty of
the starving population. With heavy sarcasm, Punch declared that the
government had "determined that as they cannot afford to give hungry
nakedness the substance which it covets, at least it shall have the shadow.
The poor ask for bread, and the philanthropy of the State accords - an
exhibition"89 (PUNCH EDITORIAL, 2018)

Já a caricatura, como apontado por A. Hyatt Mayor, é o exagero de sobrecarregar uma característica de uma pessoa para, segundo Aristóteles, trazer à tona o animal que representa sua personalidade (MAYOR, 1972, p. 137). No caso dos quadrinhos, a caricaturização traz à tona o estereótipo de uma pessoa ou um grupo

89 Em uma série de desenhos que ironicamente intitulava "cartoons", Punch contrastou a sumptuosidade dos planos parlamentares com a miserável pobreza da população faminta. Com forte sarcasmo, Punch declarou que o governo havia "determinado que, como eles não podem proporcionar a nudez faminta a substância que deseja, pelo menos ela terá a sombra. Os pobres pedem pão e a filantropia do Estado concede - uma exposição " (PUNCH EDITORIAL, 2018) [tradução da autora]. 
- ou ainda, em uma ação contrária a proposta de Aristóteles, se aproxima mais do método fabular de Esopo, antropomorfizando um animal com as características e condutas humanas.

A História em Quadrinhos vale-se da cartunização e da caricaturização, em maior ou menor grau, para criar um ícone que se adeque ao conteúdo da mensagem proposta, e remeterá o leitor a buscar sua significação individual e correlata (com os demais ícones no entorno) em seu repertório de referências pessoais.

Quando este estudo propõe que os ícones na HQ se baseiam em uma recriação de objetos, pessoas e ideias através da cartunização e da caricaturização, isso pode dar a entender que está sendo privilegiada a imagem desenhada às produzidas por fotografia, contudo é importante frisar que a fotografia, nos quadrinhos, nada mais é do que uma outra ferramenta artística, portanto ambos conceitos ainda são aplicáveis nesse meio.

Em uma página de fotonovela (fotoromanzi) (Figura 77, pág. 141) a cartunização pode ser vista na simplificação da construção da ambientação, cenários e figurinos, para o efeito de reconhecimento imediato da posição que os personagens ocupam na trama, no caso dessa página um médico (avental branco) e enfermeira (uniforme padronizado). Já a caricaturização é notada pela artificialidade da postura corporal, com ênfase na relação com o cigarro (mais como pose do que como ato de fumar) o que caracteriza, para a época de publicação, pessoas "más". Também a representação do diálogo tem postura caricatural, as personagens se posicionam em poses exageradamente construídas de frente para o leitor.

Santiago Garcia, cita a Barthes quando postula que a imagem fotográfica tem uma natureza completamente diferente da imagem desenhada, pois a fotografia autentica a existência do ser retratado (GARCIA, 2012, p. 41). Contudo na fotonovela há uma preocupação teatral com o posicionamento dos atores em relação ao leitor. A fotografia, na narrativa sequencial, não possui a espontaneidade da fotografia jornalística. Atores, cenários e texto são manipulados para a construção da mensagem. Não é uma autenticação do real e sim uma reconstrução do real, da mesma forma que o desenho.

Se a estética - que se pode aproxiamar do espetáculo teatral —é muitas vezes rejeitada pelo exagero e artificialidade frequentemente encontrados nas obras publicadas, principalmente na produção de dos anos 50,60 e 70 voltadas para o público adulto feminino, isso se deve a fatores temáticos e socioculturais, que são 
independentes da linguagem ou possibilidade do meio.

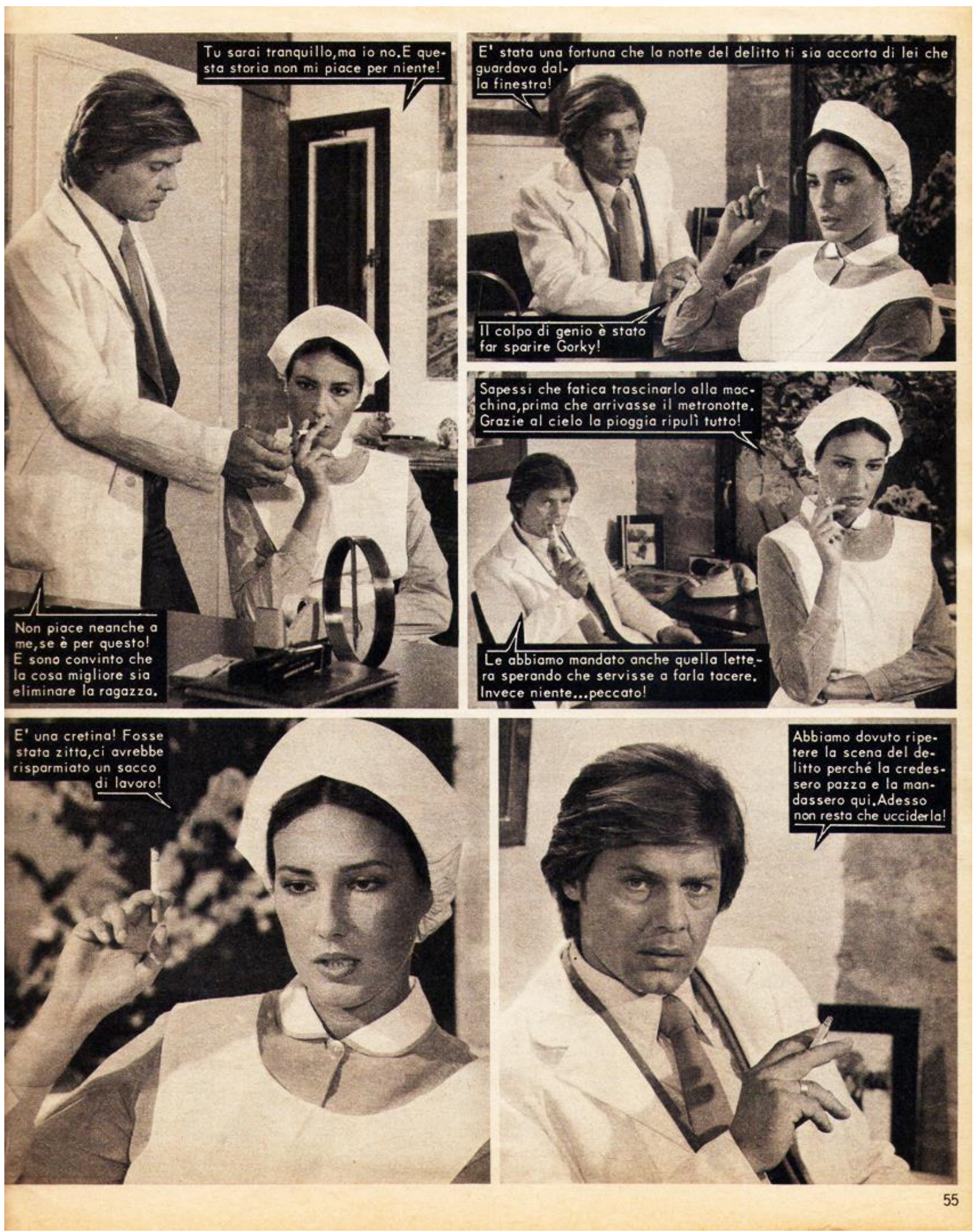

Figura 77 - Katrin - Mensile di attualita varieta e fotoromanzi - nº 46, 1978 - página 54lix 


\subsubsection{Espaço}

"O Grande Irmão está observando você."

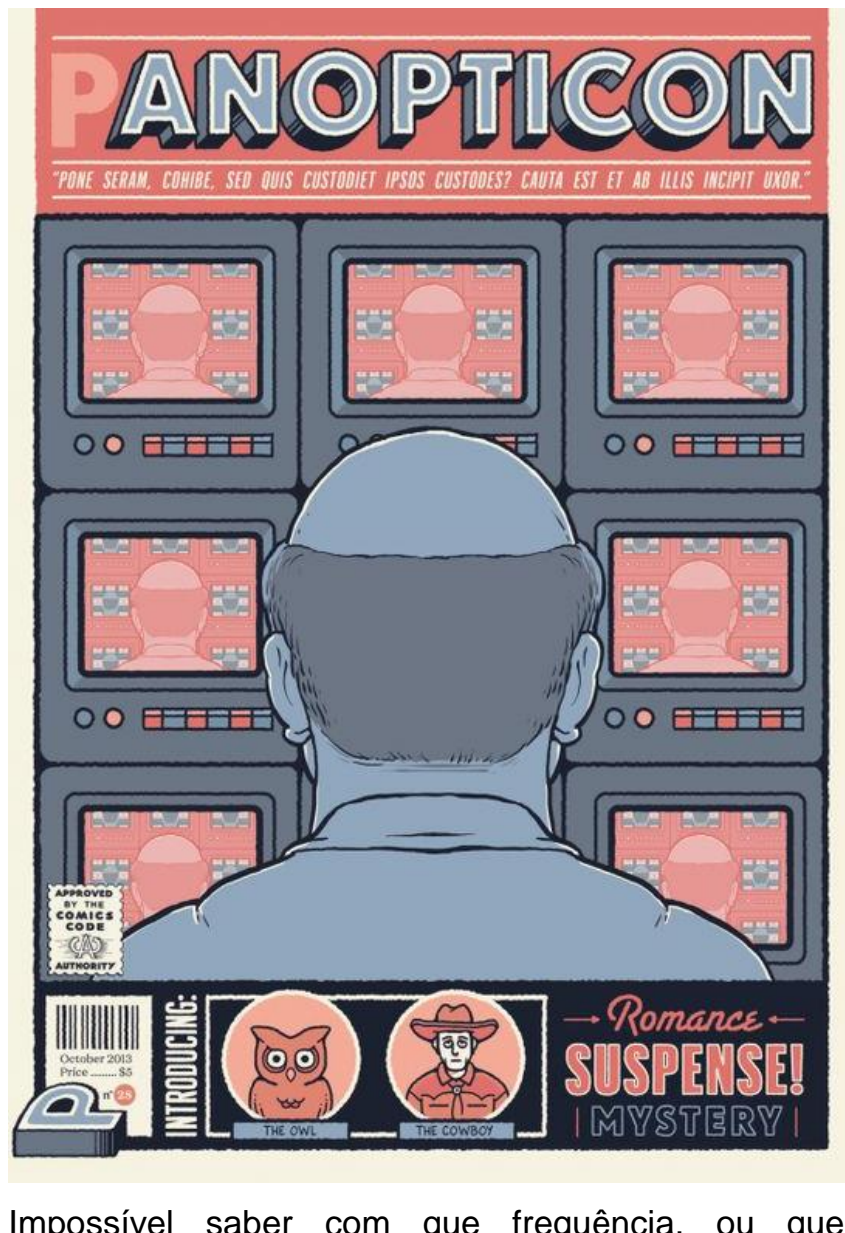
periodicidade, a Policia do Pensamento se conectava com a casa deste ou daquele indivíduo. Era concebível que observasse todo mundo ao mesmo tempo.

George Orwell e Giacomo Gambineri ${ }^{90}$

Groensteen abre o capítulo "O sistema espaçotópico" de seu livro com a citação do ensaísta Joseph Joubert (1754-1864),

É preciso que a ideia e o formato inicial de uma obra seja um espaço, um lugar onde depositar-se-á e dispor-se-á a matéria, e não uma matéria a ser depositada ou disposta (JOUBERT apud GROENSTEEN, 2014, p. 35).

Em uma obra de história em quadrinhos, vários espaços precisam ser

90 Epígrafe fontes: ORWELL, G. 1984. Tradução de Wilson Velloso. 17 ed. ed. São Paulo: Ed. Nacional, 1984. Pg. 8, e ORWELL, G. Animal Farm and 1984. Orlando, Florida: Harcourt, Inc, 2003. E ilustração de Giacomo Gambieri disponível em: LATRONICO, V.; GAMBINERI, G. Perché usiamo Internet da ubriachi. Idee e Lifestyle del Sole 24 ORE. http://24ilmagazine.ilsole24ore.com/2016/02/meglio-lacybersecurity-della-cyberfobia/?refresh ce=1, consultado em 13/05/2018. 
levados em conta de forma distinta, de acordo com a metodologia empregada em sua criação, principalmente quanto a questão da singularidade ou pluralidade da autoria.

A formulação espacial na mente do artista, por exemplo, pode ser vaga ou esquemática de acordo com a função que o artista possui no projeto. Um roteirista por exemplo, pode estar apenas preocupado com a diegese, formulando a ambientação, o tipo de cenários, época e clima nos quais seus personagens viverão suas tramas, seu foco será colocar em palavras sejam verbais ou escritas uma impressão desse espaço imaginado para outra pessoa materializar (prática muito usada pelo roteirista e editor da Marvel Comics, Stan Lee, que explicava sua ideia geral para os desenhistas em reuniões). Em contrapartida um desenhista ao receber um roteiro ou ouvir a explanação de uma ideia, tem uma preocupação com espaço físico da página, quando impressa com a limitação da grade, quando web, qual será o mecanismo de rolagem, se vertical, se carregador de páginas individual ou se visualizador de zoom imagem a imagem, etc. Já a preocupação do fotógrafo será a iluminação e detalhamento cenográfico. Mesmo um colorista terá a priori uma preocupação com a posição em que as tonalidades devam ser colocadas em cada momento para a integração com a ambientação e clima diegético no caso de narrativa, poética ou dramática, ou com a intencionalidade cromática quando dissertativa, descritiva ou instrutiva.

Já o espaço físico material: a página - seja de papel, tela, tecido, muro, tela de computador ou celular - onde a obra é reproduzida, demanda algumas considerações. Conforme já apontado por Groensteen "a imagem de quadrinhos não é a mesma da pintura" (GROENSTEEN, 2015, p. 15), por isso a tela de Roy Lichtenstein de 1963 (Figura 78, pág. 145) não é uma história em quadrinhos, uma vez que não foi concebida como tal. A tela díptica ${ }^{91}$ de $1,700 \mathrm{~cm} \times 4000 \mathrm{~cm}$ apresenta, segundo o crítico de arte e comentarista da BBC, Alastair Sooke, uma adaptação de um dos quadros da revista em quadrinhos "All American Men of War" de 1962.

\footnotetext{
91 Díptico - tela de pintura dividida em duas partes articuladas que podem ser fechadas como um livro, usadas principalmente sobre altares.
} 
In Lichtenstein's enormous painting, which imitates the reproductive techniques of cheap commercial printing (a palette of primary colours, a flat background, heavy black outlines, fields of tiny dots to simulate tone and shadow), a faceless fighter pilot unleashes a rocket that screams through the sky from left to right before detonating an enemy jet in a spectacular fireball of red and yellow ${ }^{92}$ (SOOKE, 2014).

Sooke comenta o fato do renomado quadrinista inglês Dave Gibbons categorizar o trabalho de Lichtenstein como plágio, uma vez que foi recriado quase integralmente a partir do desenho de Irv Novick, sem creditá-lo (muito similar ao conhecido processo de decalque usado no Brasil pela revista $O$ Tico-tico). De acordo com Sooke, em seu encontro com Gibbons, o quadrinista argumenta que na música, por exemplo, não é possível simplesmente usar o acorde de alguém, não importa o quão pouco, sem creditá-lo ou pagar os direitos ao artista original (GIBBONS apud SOOKE, 2014).

A diferença apontada por Sooke (entre a releitura e o plágio), é de que Lichtenstein teria transformado a arte de Novick de forma sutil, mas crucial. Simplificando e unificando a imagem para Ihe dar mais clareza como uma obra de arte coerente, para isso retirou dois caças inimigos da arte original a sombra escura da montanha, a qual Sooke considera "that was an ugly compositional mistake to the left of Novick's Picture"93 (SOOKE, 2014).

Com isso, Sooke acredita que o resultado da tela de Lichtenstein é mais equitativamente equilibrado, produzindo em efeito visual estruturado. Outro ponto de comparação entre as obras para Sooke é a bola de fogo de ambos trabalhos, enquanto a de Novick é uma explosão insignificante, com pequenas coisas desiguais saindo para fora do quadro, a bola de fogo centrada de Lichtenstein se desenrola como uma flor desabrochando. Além disso, Sooke aponta que a mudança da cor das letras que compõe a onomatopeia "WHAAM!" do vermelho para o amarelo é uma forma de unir todo conjunto, pois sua distribuição na tela guia o olhar partindo do balão de texto escrito, para a onomatopeia e depois para a explosão e de volta para o vapor horizontal deixado pelo movimento do míssil (SOOKE, 2014).

\footnotetext{
${ }^{92} \mathrm{Na}$ enorme pintura de Lichtenstein, que imita as técnicas de reprodução de impressão comercial barata (uma paleta de cores primárias, um fundo plano, pesados contornos negros, campos de pequenos pontos para simular tom e sombra), um piloto de caça sem rosto dispara um foguete que grita através de o céu da esquerda para a direita antes de detonar um caça inimigo em uma espetacular bola de fogo de vermelho e amarelo (SOOKE, 2014) [tradução da autora].

${ }^{93}$ Que era um feio erro de composição à esquerda no desenho de Novick (SOOKE, 2014) [tradução da autora].
} 


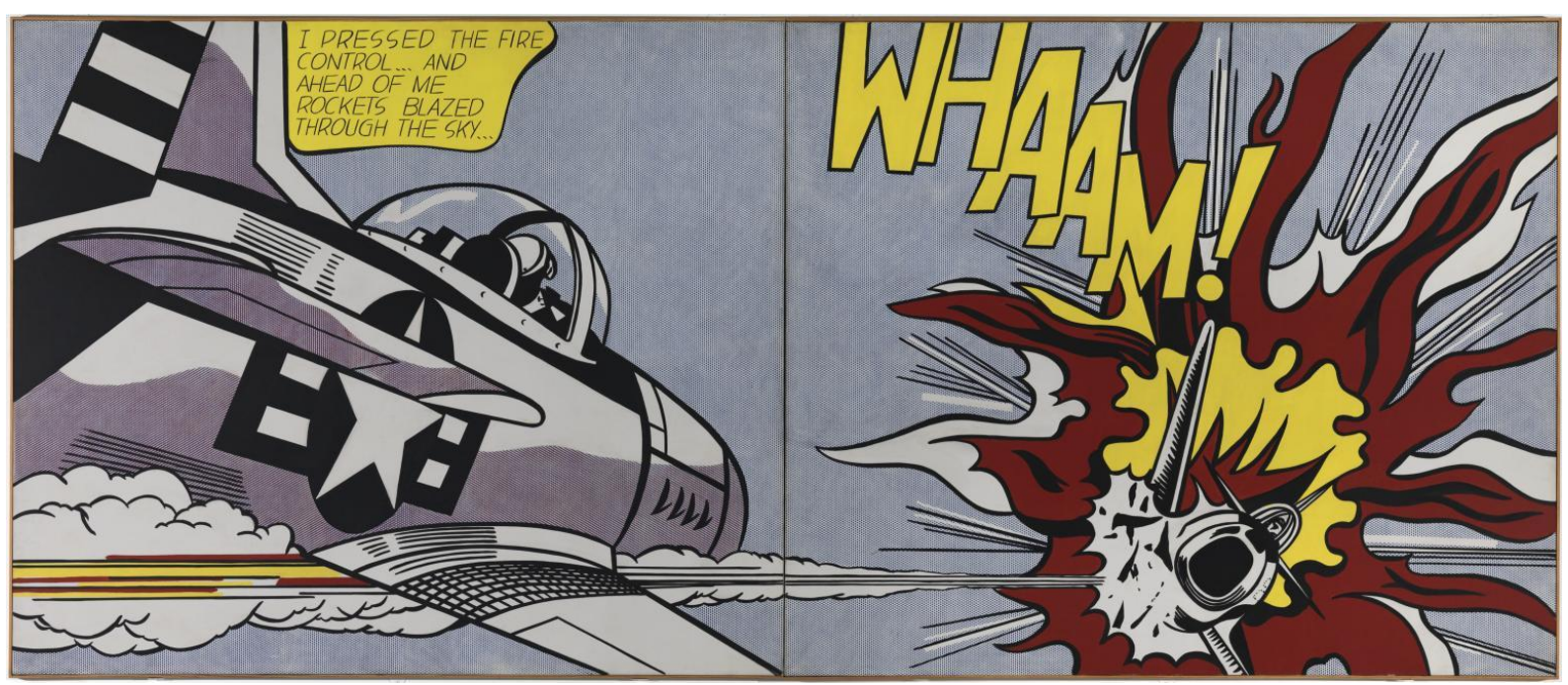

Figura 78 - Whamm! - Roy Lichtenstein de 1963 ${ }^{\mathrm{lx}}$

O trabalho de Irving "Irv" Novick, na opinião de Sooke, foi imortalizado na arte de Lichtenstein, quando é "something tiny and ephemeral - a throwaway comicstrip panel that most people would overlook ${ }^{94 "}$ (SOOKE, 2014).

O quadro único da terceira linha da página 11 (Anexo 1, pág. 293) da história "The Star Jockey" cujo protagonista Johnny Cloud, um piloto de caça apache trava uma batalha contra aviões nazistas na segunda guerra mundial, publicado na revista All American Men of War em 1963 pela editora DC Comics, na época National Periodical Publication, Inc. sob o selo do Comics Code Authority, faz parte de uma narrativa sequencial, analisar somente um quadro isoladamente fora de seu contexto diegético apresenta uma grande perda sentido semântico. Ainda assim é possível ressaltar alguns pontos apontados por Sooke para ilustrar os diferentes enfoques de uma crítica plástica e uma crítica quadrinística:

A montanha, que segundo Sooke é um erro de composição, serve para situar altura do avião em relação ao solo, demostrando a habilidade do piloto em voar tão baixo. No âmbito da diegética, a montanha tem toda razão de existência dentro do quadro, pois limita o espaço visual do piloto, demarca um território e uma dificuldade a ser superada. $O$ piloto voa rápido, baixo, ao lado de uma montanha contra três caças inimigos.

Em um quadro, Novick consegue demonstrar de forma verossimilhante a dificuldade da manobra e perícia do piloto, pela limitação do espaço em torno do herói em oposição a área livre de seus inimigos. Além disso, os três caças inimigos,

94 Uma coisa pequena e efêmera - uma tira de revista em quadrinhos que a maioria das pessoas nem iria notar (SOOKE, 2014) [tradução da autora]. 
demostram a diferença de forças entre o protagonista americano e os seus antagonistas, os nazistas. É um quadro que representa a superação de adversidades, em uma temática heroica.

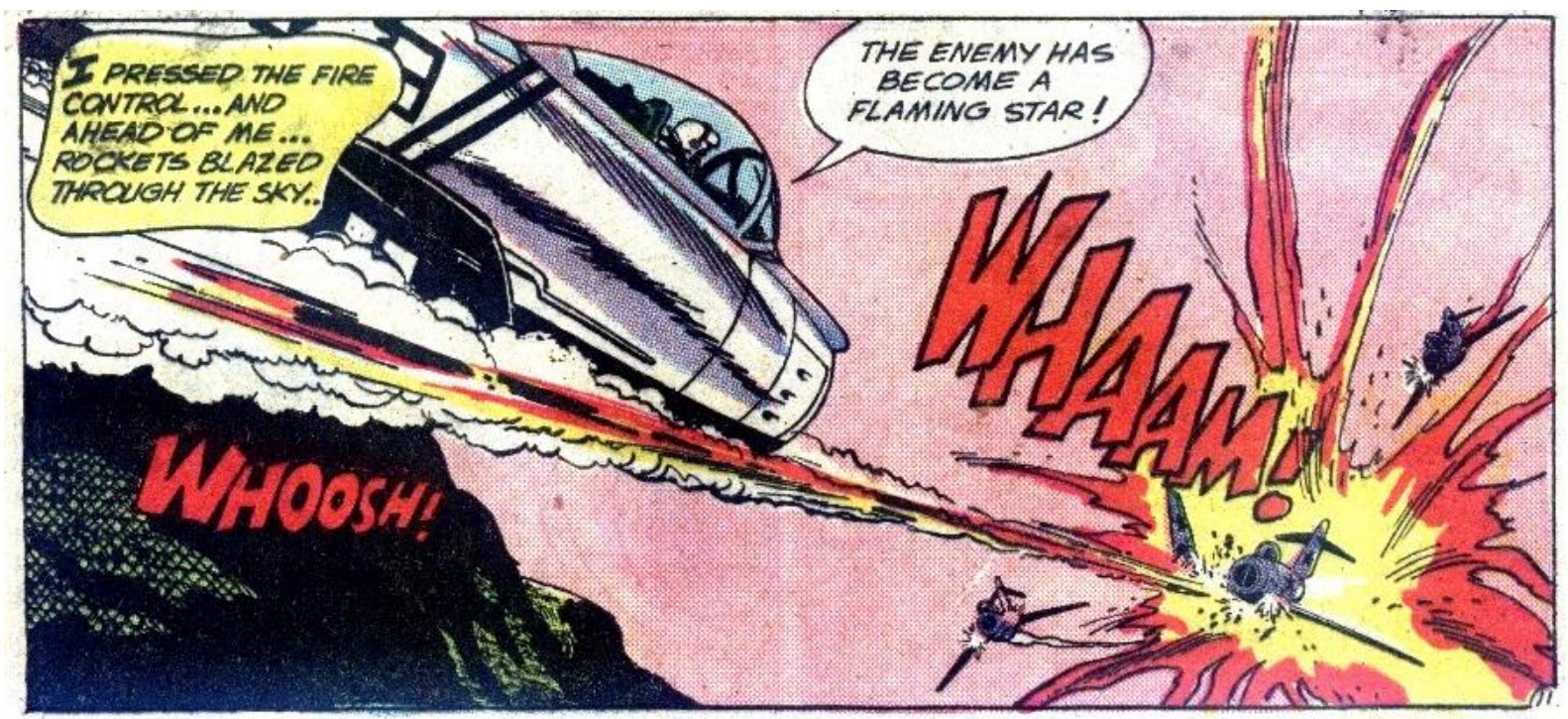

Figura 79 - Quadro único da 3ª linha - página 11 de Star Jockeylxi

A representação gráfica da explosão, também depreciada por Sooke, segue um padrão de estrela, indicado pelo roteirista Robert Kanigher, em um balão de fala do piloto apache: "the enemy has become a flaming star"95, também omitido pelo artista plástico. Esse padrão mais retilíneo e ao mesmo tempo irregular é uma das representações típicas de explosões nos quadrinhos que procuram seguir uma linha realista, de lógica cientificista.

Gravett comenta que no encontro de Alastair Sooke com Gibbons ao ouvir do crítico que Lichtenstein não só havia transformado o desenho de Novick, mas também realmente o melhorado, Gibbons rebateu:

I would disagree. This to me looks flat and abstracted, to the point of view that
to my eyes it's confusing. Whereas the original has got a three-dimensional
quality to it, it's got a spontaneity to it, it's got an excitement to it, and a way
of involving the viewer that this one lacks. For instance, the explosion here
just looks to me like a collection of flat shapes, whereas the explosion in the
original, because there are no lines in there, because it's all left to the colour,
seems to me to have to me much more of the quality of an explosion ${ }^{96}$
(GIBBONS apud GRAVETT, 2013). Deixando de lado um aprofundamento nas questões de direito autoral (um

${ }^{95} \mathrm{O}$ inimigo se tornou uma estrela flamejante [tradução da autora].

${ }^{96}$ Eu não concordaria. Isto [a tela de Lichtenstein] para mim parece plano e abstrato, até o ponto de vista que, para os meus olhos, é confuso. Considerando que o original possui uma qualidade tridimensional, uma espontaneidade, uma emoção e uma maneira de envolver o espectador que este não tem. Por exemplo, a explosão aqui apenas parece-me como uma coleção de formas planas, enquanto que a explosão no original, porque não há linhas lá, porque tudo é deixado para a cor, parece para mim ter muito mais as características de uma explosão (GIBBONS apud GRAVETT, 2013). 
ponto muito sensível e justo aos quadrinistas pelas históricas recorrências de falta de crédito e reconhecimento), as duas obras em questão são objetos díspares, com intencionalidade, abrangência e espaços distintos. A tela de Roy Lichtenstein, comprada pela galeria Tate British por 10 mil dólares na época e, de acordo com Sooke, valendo milhares de dólares nos dias de hoje, fez parte de um manifesto da pop art em ruptura com sua predecessora, os traços firmemente delineados de sua obra são uma oposição às pinceladas soltas do expressionismo abstrato (SOOKE, 2014). Há também a ruptura temática ao elevar para o status de objeto de arte um artigo de baixo valor, representante indubitável (naquele contexto) da cultura de massa, a revista em quadrinhos. De acordo com o jornalista, curador, escritor e comentarista e editor de quadrinhos inglês Paul Gravett, no catálogo da obra Lichtenstein explica:

It was hard to get a painting that was despicable enough so that nobody would hang it. Everybody was hanging everything. It was almost acceptable to hang a dripping paint rag, everybody was accustomed to this. The one thing everybody hated was commercial art; apparently they didn't hate that enough either $^{97}$ (LICHTENSTEIN apud GRAVETT, 2013).

A tela foi criada em um contexto de mobilização contraria aos esforços de guerra, em meio a degastada guerra do Vietnã. Ao tirar a cena do contexto narrativo, Lichtenstein a universaliza - em um espaço amplo a batalha de um contra um, vencedor e perdedor anônimos em uma batalha sem propósito claro - em uma contestação não só do ato de guerra em si, mas de sua banalização, e mesmo apologia, na cultura de massa.

Já o quadro de Novick, um dos 67 quadros de uma história de 13 páginas, está inserido em uma diegese, participando de uma sequência narrativa onde a imagem está subordinada a construção de um espaço, tempo e movimento verossímeis, fazendo fluir a transição do quadro anterior para o seguinte. A revista, com custo de 12 centavos de dólar, de temática de aventura militar, está inserida em um contexto de grande desprestígio dos quadrinhos, após uma década de acirrada perseguição sob a influência até hoje presentes dos argumentos de Fredric Wertham, culminando em uma forte censura do Comics Code Authority. Sob este selo, além de não ser permitido cenas sangrentas, as editoras procuravam demonstrar um forte

\footnotetext{
${ }^{97}$ Foi difícil trazer uma pintura que fosse desprezível o suficiente para que ninguém a pendurasse. Todo mundo estava pendurando qualquer coisa. Era quase aceitável pendurar um pano de tinta gotejante, todos estavam acostumados a isso. A única coisa que todos odiavam era a arte comercial; aparentemente, eles não odiaram o suficiente (LICHTENSTEIN apud GRAVETT, 2013) [tradução da autora].
} 
nacionalismo, pois estavam sendo vigiadas por supostas mensagens subliminares comunistas nas revistas em quadrinhos, desde a associação de Wertham do Superhomem como o conceito do filósofo alemão Nietzsche, o "Übermensch" traduzido na época para o inglês como "Superman" (Super-homem).

Ser publicado na revista, com uma intencionalidade narrativa determinada, para um público específico, para contar a aventura de um personagem particular, ocupa um espaço delimitado de alcance e visualização. A arte para exibição em galeria, para apreciação sensível e crítica da técnica plástica e contextualização temática, ocupa outro. A intencionalidade, dessas obras em questão, não é a mesma, já pelos espaços que ocupam.

Além do fato de Novick não ter sido creditado por Lichtenstein, a grande polêmica do quadro no âmbito dos quadrinistas, foi o teor pejorativo com o qual os quadrinhos ocuparam o espaço da galeria. Essa polêmica se deu justamente pela visibilidade e amplitude que uma ruptura no paradigma das artes plásticas alcança por sua importância hierárquica na sociedade em relação aos quadrinhos.

Em 2004, a artista mineira Rivane Neuenschwander, expôs no MOMA (Museu de arte moderna de Nova York) a instalação "Zé Carioca no. 4" (Figura 80), trazendo 12 telas com a reprodução das páginas da revista em quadrinhos do personagem, mas sem os desenhos ou textos, em uma reflexão sobre o pejorativo estereótipo do brasileiro (malandro, preguiçoso e paquerador) criada pelo personagem de Walt Disney em 1941.

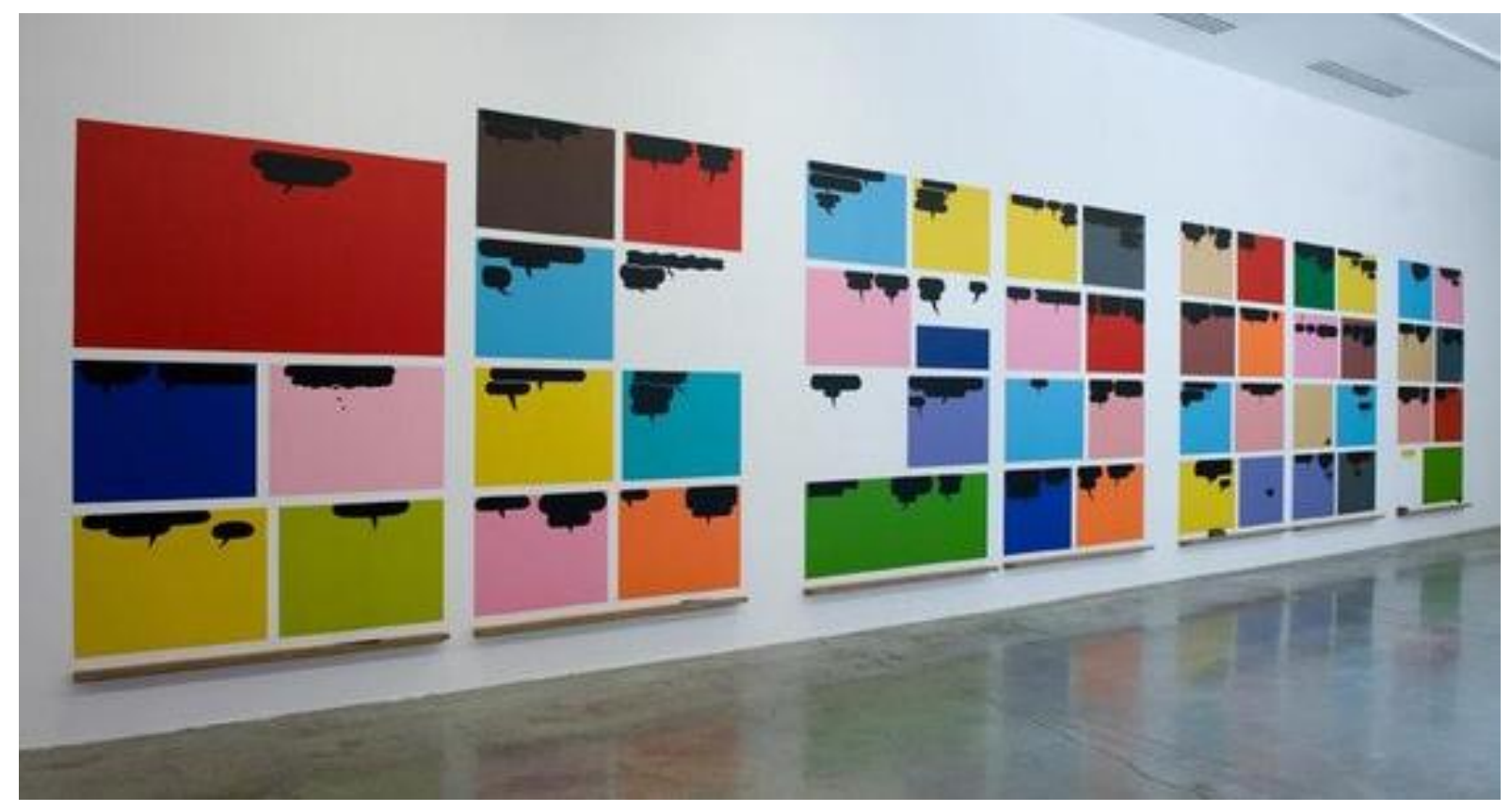

Figura 80 - Zé Carioca - Rivane Neuenschwander Ixii 
$\mathrm{Na}$ instalação, a artista disponibilizou giz para que os visitantes preenchessem os espaços com sua própria interpretação.

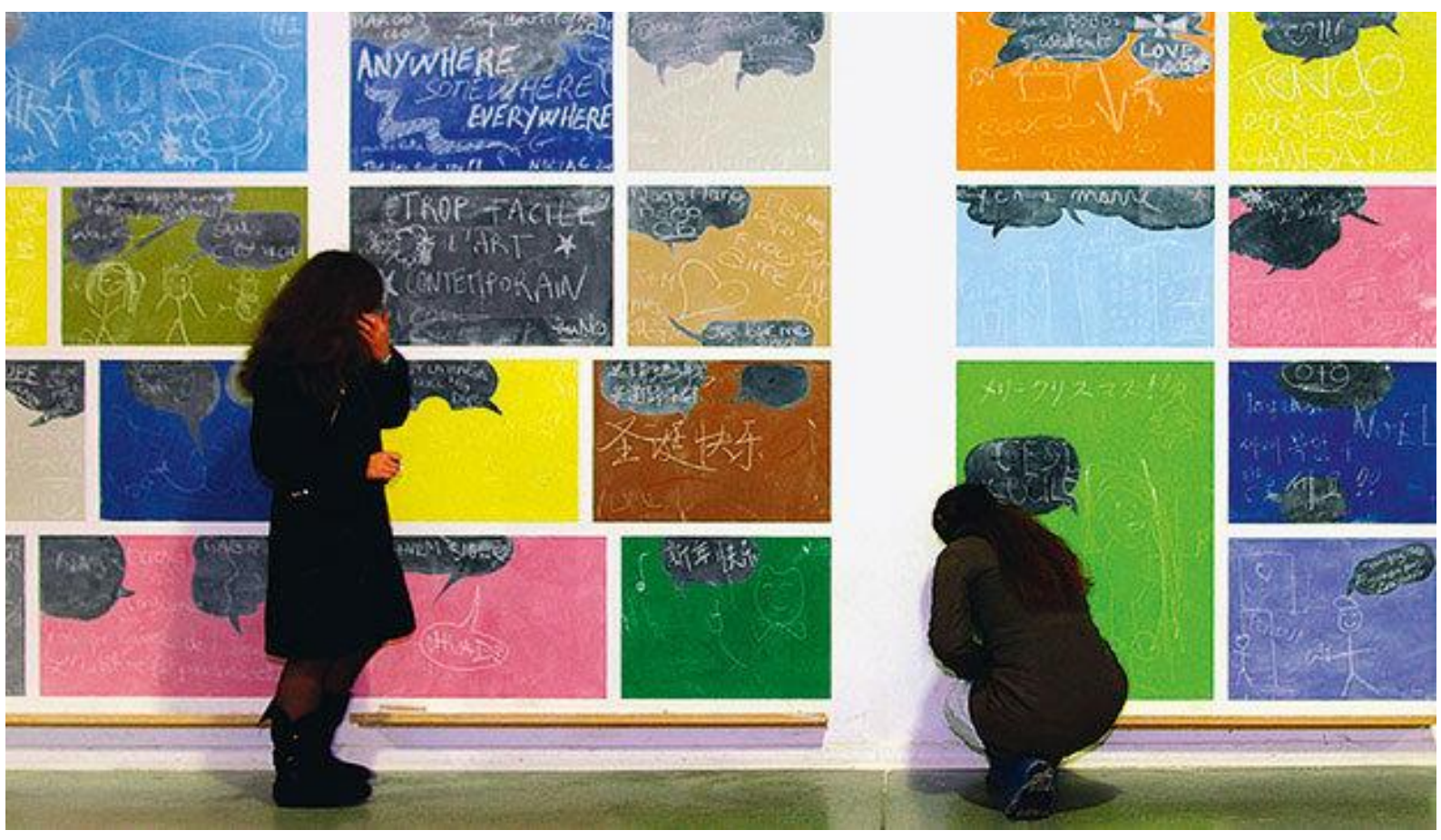

Figura 81 - Zé Carioca - Rivane Neuenschwander - intervenção dos visitantes ${ }^{\mid x i i i}$

Tanto no caso de Lichtenstein quanto Neuenschwander, a HQ foi levada para o espaço da galeria como temática, para ser apontada e discutida como cultura de massa em seu aspecto estético e cultural, por outro lado, em 2009 o Museu do Louvre em Paris, abriu a exposição "The Louvre invites the comics" (o Louvre convida os quadrinhos) onde vários quadrinistas convidados desenvolveram histórias originais com o museu como pano de fundo das obras, nesse caso a $\mathrm{HQ}$ foi a forma de arte assim como a pintura, escultura ou fotografia - utilizada para expressar uma temática. Além da exposição, o museu lançou um álbum com as obras participantes,

\begin{abstract}
A project proposed by Fabrice Douar, this comic album series is one among many manifestations of the museum's policy of openness to contemporary art. From French bandes dessinées (BDs) to Japanese mangas and American comic books, from science fiction to social commentary, from caricatures and cartoons to illustrated diaries, the comic strip universe continues to push back its boundaries and has become a key realm of contemporary cultural practice. Its vitality and importance is amply demonstratedby the increasing interest for this medium within the art market, from an artistic as well as a mercantile perspective $^{98}$ (LOUVRE, 2009).
\end{abstract}

98 Um projeto proposto por Fabrice Douar, esta série de álbuns de quadrinhos é uma das muitas manifestações da política de abertura do museu para a arte contemporânea. Das Bande Dessinée francesas (BDs) aos mangás japoneses e Comics americanas, de ficção científica a comentários sociais, de caricaturas e catuns a diários ilustrados, o universo de quadrinhos continua a empurrar seus limites e tornou-se um domínio-chave da prática cultural contemporânea. Sua vitalidade e importância são amplamente demonstradas pelo crescente interesse por este meio no mercado da arte, tanto artístico como mercantil (LOUVRE, 2009) [tradução da autora]. 
Uma das edições da exposição em 2016 com parceria com a Mori Arts Center Gallery em Tóquio, "Louvre No. 9: Bande Dessinée”, criou peças belíssimas de exposição ao visitante, sem mitigar sua característica narrativa e sua linguagem. O tratamento espacial e dimensional dos quadros e páginas foram especialmente criados para um público coletivo, com o tempo de apreciação e leitura próprios para um público em movimento e em pé. Mesmo assim o nível gráfico, estrutural e narrativos das obras não deixam dúvidas quanto ao objeto: histórias em quadrinhos.

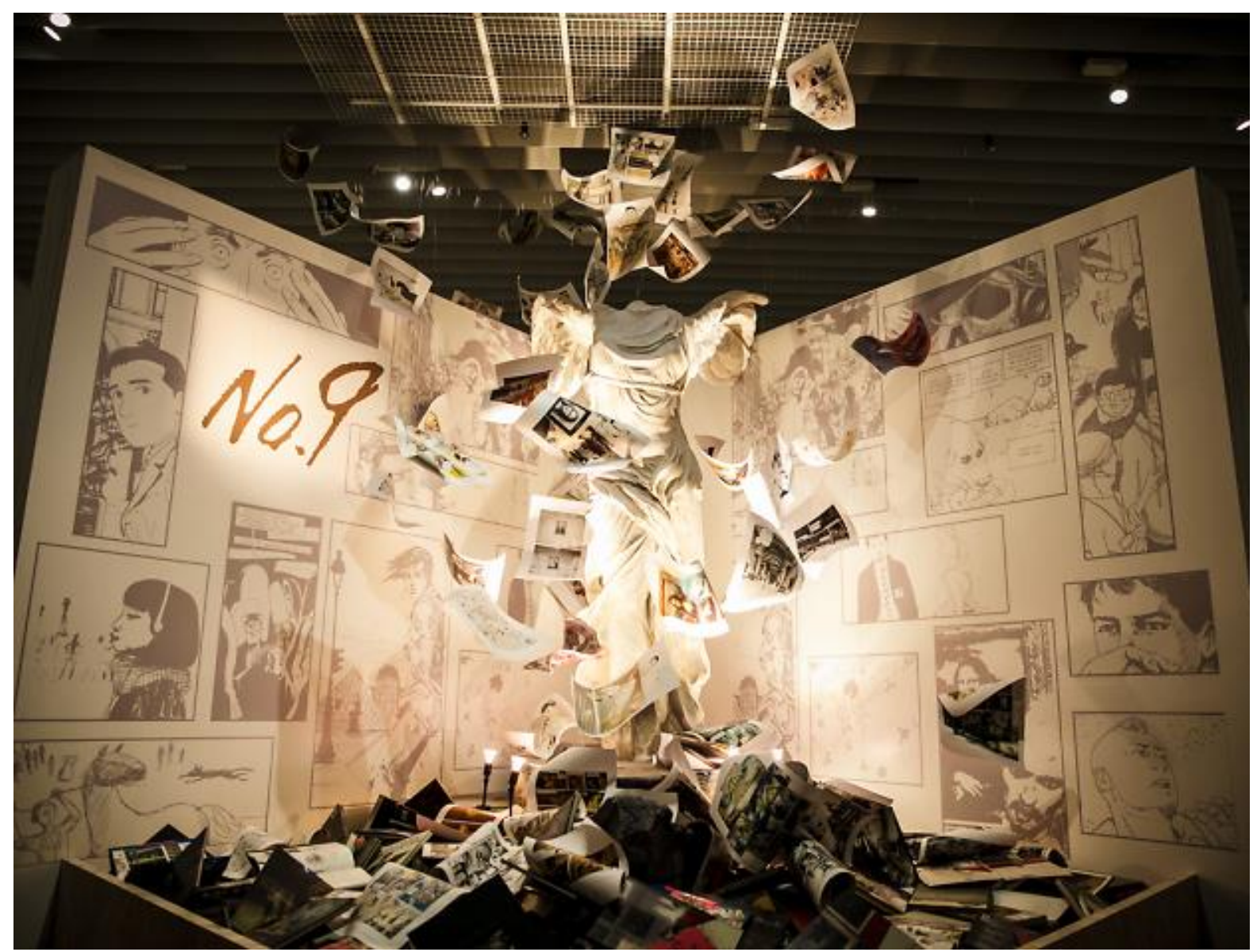

Figura 82 - Exposição Louvre no 9 - Mori Gallery - Tóquio - fotos de Keisuke Tanigawalxiv

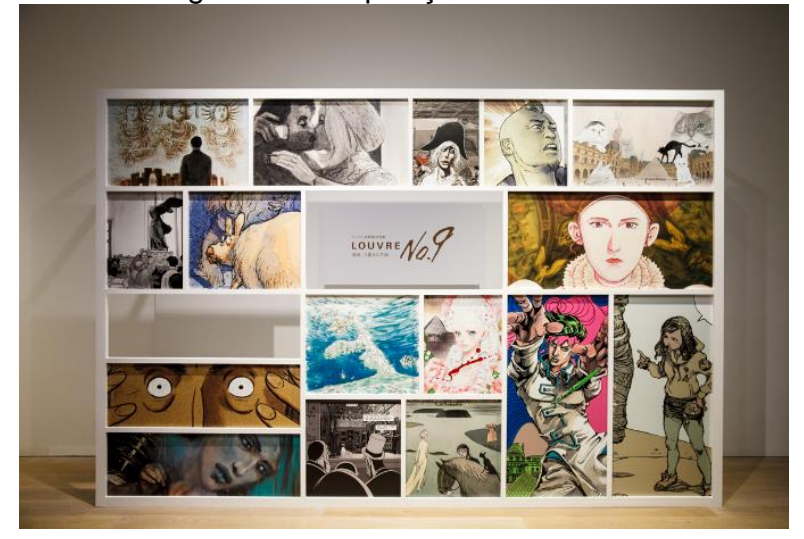

Figura 83 - Exposição Louvre no 9 9xv $^{x}$

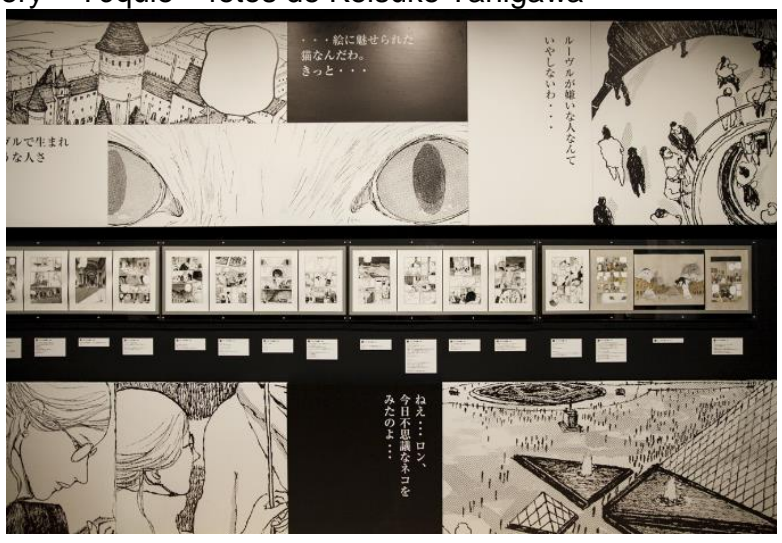

Figura 84 - Exposição Louvre no $9^{\mid x v i}$ 


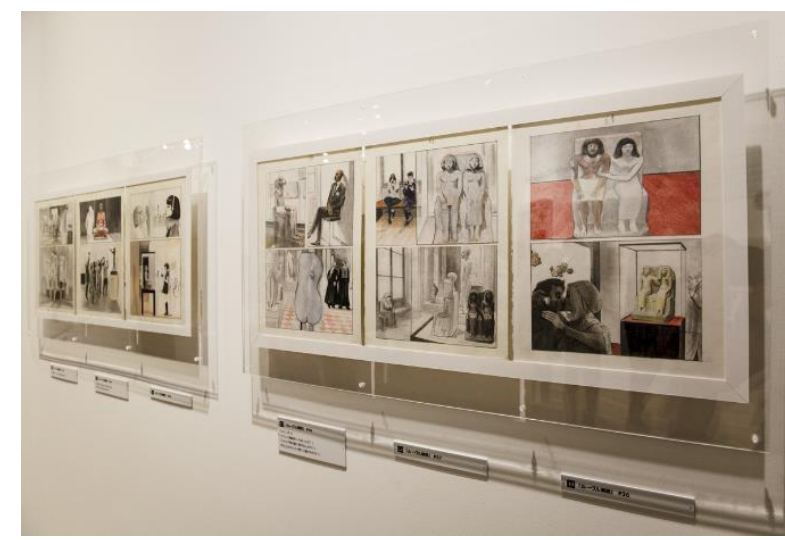

Figura 85 - Exposição Louvre no 9lxvii

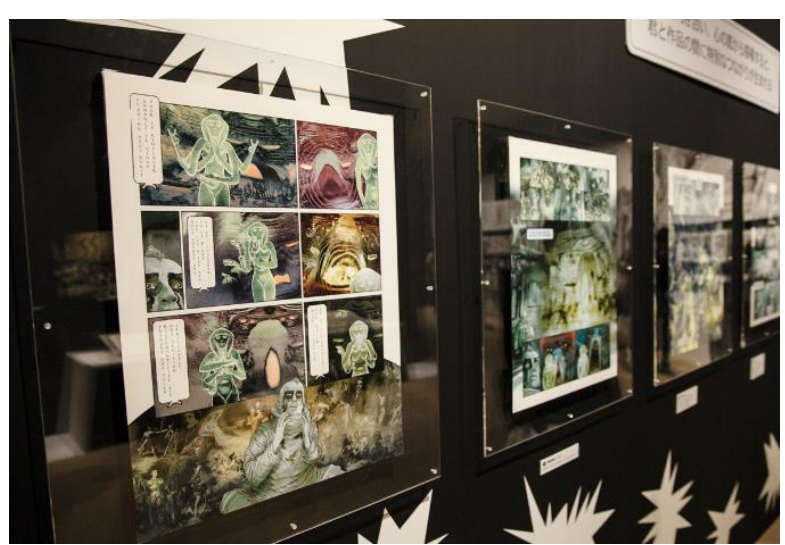

Figura 86 - Exposição Louvre no 9 $^{\text {lxviii }}$

Os quadrinhos, por sua vez, também trouxeram as "Artes Plásticas" para seu espaço, como temática, com seu amplo alcance em número de leitores e como formador de opinião, através de obras como a charge de Angeli, para o jornal Folha de São Paulo em 2014 (Figura 87, pág. 151), ou a tira de Bill Watterson de 1993 (Figura 88, pág. 152).

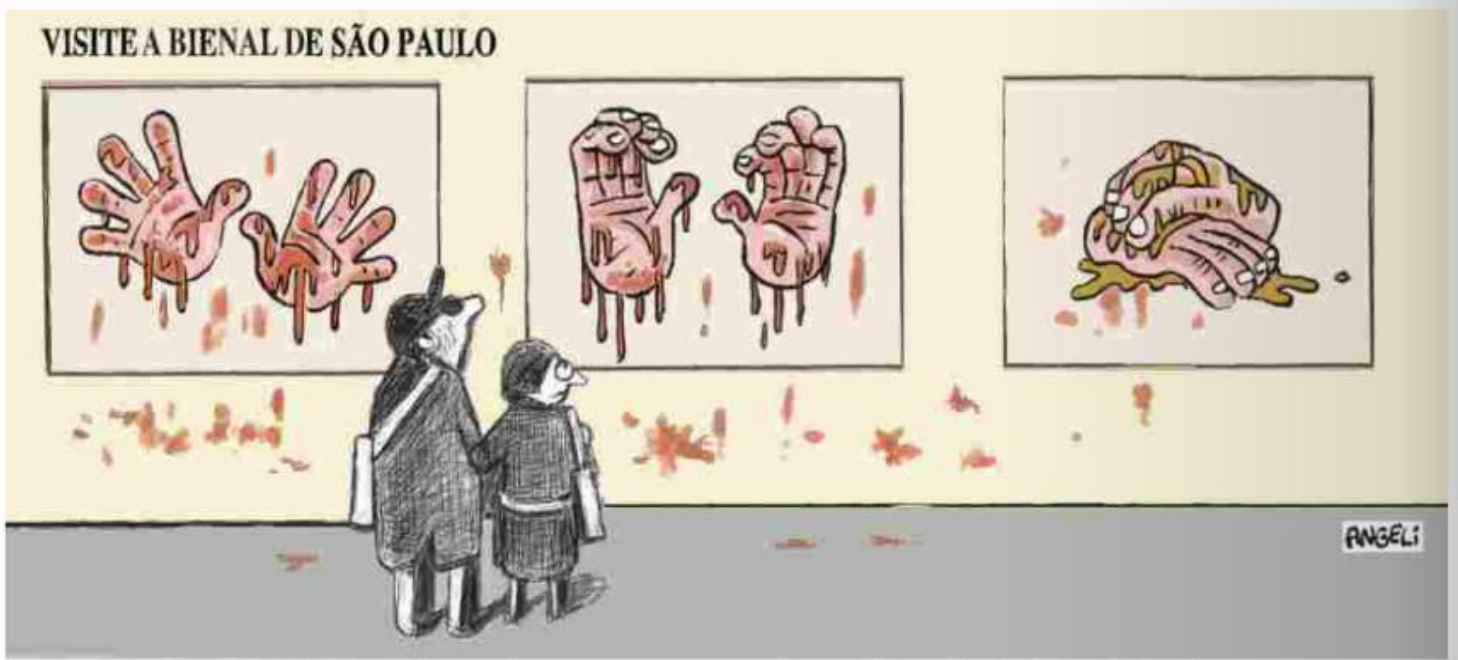

- No catálogo diz que o nome do artista é Paulo Maluf.

Figura 87 - Charge de Angeli - Jornal Folha de São Paulo - 25/09/2014|xix

$\mathrm{Na}$ charge, Angeli critica ações e índole do notório político corrupto brasileiro Paulo Maluf, comparando-as a uma "arte". Angeli coloca sequencialmente a representação de três "telas" do suposto pintor Maluf, e seus observadores. O quadrinista explora o "espaço" galeria, para demostrar a interação inexistente entre público e obra, argumentado por meio da expressão de incompreensão de seu observador quanto ao sentido dessa "arte". Além de apontar o status financeiro de uma arte de si para si, ou seja, criada por uma elite rica e famosa para ela mesma. A charge de Angeli é ao mesmo tempo uma crítica política, cultural e social, por ressaltar que a galeria é, na maior parte do tempo, percebida como um espaço elitista 
dissociado da população em geral.

O suporte, meio de distribuição, público, alcance, etc., não determina se uma obra é ou não uma história em quadrinhos. Por exemplo, se a tira de Bill Watterson, Calvin and Hobbes (Calvin e Haroldo, no Brasil) (Figura 88, pág. 152), inspirada na tela de Marcel Duchamp "Nu descendo a escada" de 1912 (Figura 89, pág. 152) - a qual já havia sido parodiada em 1913 (Figura 90, pág. 152), for reproduzida integralmente: impressa no canto de página de um jornal ou em uma folha inteira de um livro; digitalizada e compartilhada em redes sociais; copiada a mão na capa de uma agenda; pintada em tinta óleo ou acrílica em uma tela de linho; recriada em estêncil em um muro; estampada em uma camiseta, uma bolsa ou uma caneca, não deixará de transmitir a mesma mensagem cômica e, para aqueles que conhecem a pintura de Duchamp, irônica.

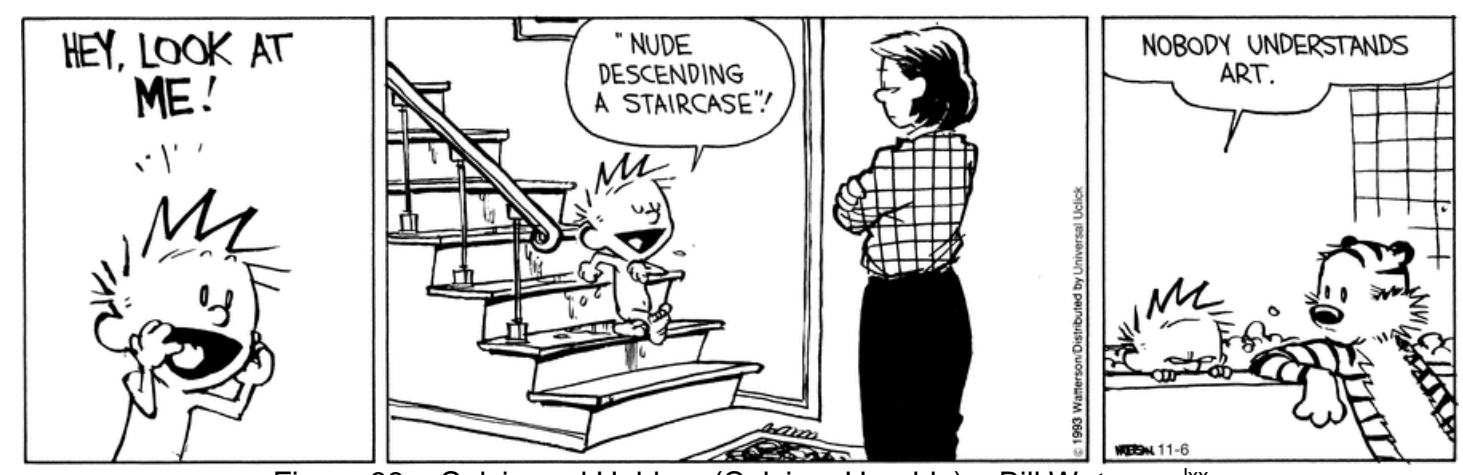

Figura 88 - Calvin and Hobbes (Calvin e Haroldo) - Bill Waterson ${ }^{\mathrm{lxx}}$

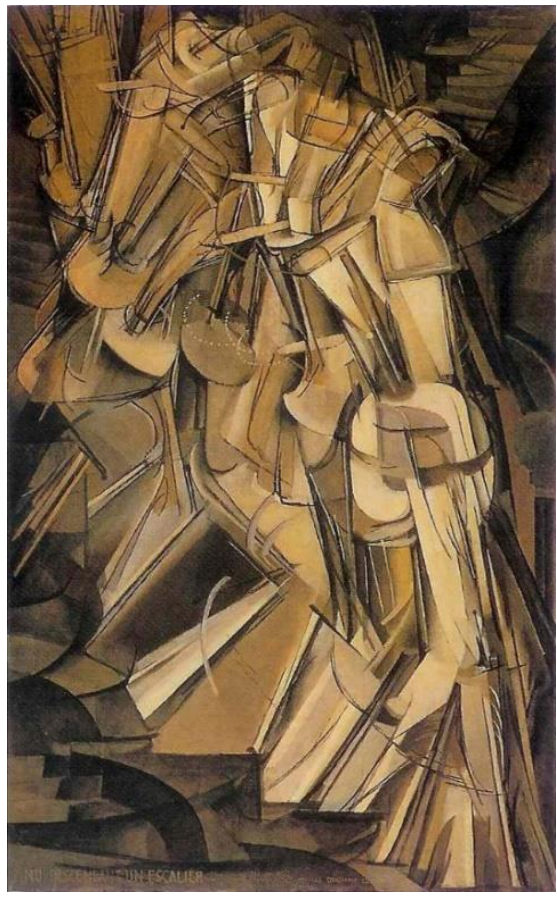

Figura 89 - Nude Descending a Staircase, No. 2 Marcel Duchamp - 1912

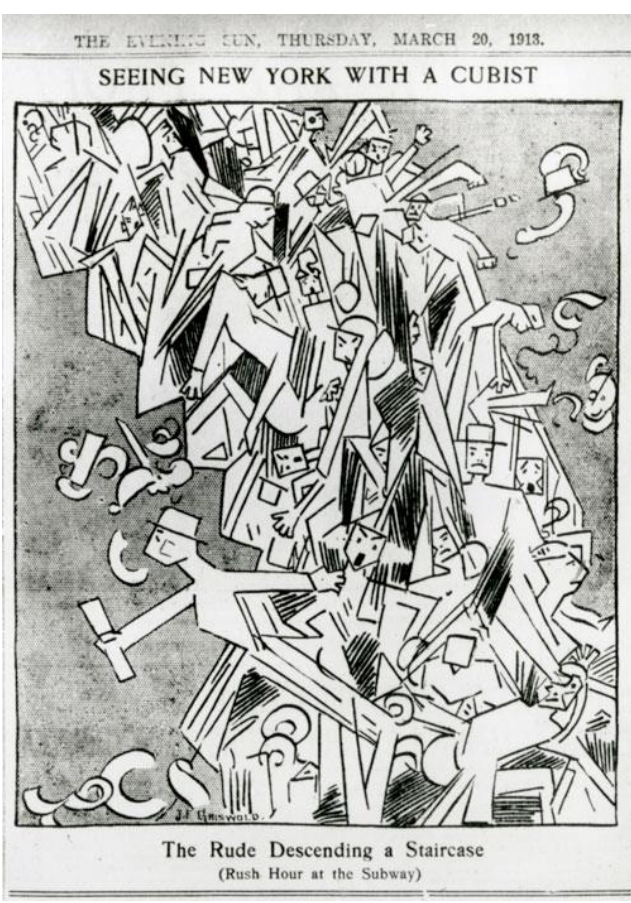

Figura 90 - The Rude descending a staircase (RushHour at the Subway) - 1913 
O espaço físico não é um definidor da identidade do meio (só é quadrinhos se estiver no jornal, na revista, no livro ou na web, etc.) a criação artística não pode ser condicionada facilmente em um container e restringida a um espaço que se julga o mais adequado. Assim, nos quadrinhos, o espaço físico é, até certo ponto, um delimitador da linguagem. Um jornal favorecerá um determinado desenvolvimento, o livro outro, assim como a web ou aplicativo de smartfone, etc. mas não é uma regra restritiva - brincar com o espaço que lhe cabe, distorcê-lo e afrontá-lo também faz parte da metalinguagem quadrinística.

Este espaço delimitado pelo suporte escolhido, comumente chamado de "grade" ou "prancha" pelos quadrinistas e alguns pesquisadores, é o espaço imaginado - eventualmente esboçado - que conterá a história em quadrinhos. Mesmo uma fotonovela, ou a arte final de colagens ou aquarela, ou mesmo um programa de ferramenta gráfica, para autores que desenham diretamente no computador, parte de um esboço inicial, um esqueleto onde serão posicionados rudemente os ícones. A forma do esqueleto seguirá o corpo que o artista deseja ou pode criar.

Ilustrando com um caso hipotético: o editor de um livro didático acredita que seja necessária uma pequena tira para compor um bas-de-page ${ }^{99}$ para compor seu conteúdo programático que verse sobre contos infantis. Ao receber essa encomenda, antes de determinar que personagens, cenário, clima, cores, diálogos e desfecho, a preocupação do quadrinista será o espaço que lhe é reservado, ou seja, a porção da mancha gráfica da página do livro que ele pode ocupar, determinado pelo editor de designer do livro.

André Furtado, professor do Departamento de Artes Gráficas da UFRGS, comenta que é comum que editoras de material impresso utilizem medidas áureas para distribuição do conteúdo na página, em geral 34 por 21 e a área de mancha gráfica terá margens com medidas: superior $3 \mathrm{~cm}$, inferior $6 \mathrm{~cm}$, interna $2 \mathrm{~cm}$ e externa $4 \mathrm{~cm}$, cuja proporção será alterada matematicamente de acordo com o tamanho do livro ou revista (FURTADO, 2009). Segundo Furtado, em geral o processo da criação das medidas de uma página retangular é desenhar um quadrado inicial, traçar uma diagonal para criar o raio do arco que marca a altura maior do retângulo, e tendo como base a proporção áurea seguir formar um esqueleto base para a mancha gráfica da

\footnotetext{
${ }^{99}$ Bas-de-page, literalmente, base da página, figuras que podem ou não ser referentes ao texto acima,
} muito usado nos livros medievais Fonte bibliográfica inválida especificada.. 
página, ou seja, tudo que vai ser impresso, seja texto, ilustrações, tabelas, etc.:
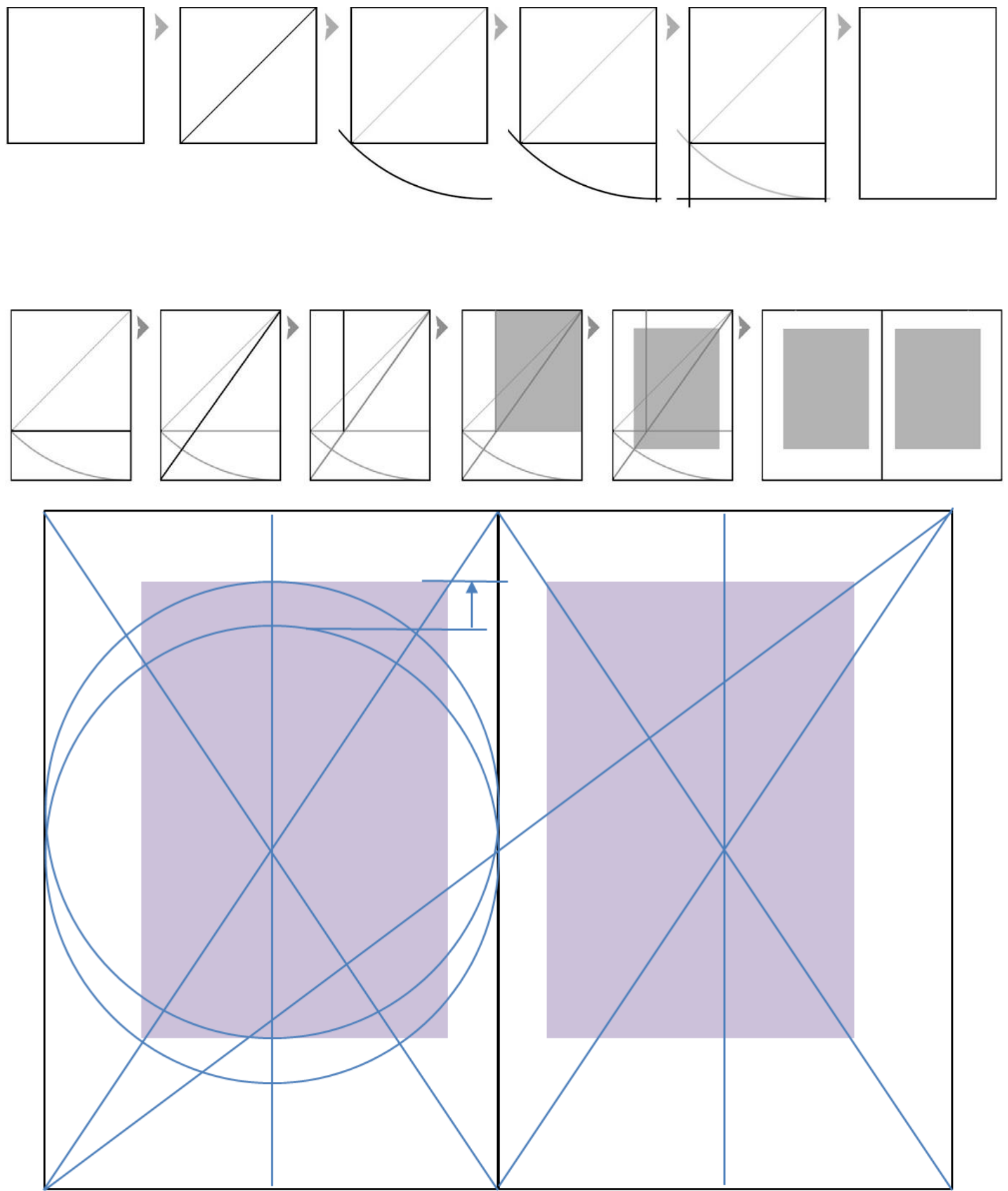

Supondo que o artista modelar recebeu como espaço de bas-de-page o retângulo laranja, para desenvolver seu pequeno conto, anedota ou paródia: 


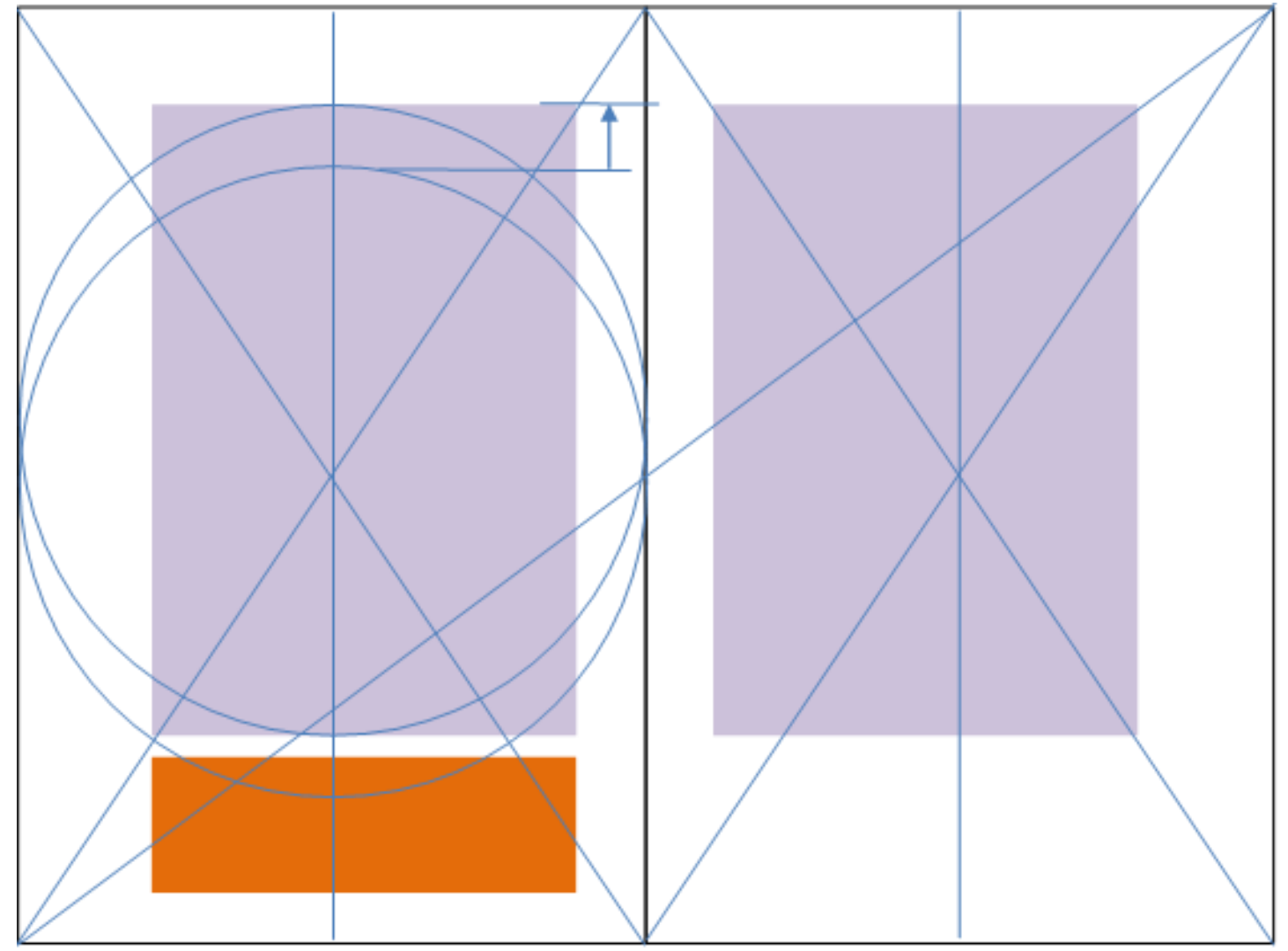

Ao desenvolver a tira de quadrinhos, o artista, ou o editor que o orientará entregando-lhe as medidas, levará em conta não só o espaço que lhe é destinado, mas o tamanho da página como um todo. A quantidade de quadros da tira, por exemplo, não pode ser grande que deixe cada quadro minúsculo, provavelmente limitará sua narrativa a um, dois, três ou no máximo quatro quadros para contar sua história. Caso ela contenha texto, o tamanho da letra não será muito diferente da usada no corpo do texto, para se unificar com o fluxo de leitura.
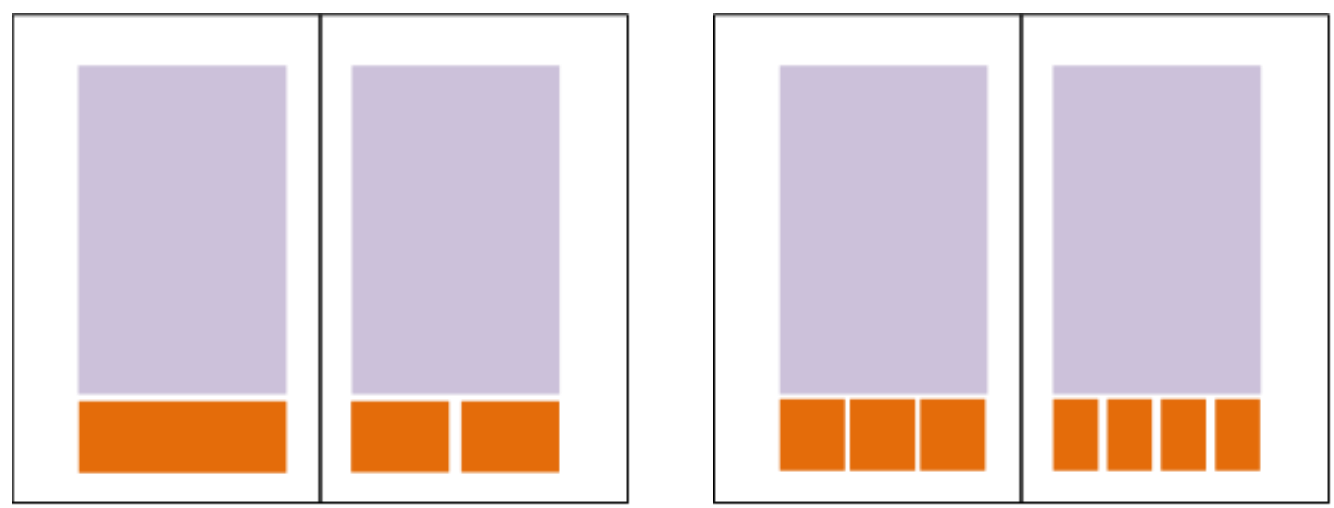

Se não houver esse cuidado gráfico de integração, haverá um 
estranhamento visual onde a tira de quadrinhos ou o cartum parecem invadir um espaço que não Ihes é natural, uma linguagem alienígena ao texto, por que se houver intenção de inovar o design do livro para algo mais livre e flexível, essa estética gráfica se aplicará na página como um todo de forma que texto didático e quadrinhos partilhem da mesma unidade.
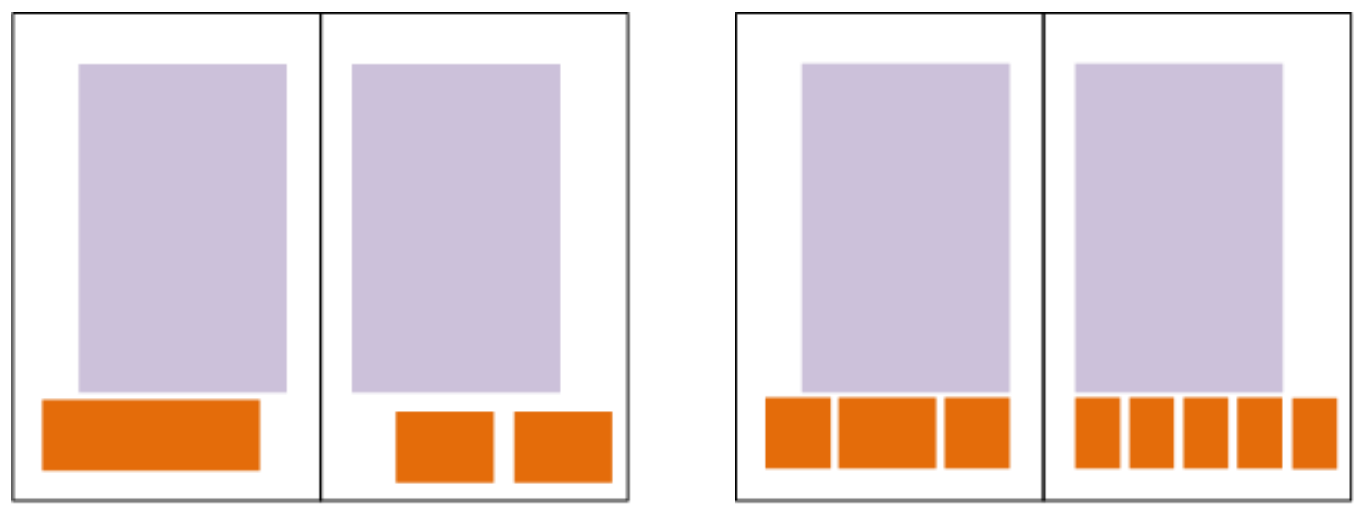

Groensteen, apesar de não falar sobre o uso dos quadrinhos fora da revista ou livro, ressalta a importância da espaçotopia, termo cunhado por ele, onde há duas instâncias de espaço na criação da HQ: o espaço diegético da narrativa, e o espaço físico do quadro na página (GROENSTEEN, 2015). É o desenvolvimento da grade (ou prancha) 0 aspecto primário da materialização espacial dos quadrinhos.

Em seu livro Comics and Narrative de 2011, Groensteen ressalta o impacto do surgimento das histórias em quadrinhos abstratas (Figura 91 a Figura 94), as quais não possuem narrativa, seja textual ou imagética, restando somente a estrutura sequencial da grade que possibilita reconhecer o meio (GROENSTEEN, 2011, p. versão ebook, $8 \%$ ).

...the identification of the apparatus as the foundation of the comics medium, as the cardinal element of its "primary machinery". If the apparatus spontaneously perceived as necessarily pertaining to comics, then it becomes a symbolic structure, a discursive operator - something, in fact, of the order of the concept. But if the reference to comics does not automatically come to mind, then this same apparatus is understood as no more than a mechanism for organizing space, and its visual elements become mere percepts ${ }^{100}$ (GROENSTEEN, 2011, p. versão ebook, 8\%).

100 ... a identificação do aparato como a base da mídia dos quadrinhos, como o elemento cardinal de "maquinaria primária". Se o aparato é percebido espontaneamente como necessariamente pertencente aos quadrinhos, então se torna uma estrutura simbólica, um operador discursivo - algo, de fato, da ordem do conceito. Mas se a referência aos quadrinhos não vem à mente automaticamente, então este mesmo aparato é entendido como nada mais que um mecanismo para organizar o espaço, e seus elementos visuais se tornam meras percepções (GROENSTEEN, 2011, p. versão ebook, 8\%) [tradução 
Sem a narratividade, Groensteen se pergunta o que sobra das tradicionais definições de história em quadrinhos, chegando à conclusão de que "Nothing more than the sharing of a space for inscription or display - in other words, the apparatus, the 'plurality of images in solidarity'."101 (GROENSTEEN, 2011, p. versão ebook, 8\%). Para ele, essa solidariedade da imagem ou, como ele chama no Sistema dos Quadrinhos, solidariedade icônica, se refere às relações dos quadros - considerados por ele como as menores unidades da HQ - entre si, e no espaço da página. Por isso sua análise parte da narrativa sequencial, mesmo que em tiras de quadrinhos, não levando em conta imagens individuais como charges e cartuns. Contudo a diferença entre um cartum e uma tira é, muitas vezes, apenas o acréscimo de um silêncio, ou um prolongamento narrativo. A imagem de quadrinhos única mantém a solidariedade icônica entre seus elementos.
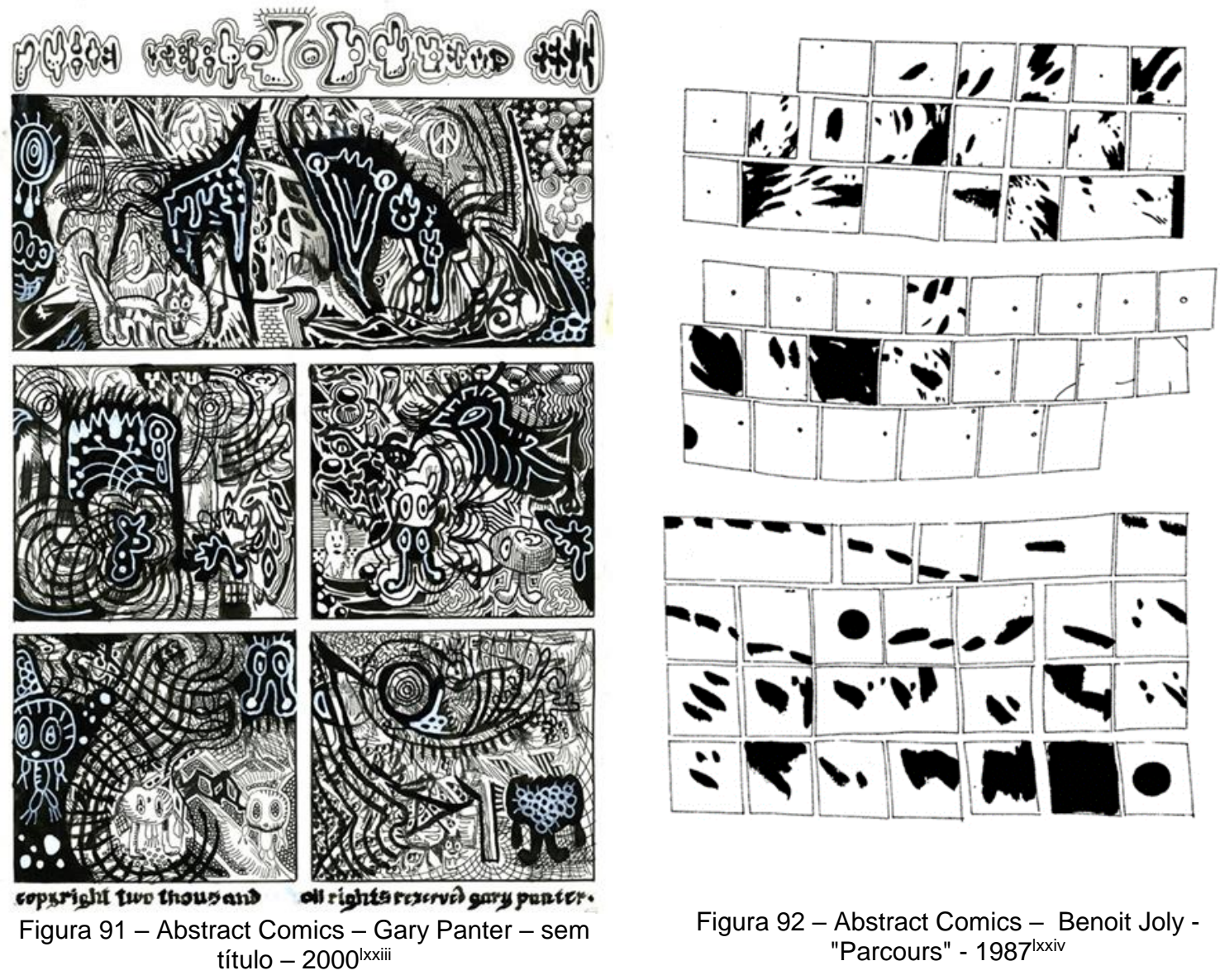

Figura 92 - Abstract Comics - Benoit Joly "Parcours" - 1987

da autora].

101 Nada mais que o compartilhamento do espaço para inscrição ou exibição - em outras palavras, o aparato, a "pluralidade das imagens em solidariedade" (GROENSTEEN, 2011, p. versão ebook, 8\%) [tradução da autora]. 


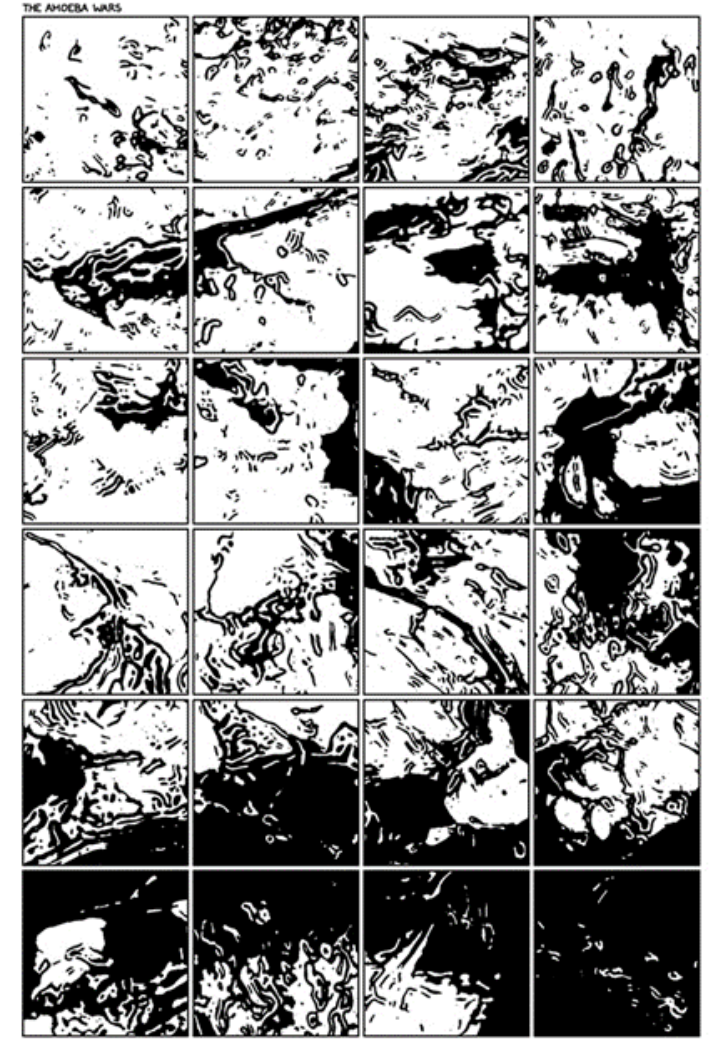

Figura 93 - Abstract Comics - A.M. - A Vague Epic$2006-2008^{1 \times x v}$

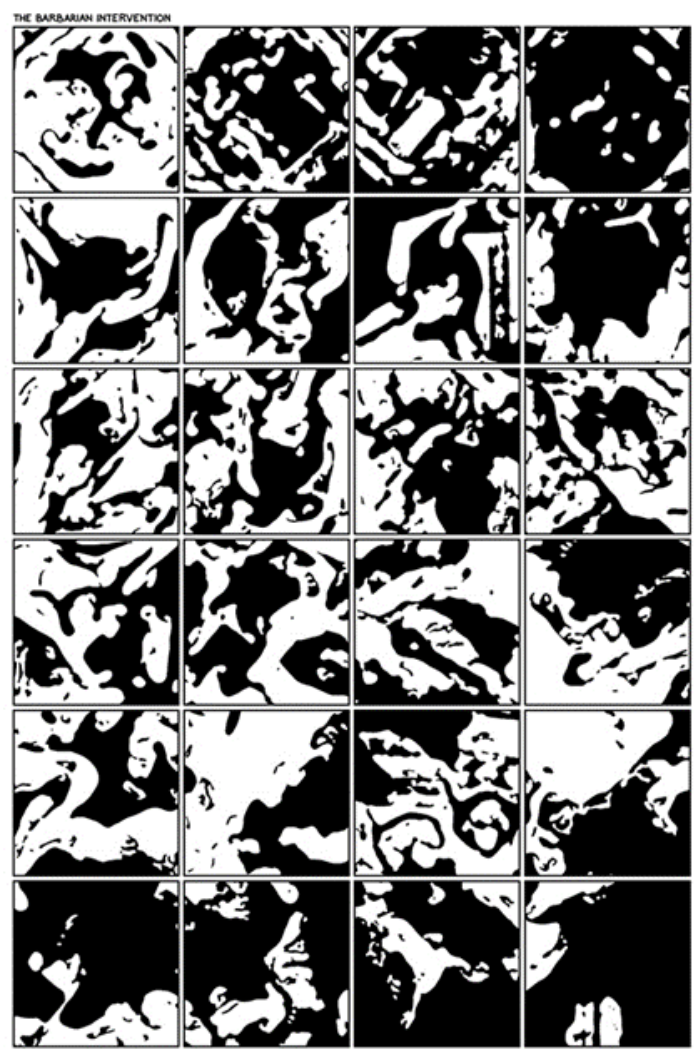

Figura 94 - Abstract Comics - A.M. - A Vague Epic2006-2008 ${ }^{\mathrm{Ixxvi}}$

Ampliando a utilização da composição básica de personagens e cenários pela cartunização, este estudo propõe, como exemplo uma tira simples sobre um conto de fadas:
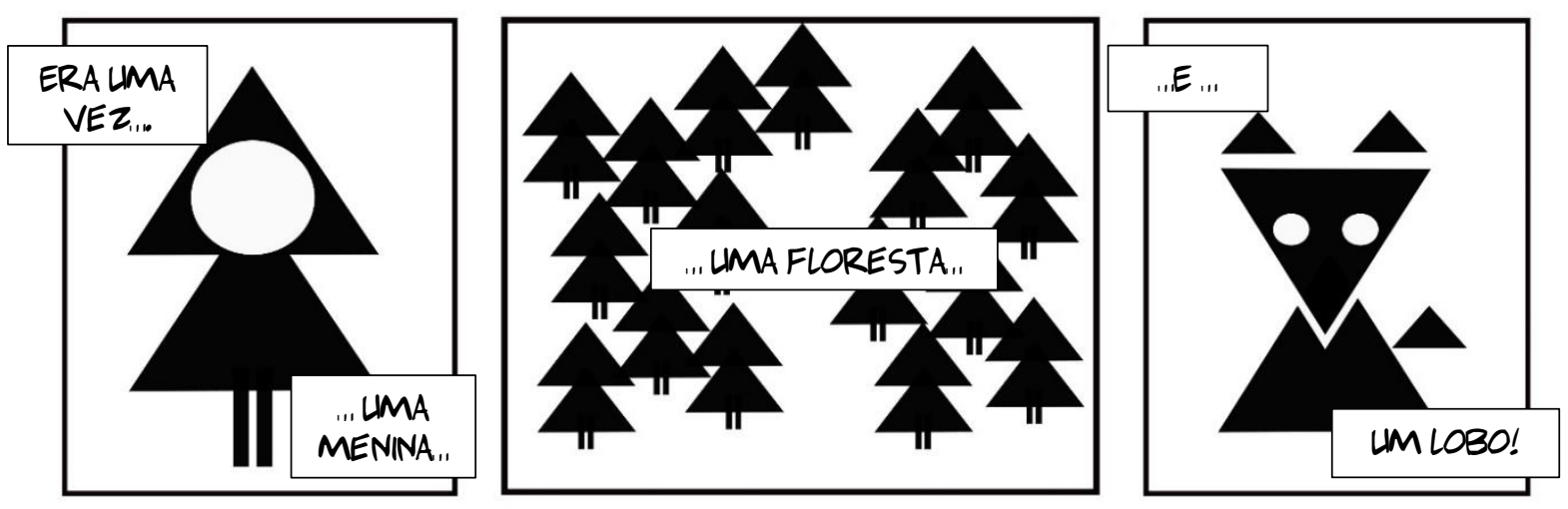

A tira é composta de três figuras (quadros), a primeira possui 2 triângulos, um círculo e dois retângulos compondo a personagem, a segunda é a repetição da primeira forma, excetuando o círculo, e a terceira uma variação de tamanho e posição de triângulos e dois círculos, em todas as figuras há presença de legendas retangulares contendo ícones linguísticos.

Seguindo o conceito de Groensteen, as imagens dos três quadros se 
solidarizam, e o leitor completa o sentido com suas referências pessoais. Não é preciso a reprodução detalhada das imagens para compor a narrativa, movimento a movimento, para que o leitor infira a ação, e neste caso específico, a conclusão.

The comics reader takes semantic and narrative coherence for granted. S/he presumes that "the positioning of any panel necessarily has some point". When images set out consecutively fail to offer any immediate coherence, the reader is naturally inclined to minimize what seems like a "breach of contract" by formulating hypotheses intended to confer intelligibility on the string of panels-to convert an amalgam into a narrative sequence ${ }^{102}$ (GROENSTEEN, 2011, p. versão ebook, 10\%).

Mas há, neste caso, uma relação de solidariedade além de um quadro a outro, que é a solidariedade entre a imagem e a legenda que contém os ícones de escrita. Pode parecer a princípio que a escrita é apenas uma paráfrase da imagem, mas como abordado anteriormente, uma palavra escrita na $\mathrm{HQ}$ recebe o mesmo tratamento da imagem, ocupa um determinado espaço na grade e seu posicionamento tem um sentido específico, tanto estético quanto semântico.

Mesmo que a princípio as imagens tenham sido vistas ao mesmo tempo pelo olhar panóptico do leitor, ao direcionar o olhar para a posição convencionada de início de leitura de quadrinhos ocidental (esquerda superior), que funciona como uma proposição, uma abertura temática para a narrativa, e receber o conteúdo "Era uma vez...", por sua vez, uma abertura convencionada dos contos de fadas tradicionais, as imagens são unificadas como parte integrante de uma narrativa de ficção (as mesmas imagens podem pertencer a outro gênero de acordo com a proposição). A forma como as legendas são dispostas ao longo da imagem provocam uma ruptura em fluxo contínuo de leitura, aplicando pausas longas propositais para criar visualmente uma expectativa. Mesmo que a imagem já tenha sido dada, a existência de um outro espaço, o das palavras escritas, trará ao leitor mais informações que se agregarão à mensagem já inferida, é a expectativa da comprovação ou contrariedade da suposição do leitor que gera esse vínculo solidário entre os ícones figurativos e linguísticos.

A solidariedade entre ícones figurativos e linguísticos, independe do número de quadros. Mesmo em um quadrinho de apenas uma imagem há uma

102 O leitor de quadrinhos tem absoluta certeza da existência da coerência semântica e narrativa. Ele(a) presume que "a posição de qualquer quadro necessariamente tem algum sentido". Quando as imagens colocadas consecutivamente falham em oferecer uma coerência imediata, o leitor é naturalmente inclinado a minimizar o que parece como uma "quebra de contrato" formulando hipóteses para conferir significado para a cadeia de painéis - para converter um amálgama em uma narrativa sequencial (GROENSTEEN, 2011, p. versão ebook, 10\%) [tradução da autora]. 
relação de complementação de sentido entre as diversas figuras presentes na cena.

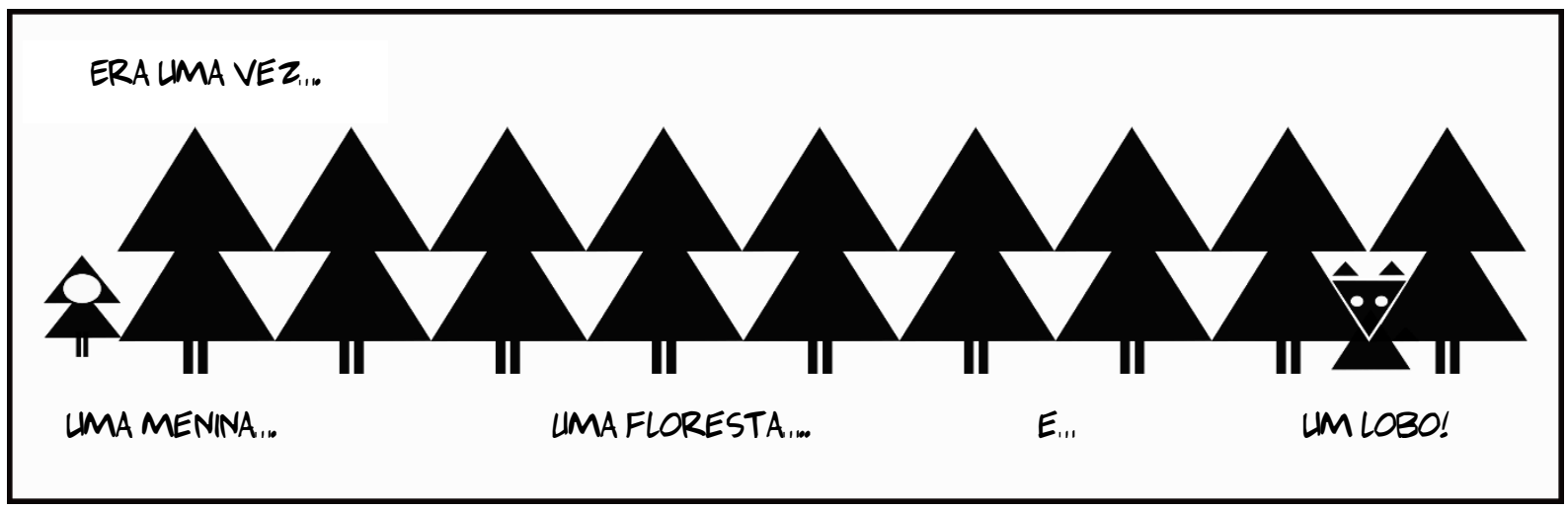

No caso da versão da tira em um quadro só, a posição dos ícones linguísticos continua seguindo a preocupação espacial da grade, em posições específicas e estratégicas, guiando a leitura, neste caso, ressaltando ironicamente o lobo escondido em meio às árvores.

O espanhol Santiago Garcia também considera problemáticas, definições de quadrinhos como as de McCloud em "Desvendando os Quadrinhos" (1993) e Groensteen em "Sistema dos Quadrinhos" (1999) que excluem para o "humor gráfico" ou "ilustrações", a HQ que se completa em apenas um quadro (GARCIA, 2012, p. 41).

Retomando o assunto em 2011, Groensteem reitera sua posição quanto a imagem única, de que uma imagem única não pode ser quadrinhos, pois não possui sequencialidade. Contrastando sua análise com a de outros estudiosos que apontaram para uma narratividade na imagem única, ele conclui,

Every situation has narrative potential. But that does not mean that it fits neatly into a precise and predetermined script; there is not one and one only before scenario, any more than one and one only after scenario, that can be deduced from it ${ }^{103}$ (GROENSTEEN, 2011).

Com base nos exemplares elencados pelos pesquisadores que ele cita, Groensteen ressalta que na maioria dos casos, a narrativa apontada nas imagens únicas era, grosso modo, baseada na mitologia religiosa ou contos populares,

103 Toda situação [cena] possui um potencial narrativo. Mas isso não significa que ele se encaixa perfeitamente em um script preciso e predeterminado; não há um cenário e o que veio imediatamente antes, assim como um que venha imediatamente depois, que pode ser deduzido da situação (GROENSTEEN, 2011) [tradução da autora]. 
The story is not recounted - it is evoked, and this evocation is readily comprehensible only because the subject matter is already well-known. The spectator is at liberty to use the image as a starting point for summoning up the story as a whole, by recalling from memory the episodes that come before and after it ${ }^{104}$ (GROENSTEEN, 2011).

Parece haver certa contradição nesse postulado de Groensteen a respeito da imagem individual, pois se ele aponta que o leitor é capaz, como citado acima, de "formulating hypotheses intended to confer intelligibility on the string of panels" (formular hipóteses para conferir significado para a cadeia de painéis), o leitor também seria capaz de fazer o mesmo em relação a uma cadeia de ícones dentro de uma imagem. Além disso, se o leitor em uma narrativa sequencial "s/he presumes that 'the positioning of any panel necessarily has some point"' (ele(a) presume que a "posição de qualquer quadro, necessariamente tem algum motivo") também presumiria que a posição de determinados ícones em uma imagem tem necessariamente um motivo.

Groensteen ressalta também que o leitor infere uma sequência lógica com base em suas referências - referências estas que podem ser o conhecimento prévio de mitos, lendas ou parábolas - e uma vez que seu imaginário e seu repertório pessoal de referências é acessado para interpretar/completar narrativas sequenciais, não há motivo para que não o faça para imagens singulares.

Nos trabalhos citados por Groensteen para explícitar a não narratividade da imagem única, é apontado a falta de uma indicação condicional de um momento anterior ou posterior, ou seja, as imagens não apresentavam uma possibilidade única de passado ou futuro possível (podendo ter qualquer cena precedente, ou seguinte, e não uma específica), como é o caso do intervalo de tempo entre um quadro e outro da narrativa sequencial, que mesmo com grandes intervalos de tempo, limita a imaginação do leitor a somente um curso de ação possível. Contudo, parece haver uma limitação do corpus estudado por Goreensten, que não permitiram visualizar as possibilidades de construção icônico-solidárias de uma $\mathrm{HQ}$ de quadro único, pois como se nota no cartum de Quino (Figura 95, pág. 162), que narra a caçada frenética de um escriturário a uma aranha, é possível inferir pelos rastros deixados pelo carimbo, toda sequência de ação que culminaram com a morte da aranha.

O cartum de Quino, não é uma narrativa em potencial, e sim uma narrativa

${ }^{104}$ A história não é recontada - ela é evocada, e esta evocação é prontamente compreensível apenas por que o assunto já é conhecido. O espectador tem a liberdade de usar a imagem como um ponto inicial para invocar a história como um todo, por recobrar da memória os episódios que vieram antes e os posteriores a ela (GROENSTEEN, 2011) [tradução da autora]. 
completa, a imagem possui diversos ícones, e a repetição de um dos elementos no espaço, induz o tempo e o movimento. Groensteen ressalta a falta de começo, meio e fim de uma imagem única, mas Quino indica um começo claro: a pilha de papeis sem carimbo ao lado de uma pilha com carimbo, partindo para os carimbos na mesa, o meio da narrativa com as marcas da perseguição, a frustração e irritação das marcas de carimbo sobrepostas, o embate na marca de carimbo apagada em um canto e o fim, a aranha morta no chão. A graça do cartum está justamente no fato de a narrativa toda estar presente.

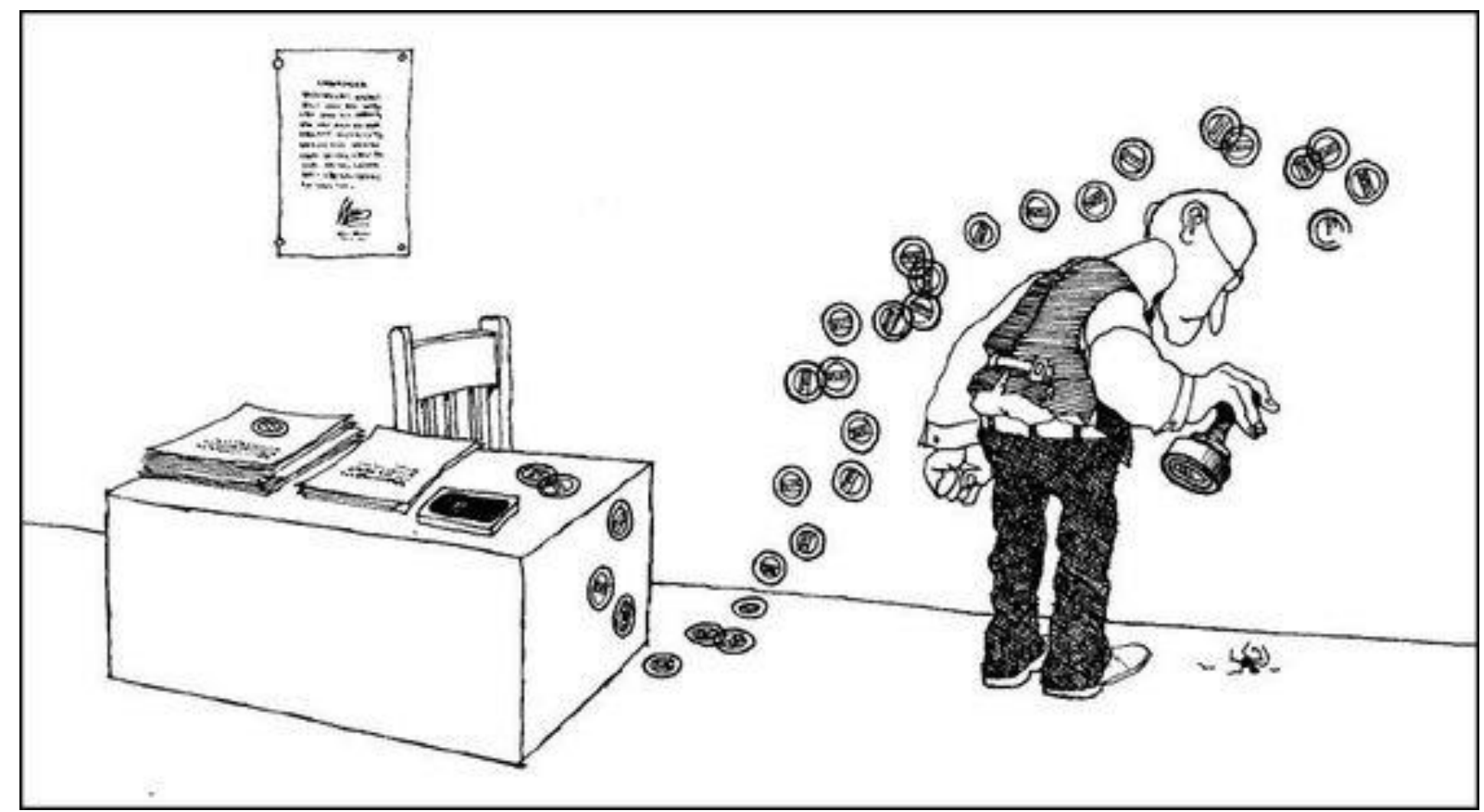

Figura 95 - "Quino, Gente en su Sitio", ed. nueva imagen 1978

Um outro exemplo é o cartum de Laerte (Figura 96, pág. 163), publicado na coletânea "Striptiras" e disponível no site do Departamento de Engenharia Civil da Escola de Engenharia da Universidade Presbiteriana Mackenzie, de responsabilidade do professor Prof. João Cucci Neto, que costuma trabalhar os cartuns com temática de trânsito em sala de aula no curso de engenharia, com o objetivo de "orientar o futuro engenheiro para que ele possa ajudar a minimizar esses aspectos negativos, que tanto afetam a vida das pessoas, especialmente as que moram nas grandes cidades" (CUCCI NETO, 2018). 


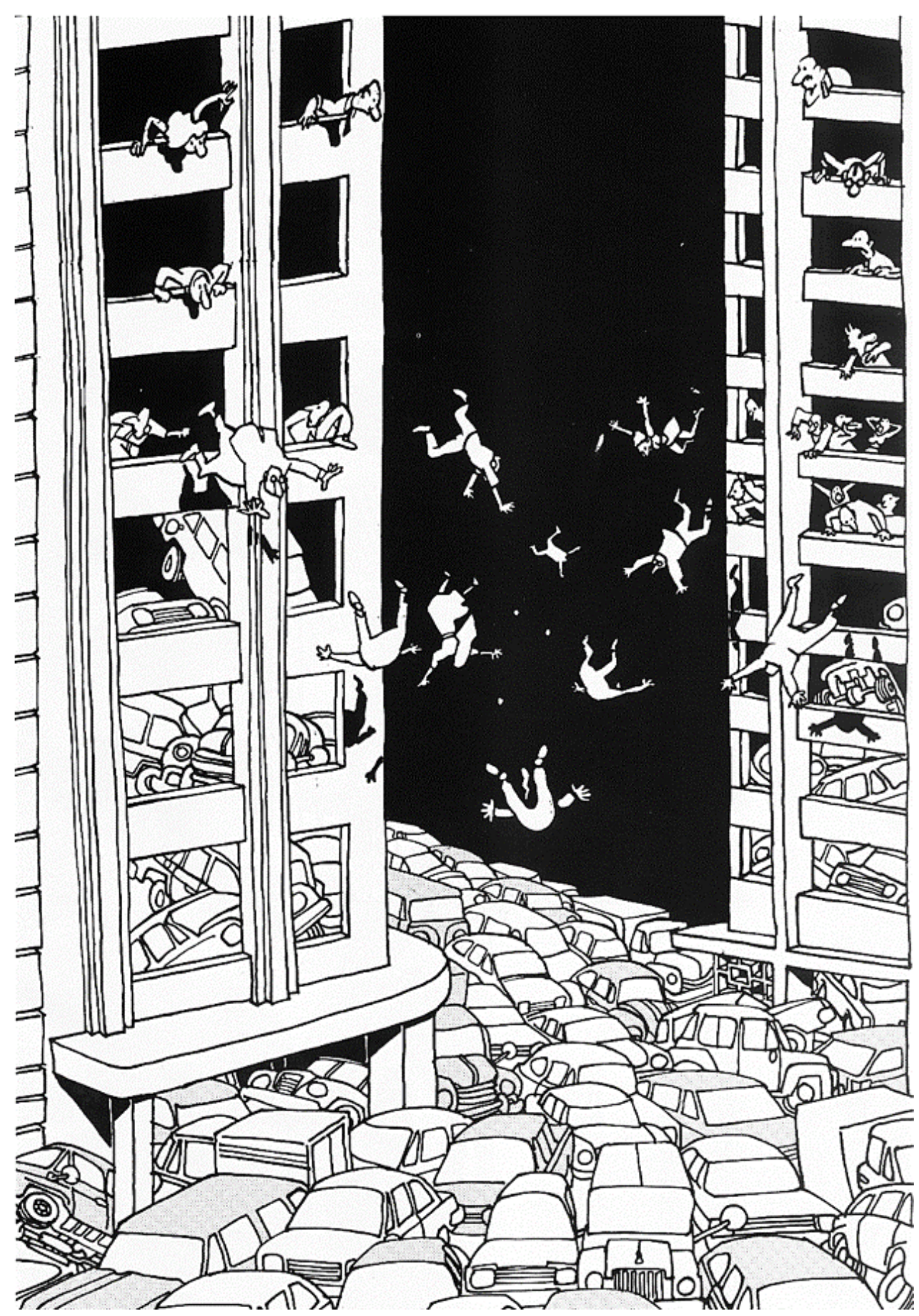

Figura 96 - Laerte - "Striptiras", Circo Editorial Ltda. ${ }^{\mid x x v i i i}$ 
No cartum, carros invadem os prédios derrubando as pessoas enquanto tomam posse do espaço. Esse cartum de imagem única possui elementos já apontados por Groensteen no "sistema dos quadrinhos" importantes para analisar uma HQ: visão panóptica do leitor; solidariedade entre os ícones que ao se relacionarem agregam sentido; espaçotopia (um espaço diegético e um espaço na prancha); e ainda, o pressuposto da anterioridade e da posteridade (de subida dos carros e queda das pessoas), com a simultaneidade na representação de passado os andares já ocupados, do presente - as pessoas caindo, do futuro - as pessoas atônitas que olham para o acontecimento dos andares superiores.

A panoscopia (visão total) é derivada do conceito de panóptico do filósofo e jurista inglês, Jeremy Bentham (1748 - 1832), que criou um modelo de estrutura arquitetônica circular para ser usado em prisões, hospícios, escolas e oficinas de trabalho. Na estrutura idealizada por Bentham, e construída em alguns países, inclusive Portugal, cubículos individuais cobrem o perímetro de um círculo e no meio existe uma torre onde um guarda, segurança, capataz, etc. observa qualquer um dos cubículos a qualquer momento, sem que os confinados saibam que estão sendo observados. Em sua carta de apresentação do projeto Bentham afirma:

Tratava-se de um novo modo de garantir o poder da mente sobre a mente, em um grau nunca antes demonstrado; e em um grau igualmente incomparável, para quem assim o desejar, de garantia contra o exagero. Esse é o mecanismo, esse é o trabalho que pode ser feito com ele (BENTHAM, 2008, p. 17).

George Orwell, na distopia futurista 1984, publicado em 1948, explora o controle tecnológico da panoscopia, a vigilância total e ininterrupta através de dispositivos eletrônicos. O filósofo Michel Foucault ao analisar o conceito de Bentham, comenta que a partir do século XVIII e descentralização do poder monárquicoabsolutista com a necessidade de circulação dos efeitos de poder com as mudanças econômicas, a análise do corpo social se tornou mais exaustiva e individualizante,

Por canais mais sutis, chegando aos próprios indivíduos, seus corpos, seus gestos, cada um de seus desempenhos cotidianos. Que o poder, mesmo tendo uma multiplicidade de homens a gerir, seja tão eficaz quanto se ele exercesse sobre um só (FOUCAULT, 1979, p. 214). 


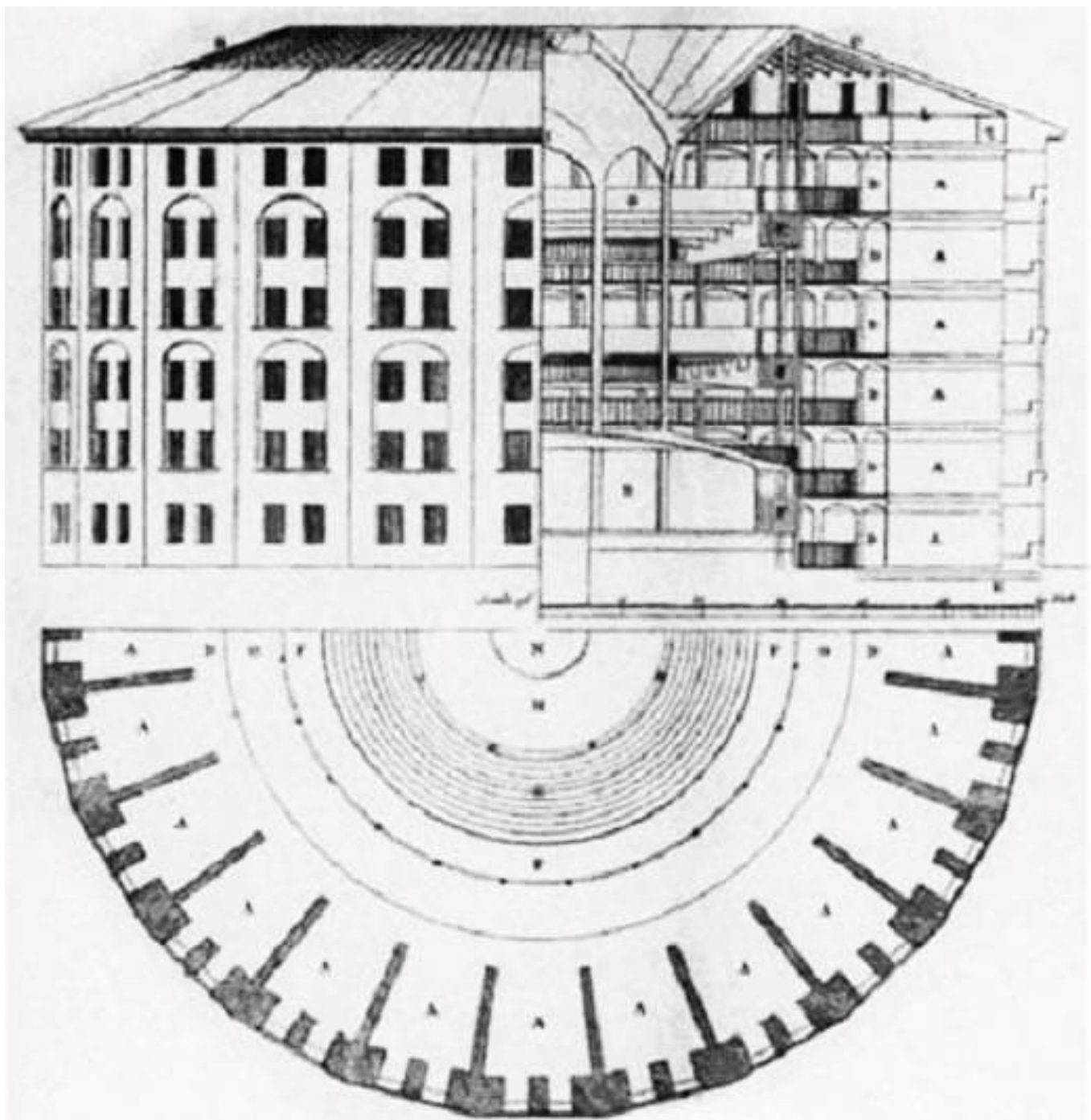

Figura 97 - Projeto de Bentham - Panóptico - desenho do arquiteto inglês Willey Reveley, 1791'lxxix

Nos quadrinhos, o artista se vale de estratégias para chamar a atenção e direcionar o olhar do leitor, como ao usar posições convencionais (principalmente a direção de leitura), ao centralizar imagens importantes que mereçam mais destaque, escolher cores fortes ou mudança bruscas de tonalidades para marcar um determinado momento ou cena, fazer contrastes de tamanho e proporção, etc. Ainda assim, a página se mostra inteira ao leitor, em todos os seus detalhes, objetos e proposições. A visão panóptica, a visão total da página, permite que o leitor inicie de imediato o processo de relações com seus conhecimentos prévios, suas referências, formulando hipóteses que serão reiteradas ou contrariadas ao longo da leitura. Mesmo que o leitor se deixe guiar pelo quadrinista, ele possui o poder de direcionar seu olhar pela totalidade da grade, comparando as informações, associando ícones, confrontando as pistas com seu referencial imagético para gerar o sentido da mensagem. 
Os quadrinhos, mais do que o cinema, beneficiam-se da colaboração dos leitores: é contada uma história que eles contam para eles mesmos; com ritmos e imaginários próprios, que vai e volta (GROENSTEEN, 2015, p. 20).

Na grade está exposta ao leitor, não apenas cenas de seres e objetos, mas as concepções e sensações que o artista tem da relação de seres e objetos em sua intimidade com o mundo, o tempo e o espaço.

No cartum de Laerte, por exemplo, a narrativa traz a tensão de várias dicotomias espaciais, por exemplo: entre a visão total e parcial, um movimento do olhar do todo ao detalhe e de volta ao todo; entre o espaço aberto e fechado; entre o esparso e o lotado. O efeito irônico da narrativa se deve à localização de cada ícone na grade ter uma função de sentido coerente e verossimilhante, mesmo que irreal. Os elementos e contraste cromático estão posicionados de forma que o fundo preto com as pessoas em queda chame a atenção do olhar em um primeiro momento, seguindo o movimento de queda há a aglutinação caótica dos carros que bifurca na subida dos prédios, indicando ao olhar uma elevação às janelas, que ao encontrar as pessoas olhando para fora volta novamente à queda em um movimento cíclico. Contudo, a indução não é delimitação, como na leitura de um texto escrito, restrita a somente uma sequência determinada e invariável: a sequência de uma letra após a outra, de uma palavra após a outra e assim por diante. Portanto, mesmo que haja mecanismos sugestivos de uma forma de leitura da imagem, o leitor poderá, principalmente no quadrinho de imagem única, realizar a leitura de forma variável e livre, com conclusões ímpares, de acordo com sua referencialidade.

$\mathrm{Na}$ visão panóptica, o leitor observa ao mesmo tempo tanto o espaço diegético quanto o espaço estrutural - está consciente da grade - por isso a alternância entre os espaços, como sair da imagem figurativa para entrar no balão de fala, não rompe a diegética. Groensteen ressalta que o leitor de quadrinhos tem "a sensação de estar colocado diante de uma multidão de enunciados narrativos de primeiro nível que se acumulam aos poucos para dar à luz o enunciado narrativo de segundo nível" (GROENSTEEN, 2015, p. 37). A posição dos ícones na grade tem função de sentido, de indução de leitura, e interpretação. Principalmente na narrativa sequencial, os elementos espaciais da grade (balão, vinheta, legenda e sarjeta) são ícones que se repetem formando não um sentido diegético, mas um sentido espacial, pois indicam como uma figura deverá ser "lida". 


\subsubsection{Vinheta e sarjeta - transições}

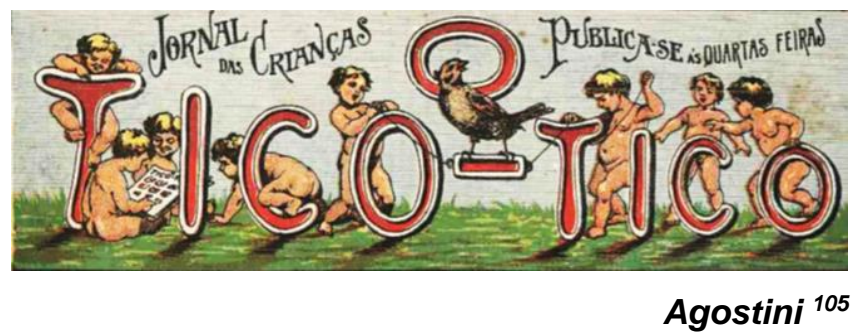

Há na moldura do quadro, na abertura do palco e na introdução de um texto como "Era uma vez..." a construção de um limiar, o qual separa percepções de realidade. $O$ conceito de realidade é extremamente complexo e ainda sob o jugo de muito estudo e debate, grosso modo, o dicionário aponta como tudo "aquilo que existe efetivamente, que é real" sendo real "aquilo que existe de fato, que é verdadeiro".

Com a alegoria da caverna, Platão expõe a realidade como algo inatingível em sua totalidade pelos limites da capacidade de percepção dos sentidos humanos. Assim estaríamos limitados a uma fração do real de acordo com nossa capacidade de percepção. Quando uma moldura ou a borda de um quadro envolve uma manifestação plástica, ou atores e cenários se posicionam em um espaço de palco, ou ainda, um texto evoca um tempo e um espaço eles abrem uma fenda na percepção de realidade tangível (extramentis) para a realidade ontológica (intramentis).

O estudo sobre o conceito de realidade é muito amplo e envolve debates em várias áreas do saber, mas vários estudiosos empregam o termo "percepção" de realidade ${ }^{106}$ : a extramentis, realidade tangível, a realidade que existe independente da nossa interpretação, e que buscamos perceber através de sentidos físicos, mecânicos ou eletrônicos; e a intramentis, a representação ou extrapolação da realidade que construímos como resultado da nossa interpretação da realidade tangível, dentro dessa percepção está o imaginário, o virtual, o possível, o referencial, o ideal, o sonho, etc.

A realidade intramentis não é uma realidade diversa da tangível, pois mesmo uma vaga memória de um brinquedo de infância há muito perdido, não torna o brinquedo menos real, apenas é um objeto que não pode ser percebido com nossos

${ }^{105}$ Epígrafe - fonte: Vinheta de Angelo Agostini para a revista O Tico-tico de 25 de abril de 1909, Rio de Janeiro, disponível em http://memória.bn.br/pdf/153079/per153079 1906 00029.pdf.

${ }^{106}$ Alguns estudiosos nomeiam como: "duas naturezas" ou "dois níveis" de realidade. 
sentidos no "aqui" e "agora", que conforme o sociólogo e teólogo autro-americano Peter L. Berger e o socólogo e professor alemão Thomas Luckmann,

\begin{abstract}
A realidade da vida cotidiana está organizada em torno do "aqui" de meu corpo e do "agora" do meu presente. Este "aqui e agora" é o foco de minha atenção à realidade da vida cotidiana. Aquilo que é "aqui e agora" apresentado a mim na vida cotidiana é o realissium de minha consciência. A realidade da vida diária, porém, não se esgota nessas presenças imediatas, mas abraça fenômenos que não estão presentes "aqui e agora". Isto quer dizer que experimento a vida cotidiana em diferentes graus de aproximação e distância, espacial e temporalmente. (BERGER e LUCKMANN, 2005)
\end{abstract}

Aquilo que ficou no passado, o que é esperado para o futuro, coisas imaginadas, sonhadas e idealizadas, os delírios e as ilusões, pertencem a percepção de realidade intramentis. As fendas que delimitam essa percepção são um contrato do "Eu" do "aqui e agora" do extramentis com a diegese.

Diferente do sentido de vinheta utilizado na tipografia, que é um pequeno ornamento tipográfico que ilustra texto, livro etc., nos quadrinhos a vinheta, geralmente um quadrado que envolve uma cena, também chamada de quadro ou quadrinho, é a fenda que encapsula a diegese fazendo a mediação entre o real e o imaginário. Para Nobu Chinen, a vinheta é "área limitada onde a ação vai ocorrer, onde se situa cada pedaço/momento da história." (CHINEN, 2011, p. 14). Contudo, a vinheta não deve ser considerada somente como um contâiner da ação, ela pode exibir várias formas (Figura 98), ou mesmo nenhuma e seu formato altera a interpretação do seu conteúdo.

Para ilustrar a variação de sentido causada pela mudança da forma dos elementos da grade, será usada tira básica do conto de fadas criada previamente. Por exemplo, a vinheta realizada com uma linha simples é a mais comum das manifestações (Figura 99), sendo um traçado tão popular que é um dos representantes do meio. A ausência de vinheta, ou vinheta não marcada, (Figura 100) fornece uma pausa e uma transição fluída entre uma imagem e outra. A vinheta também pode ser demarcada pela mudança de ambiente (Figura 101), ou pelo contraste entre eles (Figura 102). A vinheta pode ainda duplicar ou subdividir as percepções dentro da diegese, como quando bordas distorcidas ou apagadas evocam a percepção de sonho ou reminiscência (Figura 103), ou assumem a representação de outras mídias (Figura 104), ou ainda misturam a percepção intramentis e extramentis quando quebra a separação entre diegético e real no uso da metalinguagem (Figura 105, pág. 170). 

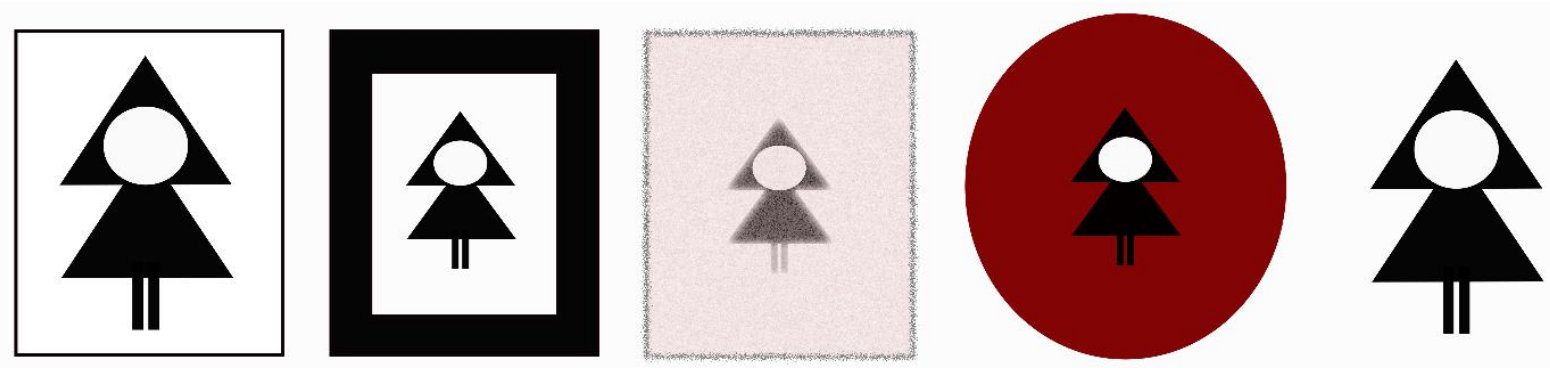

Figura 98 - Vinhetas
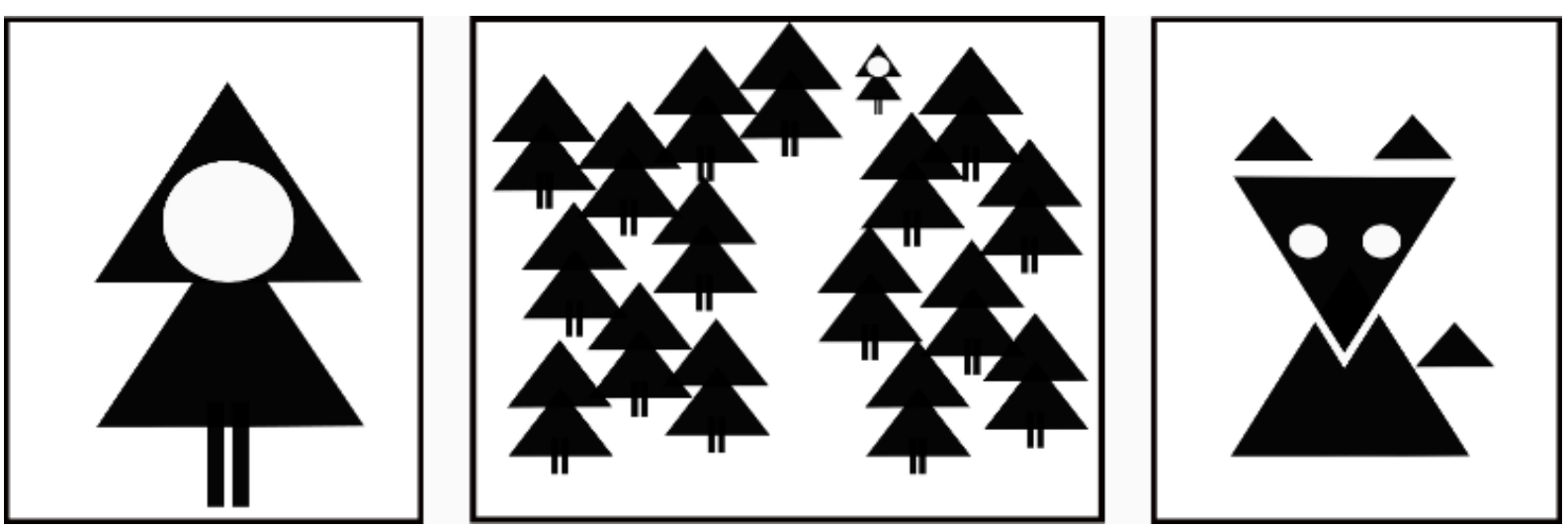

Figura 99 - Vinheta de linha simples
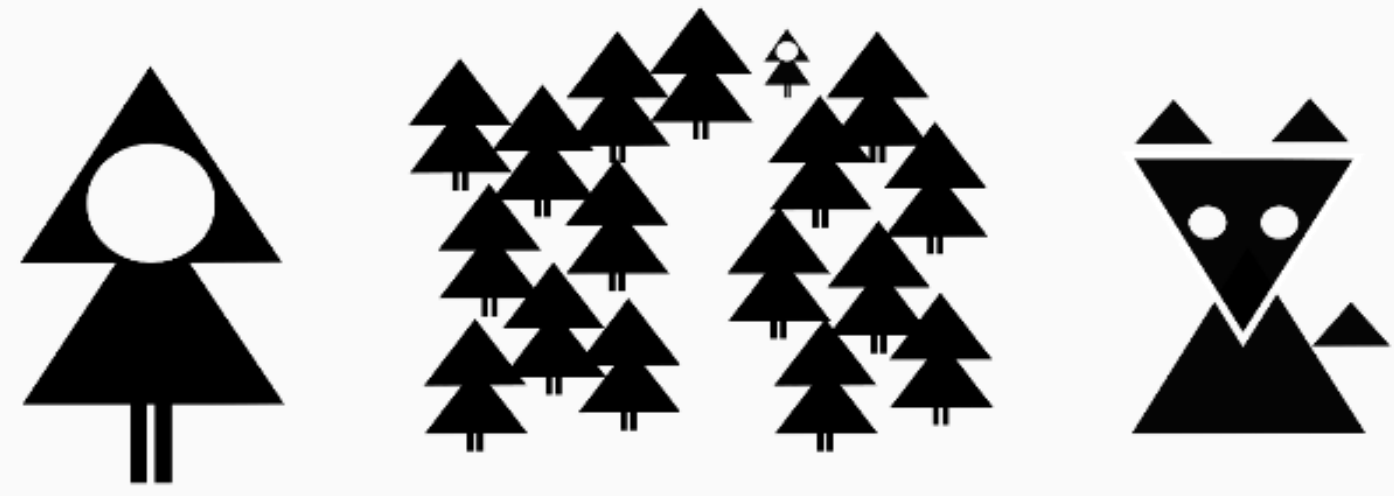

Figura 100 - Vinheta não marcada
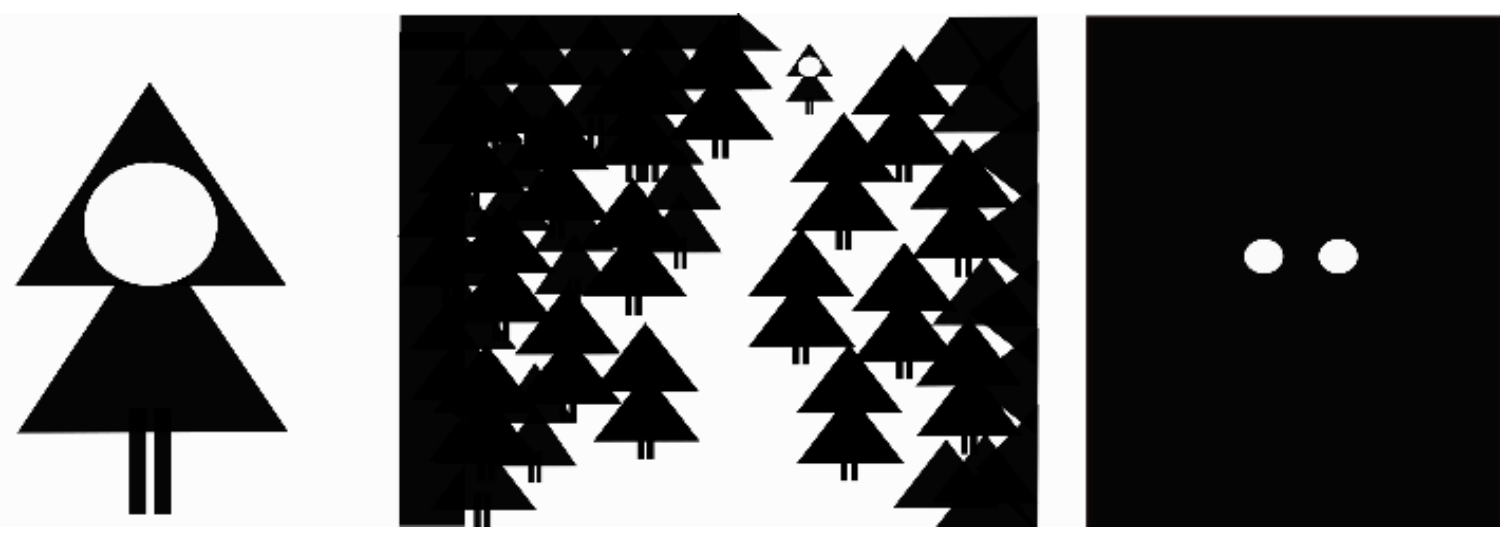

Figura 101 - Vinheta pelo ambiente 


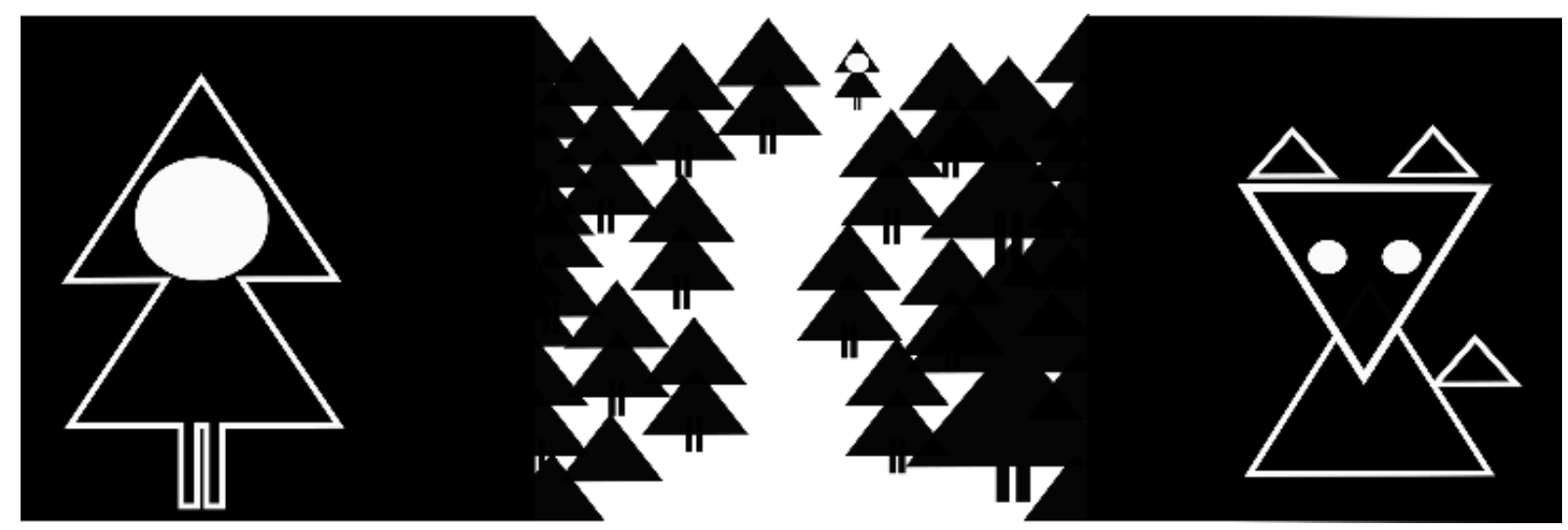

Figura 102 - Vinheta por contraste
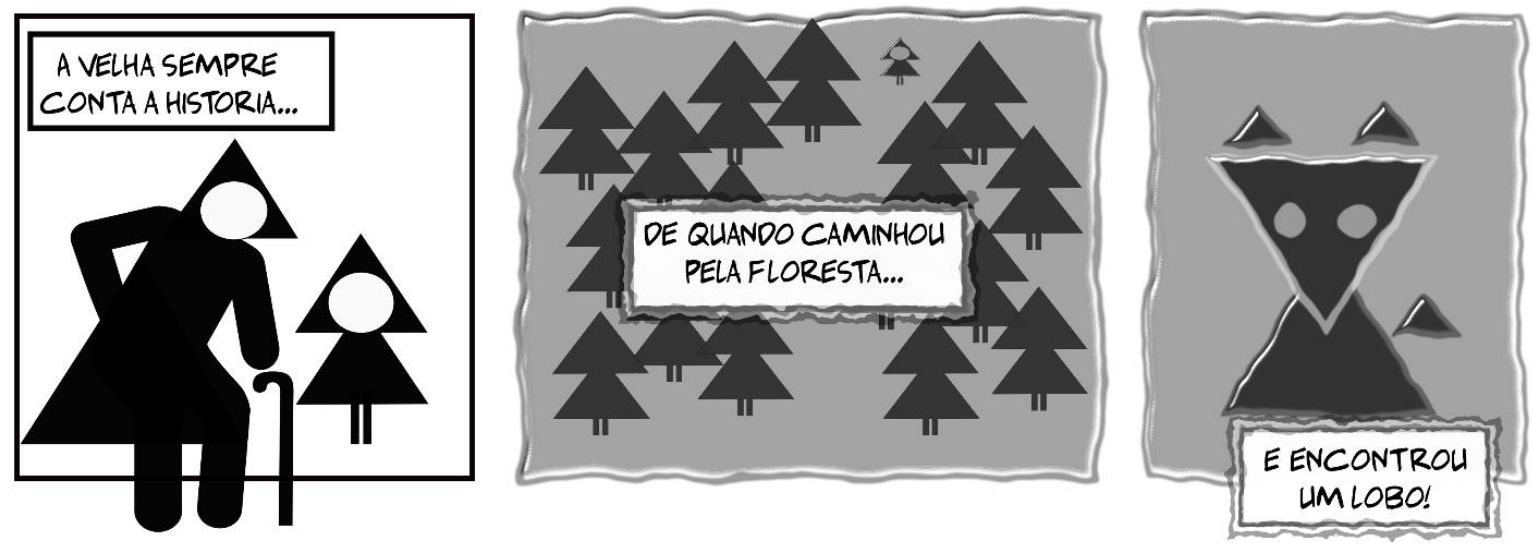

Figura 103 - Vinheta - Destaque e deslocamento temporal
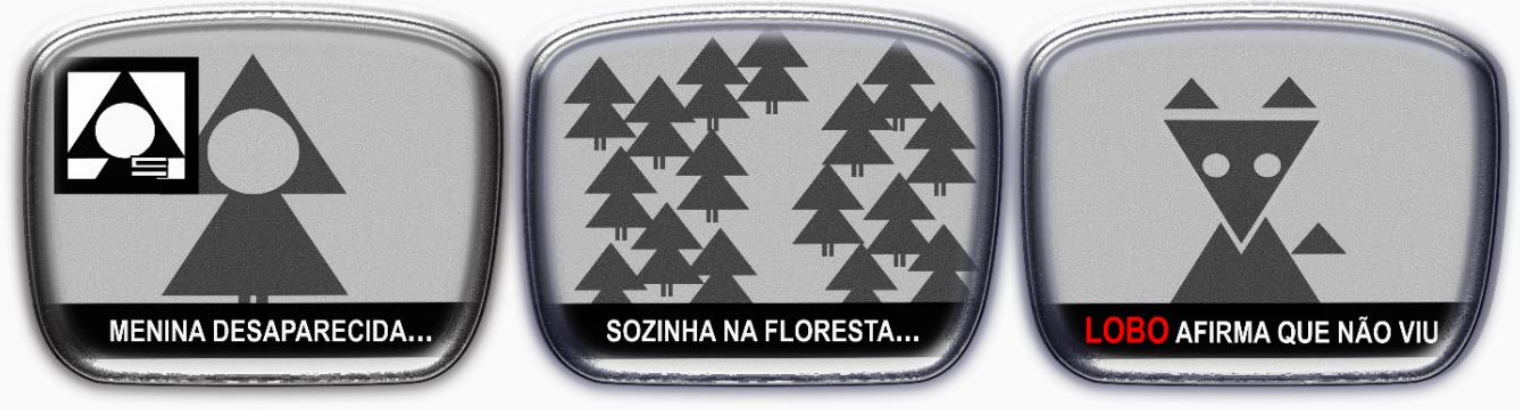

Figura 104 - Vinheta - reprodução de outras mídias
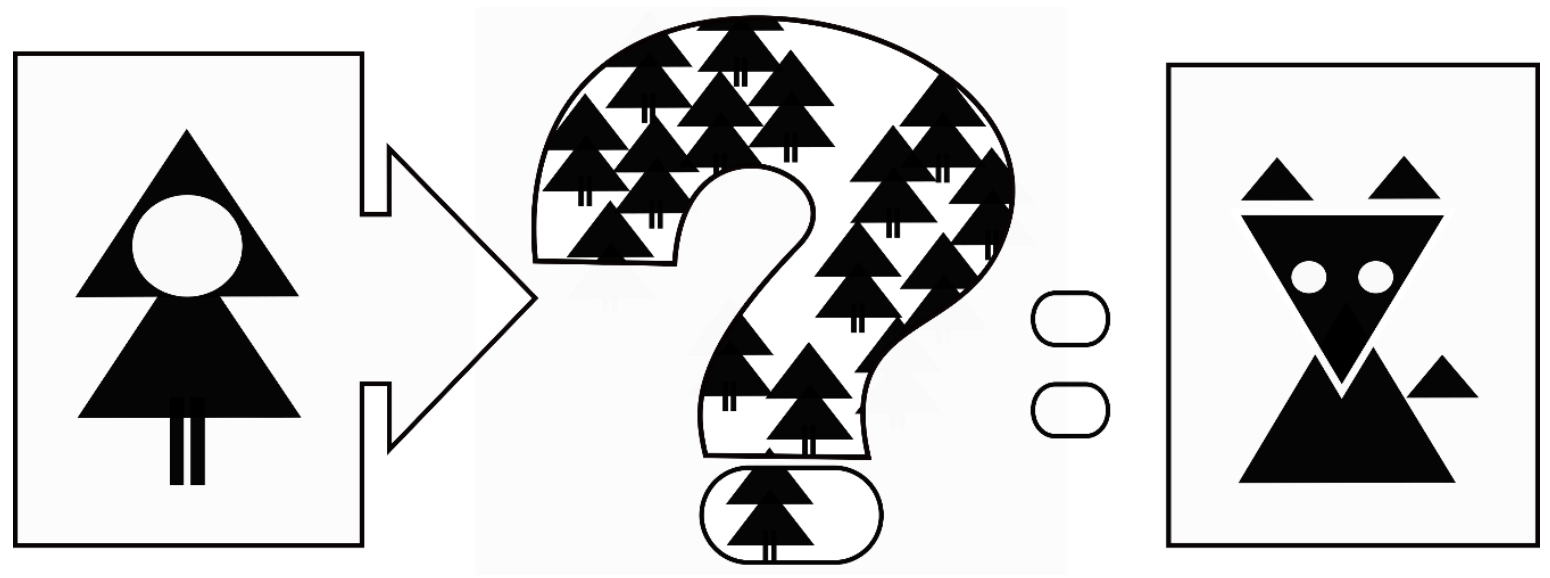

Figura 105 - Vinheta metalinguística 
O espaço entre uma vinheta e outra é comumente chamado de "sarjeta" ou "calha". Para McCloud esse é um espaço de transição entre um momento e outro em que o leitor infere aquilo que aconteceu entre as cenas. Esse processo, que McCloud chama de conclusão, é a construção da sequência de acontecimentos ausentes pelo leitor com base na interação de uma imagem com outra.
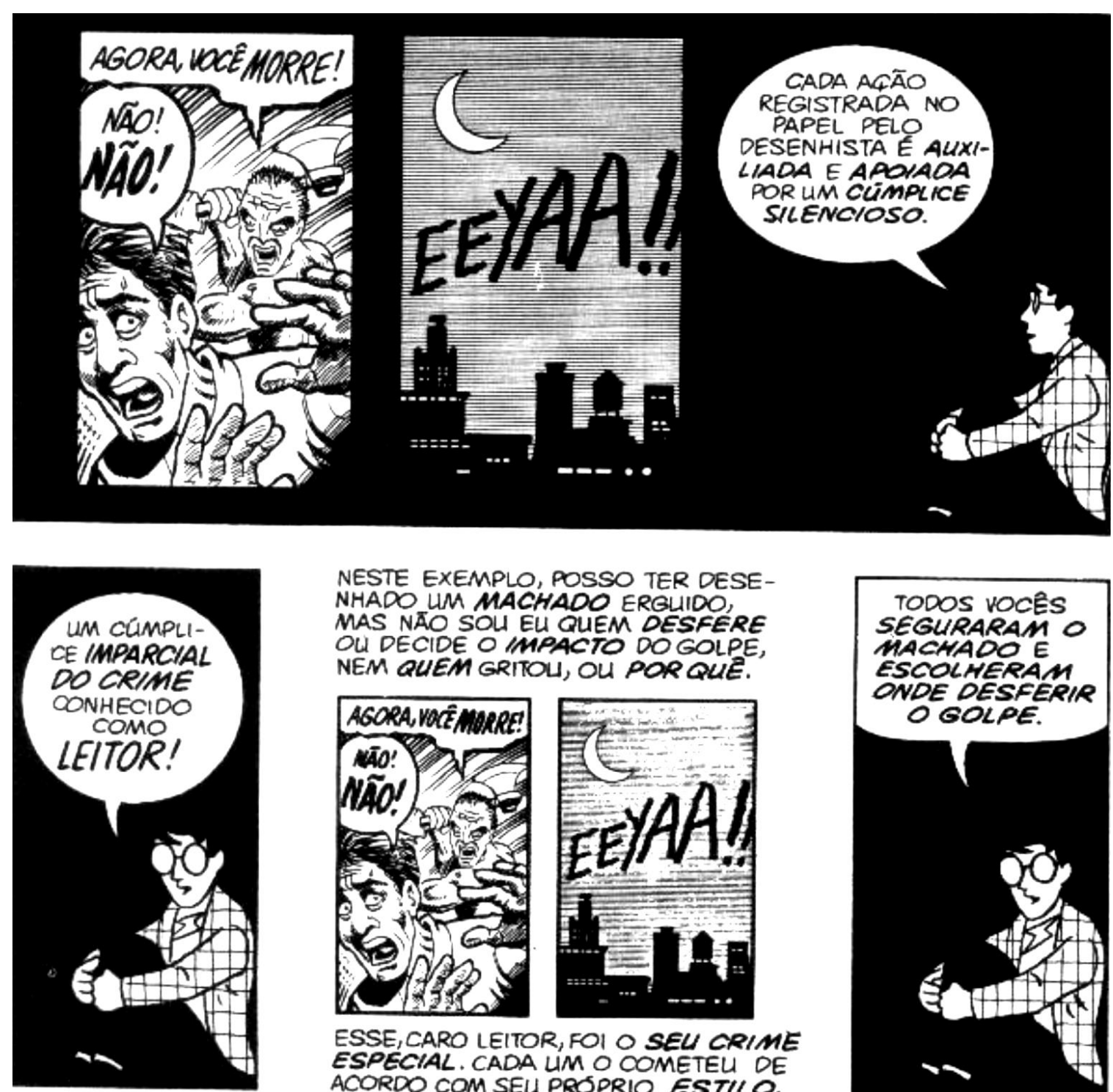

NESTE EXEMPLO, POSSO TER DESENHADO UM MACHADO ERGUIDO, MAS NAO SOU EU QUEM DESFERE OU DECIDE O IMPACTO DO GOLPE, NEM QUEM GRITOU, OU POR QUE.
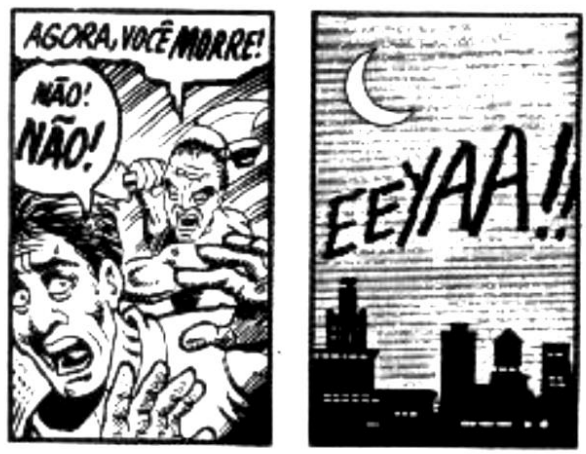

ESSE, CARO LEITOR, FOI O SEU CRIME ESPECIAL. CADA LM O COMETEU DE ACORDO COM SEU PROPRIO ESTILO.

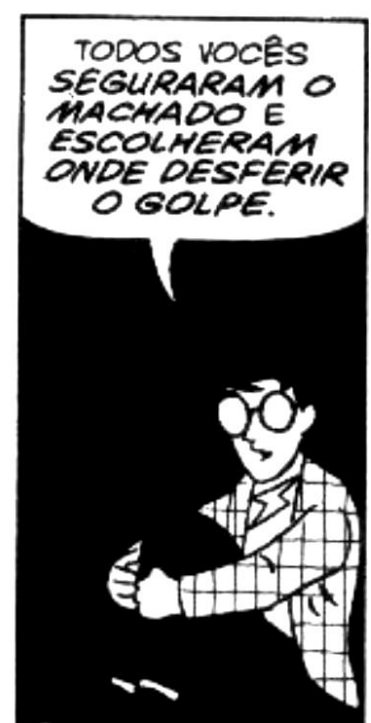

Figura 106 - McCloud - Desvendando os quadrinhos, 1995, página 68, $2^{\text {a }}$ e $3^{\text {a }}$ linhas

A sarjeta pode aparecer bem definida, como no exemplo de McCloud, mas esse espaço, que segue a estética transicional da vinheta, é na verdade um espaço virtual, um conceito sobre à participação ativa do leitor na construção do sentido, por isso que em livros como "Les Yeux du Chat" (Os Olhos do Gato) de Moebius e Jodorowsky, onde a transição de uma imagem para a outra é feita pela página, essa construção daquilo que está ausente entre as imagens pelo leitor continua existindo. 
Para Groensteen, uma vez que foi estabelecida a solidariedade icônica como um princípio fundador dos quadrinhos, e isto pressupõe a coexistência de um número de imagens em "praesentia”, seria razoável se perguntar se pertenceriam aos quadrinhos as narrativas sequenciais que possuem o ritmo de uma imagem por página, como "Les Yeux du chat” de Moebius e Jodorowsky (Figura 107, pág. 173), ou as novelas de xilográficas de Frans Masereel ou Lynd Ward, entre outras (GROENSTEEN, 2011, p. 46), às quais, por analogia, se pode acrescentar "Lobo Negro" de Antonine Guilloppé (2004) (Figura 112, pág. 177), selecionado no mesmo ano para o volume 15 da Bibliografia Brasileira de Literatura Infantil e Juvenil, como "livro sem texto".

In works of this type, there are never more than two images visible to the reader at any one time, split across two pages - one on the left-hand and one on the right-hand page (although sometimes only the latter is used). The space within which iconic solidarity comes into play is less that of the page a flat surface immediately accessible at a glance - than that of the book, a foliated space that must be discovered progressively. The dialogue among the images depends on the persistence of the memory of pages already turned ${ }^{107}$ (GROENSTEEN, 2011, p. 47).

O efeito de entrelaçamento, ressaltado por Groensteen, que é operado entre imagens espacialmente distantes pode assumir tanta importância na construção do ritmo, sentido e atmosfera como a fricção causada pela ruptura entre imagens adjacentes (GROENSTEEN, 2011, p. 47). Para ele, esses trabalhos não deixam de ser quadrinhos, a diferença é que a relação espaçotópica (a grade) não está limitada ao tamanho de uma página, e sim ao conjunto da obra.

\begin{abstract}
The page (or, more precisely, the available surface of the page, delineated by the hyperframe) coincides with the panel. But these whole-page panels, or "monoframes," still follow each other in a predetermined order and invite a reading. The main mechanisms for the production of meaning associated with graphic narratives are fully activated and operational ${ }^{108}$ (GROENSTEEN, 2011, p. 47).
\end{abstract}

A seguir, para exemplo, duas imagens de "Os Olhos do Gato":

${ }^{107}$ Em trabalhos desse tipo, não há nunca mais de duas imagens visíveis para o leitor de cada vez, divididas nas duas páginas - uma na mão esquerda e outra na mão direita da página (apesar de algumas vezes só última ser usada [quando a página verso-esquerda está em branco]). O espaço dentro do qual a solidariedade icônica entra em jogo é menos o da página - uma superfície plana imediatamente acessível de relance - do que o do livro, um espaço folheado que deve ser descoberto progressivamente. O diálogo entre as imagens depende da persistência da memória das páginas já viradas (GROENSTEEN, 2011) [tradução da autora].

${ }^{108} \mathrm{~A}$ página (ou mais precisamente, a superfície disponível da página, delineado pelo hiperquadro) coincide com o quadro. Mas esses quadros de página inteira, ou "monoquadros", ainda seguem cada um uma ordem predeterminada e convida uma leitura. $\mathrm{O}$ mecanismo principais para produção de sentido associados com a narrativa gráfica são inteiramente ativados e operacionais (GROENSTEEN, 2011, p. 47) [tradução da autora]. 


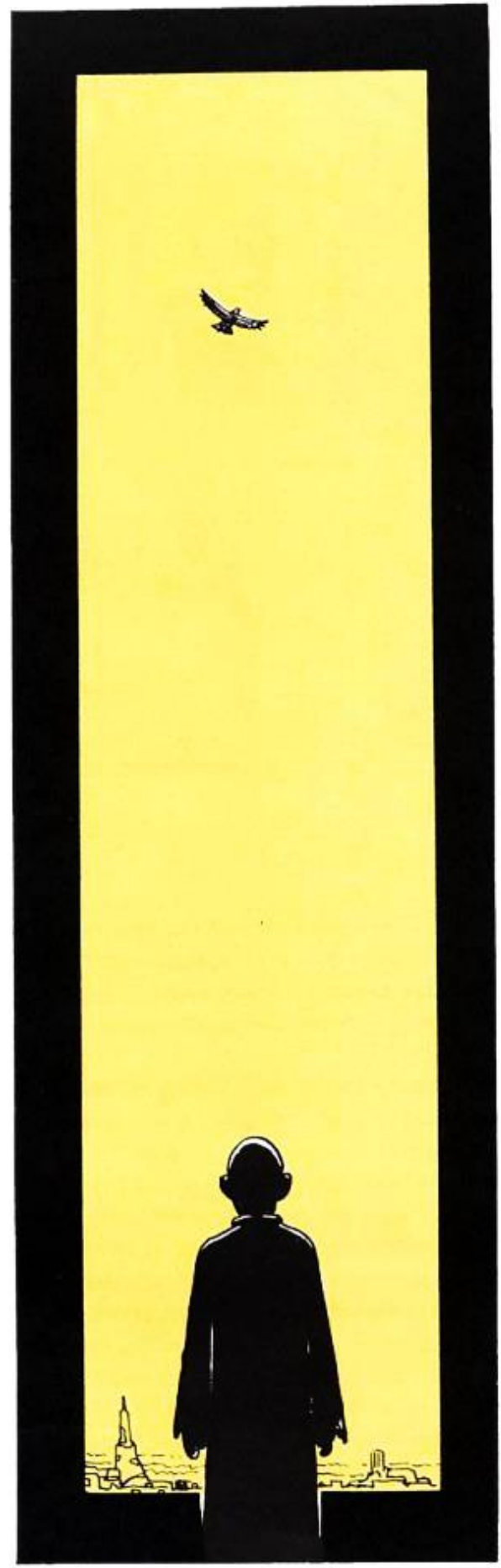

Figura 107 - Les Yeux du Chat. Jodorowsky e Moebius. (1991, p. 4), página inteira 


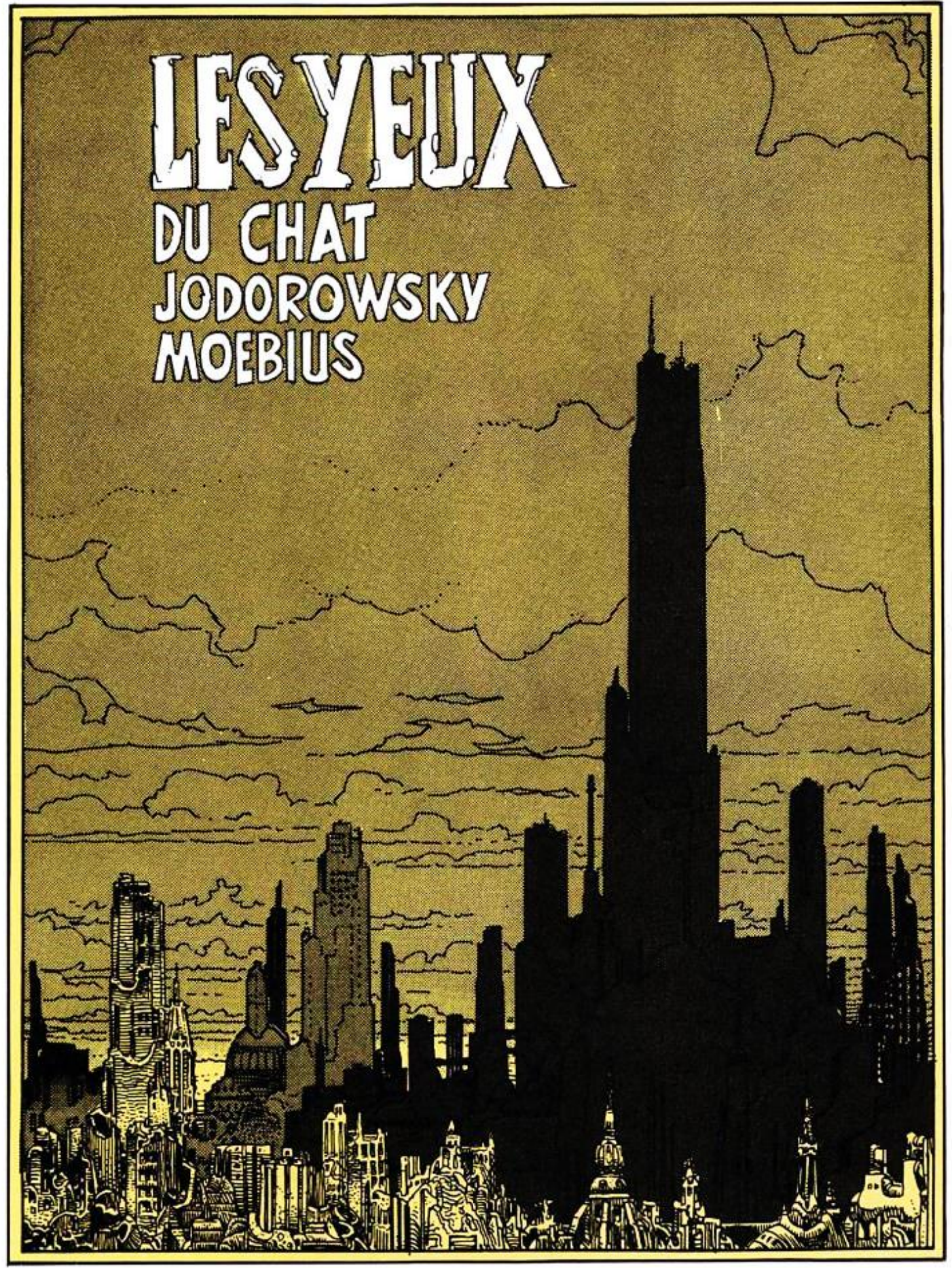

Figura 108 - Les Yeux du Chat. Jodorowsky e Moebius. (1991, p. 5), página inteira 
As imagens de Jodorowsky e Moebius (Figura 107, pág. 173) e (Figura 108, pág. 174) para "Os Olhos do Gato" foram deixadas como no original, ou seja, uma imagem por página, para que o leitor desse estudo possa ter uma noção do tamanho da figura na concepção original. Há nessa escolha de imagens isoladas em contraste com o vazio e o cheio uma construção única de atmosfera, imprensindível para diegese. A seguir, um agrupamento de seis figuras, para mostrar como as imagens são vistas em páginas lado a lado, com sua sequencialidade e ritmos construídos não pela imagem in praesentia, mas in abstensia. A obra foi publicada em capa formato de livro, lombada quadrada, impedindo da dobra no meio (possível na lombada canoa), com isso, a cada virada de página, o leitor da obra original, tem em seu campo de visão duas imagens, uma em cada página do livro aberto, mostrando a oposição entre dentro e fora, entre o estreito e o amplo, inação e ação, que seguira durante toda a obra. A obra "Lobo Negro" (Figura 112 a Figura 115, pág. 177) de Anotine Guilloppé, também é uma narrativa imagética sequencial de uma imagem por páginas, duas por leitura, seguindo um jogo de oposições de perto e longe, branco e preto, mantêm a unidade referêncial na manutenção do personagem e paisagem.
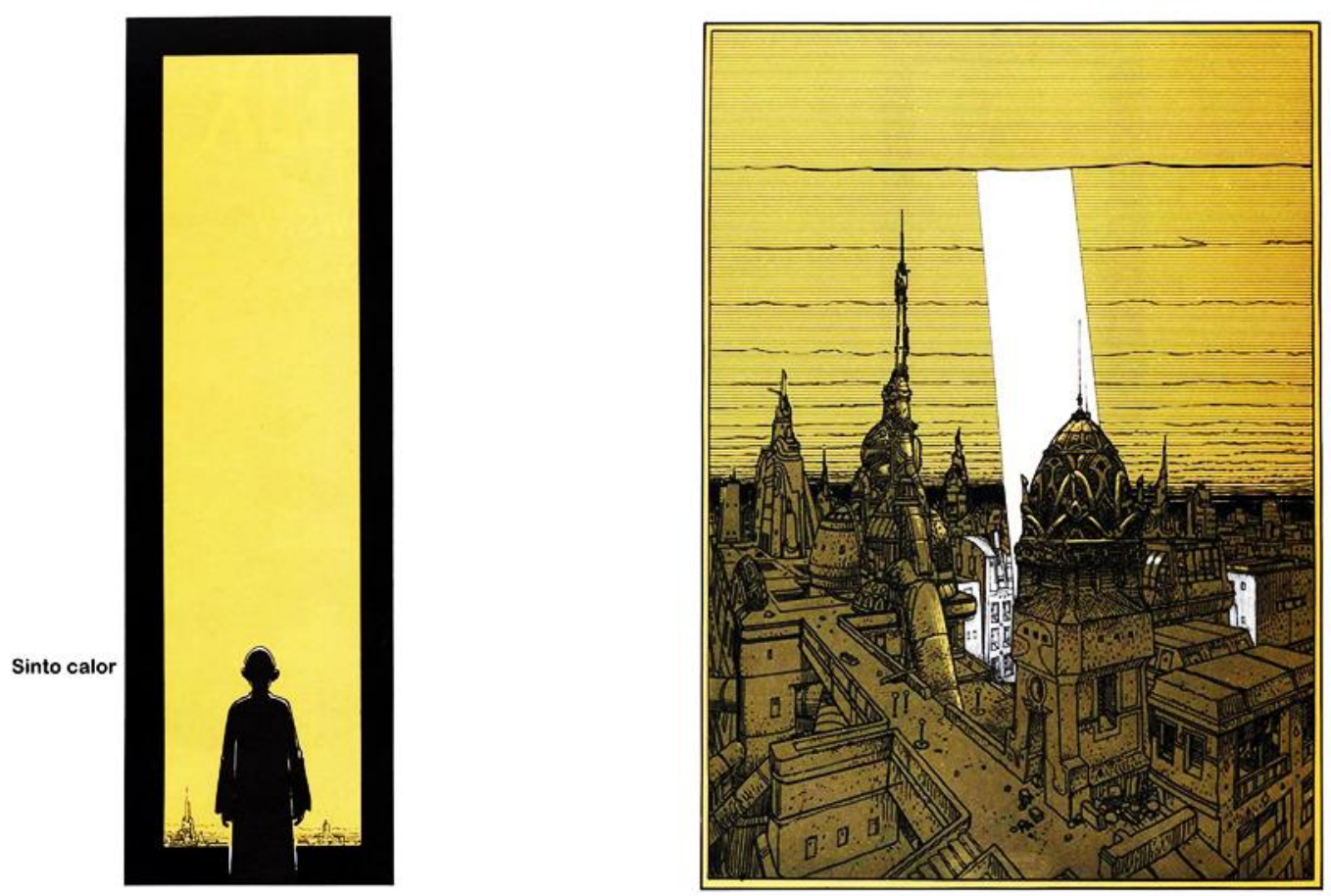

Figura 109 - Les Yeux du Chat. Jodorowsky e Moebius. (1991, p. 6-7) visão do leitor (verso e anverso) 

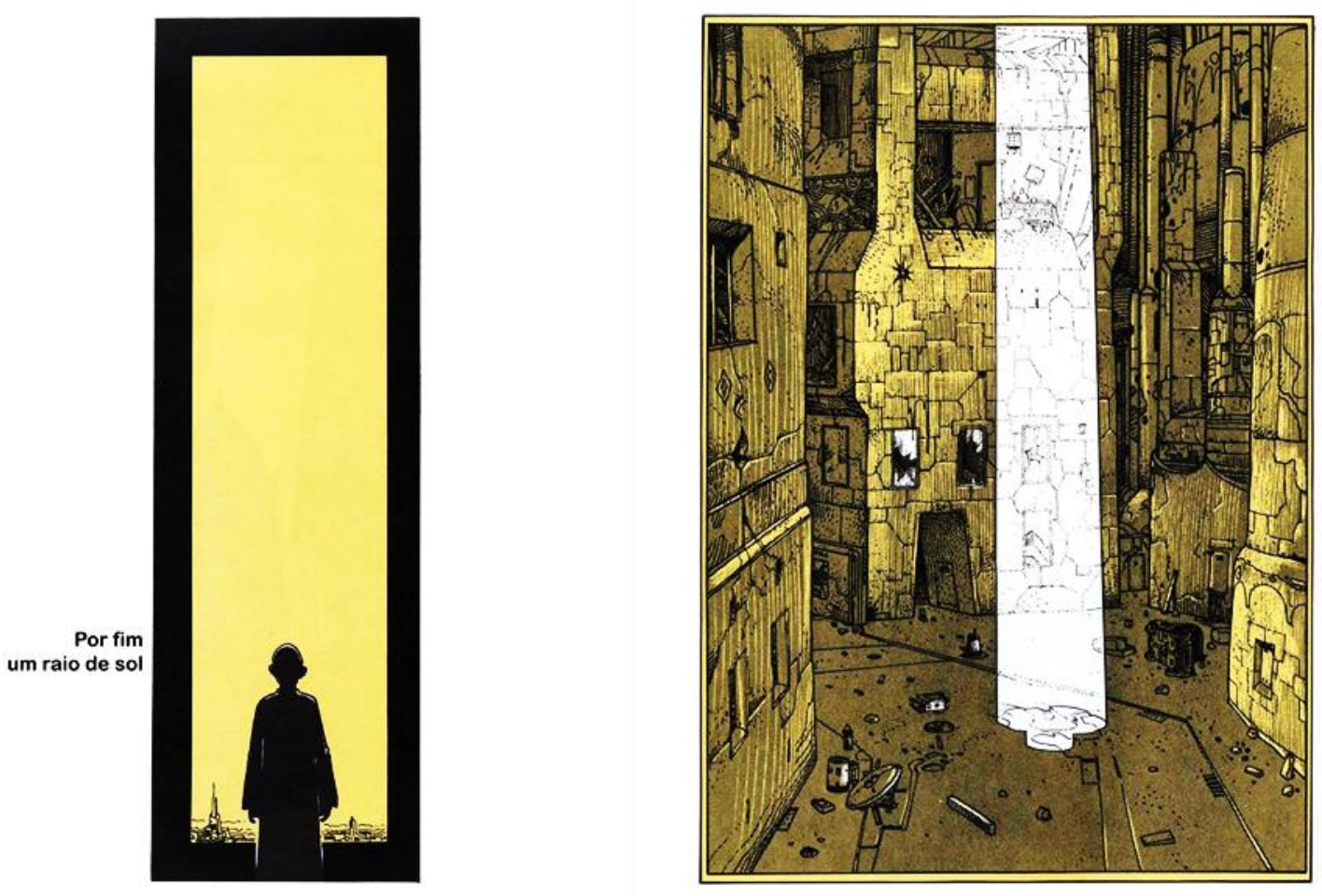

Figura 110 - Les Yeux du Chat. Jodorowsky e Moebius. (1991, p. 8-9) visão do leitor (verso e anverso)
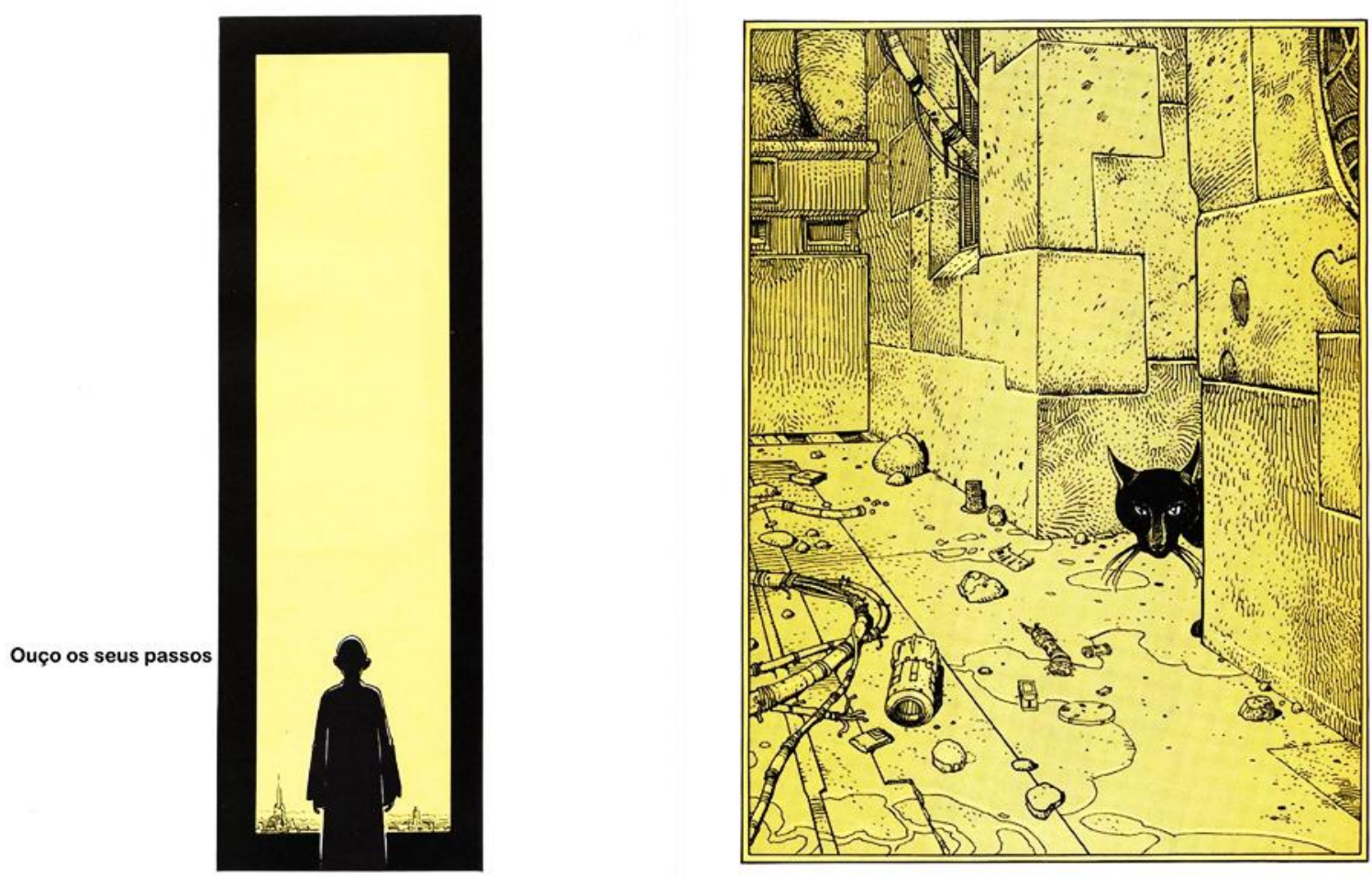

Figura 111 - Les Yeux du Chat. Jodorowsky e Moebius. (1991, p. 12-13) visão do leitor (verso e anverso) 

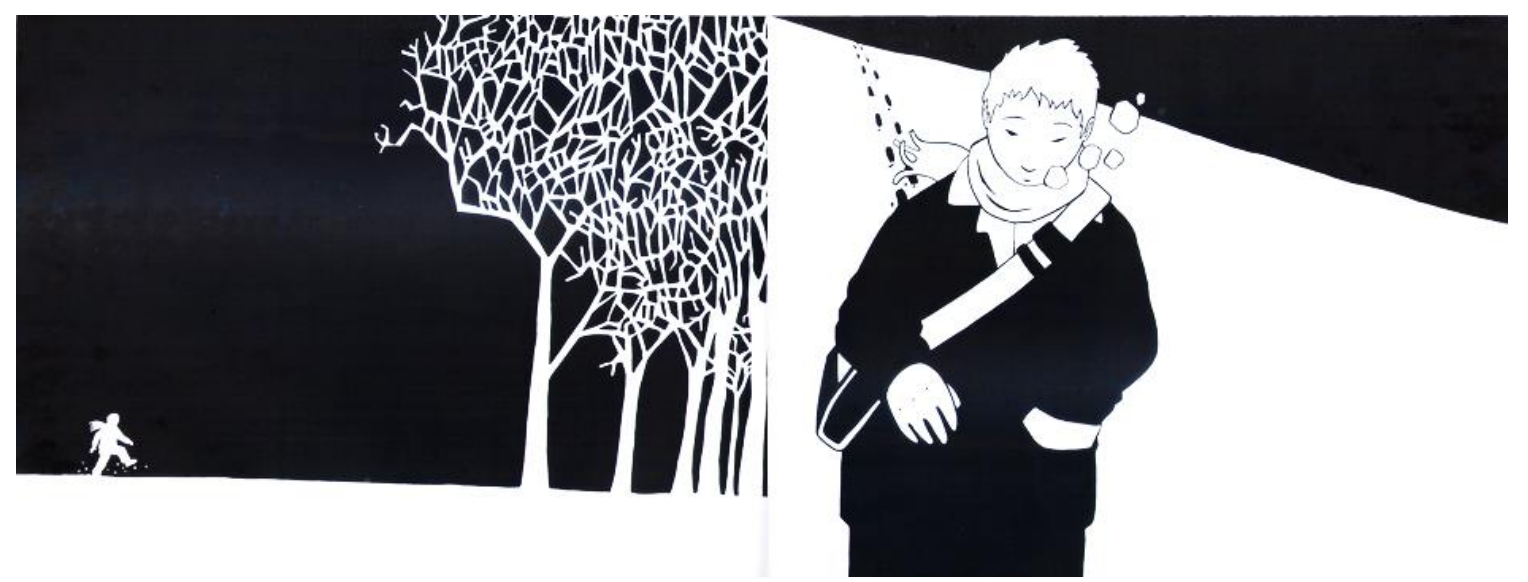

Figura 112 - Lobo Negro - Antoine Guilloppé (2006, p. 4 - 5)

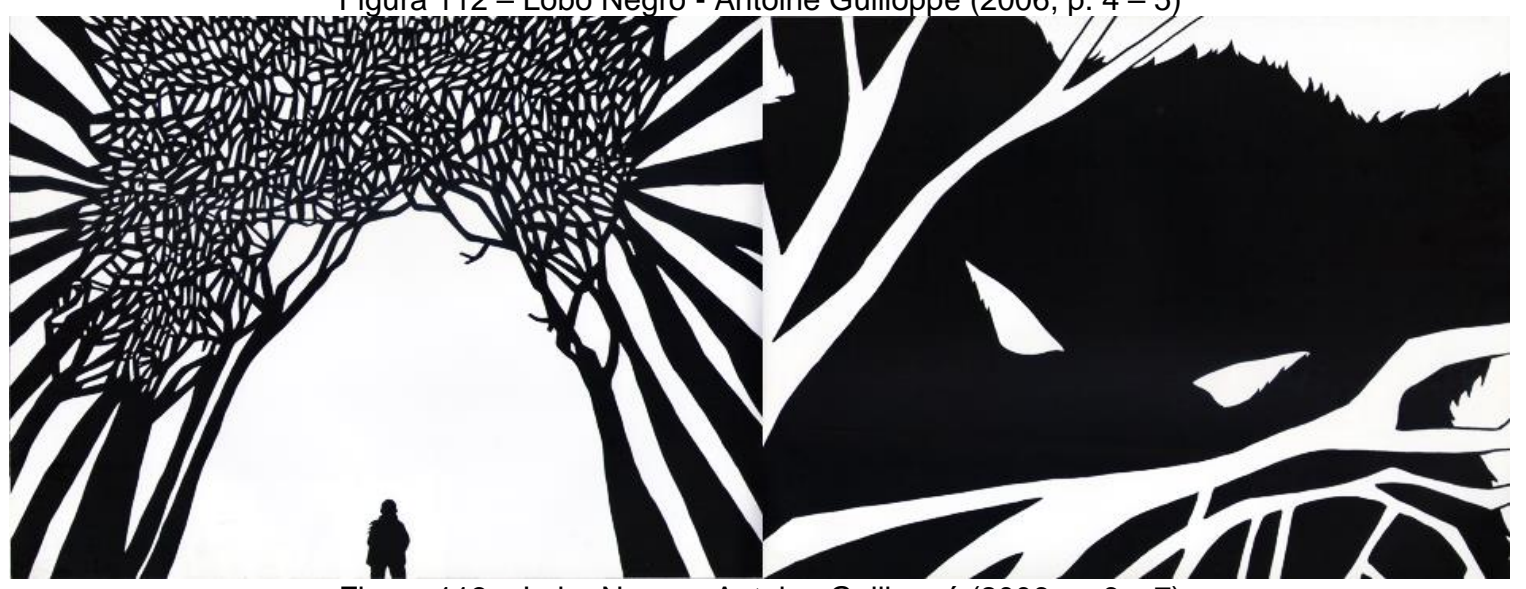

Figura 113 - Lobo Negro - Antoine Guilloppé (2006, p. 6 - 7 )

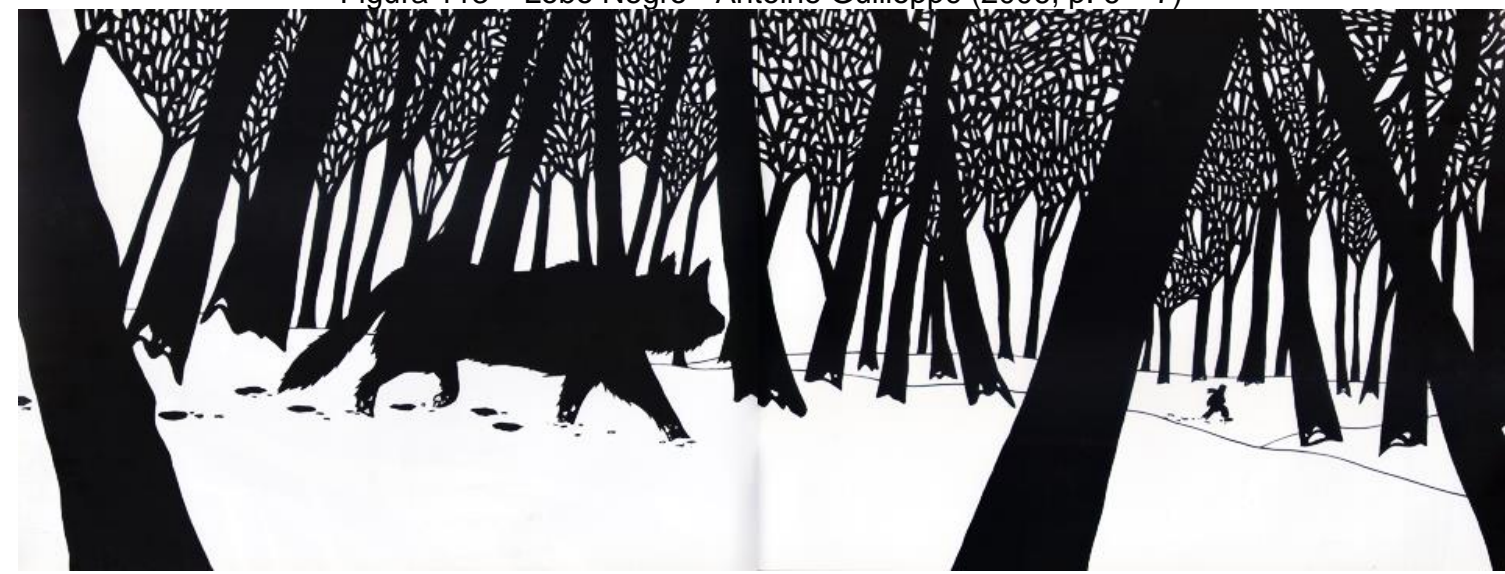

Figura 114 - Lobo Negro - Antoine Guilloppé (2006, p. 8 - 9)

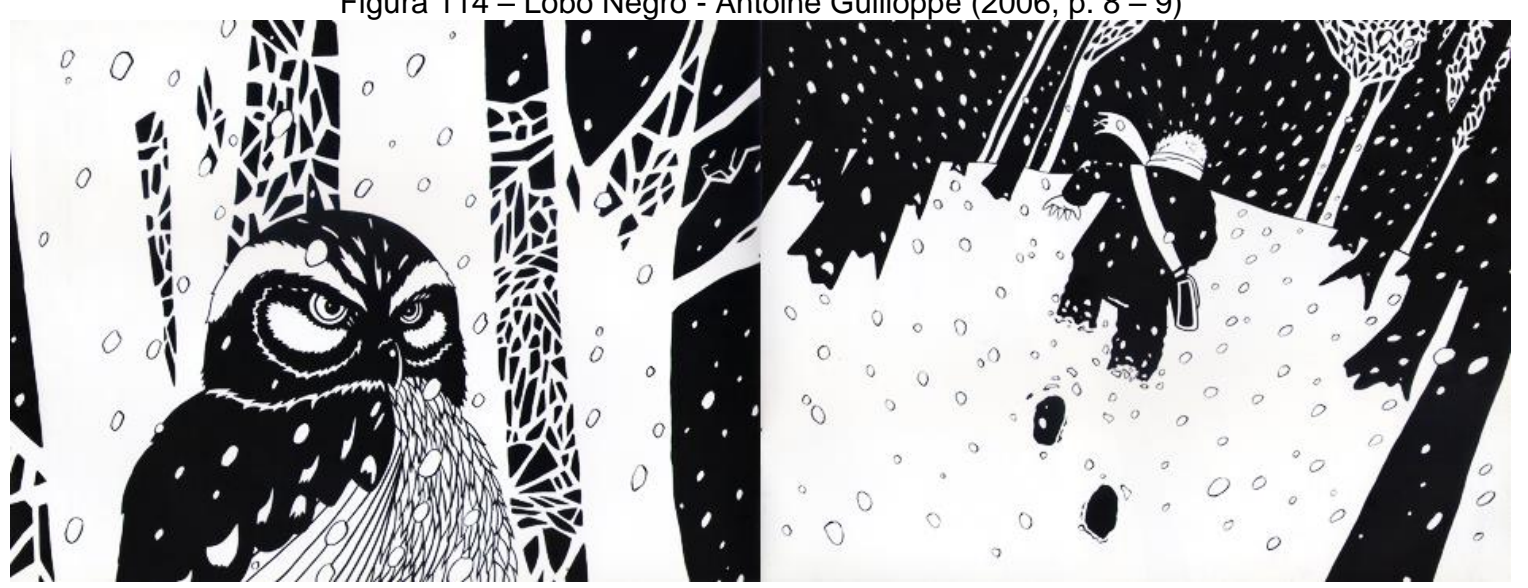

Figura 115 - Lobo Negro - Antoine Guilloppé (2006, p. 12 - 13) 


\subsubsection{Balão e apêndice}

O balão é a representação gráfica das manifestações de discurso direto: falas e diálogos, pensamentos e sussurros, interjeições e transmissões. Will Eisner teoriza a criação do balão:

Vê-se o vapor do ar quente expirado durante a conversa. Faz sentido combinar o que pode ser ouvido com o que é visto, o que resulta numa visualização do ato de falar. Os italianos referem-se às nuvens de fala como fumetti, termo que se tornou nome genérico para as histórias em quadrinhos no idioma deles. (EISNER, 2010, p. 25)
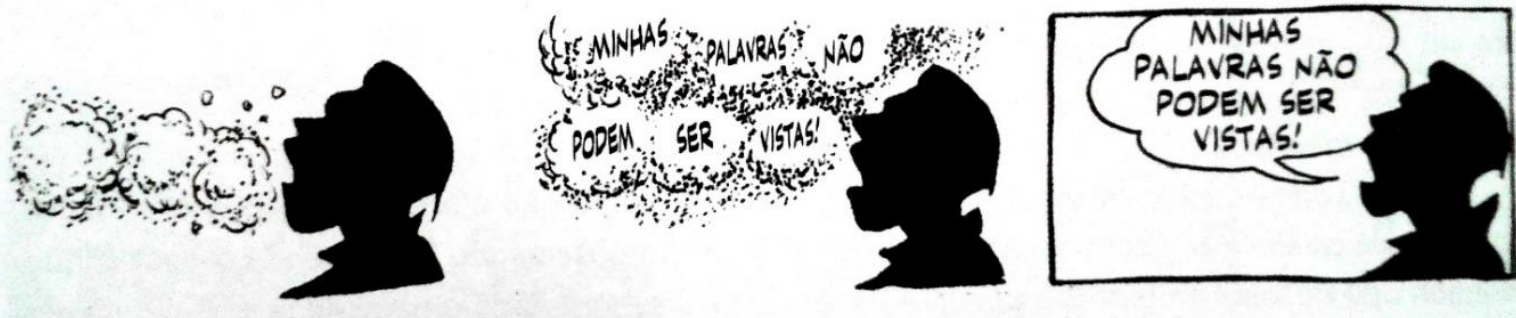

Figura 116 - Will Eisner - Quadrinhos e Arte Sequencial 2010, p. 25

Eisner considera que a primeira versão dos balões são os "filactérios medievais", pergaminhos com textos apontando para boca da pessoa representada (EISNER, 2010, p. 24), como na obra The Annunciation to Saint Anne, 1505 - 1510, do pintor alemão Bernhard Strigel, que descreve a aparição de anjos para São Joaquim e Santa Ana informando que serão os pais da Virgem Maria (Figura 118, Pág. 179). Nota-se no detalhe o pergaminho representando as palavras sagradas vindo do anjo (Figura 119, pág. 179).

Conforme o uso do balão se popularizou e, principalmente se uniformizou, com vários artistas empregando seu uso para a mesma função, variações nas formas foram adquirindo outros significados, assim surgiram os balões de sussurro, de pensamento, de grito, de comunicações radio/televisivas, inumanas e sobrenaturais, etc.
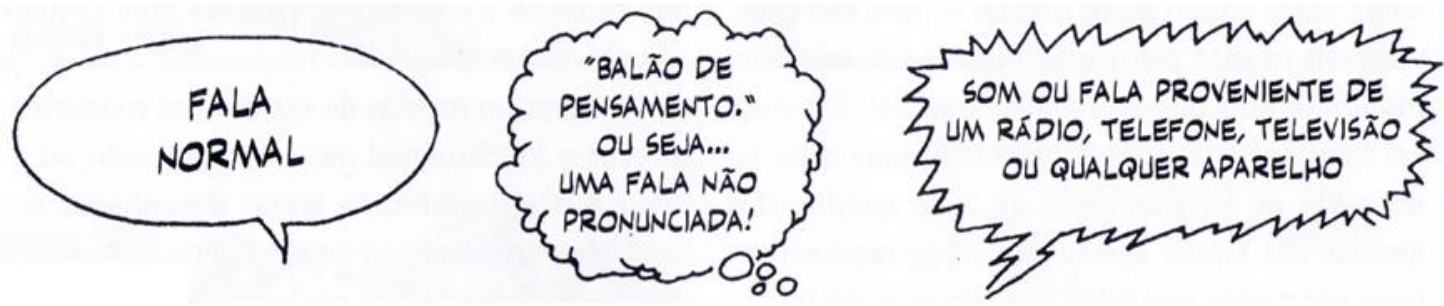

Figura 117 - Quadrinhos e Arte Sequencial - Will Eisner, 2010, p. 25 


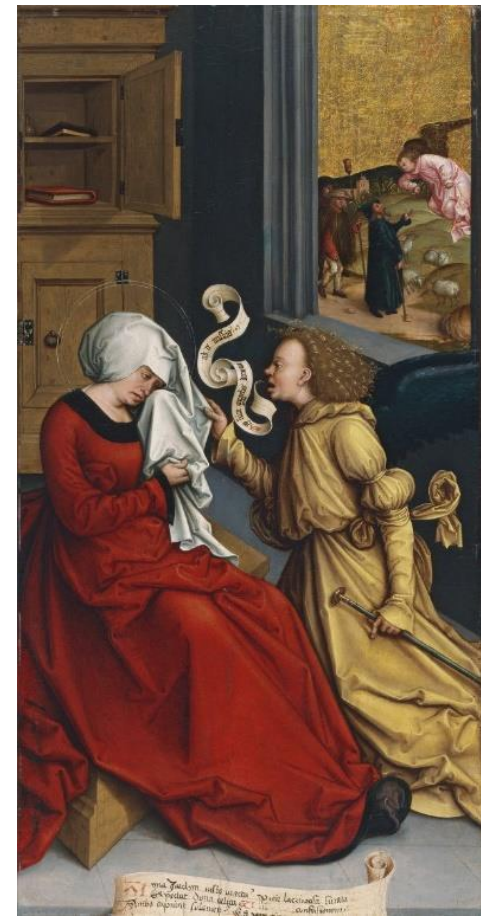

Figura 118 - The Annunciation to Saint Anne $e^{\mathrm{xxx}}$

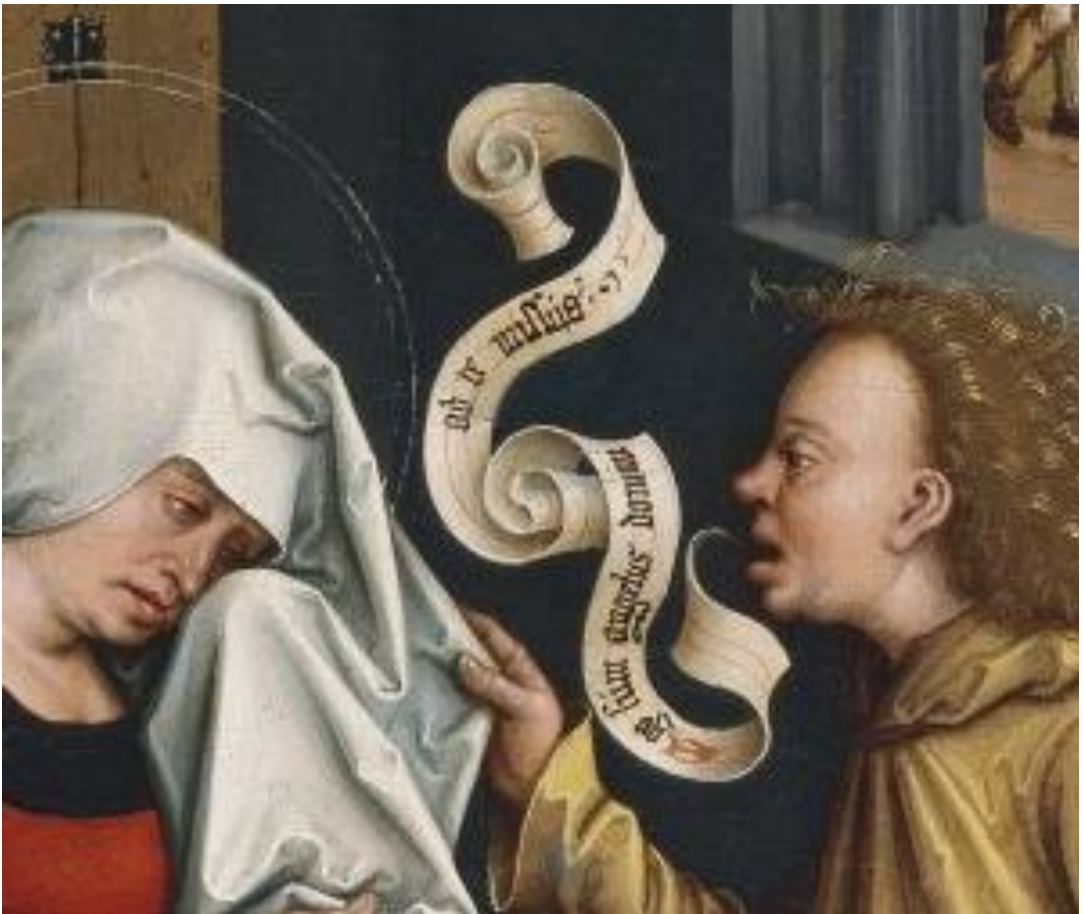

Figura 119 - Detalhe de: The Annunciation to Saint Anne, 1505 - 1510 Bernhard Strigel - Museo Thyssen-Bornemisza, Madridllxxi

O balão é constituído pela parte em que o discurso se acomoda, o balão propriamente dito, e o apêndice, a terminação que indica quem está produzindo o discurso.
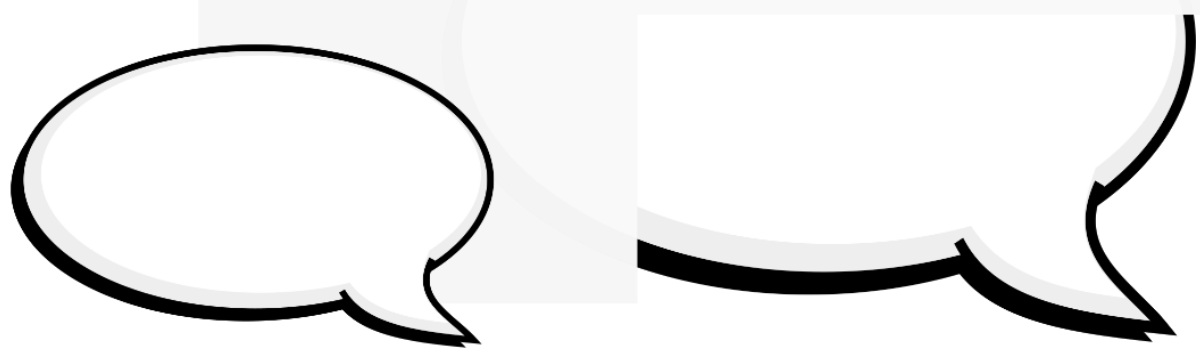

Figura 120 - Apêndice - elaborado pela autora

Apêndice é a "pontinha" que sai do balão e aponta para a pessoa que está realizando o discurso, ou o "sujeito da enunciação", contido no balão. Apesar das convenções os artistas estão sempre variando os formatos, estilos e mesmo a existência dos balões e apêndices de acordo com a intencionalidade e estética e narrativa da sua obra, o balão, seu apêndice e formato interno do conteúdo são pistas na formação do sentido. Eles revelam detalhes da construção do espaço e do tempo.

Usando novamente a tira básica desenvolvida para esse estudo, foi abordado como as variações do balão afetam a narrativa. Na Figura 121, pág.181, os 
balões indicam o tom de voz empregado, no primeiro quadrinho, o balão apresenta um formato normal e regular indicando um tom de fala normal em voz alta, sua aparência bifurcada (como "duas bolas") é usada para organizar frases longas, separando-as em períodos. Como não há um interlocutor a menina está falando sozinha ou, o que é comum na escrita para o público infantil, com o leitor. No segundo quadro, as notas musicais indicam que a personagem está cantando. Já no último quadro o tracejado demonstra que a personagem está sussurrando e como o apêndice aponta para fora do quadro, indica que ela ainda não encontrou o lobo, mas já sabe/sente que irá encontrá-lo e está compartilhando essa informação com o leitor, como um segredo entre eles.

Já no exemplo (Figura 122, pág. 181), o balão de pensamento indica que a menina tem o mesmo conhecimento, mas está em silêncio, imersa em seus pensamentos, note-se que o balão do último quadro não possui apêndice, um recurso muito utilizado na estética do mangá, na qual o leitor a infere o autor da fala pelo contexto, dando mais leveza e subjetividade a cena. Ou como no exemplo (Figura 123, pág. 181), indica que o falante está fora da cena, ou pela cor ou outra marcação na forma indicar um falante específico.

A mensagem do balão de "fala" pode ser composta por ícones figurativos (Figura 124, pág. 181), o leitor interpreta não só a cena, mas a mensagem que está sendo pronunciada. Como aponta o professor Cagnin,

Enquanto invólucro da fala, o balão também tornou-se imagem para representar as diversas reações e emoções por que passa a personagem, formas metalinguísticas portanto, como a entonação da voz, o medo, o gaguejar, a raiva e tantos outros. Não há possibilidade alguma de classificar tais produtos derivados da criatividade do desenhista (CAGNIN, 2014, p. 141).

O balão de diálogo representa a fala, interjeições, pensamentos, etc, sem se tornar um elemento alienígena na imagem. Quer sejam suas formas, letras ou símbolos, estão todos integrados na construção do sentido. 

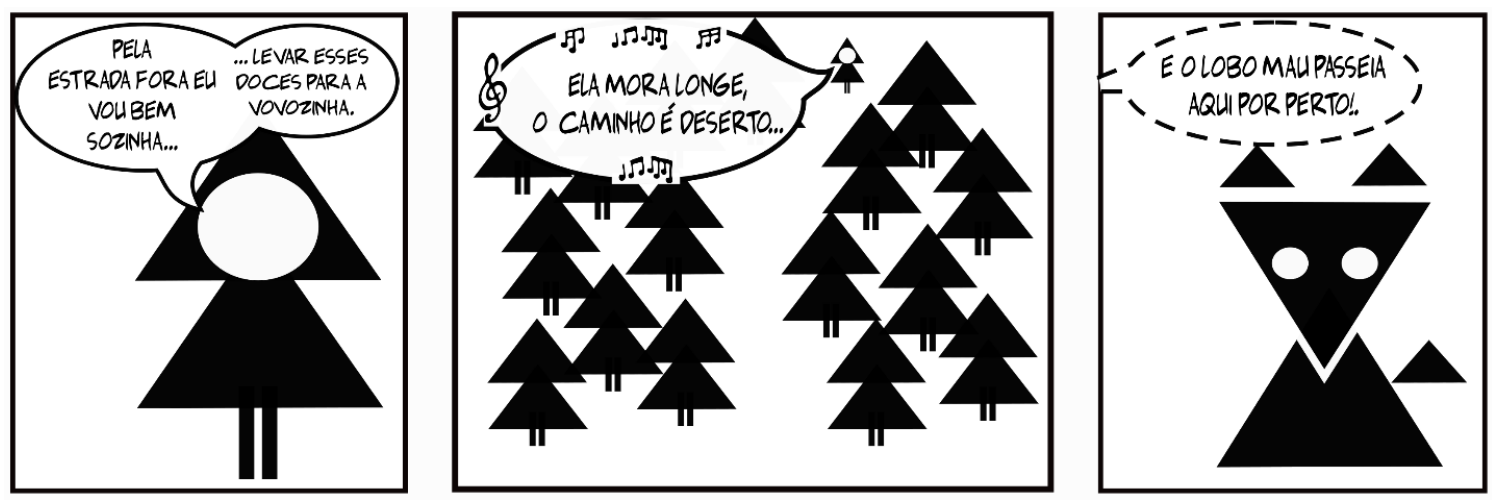

Figura 121 - Tom de voz
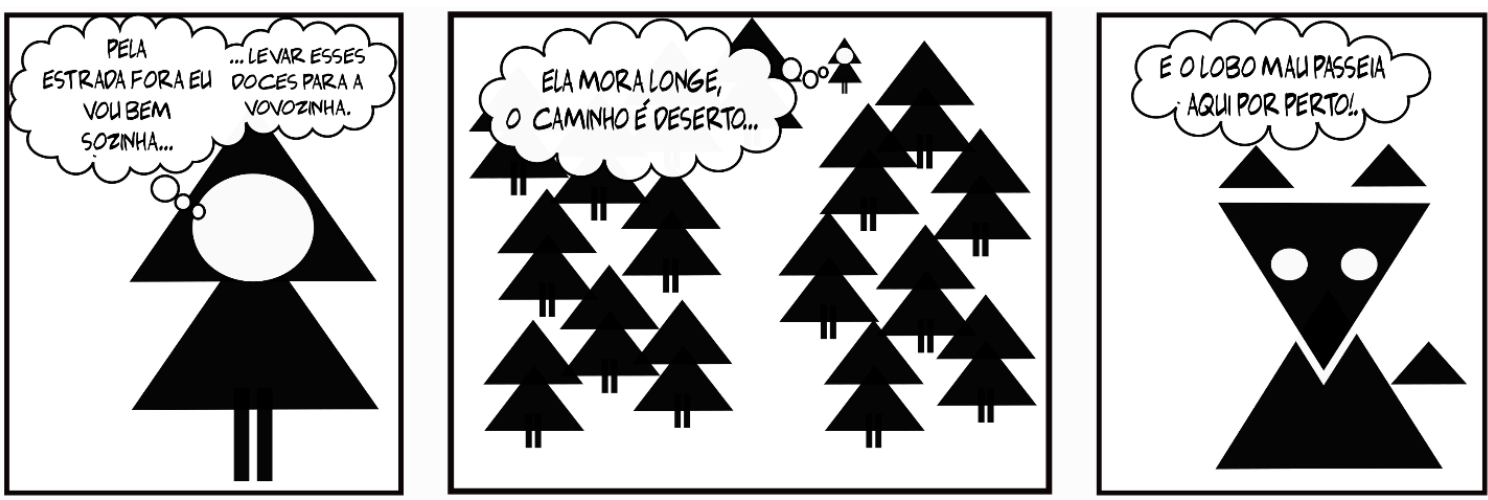

Figura 122 - Pensamento
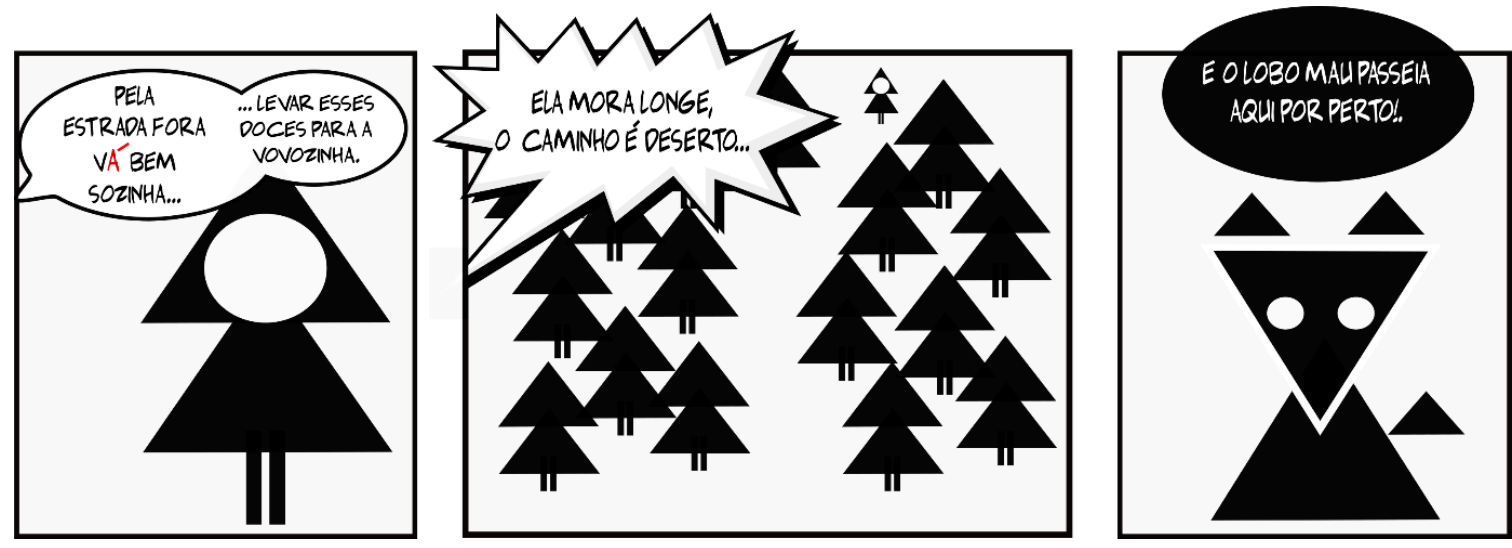

Figura 123 - Voz de personagem ausente e voz individualizada pelo formato
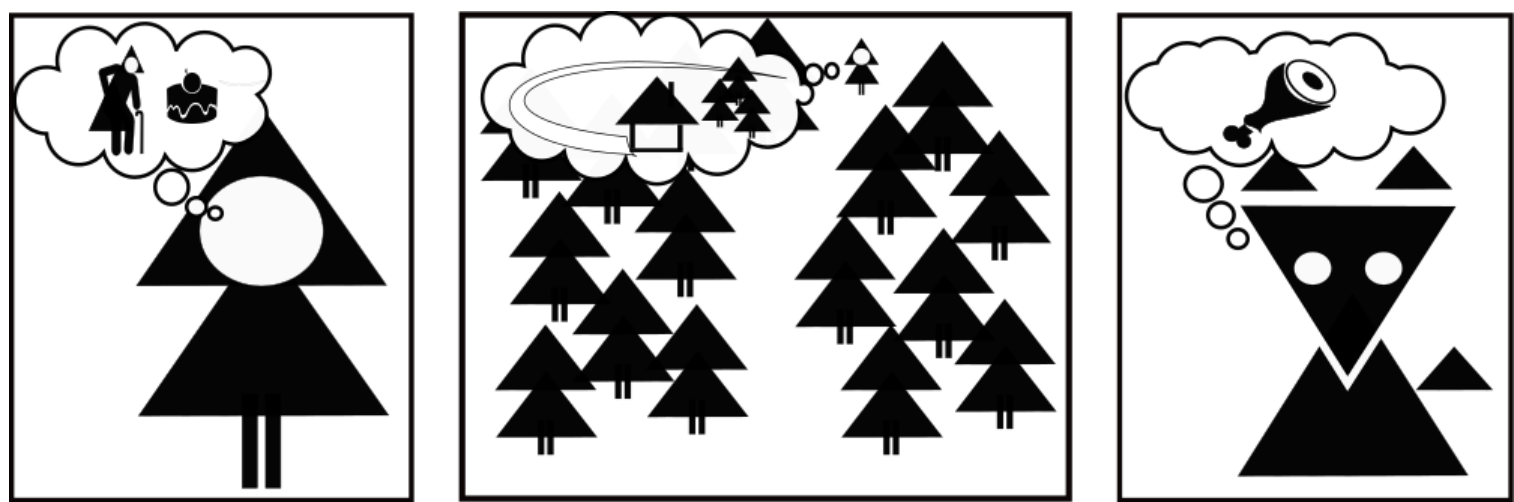

Figura 124 - Figuração 


\subsubsection{Legenda}

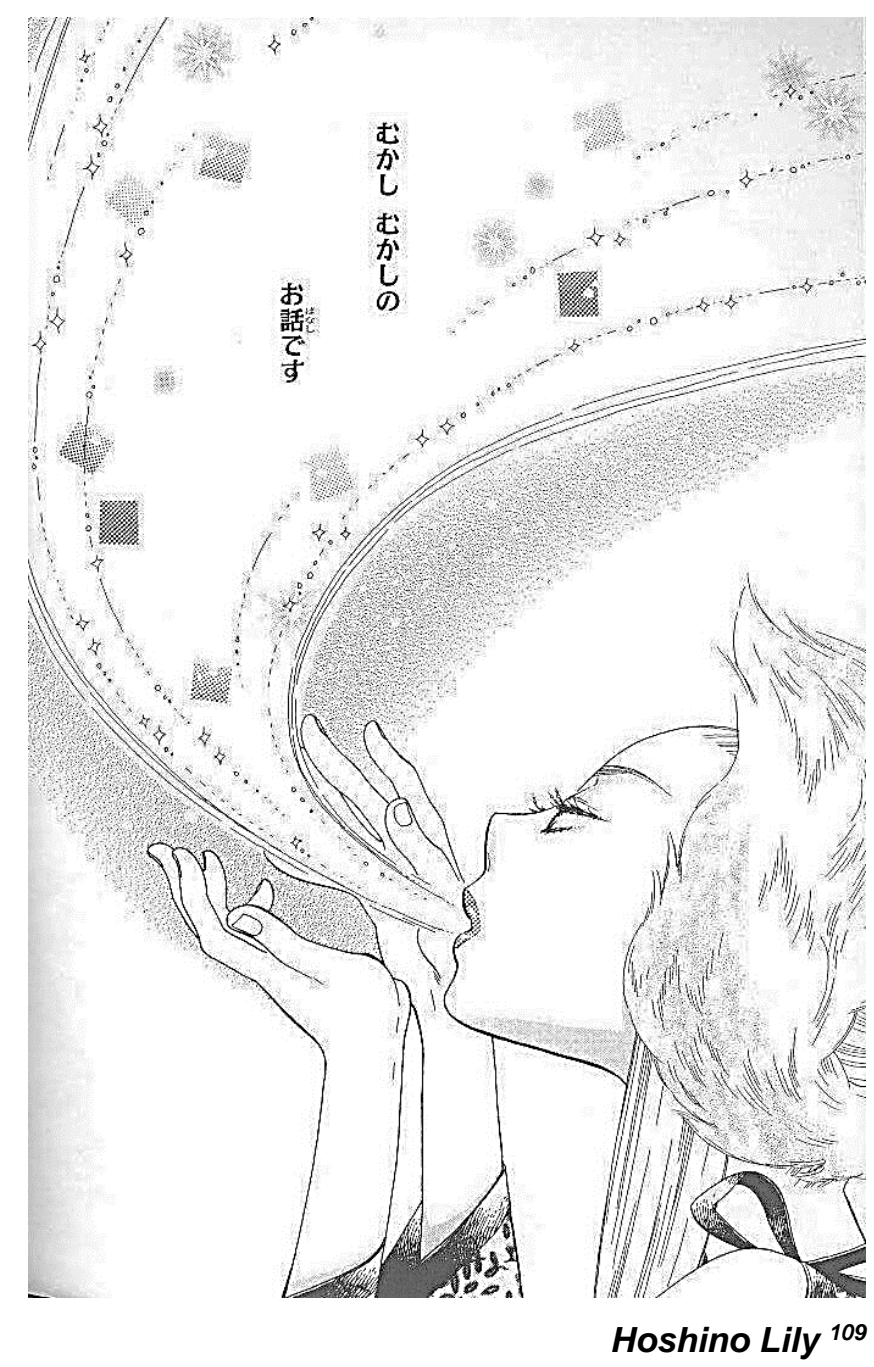

As legendas, nos quadrinhos, são os espaços dentro da imagem ou da grade destinados, principalmente para a voz do narrador, seja em primeira ou em terceira pessoa. Na tira modelar desse estudo, são os retângulos, marcados ou não, que contêm os ícones linguísticos que formam palavras e frases:

${ }^{109}$ Epígrafe - tradução e fonte: Era uma história, muito, muito antiga. [tradução da autora] fonte: LILY, H. Haremu de hitori. Tóquio: Biblos, 2004. 

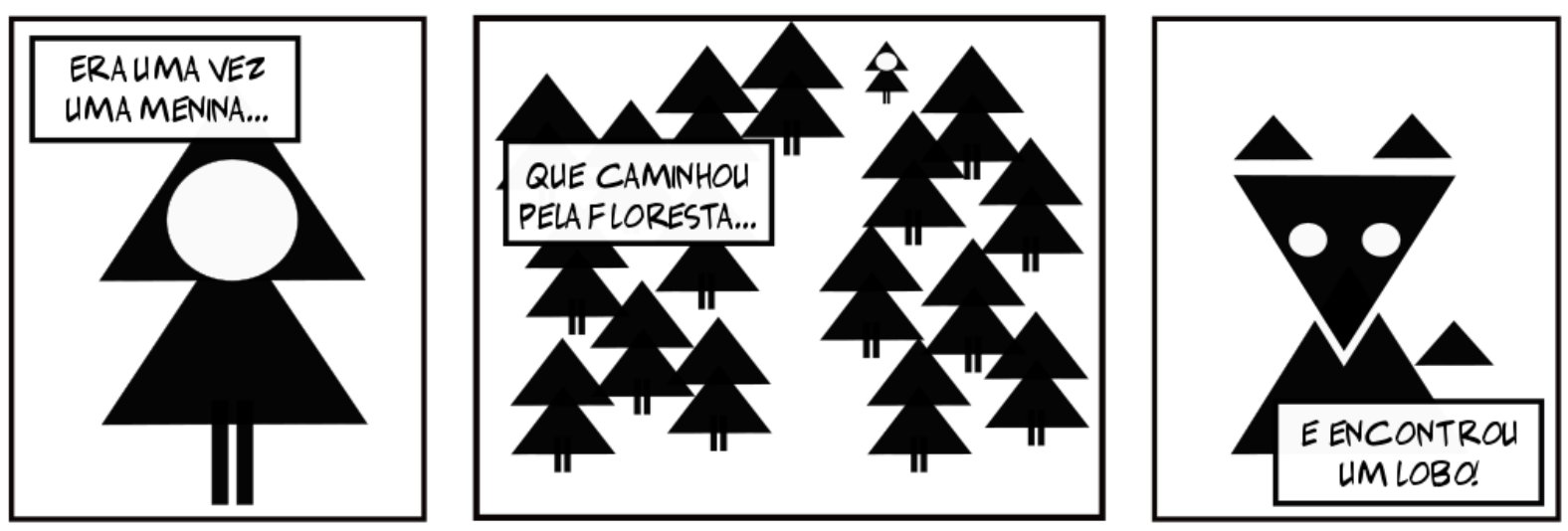

Figura 125 - Legendas

A diferença entre o narrador de um texto somente escrito o narrador dos quadrinhos é seu aspecto dual. Aquele que apresenta o espaço e o tempo, os personagens, o clima e o ritmo da narrativa através da imagem - induzindo a interpretação do leitor através das características já abordadas da cartunização e caricaturização, trabalhando os estereótipos e os simbolismos para adjetivar a narrativa.

A voz do narrador, que pode ser em primeira, segunda ou terceira pessoa, e pode corroborar, complementar ou contrariar a narrativa imagética. Não há uma hierarquia entre os dois aspectos de narração, os dois vão trabalhar juntos para deixar pistas, formar trilhas que levam a becos sem saída ou destinos possíveis para o leitor seguir. Por exemplo, se a tira modelar fosse descrita somente em palavras, poderiam ser feitas diversas adjetivações de acordo com a intencionalidade do autor, como:

Tabela 3 - Frases possíveis para descrever uma tira de quadrinhos

\begin{tabular}{|c|l|}
\hline 1 & $\begin{array}{l}\text { Era uma vez uma menina, que caminhou pela floresta e encontrou um } \\
\text { lobo. }\end{array}$ \\
\hline 2 & $\begin{array}{l}\text { Era uma vez uma menina qualquer com capuz preto, que caminhou em } \\
\text { uma floresta monocromática e encontrou um lobo indiferente. }\end{array}$ \\
\hline 3 & $\begin{array}{l}\text { Era uma vez uma singela menina de capuz, que caminhou pela floresta } \\
\text { escura e encontrou um lobo negro. }\end{array}$ \\
\hline
\end{tabular}

A imagem da tira usando somente um recurso de composição mínimo (cartunização) deixa a imagem com uma polifonia de possibilidades de interpretação. 
Por isso todos os três textos servem para descrever as imagens.

A diferença é que quem está adjetivando - "uma menina qualquer", "uma simples menina", "floresta monocromática", "floresta escura", "lobo indiferente", "lobo negro" - é o narrador, marcando sua intencionalidade, ou mesmo sua personalidade.

Já o narrador imagético da história em quadrinhos, por causa da assertividade imagética, transmite a impressão de ser um narrador imparcial, mesmo que isso não seja verdade, minimizando sua intencionalidade e personalidade, deixando para sua voz, dentro da legenda, criar uma personalidade que conversará com o leitor. Groensteen aponta que, o narrador na história em quadrinhos, articula três relações,

The first two, which are homogeneous, concern the chain of images on the one hand and the chain of speech balloons on the other; the third, which is heterogeneous, concerns the articulation of these two sequences - the one iconic, the other linguistic ${ }^{110}$ (GROENSTEEN, 2011, p. 125).

A dualidade do narrador nos quadrinhos fica mais evidente em sua manifestação na legenda. Pois a narração imagética e a da legenda podem se separar em pessoa (Figura 126, pág. 185), onde a menina está contando a história que está vivendo do seu ponto de vista e seu conhecimento enquanto o narrador imagético está contando aquilo que ela não sabe. Quando o narrador é separado em primeira pessoa, ele pode assumir o papel de qualquer personagem da história (Figura 127, página 185) sem que isso altere a importância dos personagens desenvolvidos pelo narrador imagético. A separação também pode ser temporal (Figura 128, pág. 185) ou espacial (Figura 129, pág. 185) criando duas narrativas distintas. Na Figura 128, foi empregado também a não marcação da legenda, fazendo com que o texto se integre com a imagem para outro nível de associação: ingenuidade=menina, perigoso=lobo.

${ }^{110}$ As duas primeiras, que são homogêneas, dizem respeito a cadeia de imagens de um lado e a cadeia de balões de fala de outro, a terceira que é heterogênea, diz respeito a articulação dessas duas sequências - uma icônica [figurativa] e outra linguística (GROENSTEEN, 2011, p. 125). 

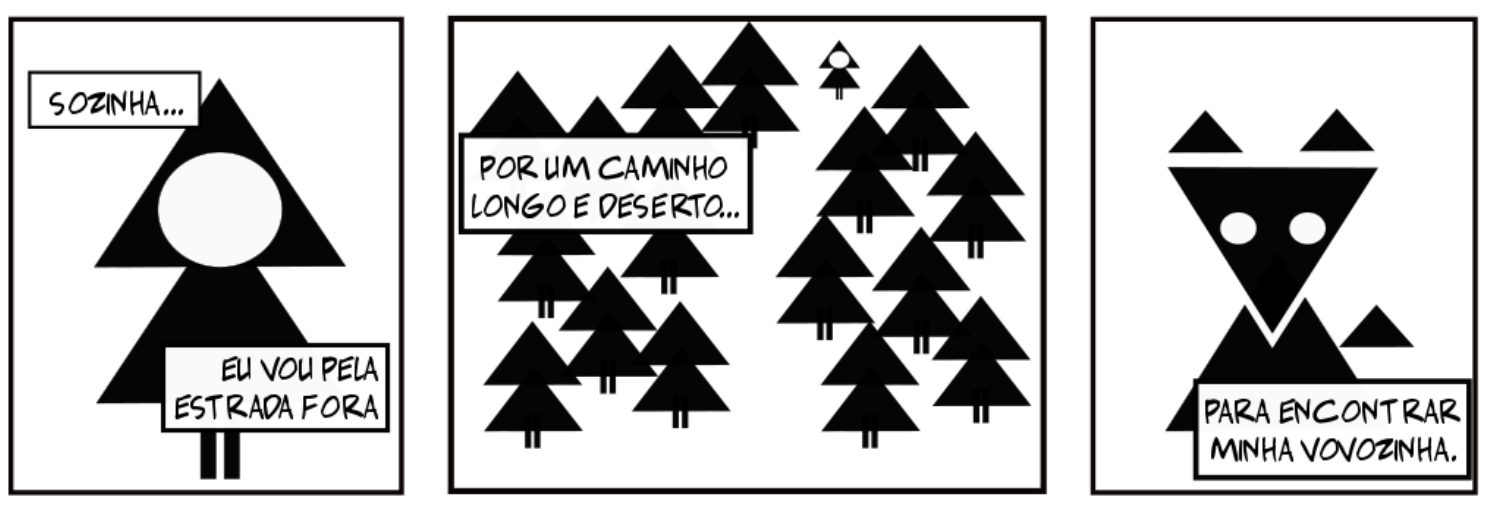

Figura 126 - Legenda - narrador em primeira pessoa - menina
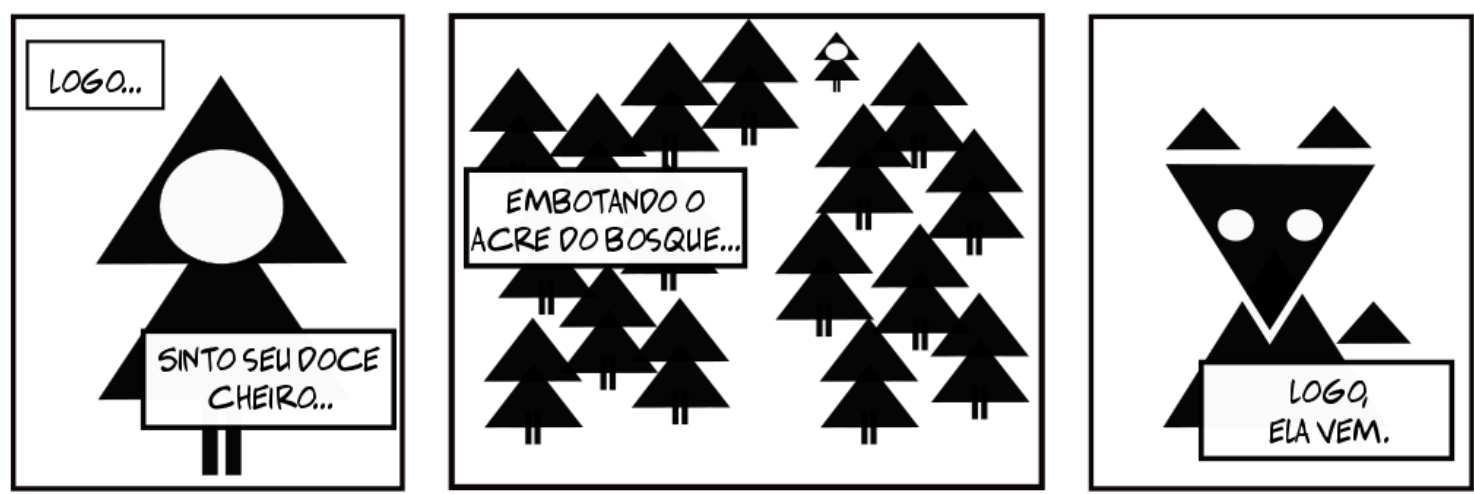

Figura 127 - Legenda - narrador em primeira pessoa - lobo
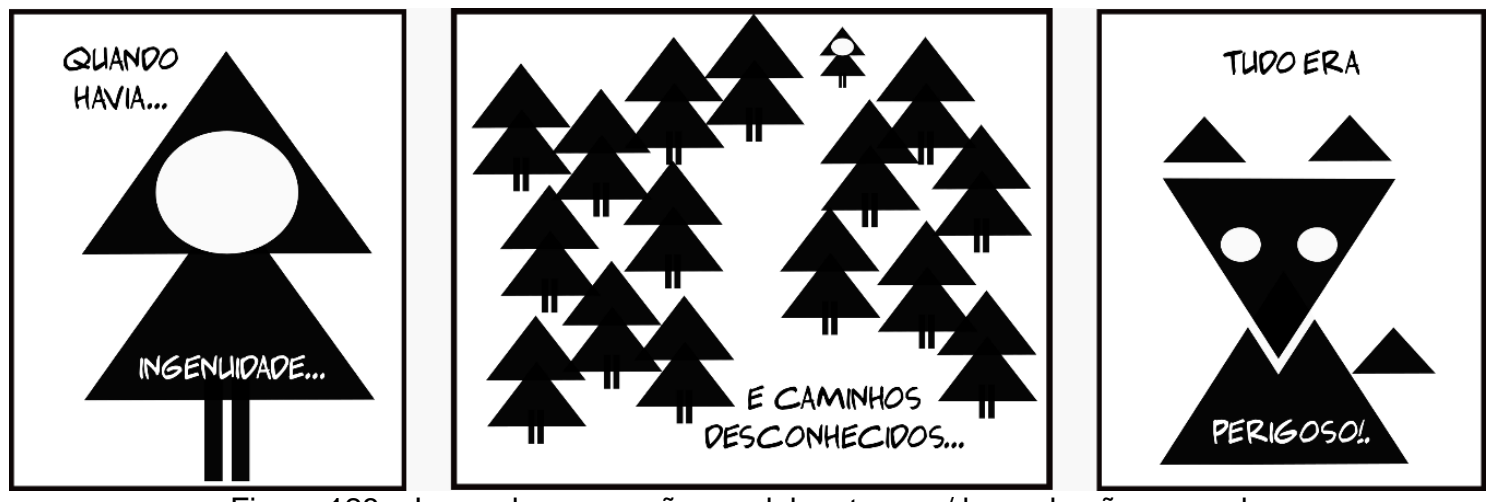

Figura 128 - Legenda - narração paralela - tempo / legenda não marcada
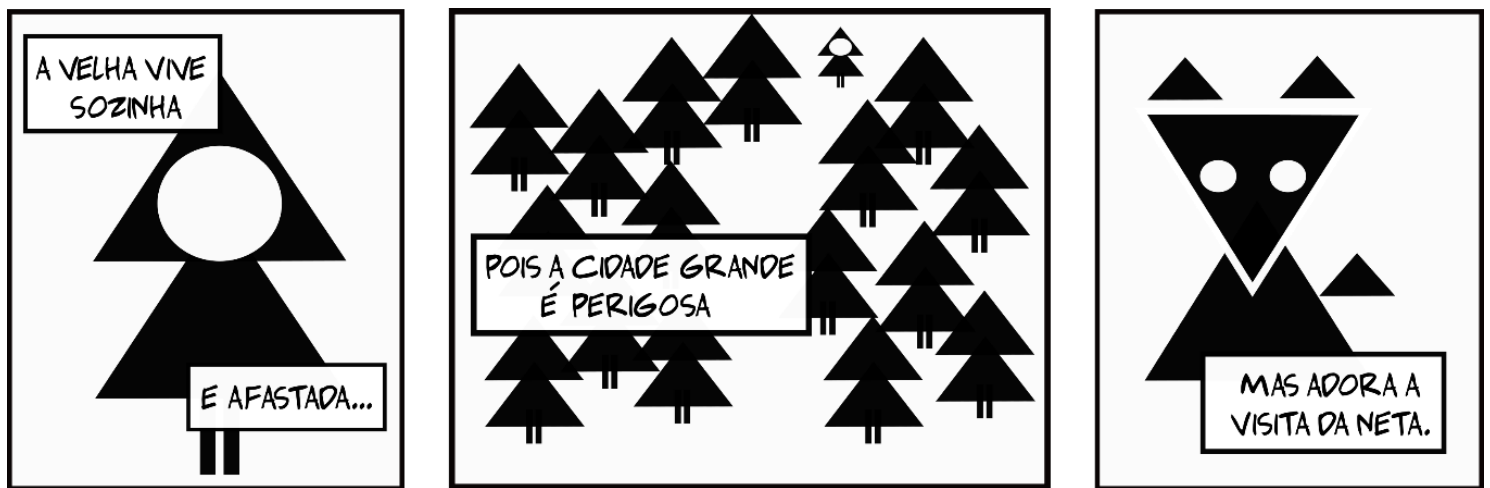

Figura 129 - Legenda - narração paralela - espaço 
Nos primórdios da interação entre palavras e imagens, a legenda ocupava o espaço externo da imagem, normalmente posicionada abaixo da figura a qual estava se referindo, como no trabalho de Töpffer e Doré, entre outros:

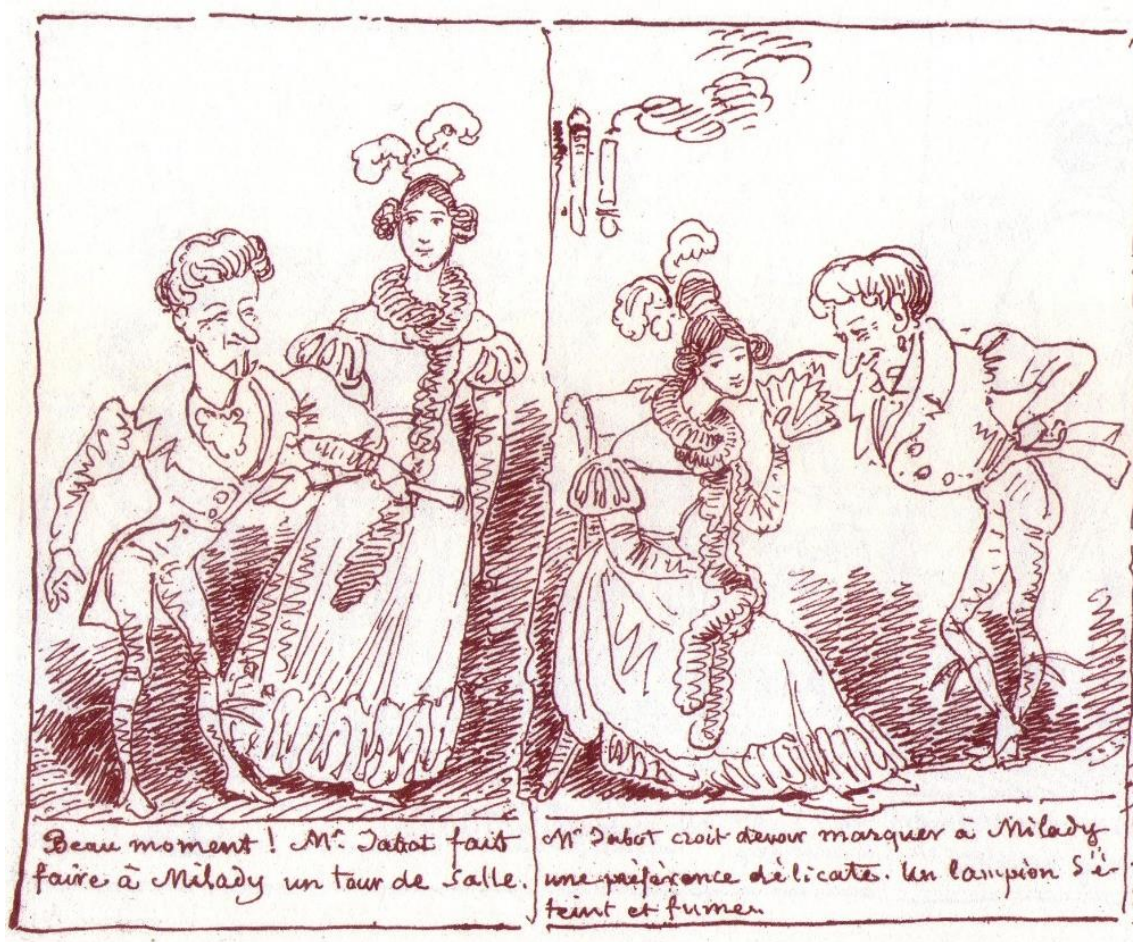

Que belo momento! M. Jabot conduz Milady em uma volta pelo salão.
M. Jabot pensa em demonstrar à Milady uma delicada preferência. Um lampião se apaga e a fumaça começa a se propagar.

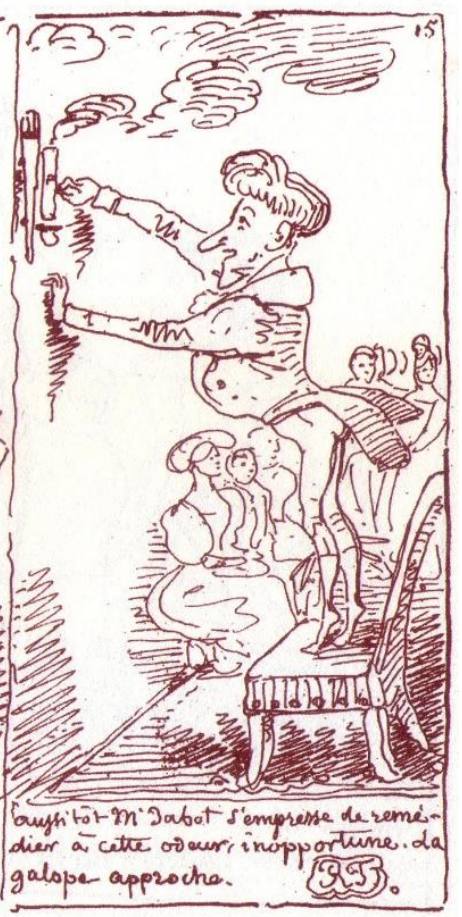

Imediatamente, $M$. Jabot apressa-se para remediar aquele odor, inoportuno ao galope que se aproxima.

Figura 130 - Legenda em Töpffer

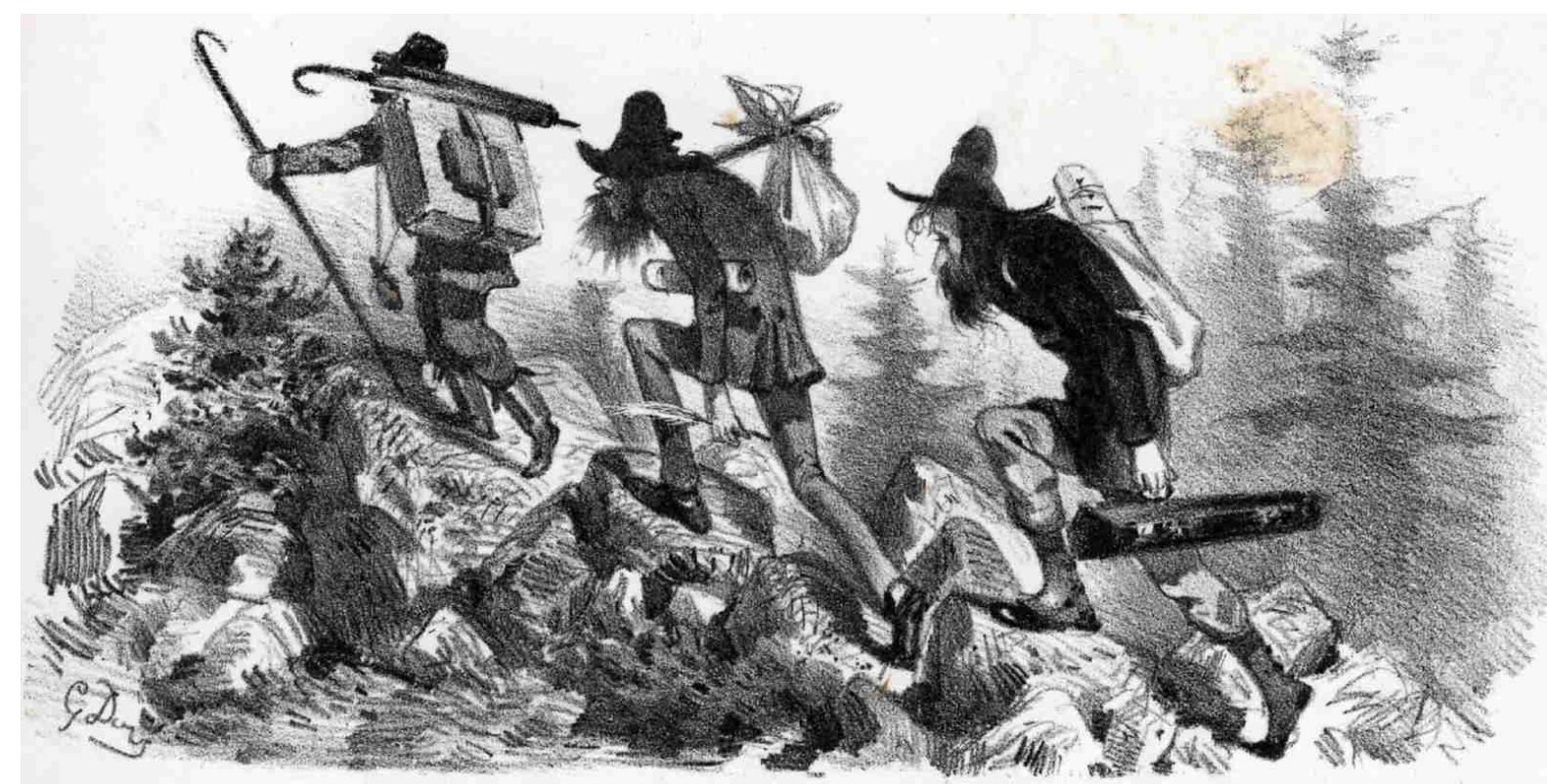

Mrs Sombremine, auteur dramatique, Badigeon artiste peintre, et Tartarini artiste musicien, voyageant en province dans le but d’y ètendre leur réputation, s'y rendent par un chemin pareil à celui de la foloire.

Figura 131 - Legenda em Gustave Dorélxxxii 
Ao longo do tempo ocorreu uma migração da legenda para dentro do quadro que referenciava. Mas ainda há artistas que gostam de utilizar o recurso, principalmente no cartum e charge, talvez para criar um efeito de hierarquização na leitura, induzindo primeiro a leitura da narrativa imagética seguida de uma conclusão textual.

Além de cartuns e charges, a legenda abaixo da imagem referenciada também pode ser usada na narrativa sequencial em uma criação estética, temática ou climática, conferindo uma ambientação temporal, simulando um tempo antigo.

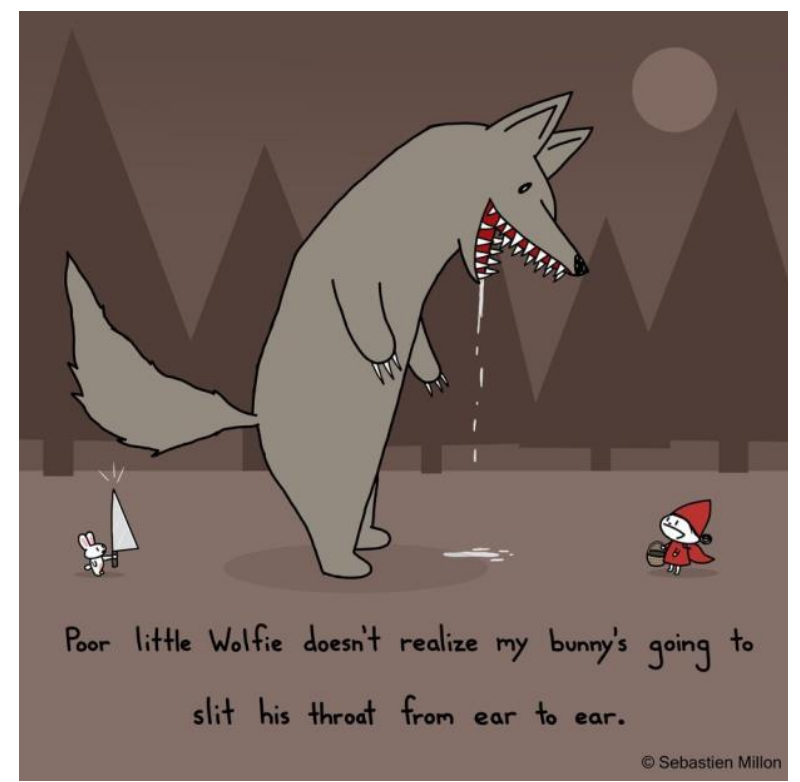

Figura 132 - Sebastien Millon (C2011-2017 sebreg ${ }^{\text {lxxxiii }}$

Pobre lobinho que não se dá conta que meu coelhinho vai cortar sua garganta de orelha a orelha. [tradução da autora].

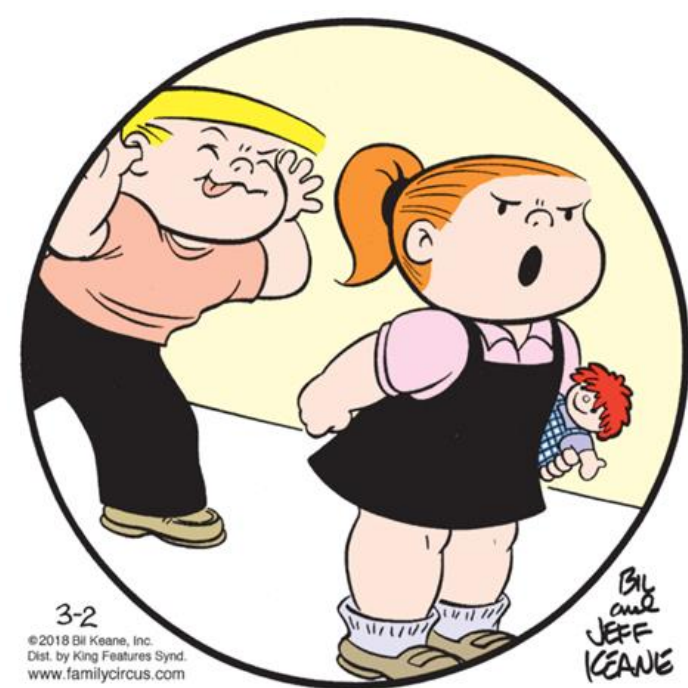

“Mommy, when I'm grown up, am I allowed to divorce my brother?"

Figura 133 - Family Circus - Jeff Keane

"Mamãe, quando eu crescer, posso me divorciar do meu irmão? [tradução da autora]

Alguns estudiosos criticam os quadrinhos que utilizam texto escrito nas legendas, reiterando a autossuficiência da imagem para criar a narrativa como o professor Cagnin,

As histórias mudas são, por definição, as verdadeiras e autênticas histórias em quadrinhos, uma vez que não se valem de outro código se não o do icônico para contar uma história, dispensam totalmente o texto servindo-se tão somente da representação dos momentos mais significativos das ações e dos gestos das personagens para sugerir, nos quadros sucessivos, o significado de movimento (CAGNIN, 2014, p. 34).

Ou Thierry Groensteen, 
Considerar que os quadrinhos são essencialmente um lugar de confronto entre o verbal e o icônico é, creio eu, uma contraverdade teórica que conduz a um impasse. Será necessário ser mais específico? Se eu suplico que a imagem seja reconhecida em posição de destaque, não é pelo fato de que, salvo raras exceções, ela ocupar nos quadrinhos um espaço mais importante que aquele reservado à escrita. O predomínio da imagem no cerne do sistema deve-se ao fato de que a maior parte da produção de sentido ocorre através dela (GROENSTEEN, 2015, p. 17)

Tais abordagens parecem não estar considerando que as palavras escritas no contexto da $\mathrm{HQ}$ também são ícones gráficos, a diferença é que, assim como o ícone figurativo, o ícone linguístico tem mecanismos e estratégias próprias de acessar o referencial do leitor, mas não deixa de estar tão subordinado visualmente à grade quanto o outro. O conteúdo verbal da legenda (ou balões) tem que ser minunciosamente escolhido para se adequar a um espaço determinado, ou seja, não é a palavra específica, mas um possível conteúdo verbal que é lapidado especificamente para conferir o significado desejado pelo artista em uníssono com a imagem. A escolha das palavras, modo de escrever, do tom e do estilo textual estão subordinados ao enquadramento visual, ou seja, as palavras não têm passagem livre pela forma e podem ser alteradas para outra construção de sentido similar se o tamanho se mostrar mais favorável. Podem até mesmo ser substituídas por símbolos ou silêncios se a construção da grade assim o determinar. As palavras nos quadrinhos se aproximam mais da construção poética do que da construção narrativa, a grade é a métrica espaçotópica na qual o conteúdo verbal deve se encaixar.

Mesmo quando a legenda contradiz a imagem, isso é feito com a intencionalidade do artista em causar um efeito cômico, irônico, mordaz, grotesco, surreal, fantástico, etc. Não é correto dizer que há simplesmente uma junção de texto e imagem nos quadrinhos, uma vez que tanto os ícones linguísticos quanto os simbólicos e os figurativos são articulados no espaço da grade, como pistas, marcas e traços que vão em conjunto induzir efeitos de sentido no leitor. 


\subsubsection{Onomatopeia}

Em resumo, as onomatopeias e as exclamações são de importância secundária, e sua origem simbólica é em parte contestável.

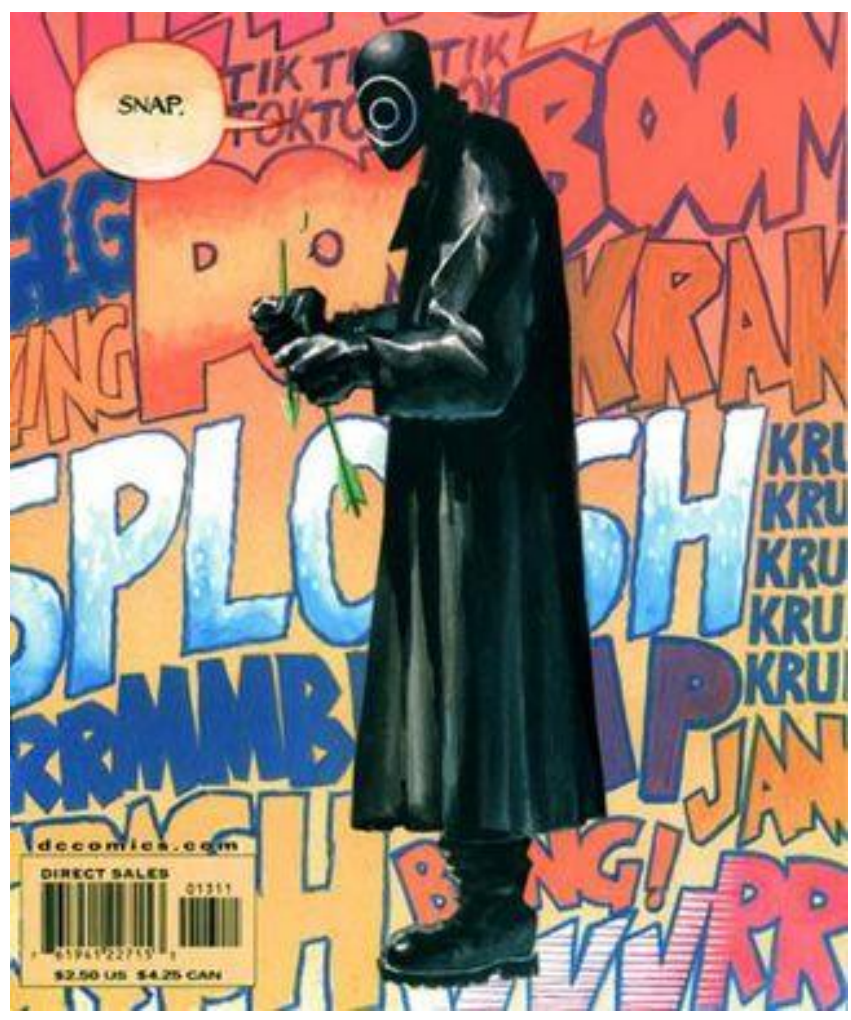

Ferdinand Saussure e Matt Wagner ${ }^{111}$

Onomatopeia do grego onomatopoiía, onde onoma quer dizer "nome" ou "palavra" e poiein: atuar, ação (GREGÓRIO, 2017) sendo o ato de nomear ou criar uma palavra para descrever algo. Diferente da onomatopeia como figura de linguagem, ou seja, criar palavras com base em sons, nas Histórias em Quadrinhos elas são usadas não apenas para representar o som, mas também movimento e estado de espírito. Nos quadrinhos a onomatopeia não é apenas um som, ela é a forma como o som (ou emoção e outras nuances, no caso dos mangás) ocupam o espaço da grade para a construção narrativa. É mais um dos argumentos, trazendo consigo o sentido absoluto e o figurado.

111 Epígrafe - fonte: SAUSSURE, F. D. Curso de Linguistica Geral. Tradução de Antonio Chelini; José Paulo Paes e Izidoro Blikstein. São Paulo: Cultrix, 2006.Pg. 84. E capa de Matt Wagner para a revista Green Arrow (Arqueiro Verde), no 13, "The Sounds of Violence (Part I of III) - Frequency" (O som da violência - parte 1 de 3 - Frequência) de 2002 da editora DC Comics. Na capa o vilão Onomatopeia, um serial killer que tem o vício de imitar os sons a sua volta. 
Por exemplo:
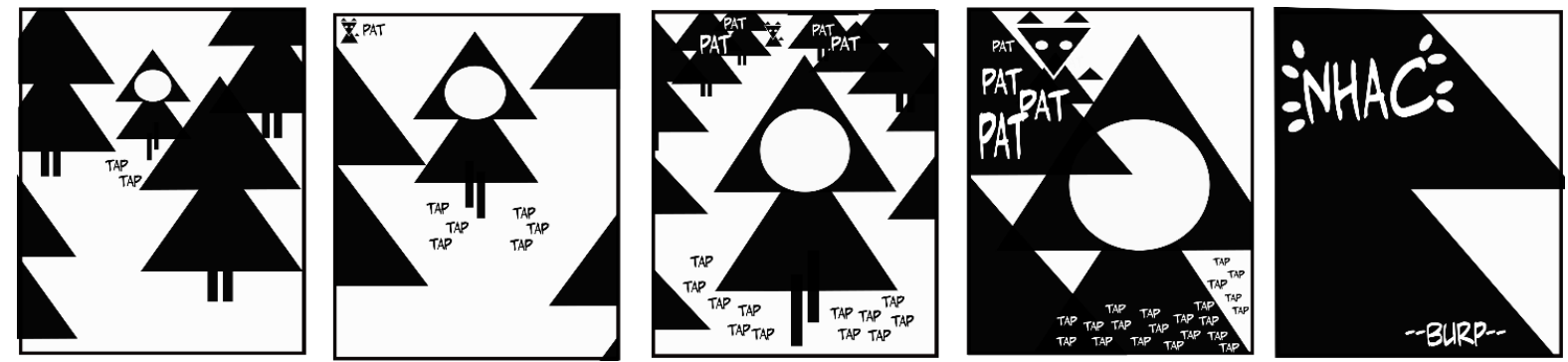

Figura 134 - Onomatopeia - elaborado pela autora

Na tira modelar as palavras que representam os passos da menina (TAP) vão progressivamente aumentados na cena para indicar o aumento do ritmo na caminhada, da mesma forma, as passadas do lobo (PAT), a cena final pôde ser suprimida pelo uso das conhecidas onomatopeias para mordida "NHAC" e para arroto "BURP".

As onomatopeias possuem dois planos de sentido, no primeiro pertencem à diegese, por estarem dentro da cena sendo a ambientação sonora do ambiente partilhado pelos personagens, no segundo, ao plano imagético pois são os desenhos das letras, formato, cores e intensidade que conferem significados emocionais e culturais traduzindo-os para o leitor como efeitos sonoros.

De acordo com Cagnin, as onomatopeias "são uma criação dos quadrinhos modernos, surgiu como uma explosão alegre que deu vida à nova arte." (CAGNIN, 2014, p. 159).

Algumas construções de significado das onomatopeias nas histórias em quadrinhos, suplantam a existência de som real. Com a construção do imaginário pela própria linguagem, os leitores aprendem esse vocabulário próprio e vinculam as letras a construções sonoras que não existem na realidade. Isso acontece frequentemente no mangá japonês, mesmo para os leitores ocidentais que assimilam o sentido das onomatopeias traduzidas mesmo sem ter o referencial da língua como suporte, como por exemplo um dos cinco tipos de onomatopeias japonesas ${ }^{112}$, o Gijoujo 擬情語, que descreve sentimentos ou estado de espírito. $O$ ato de enrubescer por exemplo, recebe o efeito sonoro de “かああっ” (kaaa), mesmo que o rubor, causado pelo aumento

\footnotetext{
112 Os cinco tipos de onomatopeias japonesas são: Giseigo 擬声語 sons produzidos por humanos e animais; Giongo 擬音語, sons produzidos objetos inanimados e natureza; Gitaigo 擬態語, sons que descrevem condições e estados; Giyougo 擬容語, sons que descrevem movimentos e ações; Gijougo 擬情語 que descrevem sentimentos (DEXTER, 2015).
} 
intenso do fluxo sanguíneo na face geralmente devido a um constrangimento, indignação, timidez etc., não provoque nenhum som real. No caso de onomatopeias desse tipo, os mangás traduzidos em geral mantêm o original com uma legenda ao lado, como optou o tradutor Arnaldo Massato Oka, para edição brasileira do mangá "Chobbits" do grupo CLAMP, publicado no Brasil pela editora JBC em 2000, que colocou acima da representação onomatopeica original (à direita) a palavra "vermelho" para indicar que o personagem ficou corado.

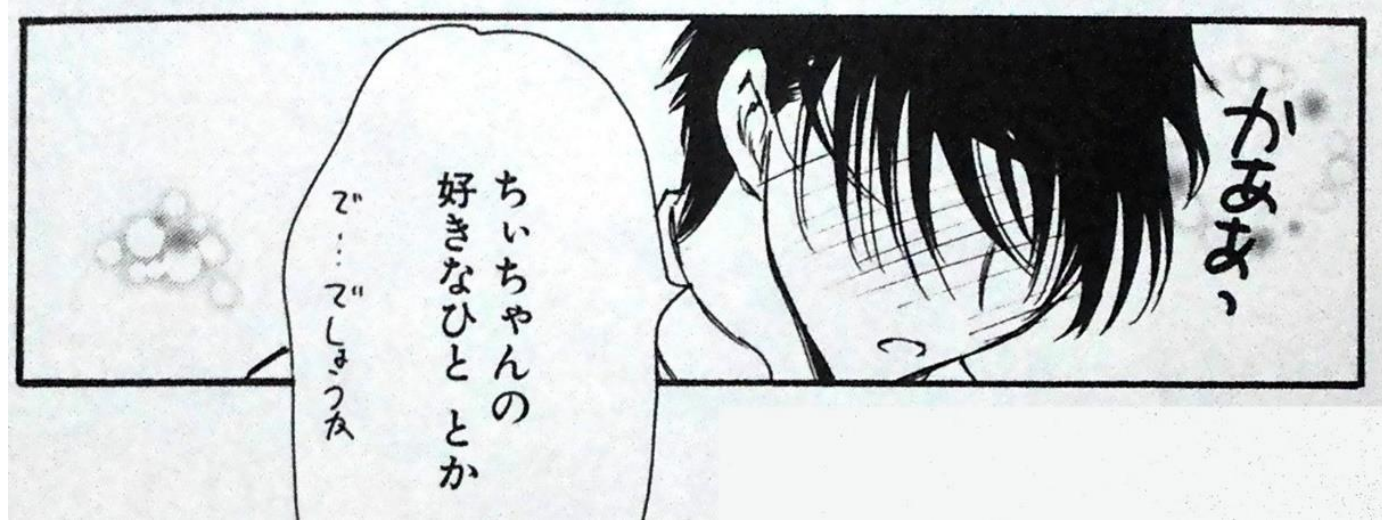

Figura 135 - Chobits - Clamp, 2000, ed. Kodensha, Tóquio, pg 92, terceiro quadro.

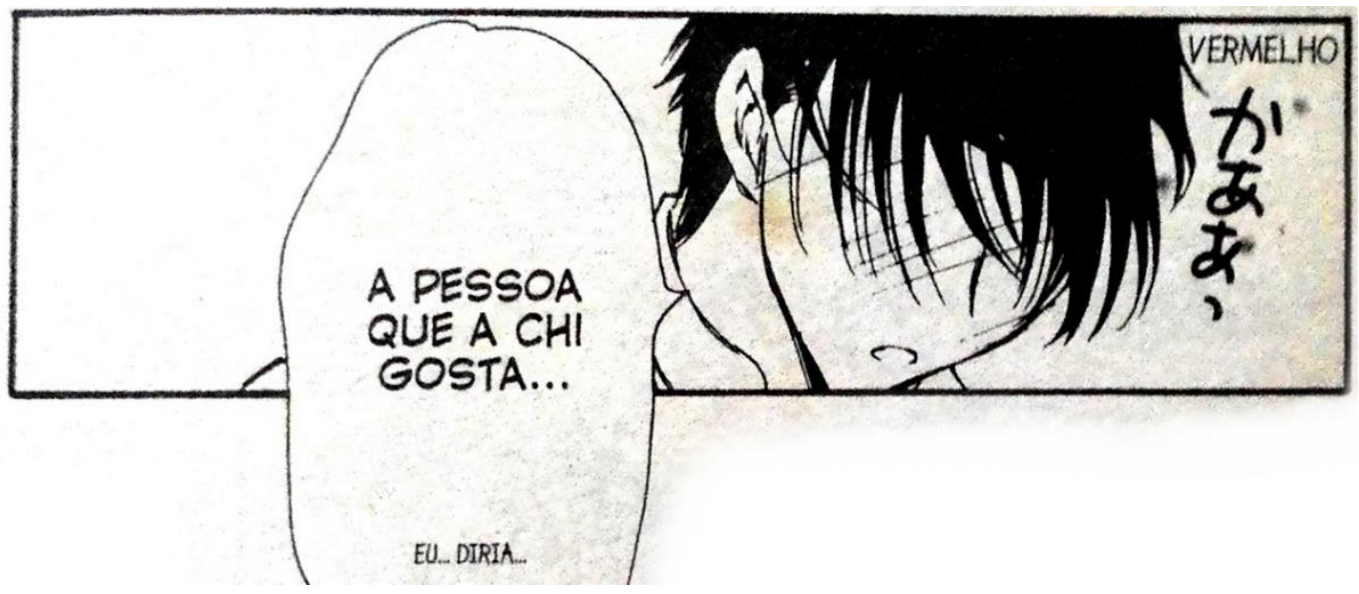

Figura 136 - Chobits - Clamp, 2000 - Ed. JBC, São Paulo, pág. 98, terceiro quadro

Nos quadrinhos as onomatopeias se encaixam nos argumentos de Saussure sobre serem ou não imotivadas ou arbitrárias na línguagem, pois elas não se limitam a uma existência sonora. Mesmo que se admita que sua manifestação, como exemplifica Saussure, não é diretamente motivada pelo som real, e sim uma convenção de cada contexto linguístico, de certa forma essa é uma discussão irrelevante para um meio que na realidade não produz som algum. A onomatopeia nos quadrinhos é uma susposição de sons reais, prováveis, possíveis e também dos completamente e terminantemente irreais, improváveis e impossíveis. 


\subsubsection{Tempo}

Espaço e tempo não apenas afetam, mas também são afetados por qualquer coisa que aconteça no universo.
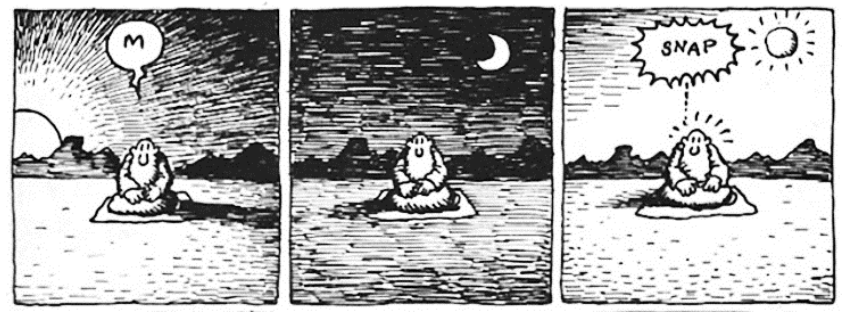

- Então, ele perguntou —, o senhor sabia o tempo todo tudo que eu ia fazer, tudo que eu ia fazer, tudo que eu fiz?

Hawking, Crumb e Asimov ${ }^{113}$

Em "Uma breve história do tempo" (1988), Stephen Hawking, em oposição aos conceitos aristotélicos e newtonianos, analisa o tempo em relação ao movimento no espaço.

Tanto Aristóteles quanto Newton acreditavam no tempo absoluto. Isto é, acreditavam que se pode, sem qualquer ambiguidade, medir o intervalo de tempo entre dois eventos, e que o resultado será o mesmo em qualquer mensuração, desde que se use um relógio preciso. O tempo é independente e completamente separado do espaço. Isto é o que a maioria das pessoas acredita; é o consenso. Entretanto, tivemos que mudar nossas ideias sobre o espaço e o tempo. Ainda que nossas noções, aparentemente comuns, funcionem a contento quando lidamos com maçãs ou planetas, que se deslocam comparativamente mais devagar, não funcionam absolutamente para objetos que se movam à velocidade da luz, ou próxima a ela (HAWKING, 1988, p. 39-40).

De acordo com Hawking, a teoria da relatividade de Einstein demostra que a posição no espaço altera o tempo, pois o tempo passará mais lentamente para algo que se encontra próximo a uma grande massa mas passará rapidamente para um objeto longe dessa massa (HAWKING, 1988).

O tempo físico, em sua complexidade trifásica (tempo, epaço, movimento), se traduz em velocidade. Já o tempo, como construção cultural está centrado na inação, pois ele parte do singular, como passado, presente ou futuro de algo, seja um indivíduo, coisa ou evento. Extrapolando o experimento mental que Schrödinger criou

113 Epígrafe - montagem de texto e imagem, fontes: HAWKING, S. W. Uma breve história do tempo: do Big Bang aos buracos negros. Tradução de Maria Helena Torres. Rio de Janeiro: Rocco, 1988. Pg. 60. CRUMB, R. Mr. Natural \#1. San Francisco Comic Book Company/Apex Novelties, Ago. 1970. ASIMOV, I. O Fim da eterninade. Tradução de Susana Alexandria. São Paulo: Aleph, 2007. Pg. 146. 
em 1935 para testar o "Princípio da Incerteza", teoria sobre física quântica criada por Werner Heisenberg, o tempo, na percepção humana, está subordinado às relações construídas com o "eu, aqui, agora". Contudo, dessa relação é excluída o fator velocidade, assim passado, presente e futuro podem ser percebidos simultaneamente.

O experimento hipotético de Schrödinger, segundo Bruno Lazaretti, editor da revista Mundo Extranho da editora Abril, consiste em:

Um gato é colocado em uma caixa selada onde um único átomo radioativo é ligado a um aparato medidor que, por sua vez, está conectado a um martelo. O martelo paira sobre um frasco de veneno. Se o medidor detectar que o átomo radioativo decaiu, ou seja, perdeu um elétron, o martelinho quebra o frasco, o veneno vaza e o gato morre (LAZARETTI, 2017).

Como a probabilidade desse átomo perder ou não um elétron é incalculável e, segundo o Princípio da Incerteza, a posição desse elétron ser múltipla: ele está tanto perto do núcleo atômico (o átomo não decaiu) quanto longe (o átomo decaiu) ao mesmo tempo. Sua posição "definitiva" só é determinada se alguém observá-lo. Assim, como a vida ou a morte do gato está diretamente ligada à posição do elétron, e este está em mais de um lugar ao mesmo tempo, o gato também está em um estado múltiplo: tanto vivo quanto morto. Então, se um observador abre a caixa e olha para dentro, ele imediatamente determina, por observação, em que posição o elétron está, o que também define a vida ou a morte do gato (LAZARETTI, 2017).

Da mesma forma que o Gato de Schrödinger, como o paradoxo ficou conhecido, a percepção humana do tempo é simultânea, o gato está vivo, pois foi colocado vivo na caixa no passado, o gato está morto porque é só uma questão de tempo até morrer, o gato está morto e vivo no presente pois as duas opções são temporalmente possíveis se o "eu" não constatou a condição do gato no "agora".

Nas histórias em quadrinhos o tempo é trabalhado pela relação espacial da solidariedade icônica na grade, ou seja, como no experimento de Schrödinger, os ícones são dispostos ao mesmo tempo na grade, e são as relações entre eles que terão o sentido de passagem do tempo, mesmo que não haja velocidade, como no cinema ou televisão. Algumas dessas relações são as formas de transições, o enquadramento e o fluxo.

No exemplo da tira de Samson (Figura 137, pág. 194), apesar do tempo que se gasta na leitura ser muito pequeno, a narrativa demonstra uma passagem de tempo diegética de aproximadamente quatro horas e desessete minutos, apenas com a variação da posição nos ícones que formam o relógio. 

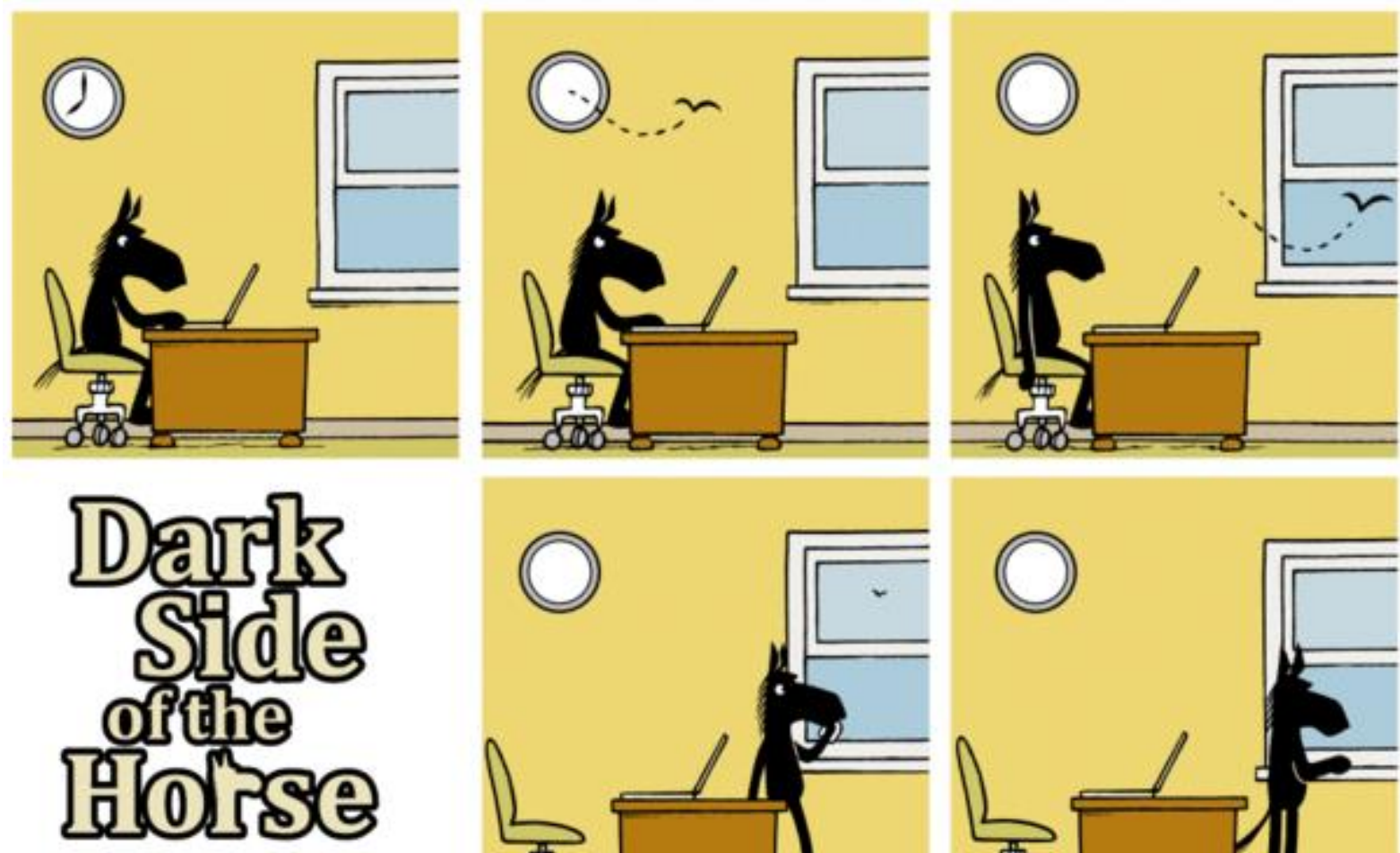

by samroll
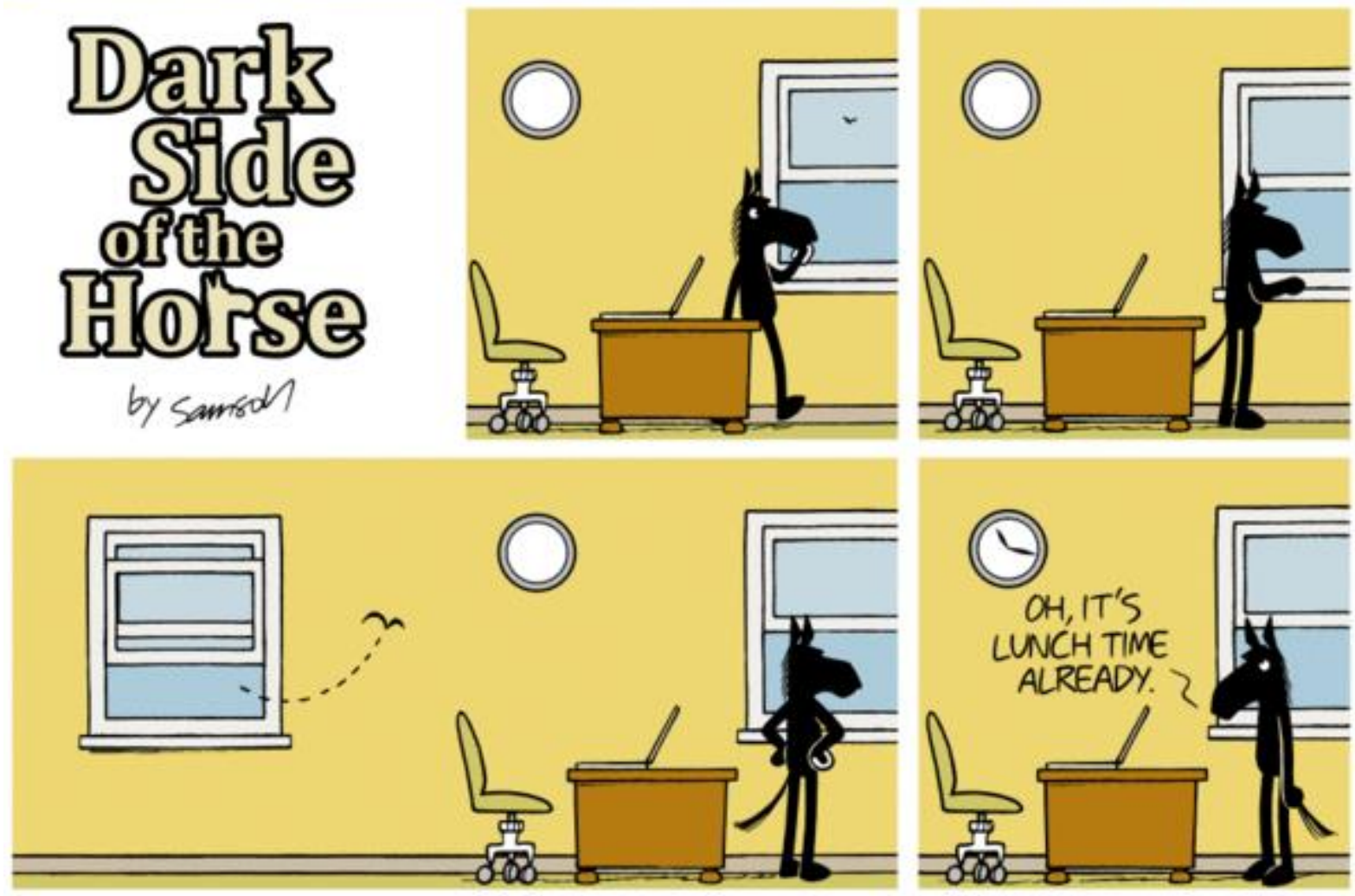

Figura 137 - Dark Side of the Horse de Samson ${ }^{1 \times x \times v}$

Para o professor Cagnin, o narrador na história em quadrinhos só aparece no título e nas legendas, segundo ele na $\mathrm{HQ}$ "não há uma narração propriamente dita, mas uma re-presentação do fato real ou fictício que é apresentado, de novo, ao espectador." (CAGNIN, 2014, p. 157) contudo, a narratividade da imagem na história em quadrinhos está muito mais próxima da construção poética do que da representação dramatúrgica, uma vez que tanto a imagem quanto a palavra terão seus significados recriados pelo leitor. Will Eisner aponta que "o espectador de um filme não tem como ver o quadro seguinte sem que o criador o permita", assim como o teatro, o filme tem absoluto controle sobre sua leitura. $O$ mesmo não acontece na $H Q$, nada impede que o leitor leia o último quadro da página antes do primeiro, veja 
primeiro as figuras e depois volte no texto, (EISNER, 2010) do mesmo modo que a forma do poema, principalmente concreto, é sentida antes de suas palavras.

Além da voz da legenda, há um narrador primário que guia todo o processo de desenvolvimento da realidade, aquele que descreve o mundo e o fluxo do tempo: a grade. O tempo nos quadrinhos é criado pelo espaço, na forma de articulação dos elementos que compõe a grade, de acordo com Mccloud "os narradores sempre quiseram duas coisas do público, que o leitor entenda a história que está sendo contada e que ele se importe o bastante para ouvir até acabar." (MCCLOUD, 2008, p. 8). As articulações temporais, chamadas de transições por McCloud, são a forma como o leitor vai ser guiado de um ícone a outro, ou principalmente na narrativa sequencial, de um quadro a outro.

No quadro único, como comentado anteriormente, o autor fará uso de alguns elementos contrastantes ou impactantes para chamar a atenção do leitor inserido na visão panótica da grade. Principalmente a tonalidade, a centralidade, e para elementos linguísticos, a ordem de leitura padronizada: ocidental da esquerda para direita, de cima para baixo, e oriental, da direita para esquerda, de cima para baixo.

Nas narrativas sequenciais, Groensteen aponta para a importância das transições entre os quadros para construir dois níveis de tempo, o tempo diegético e o tempo de leitura. Partindo do pressuposto da participação do leitor na construção de sentido, Groensteen destaca três formas transicionais: "the shown, the intervened, the signified" (o mostrado, o inferido e o significado) (GROENSTEEN, 2011, p. versão epub, 17\%). Já da perspectiva do autor, McCloud afirma que para conseguir a clareza e persuasão necessárias, que mova o leitor a acompanhar uma narrativa sequencial é preciso que o artista se preocupe com: o momento, o enquadramento e o fluxo (MCCLOUD, 2008, p. 10). Vale ressaltar que Eisner chama de "enquadramento", aquilo que McCloud específica como "momento", ou seja: a escolha ou o "congelamento" de um recorte de tempo que é segmento daquilo que é, na realidade, um fluxo ininterrupto de ação, que será encapsulado dentro da vinheta.

A representação dos elementos dentro do quadrinho, a disposição das imagens dentro deles e a sua relação e associação com as outras imagens da sequência são a "gramática" básica a partir da qual se constrói a narrativa. (EISNER, 2010, p. 40)

O enquadramento para McCloud é uma especificação da representação do momento escolhido, se refere aos vários pontos de vista que o encapsulamento de 
uma cena pode apresentar.

\subsubsection{Momento, enquadramento e transição}

Quando Eisner pensa o enquadramento, como artista, ele se refere no primeiro exemplo de seu livro (Figura 138, pág. 196), a um aspecto temporal, sobre um observador assistindo ao espetáculo da vida cotidiana como um filme ininterrupto, não selecionará um simples fotograma da sequência e sim fará uma construção que dê pistas ao leitor daquilo que veio antes e do que pode ser possível acontecer depois.

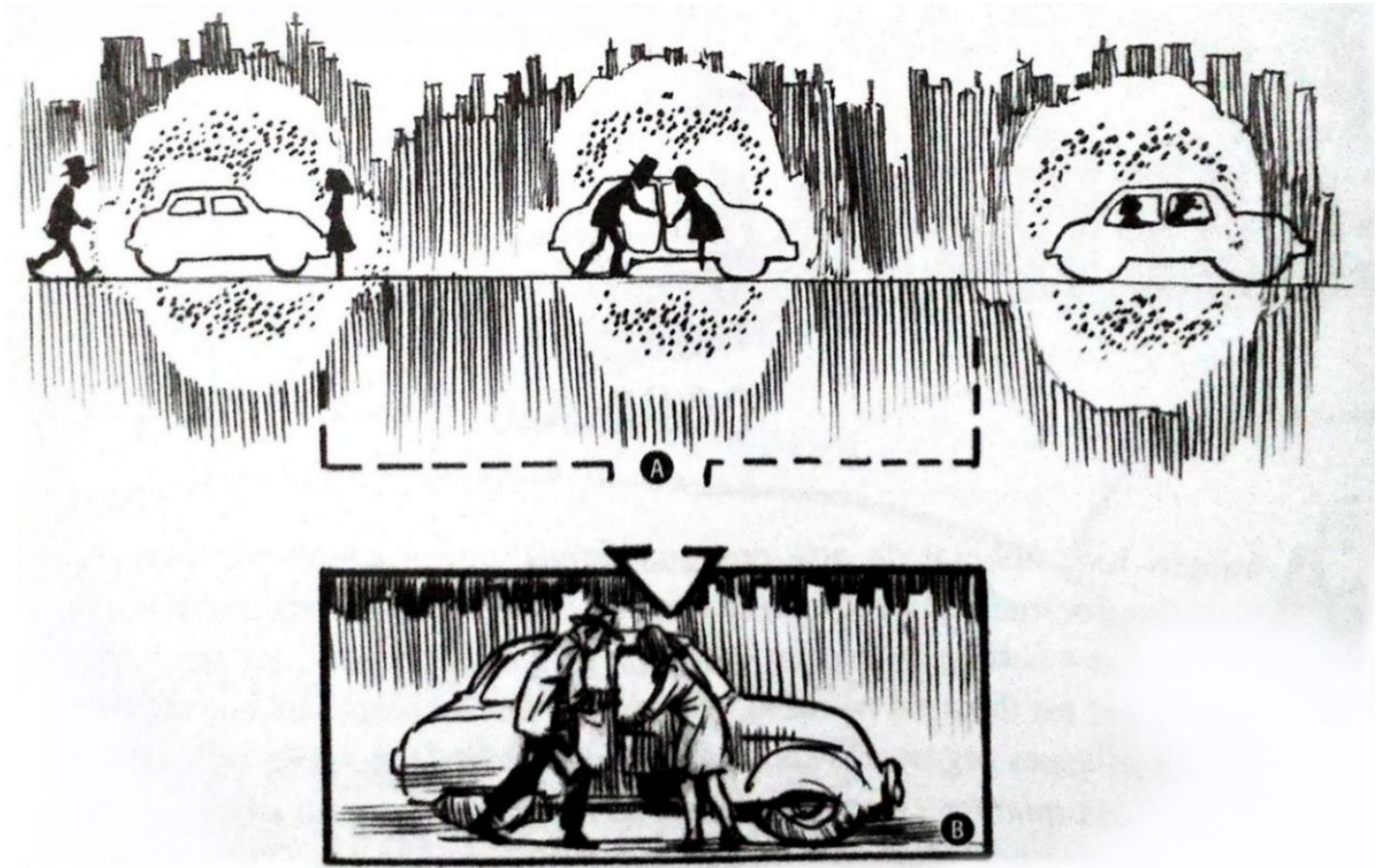

Figura 138 - (EISNER, 2010, p. 40) - Enquadramento

Da mesma forma, quando McCloud especifica o que é a "escolha do momento", seu exemplo é muito similar ao de Eisner, por indicar que a escolha dos momentos para a narrativa não é aleatória, e sim, são elencados os mais relevantes para a construção do significado. McCloud, na Figura 139, traça uma narrativa simples: "Um homem caminhando, vê um objeto no chão, se abaixa para apanhar o objeto, olhando de perto ele vê que é uma chave, continuando a andar, chega em uma porta, coloca a chave na fechadura, destranca a porta, da porta aberta surge um leão que salta sobre o homem.". 


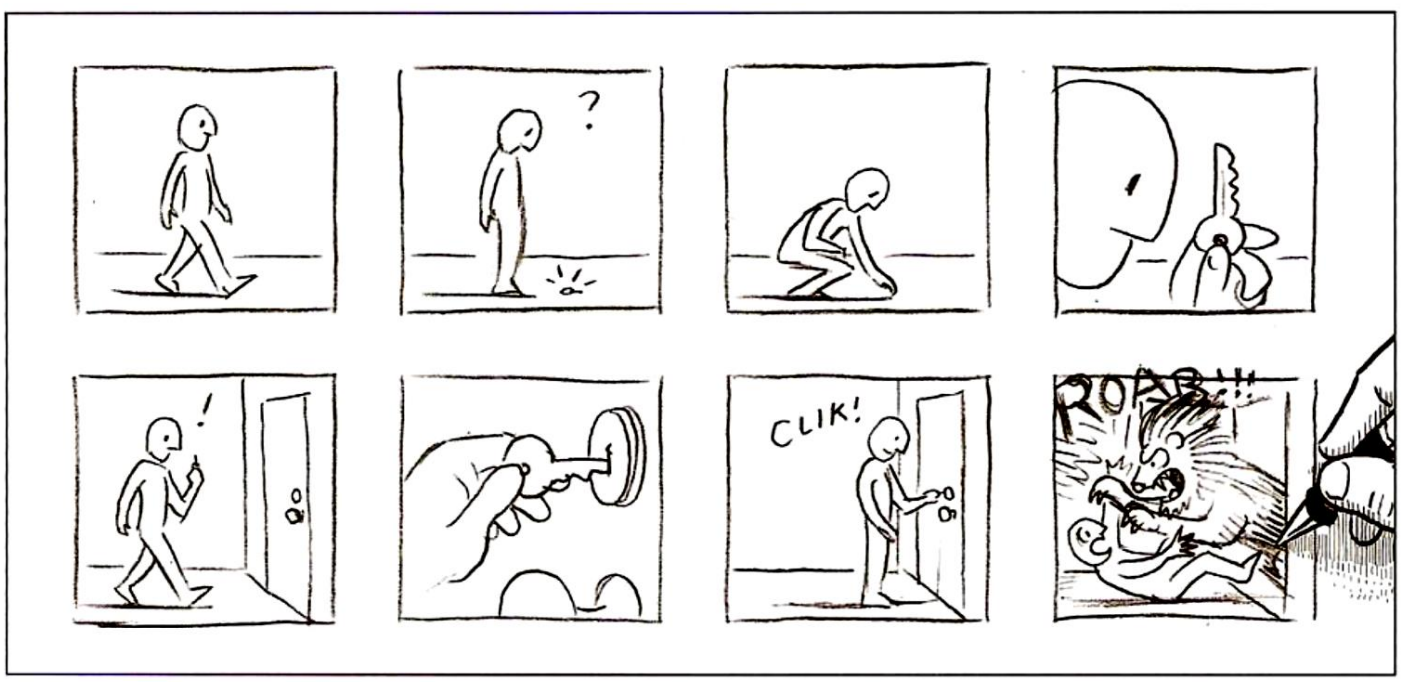

Figura 139 - (MCCLOUD, 2008, p. 12), quadro único, primeira linha

Cada um desses momentos poderia ter sido representado de uma forma diferente, e conter mais coisas na ambientação que agregariam outros significados, mas para explicar a trasicionalidade, McCloud deixa a representação o mais simples possível.

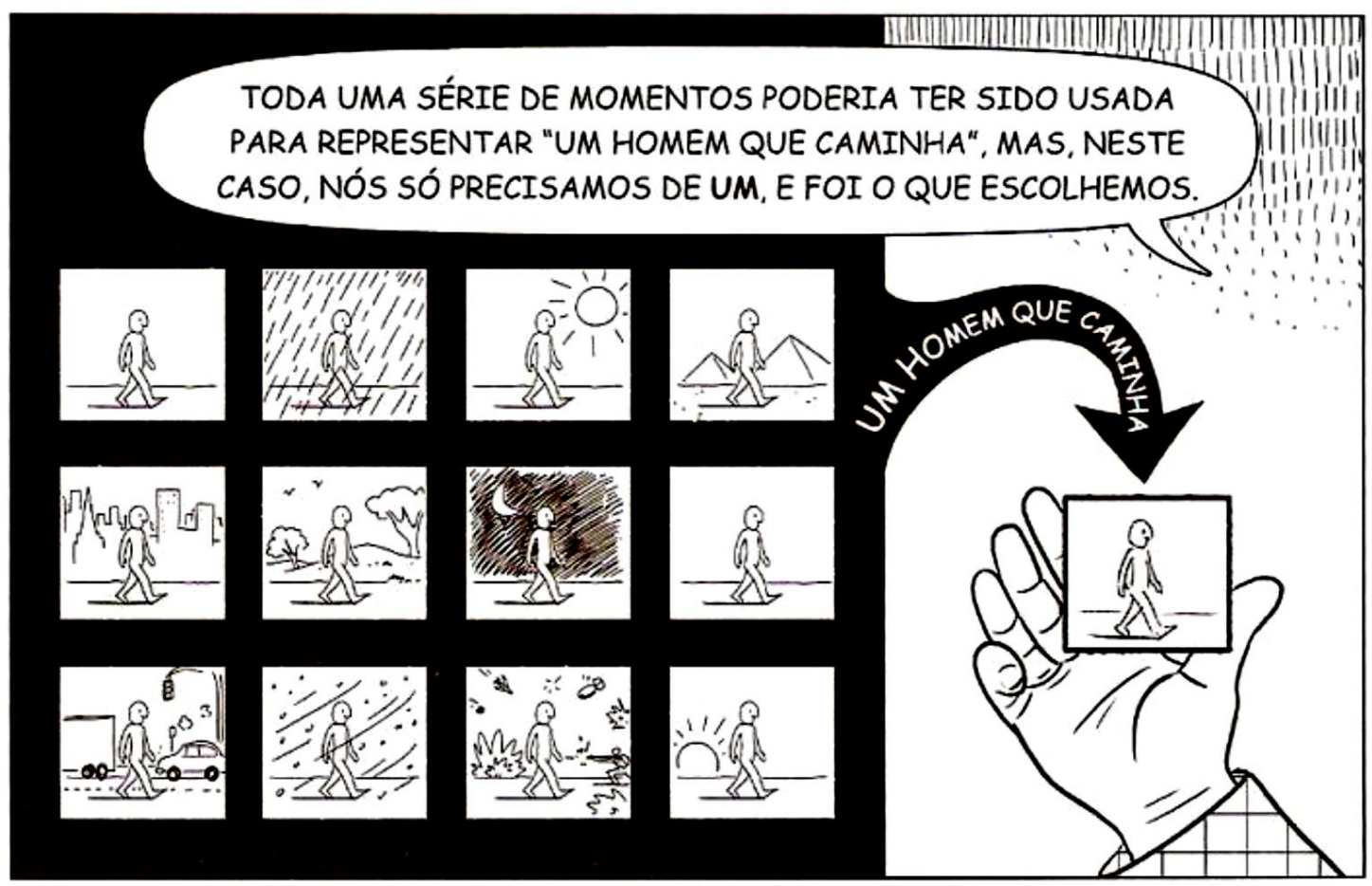

Figura 140 - (MCCLOUD, 2008, p. 12), quadro 2, última linha

Assim, parafraseando a narrativa da Figura 139 em frases verbais, ressaltam os seguintes momentos: 
Tabela 4 - Descrevendo os momentos

\begin{tabular}{|l|l|}
\hline Momento 1 & Um homem caminhando; \\
\hline Momento 2 & encontra algo no chão; \\
\hline Momento 3 & se abaixa para apanhar o objeto; \\
\hline Momento 4 & olhando de perto, o homem vê que é uma chave; \\
\hline Momento 5 & continuando a andar, chega em uma porta; \\
\hline Momento 6 & coloca a chave na fechadura; \\
\hline Momento 7 & destranca a porta; \\
\hline Momento 8 & da porta aberta surge um leão que salta sobre o homem. \\
\hline
\end{tabular}

O enquadramento, para McCloud, é a forma como o momento será mostrado ao leitor, é escolha da distância e do ângulo para ver esses momentos. Segundo Nobu Chinen, refere-se à aproximação do observador em relação à cena (CHINEN, 2011, p. 36).

Toda escolha de imagens é intencional, e carrega uma mensagem, o tipo de recorte de uma cena em si é carregado de significado, transparece a intenção do autor em direcionar o olhar do leitor na construção de sentido. Nem mesmo uma fotografia está isenta de intencionalidade e de manipulação. Abaixo o exemplo de uma foto veiculada nas redes sociais pela IMPERV Studio como exemplo manipulação midiática, que sugere que no lado esquerdo a rede Al Jazeera teria veiculado somente a cena de um soldado iraquiano sendo ameaçado por um fuzileiro americano, e no lado direito a rede CNN teria veiculado somente o fuzileiro americano servindo água ao soldado iraquiano ferido, e no meio em evidência, "a verdade".

A foto original do fotógrafo japonês Itsuo Inoye foi tirada no Iraque em 21 de Março de 2003, e retrata fuzileiros americanos que ajudam um soldado iraquiano com água no sul do Iraque quando cerca de 200 soldados iraquianos se renderam ao U.S. 15th Marine Expeditionary Unit quando a unidade cruzou a fronteira vinda do Qu'aiti (AP, March 21, 2003). 


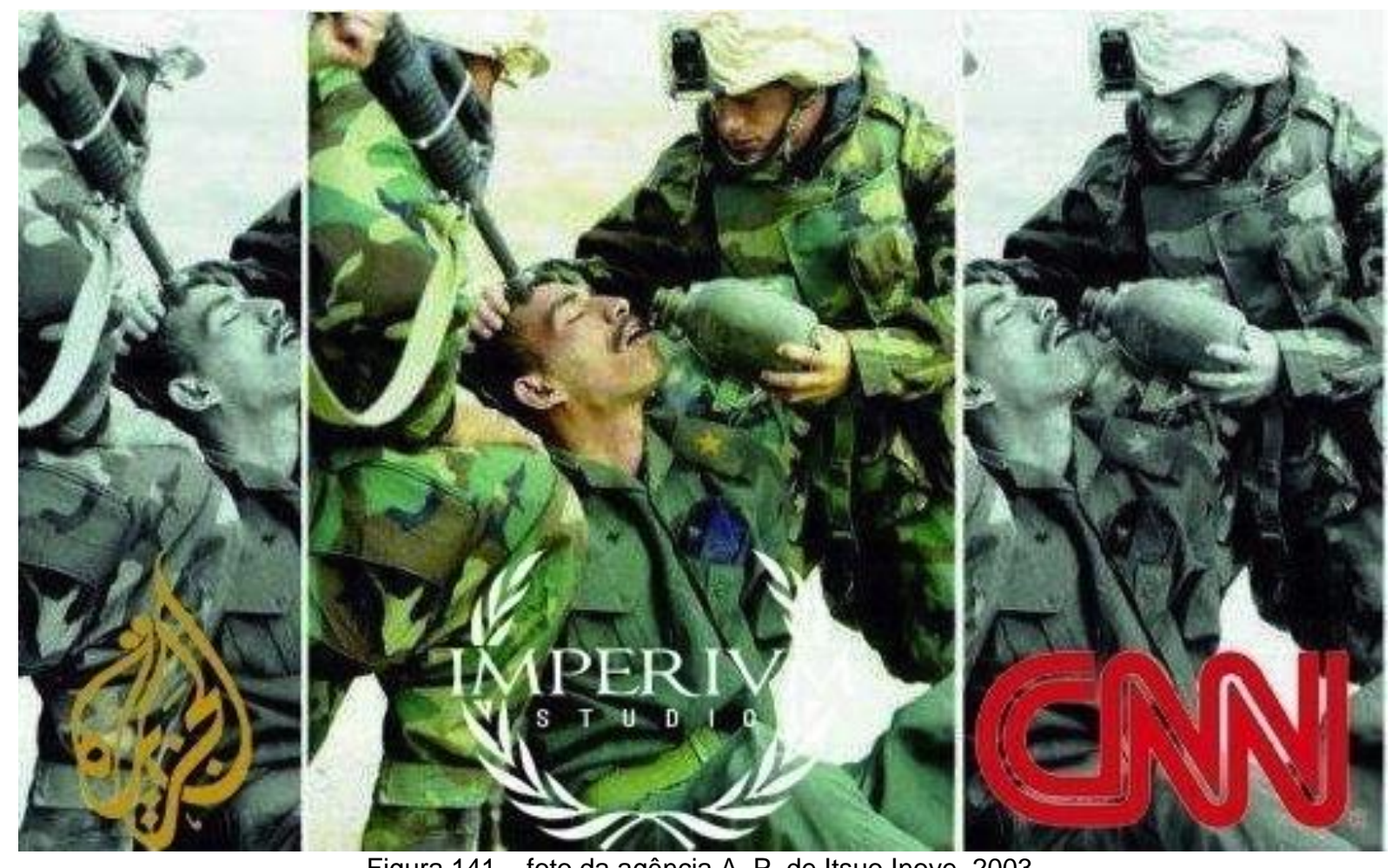

Figura 141 - foto da agência A. P. de Itsuo Inoye, 2003.

O enquadramento, o recorte escolhido de uma cena altera a mensagem e a significação da narrativa de acordo com a direção que o autor pretende guiar o leitor. A composição de uma $\mathrm{HQ}$ está consciente do olhar do leitor, isso porque os leitores dão importância às coisas colocadas no centro, como um personagem, um movimento, uma distância, uma ausência ou o invisível objeto da atenção de um personagem. Naturalmente o olhar do leitor segue do centro para as bordas. Na foto de Inoye, o destaque no centro é o soldado, no recorte à esquerda, a arma, no recorte à direita, o cantil. É dessa mesma forma que a relevância de uma informação é colocada em uma cena de $\mathrm{HQ}$.

Mccloud acrescenta que o enquadramento é onde fatores de composição como recorte, equilíbrio e inclinação afetam as impressões que os leitores têm do mundo criado pelo artista, e a posição deles nesse mundo (MCCLOUD, 2008, p. 19). O enquadramento sempre se dá sob o ponto de vista do leitor, onde 0 artista 0 posiciona na cena, que pode ser: ao nível do olho, como se o leitor estive olhando a cena de frente; vista de baixo, como se o leitor estivesse olhando para cima; de cima para baixo; visão ampla, abarcando vários detalhes da cena ou reduzida, tanto em foco médio (do tronco para cima, ou para baixo) ou close-up em detalhes muito próximos, e ainda a vista panorâmica para criar a ambientação e mostrar ao leitor onde a história se encontra. Ao falar da representação do personagem, Eisner aponta 
para a importância da inferência do leitor ao completar um enquadramento:
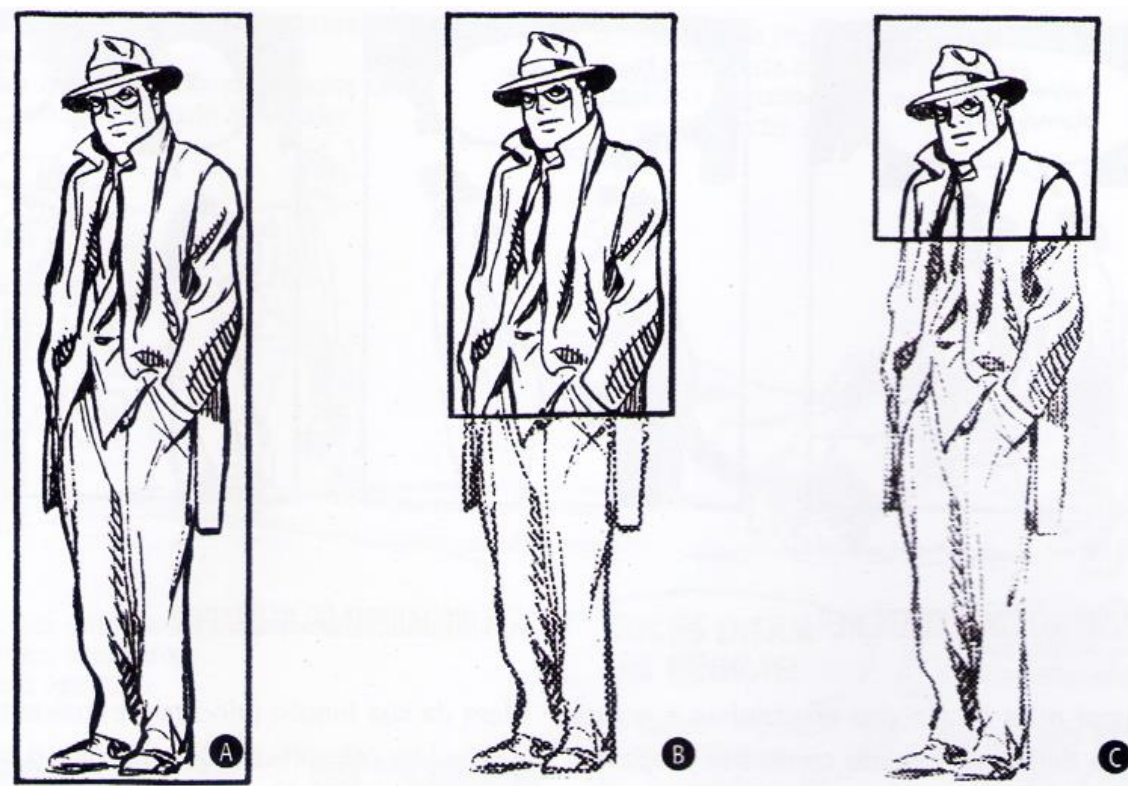

Conforme Eisner,

Figura 142 - (EISNER, 2010, p. 43), primeira figura

(A) FIGURA INTEIRA - a figura mostrada inteira não requer nenhuma sutileza de percepção. Ela não solicita nada da imaginação ou do conhecimento do leitor. (B) MÉDIA - Espera-se que o leitor complete o resto da imagem, dada uma alusão generosa a respeito de sua anatomia. (C) CLOSE-UP - Esperase que o leitor suponha a existência da figura inteira deduzindo a postura e os detalhes a partir da memória e da sua experiência (EISNER, 2010, p. 43).

Os estereótipos também são usados para direcionar a inferência do leitor:
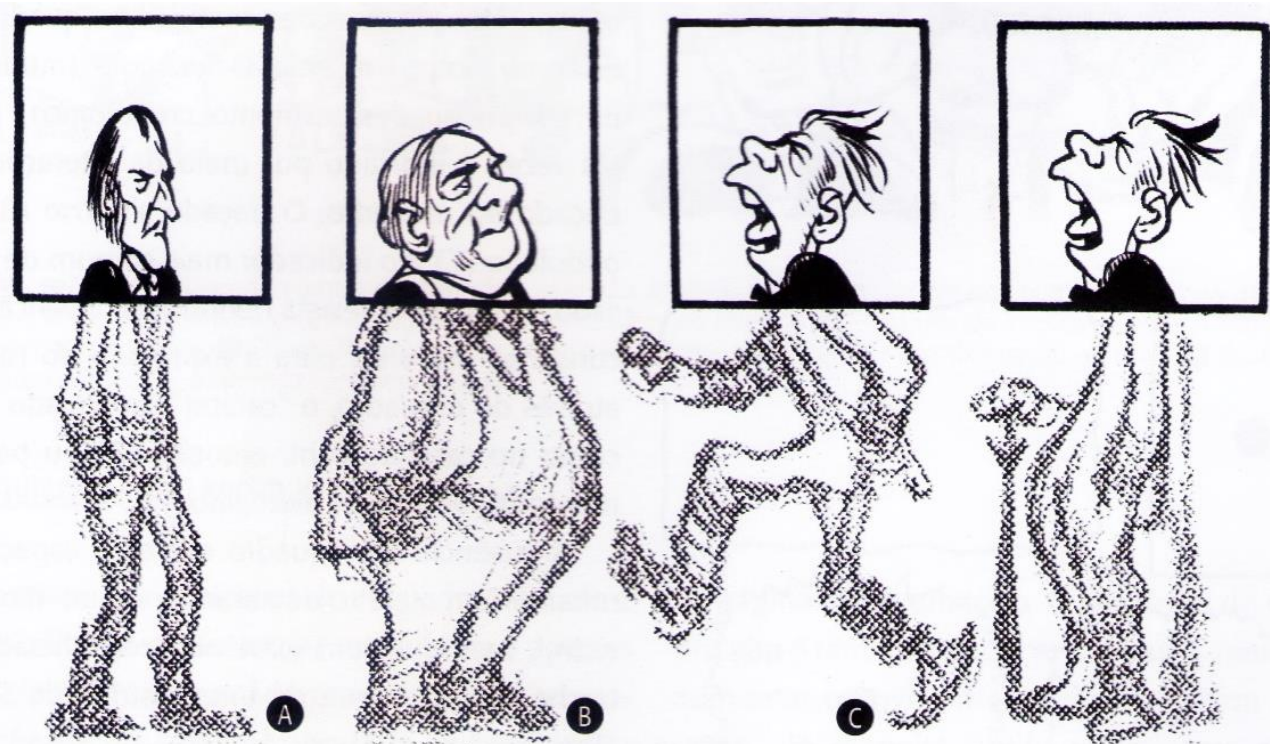

Figura 143 - (EISNER, 2010, p. 43), segunda figura 
(A) A cabeça magra sugere um corpo magro. (B) A cabeça gorda sugere um corpo gordo. É claro que a visão subsequente dos personagens é que vai consubstanciar esses pressupostos. (C) A ilustração, porém, mostra que pode ocorrer uma leitura errônea das intenções do artista, a menos que um desenho mais habilidoso seja executado no próprio quadrinho ou que um quadrinho anterior tenha estabelecido o que o leitor está vendo (EISNER, 2010, p. 43).

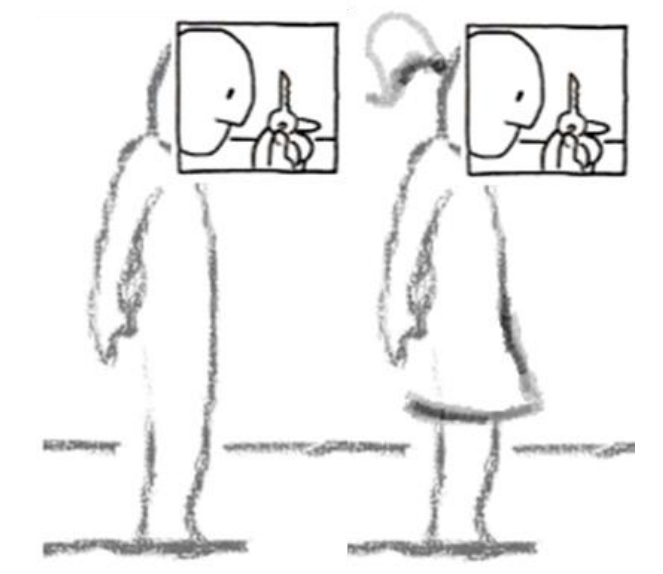

Figura 144 - montagem usando decalque de McCloud como base

A abordagem de Eisner explica por que o close-up do exemplo de McCloud não causa estranhamento na sequência de eventos, o leitor infere automaticamente que se trata do mesmo personagem inicial e que ele mantém o mesmo corpo e, provavelmente, a mesma postura. $O$ leitor não tem por que inferir que a figura completa será outra que não a apresentada.

A transição é a mudança de um momento a outro, é a forma como o leitor constrói a informação que está entre uma cena e outra. Mas essa transição nem sempre foi considerada "óbvia", conforme ressalta Joseph Witek, pesquisador de quadrinhos e professor de artes criativas da Stetson University - Flórida, muitos artistas do início do século 20, como R. F. Outcault, Winsor McCay, James Swinnerton, George Herriman, Rudolph Dirks, Fred Opper, entre outros, numeravam cada quadro (normalmente em algum canto inferior) para indicar a ordem de leitura. A construção de certa automaticidade da transição de uma cena a outra, de acordo com Witek, foi construída através do tempo, com o hábito de leitura (WITEK, 2009, p. 150).

História em quadrinhos possui uma linguagem elástica que se adapta ao contexto de criação, por isso estudos que restringem suas acepções tentando delimitar suas fronteiras acabam, como alerta Witek, em "endless profusion of 
disputed boundary cases and contradictory counterexamples ${ }^{114 "}$ (WITEK, 2009, p. 149).

Witek aponta que,

Since visual narratives and word/picture combinations of various kinds are so plentiful throughout the history of human communication [...] the delicate negotiation between sequentiality and simultaneity which we now call "comics" came into being not as the fulfillment of a previously latent formal essence but as the emergence in stages of new ways of perceiving the myriad relationships between word and image on the page. Together they show how the once-unfamiliar reading conventions of the comics audience can eventually come to be both assumed and manipulated by comics creators in the construction of the comics page ${ }^{115}$ (WITEK, 2009, p. 149-150).

A aquisição dessa naturalidade em ler as transições entre imagens é partilhada em toda narrativa sequencial, o livro "Uma chapeuzinho vermelho" de Marjolaine Leray, por exemplo, apresenta uma variação sequencial de uma cena por página à uma cena por por duas páginas. Essa organização sequencial oferece ao leitor uma relação de continuidade vertical nas transições entre as imagens. No ocidente, ao convívio com essa estrutura de grade, o leitor passa a esperar que a continuação da narrativa se dará na próxima página, da esquerda para a direita, com a comprovação dessa expectativa, o leitor adquire essa competência e passa a inferir essa lógica nas próximas leituras.
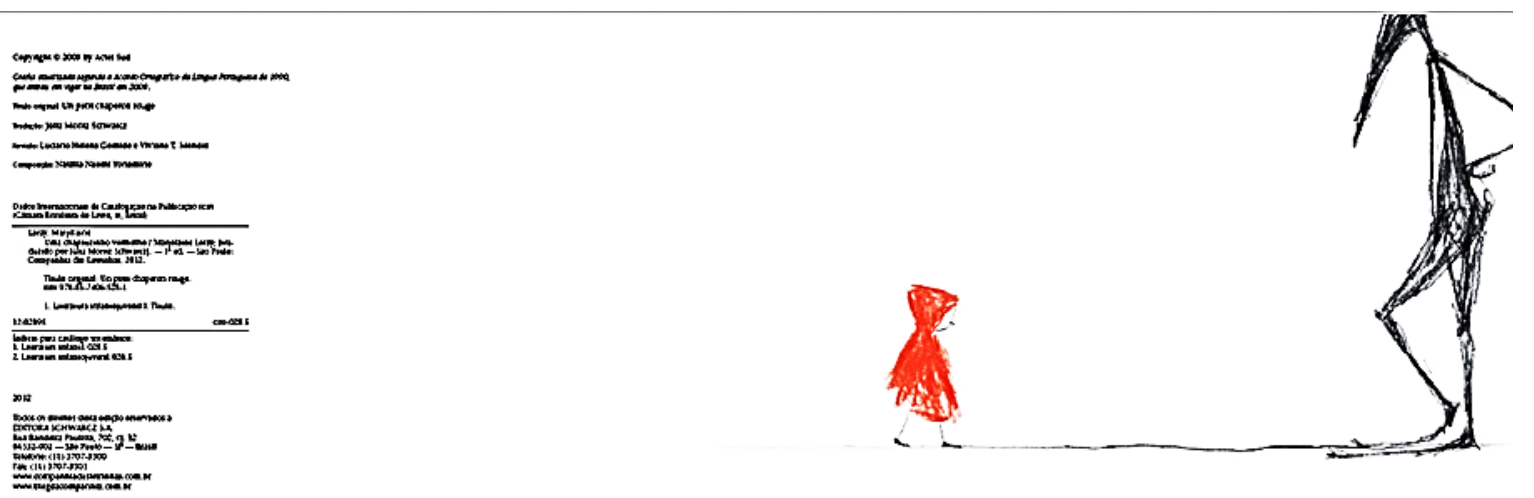

Figura 145 - Uma Chapeuzinho Vermelho, Marjolaine Leray - folha de guarda (esquerda) pagina 1 (direita)

\footnotetext{
114 Profusão sem fim de caso de disputa de fronteiras e contra-exemplos contraditórios. (WITEK, 2009, p. 149) [tradução da autora].

115 Uma vez que narrativas visuais e cominações de palavra/imagem de vários tipos são tão abundantes ao longo da história da comunicação humana [...], a delicada negociação entre sequencialidade e simultaneidade a que chamamos de "quadrinhos" não passou a existir em consequência da materialização de uma essência formal anteriormente latente, mas como o surgimento em etapas de novas maneiras de perceber a miríade de relações entre a palavra e a imagem na página. Juntos, eles mostram como as convenções de leitura até então desconhecidas da audiência de quadrinhos pôde eventualmente tanto ser presumidas quanto manipuladas por criadores de quadrinhos na construção da página de quadrinhos (WITEK, 2009, p. 149-150) [tradução da autora].
} 


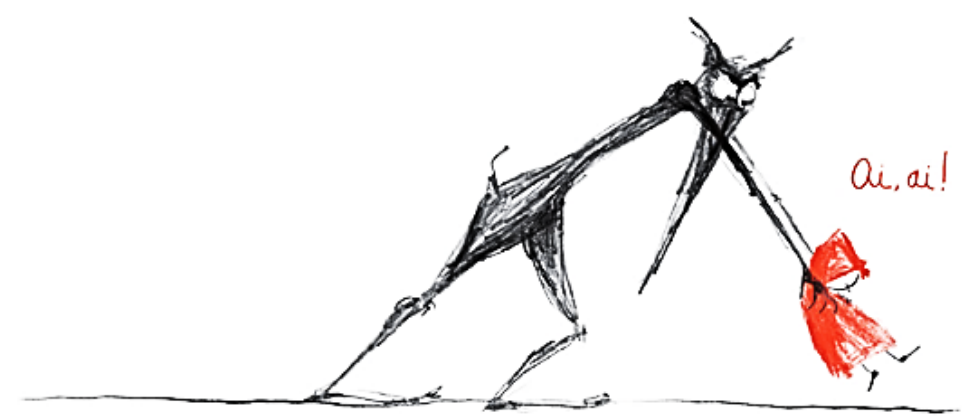

Figura 146 - Uma Chapeuzinho Vermelho, Marjolaine Leray - página 2 (esquerda) pagina 3 (direita)
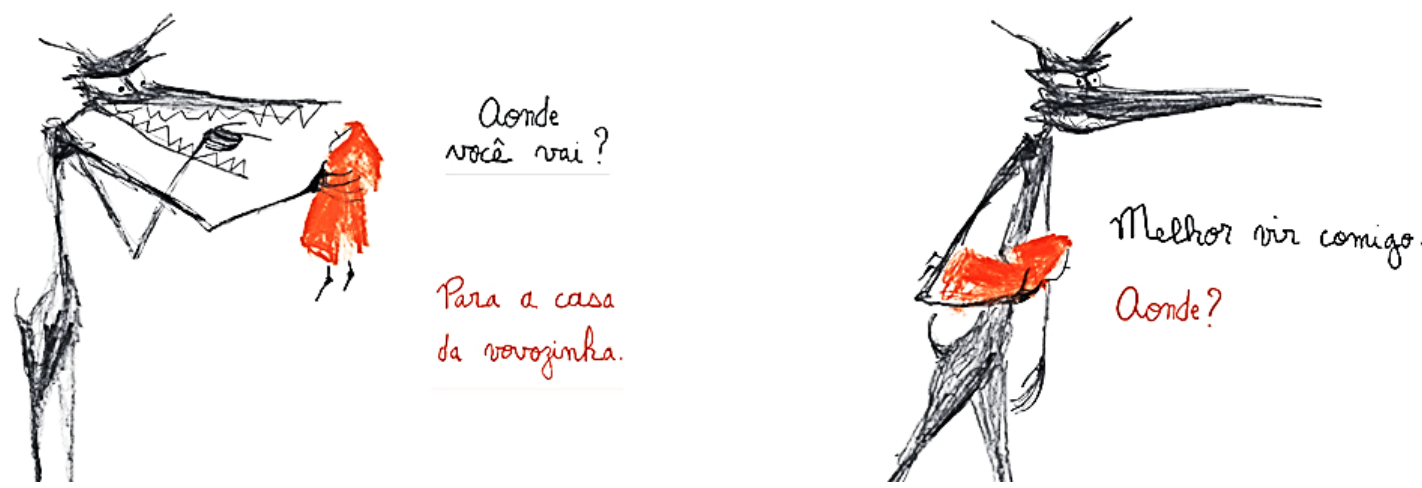

Figura 147 - Uma Chapeuzinho Vermelho, Marjolaine Leray - página 4 (esquerda) pagina 5 (direita)

O mesmo se dá com a tira de jornal, que segue a mesma ordem de transição sequencial horizontal da esquerda para direita. O leitor se acostuma que o primeiro quadro é o inicio da pequena narrativa e o último quadro o final, e mesmo podendo lê-los em qualquer ordem - uma vez que panopticamente tem acesso ao todo da obra - condiciona-se a privilegiar a ordem de leitura que lhe é mais habitual, para acessar a diegese de modo mais fácil.
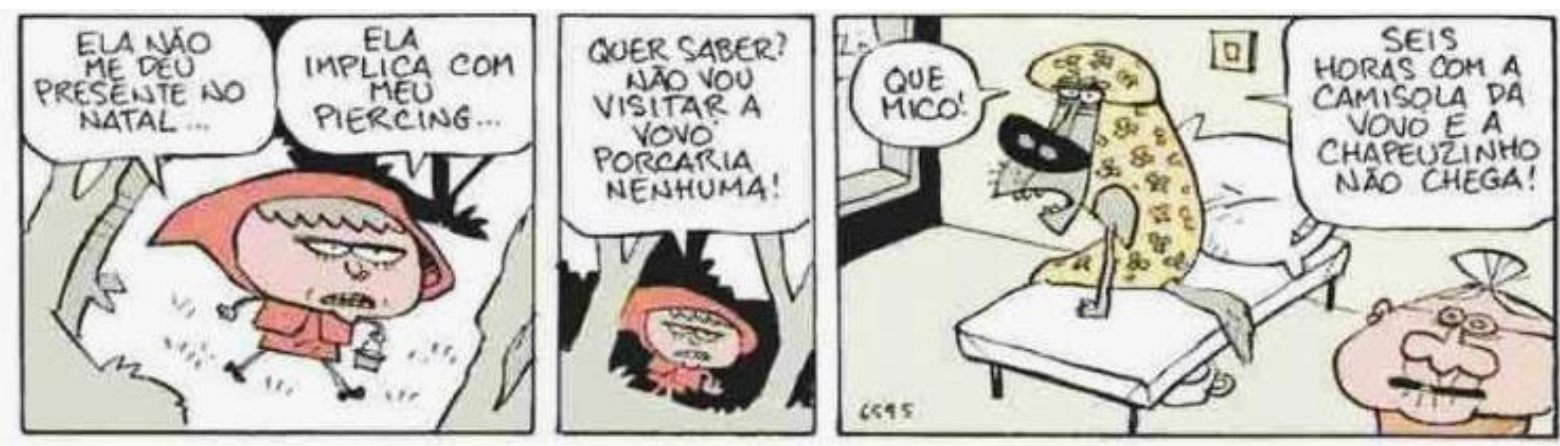

Figura 148 - Níquel Nausea - Fernando Gonzales - Jornal Folha de São Paulo, 22/07/11 p.E11

Deduzir que haverá uma sequencialidade vertical de uma cena a outra não é a única forma de interação em que o leitor confere sentido as transições entre imagens. Groensteen, ressalta que a narrativa sequencial força o leitor a vários níveis de inferência. 
The discontinuity that is the basis of the language of comics forces the reader to make inferences in order to interpret each new image appropriately, that is to say to ensure that it correlates with the previous one and to the wider context of the whole text within which it occurs ${ }^{116}$ (GROENSTEEN, 2011, p. versão ebook, 17\%)

Para Groensteen, do ponto de vista da interpretação de sentido pela inferência do leitor, há três tipos de transição: mostrado, inferido e significado. A sequência simples do exemplo de McCloud, faz parte do tipo de transição "mostrada". Isso porque o grau de inferência do leitor quanto ao que acontece entre um momento e outro é mínimo.

Para exemplificar a escolha entre os momentos importantes para construção do sentido e aqueles que seriam supérfluos, McCloud utiliza a sequência da Figura 149, parafraseada na tabela abaixo tópico (A):
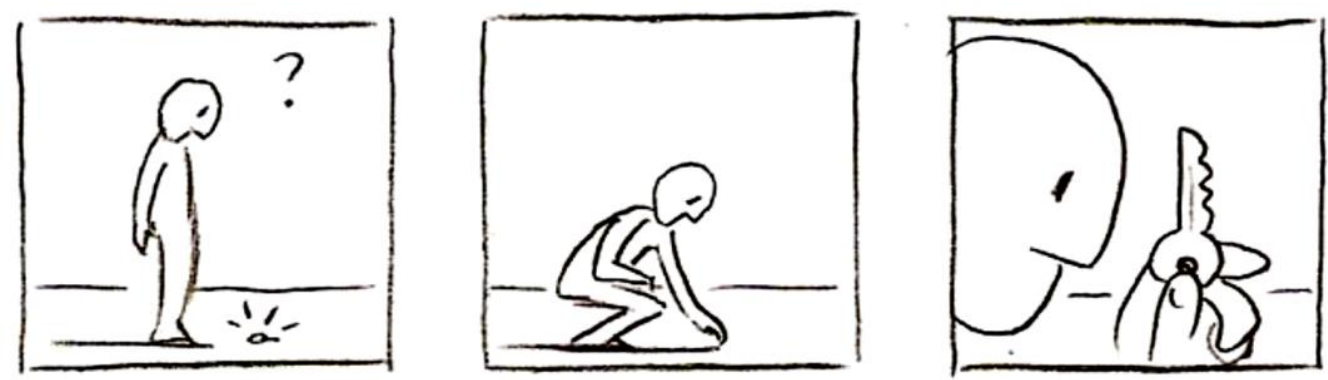

Figura 149 - (MCCLOUD, 2008, p. 14), quadro 1, última linha - extraídos somente os quadros de exemplo

$\mathrm{Na}$ Figura 150, McCloud detalha essa transição adicionando mais momentos, parafraseada na tabela abaixo no tópico (B):
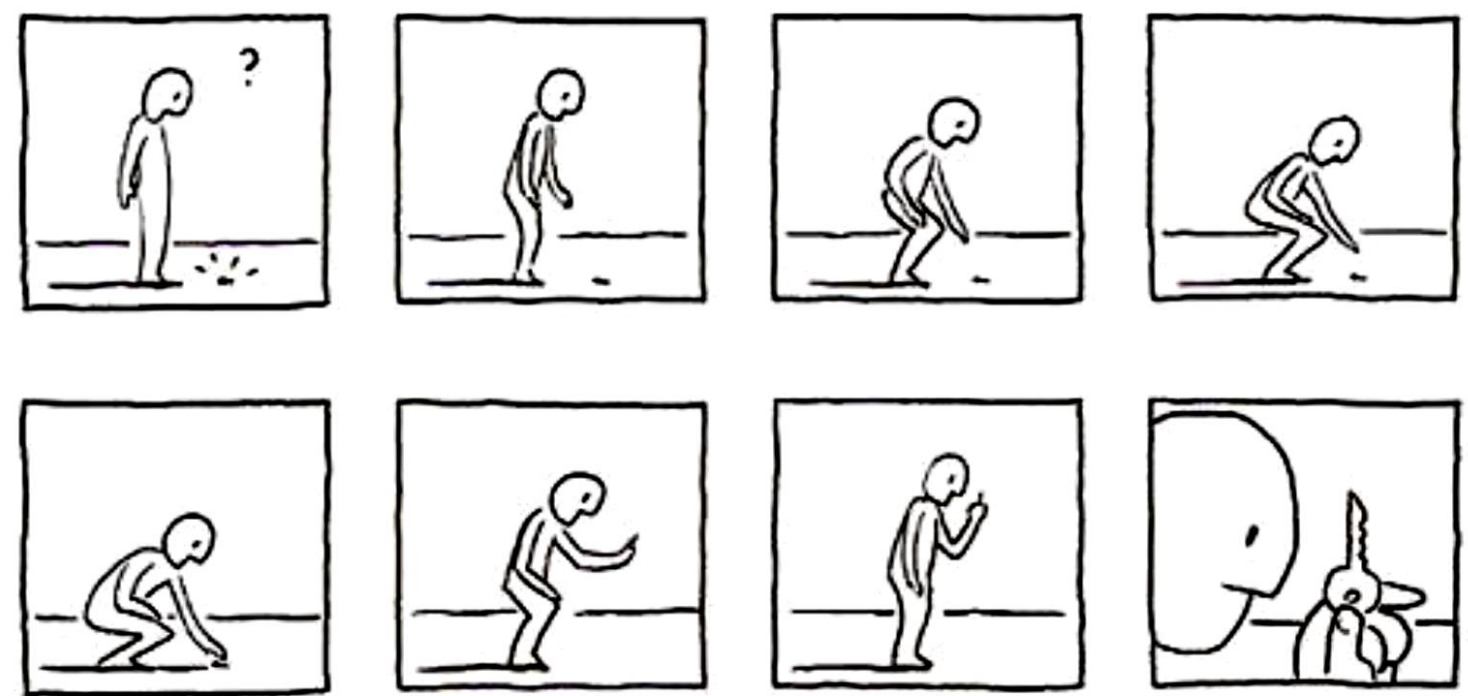

Figura 150 - (MCCLOUD, 2008, p. 14), quadro 2, última linha - extraídos somente os quadros de exemplo

${ }^{116}$ A descontinuidade que é a base da linguagem dos quadrinhos força o leitor a fazer inferências para poder interpretar adequadamente cada nova imagem, isso para assegurar que ela se correlaciona com a anterior e com o contexto mais amplo do texto no qual ocorre (GROENSTEEN, 2011, p. versão ebook, 17\%) [tradução da autora]. 
Tabela 5 - Parapraseando sequencia imagética

\begin{tabular}{|l|l|}
\hline A) Figura 149 & $\begin{array}{l}\text { O homem encontra algo no chão, se abaixa para pegar o objeto e } \\
\text { percebe que é uma chave; }\end{array}$ \\
\hline B) Figura 150 & $\begin{array}{l}\text { O homem encontra algo no chão, flexiona os joelhos, se agacha } \\
\text { e aproxima sua mão do objeto, pega o objeto, o traz para } \\
\text { próximo dos olhos e o examina, percebe que é uma chave. }\end{array}$ \\
\hline
\end{tabular}

No texto escrito, o prolongamento da frase com a adição de mais detalhes não interfere no tempo da ação do personagem diferente da narrativa imagética. A diferença entre a frase (a) e a frase (b) é que a imagem mental que o leitor produz da cena não será tão detalhada na primeira quanto na segunda. Em ambas o tempo de duração da ação é igual, mesmo que o tempo de leitura seja distinto. Já na narrativa imagética, o leitor espera que determinada imagem tenha um significado, uma razão pela qual a cena existe na sequência, como agregador de significado. Se a mesma cena, ou uma variação pequena dela, se repete, isso dá a impressão de que a ação do personagem está se prolongando, sendo realizada lentamente, e o leitor vai tentar inferir a razão dessa lentidão.

Por exemplo, uma possível inferência à leitura da Figura 150, pode ser esta:

O homem encontra algo no chão. Ele hesita, mas decide examinar o objeto. Com dificuldade ele flexiona os joelhos, deve ser um velho. Quase ao alcance do objeto, ele hesita novamente, deve estar se perguntando se deve pegar a coisa. Já agachado, ele cede à curiosidade, e aproxima sua mão do objeto. Assim que pega o objeto, ele começa a se levantar lentamente. Ele não consegue identificar o objeto de longe, provavelmente tem a vista ruim, por isso o traz para próximo dos olhos para examiná-lo e percebe que é uma chave.

A caracterização imagética do personagem de McCloud é extremamente simples, não detalhando a idade do personagem, mas se a cena dele se abaixar merece tanto destaque, o leitor vai inferir que há uma razão não explícita para isso. É nesse sentido que Einser aponta que o enquadramento de um momento contém aquilo que veio antes, e o que virá após, pois na sequência da Figura 149, os quadros suprimidos da Figura 150, são de inferência automática para o leitor, ou como dito por Groensteen, são somente o curso de ação possível. Não há como o personagem sair da posição em pé, para agachado no chão, sem que envolva o fato de ter flexionado as pernas e se abaixado, da mesma forma não há como sair de pegar a chave no chão e estar com ela próxima ao rosto, se não houvesse o ato de aproximar a mão do rosto. 
Apesar de continuar sendo óbvio o curso da ação entre a cenas que compõem a Figura 149 e as cenas da Figura 150, a forma de inferência do leitor é variada. Na segunda, apesar de serem mais "mostrados" os atos, e a correlação entre o anterior e o posterior, mais evidente, a sensibilidade do leitor é atingida de forma distinta, forçando-o a explorar os detalhes da cena para conferir uma relação de significado não só imediata (entre um quadro e outro), mas no todo do texto (na relação do quadro com a obra).

A relação temporal diegética de uma sequência de momentos determina a quantidade de inferência que o leitor vai dedicar a interpretação da narrativa. Por exemplo, McCloud cita que uma transição "momento a momento" dá ênfase a uma só ação, retratando-a em uma lenta progressão. Essas transições retardam a cena, causando um efeito de suspense e expectativa.

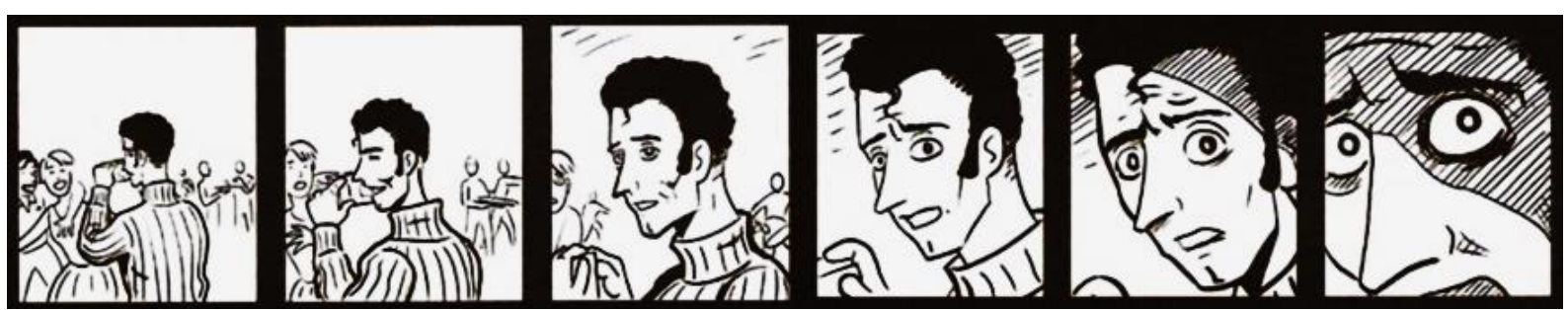

Figura 151 - (MCCLOUD, 2008, p. 16) - momento a momento

Já uma transição "ação a ação" transfere o enfoque ao personagem, o que produz um ritmo acelerado da narrativa.
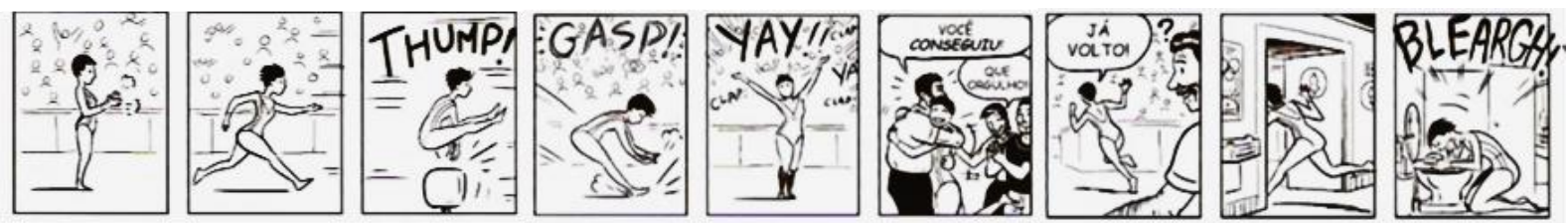

Figura 152 - (MCCLOUD, 2008, p. 16) - ação a ação

Na transição "sujeito a sujeito", a alternância dos personagens dentro de uma única cena, supende o tempo diegético mesmo mantendo o ritmo narrativo acelerado.
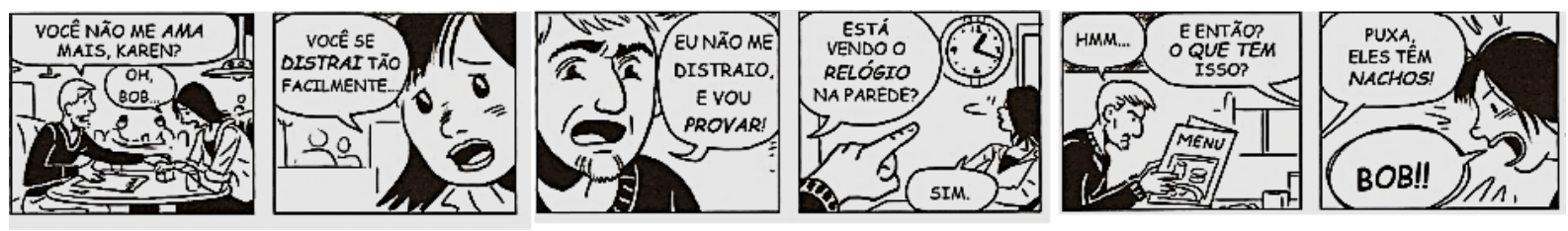

Figura 153 - (MCCLOUD, 2008, p. 16) - sujeito a sujeito

Transições do tipo "cena a cena" permitem transições significativas entre tempo e/ou espaço. Ajudam a contar uma história em extensões diferentes, permitindo diversos intervalos de tempo e uma variedade de locais. 

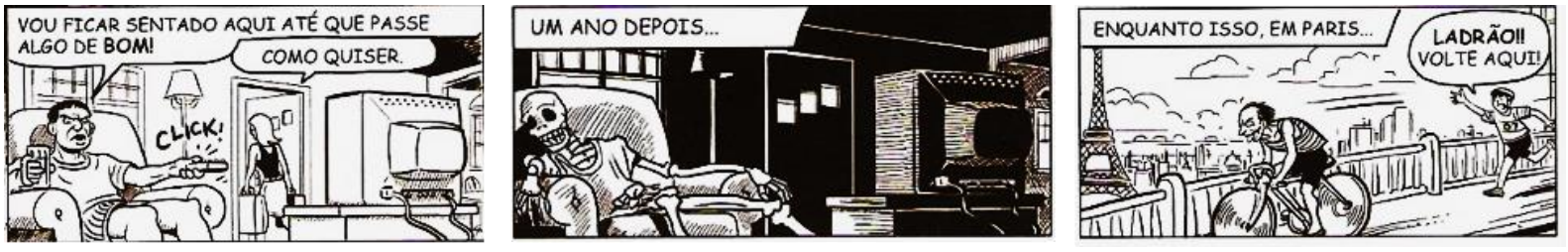

Figura 154 - (MCCLOUD, 2008, p. 17) - cena a cena

Transições "aspecto a aspecto" lugares, idéias ou estado de espírito. Muito usadas no Japão, são transições que paralisam o tempo, enquanto o leitor infere significado e relações subjetivas dos quadros entre si e com a obra, muitas vezes conferindo à narrativa uma aclimatação peculiar.
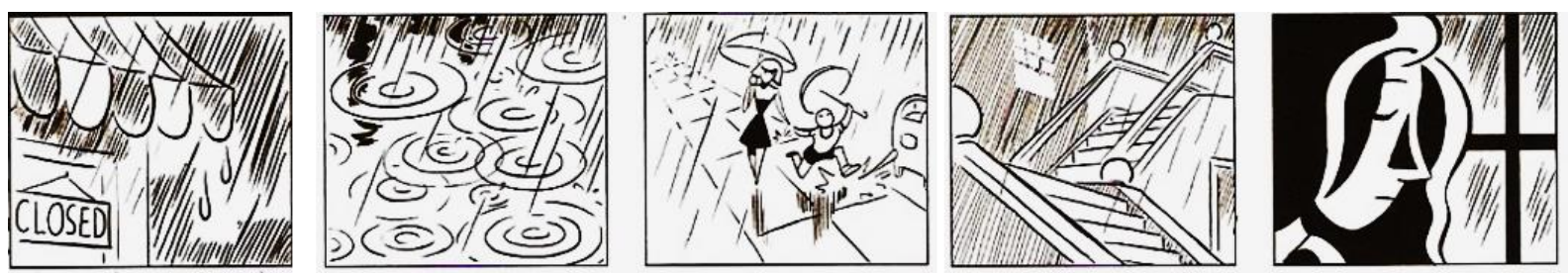

Figura 155 - (MCCLOUD, 2008, p. 17) - Aspecto a aspeto

A transição "non sequitur" (não se segue), que consiste em uma série de imagens ou palavras aparentemente não relacionadas e absurdas. Apesar de também exigirem do leitor um grande esforço de inferência, não paralizam o tempo da narrativa, como a alternância de apecto, pois aguçam a sensibilidade do leitor em outro nível, aproximando-se muito da provocação poética.

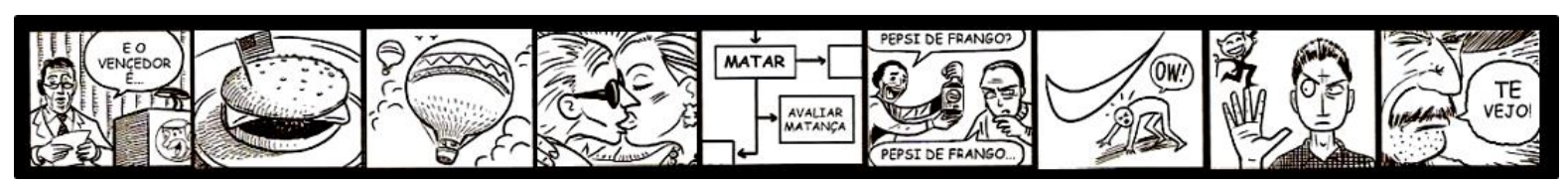

Figura 156 - (MCCLOUD, 2008, p. 17) - Non sequitur

Esses exemplos não esgotam as realizações de transições nos quadrinhos, a criatividade dos artistas em induzir a percepção e inferência dos leitores muito além da transição quadro-a-quadro. Por exemplo a tensão entre tempo e espaço nas páginas de "Gasoline Alley" de Frank King publicada de 1918 a 1959. Na Figura 157, página 208, um único espaço imutável ocupa toda a grade, o que muda é a posição dos personagens quadro a quadro, em uma variação temporal. Simulando a alteração da posição das personagens ao longo do espaço. Essa página é um exemplo da visão panóptica que o leitor possui e seu controle sobre a visualização do espaço. Como já ressaltado por Eisner,

[...] não existe modo algum pelo qual o artista possa impedir a leitura do último quadrinho antes da leitura do primeiro. O virar da página força mecanicamente certo controle, mas não de modo tão absoluto como ocorre no cinema (EISNER, 2010, p. 40). 


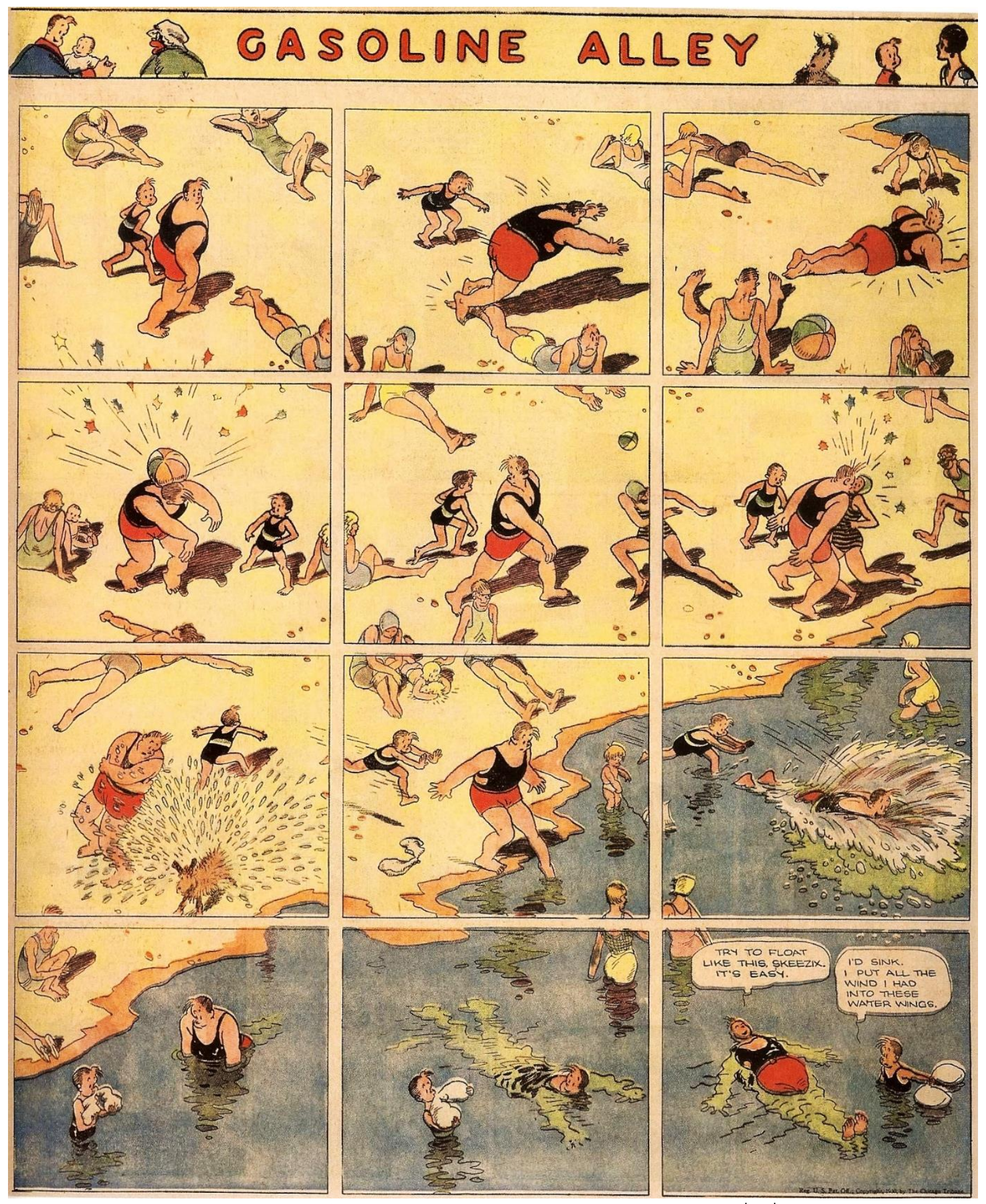

Figura 157 - Gasoline Alley - Frank King - 24 de Agosto $1930^{\mid \mathrm{Ix} \times x \mathrm{i}}$

A graça da narrativa está na dualidade de percepção do leitor em relação ao espaço e o tempo. Ao mesmo tempo que mantém a consciência do espaço total, acompanha os espaços de tempo em que as personagens interagem com esse espaço.

O livro "Bruxa, bruxa, venha a minha festa" com roteiro de Arden Druce e ilustração de Pat Ludlow, possui uma grade de página dupla (esquerda e direita) com 
uma imagem única dividida em dois momentos de tempo. O leitor alfabetizado (o livro possui na contracapa indicação de leitura das imagens a partir de 2 anos e leitura total a partir dos 6) tem uma visão panóptica da imagem e dos dois textos escritos, um à esquerda no topo e outro à direita na base.

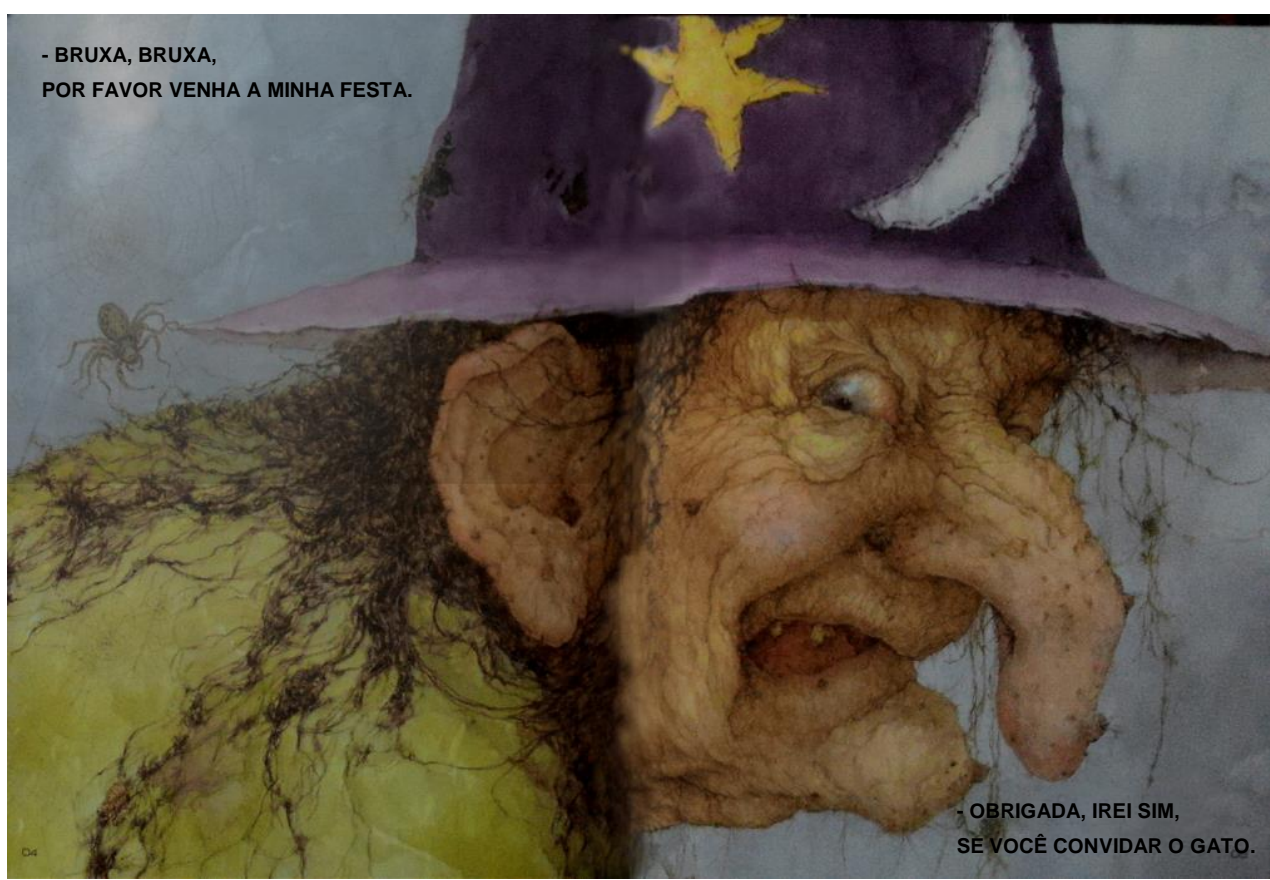

Figura 158 - Druce, Arden. Bruxa, bruxa venha a minha festa, pág. 4 e 5

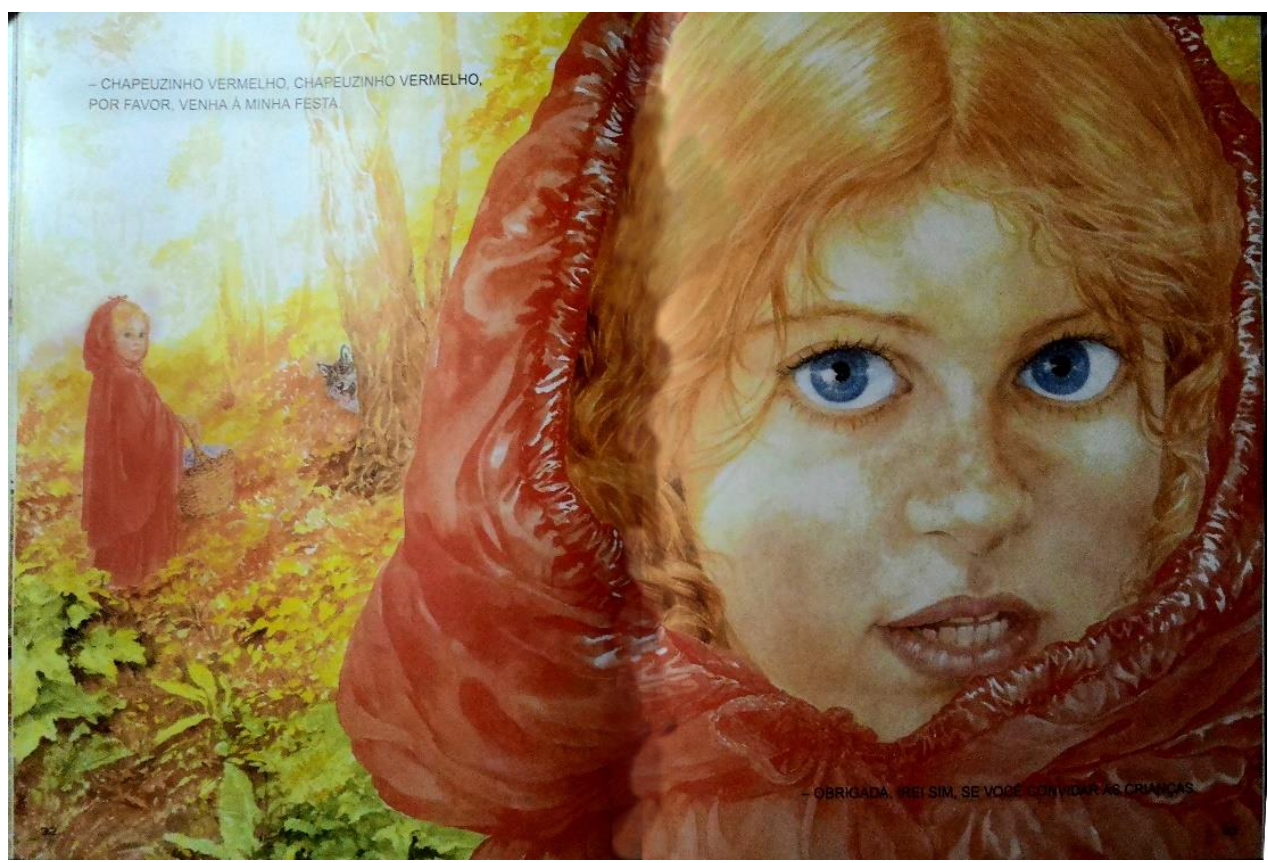

Figura 159 - Druce, Arden. Bruxa, bruxa venha a minha festa, pág. 32 e 33

A imagem, apesar de única, se divide em duas esferas temporais: o tempo do convite e o tempo da resposta. O convite, feito por um personagem in absentia, que é colocado como narrador em primeira pessoa, corroborado com o enquadramento da cena a uma perspectiva de primeira pessoa (os personagens 
olham para o leitor), ocupa um lugar de menos destaque na visualização: a página esquerda (embora para a leitura de um texto escrito seja o local inicial). Na imagem o olhar é atraído para o centro, em caso de duas páginas, a direita chama mais atenção do que a esquerda (verso). Ludlow ressalta a importância do personagem convidado ao destacá-lo em close-up na página da direita.

O ritmo de leitura é marcado visualmente, convite e resposta colocados sempre em suas devidas posições na grade criam um padrão de sequencialidade que orienta o leitor durante a progressão da narrativa a inferir nas próximas transições, mesmo antes da leitura do texto que a imagem representa a figura convidada, e que consequentemente a próxima figura será a nomeada na resposta.

É a manipulação dessa inferência que confere a dualidade semântica contraditória ao final da narrativa, porque ao mesmo tempo em que a imagem corrobora a expectativa - conforme apontado na página anterior a imagem representa as crianças a serem convidadas, ela agrega a indicação de que nega todas as imagens anteriores - as crianças vestem fantasias de todos os convidados maravilhosos.

Por causa da liberdade visual dos leitores, criadores como McCloud se preocupam tanto com o fluxo das transições, pois acreditam que é o fluxo a forma como o artista guia o olhar do leitor na narrativa, até o desfecho. Nas histórias em quadrinhos com vários quadros, a transição entre as cenas tem que ser pensada também de acordo com o suporte: jornal, revista, livro, telas de celular, tablet e computador. Para McCloud, é importante que o fluxo não seja uma distração que deixe o leitor consciente da grade e o desvie da diegese.
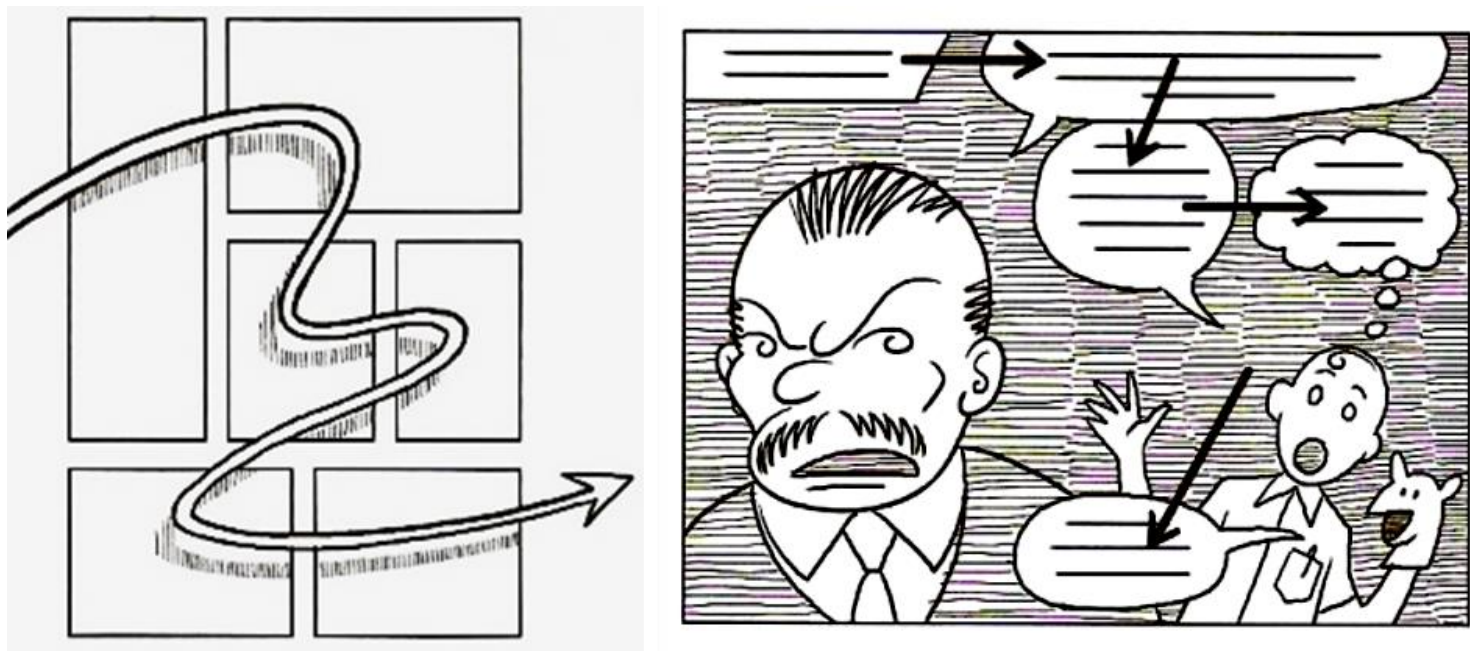

Figura 160 - (MCCLOUD, 2008, p. 32), fluxo de página e dentro do quadro 

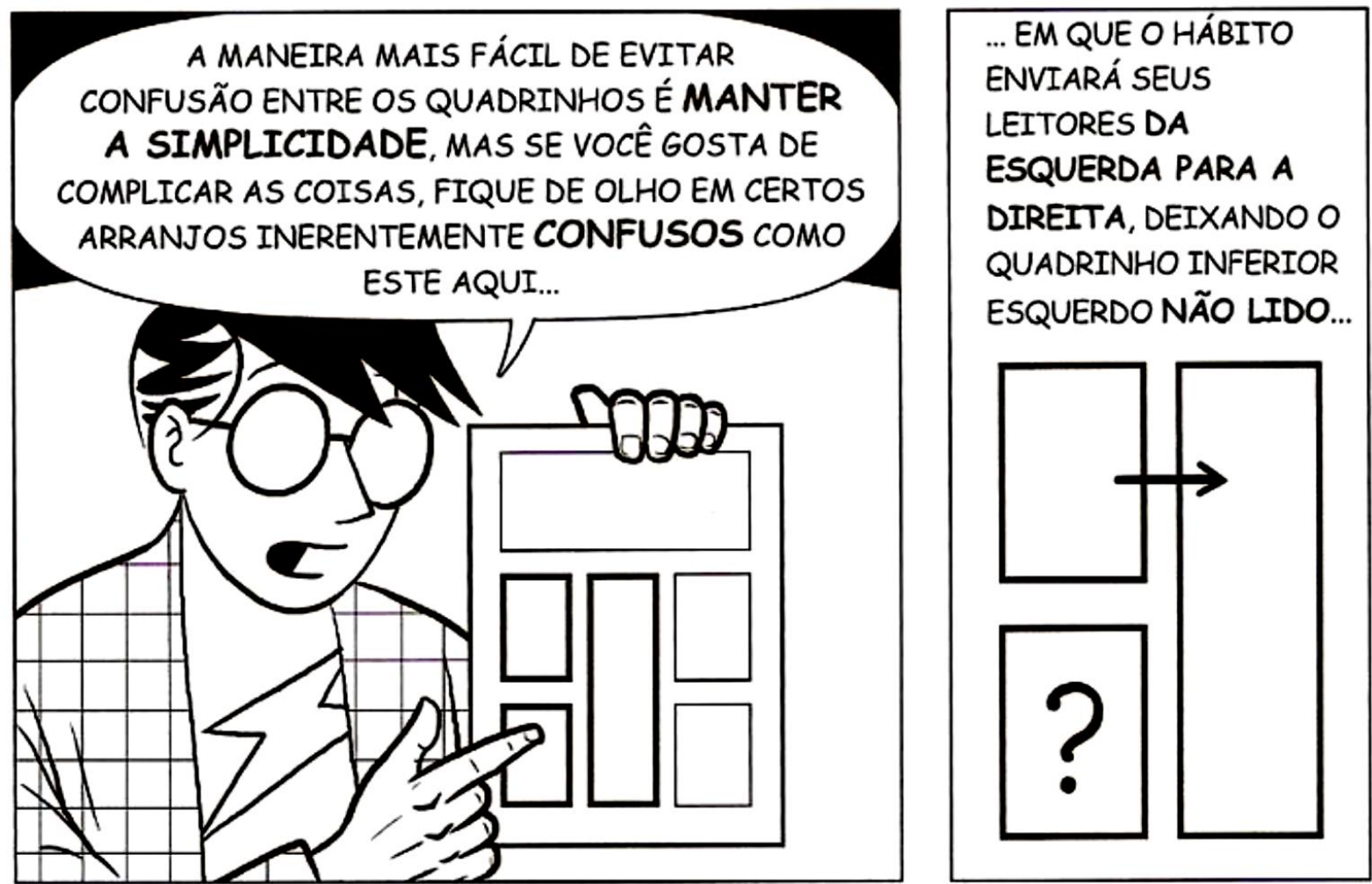

Figura 161 - (MCCLOUD, 2008, p. 33) Exemplo de fluxo 2

Segundo McCloud, a meta de toda história em quadrinhos é contar uma história que envolva completamente o leitor, que ele sinta a beleza da forma sem sair da realidade do enredo.

É para contar histórias que os quadrinhos existem, e o desejo de tornar tais histórias comoventes e inebriantes é o que confere a eles sua forma atual, ainda que muitos artistas fracassem nessa missão. (MCCLOUD, 2008, p. 54)

\subsubsection{Letreiramento}

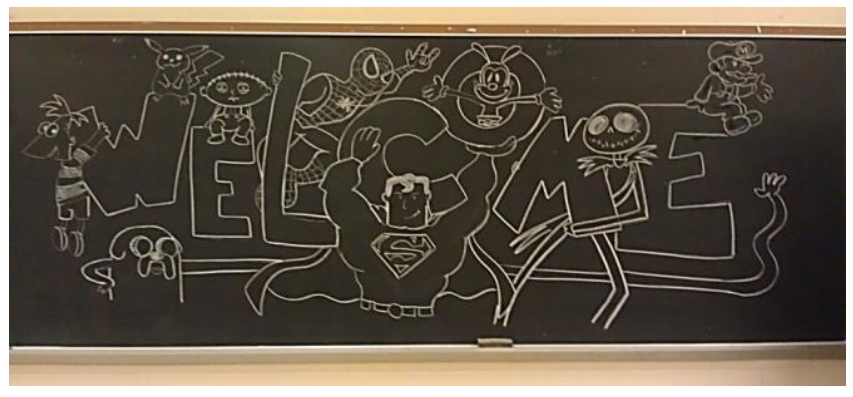

Chris Pearce ${ }^{117}$

117 Epígrafe - fonte: Chris Pearce é professor de inglês e cartunista, mantém um blog "Teachable Moments" com histórias inspiradas nas situações de aula. Tem o hábito de fazer um cartum na lousa todos os dias. Disponível em: https://chrispearce.wordpress.com/tag/pokemon/, consultado em 19/05/2018. 
A letra é um grafema, que segundo o dicionário Hoaiss é uma unidade de um sistema de escrita que, na escrita alfabética, corresponde as letras e também a outros sinais distintivos, como o hífen, o til, sinais de pontuação, os números, etc., e na escrita ideográfica, corresponde aos ideogramas. Nos quadrinhos, grafemas são ícones linguísticos, ou seja, figuras que têm um sentido, em geral, absoluto, mas que não deixam de ser tratados como figuras.

Letreiramento é a colocação do ícone linguístico na grade, o trabalho gráfico dado às letras, palavras e frases, sejam em espaços delimitados como a legenda e o balão ou integrado à imagem na forma de onomatopeia.

Will Eisner aponta que "o letreiramento manual sempre será o modo mais idiossincrático e expressivo de inserir palavras nos balões e nas caixas de texto" (EISNER, 2010, p. 24). Para o artista a importância do "desenho" do texto, que durante muito tempo foi manual, embora hoje seja comum que o letreiramento (desenho e formatação das letras na HQ) seja feito por computador, é de extrema importância. Tamanho, cor, estilo das fontes e marcas pessoais de grafia são tão valorizados que já existem formas de desenvolver um alfabeto computadorizado com base na letra manual do artista, e mesmo assim, muitos desenhistas ainda preferem o processo de desenho do texto manualmente dentro da imagem.

\footnotetext{
Até hoje, utilizamos o computador para fazer as letras e os balões das nossas histórias. Ainda assim, existe uma outra tradição de Quadrinhos, onde o estilo pessoal de cada artista vai além do desenho, incluindo também o balão e a letra. O Will Eisner incorporava as letras à narrativa, e isso dava um charme a mais às suas histórias. O Moebius achava absurdo [que] outra pessoa letreirasse suas histórias, já que os balões utilizam tanto espaço da página, e ele mesmo acabou letreirando a história do Surfista Prateado que desenhou para a Marvel em 1988, fugindo aos padrões da época para um gibi de superheróis. A ideia de que a letra do artista é parte indispensável do visual da história é muito forte no Quadrinho francês em geral, assim como no quadrinho autoral americano. Fazer as letras à mão dá trabalho pra caramba. Quando você publica suas histórias em pelo menos duas línguas (português e inglês, no nosso caso), fica impossível fazer tudo na mesma página, mas mesmo assim você quer que a aparência da página (incluindo sua letra) seja a mesma. (MOON, 2015)

O trabalho gráfico dos ícones linguísticos na $\mathrm{HQ}$ traz à tona não só o
} sentido absoluto lexical, mas também um sentido figurado pela forma como os caracteres são desenhados. 

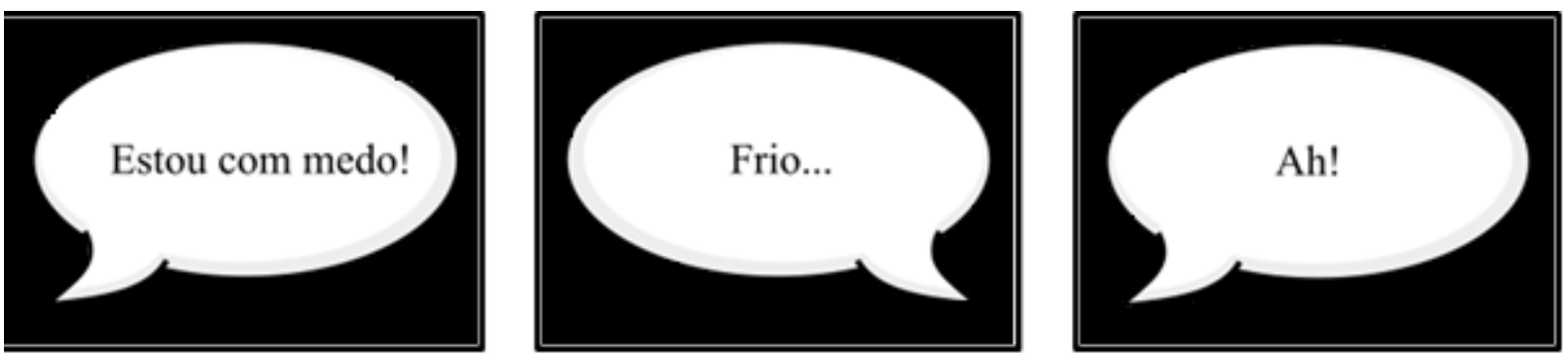

No modelo acima foi usada a fonte padrão Times New Roman, simulando uma cena no escuro, um recurso usado em muitas histórias para criar uma cena dúbia propositalmente e aumentar a expectativa no leitor. Um texto formatado dessa forma, não fornece muita pista do que se passa, nem a emoção dos personagens apesar de ser uma reprodução de fala.
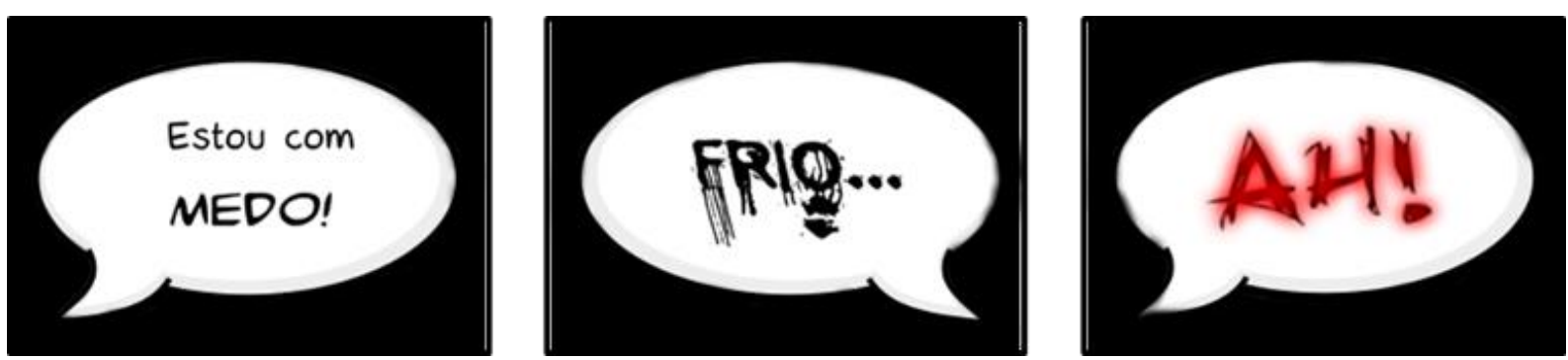

Ao mudar o tratamento gráfico dispensado às letras, seu conteúdo absoluto é acrescido de significados abstratos. A palavra "medo" do primeiro balão ao receber destaque (fonte maiúscula, aumentada e com negrito) em relação às outras palavras da frase, adquire um tom de importância e urgência; "frio" do segundo balão acolhe o sentido de sobrenatural; a interjeição "Ah" do balão final recebe uma conotação de pavor. Já no exemplo abaixo, o uso de uma fonte distorcida, em um tamanho menor e de coloração mais clara, causa um estranhamento, ocasionando uma divergência entre o sentido absoluto e sentido abstrato, o leitor percebe essa alteração como contradição ao exposto.
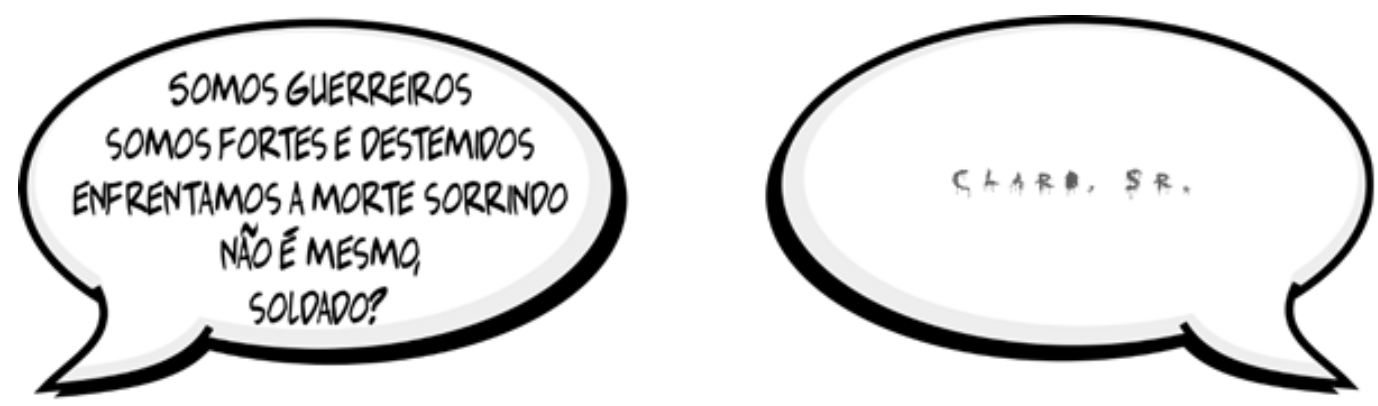

Essas são estratégias visuais para corroborar ou contrariar o sentido absoluto do conteúdo verbal, para que esse conteúdo se integre à grade, e como 
aponta Eisner, dar credibilidade das imagens.
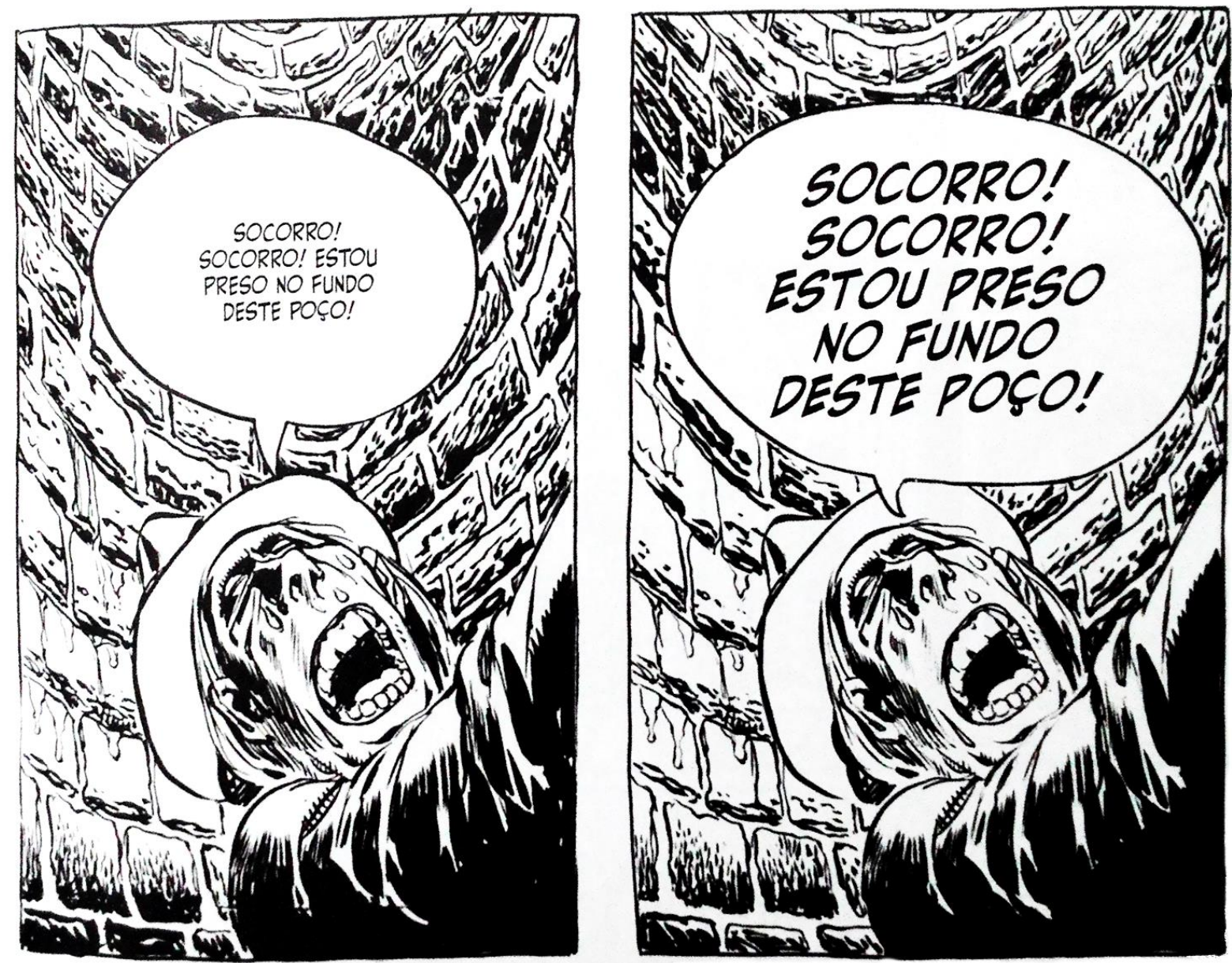

Figura 162 - (EISNER, 2013, p. 65) Simulação de entonação

O estilo de letreiramento e a simulação de entonação são as pistas que habilitarão o leitor a ler o texto com as nuances emocionais pretendidas pelo narrador. (EISNER, 2013, p. 65)

Ao contrário da opinião do professor Cagnin que afirma que:

À imagem cabe a tarefa principal de contar a história. A palavra não deveria assumir esta tarefa em detrimento da imagem, como infelizmente acontece na maioria das histórias em quadrinhos publicadas hoje em dia." (CAGNIN, 2014, p. 139)

Não há necessidade de uma história em quadrinhos ter mais imagens do que texto escrito para ser uma autêntica $\mathrm{HQ}$, como pode ser atestado em uma das páginas de "Spirit" de Eisner Figura 163, o texto escrito para ser inserido na grade é transformado em imagem, fazendo parte de seu corpo estético, sendo, portanto, indissociável tanto no sentido quanto na forma. 

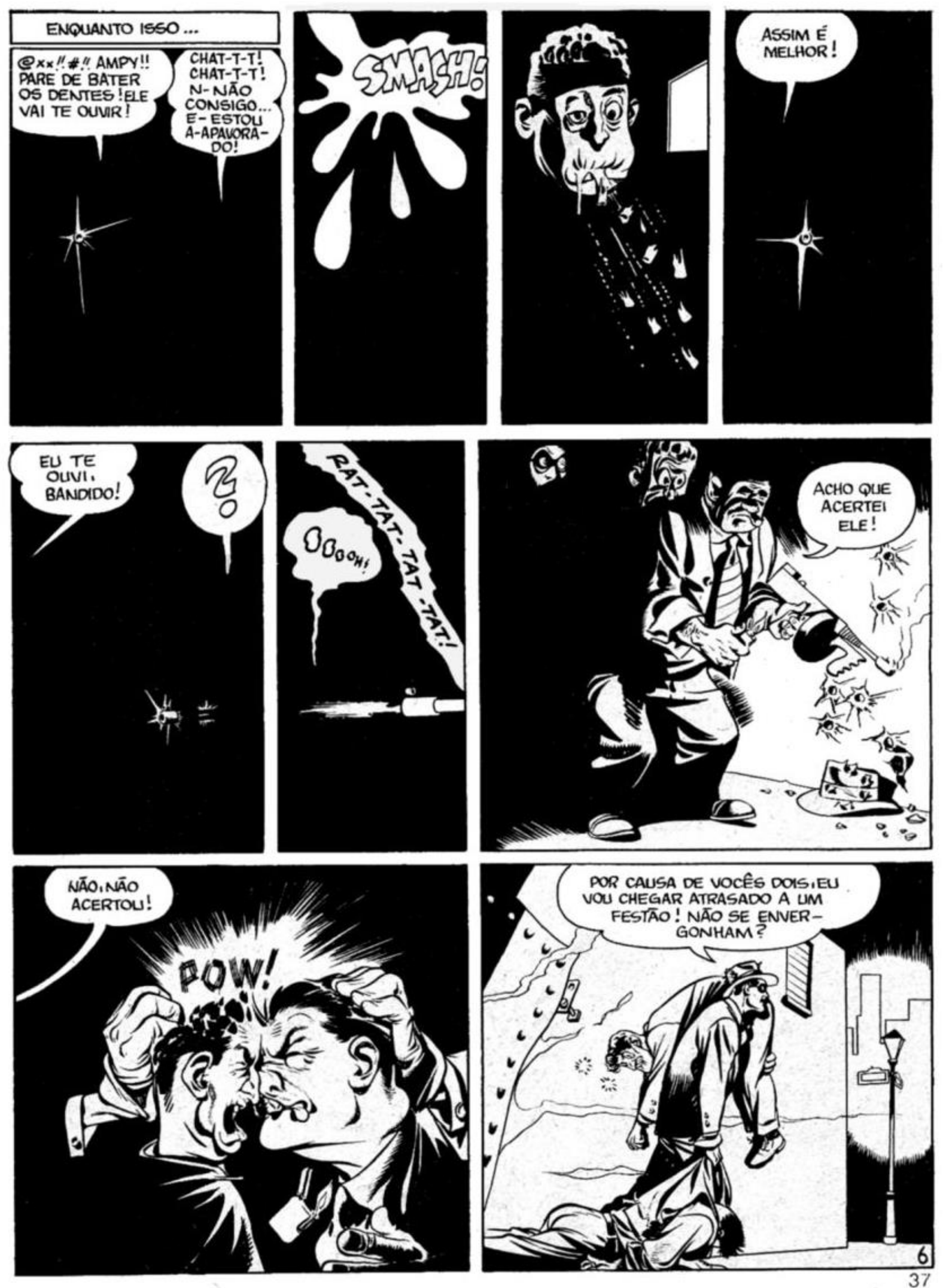

Figura 163 - A volta de Ébano - (EISNER, 1975, p. 37) 

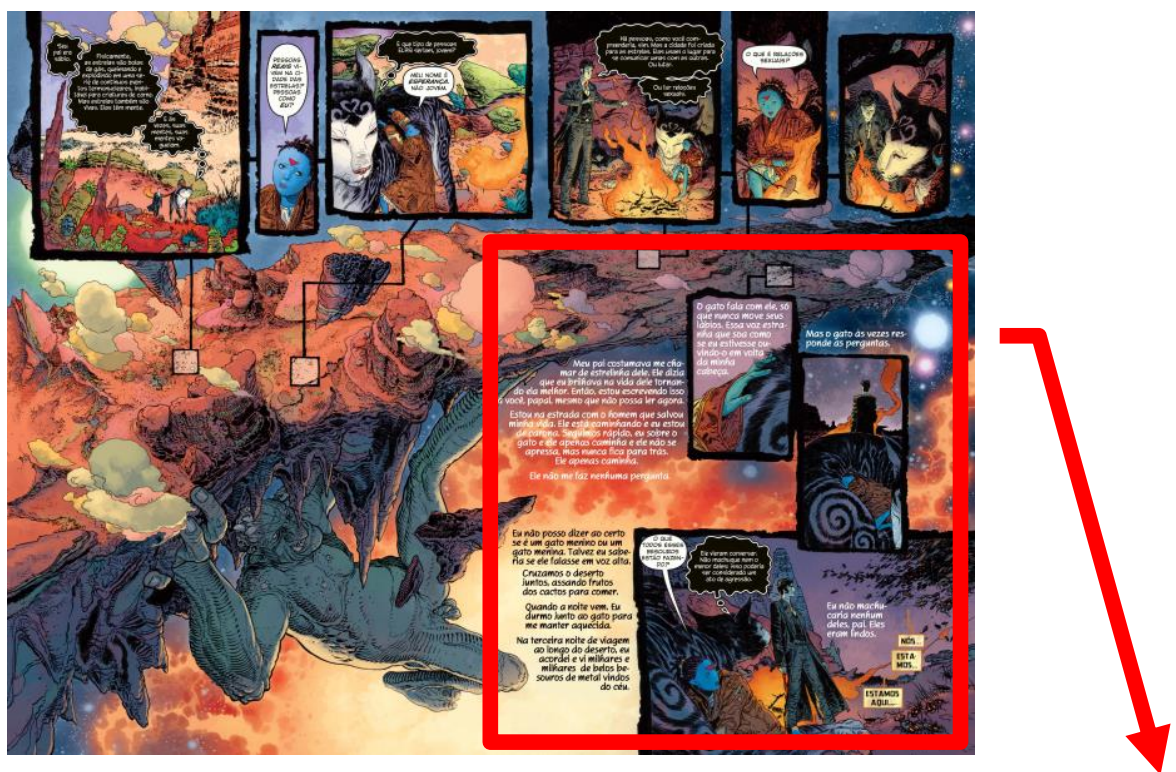

Figura 164 - Gaiman, N. Sandman: Preludio - vol 2, pág. 12-13 (página dupla)

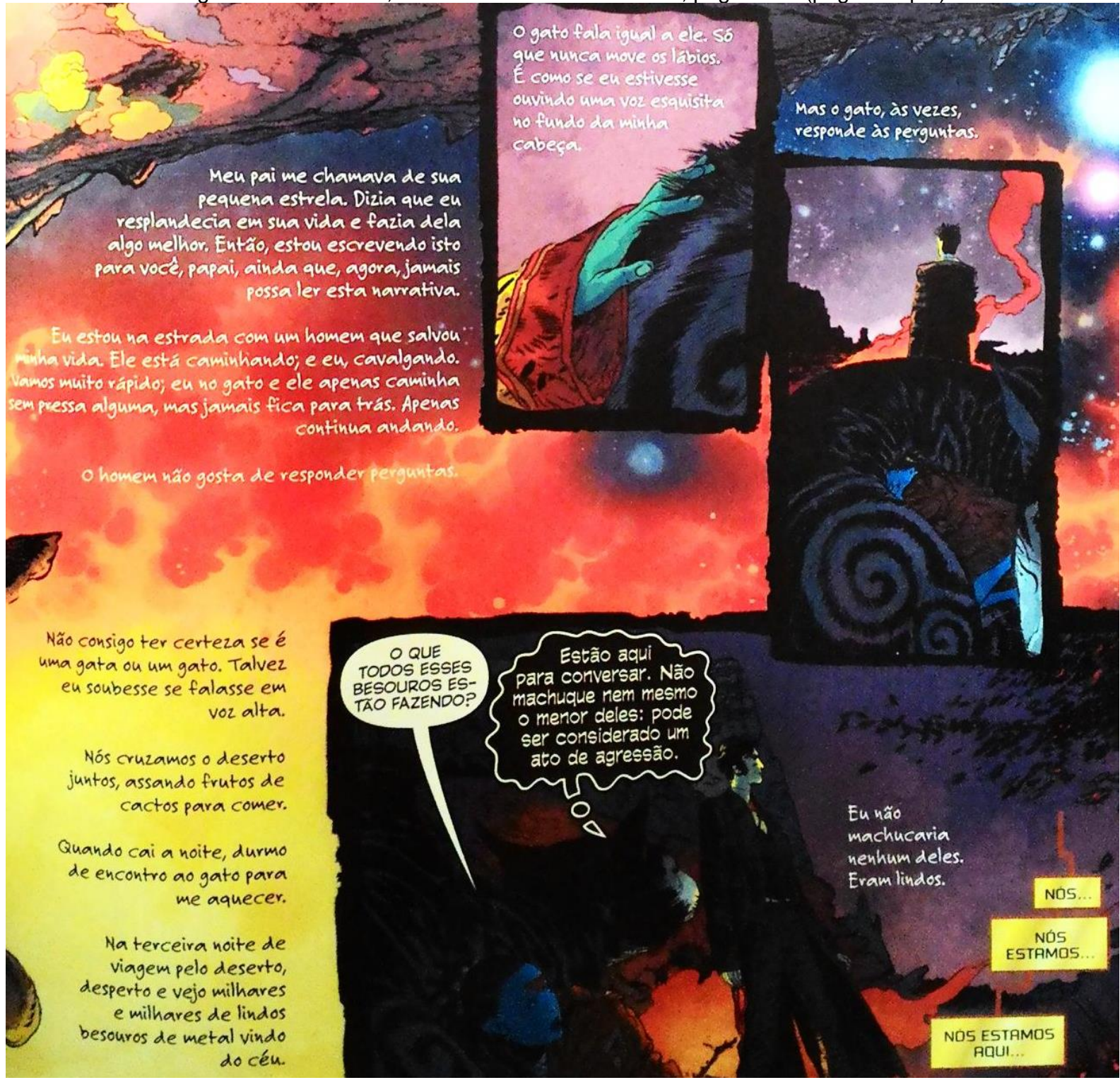

Figura 165 - Destaque de Gaiman, N. Sandman: Preludio - vol 2, pg 13, 2aㅡ e $3^{\text {a }}$ linhas, Ed. Panini 
Os quadros destacados na Figura 165, pág. 216, de Sandman: prelúdio, demostram que o conteúdo escrito está completamente integrado à imagem. Palavras e frases foram trabalhadas com delicadeza, para fazer a distinção entre o pensamento íntimo, a voz natural, a voz sobrenatural e a voz mecânica. Não é preciso que o texto contenha as explicações sobre cada voz, essa diferença é apontada pela diferença na forma e disposição do texto, tornando-se outro elemento gráfico de sentido dentro da narratividade.

Qualquer texto escrito dentro de uma $\mathrm{HQ}$, por mais simples que pareça, requer um tratamento estético, seja no original ou nas traduções.

Nas páginas da obra Black Butler (Kuroshitsuji) de Yana Toboso, em algumas de suas versões: japonesa (original) (Figura 167, pág. 219), brasileira (Figura 166, pág. 219) , americana (Figura 168, pág. 219) e chinesa (Figura 169, pág. 219), e confronta-se a preocupação com a produção de sentido através da produção gráfica do ícone linguístico.

Um detalhe importante é que as páginas em todas as versões são lidas da direita para a esquerda (sentido oriental) de cima para baixo, tanto a publicação brasileira quanto a americana seguem o padrão oriental.

No primeiro quadro da primeira linha, na versão brasileira há o texto: "Afinal Derrick já estava morto" em estilo normal de fonte, com a letra em tamanho um pouco maior do que as demais. No original japonês a mesma frase, além da fonte aumentada em relação as outras, é negritada. Na versão em inglês as letras são aumentadas, negritadas e em itálico. Já na versão chinesa a frase é pouca coisa maior e negritada. Independente do conteúdo semântico das traduções, nota-se pelo tratamento gráfico que as versões japonesa e chinesa conferem destaque ao tom de voz empregado ao negritar as letras, o leitor de uma tipologia negritada entende que o emissor do enunciado está destacando essa passagem do texto. A versão brasileira torna a frase isenta de emoção, já a americana a deixa mais emocional.

Ainda no primeiro quadro a onomatopeia もぞ (mexer-se) do original japonês é mantida tanto na versão brasileira com acréscimo ao lado em letras minúsculas de uma interpretação de sentido (ZRR); a versão americana opta em manter a original e acrescentar em letras diminutas a leitura fonética do hiragana $\mathrm{e}$ sua tradução "squirm" (contorcer-se); já a versão chinesa opta por traduzir a onomatopeia para a própria língua.

A opção pela tradução ou não das onomatopeias japonesas é uma fonte 
continua de debate no ocidente. Isso porque há no Japão uma infinidade de onomatopeias sonoras, de acordo com Renata G.C. Leitão em sua dissertação de mestrado sobre o tema,

o uso da das onomatopeias tanto na fala cotidiana quanto em outros meios
além dos mangás é intenso e amplo. Junko Baba [professora de estudos
japoneses na Universidade de Columbia] afirma que existem
aproximadamente 1.200 onomatopeias, porém, o Nihongo Onomatope Jiten
(日本語オナマトペ辞典 “Dicionário de onomatopeias Japonesas" 2007) lista
cerca de 4.500 verbetes (LEITAO, 2012, p. 79).

As onomatopeias japonesas são utilizadas na construção estilística de frases cotidianas em substituição de outras palavras mais formais. Por exemplo, uma frase como: “O corpo se mexe", por padrão seria construída como: “体が動く” foneticamente: Karada ga ugoku. (karada = corpo, ugoku = mover, mexer), mas também encontra-se a construção onomatopeica 体がもぞもぞ: karada ga mozumozu ( mozumozu $=$ mexendo-se, movendo-se).

Mozumozu é uma onomatopeia japonesa que representa o som de algo se movendo, tanto no português quanto no inglês não há uma correspondência - como no caso de um latido de cachorro que no português é au-au, no inglês arf-arf e no japonês wan-wan, por isso tanto a criação de algo semanticamente similar da versão brasileira, quanto a simples tradução do significado como a tradução americana, ou a alteração do elemento todo para língua nativa como a versão chinesa, são estratégias arbitrárias que encontrarão sua validação no uso e aquisição de hábito do leitor, uma vez que conforme apontado anteriormente por Witek, as convenções na estrutura dos quadrinhos é flexível de acordo com o contexto de uso.

Mas qualquer que seja a opção escolhida, ela terá um impacto diferente na interação do leitor. Um leitor brasileiro, interpretará a onomatopeia como um símbolo de um ruído impronunciável, o leitor americano além de interpretar a onomatopeia como ruído agregará o modo como esse ruído é produzido no original (ah! no Japão o barulho de se mexer é mozu), contudo o ganho dessa informação desvia sua atenção temporariamente da diegese. 

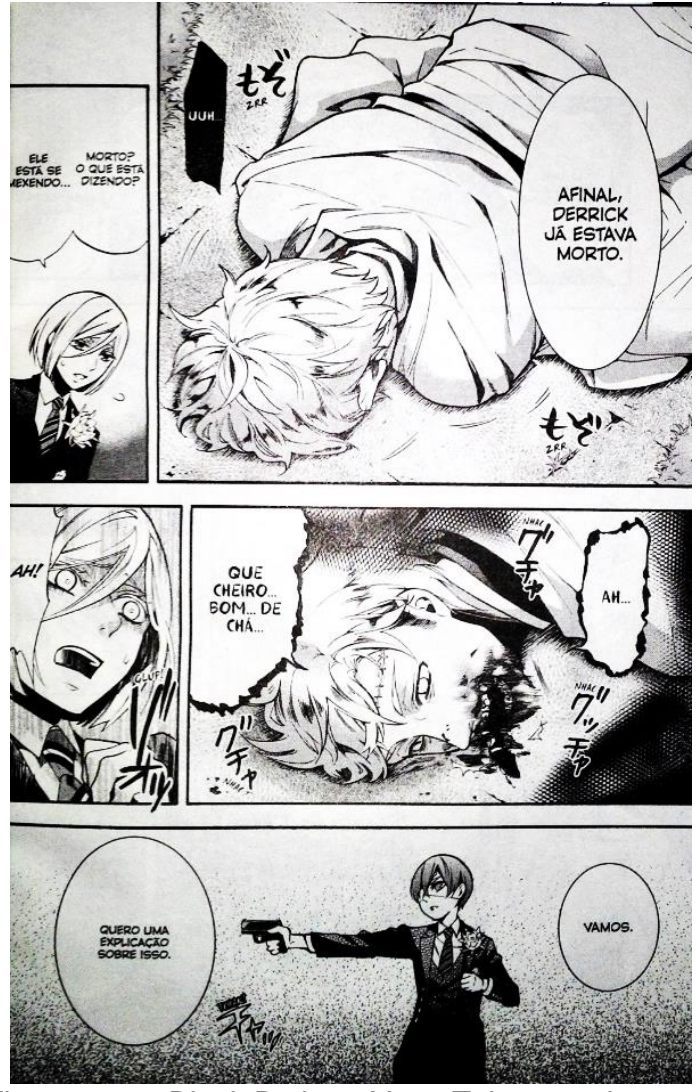

Figura 166 - Black Butler - Yana Toboso, vol. 17 pg. 154 - Editora Panini Comics, São Paulo
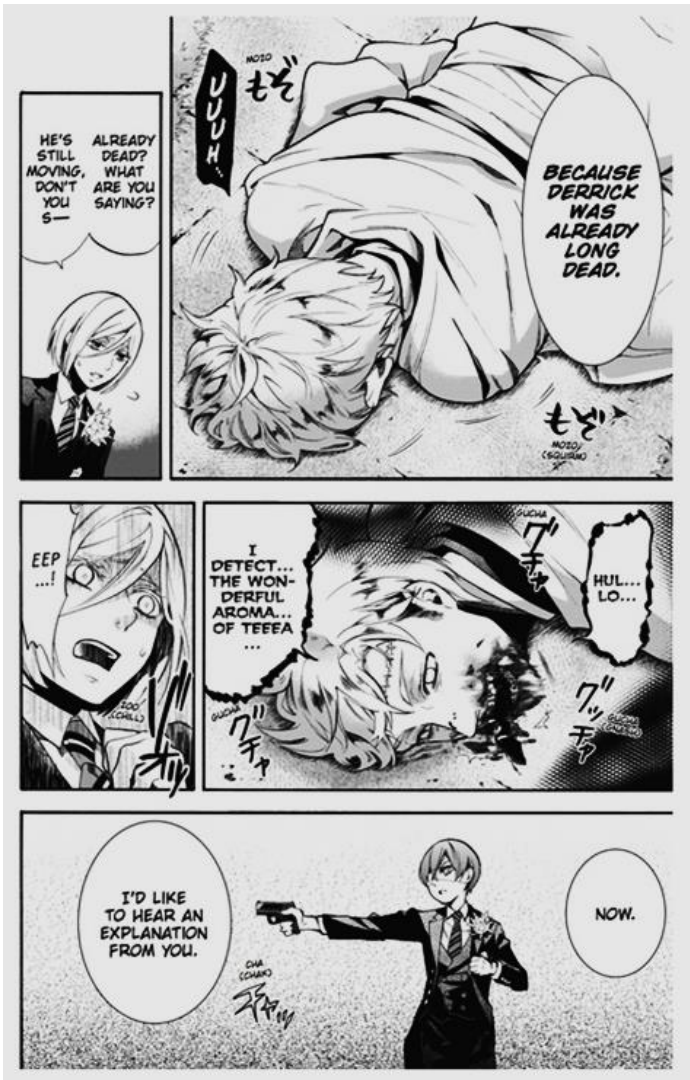

Figura 168 - Black Butler - Yana Toboso, vol. 17 pg. 154 - Editora Yen Press, Nova York
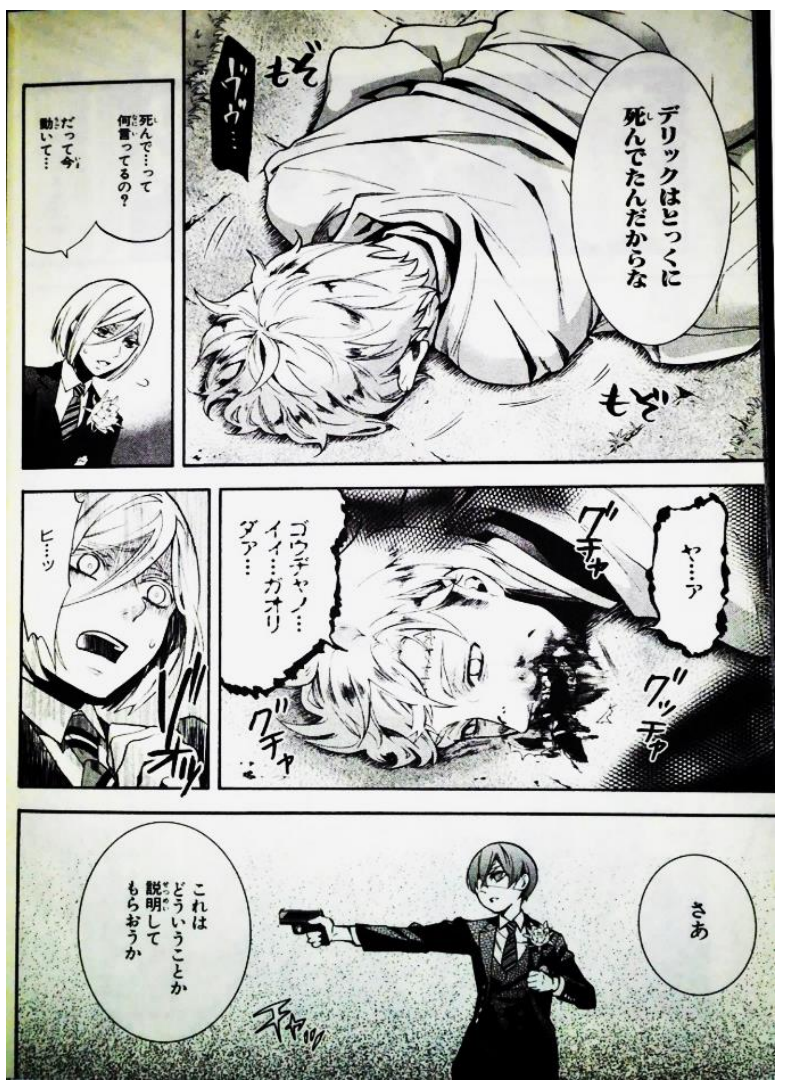

Figura 167 - Kuroshitsuji - Yana Toboso, vol. 17 pg. 154 - Editora Square Enix, Tóquio
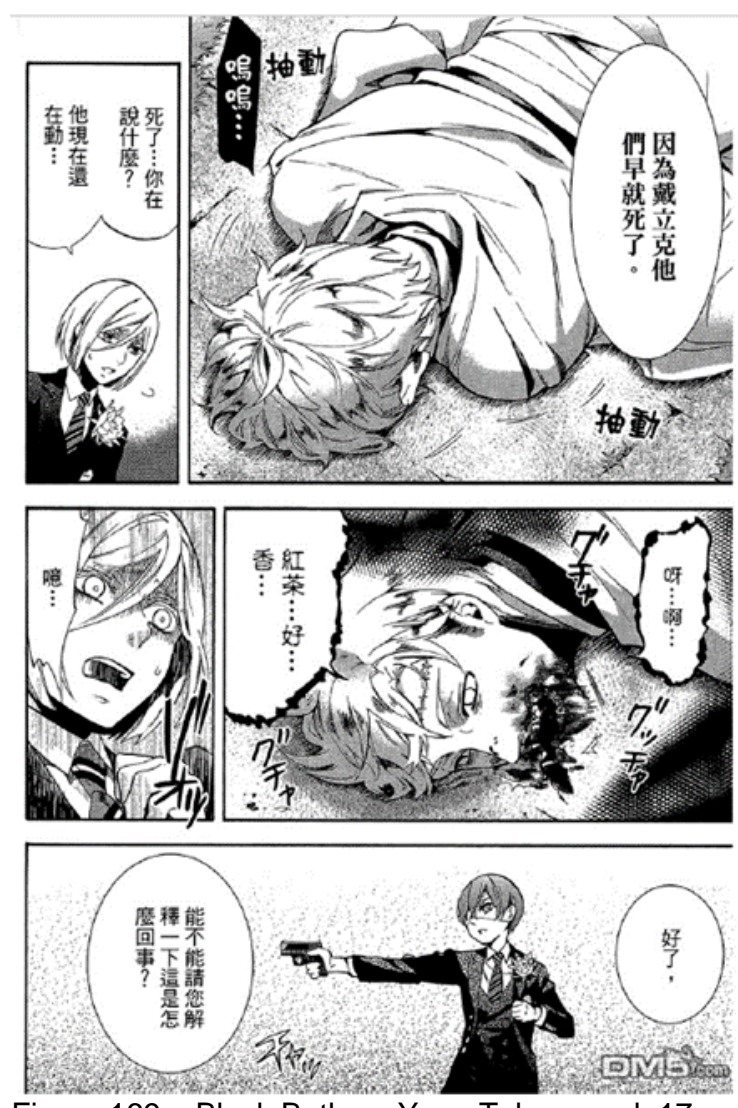

Figura 169 - Black Butler - Yana Toboso, vol. 17 pg. 154 - Editora Tong Li Comics - Taiwan 
Vale a pena ressaltar outras estratégias de adaptação no que concerne à escrita fonética katakana ${ }^{118}$ (um dos três sistemas de escrita da língua japonesa), não partilhado pelas outras línguas em suas convenções de uso. O katakana que é uma simplificação fonética do kanji, atualmente convencionada para uso de palavras estrangeiras, alienígenas ao japonês padrão. A interjeição “ヒ ‘.ッ” usada pelo personagem do segundo quadro da segunda linha, por conter esse sentido de algo diferente do normal, acrescenta à cena a percepção de um estado de espírito alterado. Tanto na interjeição traduzida para o português como "Ah!", para o inglês como “EEP...!" e para o chinês 噫 (Yī), não é agregado o sentido que é uma nuance cultural específica do katakana, mas pela forma como as letras são dispostas, negrito, itálico e tamanho, conseguem transmitir a agitação e surpresa do personagem. O katakana também é usado na fala do personagem do primeiro quadro da segunda linha, por se tratar de um morto vivo, a escolha desse alfabeto é um indicativo de que o falante não é humano.

\subsubsection{Estética}

Tomando como base os trabalhos de precursores como Töpffer e Agostini, nota-se que a classificação das obras em gêneros ou estilos não é uma tarefa fácil. Töpffer em geral abordava como temática, uma critíca jocosa ao comportamento social, em vários aspectos se aproximando do romance, direcionada para o público adulto em formato de livro. Por esses aspectos pode ser considerada, pelas convenções atuais como uma Graphic Novel, na concepção de Eisner do termo. Já a duas obras de Agostini tem um perfil temático completamente diferente uma da outra. "As Aventuras de Nhô-Quim", por ser irônica, crítica e possuir um desenho mais caricaturizado, segue a mesma linha temática de Töpffer, contudo foi publicada em fascículos de jornal, como uma história seriada. "Zé Caipora" por outro lado tem uma temática aventuresca, consagrando o personagem título como o primeiro herói de

\footnotetext{
${ }^{118} \mathrm{Na}$ língua japonesa há três sistemas de escrita que se interligam em usos específicos: o Kanji (ideograma) é a representação gráfica do sentido, como o kanji 男 (otoko) homem; o Hiragana, é um silabário fonético, usado para compor com os kanjis os casos linguísticos, como verbo, sujeito ou adjetivo como o hiragana が (ga) usado como marcador de sujeito: 男が... (otoko ga) o homem...; e o terceiro silabário, o Katakana, usado para palavras de origem estrangeira, interjeições, onomatopeias, marcas de produtos, etc. como 男がクールです (otoko ga kuuru desu) o homem é cool.
} 
quadrinhos nacionais (AGOSTINI, 2002).

Conforme visto anteriormente no capítulo "gênese", em cada contexto cultural a $\mathrm{HQ}$ seguiu caminhos estéticos diferentes, por circunstâncias alheias à linguagem, uma priorização de estilo, temática e intencionalidade de acordo com regras sociais ou de mercado. Essas convenções deixaram marcas específicas em determinadas produções fazendo com que o estilo de arte, o desenvolvimento do enredo, elementos de construção de sentido, e até mesmo letreiramento e efeitos de transição fossem reconhecidos como uma "estética" específica de determinada cultura.

Um dos fatores que constribuiu para a divergência das estéticas culturais baseou-se segundo o professor de História da Arte da Eastern Illinois University, Robert S. Petersen, no modo de produção adotado pelos mercados de quadrinhos americano, franco-belga, italiano e japonês.

That French and Belgian publishers were willing to take up to a whole year to create 46 pages, whereas most manga [and comics] artists by 1960 were producing that many pages every month. The BD albums featured a complete story arc with beautifully rendered scenes in rich and varied colors printed on high-quality paper. They were designed to be read over and over, with the result that the most popular stories of Tintin and Asterix have each sold hundreds of millions of copies ${ }^{119}$ (PETERSEN, 2010, p. 215).

Os Estados Unidos, por exemplo, possuem duas esferas de publicação de quadrinhos, o mainstream (corrente principal ou dominante) e o underground (subterrâneo). Essa classificação tipicamente americana tem origem na divisão entre a visão dominante da sociedade e o que está por escondido baixo, o moral versus o imoral, o lícito e o ilícito.

O mainstream é o âmbito das grandes editoras de quadrinhos, como a DC Comics e a Marvel Comics (as duas maiores) por exemplo. É onde circula o grosso da produção, as empresas com as maiores vendagens tanto internamente quanto externamente. Por ser uma grande indústria, o mainstrem está mais sujeito às regras e padrões dominantes em sua sociedade, além de possuir uma preocupação fundamental com o lucro. Isso não quer dizer que as obras que pertencem ao mainstream americano são isentas de arte e profundidade, uma vez que algumas das

119 Os editores franceses e belgas se permitiam levar todo um ano para criar 46 páginas, onde a maioria dos artistas de mangás [e quadrinhos americanos] por volta de 1960 estavam produzindo esse tanto de páginas todo mês. Os albúns de BD [Band Dessinée] traziam um arco histórico completo com lindas cenas renderizadas em ricas e variadas cores impressas em papel de alta qualidade. Elas eram desenhadas para serem lidas de novo e de novo, com o resultado de que as mais populares histórias de Tintin e Asterix tenham vendido, cada uma, centenas de milhões de cópias (PETERSEN, 2010, p. 215). 
obras de maior impacto e ruptura de paradigmas dos quadrinhos, como "Batman Cavaleiro das Trevas" de Frank Miller, "V de Vingança" e "Watchmen" de Alan Moore e "Sandman" de Neil Gaiman foram produzidas e publicadas no mainstream, mas sim que esses processos tranformadores acontecem no mainstream mais lentamente, pois a indústria possui uma peocupação maior com a autopreservação.

Na contra-mão da indústria está a ousadia da oposição frontal do status quo, muitas vezes agressiva e provocadora, foi dessa forma que as revistas de quadrinhos underground surgiram na América, como uma ruptura em quatro níveis: rompendo com a indústria quadrinística - lançando projetos independentes; rompendo com a censura - ignorando o Comics Code Authority; rompendo com a forma usual experimentando a carturnização e caricutização em seus níveis mais grotescos e rompendo com as barreiras temáticas - abordando temas complexos, pessoais, introspectivos e, principalmente, críticos.

Para o público americano o underground, que chegou como um enfrentamento em um movimento que combinava a rebeldia das manifestações e contestações estudantis, era uma novidade, mas o que era uma inovação nos EUA já existia na Europa de forma estruturada. Com o início do movimento de quadrinhos noir (negro) com mais violência e eroticidade, cresce o interesse sobre o fumetti-neri italiano inaugurado por Diabolik das irmãs Giussani em 1962 seguido posteriormente para outras temáticas por nomes como Dino Battaglia, Milo Manara, Guido Buzzelli, Hugo Pratt e Guido Crepax, pertencentes à "Escola de Veneza" faziam quadrinhos voltados para o público adulto com estruturas visuais e temáticas complexas, além do carregamento da sensualidade e anti-heroismo.

$\mathrm{Na}$ Europa tanto Bande Dessinée quanto Fumetti e as demais vertentes de quadrinhos europeus não possuem uma divisão tão estrita de mainstream e underground, pois suas abordagens adultas sempre receberam um cuidado gráfico e editorial primoroso de sua indústria, a divisão, na verdade, é etária, com quadrinhos mais infantis voltados à formação pedagógica de crianças e adolescentes e os adultos com liberdades criativa e temática ímpares.

Muito superficialmente, para um primeiro contato, é possível apontar que em dado momento, as circunstâncias socioculturais, políticas e econômicas traduzidas em estética culminaram em uma acuidade visual e narrativa que o quadrinista europeu pôde se permitir em oposição ao carregamento caricaturesco tanto em imagem quanto em discurso dos comics americanos. Contudo a troca de 
influências é tão presente, que somente um estudo detalhado das obras em seus contextos pode realmente realçar as diferenças estéticas entre as manifestações europeias e americanas.

Em uma simplificação realizada para ilustrar as diferenças mais significativas, foi feito um decalque de quadrinistas italianos e americanos montando uma página com a narrativa da tira modelo desse estudo: "Era uma vez, uma menina, uma floresta e um lobo":
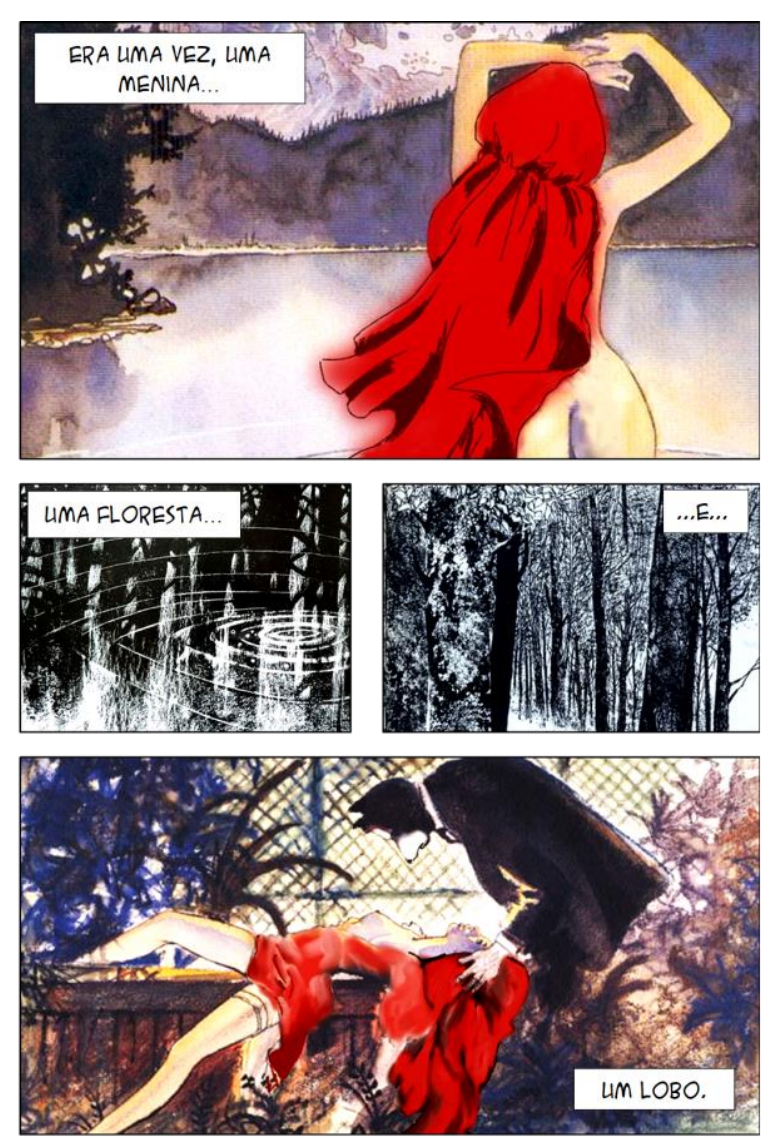

Figura 170 - Chapeuzinho pela estética europeia, decalque da autora de Milo Manara e Dino Battaglia

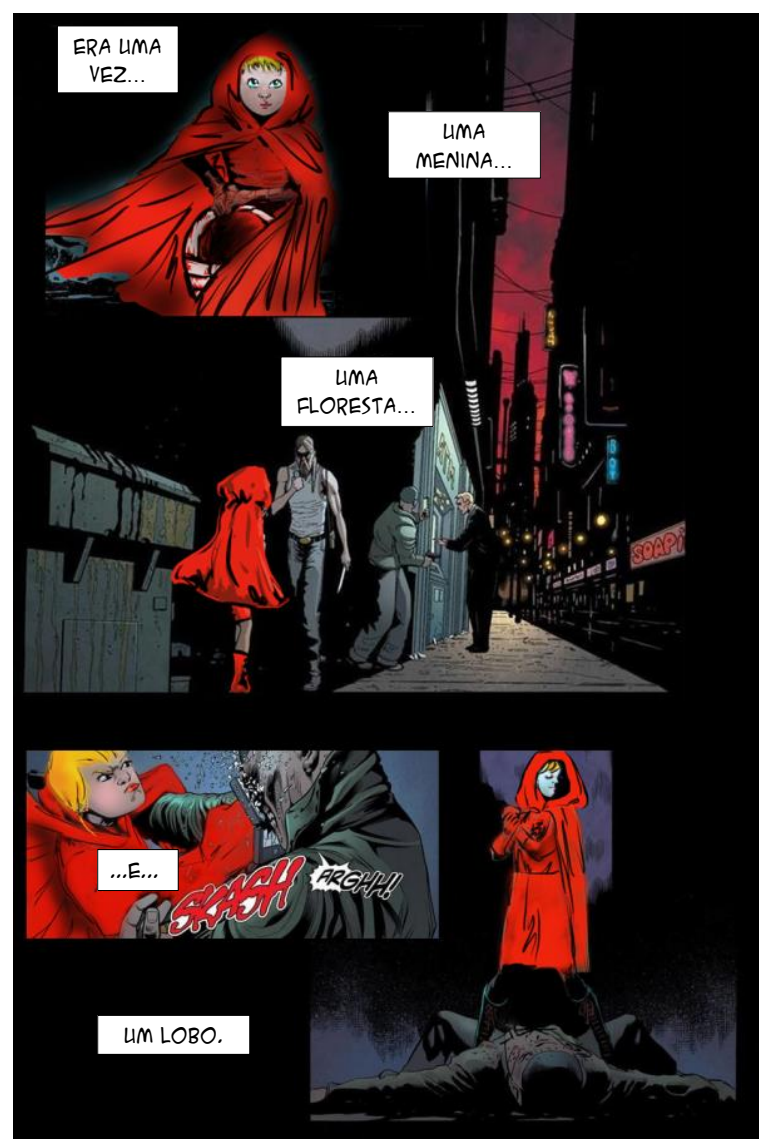

Figura 171 - Chapeuzinho pela estética americana, decalque da autora de Patrick Gleason e Thomas Giorello

Já a estética japonesa, e por ampliação, asiática, varia da ocidental principalmente pela estrutura de grade e elementos culturais específicos de sua caricatura. Com uma linguagem lida da direita para esquerda, de cima para baixo é natural que a grade tenha uma dinâmica de transição diferente, por exemplo, a sequência seguinte, é uma transformação da tira modelar desse estudo em uma estética de mangá (o texto em português "Era uma vez, uma menina, uma floresta e um lobo" foi convertido para o kanji para efeito de visualização da composição dos 
ideogramas na estutrura da página):
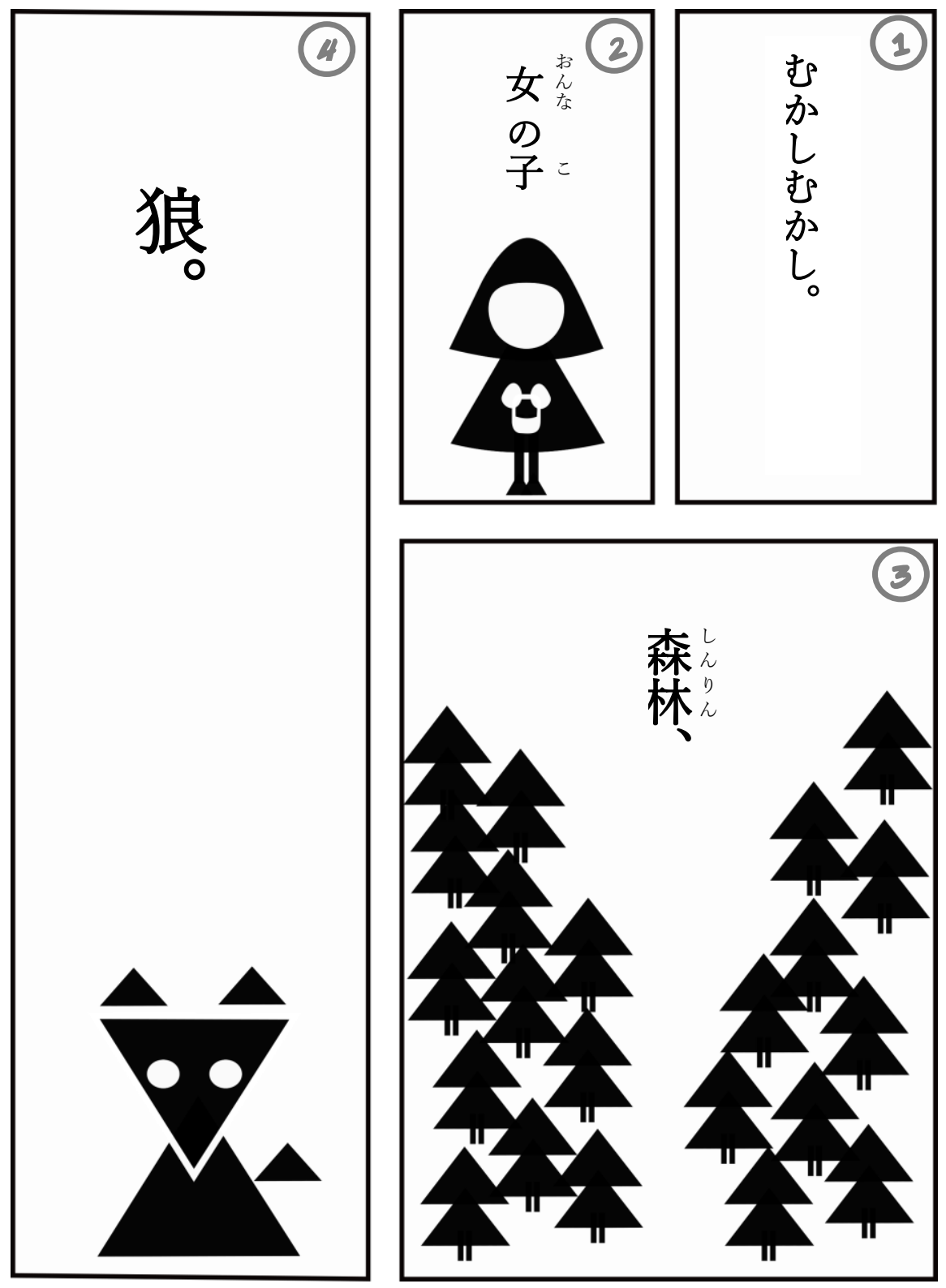

Os quadrinistas japoneses implementaram também a junção da onomatopeia com as linhas de movimento.

Uma das maiores diferenças na cartunização japonesa são os olhos, inspirados no trabalho de Osamu Tesuka, que por sua vez foi influenciado pela caricaturização de Walt Disney, os olhos nos quadrinhos japoneses representam a índole do personagem. Quanto maiores, mais inocente, puro, bom ou jovem é o personagem, quanto menor ou mais fechados, representam a vilania, dissimulação ou sensualidade, típicos de personagens mais maduros. 


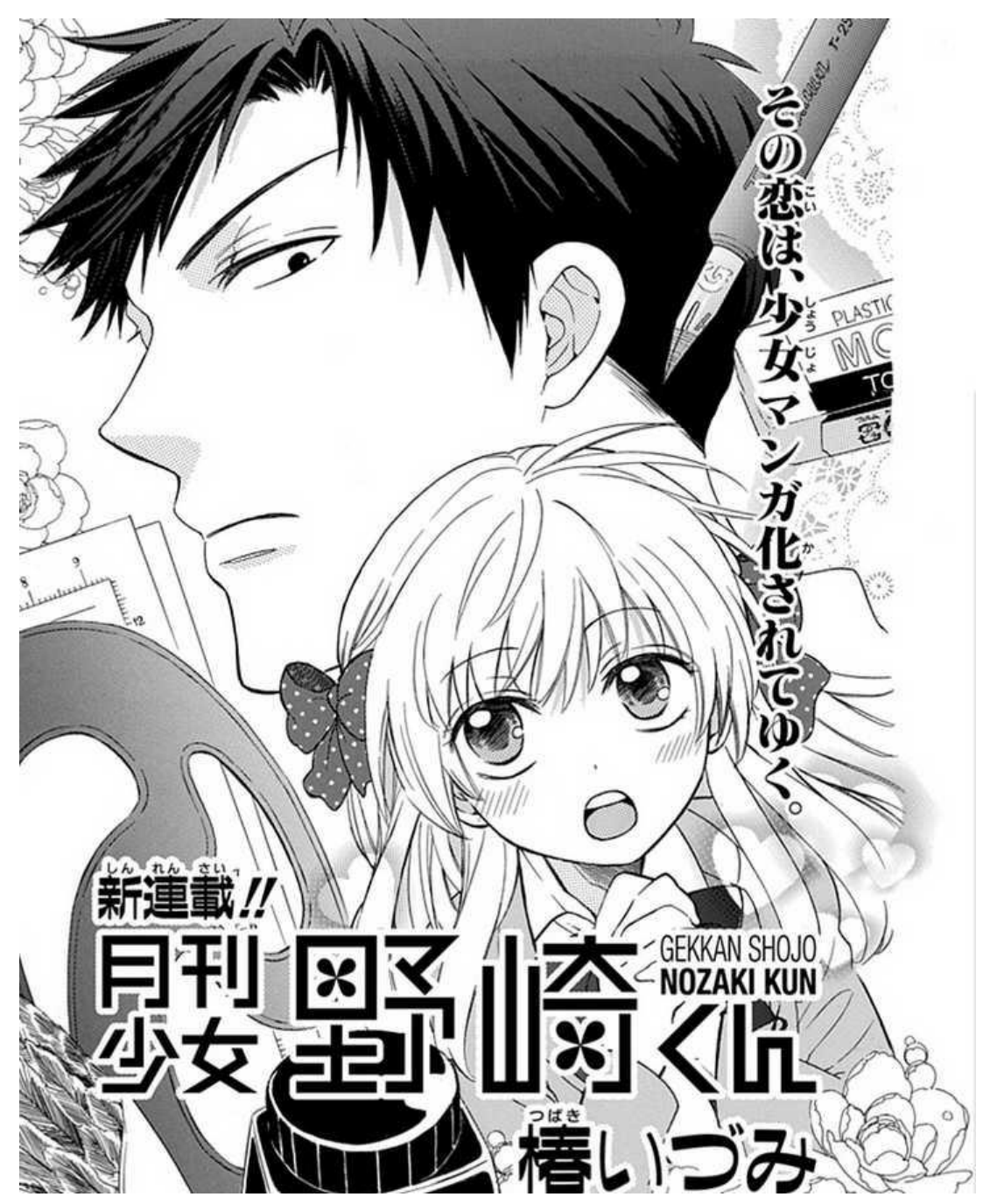

Figura 172 - Recorte de Gekkan shoujo Nozaki-kun, Izumi Tsubaki, capítulo 1, pág. 1. Editora Square Enix, 2011

Ou como no mangá “Gekkan shoujo Nozaki-kun” de Izumi Tsubaki é demonstrado como uma visão estereotipada pode estar enganada, pois a personagem principal se baseia na aparência do personagem Nozaki para formular características de maturidade e "coolness"120 que na verdade não existem.

120 Coolness: característica daquele que é "cool", Kūru no japonês, frio, indiferente, estiloso, atraente e bonito. 


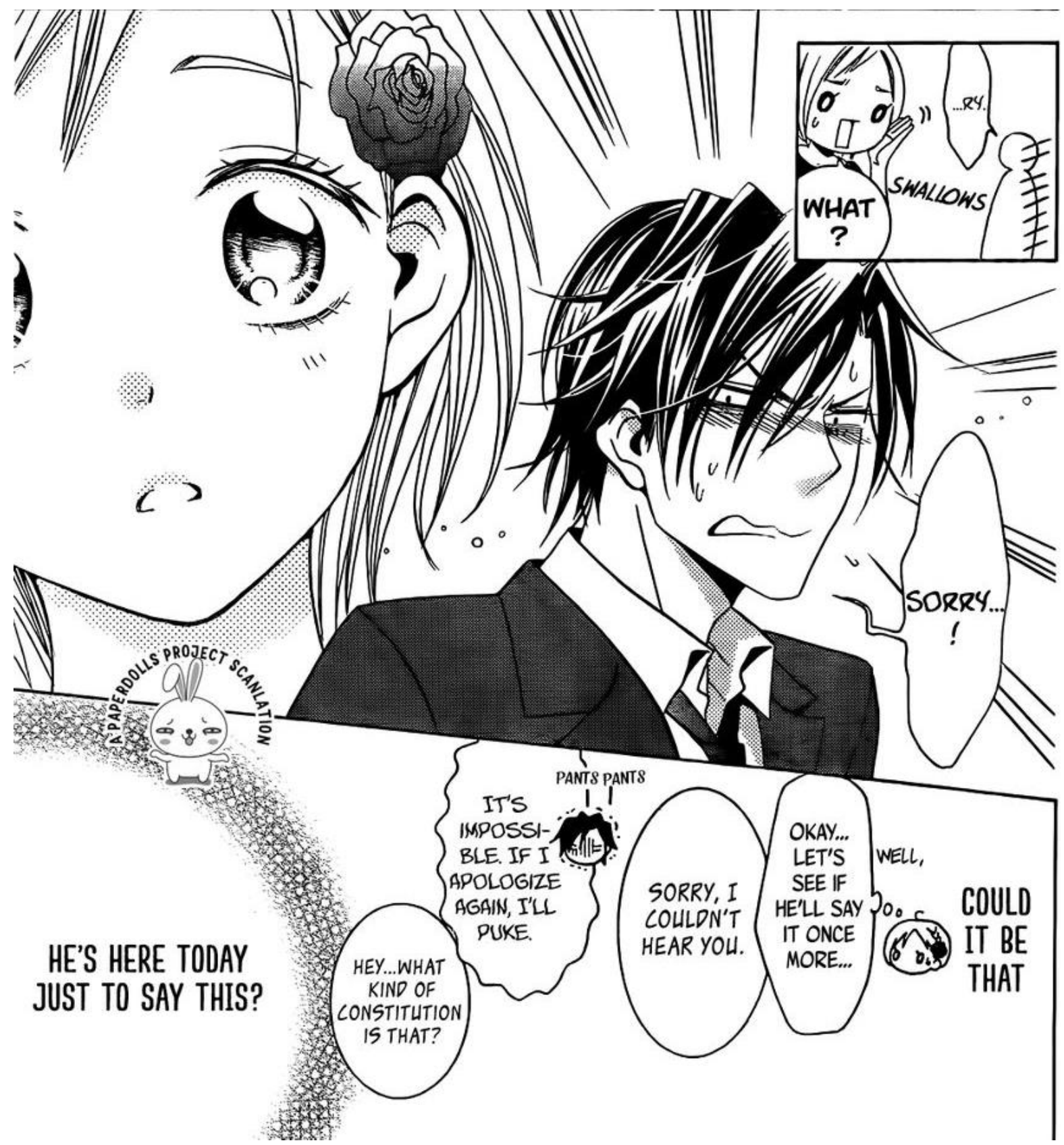

Figura 173 - Recorrte de Takane to Hana, Yuki Shiwasu, capitulo 1, pág. 16, editora Hakusensha, 2015

Como exemplifica a página 16 do mangá "Takane to Hana" de Yuki Shiwasu, a diferença dos olhares também aponta o estado de espírito dos personagens. Outra característica da estética japonesa, também encontrada nessa página é uma forma de distorção e simplificação dos personagens a seus elementos mais básicos reconhecíveis (ou não) para efeito cômico no meio da narrativa, como no primeiro quadro do recorte, onde o personagem Takane é representado como uma forma que lembra vagamente uma pessoa, com algumas linhas paralelas sobrepostas, para acentuar que naquele momento da narrativa seu ego está diminuído, pois ele não quer ter que pedir desculpas mas é obrigado. No último quadro, a representação 
básica simplificada dos rostos dos personagens, além de indicar os respectivos responsáveis pelos balões de fala, ainda demonstram um pouco do estado de espírito risível de ambos, tornando a narrativa mais divertida sem abandonar a temática romântica em prol da cômica.

\subsection{Matéria - o suporte e a ferramenta}

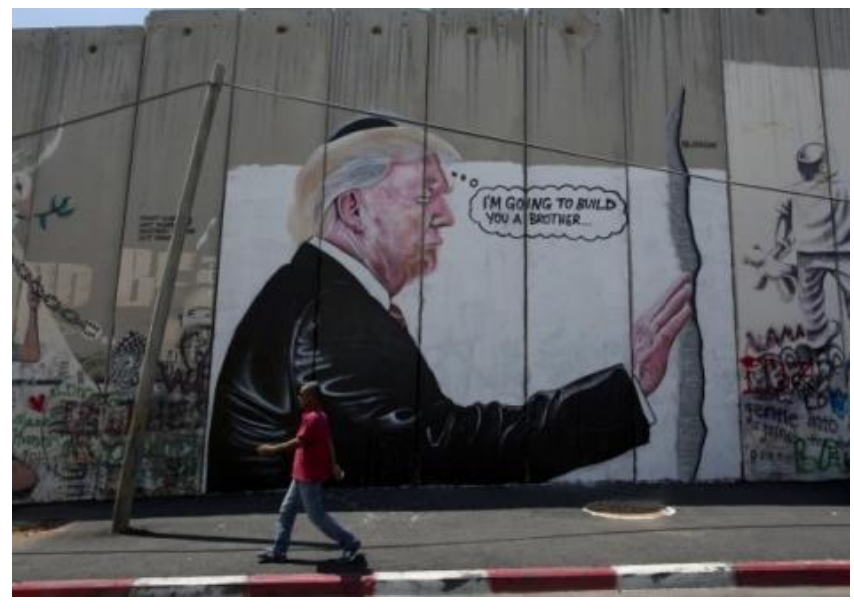

LushSux ${ }^{121}$

Diversos suportes físicos podem ser usados para conter a grade, a mancha gráfica, de uma história em quadrinhos. Uma mesma tira rascunhada em um guardanapo de papel em uma roda de amigos no bar, impressa no jornal, no livro, veiculada na internet ou exposta no museu, não perde sua característica como $\mathrm{HQ}$. Contudo alguns suportes possibilitam mais variações de técnicas, exposição e público alvo dos que outros.

Não é impossível para uma tira estar em um livro, assim como uma narrativa sequencial em um jornal. Mas alguns gêneros, por gênero, este estudo parte da definição básica do Houaiss "conjunto de seres ou objetos que possuem a mesma origem ou que se acham ligados pela similitude de uma ou mais particularidades" (HOUAISS e VILAR, 2009), principalmente pela intencionalidade, mantêm certa frequência em determinado meio. Investigar o funcionamento de um tipo de $\mathrm{HQ}$

${ }^{121}$ Epígrafe - fonte: Charge de 2017 do artista australiano LushSux no muro de Belém na Cisjordânia em referência a proposta do presidente Trump de construir um muro na fronteira dos EUA com o México por ABC NEWS. Donald Trump: Two huge murals by Australian artist Lushsux appear on West Bank barrier. ABC News, 2017. Disponivel em: <http://www.abc.net.au/news/2017-08-05/donald-trumpmurals-by-lushsux-appear-on-west-bank-barrier/8777794\#>. Acesso em: 19 Maio 2018. 
permite entender as tendências de transição de um meio ao outro.

\subsubsection{Do jornal para a web - cartum, charge e tira de quadrinhos}

A tarefa do caricaturista não é a mesma do artista clássico? Os dois vêem a verdade final por baixo da superfície da mera aparência exterior. Os dois tentam ajudar à natureza a realizar seu plano. Um pode lutar para visualizar a forma perfeita e executá-la em sua obra, o outro luta para alcançar a deformidade perfeita, e assim revelar a essência de uma personalidade. Uma boa caricatura, como toda obra de arte, é mais verdadeira à vida que a própria realidade.

Annibale Carracci'122 (1560 - 1609) pintore caricaturista italiano

Como mencionado anteriormente, a caricaturização e a cartunização podem ser apontadas como a base da estruturação da História em Quadrinhos. Isso não quer dizer que a arte de uma $\mathrm{HQ}$ não possa ser "realista", como se vê no trabalho de Alex Ross, exemplo. Mas, que determinados movimentos estéticos, como o realismo, expressionismo, cubismo, futurismo, etc, são as formas possíveis de arte final com a qual o artista vai trabalhar sua estrutura de base.

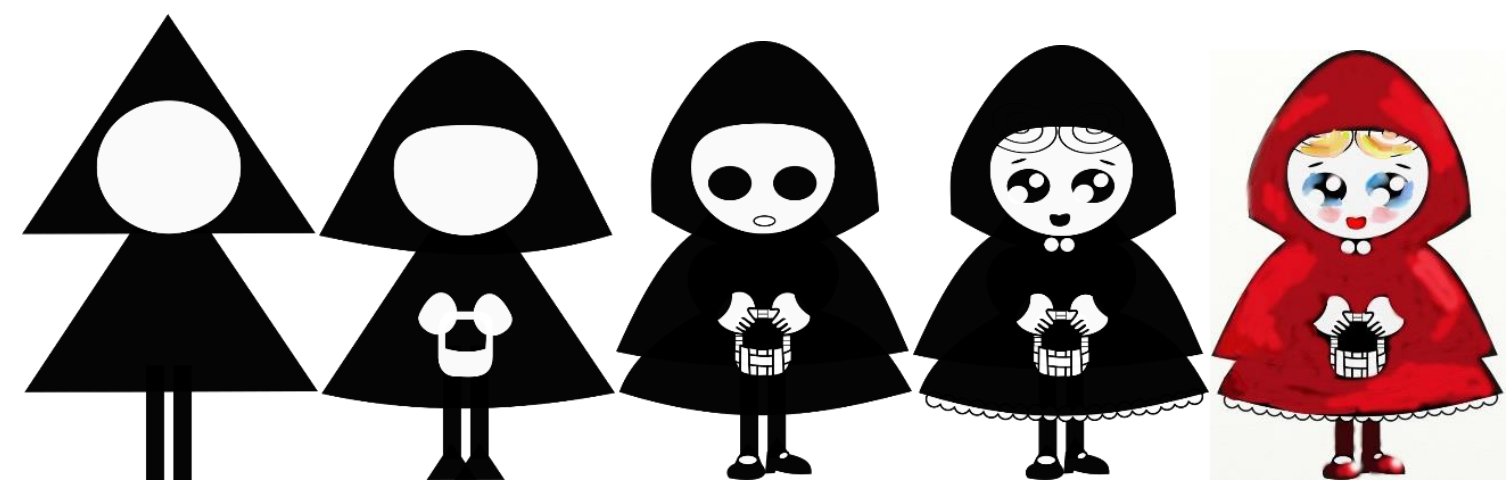

A cartunização é a etapa de construção da essência do ser, objeto ou ideia que 0 artista quer representar e a caricaturização a sobrecarga de elementos distintivos para construção do único no todo, ou melhor, a criação da marca individual

122 Apud FEAVER, W. Masters of Caricature from Hogarth and Gillray to Scarfe and Levine, pp. 21-23 (NERY, 2006, p. 29). 
dentro de uma representação esteriotipada.

A caricatura na $\mathrm{HQ}$ é um processo de construção, tanto visual quanto semântico, pois a carga (exagero) pode ser aplicada às palavras escritas associadas, e não a imagem figurativa e vice-versa.

Quando Groensteen rejeita a narratividade de alguns exemplos de cartuns de imagem única que analisa, argumentando que eles necessitam do texto escrito para se fazer entender, na verdade ele demonstra que a construção de um cartum, charge ou qualquer outro tipo de $\mathrm{HQ}$, depende da colaboração de todos os elementos que $o$ artista idealizou para a obra, inclusive o verbal.

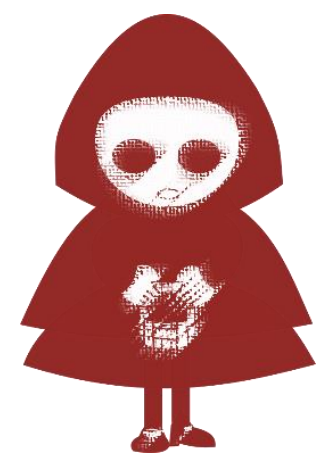

\section{ACHO TUME EN NAO DEVIA TER IDO PELA FLORESTA...}

No Brasil é chamado de charge a publicação imagética geralmente humorística ou irônica que aborda algum fato, tema ou figura pública da atualidade e do contexto do leitor. $O$ termo vem do francês "charge" (carga), tendo também sentido de encargo, obrigação e acusação, como na expressão "témoin à charge" (testemunha de acusação). Já o termo cartum é derivado da palavra inglesa "cartoon" cunhado no sentido atual pela revista britânica Punch em julho de 1843. Originalmente a palavra "cartoon" já existia na língua inglesa com o sentido de "esboço artístico", designava o material, geralmente em papel cartão, que o pintor ou escultor oferecia ao seu cliente como prévia do trabalho para aprovação. Durante uma reforma no Palácio de Westminster, também conhecido como Casas do Parlamento (avariado em um incêndio) foi feito um concurso para eleger os artistas que comporiam as obras que decorariam suas paredes, estes enviaram seus trabalhos na forma de cartuns. A revista publicou então, uma série de desenhos ironicamente chamados de 'cartuns', contrastando a suntuosidade dos projetos parlamentares em contraste com a miserável pobreza da população faminta (PUNCH, 1841-2002). Atualmente, o que distingue a charge do cartum, no Brasil, é a abrangência e universalidade dos temas. 
Charges:

TERRA EM TRANSE
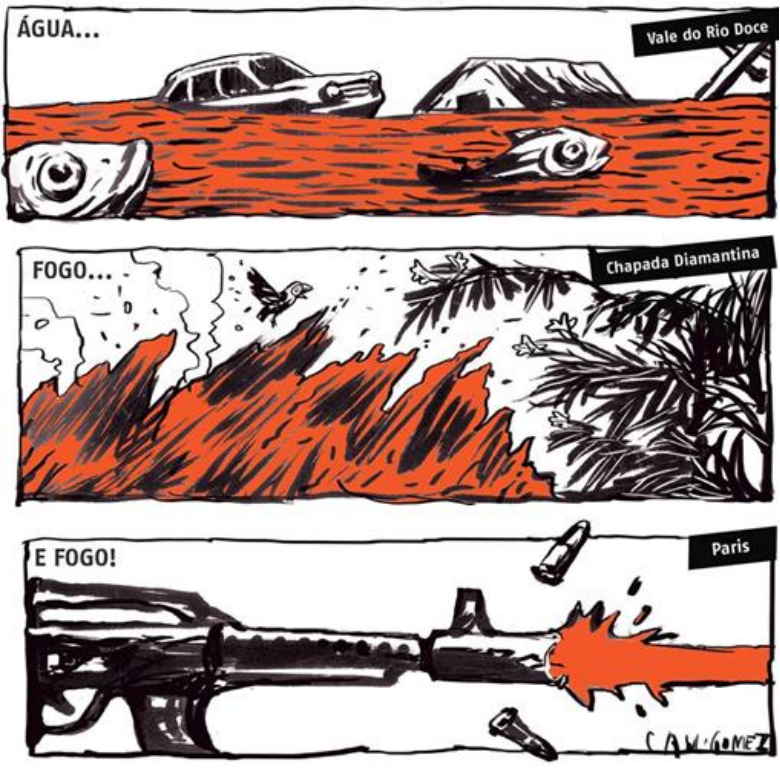

Figura 174 - Charge de Cau Gomez, publicada 18/11/2015, no jornal A Tarde

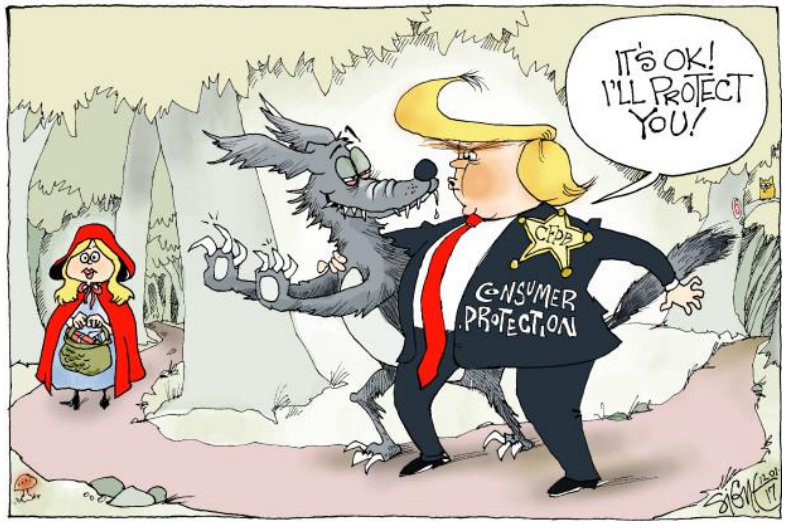

Figura 176 - Charge de Signe Wilkison, publicada em 01/12/2017 Ixxxvii
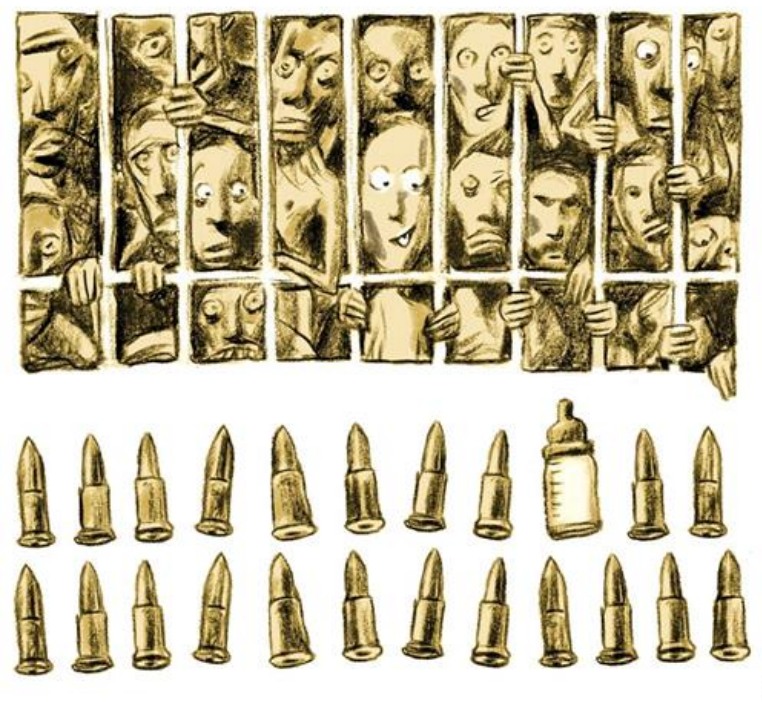

Figura 175 - Charge de Cau Gomez publicada em dia 05/06/2015 - jornal A Tarde

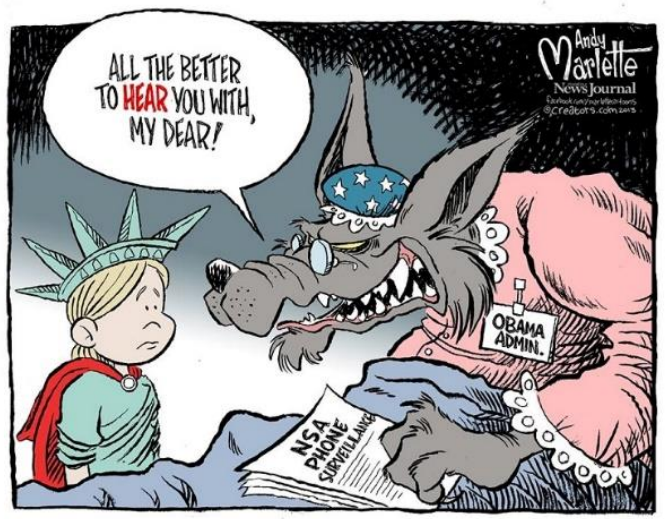

Figura 177 - Charge de Andy Marlette $e^{\mid x \times x v i i i}$

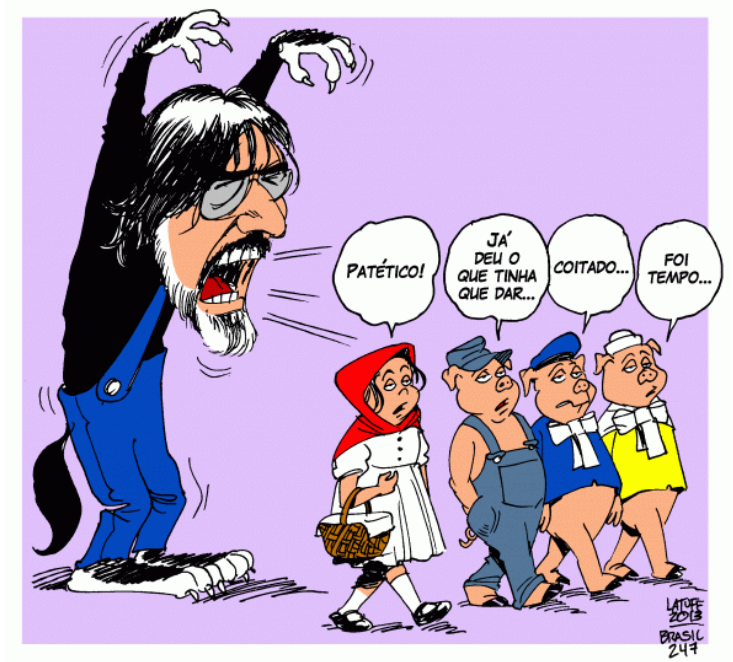

Figura 178 - charge de Carlos Latuff, 06/12/2013

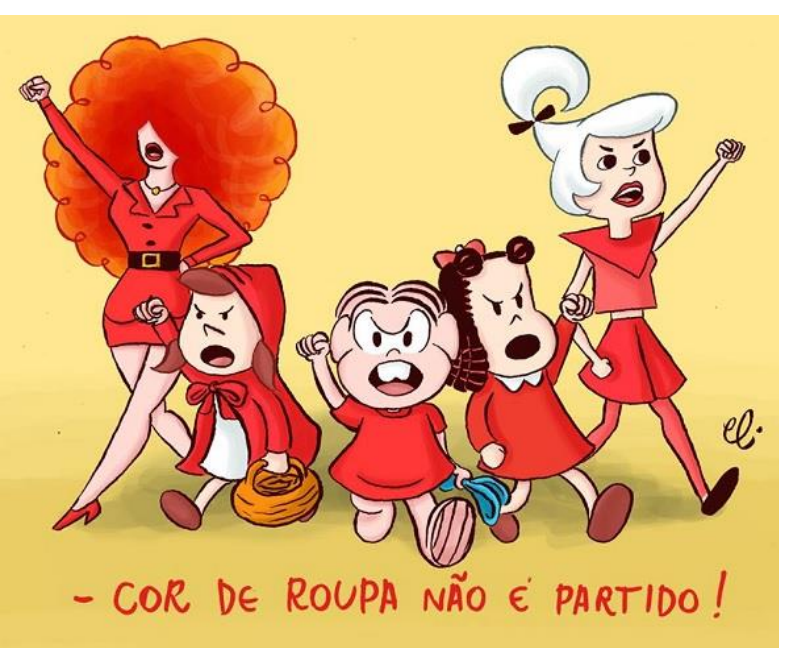

Figura 179 - Charge de Clayton Correa, $24 / 03 / 2016^{\text {Ixxxix }}$ 
Cartuns

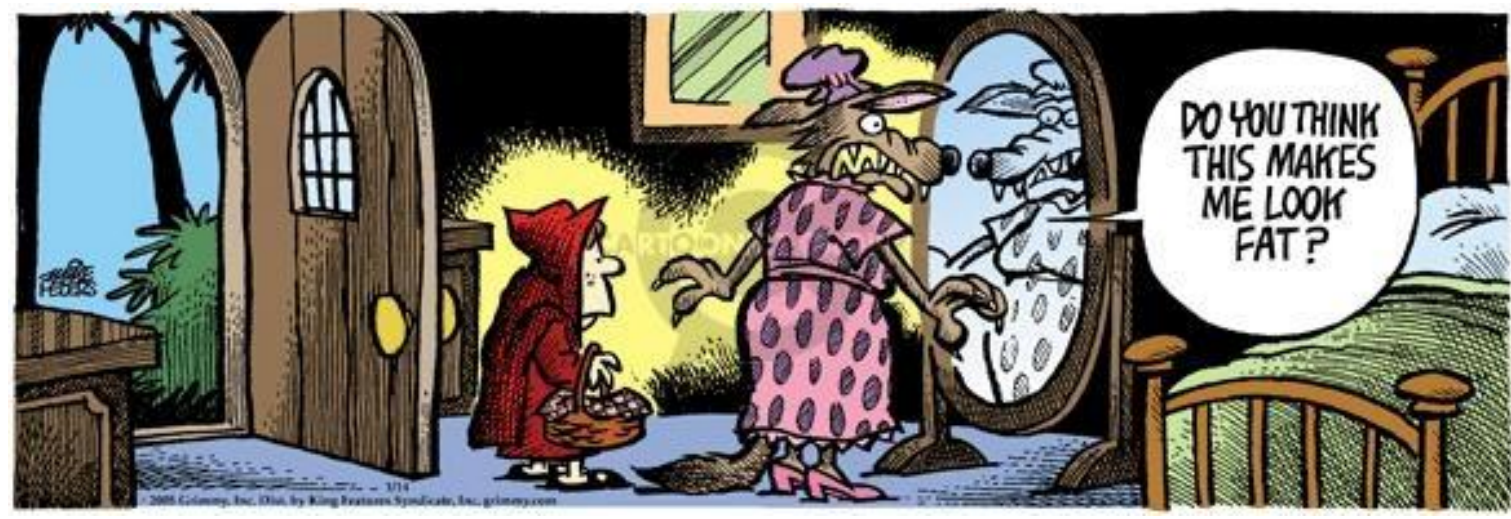

Figura 180 - Cartum de Mike Peters, 25-01-2014 ${ }^{\mathrm{xc}}$ (Você acha que este me faz parecer gorda?) [tradução da autora]

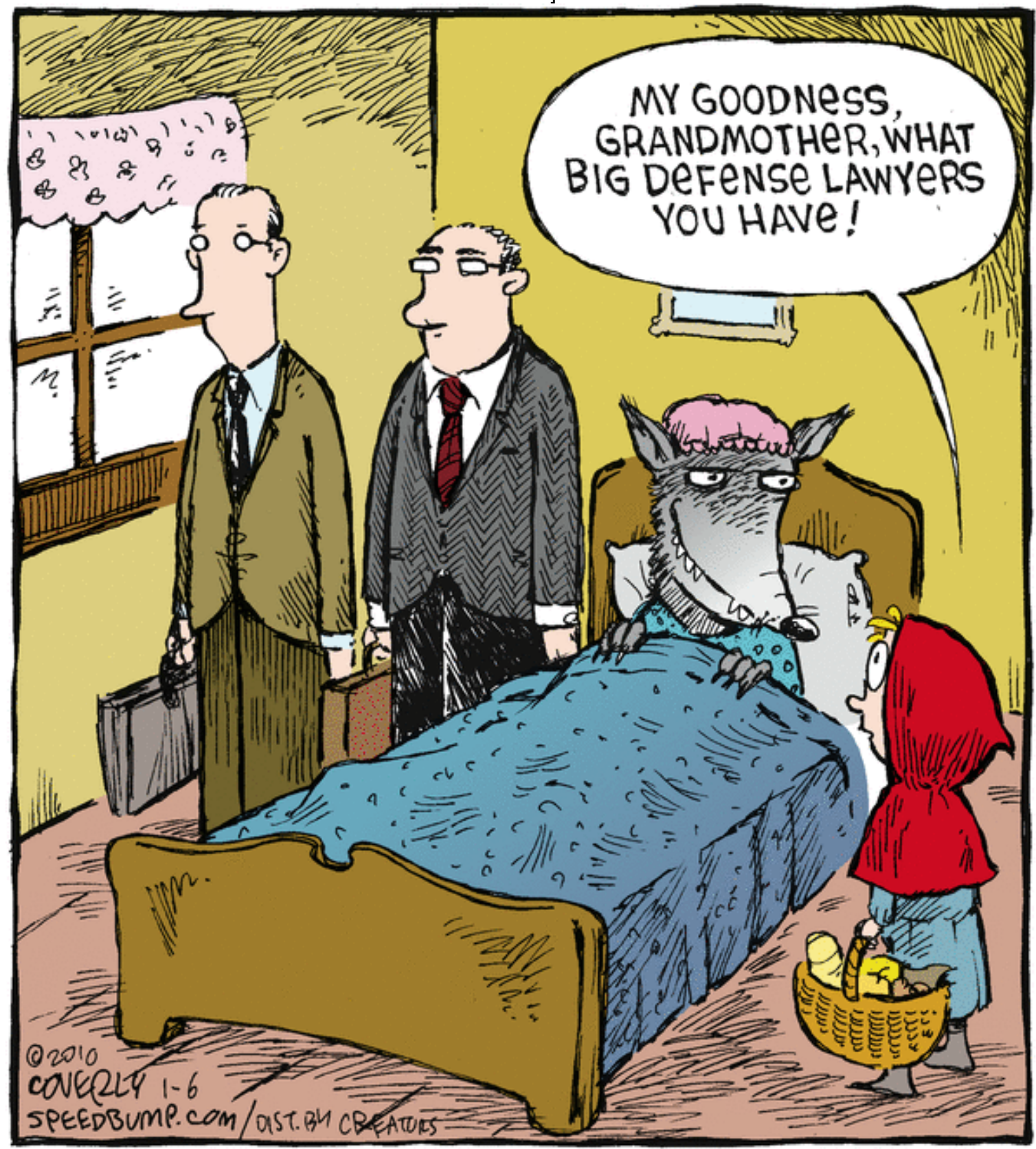

Figura 181 - Cartum de Dave Coverly, 06/01/2010 
A primeira charge, de Cau Gomes (Figura 174, pág. 230) apresenta uma referência ao desastre no Vale do Rio Doce, as queimadas na chapada Diamantina e ao atentado terrorista em Paris, todos em 2015. A segunda, também de Cau Gomes, (Figura 175, pág. 230) foi sobre a discussão sobre a redução da maioridade penal na justiça brasileira, também em 2015. Já a terceira, da cartunista Signe Wilkison (Figura 176, pág. 230), apesar de usar como pano de fundo a narrativa da chapeuzinho vermelho é uma crítica à política do atual presidente dos Estados Unidos, Donald Trump, de defesa do consumidor.) A charge de Andy Marlette (Figura 177, pág. 230) que também faz referência à chapeuzinho vermelho, critica a liberação à agência NSA, durante o governo do presidente americano Obama, a ampla vigilância telefônica e coleta de dados de internet à cidadãos não americanos divulgada por Edward Snowden. No Brasil, a charge de Carlos Latuff (Figura 178, pág. 230) é uma crítica ao cantor de rock Lobão, que por muito tempo foi opositor da situação, após um período de ausência da grande mídia, retorna como grande direitista. A charge de Clayton Correa (Figura 179, pág. 230) é uma crítica à associação midiática produzida no período do processo de impeachment da presidente Dilma Roussef, da cor vermelha para partidários do PT (Partido dos Trabalhadores), o que gerou agressões contra usuários da cor por determinado período.

Em todos os exemplos de charge, para entender a mensagem é preciso que o leitor tenha conhecimento do contexto do fato. Por muitas vezes, suscitar o riso, a charge é tida como cômica, mas na verdade, a charge é uma mensagem crítica, que usa da caricaturização e do exagero para induzir não só a uma reflexão, mas a uma indignação.

O cartum por sua vez trabalha temas, até certo ponto, universais e atemporais. Como o cartum de Mike Peters (Figura 180, pág. 231) que ressalta a preocupação com o padrão de beleza e autoestima, ou o cartum de Dave Coverly (Figura 181, pág. 231) que retrata a desconfiança nos advogados. Algumas reflexões são mais datadas e contextualizadas que outras. Talvez por isso que em outros países não haja distinção entre charge e cartum.

Pode parecer, à princípio que charges e cartuns sejam restritos a uma só figura, mas não é o caso, como demonstrado nas charges de Cau Gomez, mas sem dúvida são textos curtos, pois a força de ambos, parafraseando Júlio Cortázar, é que no "combate que se trava entre um texto apaixonante e o leitor, a narrativa sequencial sempre ganha por pontos, enquanto o cartum deve ganhar por nocaute". 
Esse tipo de atitude com o texto influenciou também a criação da tira seriada, que se diferencia do cartum e da charge pelo continuum da ambientação temática, que pode ser um personagem ou universo ficcional onde habita. A tira, em geral, ocupava nos jornais uma linha da grade da mancha gráfica, podendo possuir de um a três quadros em média. Suas narrativas ao mesmo tempo que podiam fazer parte de uma sequência maior, eram independentes com desfecho na própria obra.

O formato padrão de tira tem origem em uma necessidade comercial e não estética. O sistema utilizado nos jornais da época era o de clichês tipográficos (placas de zinco ou vidro), a tira era gravada inteira no clichê que depois era disposto com os outros para impressão. Os meios de entrega ainda eram físicos e as distâncias longas, então na falta de uma tira por qualquer razão, o clichê era facilmente substituído por outro. Esse formato padrão possibilitava a um artista vender seu trabalho para vários jornais e estes comprarem de vários artistas diferentes.

Maurício de Sousa conta que ao deixar o emprego no jornal para distribuir ele mesmo suas tiras, no começo traçou uma distância de $100 \mathrm{~km}$ no mapa a partir de sua casa para oferecer suas tiras aos jornais, pois era o máximo de distância que conseguia chegar de ônibus para entregar os clichês (GUSMAN, 2006).

Com a informatização do processo de impressão a tira não mais é entregue em clichês, uma vez que a edição da página é feita no computador antes de ser enviada para a gráfica para impressão offset ou digital, ainda assim, pelo convenção estética da página destinada aos quadrinhos, o formato da tira ainda se mantém, pois ela deve dividir um espaço pré-determinado na grade da página de jornal, disputado com outras informações que não histórias em quadrinhos (Figura 182, pág. 234).

Assim como o jornal como um todo migrou para o ambiente virtual da internet, o mesmo aconteceu com charges, cartuns e tiras. Primeiramente associados às páginas dos jornais de origem, muitos ainda vão para a rede dessa forma, posteriormente, em páginas pessoais como blogs dos próprios autores, e através de redes sociais, tanto no perfil do autor, como divulgadas por outros usuários.

Hoje o formato já está consolidado e, mesmo trabalhos divulgados prioritariamente pela internet acabam mantendo-o, como é o caso de Armandinho do quadrinista Alexandre Beck (Figura 184, pág. 235). 


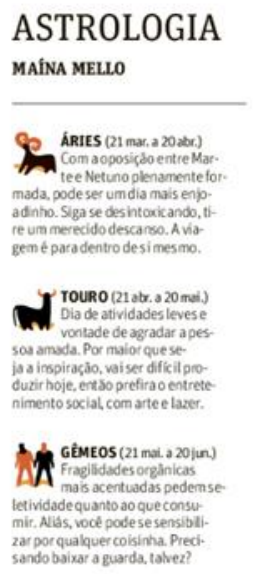

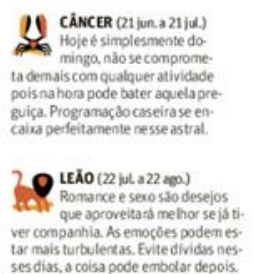

Af virgem (23 aro a 22 set) se meter con situachese pesso-
as estranhas. Éfiscilise enganar ho. je. Equem mereceria sev sacrit:-
cio? Siga sentindo e coservanda.

LBRa(23 se.a 2200u)

- Dominga, dia do Soll Quees.

mento anval Um bom momento pa se mativiza, rem nadatorcar.

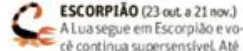

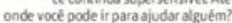
Sensibalidade e compaicido fardo mais
bem do que expect tativas e cobrancas.

H S SAGITíRIO (22 nov.a 21 6ez $\}$ Guarde seus misterios pr.

mas en peimeirolugat voct pred

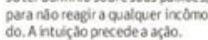

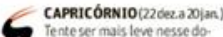

A Tiente ser muis leven nesse bém comprar brigassobre pla nos ou crencas. Dedique se mis soseuau

AQUÁrio (21 isn.a 19fec) pas, inclusive porquevoce to

fiaben em nos seexpor hoje, reem pubicamente. Até a experiencias. thor compreender seus deseion.

- $P$ PEXXEs $(20$ ler. 020 max)

Wo No ha signo mais proper

tros que o sev, mas atenglo pa.

mente. Denararye sers initios ese.

aemalanetio
QUADRINHOS

PIRATAS DO TIETÊ LAERTE
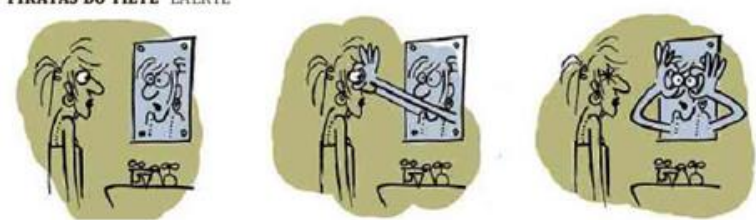

DAIQUIRI CACO GALHARDO
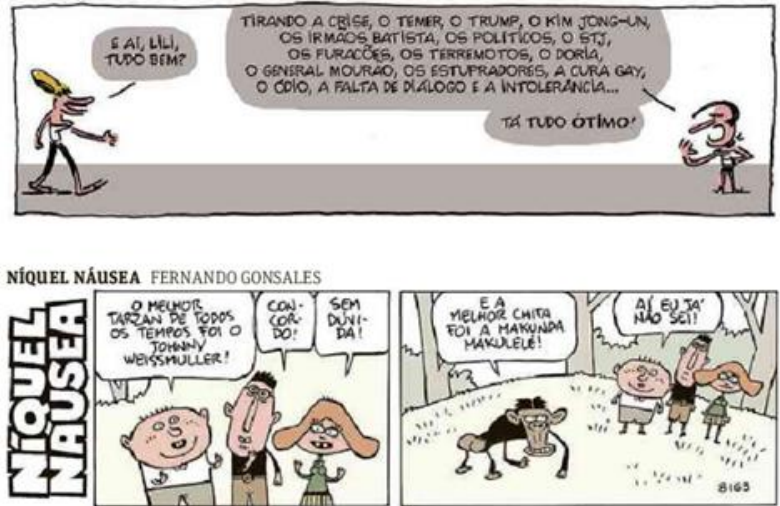

A VIDA COMO ELA YEAH ADAO ITURRUSGARAI

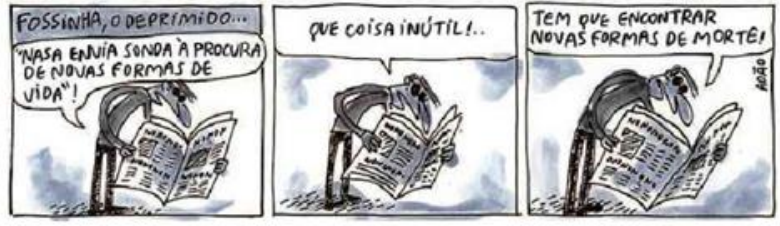

PRETO NO BRANCO ALAN SIEBER.

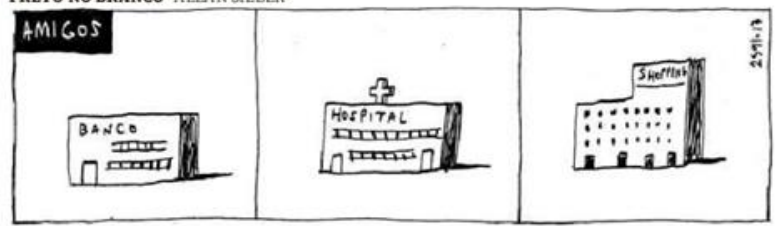

MALVADOS ANDRÉ DAHMER

Dalestra sobre os novos tempos
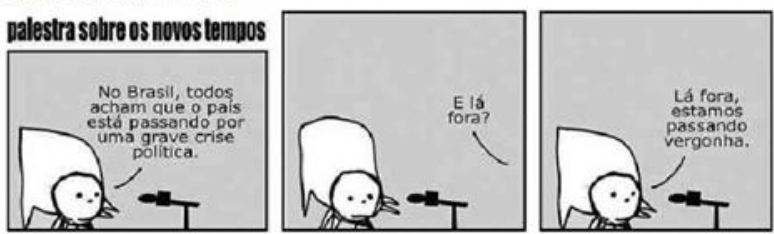

POLITICOPATAS Cl

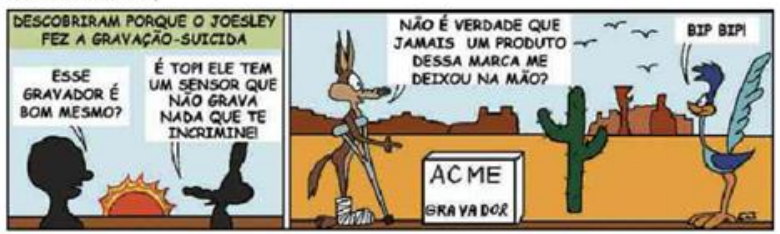

\section{SUDOKU}

A RECREATIVA www.recereativa.comberitip

Dorical

\begin{tabular}{|l|l|l|l|l|l|l|l|l|}
\hline 7 & & 1 & & & & 6 & & \\
\hline & & 3 & & 5 & & & 7 & 4 \\
\hline & & & & & 8 & & & \\
\hline & & & & & 7 & & 4 & 6 \\
\hline 6 & & 2 & 5 & & 9 & 3 & & 8 \\
\hline 8 & 4 & & 6 & & & & & \\
\hline & & & 1 & & & & & \\
\hline 5 & 9 & & & 2 & & 1 & & \\
\hline & & 6 & & & & 4 & & 3 \\
\hline
\end{tabular}

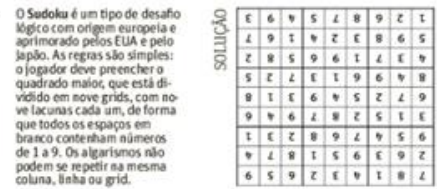

\section{CRUZADAS}

HORIzONTAIS
1. Plano de Aceleração do Crescimento / Mandioca-doce 2 io 3. Palavra inglesa oue designa lugar muito badaladof As consoantes de rajada 4. (Ingi.) Um modelo de pequena usado para plantar fores 6 . Passar (uoces ri) Recipiente Diz-se de um tipo de linguiça apimentada 8. Unidade da Federaçáa / Tưfo maciç, de plantas arvorecentes ou

o. Pearias bova sao Carl los / (Irigon.) Simbolo da funça de definida pela razzo entre o seno e cosseno de un ángulo 12. Produto de por uma pressáo na regiaso peitorat. VERTICAIS

. ça, funçà que se desempenha ou cumpre / Ponta alongada 2. As vogais de Paulo / Ato de cobriir para conservar o calor Uubagem 5 . Elevado / Famoso canal de filmes da TV paga I Período de tempo caracterizado por falta de chuvas 6. 0 Dom edro 506 cujo reinado toi sancionada a lei Aurea / (Med.) Tesouro Nacional 7. Moldura com vidro para se colocar fotos. que se póe sobre um móvel 8. Grupo etnografico ao qual pertencerm muitas tribos tapuias / 0 antônimo de entrada 9.

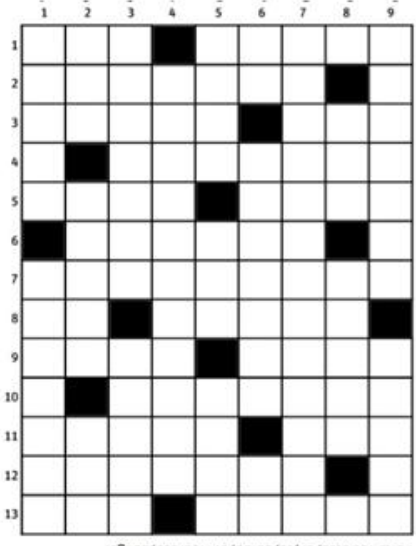

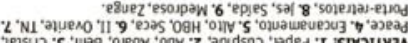

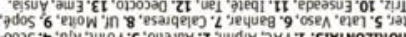

Figura 182 - Recorte da página do jornal Folha de São Paulo de 24/09/2017. 


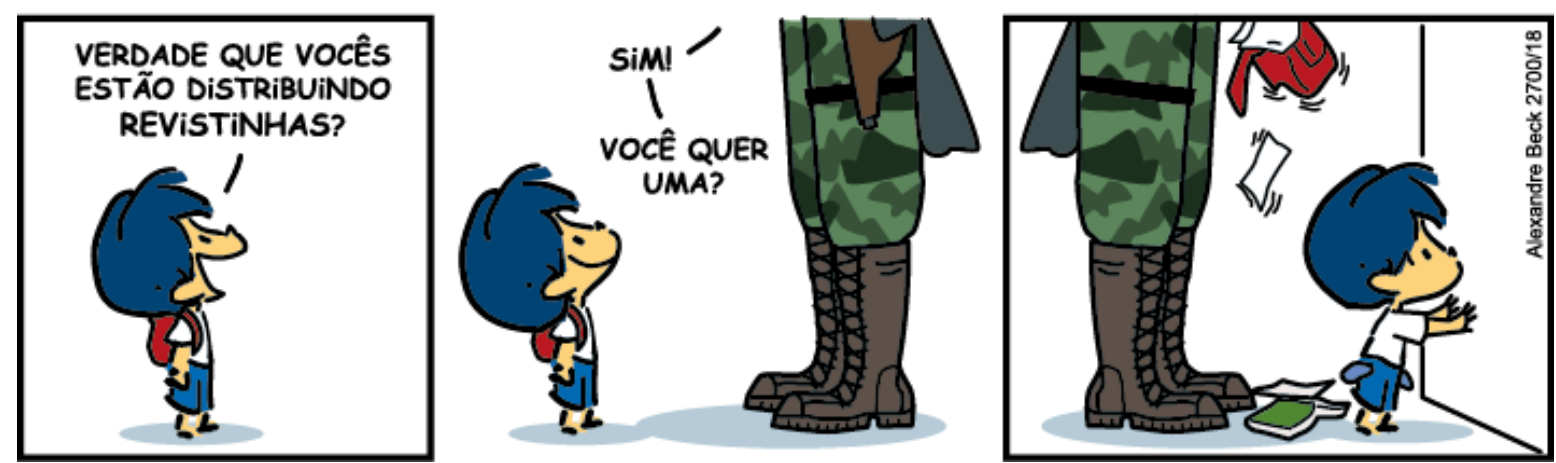

Figura 183 - Armandinho - Alexandre Beck - Facebook - 09/03/2018

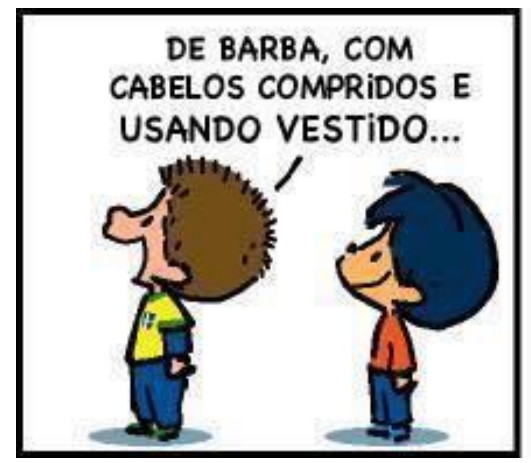

...E AINDA COM UM PANINHO VERMELHO NO OMBRO, Ui! Ui!

Figura 184 - Armandinho - Alexandre Beck - Facebook 20/05/2016
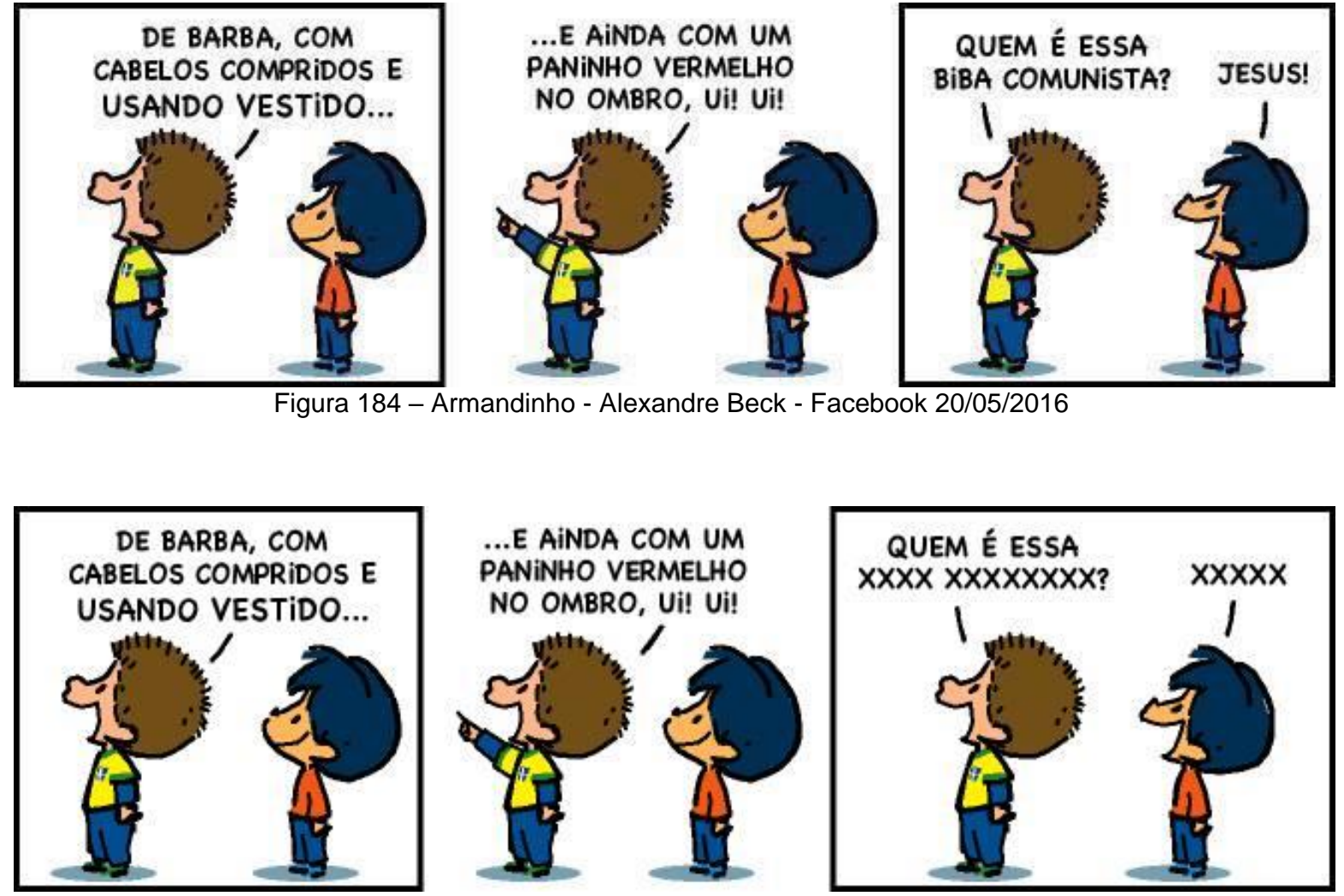

...E AINDA COM UM PANINHO VERMELHO NO OMBRO, Ui! Ui!

Figura 185 - Armandinho - Alexandre Beck - Facebook 20/05/2016
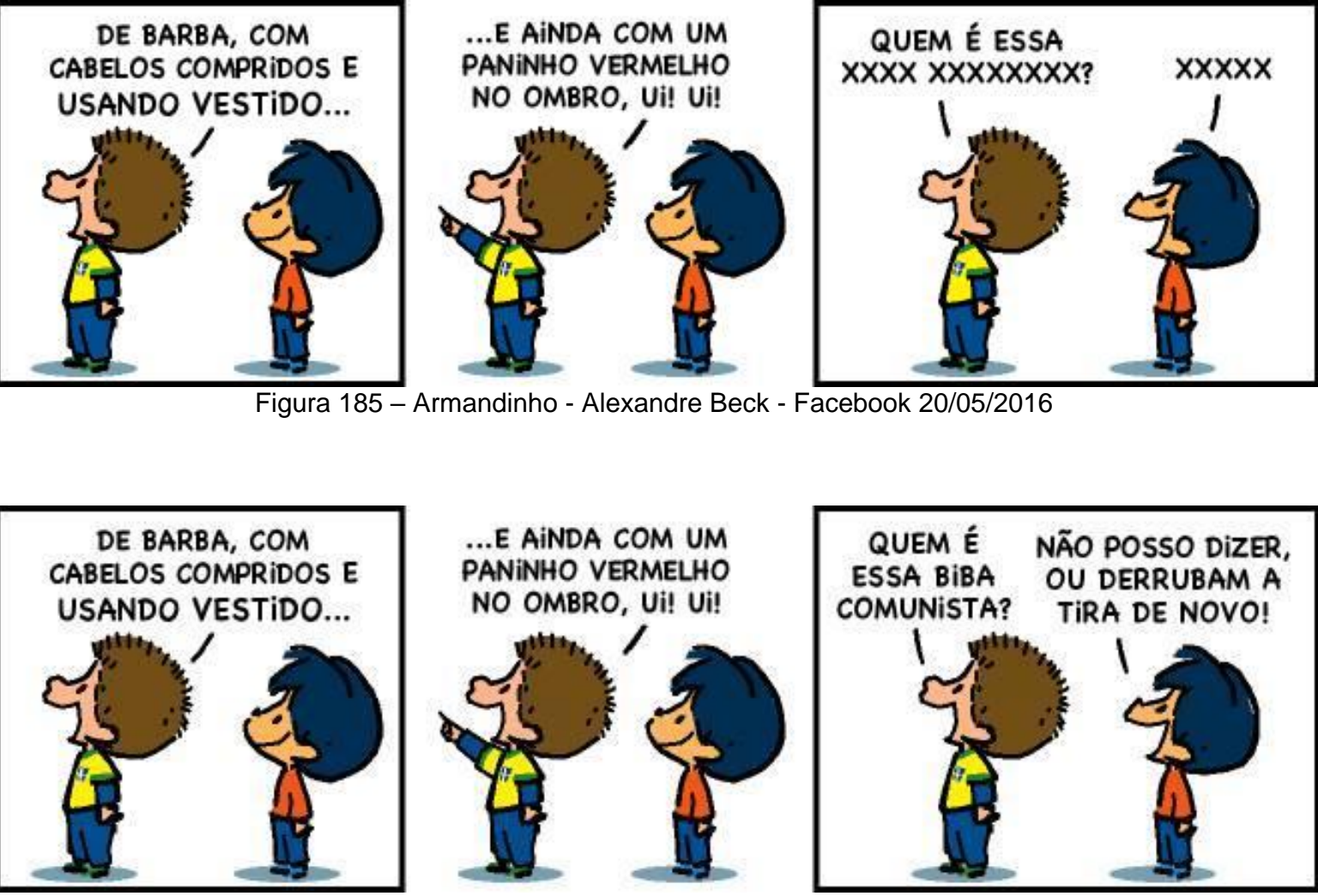

...E AINDA COM UM PANINHO VERMELHO NO OMBRO, Ui! Ui!

Figura 186 - Armandinho - Alexandre Beck - Facebook 20/05/2016
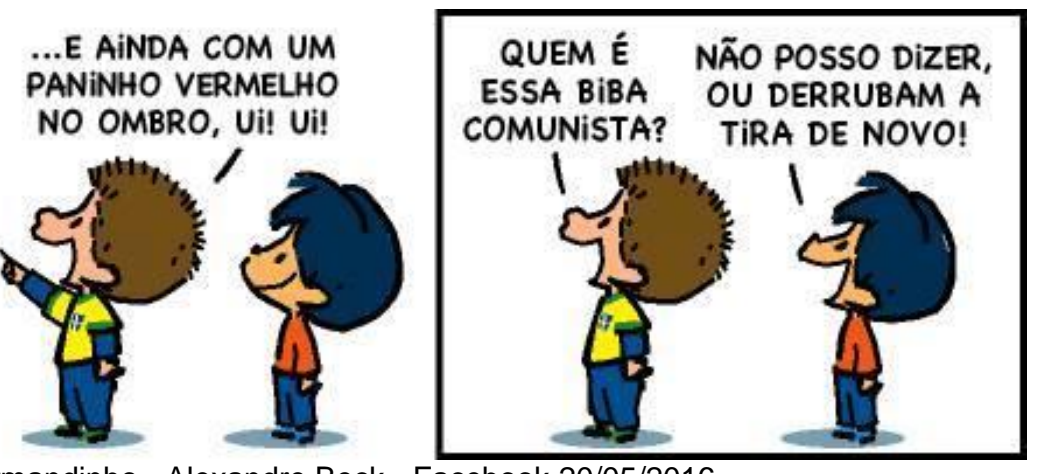
Um fato curioso sobre a veiculação de quadrinhos nas redes sociais é que, diferente da mídia impressa, a censura e o banimento se dá pela força do leitor. Em uma simplificação grosso modo, supõe-se que o leitor aplica seu controle panóptico dentro e fora da diegese, pois nas redes sociais, se muitos usuários "denunciam" uma publicação como ofensiva, ela é automaticamente retirada do ar, sem explicação, por intermédio de uma autoridade ou aplicação de algum código de conduta ou lei. Não há nada que salvaguarde a veiculação da obra do autor. Isso aconteceu com a tira de Alexandre Beck (Figura 184, pág. 235), publicada na página do Facebook do personagem, no dia 20 de maio de 2016. A tira foi "derrubada" cerca de meia hora após a publicação, o autor publicou uma versão mutilada (Figura 185, pág. 235), que também foi derrubada e por fim publicou uma sátira à situação em uma terceira tira (Figura 186, pág. 235). O controle sobre o material publicado não é exclusivo dos leitores, os proprietários das empresas, assim como as editoras de material impresso, podem vetar ou derrubar as publicações que consideram contrárias as suas políticas, como o caso do facebook, de propriedade de Mark Zuckerberg, que censurou como pornografia um pôster de uma peça de teatro que trazia a reprodução da tela "A Liberdade guiando o povo", do francês Eugène Delacroix, pois no quadro de $1830 \mathrm{a}$ liberdade, é representado por uma mulher com seios à mostra. Na mesma linha de conduta derrubou também um post que mostrava a Vênus de Willendorf, considerada obra-prima da era paleolítica, exposta no Museu em Viena.

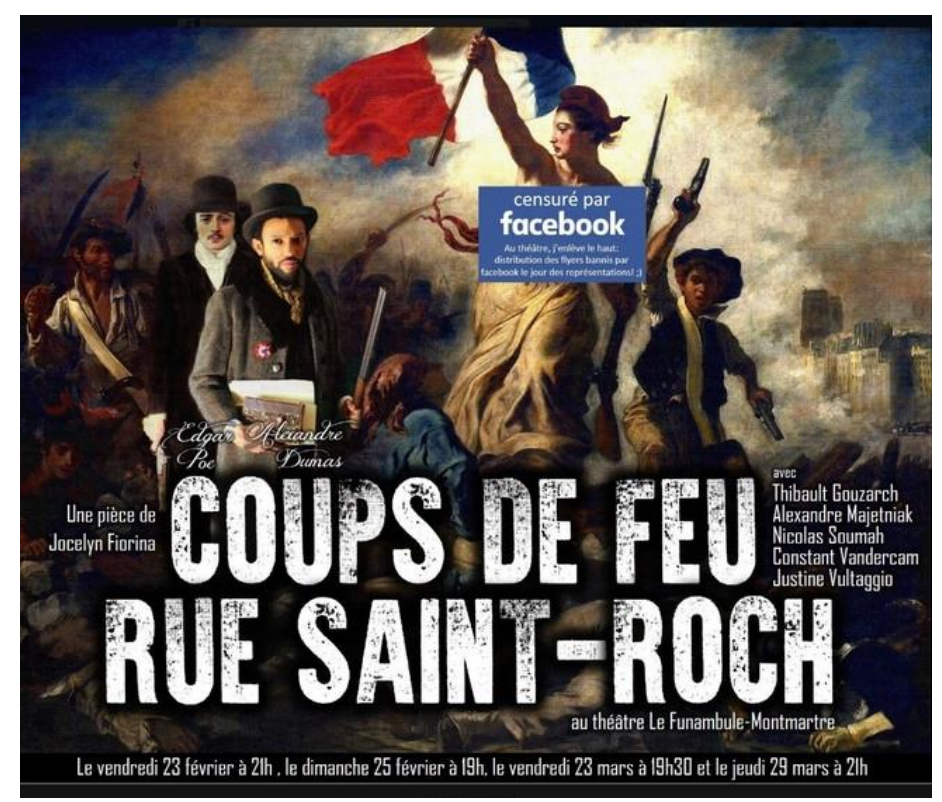

Figura 187 - Pôster da peça Coups de feu rue Saint-roch, com acréscimo de tarja colocada pela diretora Jocelyn Fiorina ${ }^{\mathrm{xci}}$

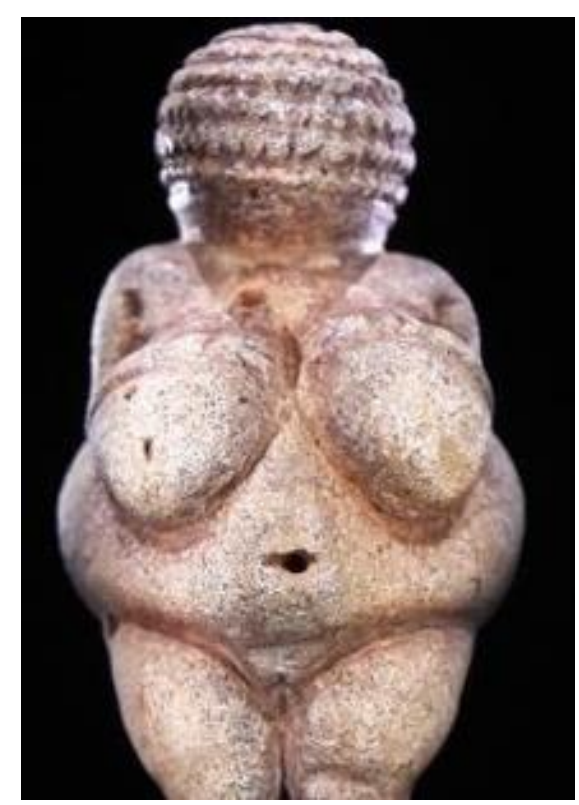

Figura 188 - Museu de História Natural de Viena, Vênus de Willendorfxcii 
Se por um lado as redes sociais possibilitam uma maior visibilidade aos autores, também os colocam sob uma censura unilateral sem direito de resposta. Sites de internet, assim como editoras, são empresas com fins lucrativos e regras privadas, mesmo que seu alcance seja global, os donos das empresas seguem os códigos de seu país de origem, quando existem.

Existe também o problema do respeito ao direito autoral do artista, alguns sites como Deviant Art, que muitos quadrinistas utilizam para expor seu trabalho, por exemplo, possuem uma página explicativa sobre copyright ${ }^{123}$ para inibir o uso das imagens sem creditar o autor, mas é comum uma charge, cartum ou tira viralizar como "meme" sem crédito ao autor.

Meme, baseado no latim "mimeme" (imitação) é o termo criado por Richard Dawkins em seu livro "O gene egoísta" para descrever a forma como a teoria genética evolucionista de Charles Darwin pode ser aplicada à transmissão cultural, como uma entidade reprodutiva. De acordo com o escritor e jornalista Jerônimo Teixeira,

O conceito de meme é bastante amplo, incluindo hábitos, superstições, crenças, doutrinas, teorias - em suma, qualquer representação mental que dependa dos limitados recursos do cérebro humano para sobreviver e se difundir. [...] Tudo o que é ensinado ou transmitido socialmente pode ser um meme. A fórmula da relatividade $(E=m c 2)$ e o logotipo da Coca-Cola, os quartetos de Beethoven e a eguinha Pocotó, os sonetos de Camões e as piadas do Casseta \& Planeta são todos memes (TEIXEIRA, 2003).

Teixeira aponta para a tendência do comportamento do meme ser mais próximo do vírus do que do gene, pela capacidade de um meme contagiar outras mentes e se expandir,

A moda e certas febres de consumo são talvez o exemplo mais evidente desse processo. Um garoto aparece com um ioiô ou um tamagotchi'124 no recreio e em poucos dias todos na escola estão brincando com o mesmo artefato (TEIXEIRA, 2003).

O próprio conceito de meme, segundo Teixeira, tornou-se um meme, propagando-se de forma errática e adulterada, muito distante do original, o jornalista cita o pesquisador mimeticista David Hull "Os memes não dão a mínima para a lógica. Eles não são selecionados pelo seu valor de verdade” (HULL apud TEIXEIRA, 2003). Teixeira explica que quando um memeticista diz que determinado meme é bom ou apto, não significa que ele seja moralmente aceitável ou cientificamente correto, e sim que ele teve sucesso infectando um grande número de mentes (TEIXEIRA, 2003).

\footnotetext{
${ }^{123}$ Página do site Deviantart sobre copyrignt: https://about.deviantart.com/policy/copyright/

124 Tamgotchi é um brinquedo em que se cria um animal de estimação virtual. O tamagotchi foi lançado em 1996 e relançado em 2017 pela Bandai, no Japão.
} 
Uma das versões distorcidas da teoria mimética é o meme de internet, que são frases ou figuras ou fotos (com ou sem texto) que "viralizam" nas redes sociais, blogs e aplicativos de comunicação como Whatsapp. Uma pessoa produz uma frase ou montagem qualquer e compartilha no ambiente virtual, pessoas de sua relação visualizam, acham interessante e, por sua vez, compartilham essa figura, e assim por diante.

A palavra meme virou sinonimo dessas publicações, ganhando espaço como entidade independente do conceito científico, o dicionário oxford, por exemplo, traz as duas definições:

1. An element of a culture or system of behaviour passed from one individual to another by imitation or other non-genetic means.

2. An image, video, piece of text, etc., typically humorous in nature, that is copied and spread rapidly by Internet users, often with slight variations. ${ }^{125}$ Dicionário Oxford On-line (https://en.oxforddictionaries.com/definition/meme).

O meme não é uma História em Quadrinhos, mas uma $\mathrm{HQ}$ pode se tornar um meme. Pela concisão, muitos cartuns e charges se tornam memes, às vezes adulterados. A diferença entre a publicação de uma obra na internet pelo artista, é que o público entra em sua página ou perfil para ler seus trabalhos dentro do seu contexto artístico. Já o meme é uma entidade independente e incontrolável. O artista não tem controle após sua disseminação, nem ao menos da sua integridade.

Um caso flagrante de adulteração que provocou reação dos quadrinistas foi o de Ivan Cabral, chargista do Novo Jornal de Natal (RN), onde a charge original (a esquerda), critcando o movimento de direita pelo anafalbetismo histórico, foi adulterada para uma crítica ao movimento dos trabalhadores, em evidente antagonismo à proposta original.

125 1. Um elemento da cultura ou sistema de comportamento passado de um indivíduo a outro por imitação ou outro meio não genético. 2. Uma imagem, video, parte de texto, etc., tipicamente de natureza homorística, que é copiado e espalhado rapidamente pelos usuários da internet, frequentemente com pequenas variações (Dicionário Oxford On-line (https://en.oxforddictionaries.com/definition/meme) [tradução da autora]. 


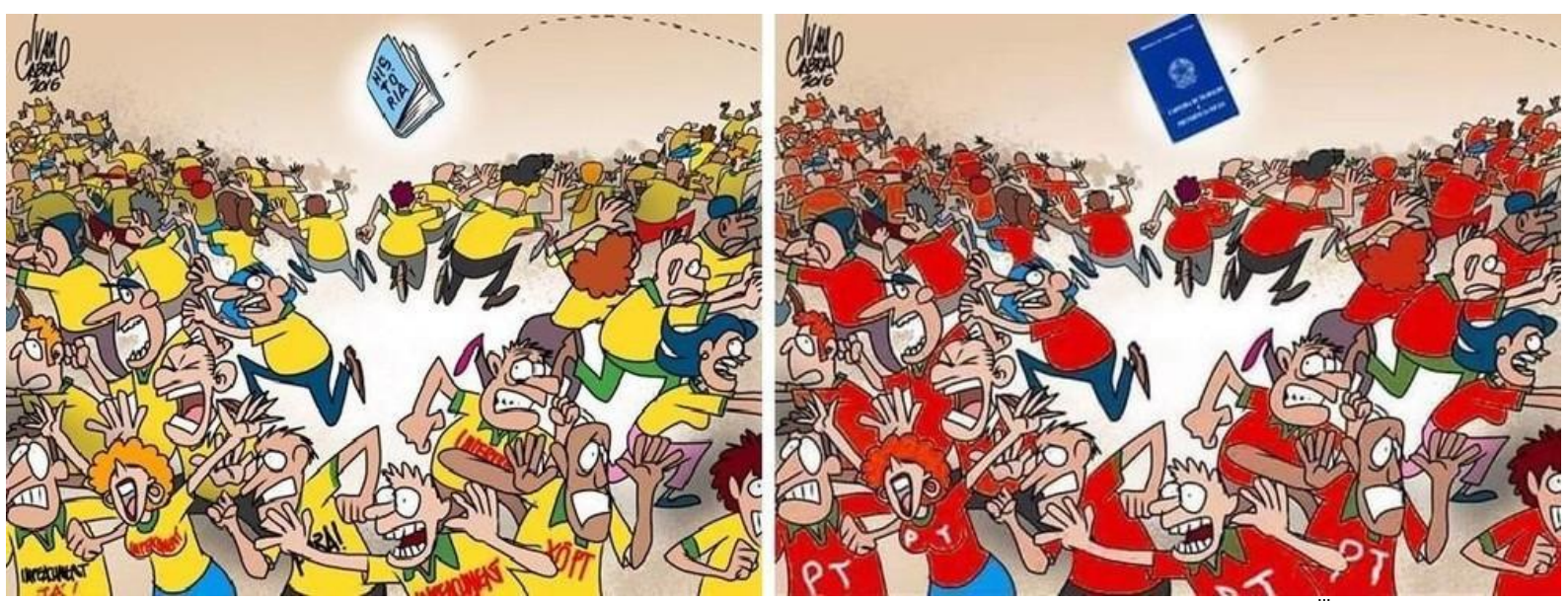

Figura 189 - Charge de Ivan Cabral, original (esquerda) e adulterada (direita) ${ }^{x i i i}$

Um dos memes baseados em figuras de quadrinhos mais popular é um quadro da revista World's Finest, número 153, onde o personagem Batman de um universo paralelo esbofetea seu sidekick Robin, em um contexto onde se torna um vilão por assumir que o Super-homem seja o responsável pela morte de seus pais. $\mathrm{Na}$ história, a cena marca a derrocada do personagem para o caminho do "mal".
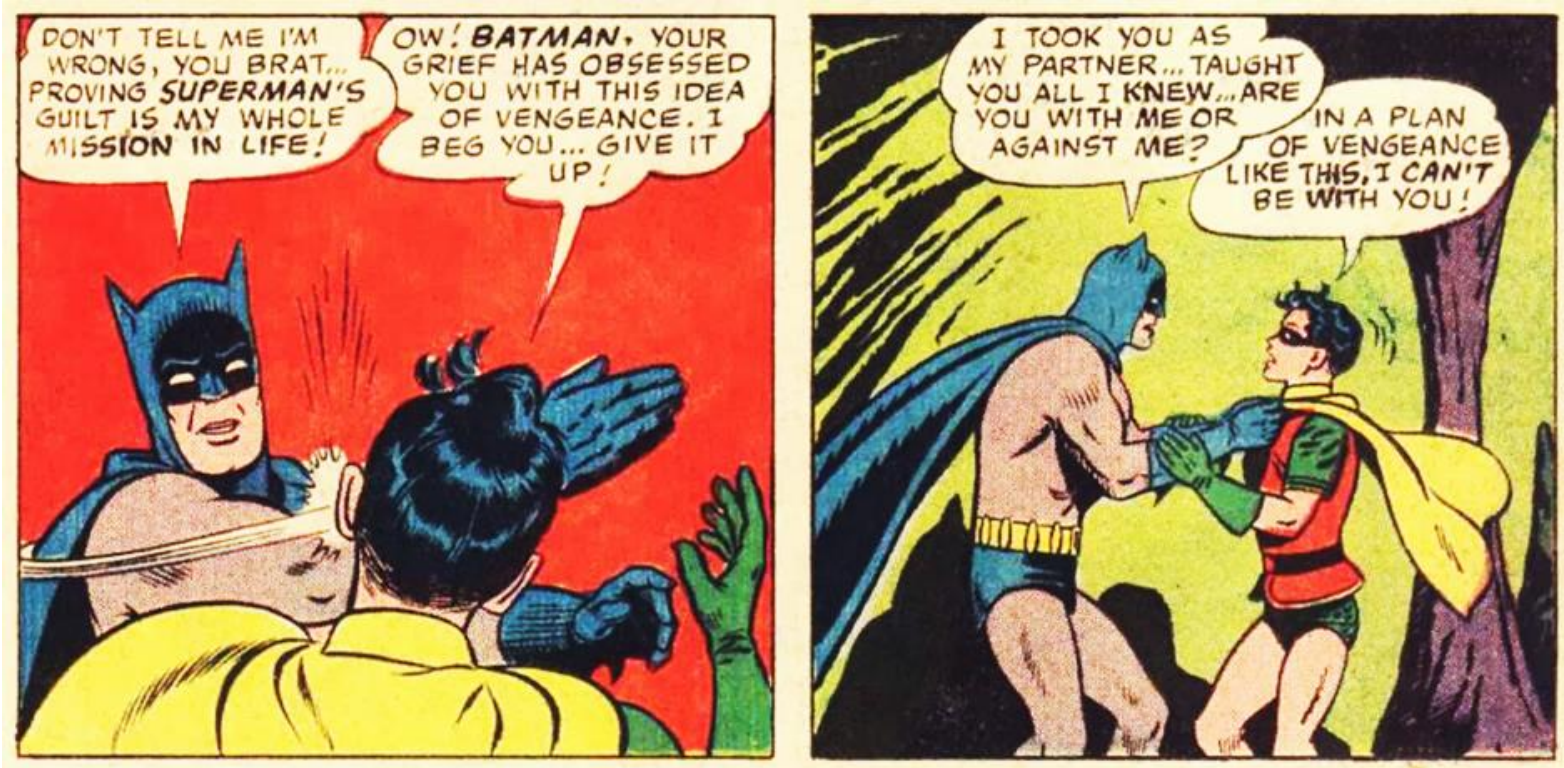

Figura 190 - World's Finest Comics, número 153, DC Comics, página 5, linha 2, 1ำ e 2ํquadros

O primeiro quadro da linha 2 da página 5 (Anexo 1), retirado de seu contexto, foi (e ainda é) usado nos mais variados memes, para ilustrar as mais diversas broncas. Por sua própria natureza, é praticamente impossível, sem intervenção das empresas hospedeiras, descobrir a identidade do autor de um meme. 


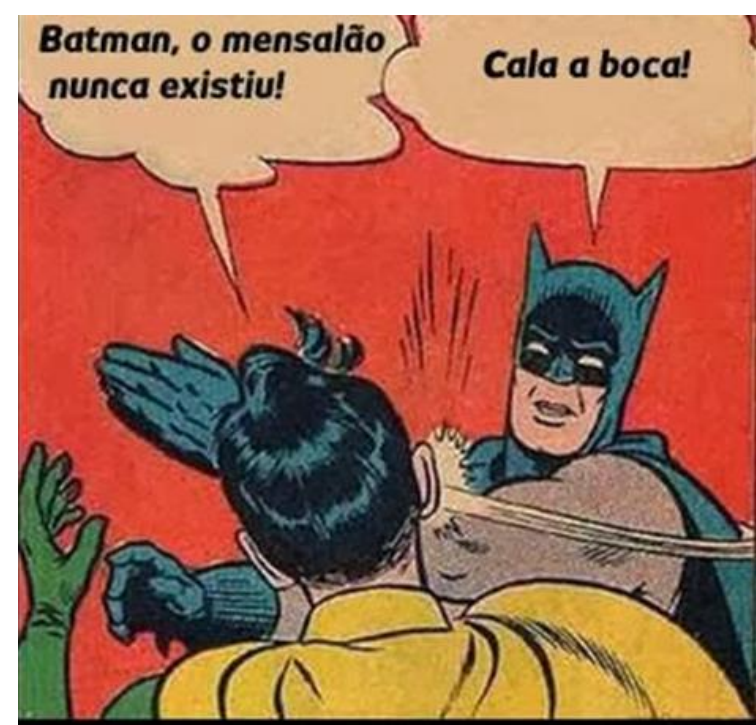

Figura 191 - Meme Batman bate em Robin ${ }^{\text {xciv }}$

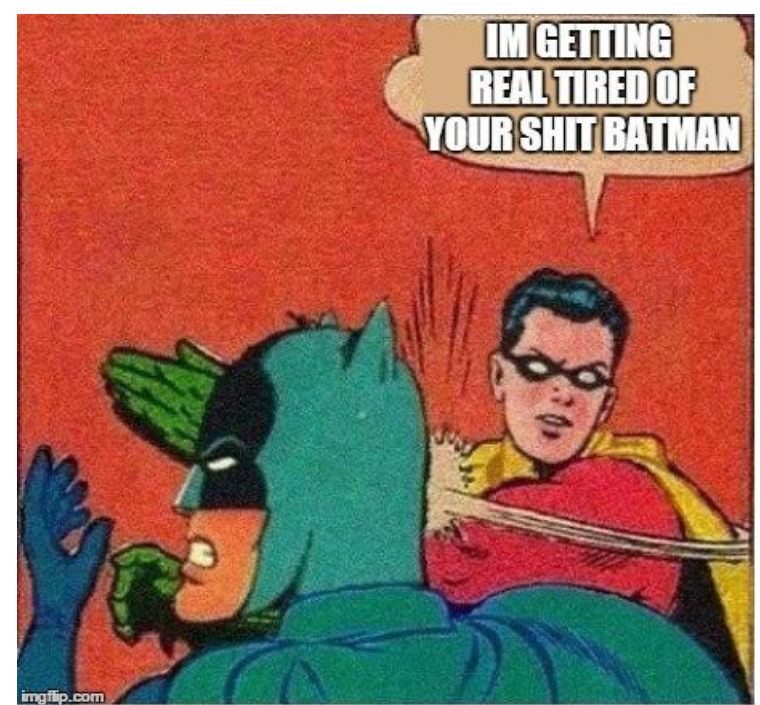

Figura 193 - Meme Robin slaps Batman ${ }^{\text {xcvi }}$

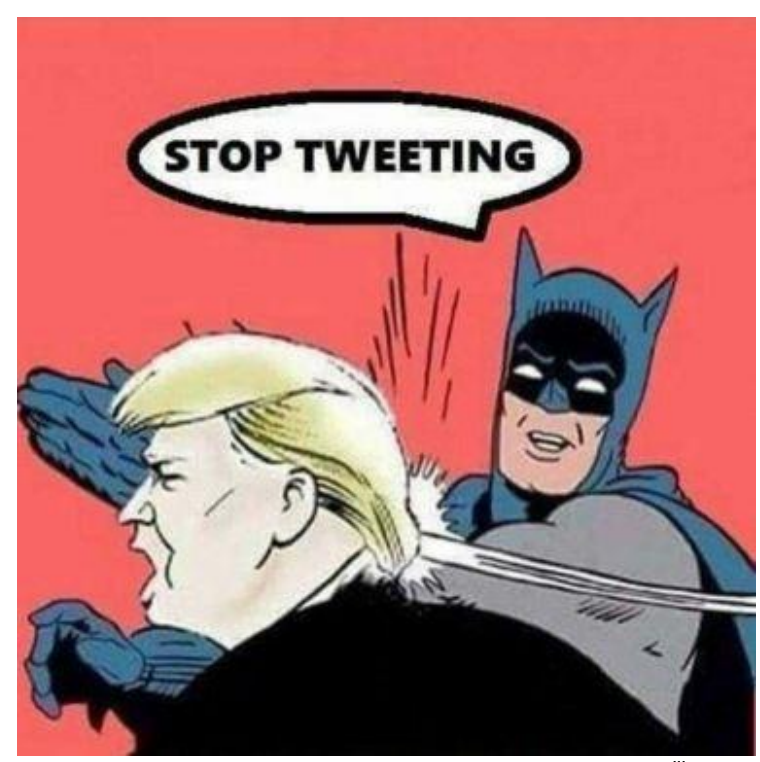

Figura 195 - Meme Batman slaps Trump ${ }^{\text {xcviii }}$

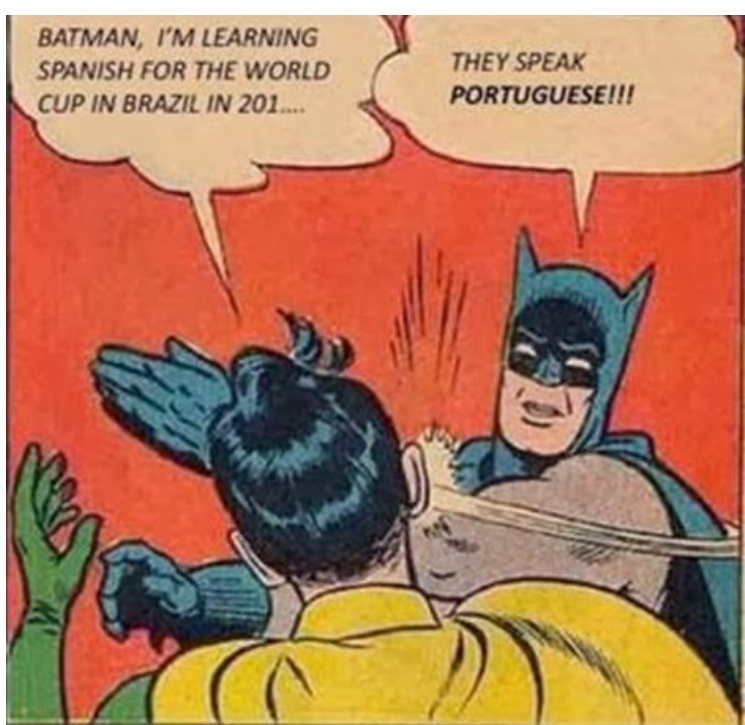

Figura 192 - Meme Batman bate em Robin ${ }^{x c v}$

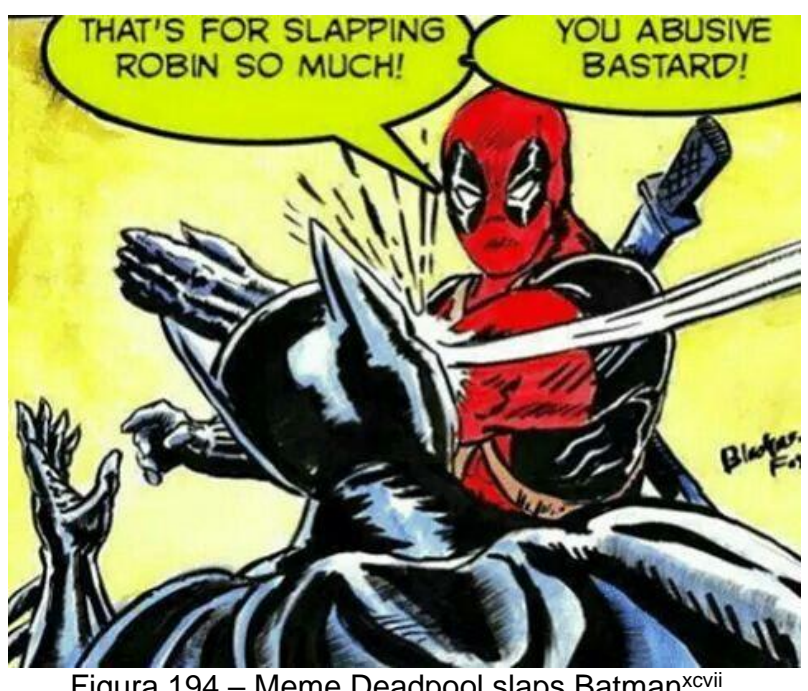

Figura 194 - Meme Deadpool slaps Batman ${ }^{\text {xcvi }}$

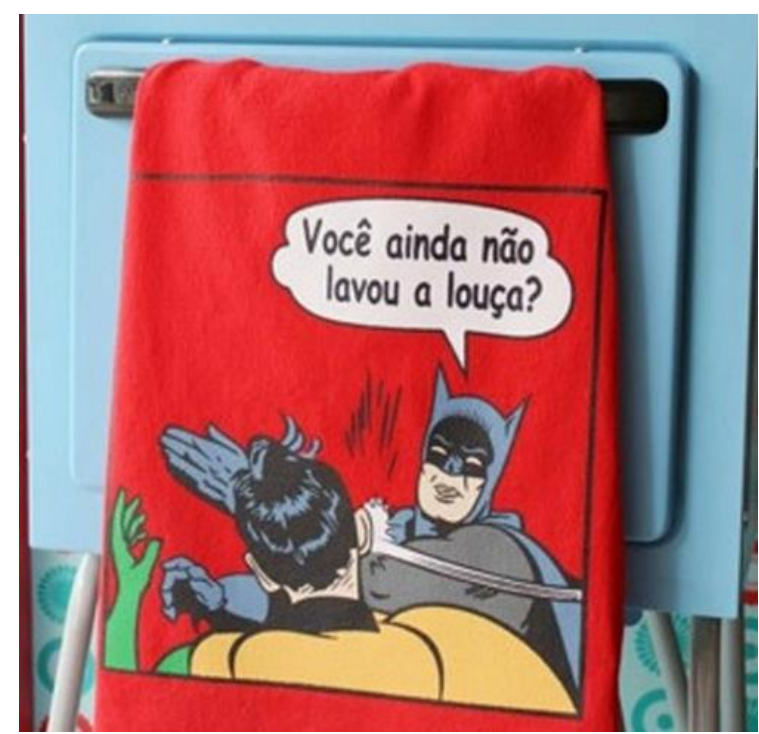

Figura 196 - Meme Batman bate em Robin - pano de prato $^{\text {xcix }}$ 


\subsubsection{Revistas, livros e Web-Narrativas sequenciais}

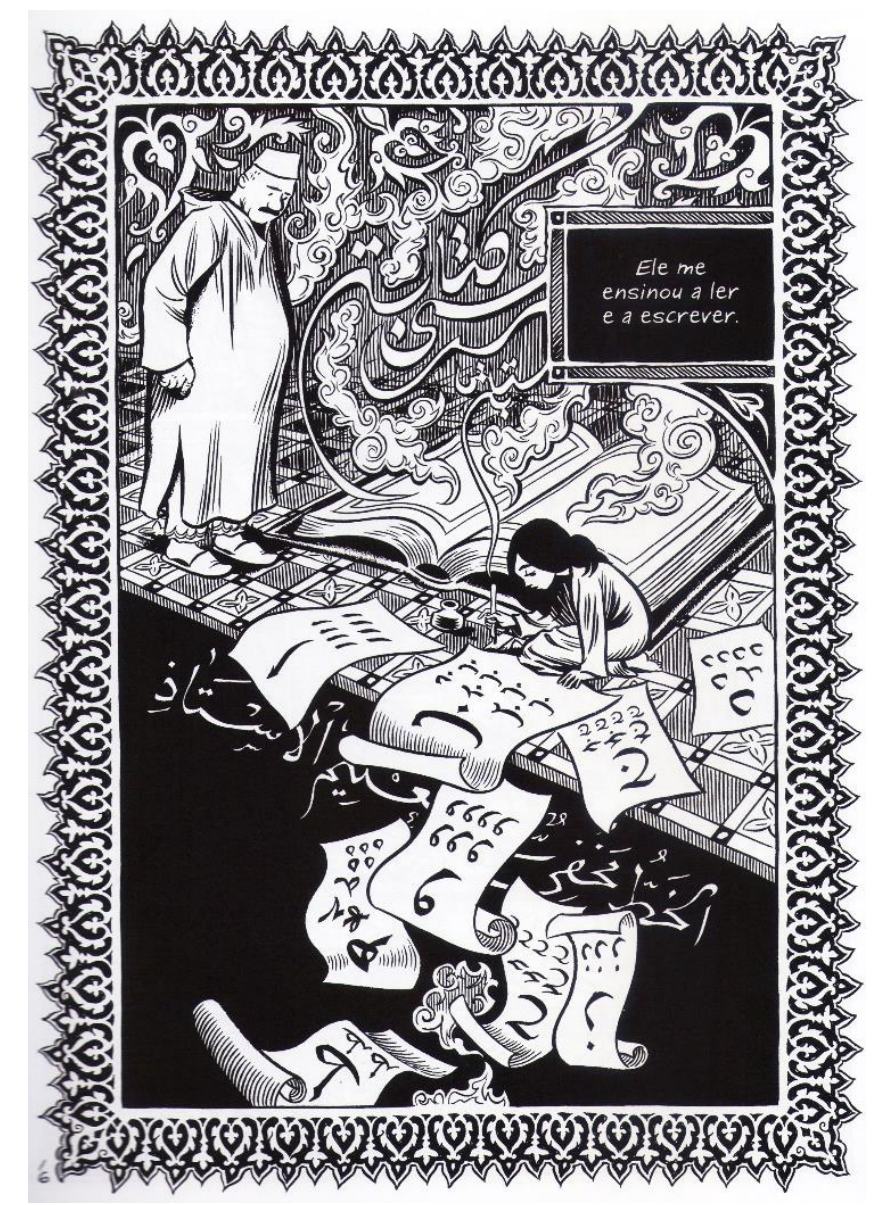

Craig Thompson ${ }^{126}$

Além da temática humorística, as tiras abrigaram por um período outras temáticas como aventura e romance, sendo conhecidas como "tira seriada", pois faziam parte de uma narrativa maior a ser publicada na edição seguinte. As tiras seriadas migraram para $\mathrm{o}$ formato da revista em quadrinhos, praticamente desaparecendo dos jornais.

Uma vez na revista, a história em quadrinhos pôde desenvolver narrativas maiores, com mais variações temáticas e estéticas. As múltiplas abordagens de enquadramento e transições e das relações de espaço e tempo, narrador e personagens fizeram com que a narrativa sequencial se tornasse, em muitos aspectos, a tradução de História em Quadrinhos. O funcionamento de algumas narrativas sequencias é tão distante das narrativas curtas que, à primeira vista, parecem objetos

${ }^{126}$ Epígrafe - fonte: THOMPSON, C. Habib. Tradução de Érico Assis. São Paulo: Schwarcz, 2015. Pg. 16. 
diferentes, mas com base na relação histórica da ilustração como forma de comunicação, é possível averiguar que muitas diferenças são especializações de uso, ou seja, determinada finalidade e intenção moveram a linguagem, a estética e a temática para determinada realização.

A revista em quadrinhos surgiu em um contexto específico, nos Estados Unidos, no final da década de 20 , mas a experimentação da imagem como forma comunicativa em outros suportes e outras temáticas se dava em várias partes do mundo, com resultados diferentes, como o livro infantil que desde Töpffer explorava novas relações semânticas entre o ícone figurativo e o ícone semântico.

De um lado, as revistas, cuja proposta de realização envolveu em grande parte uma demanda mercadológica, se especializaram em um aproveitamento maior do espaço por página, criando grades de até $4 \times 4$ (quatro quadros por linha). Essa densidade gráfica implica em uma narrativa ao mesmo tempo rápida (as coisas parecem acontecer mais rapidamente) e referencialmente dinâmica, pois a panopticidade da página envolve o leitor com uma grande quantidade de imagens para que sejam interpretadas tanto buscando em seu referencial por associações já conhecidas, como acrescendo seu referencial com novas associações.

Do outro lado há o livro de imagens infantil, com uma grade de um a dois quadros por página dupla, com uma proposta didática de iniciação tanto a leitura da imagem quanto do texto escrito, fornecendo ao leitor um ritmo lento de leitura e absorção do conteúdo. A virada da página do livro para a nova imagem, é um tempo de pausa no ritmo, que cria a sequencialidade da narrativa na memória, ou seja, a criança tem que acessar sua memória para lembrar da página anterior e assim dar continuidade a sequência imagética.

Pode parecer, a princípio, que são tratados dois objetos alienígenas entre si, uma revista em quadrinhos e um livro ilustrado, mas quando a base criacional da estrutura é a mesma, ou seja, há a cartunização e caricaturização na criação da ambientação e/ou dos personagens, há a solidariedade icônica na grade entre os elementos tanto figurativos quanto linguísticos, então a análise comparativa aponta para um mesmo objeto em variações de suporte, arte-final, temática e intencionalidade.

Contudo, possuir um projeto de mancha gráfica de grade com o cuidado na manipulação e enquadramento do texto escrito não necessariamente transforma uma obra em História em Quadrinhos. Quando o quadrinista inglês Neil Gaiman convidou 
o artista plástico japonês Yoshitaka Amano para participar de uma de suas histórias do personagem Sandman, publicado na revista Vertigo da DC Comics de 1989 a 1996, Amano, reconhecido por seus trabalhos permeados de misticismo e cultura pop aceitou com a condição de que não fosse quadrinhos.

Well, we asked Amano-san if he would like to do a comic, and he said no but that he would love to do an illustrated book. Which made the choice of format pretty easy ${ }^{127}$ (GAIMAN apud VESTAL e MARAGOS, 1999).

A obra "Sandman - Caçadores de Sonho" de 1999, tanto na versão brasileira (Figura 197, pág. 244) quanto na americana (Figura 198, pág. 244) a disposição da mancha gráfica é idêntica, contudo a edição textual não segue o mesmo padrão de fonte, tamanho e diagramação. Mesmo que à primeira vista o espaço destinado ao texto escrito seja semelhante a uma legenda (pelas bordas trabalhadas em volta do texto), o conteúdo escrito é independente da imagem adjacente, ou seja, em caso de subtração desta imagem específica ou alteração para alguma outra imagem que também remeta ao contexto, a diegese não é alterada.

A imagem, situada nessa forma textual é somatória, ela agrega referencial estético e contextual à obra. Pois acrescenta aclimatação tanto no espaço diegético, conferindo uma ideia aproximada de um país oriental imaginário, quanto na sensibilidade rítmica da obra, uma vez que as grandes imagens ricas em detalhes e cores vibrantes demandam um tempo de apreensão e apreciação que diminuem o ritmo da leitura continua.

Contudo, mesmo que a combinação do conteúdo verbal com o imagético enriqueça a experiência textual do leitor - caso o leitor não queira se deter nas imagens ou acompanhe a narrativa como ouvinte - a imagem não é indispensável à diegese, ou seja, a solidariedade icônica entre o ícone figurativo e o linguístico na grade é fraco, pois mantém os elementos soltos cada um em sua própria estrutura, o que exclui a produção da História em Quadrinhos.

${ }^{127}$ Bem, nós perguntamos para o senhor Amano se ele gostaria de fazer uma história em quadrinhos, e ele disse não - mas que adoraria fazer um livro ilustrado. O que tornou a escolha do formato muito fácil (GAIMAN apud VESTAL e MARAGOS, 1999) [tradução da autora]. 

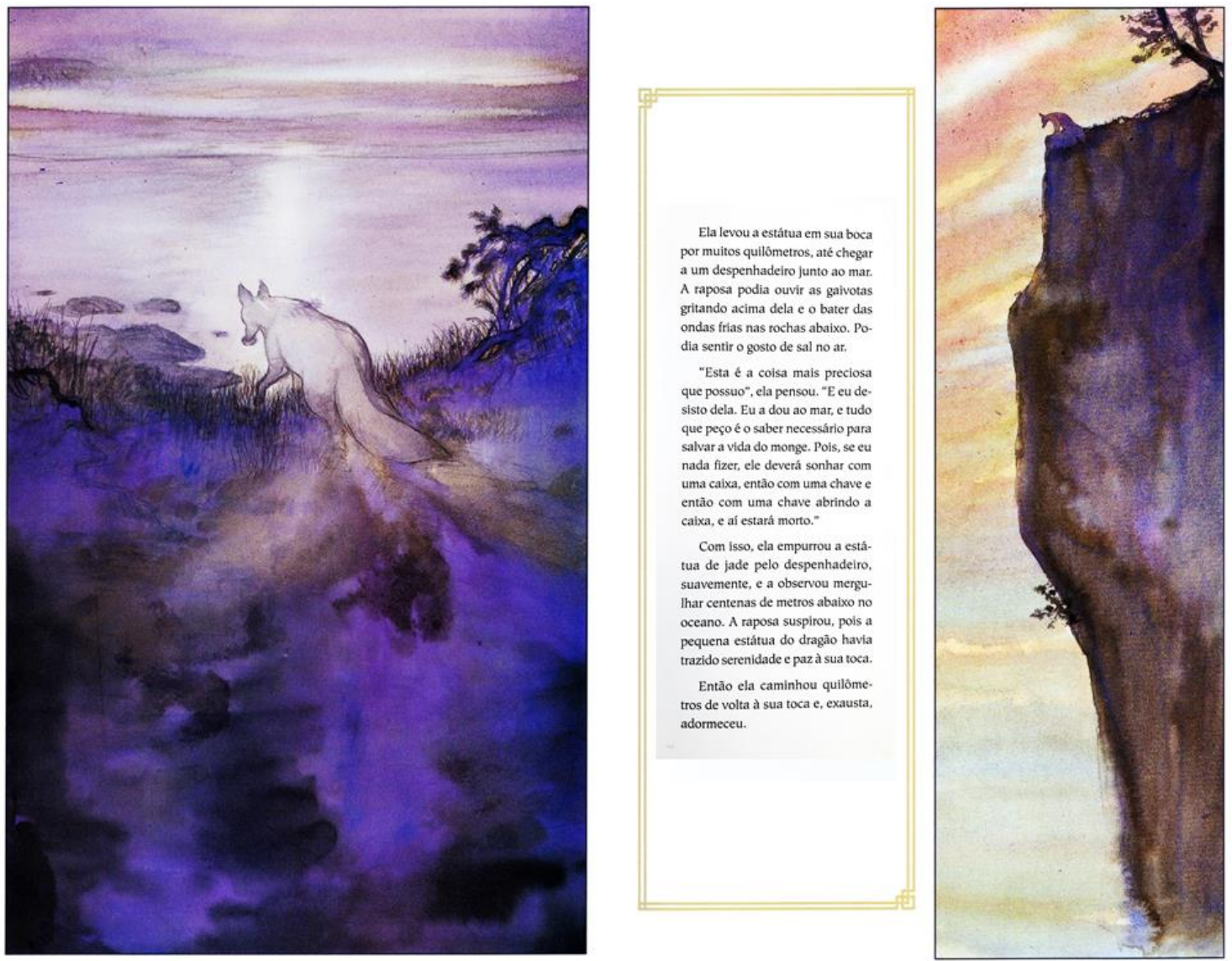

Figura 197 - Sandman - os caçadores de sonhos, 2000 - Ed. Conrad, pg. 28 e $29^{c}$
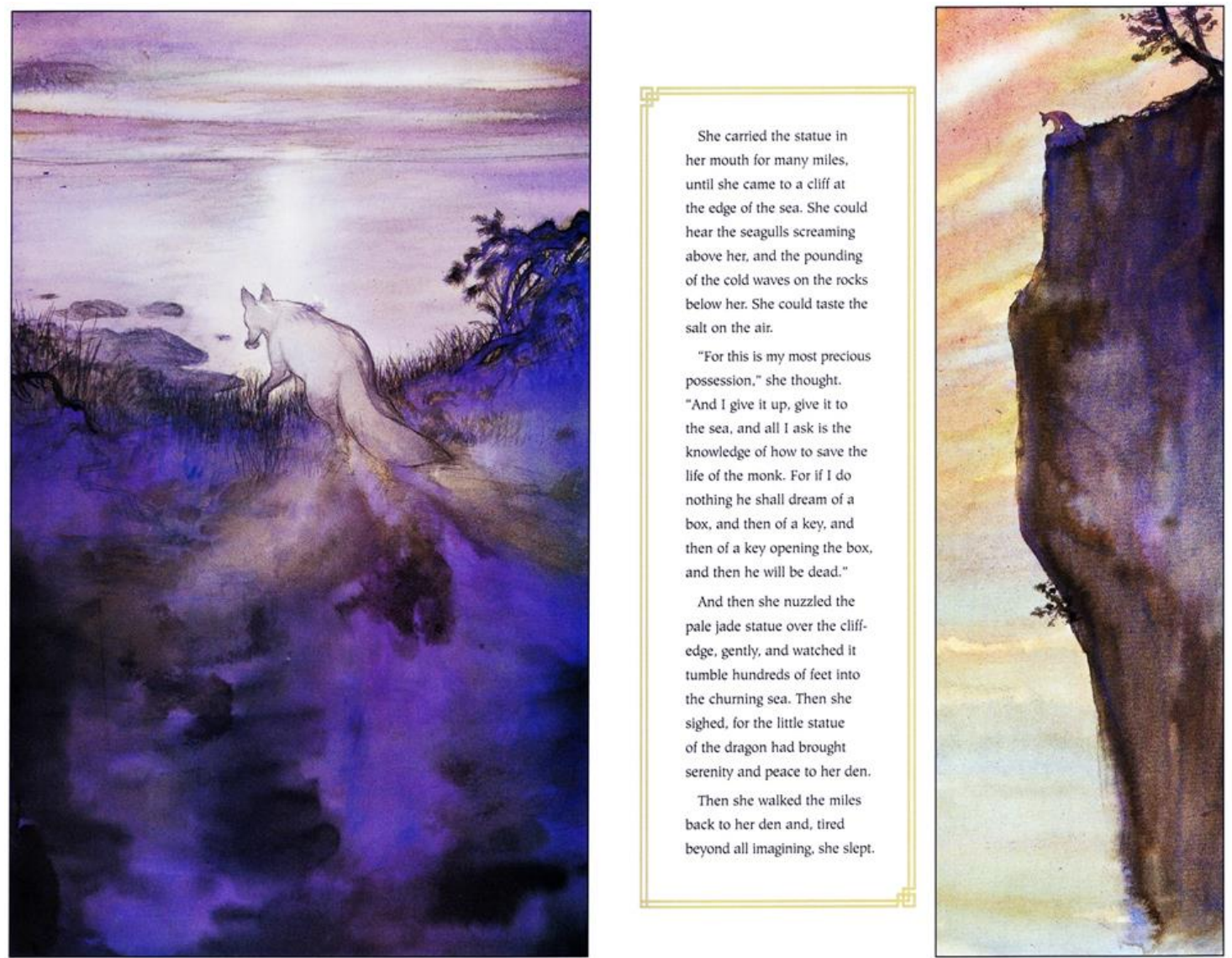

Figura 198 - Sandman - The Dream Hunters - Ed. DC Comics 1999, pg. 28 e $29^{c i}$ 
Apesar de se passar em uma diegese vinculada à História em Quadrinhos, uma vez que, tanto o personagem Sandman, quanto o universo ficcional em que habita, pertencem a um continuum diegético na DC Comics, Gaiman e Amano realizam uma outra forma narrativa: um conto literário com ilustrações. Então mesmo que não exista relação estrutural da obra com quadrinhos, ainda há um vínculo diegético, contextual e mercadológico, pois permanece o vínculo industrial, por isso Gaiman, apesar de possuir certa liberdade criativa sobre a mídia e linguagem para escrever sobre este personagem de quadrinhos por muitos anos engavetado dandoIhe nova significação, não possui, como ele comenta em um $F A Q^{128}$ de seu site, os direitos da obra.

\footnotetext{
Question: I want to make a concept album/stage play/short film/set of tee shirts/something to sell based on Sandman. Please give me permission.

Gaiman: And the answer is simply, I can't. I don't own Sandman. DC Comics does. If you want to make something using the material I did for Sandman, you have to ask them. Feel free to ask me or my agent about things I control. But I'm not going to be any use for Sandman ${ }^{129}$ (GAIMAN, 2018).
}

Entretanto, assim como estar relacionado à indústria quadrinística não torna uma obra uma história em quadrinhos, não estar relacionado e possuir sua estrutura mesmo que autores, editores ou críticos a classifiquem com outra nomenclatura não as torna menos quadrinhos, como a obra de Jan Ormerod, "Sunshine" de 1981 (Figura 199 a Figura 206, pág. 247), ganhadora do "Australian Picture Book of the Year Award" (prêmio de livro ilustrado australiano do ano) e do "Mother Goose Award" (prêmio Mamãe Ganso).

O livro é apontado pela professora de Educação da Universidade de Cambridge, Maria Nikolajeva, e pela professora emérita de inglês e ex-reitora de graduação da Universidade de San Diego State, Carole Scott, como livro-imagem "uma narrativa sem texto, apenas com imagens" (NIKOLAJEVA e SCOTT, 2011, p. 23).

O livro, uma narrativa sequencial, segue o ritmo de transição ação a ação, seguindo a personagem principal, uma menina pequena, na interação com seus pais.

${ }^{128} \mathrm{FAQ}$, do inglês frequently asked questions em português simpliplificado para: perguntas frequentes. ${ }^{129}$ Questão: Eu quero fazer um album conceitual/peça de teatro/curta-metragem/série de camisetas/ ou alguma coisa para vender baseada em Sandman. Por favor me dê permissão. Resposta: E a resposta é simplesmente, não posso. Eu não sou dono de Sandman. A DC Comics é. Se você quer fazer alguma coisa usando o material que eu fiz para o Sandman, você tem que pedir para eles. Se sinta livre para me perguntar ou ao meu agente sobre coisas que eu controlo. Mas eu não serei de uso algum no caso de Sandman (GAIMAN, 2018) [tradução da autora]. 
Não é intenção desse estudo fazer uma análise detalhada da obra página a página, mas alguns pontos merecem observações nesse aspecto. Por exemplo, a primeira página dessa narrativa sequencial (Figura 199, pág. 246) apresenta a visão panóptica de uma grade regular de 2 x 3 (duas linhas e três quadros), a transição ação a ação acontece em ritmo lento com pequenas alterações, mostrando as várias nuances do processo de acordar. Essa grade regular - quadros do mesmo tamanho, apontada por Groensteen como ortogonal ou waffle-iron (literalmente "forma para waffles", por ter o formato de uma assadeira para waffle, ou seja, uma forma com quadrados simétricos decalcados no interior), logo como abertura da narrativa, aponta para o leitor, o personagem como o foco visual da narrativa.

Em uma ilustração de página cheia, por exemplo, haveria várias informações acontecendo ao mesmo tempo, essa quadrinização na página inicial permite que o autor direcione o olhar do leitor apontando um momento específico. $\mathrm{Na}$ segunda página a grade muda para $1 \times 3$ (uma linha e três quadros), essa variação segue o enquadramento das personagens e a alternância de ambientes. A grande área de sarjeta delimita bastante bem as transições de cena, facilitando a leitura das imagens individuais, e a sobreposição da vinheta com a invasão da sarjeta por pequenos detalhes da composição indicam sutilmente a construção artificial do espaço, dando uma ideia da continuidade da ação, ou da passagem do tempo (objetos e personagens estão em parte contidos e, ao mesmo tempo, não contidos, em determinado momento encapsulado do tempo e do espaço).
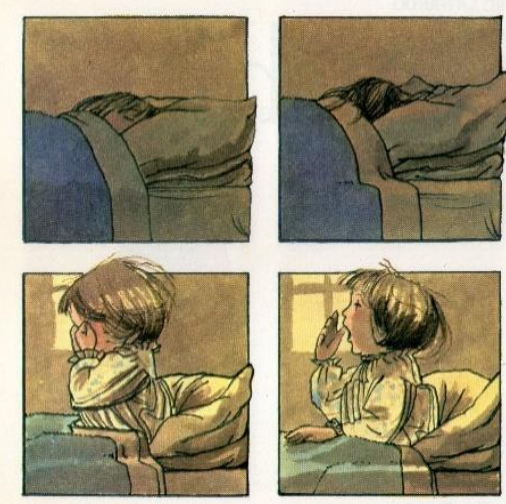

Figura 199 - Sunshine (ORMEROD, 1983), pág.6
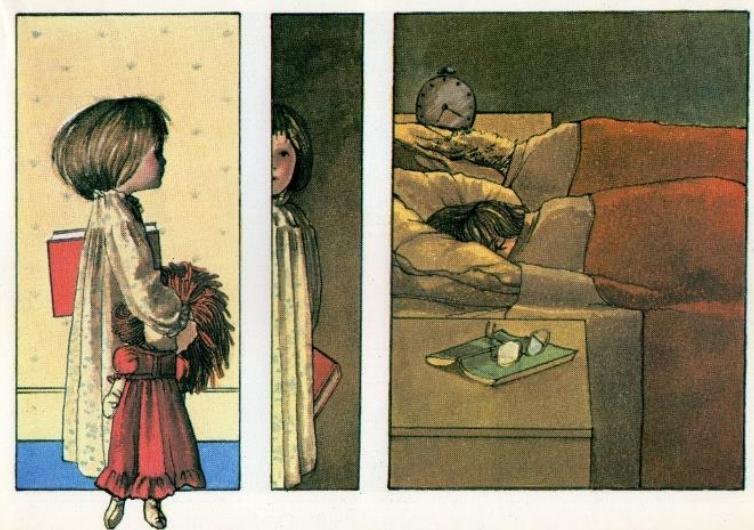

Figura 200 - Sunshine (ORMEROD, 1983), pág. 7 


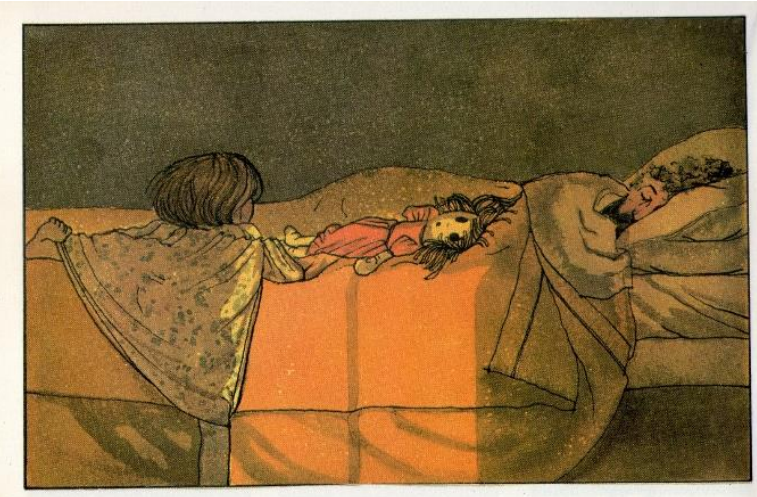

Figura 201 - Sunshine (ORMEROD, 1983), pág.8

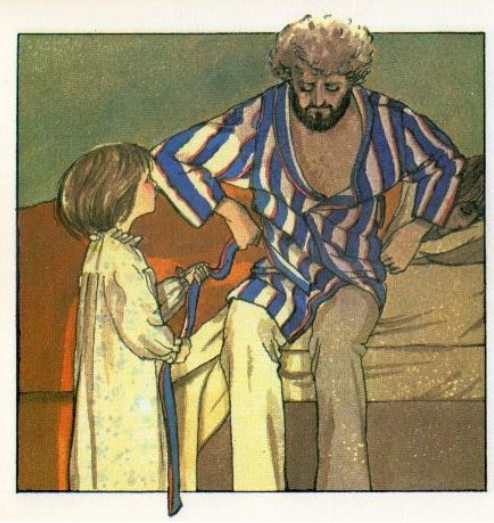

Figura 203 - Sunshine (ORMEROD, 1983), pág.10
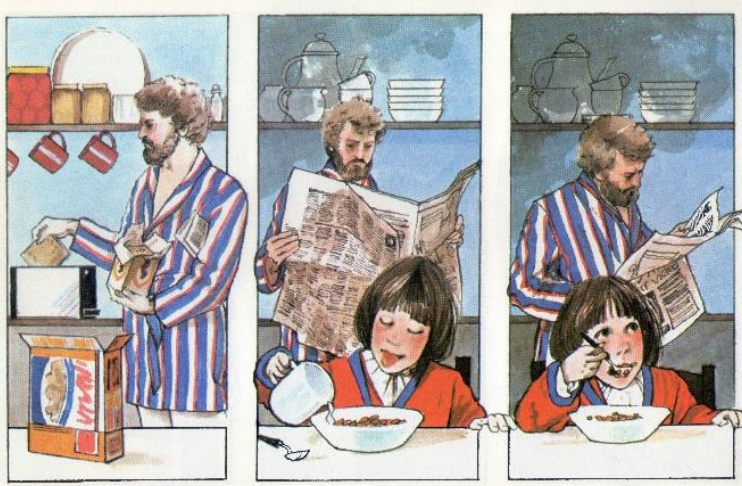

Figura 205 - Sunshine (ORMEROD, 1983), pág.12

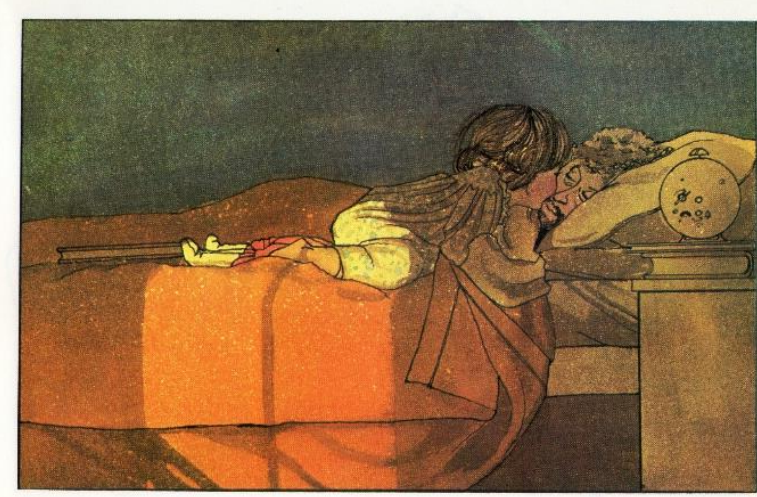

Figura 202 - Sunshine (ORMEROD, 1983), pág. 9
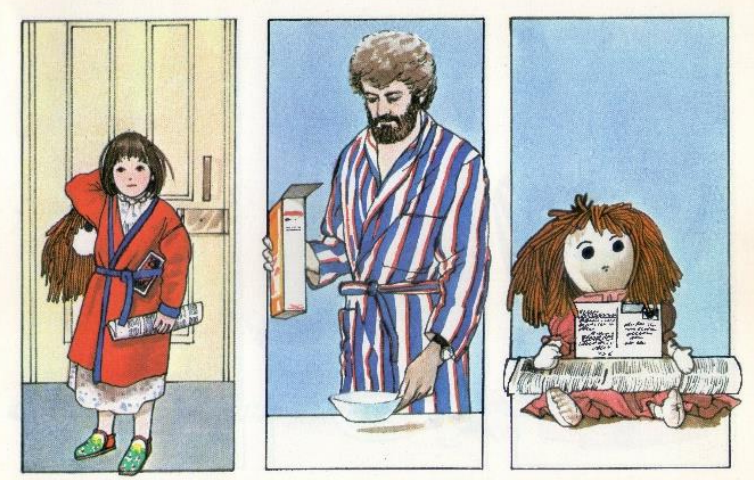

Figura 204 - Sunshine (ORMEROD, 1983), pág. 11
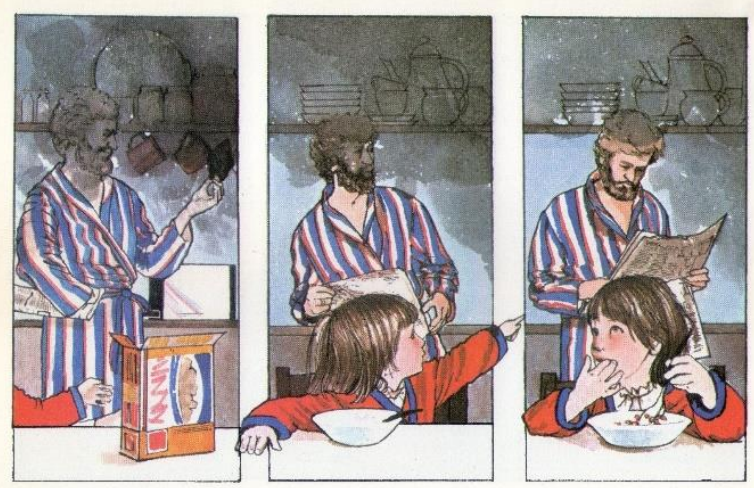

Figura 206 - Sunshine (ORMEROD, 1983), pág. 13

Mesmo na alternância para as páginas cheias, de quadro único, a delimitação do espaço diegético através da vinheta permanece, demostrando o segmento da estrutura de grade escolhida para a linguagem narrativa.

É certo que ainda há muita discussão sobre as fronteiras da $H Q$, principalmente quanto à imagem única, poesias sequenciais e sequências não narrativas, contudo narrativas imagéticas sequênciais, por apresentarem a relação de solidariedade icônica e panoscopia da grade que são elementos já consolidados entre os pesquisadores do meio, fazem parte da História em Quadrinhos. Como aponta Groensteen, as diferenças entre o livro ilustrado e uma história em quadrinhos, 
can sometimes be attenuated, as there is a certain permeability between the two areas. Some illustrated children's books could quite reasonably be called comics; if they are not regarded as such, this is solely on account of their positioning by the publishing industry (inclusion in a children's series, on the list of a specialized children's publisher, and, consequently, in the children's section of bookstores) ${ }^{130}$ (GROENSTEEN, 2011, p. versão e-book 24\%).

Justamente por ter certa concepção estrutural consolidada que a variação entre os suportes midiáticos é possível. A transição entre o jornal, a revista, o livro e a web se dá pela acomodação da linguagem, da estética e da temática às mídias disponíveis.

Há, em relação às histórias em quadrinhos disponíveis no meio virtual, certa ressalva entre os pesquisadores, da mesma forma que existe para a Literatura digital. Groensteen por exemplo, acredita que há uma perda de sensibilidade na relação do leitor com o objeto ao mudar sua relação com a página que envolve seus braços ou mesmo toda a parte de cima do corpo, substituída pelo intermitente clicar do botão pelo dedo indicador. O pesquisador aponta para uma perda em relação à mobilização, participação, sensação tátil e por vezes até olfativa e até mesmo interatividade (GROENSTEEN, 2011, p. versão ebook 30\%). Argumentos similares são ditos da transição do material escrito do livro físico para o ebook.

Contudo, os depoimentos dos autores nas introduções da grande maioria dos livros pesquisados para este estudo, demonstram em geral que nas experiências com a leitura de quadrinhos, as preferências táteis se mostraram irrelevantes. $\mathrm{Na}$ grande maioria dos casos, a relação do leitor com seu objeto, muitas vezes um gibi de papel de baixa qualidade dobrado e enfiado dentro de uma mochila ou escondido debaixo da cama, lido em pontos de ônibus ou sorrateiramente no meio da aula, partilhados na surdina de mão em mão por adolescentes abaixo da classificação indicativa, não diminuíram as experiências diegéticas.

Pode-se dizer que algumas experiências relatadas apenas agregaram os sentimentos, para alguns, de uma pueril futilidade de um objeto descartável e, para outros, de uma rebeldia contraventora de um objeto proibido ou condenável. A sensação agregada ao ato de ler não é apenas do objeto em si, e sim do contexto do leitor, do momento em que essa leitura penetra no seu espaço e o arrebata.

\footnotetext{
${ }^{130}$ podem algumas vezes ser atenuadas, já que exite certa permeabilidade entre as duas áreas. Alguns livros ilustrados infantis podem bem razoavelmente ser chamados de quadrinhos, se eles não são chamados como tal, é somente pelo fato de sua classificação pela indústria editorial (inclusão em uma série infantil, em uma lista específica de editora infantil, e, consequentemente, na seção infantil das livrarias) (GROENSTEEN, 2011, p. versão e-book 24\%) [tradução da autora].
} 
Ian Gordon aponta que o exército americano foi um dos maiores compradores de quadrinhos durante a segunda guerra mundial.

Through 1943 and early 1944 the Army distributed at least 100,000 copies of this comic book every other month, or about 10 percent of the comic's sales ${ }^{131}$ (GORDON, 1998, p. 140).

Durante o curso ministrado na Escola de Comunicação e Arte da Universidade de São Paulo em 2015, Gordon ressaltou que, diferente do que as pessoas imaginam, o campo de batalha é um grande tempo a espera por algo acontecer e brevíssimos momentos decisivos. E, durante esse tempo, que parece interminável, é preciso algo para distrair e relaxar os ânimos dos homens na linha de frente, os quadrinhos, eram um objeto leve e de fácil manuseio - bastava dobrar e colocar no bolso de trás da calça, e de amplo compartilhamento, que garantiam uma fuga da realidade em volta (GORDON, 2015).

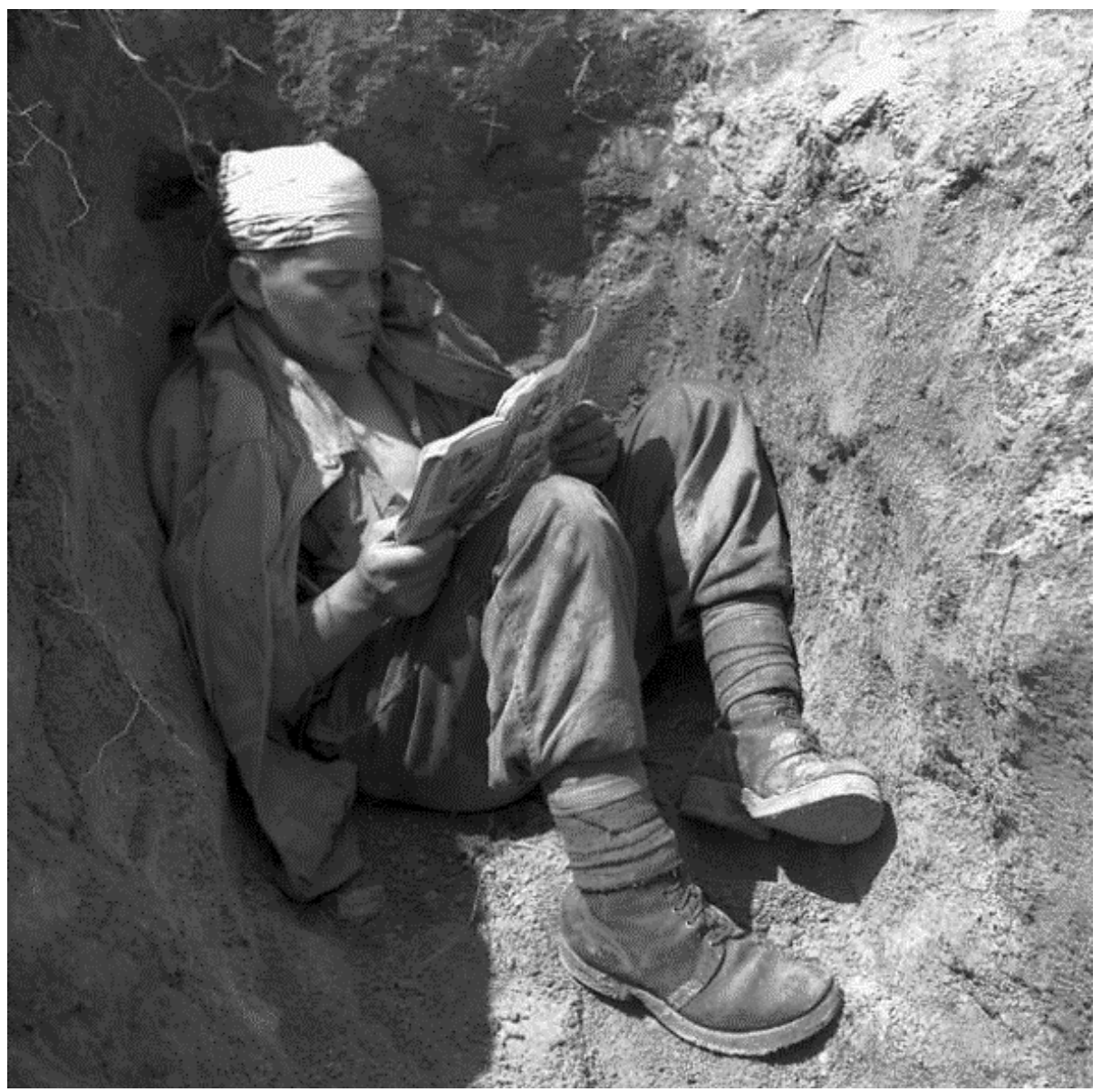

Figura 207 - Soldado G.U.I. Lambert, B2nd Battalion Royal 22e Regiment, lendo uma revista em quadrinhos, Coréia, 28 de maio de 1951, Royal 22nd Regiment. Fotográfo: Paul E. Tomelincii

131 Durante 1943 até começo de 1944 o Exército distribuiu pelo menos 100.000 cópias dessas revistas de história em quadrinhos todo mês, ou cerca de 10 por cento das vendas de quadrinhos (GORDON, 1998, p. 140). 
A experiência de leitura é particular e pessoal, tanto na literatura quanto nos quadrinhos, não é pertinente inferir que a experiência de um projeto gráfico bem cuidado, com papel de alta qualidade e uma paleta refinada de cores é mais valorosa para o leitor do que um manchado folheto mimeografado ou um aplicativo de celular se em seu contexto aquilo Ihe é transformador. Em muitos aspectos, quadrinhos e literatura online representam a abertura de fronteiras tanto para leitores quanto para autores independentes, que de outra forma não teriam acesso a esse material, por causa de barreiras mercadológicas, culturais e políticas.

Para uma análise comparativa entre suportes foram adquiridas quatro edições do mangá Kuroshitsuji de Yana Toboso.

A edição brasileira de 2015 da editora Panini Comics em formato de revista de lombada quadrada tamanho $20 \mathrm{~cm}$ de altura por $13,5 \mathrm{~cm}$ de largura com uma lombada de 0,8 cm, 178 páginas em papel pisa-brite (papel jornal) de $52 \mathrm{~g}$ de gramatura aproximadamente e capa dura, adquirida em banca de jornal.

A edição japonesa de 2013 da editora Square Enix em formato de revista de lombada quadrada, tamanho $18,5 \mathrm{~cm}$ de altura por $13 \mathrm{~cm}$ de largura com uma lombada de 1,5 cm, 178 página em papel pisa-brite (papel jornal) de aproximadamente $75 \mathrm{~g}$ de gramatura e capa dura, contendo também uma sobrecapa avulsa em papel fotográfico. Essa edição foi adquirida por intermédio de uma pessoa residente no Japão que a trouxe como bagagem no retorno a passeio no Brasil.

A edição americana de 2014 da editora Yan Press, pertencente ao grupo editorial Hachette Books, em formato digitalizado e-book no aplicativo Kindle para plataforma $^{132}$ Windows PC, adquirido pela loja virtual Amazon.

A edição chinesa de 2013 da editora Tong Li Comics, em formato digitalizado no aplicativo navegador de web online, plataforma Windows PC, disponibilizado pela página DM5.com.

\footnotetext{
132 Nesse estudo o termo plataforma se refere ao hardware empregado na publicação das histórias em quadrinhos: PC (personal computer) com sitesma operacional Windows e Linux; Mac (Macintosh) com sistema operacional IOS; smarthfones e tablets com sistema operacional IOS e Android, leitores digitais (e-reader) com aplicativos específicos Kindle, Kobo, etc, com tecnologia e-ink o que deixa todas as publicações monocromáticas (preto e branco).
} 

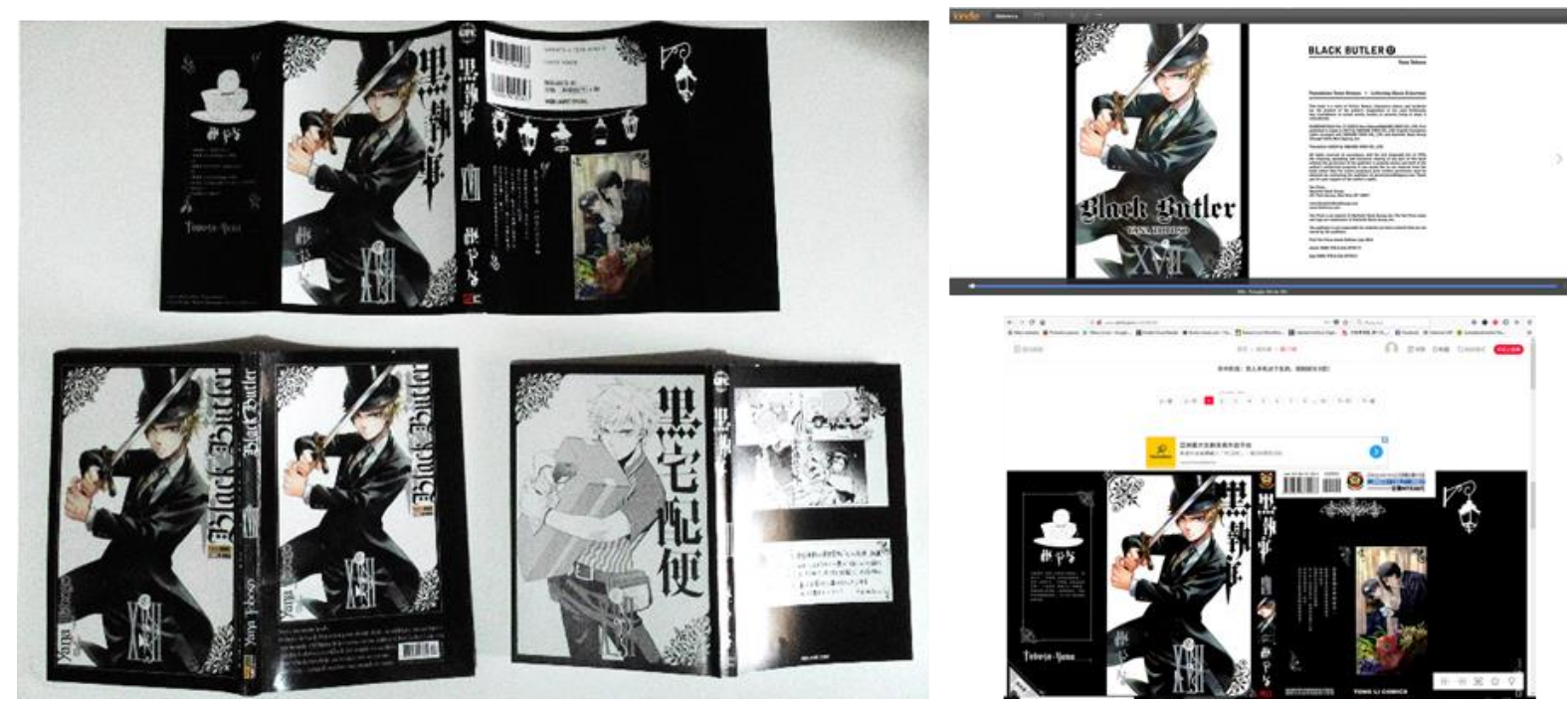

Figura 208 - Kuroshitsuji (Black Butler), Yana Toboso, versões japonesa, brasileira, americana e chinesa

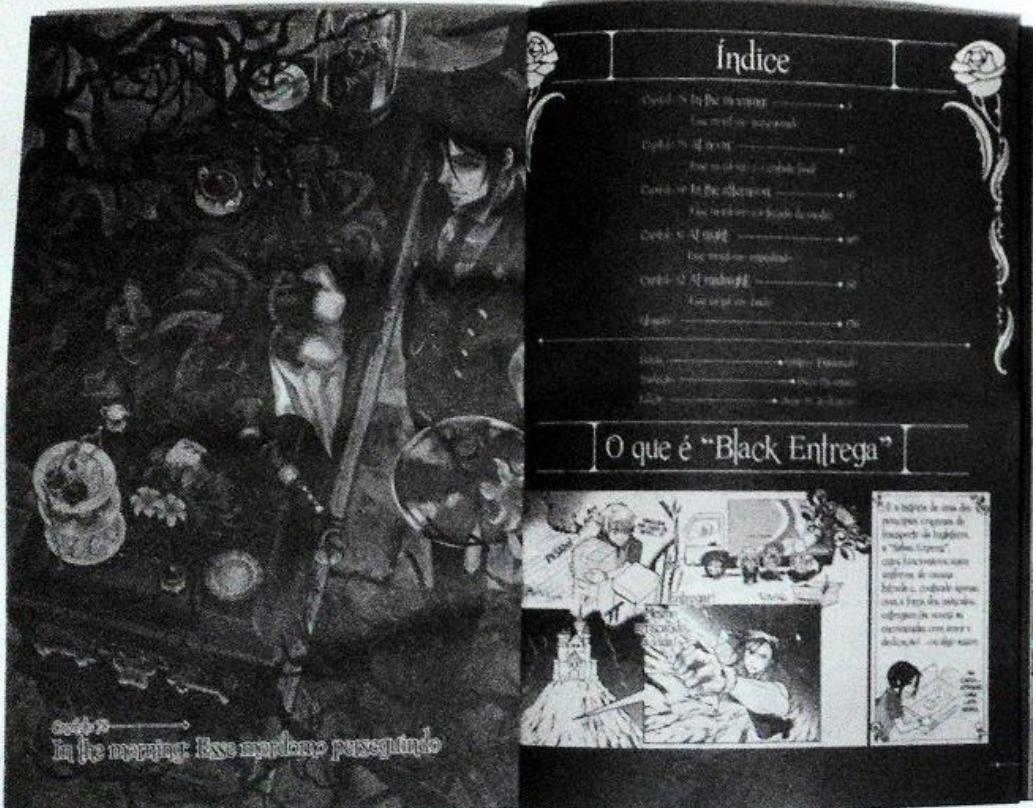

Figura 209 - Kuroshitsuji, Yana Toboso, páginas 2 e 3 das versão japonesa impressa em papel

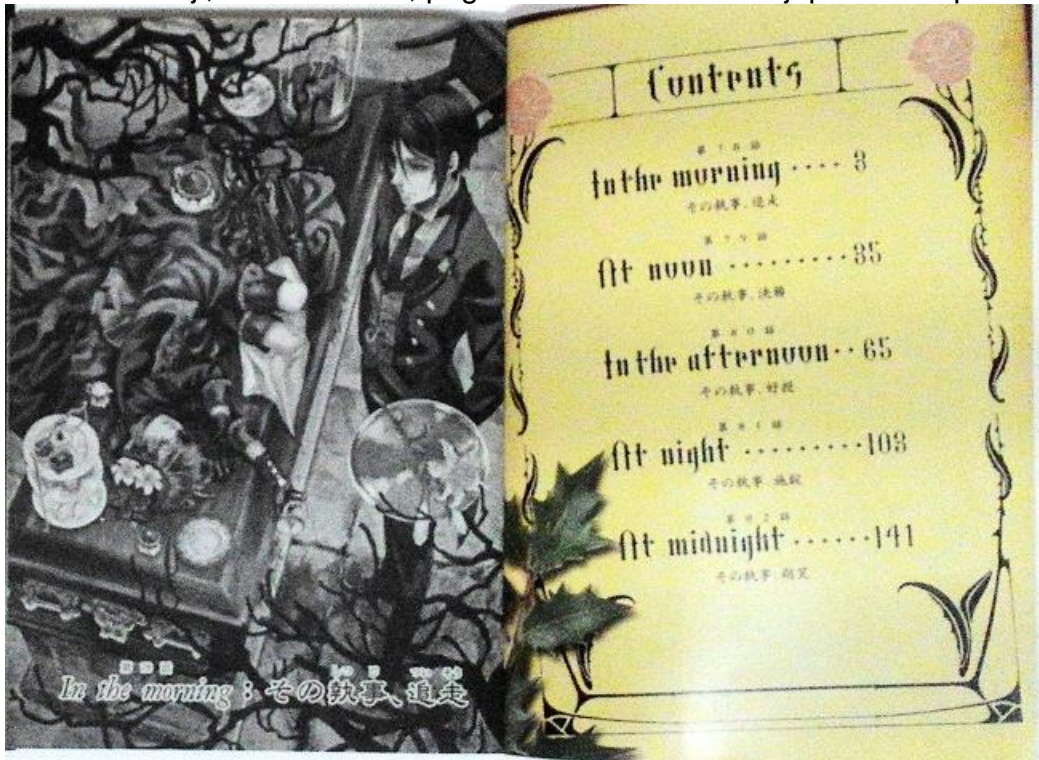

Figura 210 - Kuroshitsuji (Black Butler), Yana Toboso, páginas 2 e 3 das versão brasileira impressa em papel 


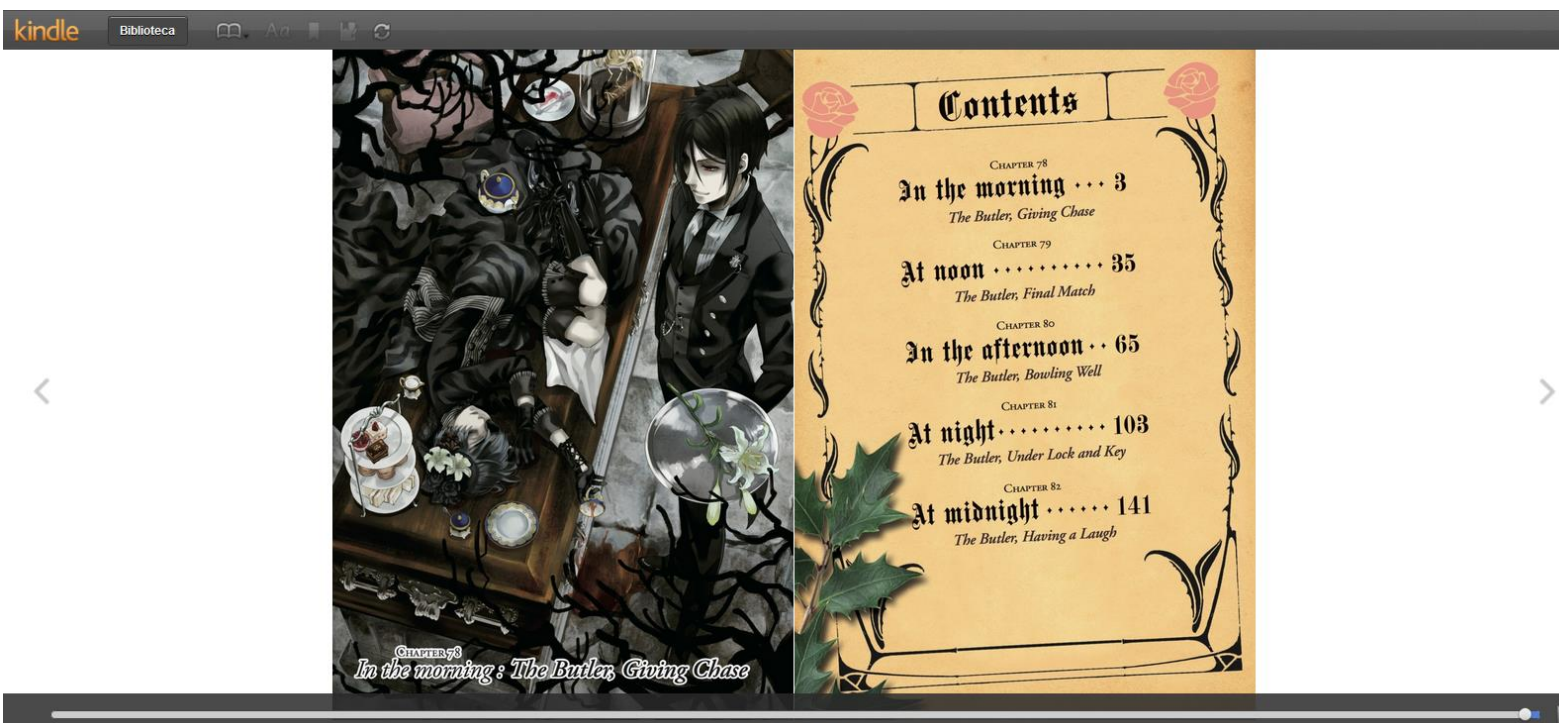

Figura 211 - Black Butler página versão ebook 2\% kindle (4 de 183)
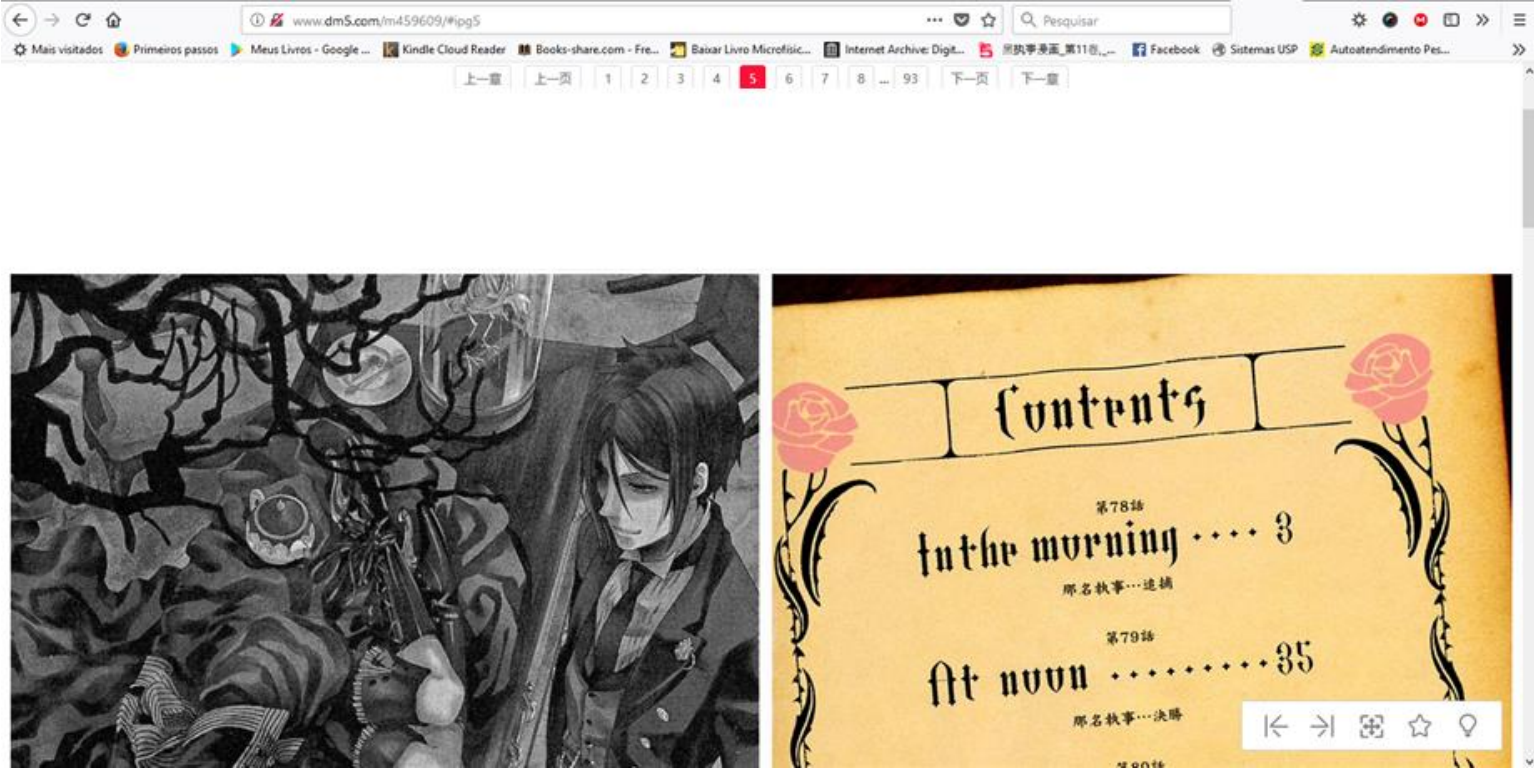

Figura 212 - Kuroshitsuji - página 5 versão chinesa, primeira rolagem
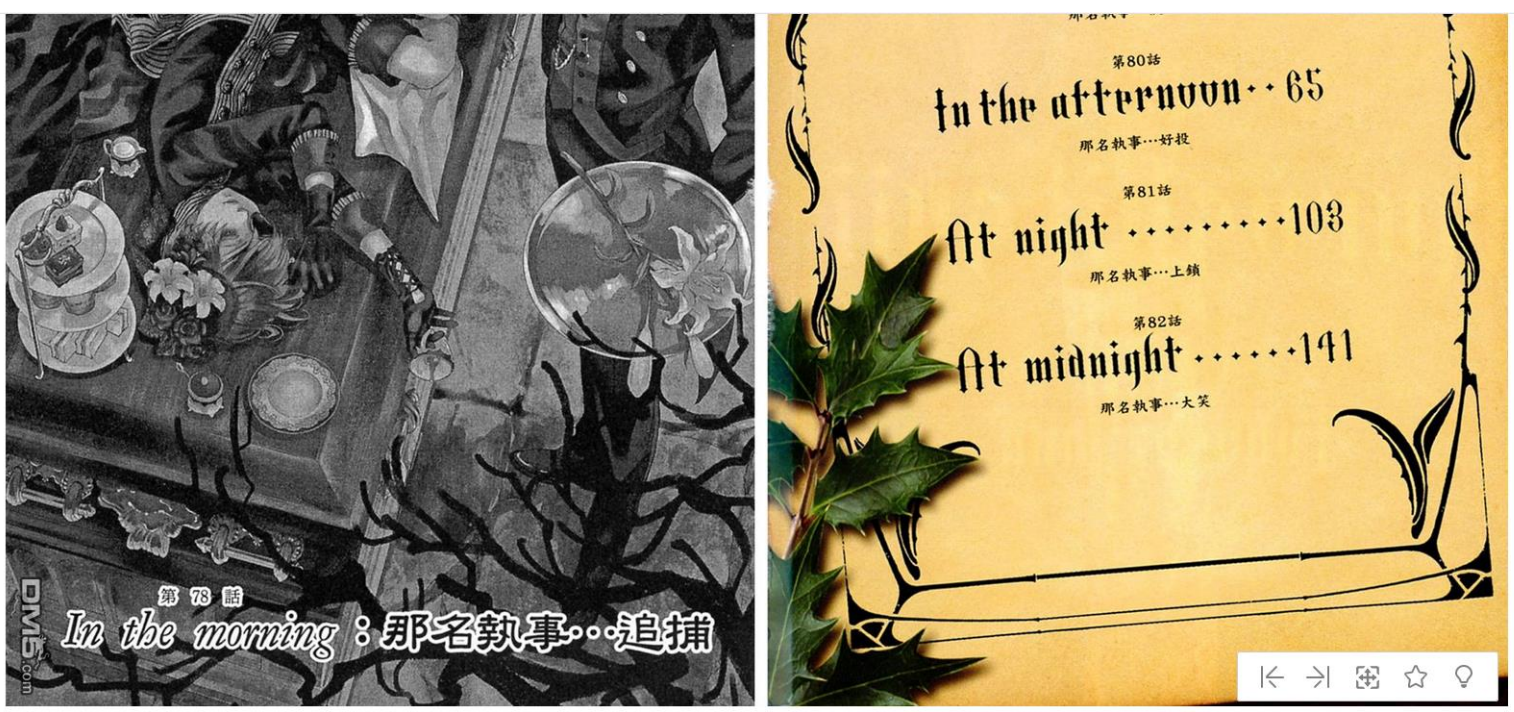

Figura 213 - Figura 143 - Kuroshitsuji - página 5 versão chinesa, segunda rolagem 
Mesmo que a obra seja a mesma, cada versão possui uma particularidade, um ponto positivo e negativo em relação uma a outra, por exemplo, a versão brasileira usa um papel de gramatura mais fina o que acabou gerando um "enrugamento" das páginas quando foram encadernadas na lombada quadrada, além de ter uma qualidade inferior no processo de branqueamento causando uma cor mais escura de fundo em comparação com a versão original japonesa.

Por exemplo, na página 4, abertura do capítulo 78 "In the morning: esse mordomo perseguindo" (Figura 210, pág. 251), a versão brasileira possui um papel tão escuro que torna praticamente impossível distinguir os detalhes de meio tom da figura do personagem principal deitado sobre o caixão, como é possível na versão original, também em papel jornal, mas cujo processo de branqueamento e gramatura é melhor. Na versão americana no Kindle, a página ganha colorização, contudo há o inconveniente da padronização da ordem de leitura ocidental, como o kindle não foi desenvolvido para a leitura de quadrinhos e sim para a literatura escrita, sua interface é limitada, por exemplo, o carregamento da história começa da página final e o leitor tem que manualmente levar a barra de rolagem horizontal do kindle até o ponto extremo à direita e só então começar a ler na ordem da obra, além disso o kindle apresenta somente uma visualização possível: a página dupla, não é possível ver páginas isoladamente ou ampliá-las, o que faz com que a apresentação da página esteja limitada ao tamanho do suporte utilizado (nesse estudo foi utilizado um notebook com tela de 17 polegadas, seria inviável a leitura do mesmo capitulo se o kindle fosse aberto em um dispositivo androide de por exemplo 4, 5 ou 6 polegadas. Já a versão chinesa tem o inconveniente de apresentar uma página de cada vez, com isso o leitor não tem acesso à grade original de apresentação de duas páginas (a lombada quadrada impede que a impressão em papel seja dobrada para trás como na lombada canoa, forçando o leitor a sempre ver duas páginas de cada vez, como no formato livro), além disso, nesse site de hospedagem específico, não é possível reduzir o tamanho da página para visualização da página inteira, fazendo com que a leitura de uma só imagem como essa seja particionada em duas rolagens verticais (forçando uma divisão de grade que não existe no original).

Qual experiência de leitura é a melhor torna-se uma discussão menor se comparada com a capacidade de acesso à obra. No caso da edição japonesa, para esse estudo, o acesso foi fortuito e casual, mas no Brasil já é possível a importação padronizada de obras estrangeiras de fornecedores especializados, tanto em lojas 
virtuais quanto físicas, mas o custo de envio é alto e o prazo de entrega longo pois varia de um a seis meses dependendo do fornecedor. O que torna edições virtuais como a americana e chinesa, o método de acesso mais rápido e financeiramente mais atrativo, dependendo apenas da conectividade à uma rede de internet. Em caso de obras que não despertaram interesse das editoras para uma publicação física, a publicação virtual é a única forma de acesso possível.

O trabalho de digitalização para publicação na internet de obras físicas, como Kuroshitsuji (Black Butler) usado como exemplo, sempre sofrerá com a adaptação ao novo suporte, afinal ele foi estruturado para o suporte impresso, sua conversão em imagem digital é uma adaptação, e por isso há certos estranhamentos e imprecisões, o mesmo já não acontece com narrativas sequenciais feitas para o suporte virtual, o caso das webcomics - em sua grande maioria, projetos independentes que possuem em sua essência o experimentalismo dos fanzines - e webtoons - contextualmente de origem coreana, é também uma vertente de publicação de material independente, mas que segue uma tendência de formalismo estrutural em detrimento do hibridismo encontrado em webcomics experimentais.

Tanto Groensteen quanto McCloud comentam sobre a webcomic e suas experiências com a estrutura e forma da HQ. Por exemplo, a introdução de som e movimento, zoom de imagem e transição controlada de quadros, além da interatividade que em algumas manifestações levam o leitor a escolher entre diferentes rotas narrativas, aproximando a narrativa do RPG, sigla para expressão inglesa role playing game, jogos narrativos.

Narrativas como "Homestuck" (Figura 214) de Andrew Hussie, publicada de 2009 a 2016, e que atingiram grande popularidade, apresentam uma mistura de elementos de várias mídias para contar a história de um grupo de amigos que ao jogar um game online, inadvertidamente destroem o mundo.

A primeira página da webcomic apresenta a imagem cartunizada e caricaturizada de um menino em seu quarto, na legenda abaixo da figura está sua introdução e, na sequência, uma pergunta ao leitor: "What will the name of this young man be?' (qual será o nome que este jovem terá?). Logo abaixo o link (comando) para colocar o nome. "> Enter name." (coloque o nome). 


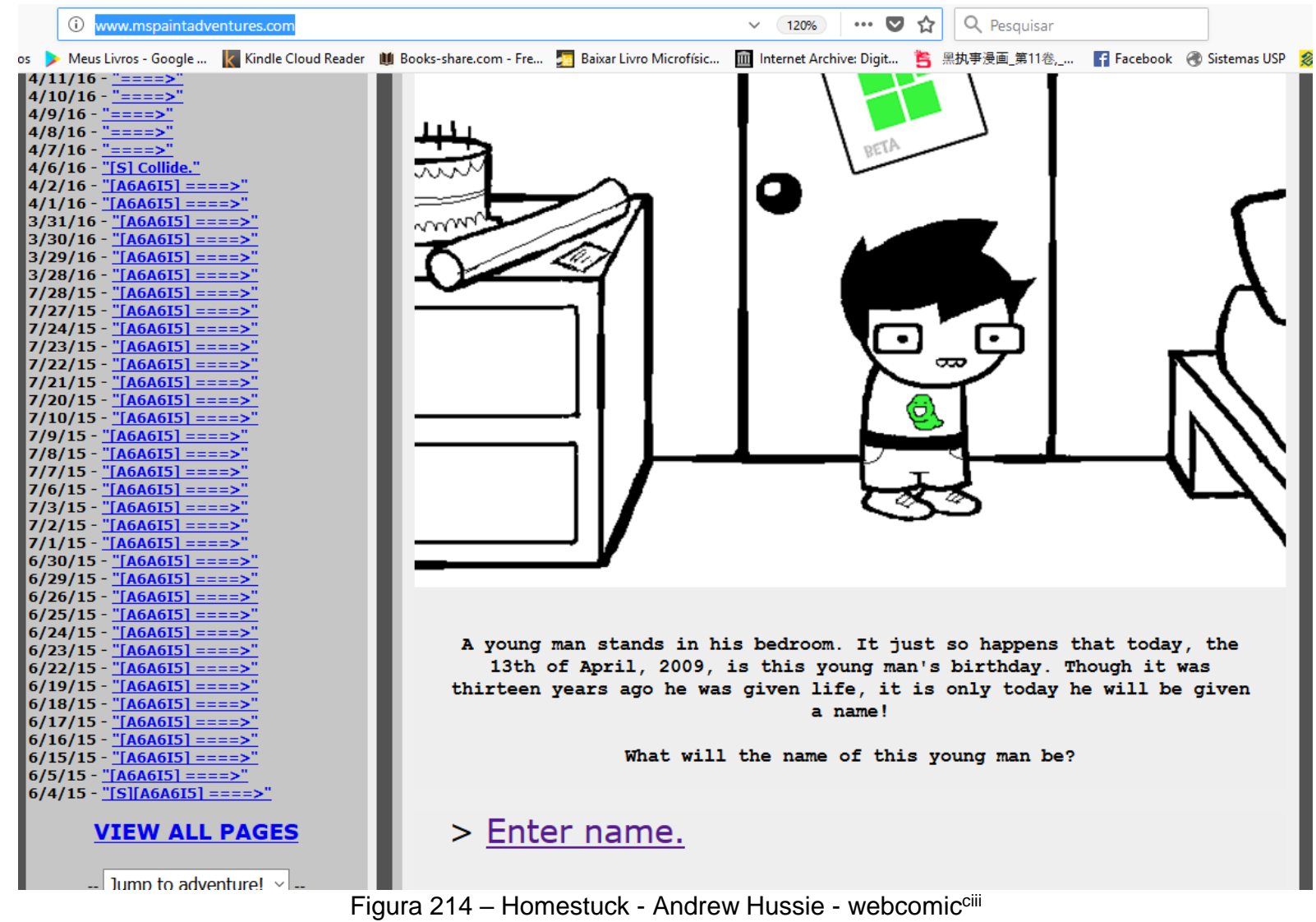

O link leva para outra cena, onde há uma imagem do personagem que mexe os olhos, um espaço para digitar o nome que é preenchido automaticamente, completado com uma mensagem de erro, induzindo o leitor a outro link: " $>$ Try again". A sequência de movimentos acontece em uma imagem única, alternando imagens sobrepostas (processo simples de animação), foi desmembrada a sequência apenas para ilustração da ação, mas ela acontece em um quadro somente, e enquanto o leitor não executar o próximo comando a cena não muda para a próxima página.

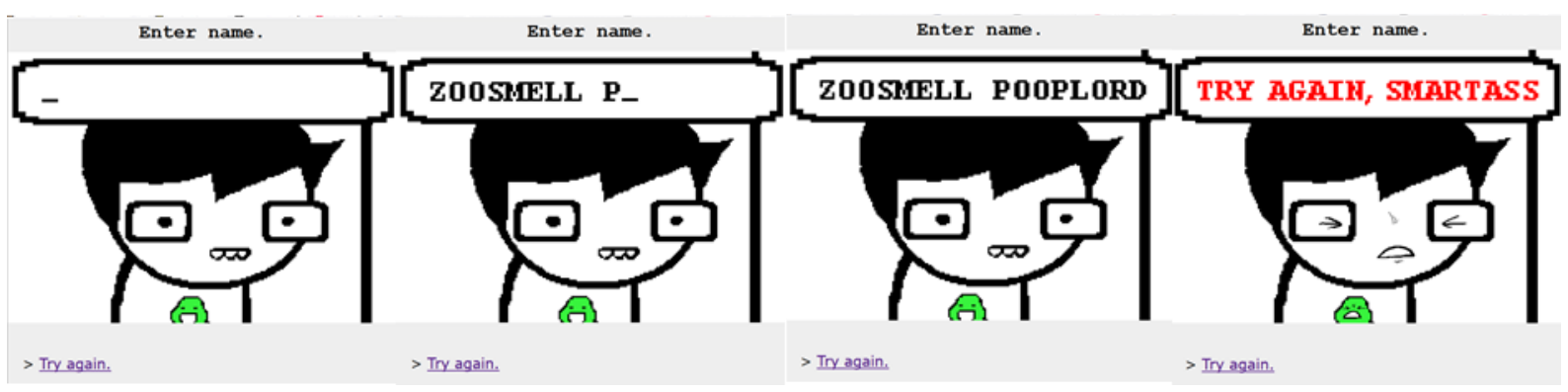

Quando a webcomic foi lançada, havia mais interatividade nos comandos, era possível digitar um nome qualquer e dentre todos os nomes digitados, um foi escolhido para continuidade narrativa, que foi prosseguindo passo a passo de acordo com as escolhas dos leitores em intertividade com o criador, uma vez processada a 
escolha a narrativa se concretizou e hoje, um novo leitor pode apenas ser induzido ao processo, sem realmente interagir com o criador. A interatividade nesse caso foi datada e contextual. Atualmente, a obra é apenas indutiva, o leitor pode apenas seguir passos pré-determinados pelo criador até chegar a sequência final, sem opções de escolha de finais alternativos, como é possível em games narrativos.

Há uma discussão acadêmica em formação sobre se a narrativa interativa deve ser considerada uma história em quadrinhos interativa, ou uma nova forma de comunicação midiática.

Alheios a essa discussão conceitual, muitos artistas, optam pela publicação virtual por uma questão de abertura de espaço, e não por uma ruptura estrutural. Nesse aspecto tanto webcomics ocidentais como as webtoons orientais encontram se em uma adequação estrutural de grade à platorma virtual, sem perder as características mais usuais da $\mathrm{HQ}$ impressa, como a cartunização e caricaturização, a solidariedade icônica dos elementos dentro do quadro e fora dele, a preocupação com o espaço das palavras dentro da grade, as onomatopeias, etc.

A webcomic "Year In Hereafter" do artista finlandês Mikael Hankonen (Figura 215, pág. 257) começou em 14/7/2015 no site de publicação coletiva Tapastic (atualmente somente Tapas), migrando para hospedagem independente em 2016.

Segundo o autor, suas ferramentas de trabalho são digitais,

The tools I use for drawing are currently Adobe Photoshop CS5 for colours and general editorial, Clip Paint Studio Pro for inking the artwork, and I sport a Wacom Cintiq 13HD ${ }^{133}$ (HANKONEN, 2016).

As páginas seguem a estrutura de grade de uma página impressa em papel, contudo na web a visualização de cada página é parcial, sendo utilizada a barra de rolagem vertical, isso faz com que as linhas da grade tenham a tendência de serem mais horizontais do que verticais, mesmo em quadros maiores como o primeiro quadro da página 13, aparecem inteiros na visualização, para em seguida o leitor rolar a barra para ver os quadros inferiores. Mesmo que a visão da página não seja completamente inteira ela está ao alcance da rolagem, diferente da mudança de página pelo comando avançar na parte inferior da imagem que significa uma mudança de página do mesmo modo que virar a página em uma versão impressa.

${ }^{133}$ As ferramentas que eu uso para desenhar são atualmente o Adobe Photoshop CS5 para cores e edição geral, Clip Paint Studio para o delineamento da arte e, também o uso de uma Wacom Cintiq 13HD (HANKONEN, 2016) [tradução da autora]. 


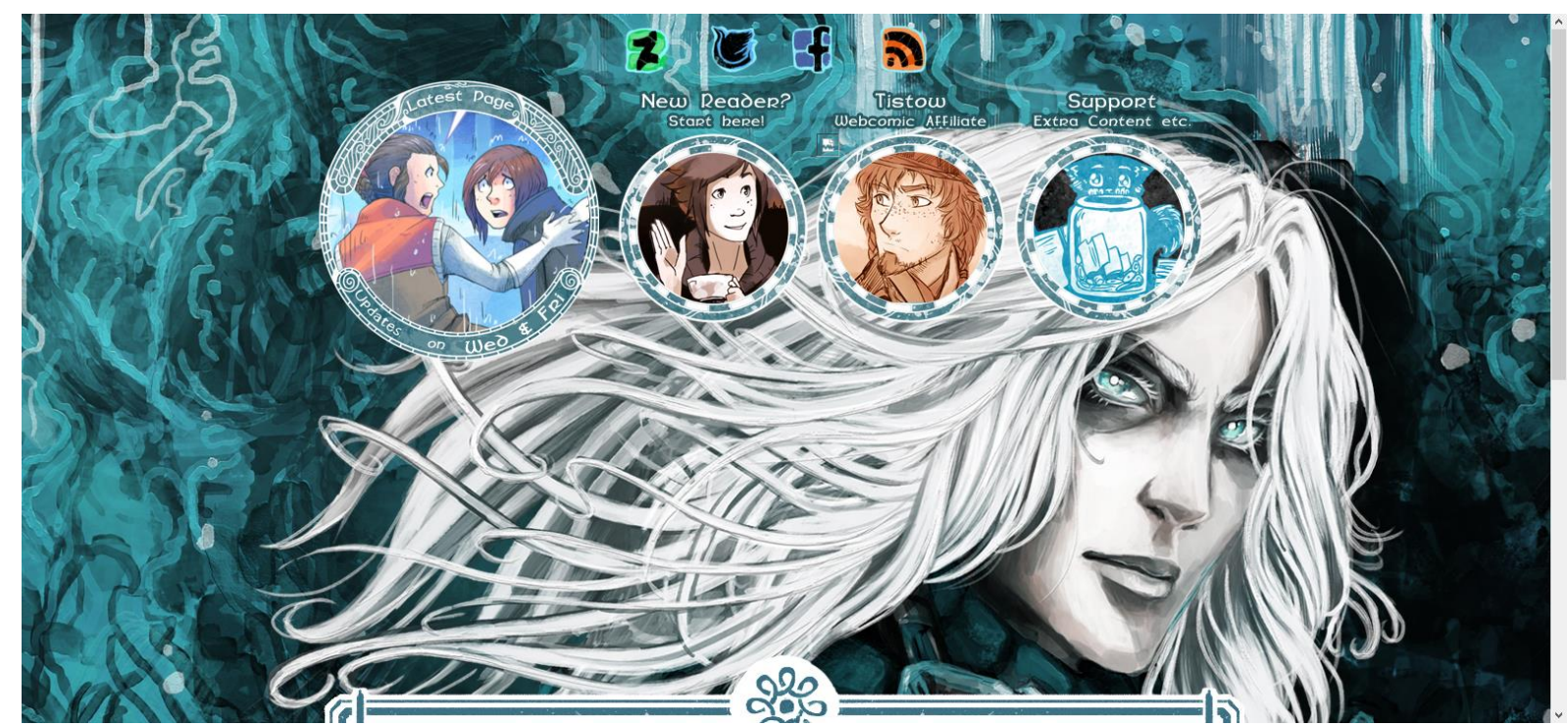

Figura 215 - Year in Hereafter - página menu

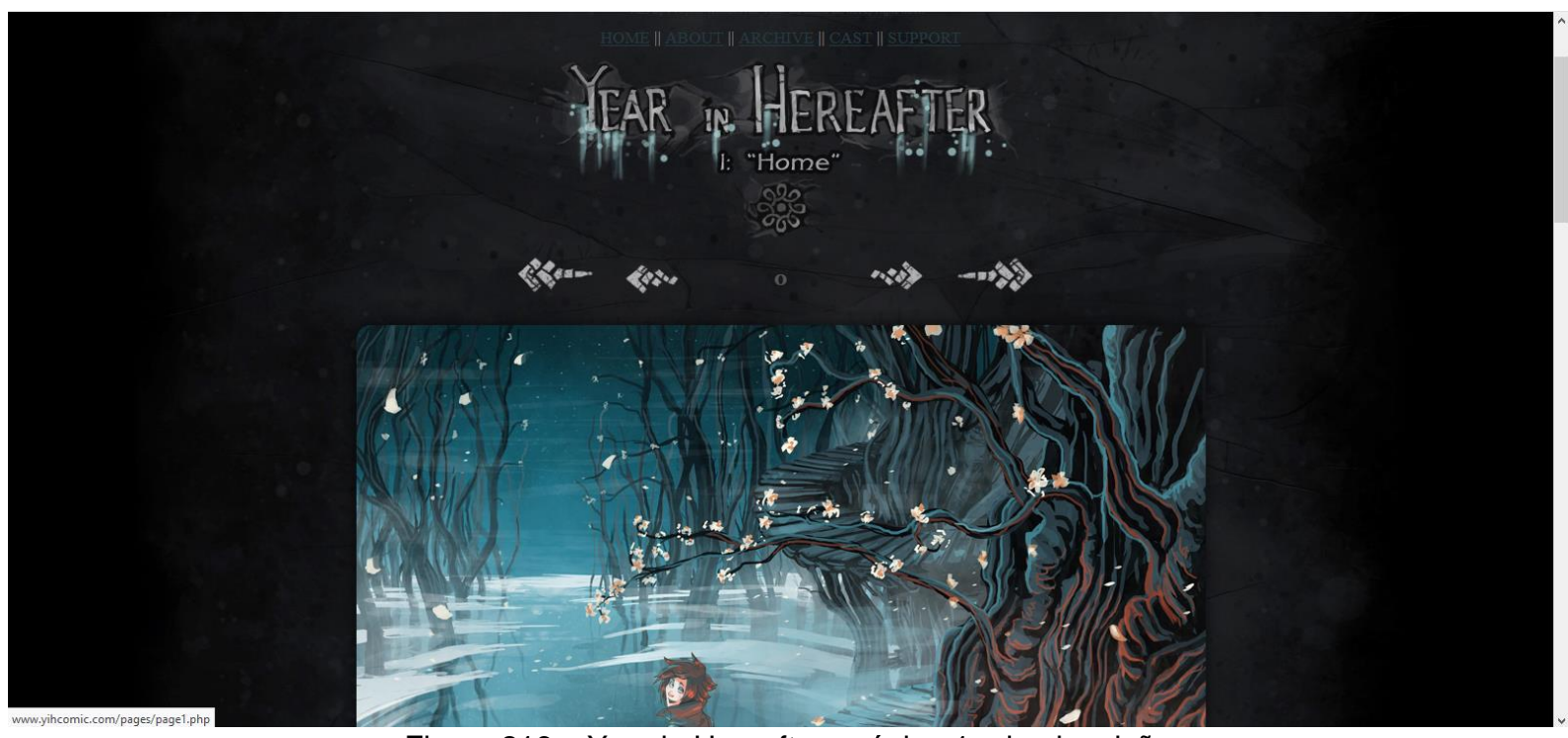

Figura 216 - Year in Hereafter - página 1 primeira visão

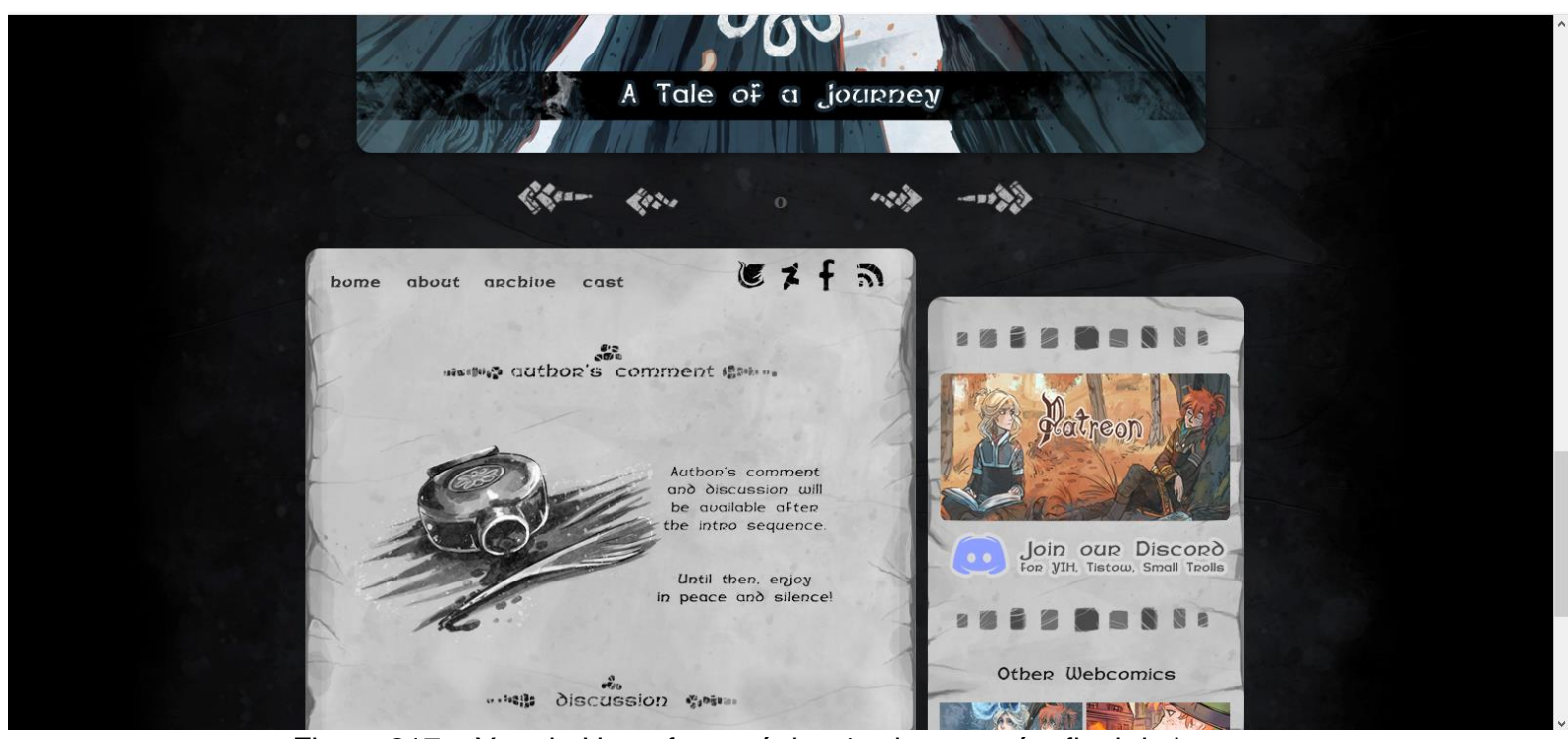

Figura 217 - Year in Hereafter - página 1 rolagem até o final da imagem 


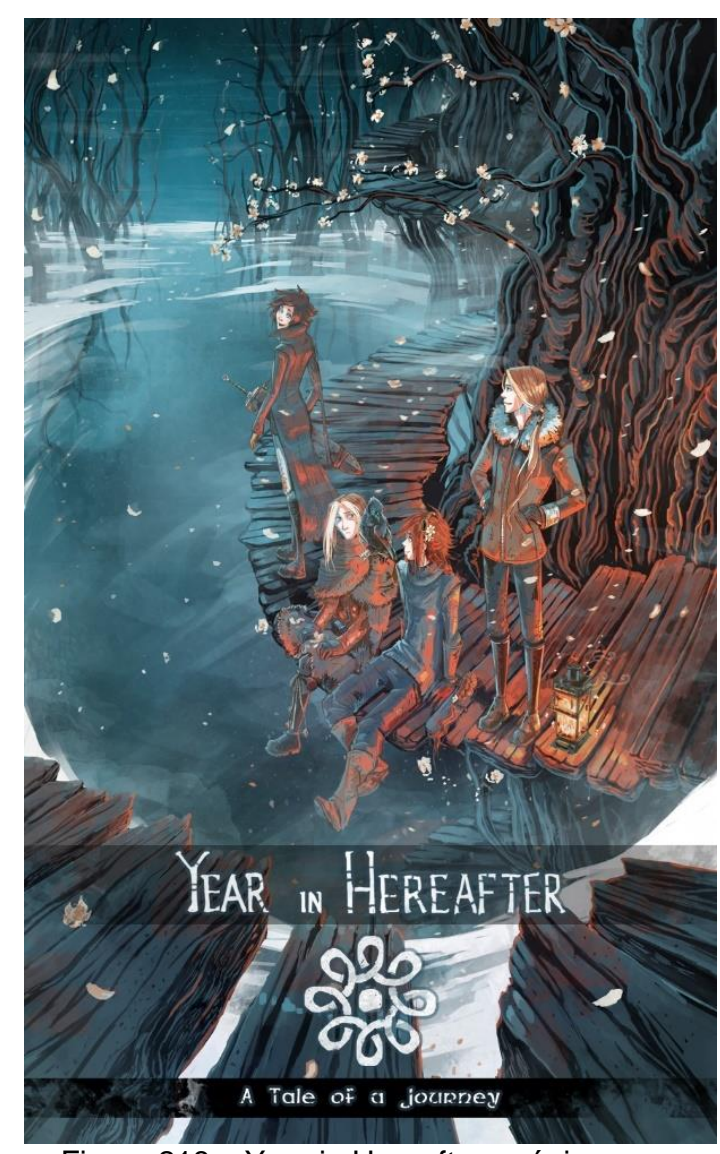

Figura 218 - Year in Hereafter - página capa

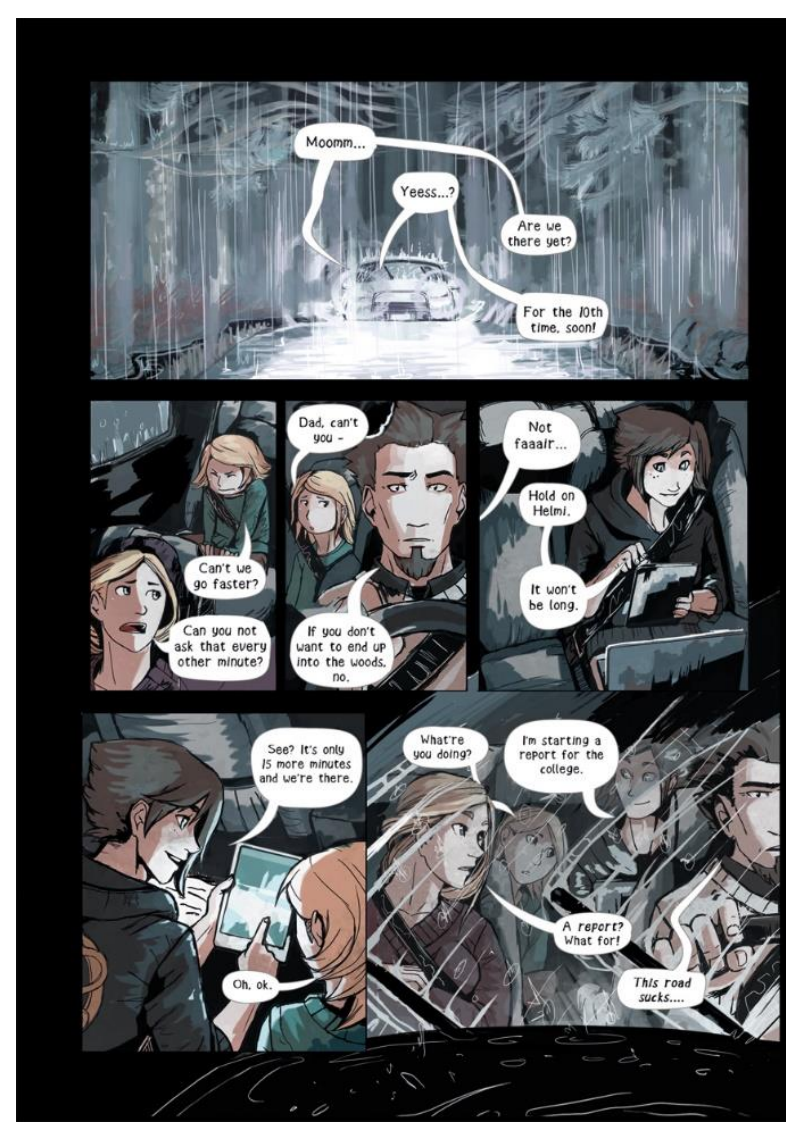

Figura 220 - Year in Hereafter - página 3

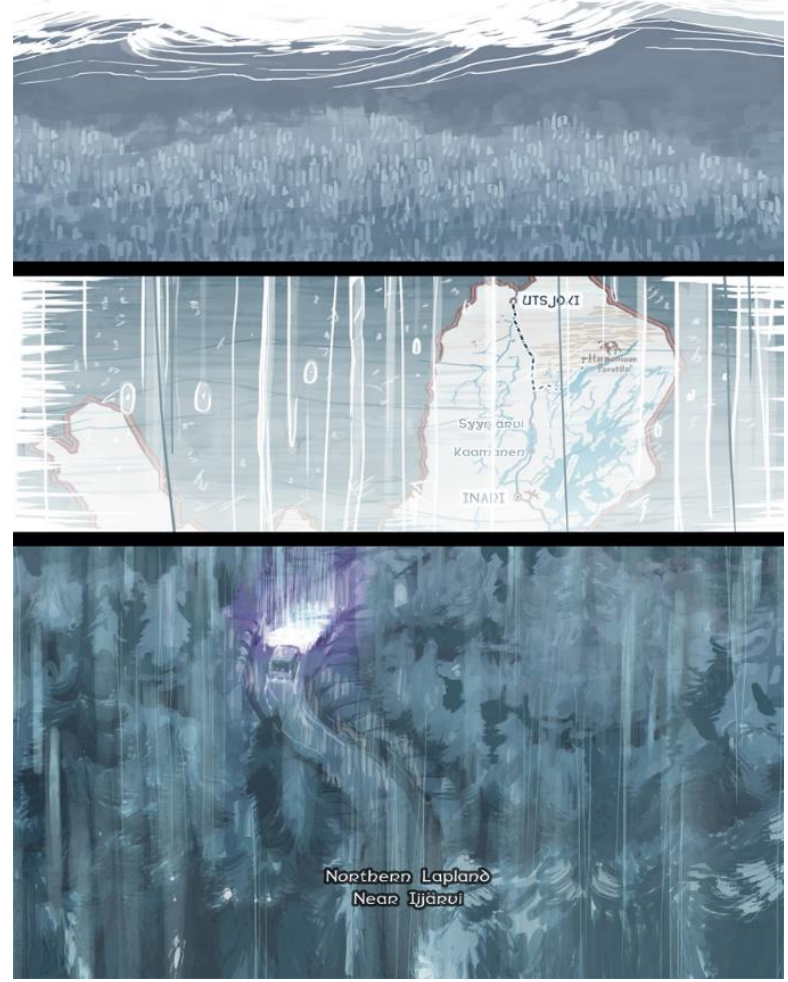

Figura 219 - Year in Hereafter - Página 2

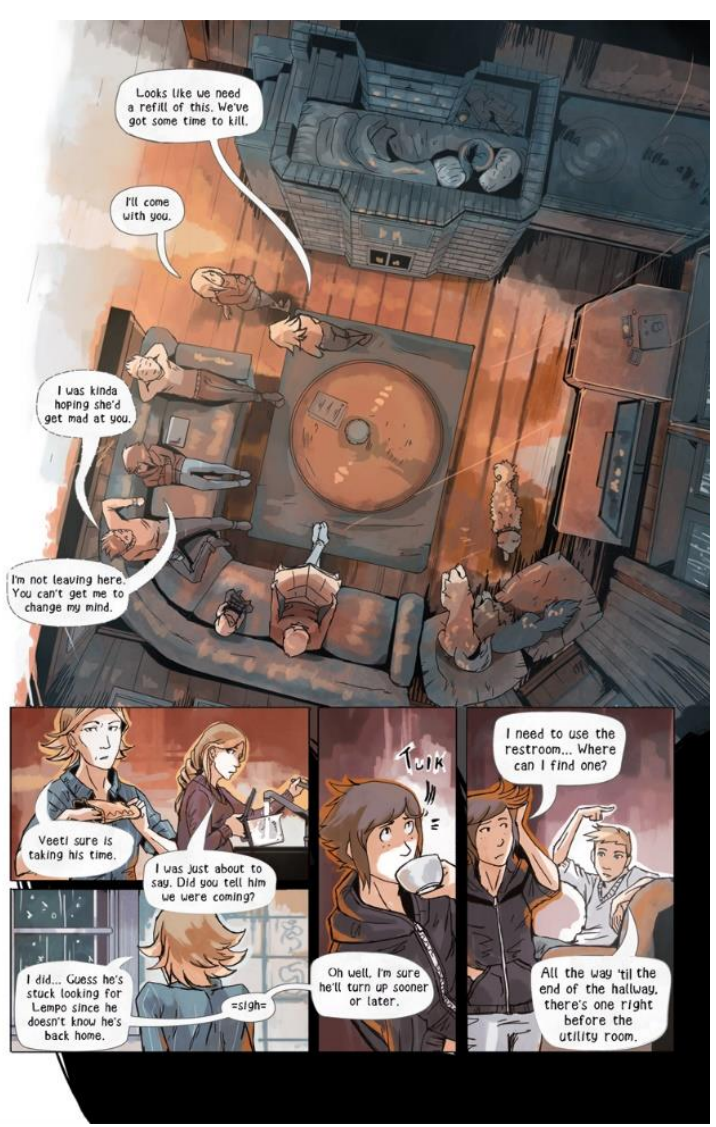

Figura 221 - Year in Hereafter - página 13 
Webtoons orientais, principalmente coreanas, desenvolveram uma grade vertical, com um ou dois quadros por rolagem vertical, e amplas áreas vazias. Cada capítulo parece uma grande página verticalmente infinita, algumas imagens são extremamente longas, causando um efeito de prolongação de expectativa e suspensão na construção do sentido singulares. A imagem a seguir foi cortada da imagem vertical alongada original do episódio 53 da webtoon "Yun T'aeho's P'ain”, na página seguinte a figura inteira diminuída para uma noção da sua proporção.

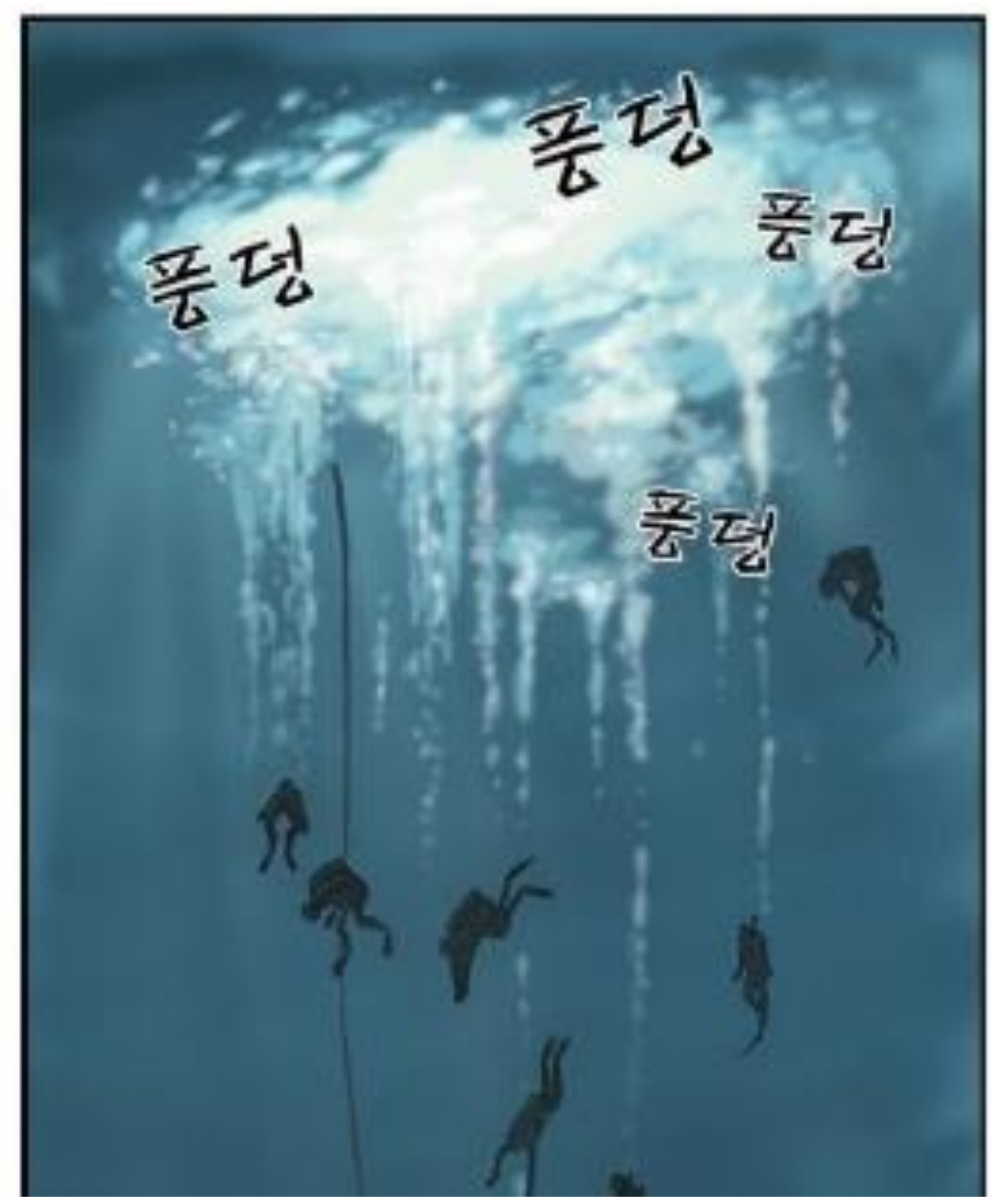

Figura 222 - Corte de quadro da webtoon Yun T'aeho's P'ain, episódio 53civ 


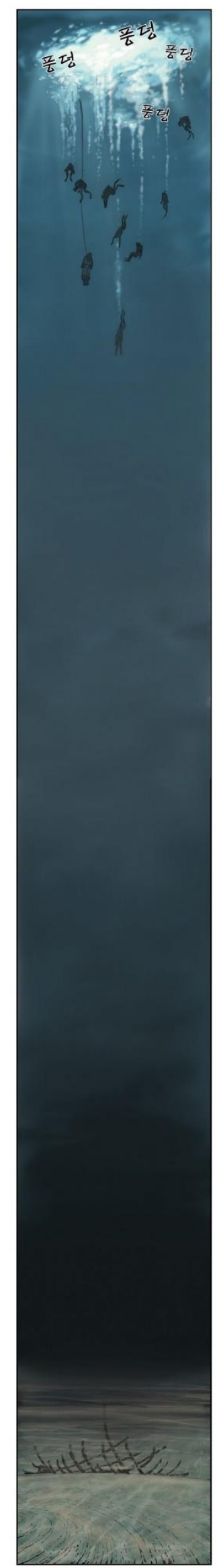

Figura 223 - Exemplo de imagem de alongamento vertical da webtoon 


\section{A professora de estudos coreanos da Whashington University, Heekyoung}

Cho, comenta a respeito do funcionamento da sarjeta na webtoon,

Despite their critical role, the gutters in conventional print comics are a visually dull, monotonous space, usually a narrow, white space between panels. But in webtoons, the gutter is used to create a diversified visual space to accompany the text. The gutter sometimes occupies more space than the panels and actively contributes to the narrative in various ways. In some cases, it is used to express the duration of time and/or changes of location by its length. A distinctively long gutter implies a long span of time or major change of scene. In other cases, the gutter uses a background color or design that defines the tone of the whole story ${ }^{134}(\mathrm{CHO}, 2016)$.

Tanto a webtoon de rolagem vertical, quanto a webcomic com mudança de página encontraram uma estrutura funcional de desenvolvimento diegético dentro do ambiente virtual, consagrando o meio como mais um suporte viável de publicação e acesso.

${ }^{134}$ Apesar de seu papel crítico, as sarjetas na impressão convencional de quadrinhos são visualmente sem graça, um espaço monótono, geralmente um espaço estreito e branco entre os painéis. Mas nas webtoons, a sarjeta é usada para criar um espaço visual diversificado para acompanhar o texto [escrito]. A sarjeta às vezes ocupa mais espaço que os painéis e contribui ativamente para a narrativa de várias maneiras. Em alguns casos, é usado para expressar a duração do tempo e / ou alterações de localização pelo seu comprimento. Uma sarjeta distintamente longa implica um longo período de tempo ou uma grande mudança de cenário. Em outros casos, a sarjeta usa uma cor de fundo ou design que define o tom de toda a história (CHO, 2016) [tradução da autora]. 


\subsection{Conteúdo - a ideia e a intenção}

É para contar histórias que os quadrinhos existem...

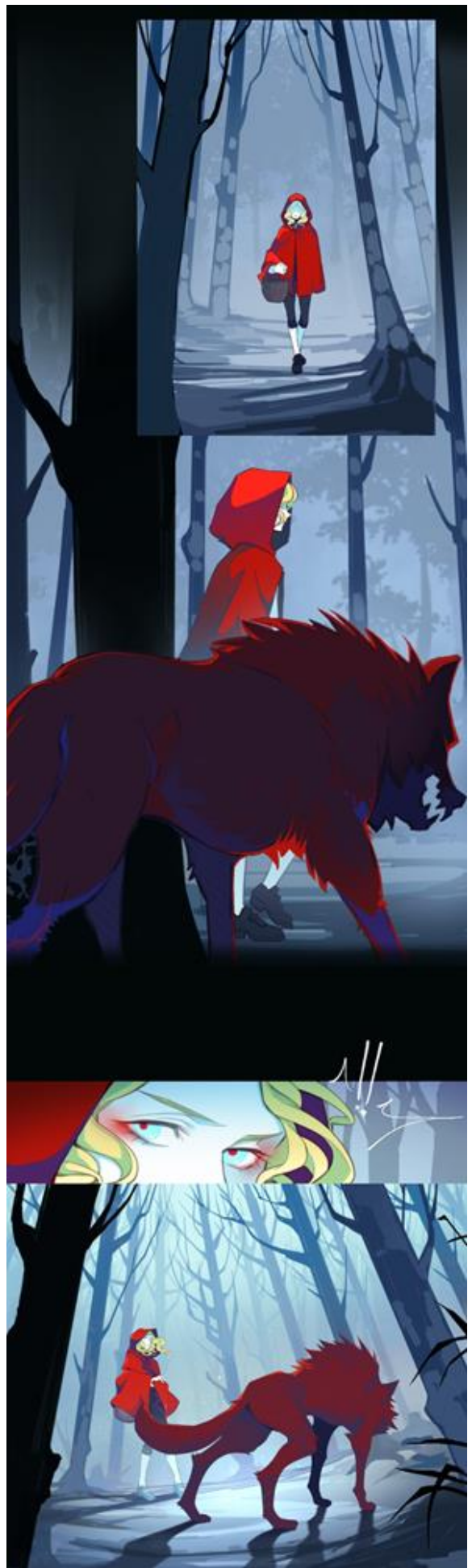

McCloud e SaraDeek ${ }^{135}$

135 Epígrafe - fonte: MCCLOUD, S. Desenhando quadrinhos. Tradução de Roger Maioli dos Santos. 1ª ed. São Paulo: M. Books do Brasil, 2008. Pg. 54 e sequência da webtoon de temárica boys-love 
Segundo Will Eisner, para se contar uma história, o perfil do leitor - sua experiência e características culturais - tem de ser levado em conta antes que o narrador possa contar a história com sucesso, pois uma boa comunicação depende da memória, experiência e do vocabulário visual do próprio narrador (EISNER 2013). É para o leitor que as perguntas e respostas do artista se destinam, é nesse diálogo que uma obra vive ou definha.

O leitor de quadrinhos vive uma contradição, pois ao mesmo tempo em que faz parte da cultura de massa, é estigmatizado pela sociedade. É alguém que a despeito da desaprovação geral, entrega-se à fruição de um objeto considerado infantil, alienante ou torpe.

O fato de grande número de adolescentes ou adultos continuarem presos a esse único tipo de leitura indica a precariedade do amadurecimento cultural do homem contemporâneo, em geral. Embora amadurecido organicamente e bem informado dos fatos do dia a dia, permanece psicologicamente imaturo (COELHO, 2000, p. 217-218).

Há um lamento quase unânime entre os pesquisadores de quadrinhos nas introduções de seus trabalhos com um desabafo sobre sua relação com as HQs, pois todos relatam um período em que liam $\mathrm{HQ}$ à margem da vida pública. Ler quadrinhos era uma coisa privada, pessoal e solitária,

\begin{abstract}
De uma forma ou de outra, eles [os quadrinhos] sempre me acompanharam não só como meio de entretenimento ou hobby de colecionador, mas também profissionalmente. Fui livreiro do ramo, fui tradutor de quadrinhos, escrevi como crítico nos meios especializados e generalistas, e escrevi roteiros de histórias em quadrinhos. $E$ se consegui manter o interesse pelo que comumente se considerava uma forma de lazer infantil, foi porque os quadrinhos cresceram comigo (GARCIA, 2012, p. 13).

Minha paixão pelo gibi originou-se nos círculos infanto-juvenis. Na cidade [Santana do Ipanema, Alagoas, 1950], não havia livrarias ou bancas de revistas. Mas funcionavam representantes da indústria editorial massiva. As revistinhas chegavam através do ônibus que fazia o percurso MaceióSantana. A compra era feita por encomenda. (MELO, 2013, p. 16).
\end{abstract}

Alvaro de Moya comenta que sua interação com os quadrinhos começou ainda criança "Eu comecei a ler histórias em quadrinhos antes de aprender a ler português." (MOYA, 2013). Como Moya, muitos leitores têm contato com a linguagem de quadrinhos ainda na infância em uma fase pré-alfabetização, tanto em revistas em quadrinhos infantis nas bancas, em tiras de jornal dos pais ou nos livros-imagem.

A elasticiadade da $\mathrm{HQ}$ permite que ela se adeque ao amadurecimento do

independente SARADEEK. Vermelho. Webtoon, 2018. Disponivel em: <https://www.webtoons.com/en/challenge/vermelho-bl/episode-1-applepie/viewer?title_no=171841\&episode_no=2>. Acesso em: 19 Maio 2018. 
leitor, abordando estéticas e temáticas com um nível de leitura cada vez mais desafiador sem, contudo, abandonar uma preocupação com o leitor iniciante que requer uma abordagem mais direta e intuitiva, facilitando o aprendizado da leitura da linguagem específica dos quadrinhos de forma natural.

A professora, ensaísta e crítica literária, Nelly Novaes Coelho, em seu estudo sobre a literatura infantil de 2004 comenta brevemente a História em Quadrinhos, sob a perspectiva do leitor criança, o que torna sua abordagem para com a $\mathrm{HQ}$, enquanto manifestação, rígida e unilateral.

Quanto a reiterada acusação dos malefícios que podem ser causados pela leitura de histórias em quadrinhos sobre mentes infantis, seria preciso uma nova reflexão, que distinguisse o processo de leitura proporcionado pelos quadrinhos e o conteúdo que é veiculado pela grande massa dessa literatura (a maior parte, realmente negativa...) [grifo nosso] (COELHO, 2000, p. 248)

Mesmo uma grande estudiosa quanto a professora Nelly, que trouxe uma ampliação e inovação no estudo da literatura voltada para crianças ajudando a reiteirar sua importância e seu estatuto como arte, parte, nessa questão, de que a HQ é uma manifestação infantil: "As histórias em quadrinhos são tão válidas quanto os livros com figuras como processo de leitura acessível ou adequado às crianças pequenas." (COELHO, 2000, p. 217) [grifo nosso], por isso o conteúdo negativo ao qual se refere, é negativo para as crianças pequenas. Com isso ela constrói uma análise limitada do meio, pois está sob o prisma do leitor criança ou, o que é mais problemático, do leitor adolescente e adulto "não amadurecido".

Editoras especializadas em quadrinhos tentam uma classificação indicativa de faixa etária na capa, mas esse recurso é arbitrário e as concepções do conteúdo adequado a cada faixa etária varia de uma editora a outra. Por exemplo, a classificação da DC Comics (DC Entertainment):

Tabela 6 - Classificação etária DC Comics ${ }^{136}$

\begin{tabular}{|l|l|}
\hline E - EVERYONE & $\begin{array}{l}\text { Appropriate for readers of all ages. May contain cartoon violence and/or some } \\
\text { comic mischief. }\end{array}$ \\
\hline T - TEEN & $\begin{array}{l}\text { Appropriate for readers age } 12 \text { and older. May contain mild violence, language } \\
\text { and/or suggestive themes. }\end{array}$ \\
\hline T+ - TEEN PLUS & $\begin{array}{l}\text { Appropriate for readers age } 15 \text { and older. May contain moderate violence, mild } \\
\text { profanity, graphic imagery and/or suggestive themes. }\end{array}$ \\
\hline M - MATURE & $\begin{array}{l}\text { Appropriate for readers age 17 and older. May contain intense violence, } \\
\text { extensive profanity, nudity, sexual themes and other content suitable only for } \\
\text { older readers. }\end{array}$ \\
\hline $\begin{array}{l}\text { *Please note, ratings across all digital platforms may vary slightly. The above ratings are meant solely } \\
\text { as a guideline. }\end{array}$
\end{tabular}

136 Extraído do site oficial da DC Comics, disponível em: https://www.dccomics.com/ratings. 
Como abordado em suas origens, não há uma intencionalidade, uso ou público alvo específico na HQ. Não há nada que limite seu escopo, ou que direcione sua abrangência a não ser a intenção no momento de criação de uma obra específica. Sua facilidade no processo de leitura também é algo questionável, pois se e quando sua leitura é fácil isso depende da intenção do autor para a mensagem que deseja transmitir, da mesma forma que qualquer outro meio.

O fato de existirem os chamados "romances de banca" iniciados no Brasil em 1977 com a série Sabrina trazendo "Passaporte para o Amor", de Anne Mather pseudônimo de Mildred Grieveson, que fizeram muito sucesso durante as décadas de 80 e 90 influenciando milhares de "leitoras", não afeta o meio literário como um todo. Mesmo que haja certo consenso social equivocado em afirmar que esses são livros rasos, de leitura fácil e enredos previsíveis, ainda assim, não deixam de ser Literatura e, o fato de serem Literatura, não faz com que definam todos os limites e possibilidades da Literatura.

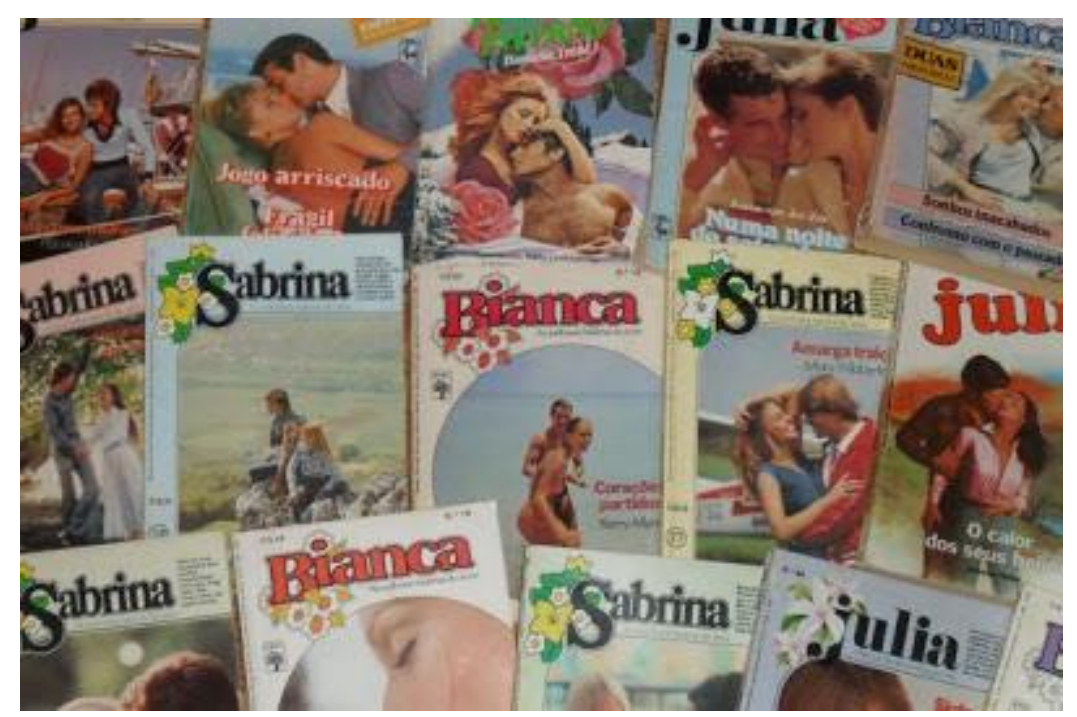

Figura 224 - "Romance de banca" - coleções Sabrina, Bianca, Julia, ect.

Ou o fato de existirem jingles ${ }^{137}$ não caracteriza toda a Música como uma coisa comercial.

Por isso leitores e estudiosos de quadrinhos sentem certa frustração quando a História em Quadrinhos é confundida com as obras em histórias em quadrinhos descontextualizadas de sua intencionalidade, temática e púlbico alvo.

137 Jingle: uma mensagem musical publicitária e elaborada com um refrão simples e de curta duração, a fim de ser lembrado com facilidade. 


\subsubsection{Intencionalidade}

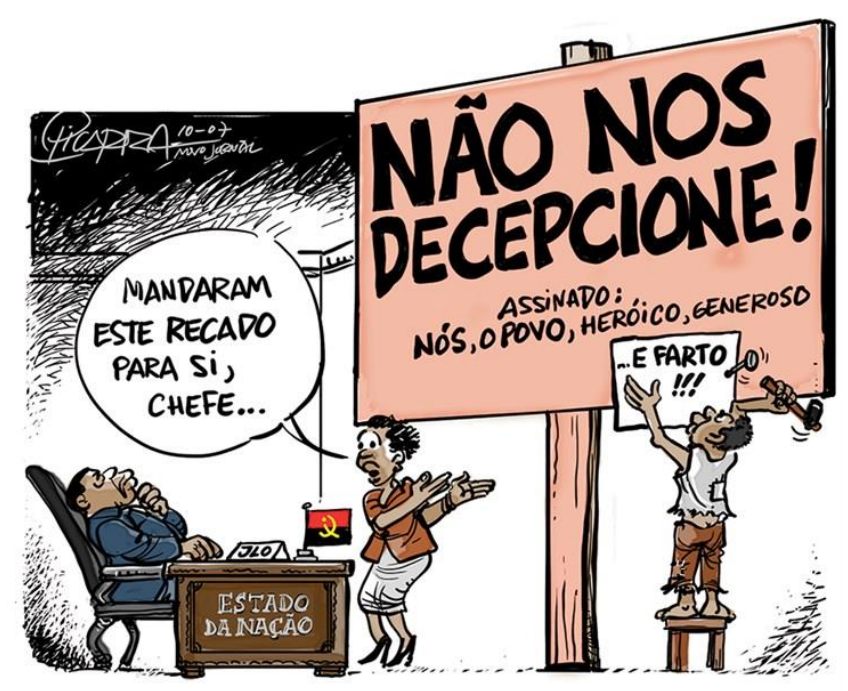

Lancei um livro coletânea há pouco tempo, e são muitos os parabéns e elogios pela coragem, pela coragem e pela coragem. Se eu fosse cartunista em Portugal, no Brasil ou na África do Sul, eu não seria corajoso coisa nenhuma, né, eu seria mais um dos cartunistas que estão lá e todos os dias satirizando a classe política dos respectivos países. Então por que aqui me chamarem de corajoso?

Sergio Piçarra - cartunista angolano ${ }^{138}$

Quadrinhos, como um meio de comunicação, podem ser utilizados para transmitir uma série de informações, com os mais variados intuitos. O mais conhecido é o entretenimento.

Both [Johann Peter Eckermann e Frédéric Soret] calculated that something humorous and light [as narrativas imagéticas de Töpffer] was just the thing to brighten the long winter evenings which weighed so heavily on an octogenarian [Goethe] who had long since ceased to travel and was particularly lonely in the abstence of his friends [e recente perda do filho] ${ }^{139}$ (KUNZLE, 1985, p. 182).

\footnotetext{
${ }^{138}$ Epígrafe - fontes: charge - PIÇARRA, S. Cartoon da semana: Recado do povo. Novo jornal, 2017. Disponivel em: <http://novojornal.co.ao/cartoon/interior/cartoon-da-semana-recado-do-povo44098.html>. Acesso em: 24 Maio 2018 e PIÇARRA, S. Cartoon. Youtube - TEDxLuanda, 2016. Disponivel em: <https://www.youtube.com/watch?v=YY14ofdh5MY>. Acesso em: 24 Maio 2018.

139 Ambos [Johann Peter Eckermann e Frédéric Soret] calcularam que algo humorístico e leve [as narrativas imagéticas de Töpffer] era justamente o que aqueceria as longas tardes de inverno que tão pesavam sobre um octogenário [Goethe] que havia há tempos parado de viajar e estava particularmente solitário na ausência de seus amigos [e recente perda do filho] (KUNZLE, 1985, p. 182) [tradução da autora].
} 
Goethe só tomou conhecimento da obra inovadora de Töpffer, porque seu editor e amigo sentiram que deviam entretê-lo depois da perda do filho e outros eventos políticos que o mantinham recluso e solitário.

Durante muito tempo a $\mathrm{HQ}$ foi utilizada com esse intuito, mas mesmo antes das revistas em quadrinhos, quando a linguagem se limitava apenas ao cartum e caricatura, o poder de mobilização e propaganda já era evidente.

Toda comunicação tem, em menor ou maior grau, uma intencionalidade, seja ela moral, política, comercial ou ideológica. E porque o emissor não está isento desses aspectos, sua obra vai refletir parte de sua forma de pensamento e interação social. Algumas vezes a intencionalidade é clara, pois faz parte da mensagem que o autor deseja transmitir, outras vezes está integrada no discurso sem que o autor se dê conta.

Em 2011, Bienvenu Mbutu Mondondo, cidadão congolês residente na Bélgica, moveu um processo judicial pedindo a proibição do livro Tintin au Cougo, publicado no Brasil como Tintin na África, por conter conteúdo racista (OPERA MUNDI, 2011).

Em um livro-entrevista publicado pela Casterman em 1989, Hergé admitiu que, na época da história original, desenhou os congoleses com o espírito e os preconceitos da época, refletidos como "pensamento católico e burguês". No entanto, defendeu que o livro fosse lido e interpretado em seu devido contexto histórico (OPERA MUNDI, 2011).

Mesmo o personagem símbolo da Bélgica e um autor conceituado como Hérge não estão imunes às influências da sociedade na qual estão inseridos, por isso não é possível analisar uma história em quadrinhos fora de seu contexto.

A leitura da imagem é ao mesmo tempo direta e subliminar. Isso porque a imagem agrega mais do que uma só mensagem. Usando a imagem básica modelar desenvolvida para esse estudo:
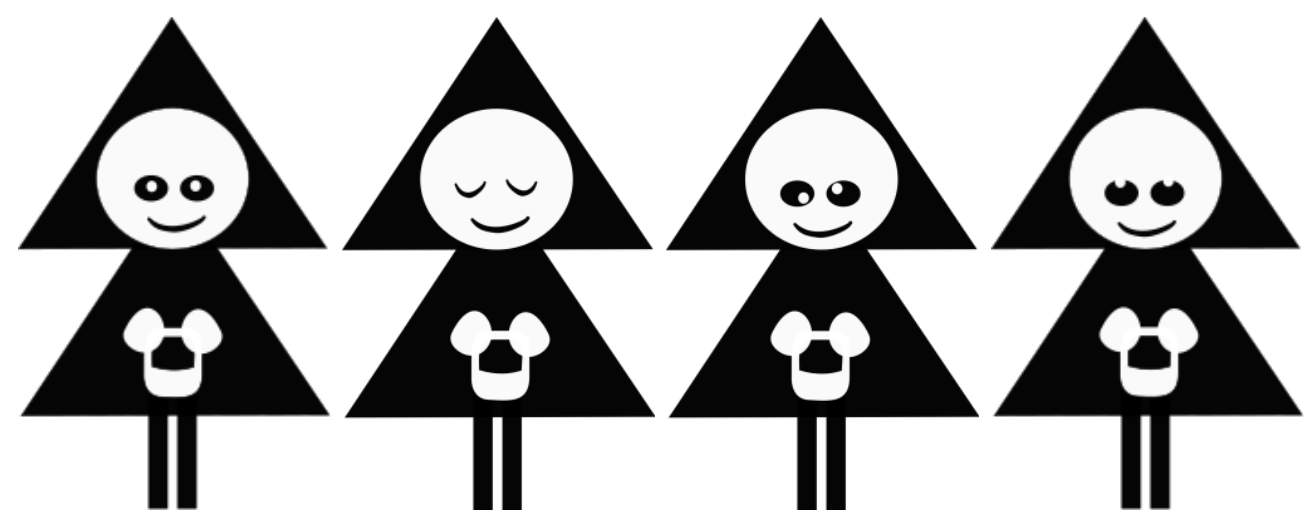

Nos quatro casos a imagem deveria representar a mesma menina, mas a 
expressão no rosto muda completamente a índole da personagem, mesmo que o enredo, ação ou contexto da história nada digam a esse respeito. Na primeira imagem a menina está olhando para frente em uma expressão normal, na segunda os olhos estão fechados em uma expressão inocente e feliz, na terceira os olhos parecem tortos, representando um comportamento abobado ou idiota ${ }^{140}$, na quarta os olhos voltados para cima podem dar a impressão de enfado ou de alguém que sabe algo que os outros não sabem.

Pode parecer uma nuance irrelevante, mas quando aplicada à sequência narrativa, principalmente uma sequência curta com a tira modelar, acontece uma transformação de uma menina em um estado normal que entra na floresta e encontra um lobo, isto é, pode acontecer com qualquer menina, para na segunda, uma menina inocente e boazinha, que foi enganada, na terceira uma menina tola e a última pode levar a uma suposição de que é uma menina maliciosa, que sabia que estava fazendo algo errado ao entrar na floresta, mas o fez mesmo assim.

Um suposto artista pode não ter nenhuma intenção profunda ao escolher a posição dos olhos, ele poderia, por exemplo, simplesmente achar que a terceira figura, a de olhos tortos, fosse mais cômica, por já ter sido usada em inumeráveis outras representações cômicas, contudo uma representação da narrativa de chapeuzinho vermelho onde se parte do princípio de que a menina não tinha inteligência para discernir suas ações, tornando inevitável seu fim, torna a narrativa ainda mais cruel e, até, preconceituosa.
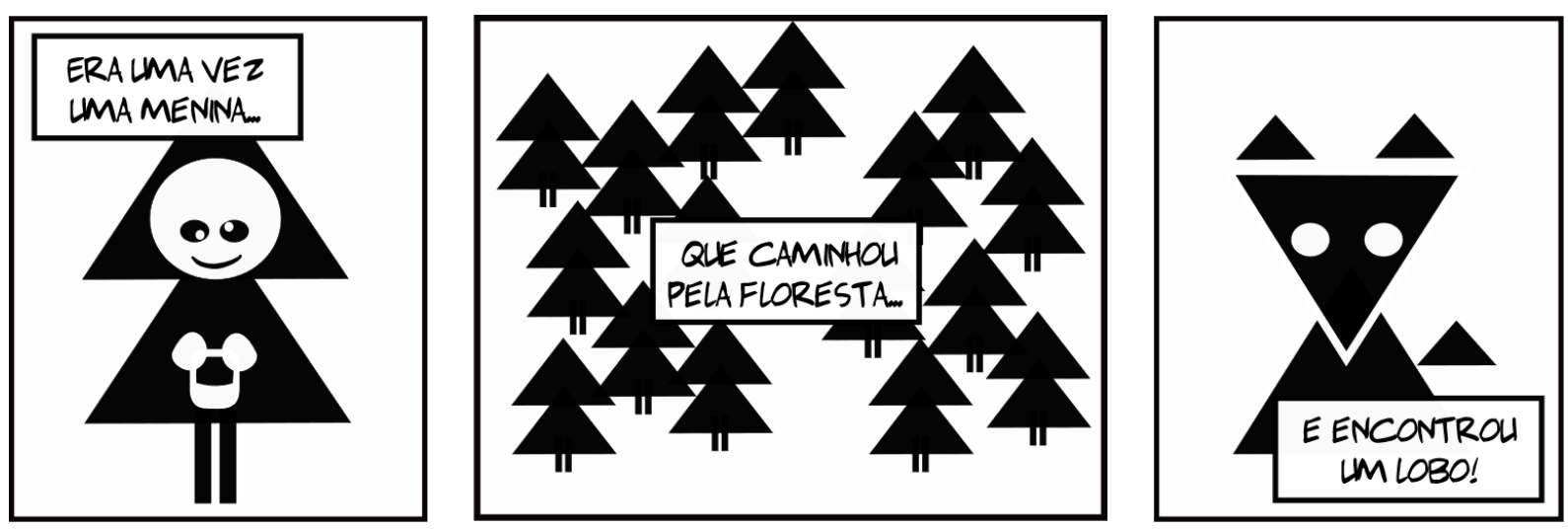

Nesse sentido é preciso avaliar não somente a obra em si, em seus elementos formais, mas sua relação com o contexto de criação, ou seja, analisar em que contexto social se acha graça de uma menina ser representada como boba,

${ }^{140}$ A representação dos olhos tortos como um esteriótipo para estupidez é usada na caricatura e humor gráfico a muito tempo, apesar de muito usado, é um esteriótipo preconceituoso e negativo. 
porque a representação da menina segue esse aspecto, qual o papel das meninas nessa sociedade, o quanto a atitude da menina, suas escolhas de caminhos e seus destinos são avaliados pela sua capacidade intelectual. É preciso, pois, discernir se a intencionalidade em demostrar que são tolas, meninas que entram na floresta, é do artista ou da sociedade em que ele está inserido que espera que ela seja assim.

$\mathrm{Na} \mathrm{HQ}$, cada elemento tem uma participação na construção de sentido de uma imagem, por isso que apesar de haver uma mensagem imediata em primeiro nível, há também várias outras concorrendo para construir outros sentidos, que em determinado contexto tem uma interpretação e em outro contexto, outra.

Na história de Hérge, Tintin na África de 1931, criticada por racismo, por exemplo, além da ação acontecendo, isto é, o descarrilhamento do trem causado por Tintin e a solução do personagem (que termina com herói fazendo com que os congoleses coloquem o trem de volta nos trilhos sem que ele mesmo faça força), há na imagem a interpretação de Hérge sobre como deveria ser o povo africano (Hergé não costumava fazer viagens de campo para conhecer os locais que retratava).
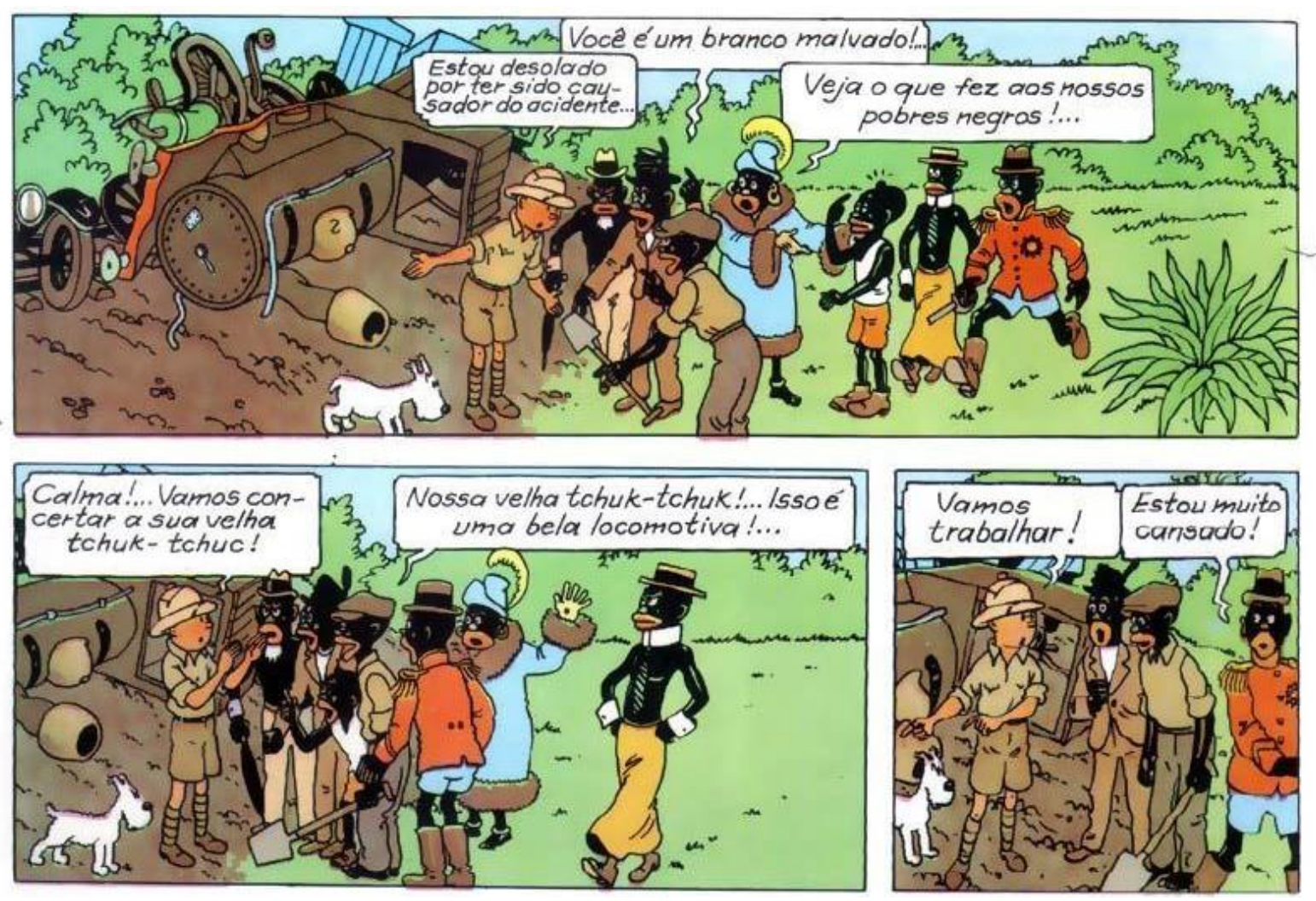

Figura 225 - Tintim na África - Herge - Edição brasileira de 1970 - Editora Record, página 22, $1^{\mathrm{a}}$ e $2^{\mathrm{a}}$ linhas ${ }^{\mathrm{cv}}$

Hérge, recorre ao "black face", conhecido estereótipo pejorativo usado na época para retratar o negro de maneira cômica. Além disso, na indumentária dos nativos é ressaltada a condição de adequação à vestimenta europeia de forma 
equivocada, principalmente no personagem com gravata, de saia e sem camisa e no outro com blusão oficial e bermudas.

Analisando somente a obra, pode-se chegar a conclusão, muito facilmente na verdade, de que a história é realmente racista, além de apresentar crueldade contra os animais e mais alguns outros aspectos negativos para o consenso social contemporâneo, mas quando colocada no contexto de época (década de 30), revela um perfil do que era comumente aceito e popular no período. Pelo fato de ter sido tão popular, sendo traduzida para um grande número de países, a obra revela de forma inequívoca, o pensamento usual da maioria da sociedade ocidental em determinado período, assim não é o pensamento individual de uma artista que está sendo avaliado e, sim, o pensamento de uma época.

A representação estereotipada do negro não surgiu com as histórias em quadrinhos, esse foi um traço herdado dos minstrels, artistas performáticos, dançarinos e comediantes que faziam shows itinerantes, por volta do final do século XVIII ao começo do século XX. Nesses shows era comum os black face, artistas brancos inspirados no personagem cômico Jim Crow, que pintavam seus rostos e se caracterizavam como escravos ou negros pobres para satirizá-los.

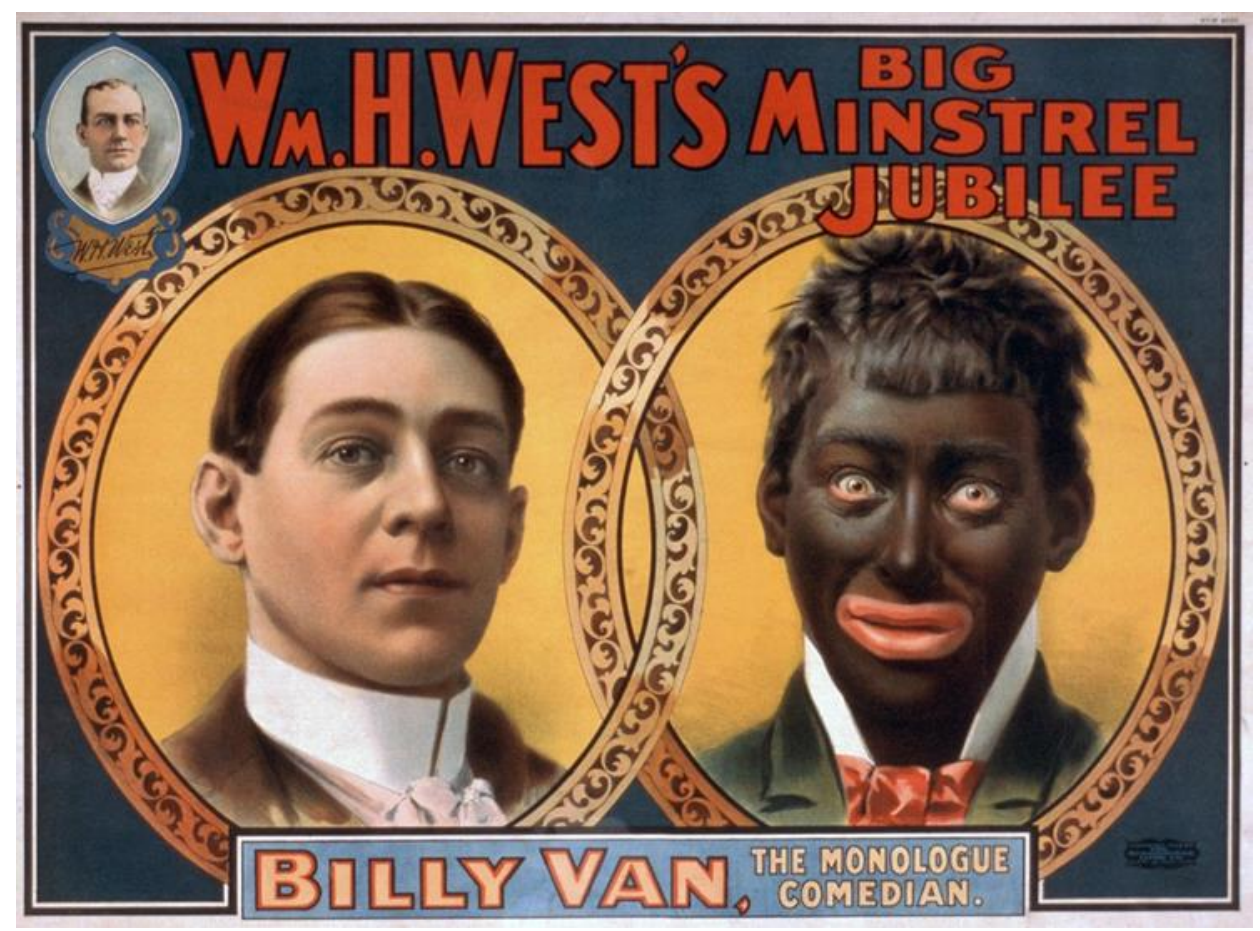

Figura 226 - Minstrel - Black Face ${ }^{\mathrm{cvi}}$

A Figura 226 é uma reprodução de um pôster de um minstrel show estrelado por William H. West em 1900. William H. West foi um dos mais populares 
sapateadores de minstrel show de sua época, principalmente no período de sua parceria com o também popular George Primrose.

Além das performances, começaram a surgir as paródias em texto nos jornais e a seguir as caricaturas e tiras humorísticas. Em 1847, o escravo fugido Frederick Douglas, fundou o jornal The North Star, em Rochester, Nova lorque, e a partir de seus editoriais a crítica racial encontrou a força da argumentação para enfrentar o estereótipo degradante revestido de entretenimento.

Blackface imitators, he [Frederick Douglass] said, were "...the filthy scum of white society, who have stolen from us a complexion denied them by nature, in which to make money, and pander to the corrupt taste of their white fellow citizens."141 (LOTT, 1991).

Infelizmente o estereótipo pejorativo perdurou como referência imagética tanto nas ilustrações em geral, quanto nos cartuns e nas histórias em quadrinhos americanas, que exportadas mundo afora, se viu reproduzida e imitada como padrão para representação de pessoas negras.

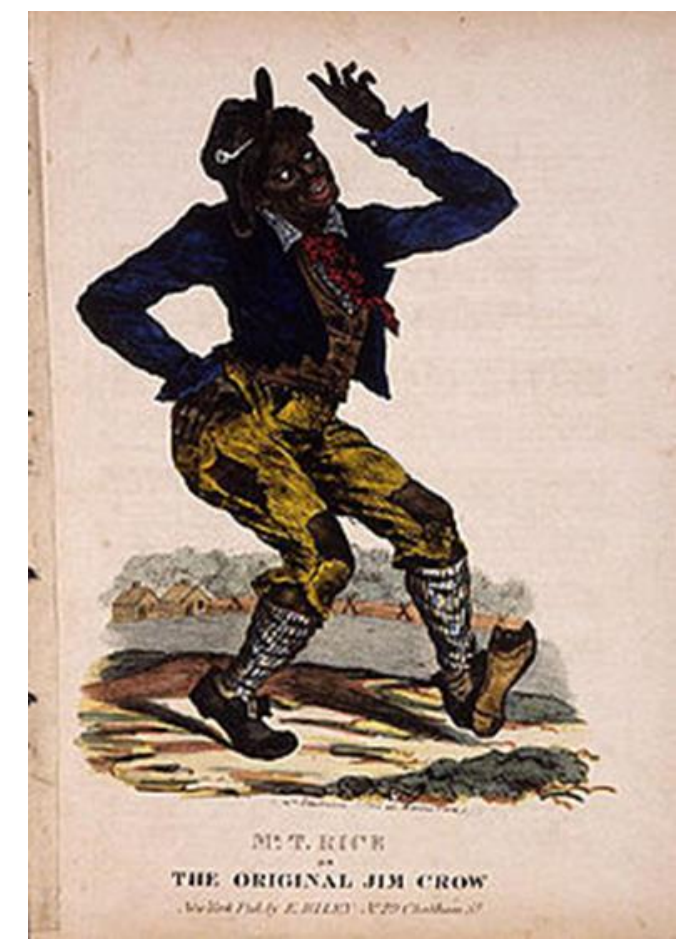

Figura 227 - Capa da partitura de "Jump Jim Crow" - 1832

No Brasil, em 1930, a revista Tico-Tico apresentava as histórias de Lamparina, uma menina negra, praticamente sem gênero (somente o nome e a saia

141 Imitadores "Blackface", ele [Frederick Douglas] disse, eram "a escória imunda da sociedade branca, que têm roubado de nós uma tez negada a eles por natureza, com o intuito de ganhar dinheiro, e agradar ao gosto corrupto de seus concidadãos brancos" (LOTT, 1991) [Tradução da autora] 
a representava como do sexo feminino) era uma figura quase animalesca, privada de intelecto ou cultura.

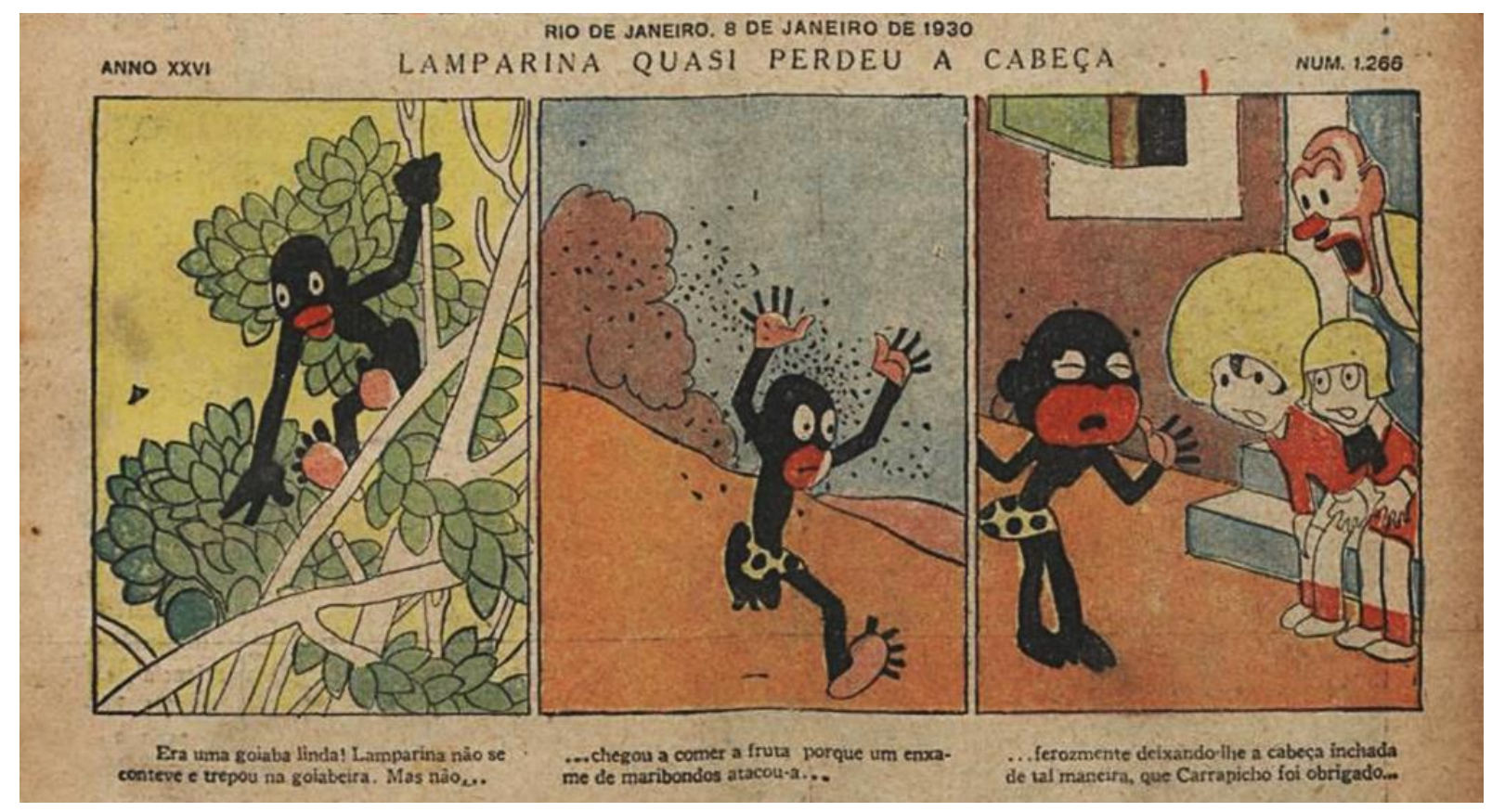

Figura 228 - Lamparina - Revista Tico-tico, 08/01/1930 pg. 1

A representação do negro nos quadrinhos, teatro, cinema e mesmo, literatura, estava subordinada aos interesses da elite branca, que lucrava com a desqualificação do indivíduo como uma pessoa. Entender a intencionalidade de uma representação faz parte da análise contextual de uma obra.

Jogchum Vrielink, cordenador de pesquisas em leis de discriminação do Research Centre on Equality Policies da University of Leuven, e correspondente do jornal The Guardian afirma que em alguns países como a Inglaterra, a publicação de "Tintin au Congo", está sendo colocada a venda na seção de livros adultos e

it included a cautionary wrapper indicating that it contained "bourgeois, paternalistic stereotypes of the period" that may be offensive to contemporary readers. The edition also encompassed an introduction providing additional historical contextualization ${ }^{142}$ (VRIELINK, 2012).

Decidir se uma obra é adequada ou não a determinado público não é uma tarefa fácil em razão de inúmeros fatores, mas o principal está na questão entre o direito e o poder. Sobre quem tem o direito e o poder de determinar aquilo ao qual o outro tem acesso.

142 incluía uma traja de advertência na capa indicando que continha "estereótipos burgueses, paternalistas do período" que podem ser ofensivos para os leitores contemporâneos. A edição também englobou uma introdução que fornece contextualização histórica adicional (VRIELINK, 2012) [tradução da autora]. 
Em um debate entre os filósofos Noam Chomsky e Michel Foucault em 1971 na Eindhoven University of Technology, na Holanda, Foucault ressalta a problemática de determinar a natureza humana, partindo das premissas do próprio contexto de quem está fazendo esta determinação.

If you say that a certain human nature exists, that this human nature has not been given in actual society the rights and the possibilities which allow it to realise itself...that's really what you [Chomsky] have said, I believe. And if one admits that, doesn't one risk defining this human nature which is at the same time ideal and real, and has been hidden and repressed until now - in terms borrowed from our society, from our civilisation, from our culture? ${ }^{143}$ (Debate Noam Chomsky \& Michel Foucault - On human nature, 1971).

Pela argumentação de Foucault percebe-se que o que determinada sociedade considera ideal, muitas vezes pode-se tornar autoritário, abusivo ou pernicioso. Na entrevista ele cita as divergências entre o ideal socialista e sua realização. A sociedade justa que a sociedade contemporânea idealiza, por estar baseada em concepções de justiça limitadas pelo seu contexto pode se materializar em uma sociedade com injustiças diferentes, ainda mais problemáticas.

O poder de decisão do que é uma "leitura ideal" a determinado tipo de público segue essa mesma problemática. Pois a determinação dessa "leitura ideal" está limitada ao contexto do órgão ou pessoas com o poder de decisão. Em que medida e sob quais parâmetros uma obra de $\mathrm{HQ}$ é analisada antes de uma determinação, quais são os aspectos levados em conta, e qual a intenção por trás de limitação de abrangência são questões muitas vezes ignoradas por aqueles com o poder de determinar quem pode ou não ter acesso a determinado conteúdo. O processo acaba sendo muitas vezes arbitrário e condicionado à intencionalidade de fatores políticos, mercadológicos e pedagógicos.

\footnotetext{
${ }^{143}$ Se você diz que uma certa natureza humana existe, que esta natureza humana não recebeu na sociedade atual os direitos e as possibilidades que permitem que ela se realize. Isso é realmente o que você [Chomsky] disse, eu acredito. E se alguém admite isso, não corre o risco de definir essa natureza humana - que é ao mesmo tempo ideal e real, e que foi ocultada e reprimida até agora - em termos emprestados de nossa sociedade, de nossa civilização, de nossa cultura? (Debate Noam Chomsky \& Michel Foucault - On human nature, 1971).
} 


\subsubsection{Educação}

Uma linguagem ganha mais autonomia e passa a ser mais bem compreendida após um criterioso olhar sobre ela...

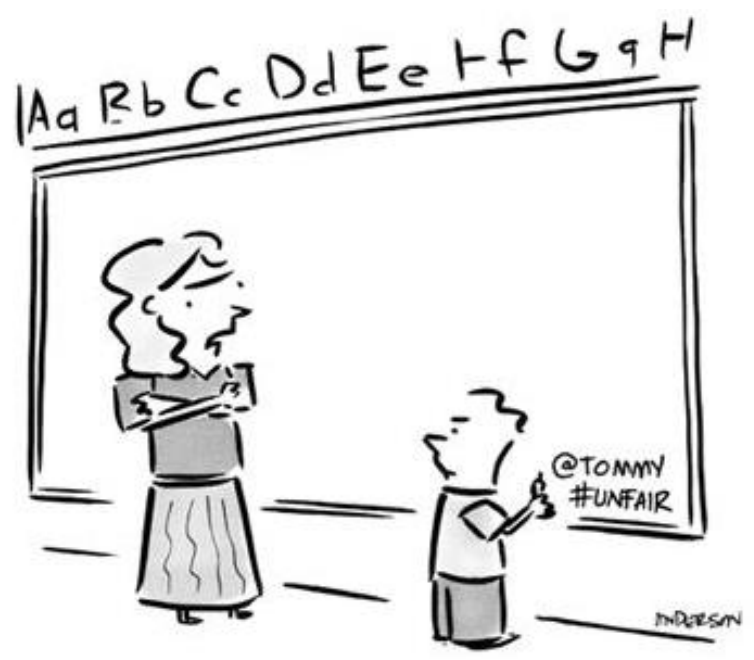

"Just your name would be fine."

Vergueiro, Paulo e Mark Anderson ${ }^{144}$

Segundo Waldomiro Vergueiro e Paulo Ramos, no Brasil, nos últimos anos há uma crescente presença dos quadrinhos na escola, pois se tornaram parte de uma política educacional do país, com inclusões nos Parâmetros Curriculares Nacionais (PCN) e no Programa Nacional Biblioteca na Escola (PNBE), possibilitadas a partir da Lei de Diretrizes e Bases da Educação Nacional (LDB) promulgada em 20 de dezembro de 1996 (VERGUEIRO e RAMOS, 2015).

O texto já apontava para a necessidade de inserção de outras linguagens e manifestações artísticas nos ensinos fundamental e médio: o item II do art. 3o da lei diz que a liberdade de aprender, ensinar, pesquisar e divulgar a cultura, o pensamento, a arte e o saber "é uma das bases do ensino"; e o item II do $\S$ $11^{\circ}$ do art. 36 registra, de forma mais explícita, que, entre as diretrizes para 0 currículo do ensino médio, está o conhecimento de "formas contemporâneas de linguagem" (VERGUEIRO e RAMOS, 2015, p. 10).

Vergueiro e Ramos ressaltam a introdução de tiras e charges como

${ }^{144}$ Epígrafe - fontes: VERGUEIRO, W.; RAMOS, P. Quadrinhos na educação: da rejeição à prática. São Paulo: Contexto, 2015 e ANDERSON, M. Teacher Cartoon \#6302. Andertoons, s/d. Disponivel em: <https://www.andertoons.com/teacher/cartoon/6302/just-your-name-would-be-fine>. Acesso em: 24 Maio 2018. 
gêneros, na concepção de Bakhtin ${ }^{145}$, como "adequados para o trabalho com a linguagem escrita" (VERGUEIRO e RAMOS, 2015, p. 11).

Os pesquisadores apontam também as indicações mais abrangentes de aproveitamento da $\mathrm{HQ}$ no ensino médio, com o destaque da $\mathrm{HQ}$ como fonte histórica e sociológica, por serem "dispositivos visuais gráficos que veiculam e discutem aspectos da realidade social, apresentando-a de forma crítica e com muito humor" (PNBE 2008 apud VERGUEIRO e RAMOS, 2015, p. 11).

A partir de 2006, algumas histórias em quadrinhos passaram a fazer parte da lista de obras adquiridas pelo governo federal para distribuição nas escolas públicas através do PNBE, de acordo com Vergueiro e Ramos, dos 225 títulos selecionados, 10 foram quadrinhos. Entre as obras escolhidas estavam cinco de temática humorística: "Asterix e Cleópatra" dos franceses René Goscinny \& Albert Uderzo, primeira publicação 1965, "Níquel Nausea - Nem tudo que balança cai” do brasileiro Fernando Gonsales, de 2003, "Pau pra toda obra" do brasileiro Gilmar de 2005, "A turma do Pererê - as gentilezas" do brasileiro Ziraldo de 2006, "Toda Mafalda" do argentino Quino de 1991; dois romances adaptados: "A metamorfose" de Franz Kafka quadrinizado pelo americano Peter Kuper de 2004 e "Dom Quixote - em quadrinhos", quadrinizado pelo brasileiro Caco Galhardo em 2005; a Graphic Novel original "O nome do jogo" do americano Will Eisner, publicação original em 2001, a biografia "Santô e os pais da aviação: jornada de Santos-Dumont e de outros homens que queriam voar" do brasileito Spacca de 2005 e o mangá autobiográfico "Na Prisão" (刑務所の中 Keimusho no Naka) do japonês Kazuichi Hanawa publicado no Japão entre 1998 e 2000.

Vergueiro e Ramos apontam que o edital para aquisição das obras,

sugere a interpretação de que o governo vê os quadrinhos como gêneros literários. $O$ artigo $1^{\circ}$ do edital dizia que o objetivo era "determinar a distribuição de obras de literatura pelo Programa Nacional Biblioteca Escola" (VERGUEIRO e RAMOS, 2015, p. 17).

E ainda, destacam que houve uma preocupação com o tema "obras clássicas da literatura universal" que constava da proposta geral do PNBE, o que pautou parte da produção editorial daquele ano e dos seguintes, inclusive com editoras que nunca haviam travalhado com $\mathrm{HQ}$, que passaram a lançar obras literárias adaptadas para quadrinhos, que segundo os autores,

145 Gênero por Mikhail Bakhtin: chamados de gênero do discurso - são tipos relativamente estáveis de enunciado, usados em situações interativas de comunicação (VERGUEIRO e RAMOS, 2015). 
Essa corrida para inserir as obras na lista do governo aqueceu o mercado nacional, mas acarretou algumas redundâncias. Entre 2006 e 2008, houve quatro adaptações em quadrinhos de "O alienista" e três de "A cartomante", baseados nos contos de Machado de Assis (1839-1908) (VERGUEIRO e RAMOS, 2015).

Apesar dos equívocos, escolhas questionáveis e escopo diminuto, a abertura das HQs para a escola representa um avanço enorme na ampliação das práticas e possiblidades do meio.

Gonçalo Junior apontou como Aizen quase desistiu do ramo de quadrinhos antes de fundar a editora EBAL (uma das maiores editoras de quadrinhos brasileira, que funcionou de 1945 a 1995), por causa das crescentes críticas negativas,

Sua decisão foi reforçada quando o Instituto Nacional de Estudos Pedagógicos (INEP), do Ministério da Educação e Saúde, publicou um minuncioso estudo sobre o conteúdo das revistas em quadrinhos, elaborado por uma conceituada comissão de professores e orientadores educacionais. As conclusões foram publicadas entre os números 6 e 9, de julho a novembro daquele ano [1944], na Revista Brasileira de Estudos Pedagógicos. A publicação funcionava como uma espécie de guia de orientação na área educacional e constatou o que até então seus técnicos acreditavam ser um mal desconhecido das revistinhas: o prejuízo que provocavam no desempenho escolar das crianças. Além das teses de dominação cultural e do estímulo à violência promovido pelos quadrinhos, O INEP trouxe uma preocupação a mais aos pais: segundo aquela pesquisa, quem lia quadrinhos ficava com preguiça mental e avesso a livros (GONÇALO JUNIOR, 2004, p. 114).

A divulgação do estudo trazia a comparação entre material de jornal e revistas ilustradas, sem divulgar seus nomes, um dos parâmetros de avaliação apontados foi:

Em publicações destinadas a crianças e adolescentes, a questão da linguagem é, por certo, das mais importantes. O ideal será o emprego de forma sempre correta; de vocabulário adequado às várias idades a que as publicações se destinem; e, ainda, de redação clara e simples, mas capaz de inspirar bom gosto literário (INEP, 1944, p. 401).

Além da análise das histórias, o INEP também fez entrevistas com crianças e jovens e considerou um absurdo que seis personagens de quadrinhos figurassem entre as vinte personalidades apontadas como as mais conhecidas da história brasileira, ainda mais com nomes de personagens inventados como "Flash Gordon", "Brucutu" ou "Fantasma" figurando na frente de pessoas reais como Osvaldo Cruz, Olavo Bilac, almirante Tamandaré ou o pintor Pedro Américo (GONÇALO JUNIOR, 2004).

Gonçalo Junior ressalta que o alerta do INEP provocou uma reação imediata na imprensa e os quadrinhos se tornaram uma das principais fontes de preocupação dos professores em todo país. 
Além do texto escrito, a análise do INEP avaliou também as figuras, que classificou como: desenho caricato; desenho singelo, sem sombras; desenho rudimentar, com representação apenas de 1. plano; desenho artístico; desenho técnico e fotografias (INEP, 1944).

Como texto e imagem, no INEP foram avaliados separadamente, houve argumentos criticando que as obras apresentavam imagens confusas ou pouco claras, "quer pela composicão quer pela técnica do desenho" (INEP, 1944), um dos exemplos apontados, a Figura 229 da página 277, demostra os caminhos que a cartunização e caricaturização tomavam no sentido de criar uma imagem codificada à linguagem dos quadrinhos, ou seja, uma imagem estática para representação de um movimento caótico e conflitante. Mesmo extraída do contexto da narrativa, a imagem em si, é capaz de transmitir o conteúdo semântico intencionado ao seu leitor.

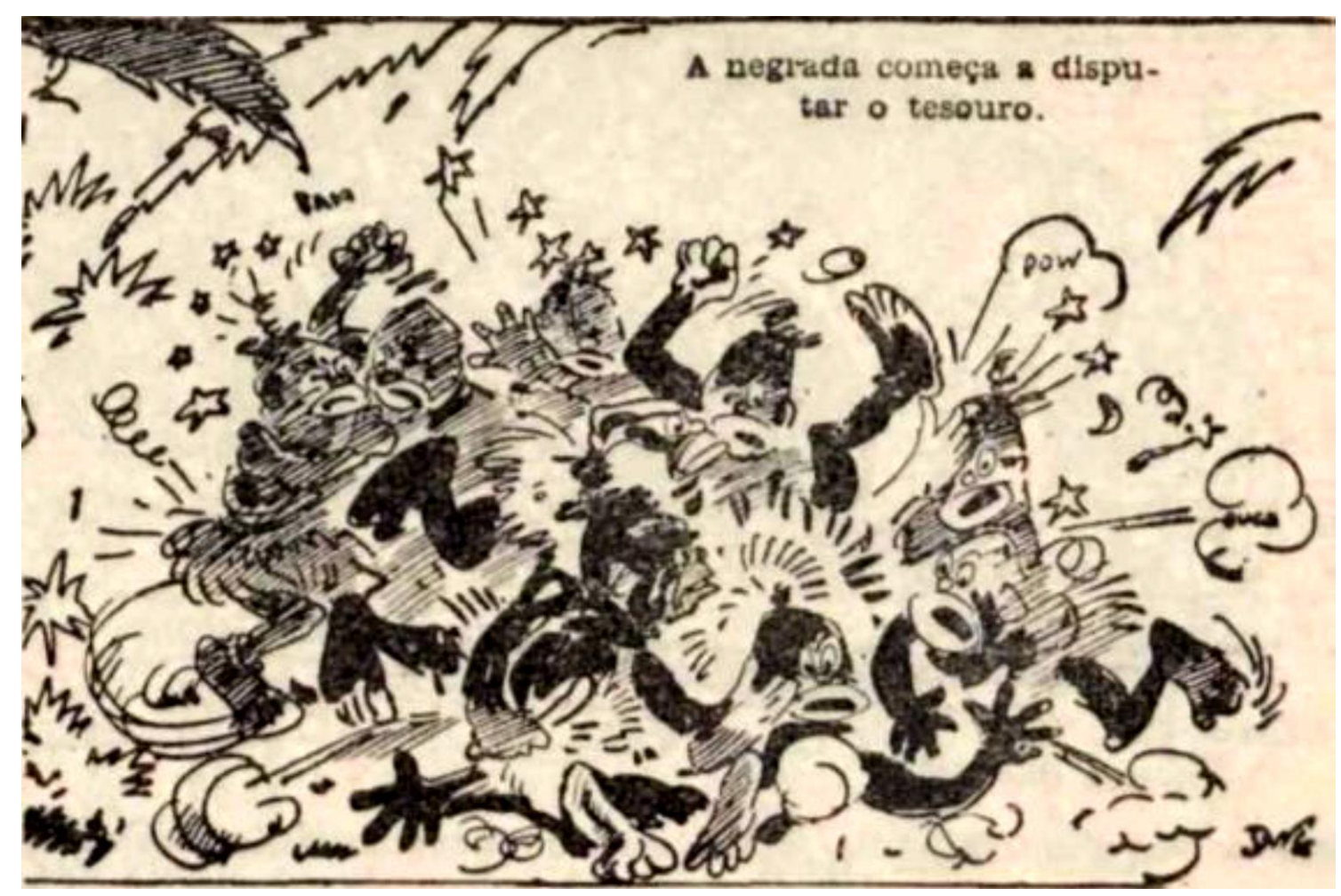

Figura 229 - Imagem "sem clareza" segundo o INEP em 1944cvii

A imagem é tão representativa da linguagem que, não por acaso, a capa do livro de Gonçalo Junior traz uma imagem similar, ainda mais minimalista e, ainda assim, seu sentido permaneça claro. 


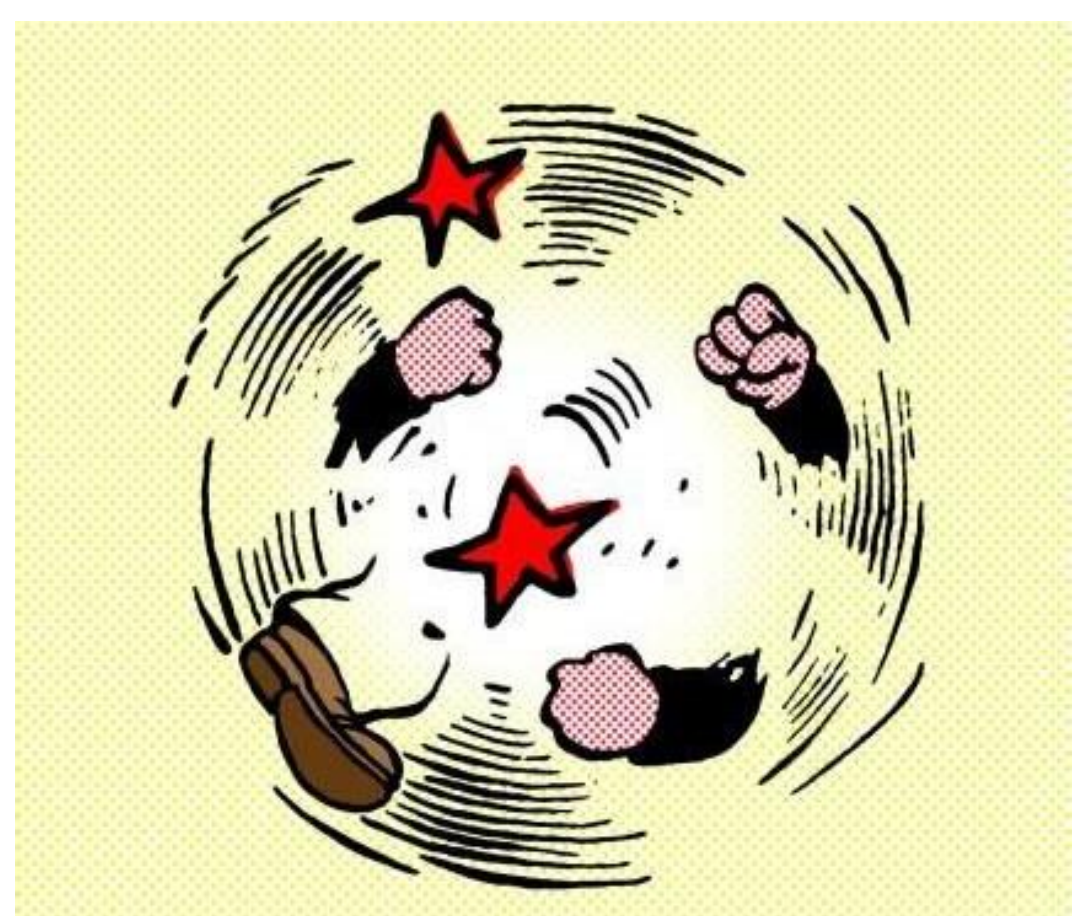

Figura 230 - Ilustração de Ettore Bottini para a capa do livro "A guerra dos gibis" de Gonçalo Junior, 2004cviii

As análises de quadrinhos sob a perspectiva pedagógica levou a uma série de pressupostos que culminaram em uma prerrogativa, conforme ressalta Vergueiro e Ramos, de que, para o governo,

quadrinhos constituíam uma ferramenta - mais atraente do que o livro tradicional por articular imagens e palavras, é certo, mas, ainda assim, ferramenta - que poderia levar os estudantes a outras formas de leitura (VERGUEIRO e RAMOS, 2015, p. 24).

O que começou a mudar a partir do edital de 2008, onde histórias em quadrinhos foram considerados um gênero de leitura, ao lado de poema, conto, crônica, romance, biografia, etc. (VERGUEIRO e RAMOS, 2015).

Um outro avanço apontado por Vergueiro e Ramos é a ruptura com o antigo estigma de que quadrinhos são leituras para crianças, já na lista de 2006 com as publicações maduras "Na Prisão" de Kazuichi Hanawa e "O nome do jogo" de Eisner (VERGUEIRO e RAMOS, 2015).

Vergueiro e Ramos, contudo, ressaltam que a $\mathrm{HQ}$ ainda se mantém, sob a perspectiva governamental como um gênero da literatura, o que impede de ser tabalhado em sua potencialidade, como uma manifestação independente (VERGUEIRO e RAMOS, 2015).

Em 2015, o pesquisador, crítico de arte e cartunista, Nick Sousanis, chamou a atenção do meio acadêmico ao publicar sua dissertação de pós doutorado em Educação na universidade de Columbia, Nova York, em quadrinhos. A obra 
"Unflattening” (no Brasil "Desaplanar" com tradução de Érico Assis) foi publicada pela Unversidade de Harvard apresentando uma investigação filosófica sobre o ser humano e as dimensões do aprendizado.

O formato da dissertação de Sousanis demonstrou a potencialidade da linguagem da $\mathrm{HQ}$ para transmição de outras áreas do saber além da literatura, nesse momento tornou-se evidente que a HQ não existe "apenas" para contar histórias, mas é possível integrar a solidariedade ícônica entre os elementos em uma grade para os mais diversos conteúdos e intencionalidades textuais. 


\section{CONSIDERAÇÕES FINAIS}

Ao longo da gênese, este estudo procurou apontar alguns pontos que sobressairam nos estudos levantados, como a importância de aproveitar a capacidade humana, adquirida desde os primórdios, de desenvolver a leitura do que está ausente, ou seja, extrapolar as marcas, rastros e pistas deixadas nas imagens para compor a história do que aconteceu antes. A História em Quadrinhos está centrada na imagem, é uma das vertentes de como a imagem é usada para comunicação de ideias e sentimentos.

Diferente das artes plásticas que seguiu uma trajetória fundamentalmente estética e conceitual, a imagem na $\mathrm{HQ}$ é o resultado da articulação do imaginário coletivo na cultura de massa. Dentre vários tipos de articulação, a narrativa imagética, grande expoente dos quadrinhos, teve várias manifestações em distantes partes do mundo com soluções e resultados ímpares, e quando uma forma quadrinística mais universal começou a se consolidar, as formas originais de cada cultura se converteram em influências contextuais que enriqueceram a manifestação.

A oposição aos quadrinhos começa com a oposição à imagem nos países de forte influência cristã, pela sacralidade do verbo em detrimento do paganismo da imagem. Nos países asiáticos esse preconceito não existe até a abertura para o ocidente, com novos conceitos educacionais, onde a canonidade da literatura passou a fazer oposição à vulgaridade popular dos quadrinhos e livros ilustrados, mas mesmo assim, a relação dos quadrinhos dentro da cultura oriental possui um espaço privilegiado e estruturado.

A $\mathrm{HQ}$ é indutiva e dedutiva, o primeiro porque $\mathrm{o}$ artista escolhe os elementos que ele acredita que o leitor conhece de forma a chamar a atenção do leitor, e o segundo porque o leitor deduzirá a mensagem com base em seu referencial, caso desconheça o assunto, seres ou objetos que compõe o quadrinho, a mensagem não será transmitida. Em geral, em suas primeiras manifestações, os artistas conseguiam induzir uma determinada mensagem, de sentido de certa forma inequivoco - mesmo que sincrônico - de forma rápida e na maior parte do tempo, de cunho político e transgressor. A principal temática, o humor - que se espalhou rapidamente pela nova mídia em nascimento: o jornal - custou a carreira aos politicos e libertade à seus artistas.

A grande amplitude da comunicação de massa tornou os quadrinhos um 
bem de consumo, um item de compra e venda, não só sua materialização, assim como um livro, uma tela de pintura ou uma escultura (que também são comercializados), mas também seu conteúdo. Seus personagens se tornaram uma mercadoria, uma ideia com um preço determinado, raptada de seus criadores comercializada por grandes editoras.

Através das histórias em quadrinhos regimes autoritários e repressivos tiveram tanta voz e espaço quanto ideologias revolucionárias. A $\mathrm{HQ}$ não é mais ou menos proprícia a determinada concepção ou conceito, ao bom ou ao mal, ela está inserida na intencionalidade humana de transmitir uma mensagem, não é sua linguagem ou suporte que determinam a moralidade ou não de seu conteúdo.

Estudar a origem dos quadrinhos permite que o olhar saia do objeto singular para o seu contexto e suas possibilidades. Sendo uma manifestação que agrega diversas influências e se hibridiza com as mais variadas formas de arte e comunicação, foi importante perceber que a tendência por determinado percurso de desenvolvimento não eliminou os outros, que seguiram em um paradigma independente, mas ainda assim ligado pela raiz em comum.

O conteúdo da $\mathrm{HQ}$ é ilimitado, mas percebe-se que para ser reconhecida como história em quadrinhos, é preciso que certas condições primárias sejam encontradas, as quais não são delimitações formais, posto que qualquer linguagem será colocada em tensão pelo artista, e sim aspectos construtivos básicos.

O primeiro aspecto é o olhar do artista sobre o mundo ao seu redor, analisando as formas que o compõe, chegando a sua concepção mais simples de representação, assim algumas linhas, pontos, traços, tons e ângulos são reunidos em uma forma singular para representar verrossimilhantemente outra coisa na transmissão de uma mensagem. Esse processo é a cartunização. A partir daí, a caricaturização é a tranformação do básico, do modelo universal em um objeto único e individual sem perder sua essência de representatividade, de causar no leitor uma identificação, uma aproximação.

Outro aspecto é a construção da mensagem pela junção das pistas que induzirão o leitor a acessar suas referências pessoais, em uma estrutura de relação entre os elementos, sejam figurativos, linguísticos ou metalinguísticos.

Verifica-se que o desenvolvimento da linguagem da $\mathrm{HQ}$ se aplica para obras que a princípio não parecem pertencer ao seu universo, como o livro ilustrado sem palavras e a fotonovela que se afastam da História em Quadrinhos mais por uma 
questão cultural do que estrutural. Contudo, como abordado no ínicio do estudo, o termo História em Quadrinhos é um nome insuficiente e restritivo que hoje não abarca o que a manifestação se tornou, sendo adotado, assim como suas contrapartes estrangeiras não literais, pela força do hábito de convenções culturais e mercadológicas.

A História em Quadrinhos é uma forma de comunicação que produz textos para serem lidos em diversos suportes, como já abordado, sua complexa linguagem trabalha como elemento fundamental: a imagem, seja em seu aspecto figurativo, simbólico ou linguístico. Sua operações semânticas se dão nas contruções de relações internas entre os seus ícones e externas com o referencial do leitor. O leitor é a quem se destina a mensagem de acordo com a intencionalidade, sendo o receptor dos mais variados conteúdos, como didáticos, entretenimento, religiosos ou políticos, contudo além da intencionalidade expressa há a intencionalidade contextual das mensagens não intencionais determinadas pelo tempo-espaço do quadrinista.

Este estudo introdutório versou sobre os aspectos mais distintivos da $\mathrm{HQ}$ visando a um olhar para os quadrinhos como manifestação independente, e não como um gênero da literatura ou das artes gráficas. 


\section{REFERÊNCIAS BIBLIOGRÁFICAS}

ABC NEWS. Donald Trump: Two huge murals by Australian artist Lushsux appear on West Bank barrier. ABC News, 2017. Disponivel em: <http://www.abc.net.au/news/2017-08-05/donald-trump-murals-by-lushsux-appearon-west-bank-barrier/8777794\#>. Acesso em: 19 Maio 2018.

ABELL, C. Comics and Genre. In: MESKIN, A. The art of comics: a philosophical approach. West Sussex, UK: Blackwell Publishing Ltd., 2012. p. 68-84.

AGOSTINI, A. As aventuras de Nhô-Quim \& Zé Caipora: os primeiros quadrinhos brasileiros 1869-1883/Angelo Agostini; pesquisa, organização e introdução Athos Eicher Cardoso. Brasília: Senado Federal, Conselho Editorial, 2002.

AKI. Olympus. Tóquio: Ichijinsha, v. 2, 2007.

ALANIZ, J. Komiks: Comic art in Russia. Jackson - Mississippi: University Press of Mississippi, 2010.

ALMEIDA, A. Ainda sem título. André Almeida Quadrinhos e llustrações, 2012. Disponível em: <https://andrehq.wordpress.com/2012/08/07/ainda-sem-titulo/>. Acesso em: 08 Abr. 2018.

ANDERSEN, S. Sarah's Scribbles. Tapas, 2017. Disponivel em: <https://tapas.io/series/Doodle-Time>. Acesso em: 18 Maio 2018.

ANDERSON, M. Teacher Cartoon \#6302. Andertoons, s/d. Disponivel em: <https://www.andertoons.com/teacher/cartoon/6302/just-your-name-would-be-fine>. Acesso em: 24 Maio 2018.

ANSELMO, Z. A. Histórias em quadrinhos. Petrópolis: Vozes, 1975.

ARISTÓSTELES. A arte poética. [S.I.]: [s.n.], 335 a.C. e 323 a.C. (Eudoro de Souza, 1993, pg.8). Disponivel em: $<$ http://www.dominiopublico.gov.br/pesquisa/DetalheObraForm.do?select_action=\&c o_obra=2235>. Acesso em: 13 Junho 2016.

ARROYO, L. Aparecimento de O Tico-Tico. In: ARROYO, L. Literatura Infantil Brasileira. São Paulo: Melhoramentos, 1990. p. 152.

ASIMOV, I. O Fim da eterninade. Tradução de Susana Alexandria. São Paulo: Aleph, 2007.

BAETENS, J. Le roman-photo: Images d'une histoire. Arabeschi, Catania - Sicília, p. 177-202, Dez. 2014.

BAUDRY, J. La bande dessinée entre dessin de presse et culture enfantine: relecture de l'oeuvre d'Alain Saint-Ogan (1895-1974). Thèse de doctorat en Langue, Littérature, Image: civilisation et sciences humaines - Université Paris Diderot. Paris, p. 515. 2014. (NNT : 2014PA070039).

BELTING, H. An anthropology of images. Tradução de Thomas Dunlap. Oxford: Princeton Unversity Press, 2011. 
BENTHAM, J. O Panóptico. Tradução de Guacira Lopes Louro; M. D. Magno e Tomaz Tadeu. Belo Horizonte: Autêntica Editora, 2008. (BENTHAM, 2008)

BERGER, P. L.; LUCKMANN, T. A construção social da realidade: tratado de sociologia do conhecimento. Tradução de Márcia Sá Cavalcante Schuback. Petrópolis: Vozes, 2005.

BLANCHARD, G. The origins of Stories in Images. In: MILLER, A.; BEATY, B. The French Comics Theory Reader. Leuven - Belgium: Leuven University Press, 2014. p. 25-38.

BOOKER, M. K. Comics through time: a history of icons, idols, and ideas. Santa Barbara, California: ABC-CLIO, LLC, v. I, 2014.

BOSCHI, L. Ancora sull'origine del termine "fumetto". Nova - Gruppo II Sole 24 ORE - Cartoonist globale, 2010. Disponível em: <http://lucaboschi.nova100.ilsole24ore.com/2010/06/29/ancora-sullorigine-deltermine-fumetto/?refresh_ce=1 >. Acesso em: 21 Abr. 2017.

BUSARELLO, R. Dicionário Básico Latino-português. Florianópolis: Editora da UFSC, 2007.

CAGNIN, L. A. Os Quadrinhos: um estudo abrangente da arte sequencial: linguagem e semiótica. São Paulo: Criativo, 2014.

CAMPOS, M. D. F. H. Nair de Teffé: artista do lápis e do riso. Curitiba: Appris, 2016.

CARDOSO, A. E. Nhô Quim e Zé Caipora. In: AGOSTINI, A. As aventuras de Nhô Quim e Zé Caipora: os primeiros quadrinhos brasileiros 1869-1883. Brasília: Senado Federal, Conselho Editorial, 2002. p. 19-20.

CHAPMAN, J. British Comics: A Cultural History. London: Reaktion Books Ltd, 2011.

CHATFIELD, J. On Comic Strips, Commercialism and Selling out as an Artist. The Coffeelicius, 2015. Disponivel em: <https://thecoffeelicious.com/on-comic-stripscommercialism-and-selling-out-as-an-artist-c28e08bfea7c>. Acesso em: 18 Maio 2018.

CHINEN, N. Aprenda e faça arte sequencial: linguagem $\mathrm{HQ}$ : conceitos básicos. São Paulo: Criativo, 2011.

$\mathrm{CHO}, \mathrm{H}$. The Webtoon: A New Form for Graphic Narrative. The Comics Journal, 2016. Disponível em: <http://www.tcj.com/the-webtoon-a-new-form-for-graphic-narrative/>. Acesso em: 02 Abr. 2018.

CIRNE, M. D. C. Para ler os quadrinhos: da narrativa cinematográfica a narrativa quadrinizada. 2‥ ed. Petrópolis: Vozes, 1975.

CLAYTON, E. C. English Female Artists. Londres: Tinsley Brothers, 1876.

CMPPM. Glossário - Imago. Centro de Medicina Psicossomática e Psicologia Médica, $2017 . \quad$ Disponível em: <http://www.medicinapsicossomatica.com.br/glossario/imago.htm>. Acesso em: 03 
nov. 2017.

CRUMB, R. Mr Natural's 719th meditation. Modern comics, 1970. Disponivel em: <https://en.wikipedia.org/wiki/Mr._Natural_(comics)>. Acesso em: 17 maio 2018.

CUCCI NETO, J. Engenharia de tráfego urbano. Departamento de engenharia civil da Universidade Presbiteriano Mackenszie, 2018. Disponível em: <http://meusite.mackenzie.br/professor_cucci/cartuns.htm>. Acesso em: 05 Mar. 2018.

DC - NATIONAL COMICS. Star Jockey. All American Men of War, Nova York, p. 1123, Fevereiro 1962.

DEBATE Noam Chomsky \& Michel Foucault - On human nature. Apresentação e comentários: Prof. L. W. Nauta. Intérpretes: Noam Chomsky e Michel Foucault.: Dutch National Television. 1971.

DEXTER, K. Japanese Onomatopoeia: The Definitive Guide. Tofugu, 2015. Disponível em: <https://www.tofugu.com/japanese/japanese-onomatopoeia/>. Acesso em: 16 Mai. 2018.

DIAS, J. A. F. Saberes - Imagem - Dicionário Crítico - Imago / Máscara. Fundação Coa Parque, 2017. Disponível em: <http://www.artecoa.pt/index.php? Language=pt\&Page=Saberes\&SubPage=ComunicacaoELinguage mlmagem\&Filtro=38\&Menu2=Imagem\&Slide=38> . Acesso em: 02 Nov. 2017.

EISNER, W. A vota do Ébano. Gibi Especial, Rio de Janeiro , v. 4, n. 1aㅗ p. 32-38, Agosto 1975.

Quadrinhos e arte sequencial: princípio e práticas do lendário cartunista. Tradução de Luis Carlos Borges. São Paulo: WMF Martins Fontes, 2010.

. Narrativas Gráficas de Will Eisner / escrito e ilustrado pelo autor. Tradução de Leandro Luigi Del Manto. São Paulo: Devir, 2013.

ELLIS, W. Foreword. In: MESKIN, A.; COOK, R. T. The art of comics: a philosophical approach. Sussex, UK: Blackwell Publishing Ltd., 2012. p. 12-13.

FERRARA, L. D. Leitura sem palavras. São Paulo: Ática, 1986.

FERREIRA, A. B. D. H. Miniaurélio: o minidicionário da língua portuguesa. 6ํ․ ed. Curitiba: Positivo, 2004.

FOUCAULT, M. O olho do poder. In: FOCAULT, M. Microfísica do poder. Tradução de Roberto Machado. Rio de Janeiro: Edições Graal, 1979. p. 209-227.

FURTADO, A. Definindo a mancha gráfica. Design Edioria Wiki, 2009. Disponível em: <http://pt-br.designeditorial.wikia.com/wiki/Margens>. Acesso em: 03 Mar. 2018.

GABILLIET, J.-P. Of comics and men: a cultural history of American comic books. Tradução de Bart Beaty e Nick Nguyen. Jackson - Mississipi: University Press of Mississippi, 2010.

GAIMAN, N. Sandman FAQs. Neil Gaiman, 2018. Disponível em: <http://www.neilgaiman.com/FAQs/Sandman>. Acesso em: 18 Mar. 2018. 
GARCIA, S. A novela gráfica. São Paulo: Martins Fontes, 2012.

GLASSER, J.-C. The Origin of the Term 'Bande Dessinée' (1988). In: MILLER, A.; BEATY, B. The French Comics Theory Reader. Leuven, Belgium: Leuven University Press, 2014. Cap. 1, p. 21-25.

GONÇALO JUNIOR. A guerra dos gibis: a formação do mercado editoria brasileiro e a censura aos quadrinhos, 1933-64. São Paulo: Companhia das Letras, 2004. ISBN 85-359-0582-0.

GORDON, I. Comic scrips and consumer culture, 1890-1945. Washington and London: Smithsonian Institution, 1998.

GORDON, I. Histórias em Quadrinhos, Cinema e Televisão: das Tiras em Jornal às Grandes Produções Cinematográficas e Seriados Televisivos (Escola de Comunicações e Artes - Universidade de São Paulo). Universidade de São Paulo. São Paulo, aula Ago. 2015.

GRAAF, R. Introducion Comunication Science - What is Communication? Coursera, $2016 . \quad$ Disponível em: <https://www.coursera.org/learn/communication/home/welcome>. Acesso em: 24 Nov. 2016.

GREGÓRIO, S. B. Termos Filosóficos Gregos. Dicionário de Filosofia, 2017. Disponível em: <https://sites.google.com/view/sbgdicionariodefilosofia/termosfilos\%C3\%B3ficos-gregos>. Acesso em: 28 Nov. 2017.

GRIMM, J.; GRIMM, W. Chapeuzinho Vermelho. In: TATAR, M. Contos de fadas. Tradução de Maria Luiza X. de A. Broges. Rio de Janeiro: Zahar, 2013. p. 36-43

GROENSTEEN, T. Why are Comics Still in Search of Cultural Legitimization. Copenhagen: Museum Tusculanum Press, 2004. p. 29-42.

of Mississipi, 2011.

Comics and Narration. Tradução de Ann Miller. Jackson: University Press Definitions (2012). In: MILLER, A.; BEATY, B. The French ComicsTheory Reader. Leuven (Belgium): Leuven University Press, 2014. p. 93-114.

O sistema dos quadrinhos. Tradução de Érico Assis. Rio de Janeiro: Marsupial, 2015.

GROPPER, C. A short biography. Will Eisner Studios, Inc., 2018. Disponível em: $<$ http://www.willeisner.com/biography/index.html>. Acesso em: 08 Jan. 2018.

GUSMAN, S. Mauricio quadrinho a quadrinho. São Paulo: Globo, 2006.

HANKONEN, M. About. Year in Hereafter - comic, 2016. Disponível em: <http://www.yihcomic.com/about.php>. Acesso em: 02 Abr. 2018.

HAWKING, S. W. Uma breve história do tempo: do Big Bang aos buracos negros. Tradução de Maria Helena Torres. Rio de Janeiro: Rocco, 1988.

HERGÉ. Tintin na África. Tradução de Distribuidora Record de Serviços de Imprensa. Rio de Janeiro: Record, 1970. 
HOAGLIND, L. Protest Art in 1950s Japan: The Forgotten Reportage Painters. MIT Visualizing Cultures, 2012. Disponível em: <https://ocw.mit.edu/ans7870/21f/21f.027/protest_art_50s_japan/anp1_essay01.html >. Acesso em: 14 Fev. 2018.

HÖLLMANN, T. O. Chinese script: history, characters, calligraphy. Tradução de Maximiliane Donicht. New York: Columbia University Press, 2017.

HOUAISS, A.; VILAR, M. D. S. Dicionário Houaiss da língua portuguesa. Rio de Janeiro: Objetiva, 2009.

INEP. Revista Brasileira de Estudos Pedagógicos. Brasilia: Imprensa Nacional, 1944.

IVES, C. F.; STUFFMANN, M.; SONNABEND, M. Daumier Drawings. New York: THE METROPOLITAN MUSEUM OF ART, 1992.

KUNZLE, D. Goethe and Caricature: from Hogarth to Töpffer. Journal of the Warburg and Courtauld Institutes, Londres, V. 48, 1985. 164-188. Disponivel em: <http://www.jstor.org/stable/751215 >.

Marie Duval: A Caricaturist Rediscovered. JSTOR, Nova York, 1986. Disponível em: <http://www.jstor.org/stable/1358233>. Acesso em: 03 Fevereiro 2018. Mississipi, 2015.

Gustave Doré: twelve comic strips. Mississipi: University Press of KUSKIN, W. Comic Books and Graphic Novels. Coursera, Universidade do Colorado em Boulder, 07 Julho a 24 de Novembro 2014. Disponível em: $<$ https://www.coursera.org/>. Acesso em: 06 Set. 2014.

LACASSIN, F. Dictionary Definition (1971). In: MILLER, A.; BEATY, B. The French Comics Theory Reader. Leuven - Belgium: Leuven University Press, 2014. p. 39-46.

LAMBECK, P. Max and Moritz: How Germany's naughtiest boys rose to global fame. DW- Made for Minds, 2015. Disponível em: <http://www.dw.com/en/max-and-moritzhow-germanys-naughtiest-boys-rose-to-global-fame/a-18808584>. Acesso em: 1 Fev. 2018.

LANGLEY, T. Batman and psychology: a dark and stormy knight. Hoboken, New Jersey: John Wiley \& Sons, Inc., 2012.

LATRONICO, V.; GAMBINERI, G. Perché usiamo Internet da ubriachi. Idee e Lifestyle del Sole 24 ORE. Disponivel em: <http://24ilmagazine.ilsole24ore.com/2016/02/meglio-la-cybersecurity-dellacyberfobia/?refresh_ce=1>. Acesso em: 13 Maio 2018.

LAZARETTI, B. O que é a teoria do gato de Schrödinger? Mundo Estranho, 2017. Disponivel em: <https://mundoestranho.abril.com.br/cultura/o-que-e-a-teoria-do-gatode-schrodinger/>. Acesso em: 17 Maio 2018.

LEITAO, R. G. C. O "Som" do Silêncio: traduções/adaptações de onomatopeias e mimésis japonesas nos mangás traduzidos para a língua portuguesa. (Dissertação de mestrado). Universidade de São Paulo. São Paulo, p. 193. 2012. 
LINDEN, S. V. D. Para ler o livro ilustrado. Tradução de Dorothée de Bruchard. São Paulo: Cosac Naify, 2014.

LOUVRE. Exhibition - The Louvre invites the comics. Louvre, 2009. Disponivel em: <https://www.louvre.fr/en/expositions/louvre-invites-comics>. Acesso em: 01 Mar. 2018.

LUYTEN, S. M. B. L. Um depoimento sobre Antonio Luiz Cagnin: alino, docente, amigo e grande pesquisador. In: CAGNIN, A. L. Os quadrinhos: um estudo da arte sequencial: linguagem e semiótica. 1a. ed. São Paulo: Criativo, 2014. p. 20-23.

MAGNUSSEN, A.; CHRISTIANSEN, H.-C. Comics Culture - Analitycal and Theorical Aproaches to Comics. Copenhagen: Museum Tusculanum Press, 2000.

MANETTI, F. G. Fascismo, fumetto e cartone animato: Mussolini e Disney. EreticaMente, 2014. Disponível em: <http://www.ereticamente.net/2014/11/fascismofumetto-e-cartone-animato-mussolini-e-disney.html>. Acesso em: 10 jun. 2017.

MANGA!. Intérpretes: Jonathan ROSS. [S.I.]: British Broadcasting Corporation (BBC). 1994.

MAYOR, A. H. Prints \& People - a social history of printed pictures. Nova York: The Metropolitan Museum of Art, 1972.

MAZUR, D.; DANNER, A. Quadrinhos - História moderna de uma arte global - de 1968 até os dias de hoje. Tradução de Marilena Moraes. São Paulo: WMF Martins Fontes Ltda., 2014.

MCCARTHY, H. A Brief History of Manga: The Essential Pocket Guide to Japanese Pop Culture. Lewes, United Kingdom: llex - Octopus Publishing Group, 2014.

MCCLOUD, S. Desvendando os quadrinhos. Tradução de Marisa do Nacimento Paro Helcio de Carvalho. São Paulo: Makron Books, 1995.

. Desenhando quadrinhos. Tradução de Roger Maioli dos Santos. $1^{1}$. ed. São Paulo: M. Books do Brasil, 2008.

MEDEIROS, M. Imagem - Dicionário Crítico - Imagem. Fundação Côa Parque, 2017. Disponível em: <http://www.artecoa.pt/index.php? Language $=$ pt\&Page $=$ Saberes $\&$ SubPage $=$ ComunicacaoELinguage mlmagem>. Acesso em: 02 Nov. 2017.

MELO, J. M. D. Da Gibimania à Quadrinhologia. In: VERGUEIRO, W.; RAMOS, P.; CHINEN, N. Os pioneiros de estudos de quadrinhos no Brasil. São Paulo: Criativo, 2013. p. $12-27$.

MERLO, M. C. O TICO-TICO UM MARCO NAS HISTÓRIAS EM QUADRINHOS NO BRASIL (1905-1962). II Encontro Nacional da Rede Alfredo de Carvalho, Florianópolis, 15 a 17 Abr. 2004.

MESKIN, A.; COOK, R. T. The Art of Comics: A Philosophical Approach. Chichester - West Sussex: Blackwell Publishing Ltd., 2012. 
MILLER, A.; BEATY, B. The French Comics Theory Reader. Leuven, Belgium: Leuven University Press, 2014.

MOLITERNO, G. Comics. In: MOLITERNO, G. Encyclopedia of Contemporary Italian Culture. London: Routledge, 2000. p. 177-179.

MOON, F. As nossas letras. Blog do Fábio moon e Grabiel Bá - Quadrinhistas, contadores de histórias, brasileiros, 2015. Disponível em: <http://10paezinhos.blog.uol.com.br/arch2015-02-01_2015-02-28.html>. Acesso em: 27 Ago. 2016.

MOORE, A.; GIBBONS, D. Watchmen. Tradução de Estúdio Criarte. São Paulo: Abril, v. 1, 1988.

MOYA, Á. D. História da História em Quadrinhos. Porto Alegre: L \& PM Editores S/A, 1986.

Pioneiro dos quadrinhos brasileiros, como desenhista e pesquisador. In: VERGUEIRO, W. \&. O. Os Pioneiros no Estudo de Quadrinhos no Brasil. São Paulo: Criativo, 2013.

NATSUME, F. Japanese Manga: Its Expression and Popularity. ACCU - Asia Cultural Centre for Unesco, 2003. Disponível em: <http://www.accu.or.jp/appreb/09/pdf34-1/34-1P003-005.pdf>. Acesso em: 16 janeiro 2018.

NERY, L. M. A. Caricatura: microcosmo da questão da arte na modernidade. PUC - Pontifícia Universidade Católica do Rio de Janeiro. Rio de Janeiro, p. 233. 2006.

NIKOLAJEVA, M.; SCOTT, C. Livro ilustrado: Palavras e imagens. Tradução de Cid Knipel. São Paulo: Cosac Naify, 2011.

NOAK, D.; NOAK, L. Le Charivari. DAUMIER'S LIFE AND WORK, 2017. Disponível em: <http://www.daumier.org/57.0.html>. Acesso em: 25 Janeiro 2018.

OPERA MUNDI. Acusada de racismo, $\mathrm{HQ}$ 'Tintim na África' vai a julgamento na Bélgica. Opera Mundi, 2011.2 Disponivel em: <http://operamundi.uol.com.br/conteudo/noticias/15596/acusada+de+racismo+hq+\% $26 \% 2339$ tintim+na+africa $\% 26 \% 2339+v a i+a+j u l g a m e n t o+n a+b e l g i c a . s h t m l>$. Acesso em: 20 Maio 2018.

ORMEROD, J. Sunshine. Harmondsworth, Middlesex: Pemguin Books Ltd., 1983.

OSSINO, A. MEZZATINTA. L' angolo dell' ARTE, 2017. Disponível em: <http://angoloarte.altervista.org/MEZZATINTA.htm>. Acesso em: 03 Jun. 2017.

PEETERS, B. Reading Tintin: The Stolen Jewels. In: MILLER, A.; BEATY, B. The French Comics Theory Reader. Leuven (Belgium): Leuven University Press, 2014. p. 251-262.

PETERSEN, R. S. Comics, Manga, and Graphic Novels: A History of Graphic Narratives. ebook kindle. ed. Santa Barbara, California: Praeger, 2010.

PIÇARRA, S. Cartoon. Youtube - TEDxLuanda, 2016. Disponivel em: 
<https://www.youtube.com/watch?v=YY14ofdh5MY>. Acesso em: 24 Maio 2018.

Cartoon da semana: Recado do povo. Novo jornal, 2017. Disponivel em: $<$ http://novojornal.co.ao/cartoon/interior/cartoon-da-semana-recado-do-povo44098.html>. Acesso em: 24 Maio 2018.

PUNCH EDITORIAL. History of Punch. Punch, 2018. Disponível em: <https://www.punch.co.uk/about/index>. Acesso em: 28 Jan. 2018.

RAMIREZ, J. A. A novela gráfica e a arte adulta. In: GARCIA, S. A novela Gráfica. Tradução de Magda Lopes. São Paulo: Martins Fontes, 2012. p. 9-11.

RAMOS, P. A leitura dos quadrinhos. São Paulo: Contexto, 2010.

ROSE, C. The Power of the Pear: When Caricature Met Poster Art. The Comics journal, 2016. Disponivel em: <http://www.tcj.com/the-power-of-the-pear-whencaricature-met-poster-art/>. Acesso em: 17 Maio 2018.

SANDREANI, E. A mezzanotte nel parco. Katrin, Roma, p. 5-62, Novembro 1978.

SARADEEK. Vermelho. Webtoon, 2018. Disponivel em: $<$ https://www.webtoons.com/en/challenge/vermelho-bl/episode-1-applepie/viewer?title_no=171841\&episode_no=2>. Acesso em: 19 Maio 2018.

SAUSSURE, F. D. Curso de Linguistica Geral. Tradução de Antonio Chelini; José Paulo Paes e Izidoro Blikstein. São Paulo: Cultrix, 2006.

SCHEDDEBOOM, B.; KNUDDE, K. Peter Beekman. Lambiek Comiclopedia, 19942017. Disponível em: <https://www.lambiek.net/aanvang/beekman_peter.htm>. Acesso em: 06 Jul. 2017.

. Comics History: Dutch Comics after WW II. Lambiek Comiclopedia, 19942018. Disponível em: <https://www.lambiek.net/dutchcomics/1945.htm>. Acesso em: 13 Fevereiro 2018.

. Comics History: Dutch Comics around WW II. Lambiek Comiclopedia, 19942018. Disponível em: <https://www.lambiek.net/dutchcomics/1940.htm>. Acesso em: 12 Fev. 2018.

. Comic History: Early Dutch Comics. Lambiek Comiclopedia, 1994-2017. Disponível em: <https://www.lambiek.net/dutchcomics/1800.htm>. Acesso em: 01 Jul. 2017.

SERGI, J. Tales From the Code: The Christmas Panic. Comic Book Legal Defense Fund, 2013. Disponível em: <http://cbldf.org/2013/12/tales-from-the-code-thechristmas-panic/>. Acesso em: 13 Fev. 2018.

SHAMOON, D. Films on Paper: Cinematic Narrative in Gekiga. In: PEPER, T.; CORNOG, M. Mangatopia - Essays on Manga and Anime in the Modern World. Santa Barbara, California: ABC-CLIO, LLC, 2011. p. 21-36.

SHIPPER, N. Erich Ohser (e.o.plauen) e o espírito do seu tempo. In: PLAUEN, E. O. Pai e filho. São Paulo: Octavo Ltda., 2015. Cap. Apresentação, p. 7-10.

SHIWASU, Y. Takane to Hana. Tóquio: Hakusensha, 2015. 
SIMKIN, J. Punch Magazine. Spartacus Educational, 2014. Disponível em: $<$ http://spartacus-educational.com/Jpunch.htm>. Acesso em: 27 jan. 2018.

SMOLDEREN, T. The Origins of Comics - from William Hogarth to Winsor McCay. Tradução de Bart Beaty e Nick Nguyen. Jackson: University Press of Mississipi, 2014.

SOOKE, A. Is Lichtenstein a great modern artist or a copy cat? BBC Culture, 2014. Disponível em: <http://www.bbc.com/culture/story/20130717-pop-artist-or-copy-cat>. Acesso em: 26 Fev. 2018.

SOUSANIS, N. Unflatening. Cambridge, Massachusetts: Harvard University Press, 2015.

TASOVAC, T. O mau, o errado e o feio em Wilhelm Busch. DW Made for Minds, 2007. Disponível em: <http://www.dw.com/pt-br/o-mau-o-errado-e-o-feio-em-wilhelmbusch/a-2462464>. Acesso em: 01 Fev. 2018.

TATAR, M. Contos de Fadas - edição comentada e ilustrada. Tradução de Maria Luiza Xavier de Almeida Borges. Rio de Janeiro: Zahar, 2013.

TEIXEIRA, J. O DNA das idéias. Revista Superinterresante, 2003. Disponível em: <https://super.abril.com.br/ciencia/o-dna-das-ideias/>. Acesso em: 25 Mar. 2018.

THE BROTHERS DAZIEL. A Record of fifty years of work - 1840 - 1890. Londres: METHUEN AND CO., 1901.

THOMPSON, C. Habib. Tradução de Érico Assis. São Paulo: Schwarcz, 2015.

THOMSON GALE - ENCYCLOPEDIA.COM. Genteel Tradition. American History Through Literature 1870-1920, 2006. Disponível em: $<$ http://www.encyclopedia.com/history/culture-magazines/genteel-tradition>. Acesso em: 24 Jan. 2018.

TISSERAND, M. Krazy - George Herriman, a life in black and white. Nova York: HarperCollins Publishers Inc., 2016.

TOBOSO, Y. Kuroshitsuji. Tóquio: Square Enix CO, v. XVII, 2013.

. Kuroshitsuji. Tradução de 尤靜慧 - Jinghui You. Taiwan: Tong Li Publications, v. XVII, 2013.

. Black Butler - Kuroshitsuji. Tradução de Tomo Kimura. Nova York: Yen Press - Hachette Group Book, v. XVII, 2014.

Black Butler - Kuroshitsuji. Tradução de Dirce Miyamura. São Paulo: Panini, V. XVII, 2015.

TÖPFFER, R. Mousieur Jabot. Tradução de Flavia Lago. São Paulo: SESI-SP, 2017.

TSUBAKI, T. Gekkan Shōjo Nozaki-kun. Tóquio: Square Enix, 2011.

UCHA, F. Álvaro de Moya e os 60 anos da exposição de 1951. Um blog! em quadrinhos, $2011 . \quad$ Disponível em: <https://quadrinhos.wordpress.com/category/comics-quadrinhos/desenhistas/alvarode-moya/>. Acesso em: 20 Ago. 2016. 
VERGUEIRO, W. O legado de Will Eisner. Omelete, 2005. Disponível em: $<$ https://omelete.uol.com.br/quadrinhos/artigo/o-legado-de-will-eisner/>. Acesso em: 08 Jan. 2018.

. "O Tico-Tico" a primeira revista brasileira a publicar histórias em quadrinhos. In: VERGUEIRO, W. Panorama das histórias em quadrinhos no Brasil. São Paulo: Editora Peirópolis LTDA, 2017. p. 31-40.

.; RAMOS, P. Quadrinhos na educação: da rejeição à prática. São Paulo: Contexto, 2015.

.; RAMOS, P.; CHINEN, N. Os Pioneiros no Estudo de Quadrinhos no Brasil. São Paulo: Criativo, 2013. ISBN 978-85-8258-034-9.

VESTAL, A.; MARAGOS, N. Interview with Neil Gaiman. Gaming Intelligence Agency, 1999. Disponível em: <http://thegia.com/archive/features/f991026.html>. Acesso em: 03 Set. 2016.

VRIELINK, J. Effort to ban Tintin comic book fails in Belgium. The Guardian, 2012. Disponivel em: <https://www.theguardian.com/law/2012/may/14/effort-ban-tintincongo-fails>. Acesso em: 21 Maio 2018.

WILLIANS, N. K. The key to kanji: a visual history of 1100 characters = kanji etoki. Boston: Cheng \& Tsui Company, Inc., 2010.

WILLMANN, A. Japanese Illustrated Handscrolls. In Heilbrunn Timeline of Art History, 2002. Disponível em: <http://www.metmuseum.org/toah/hd/jilh/hd_jilh.htm>. Acesso em: 19 Jan. 2018.

WITEK, J. The Arrow and the Grid. In: HEER, J.; WORCESTER, K. A comics studies reader. Mississipi: University Press of Mississippi, 2009. p. 149-156.

WORDSWORTH, W. Illustrated books and newspapers. In: WORDSWORTH, W. Delphi Complete Works of William Wordsworth (Illustrated) e-book. Hastings, East Sussex: Delphi Classics, 2013.

ZAN, M. Busch, Heinrich Christian. In: BOOKER, M. K. Comics through time: a history of icons, idols, and ideas. Santa Barbara, California: ABC-CLIO, LLC, 2014. p. 48-50.

Z-PICO. The Boy and the Wolf. Tapas, 2016. Disponível em: <https://tapas.io/episode/500166>. Acesso em: 06 Abr. 2018 


\section{ANEXOS}

Anexo 1 - American Men of War - número 89 - 1962 - página 21 cix
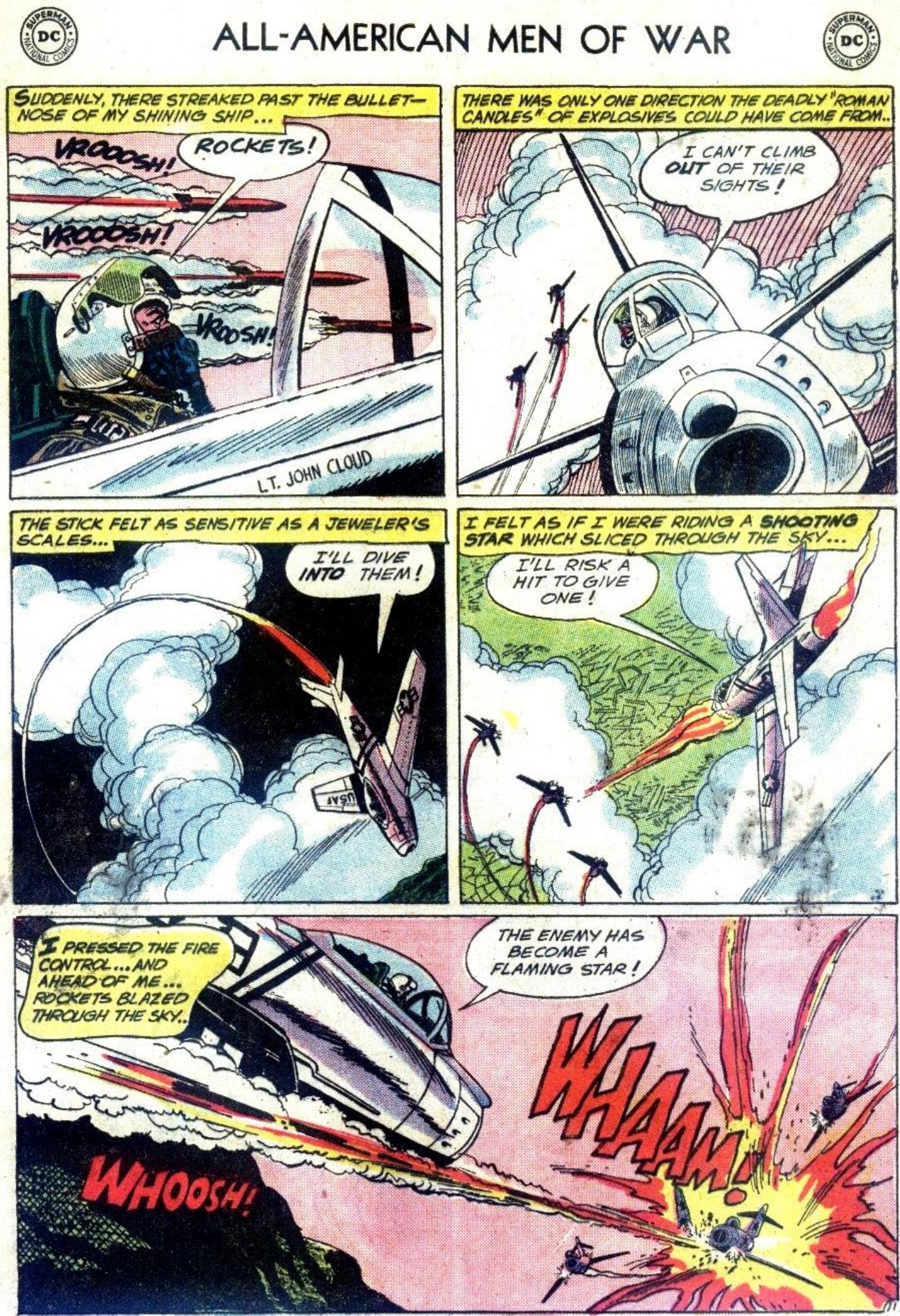
Anexo 2 - World's Finest Comics, número 153, DC Comics, página 5
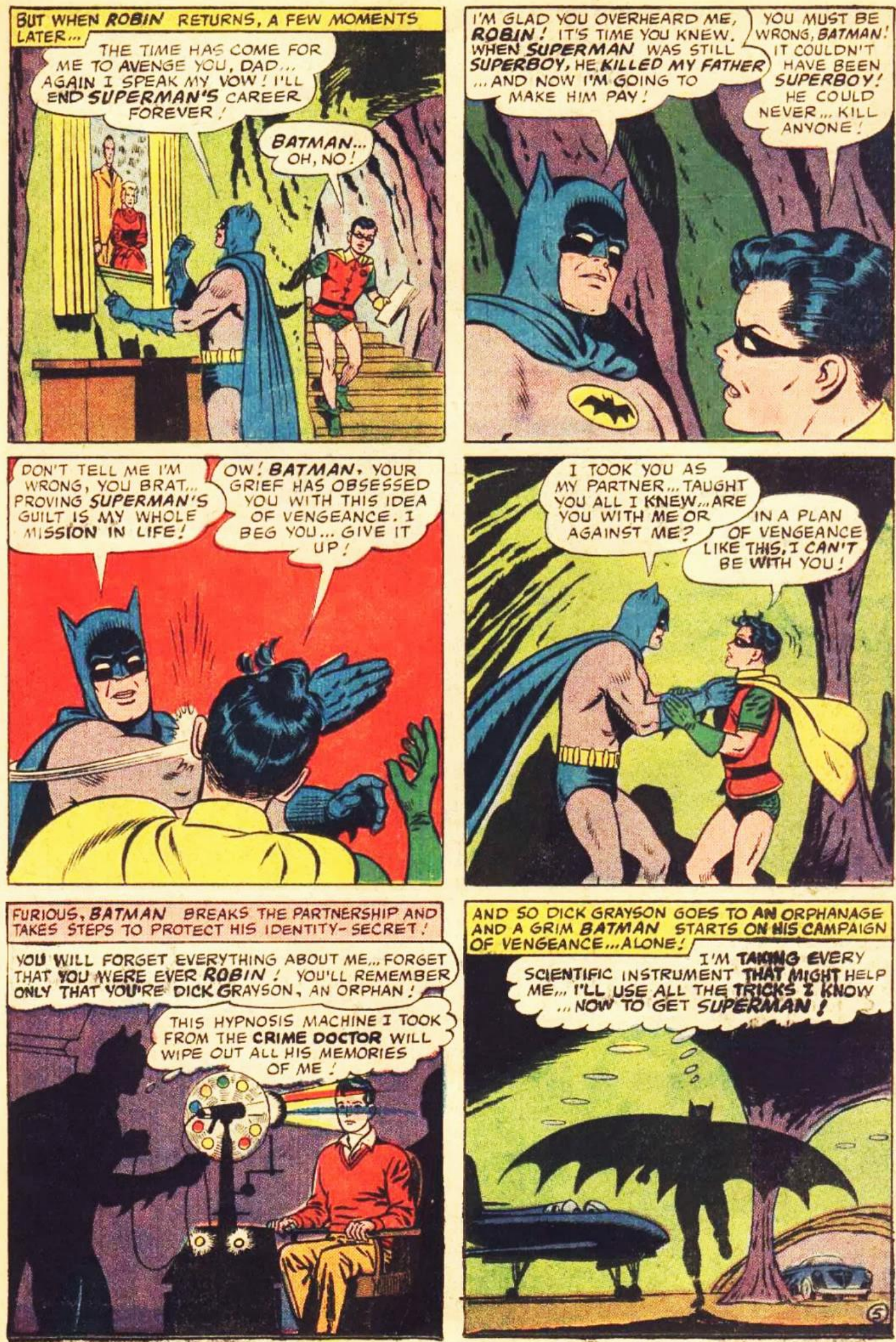
Anexo 3 - Milo Manara - Erotic Tarot ${ }^{\mathrm{cx}}$ e ilustração litográfica ${ }^{\mathrm{cx}}$
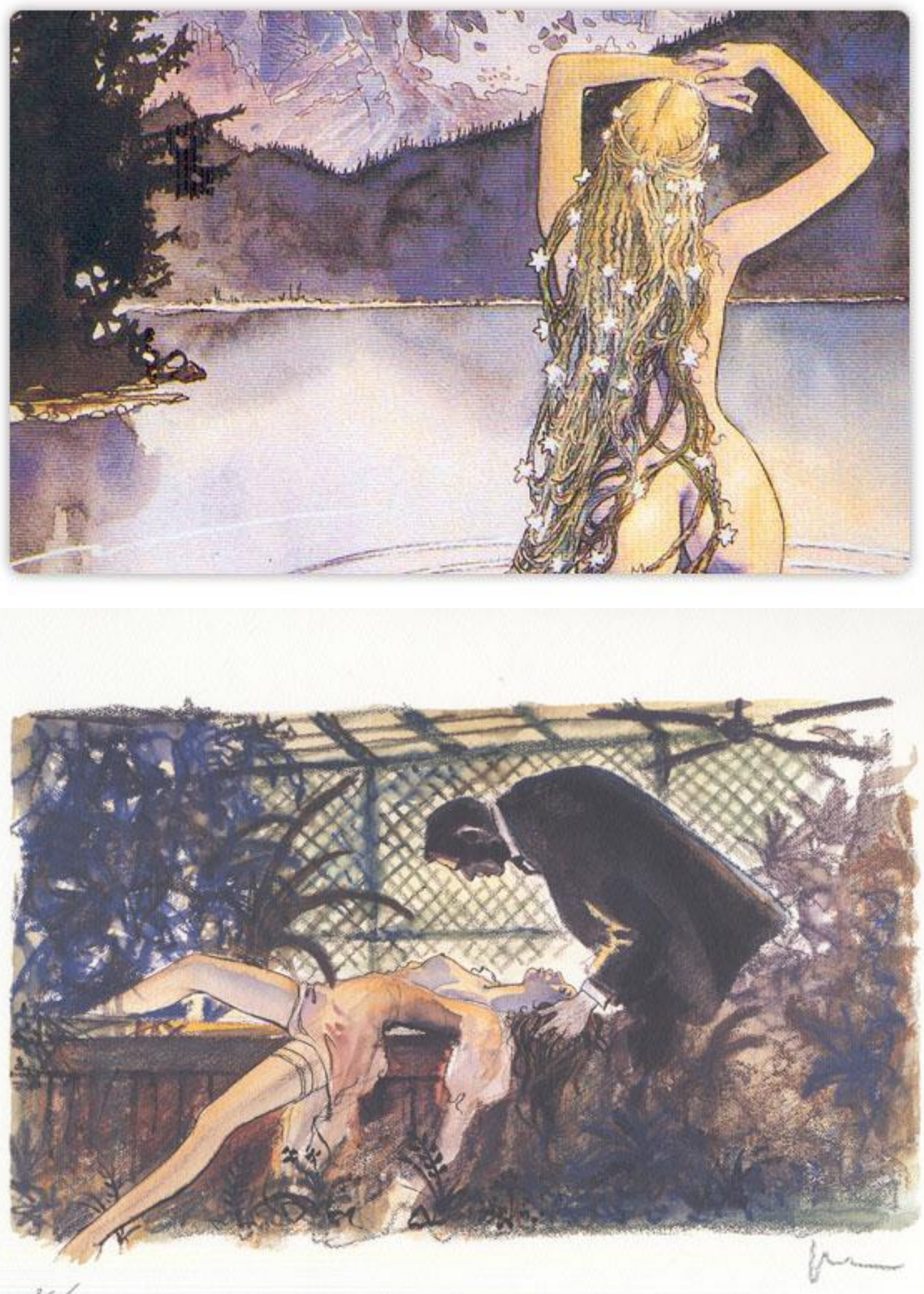

$34 / 200$ 
Anexo 4 - Bianco, nero e grigio: l'unicità dello stile di Dino Battaglia.cxii

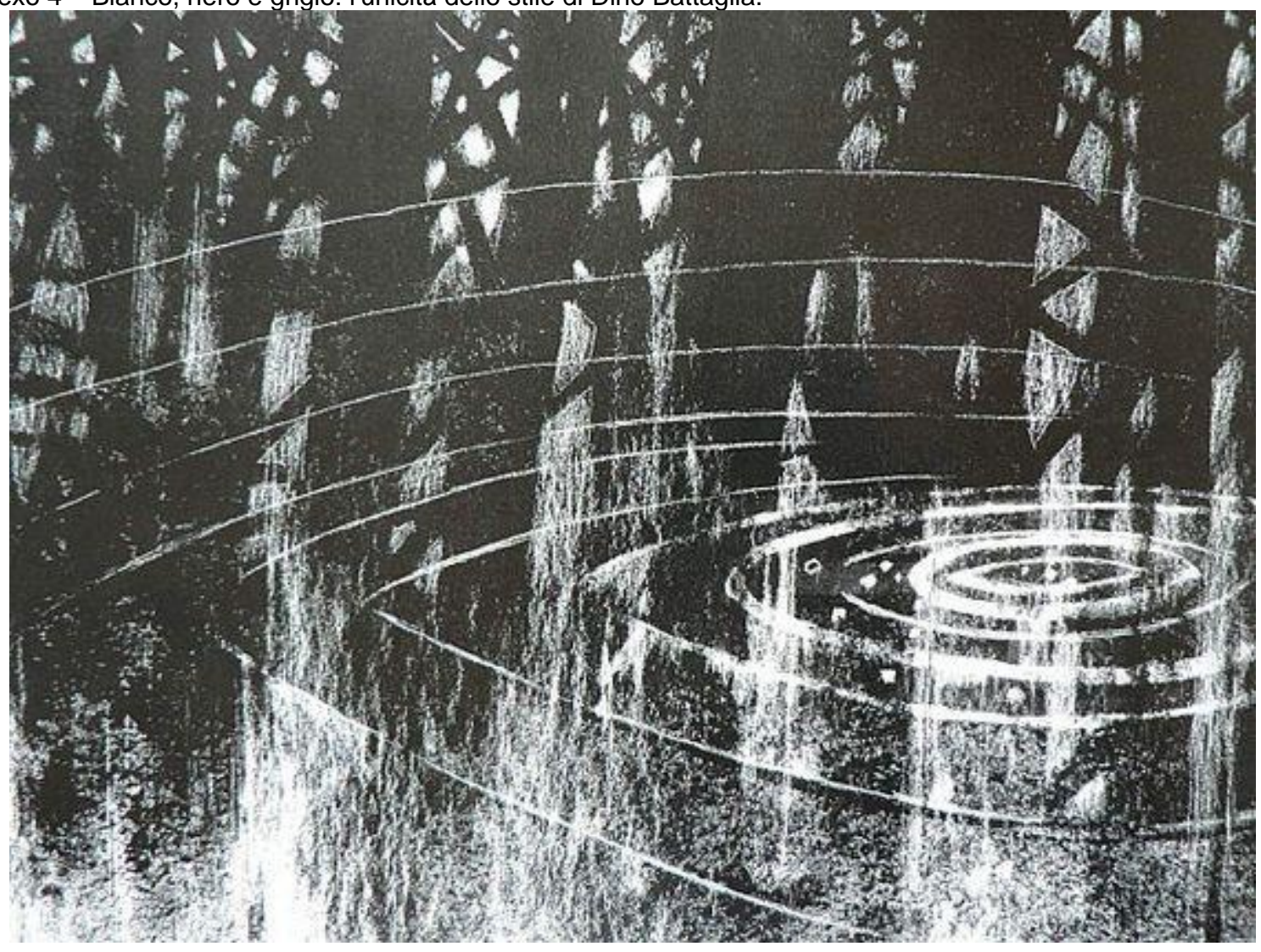


Anexo 5 - Ilustração de Dino Bataglia para "IL RACCONTO" de Italo Calvinocxiii

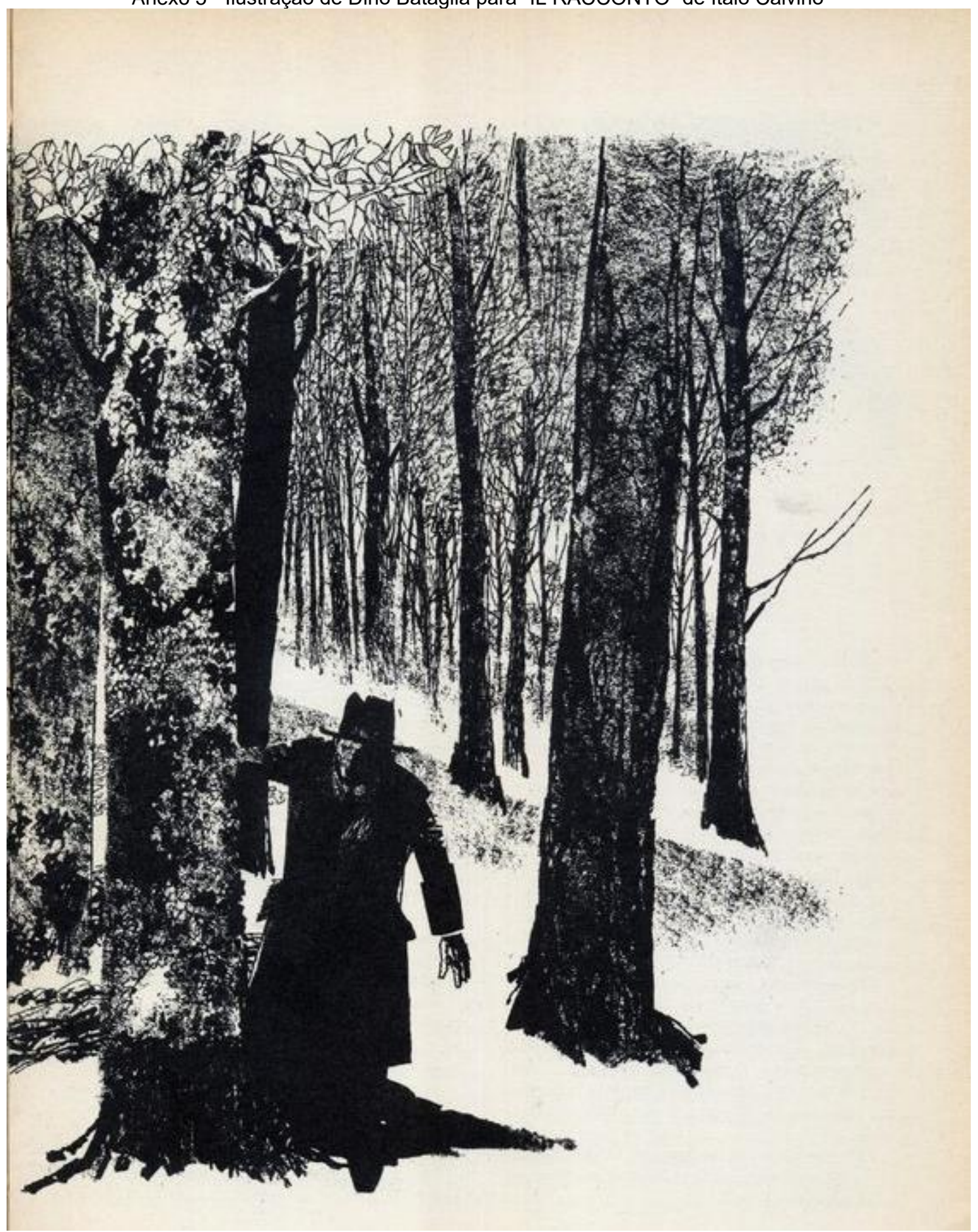


Anexo 6 - Utilizada para decalque, a figura única da quarta linha da Revista Batman e Robin, no 13 página 16, DC Comics 201 .

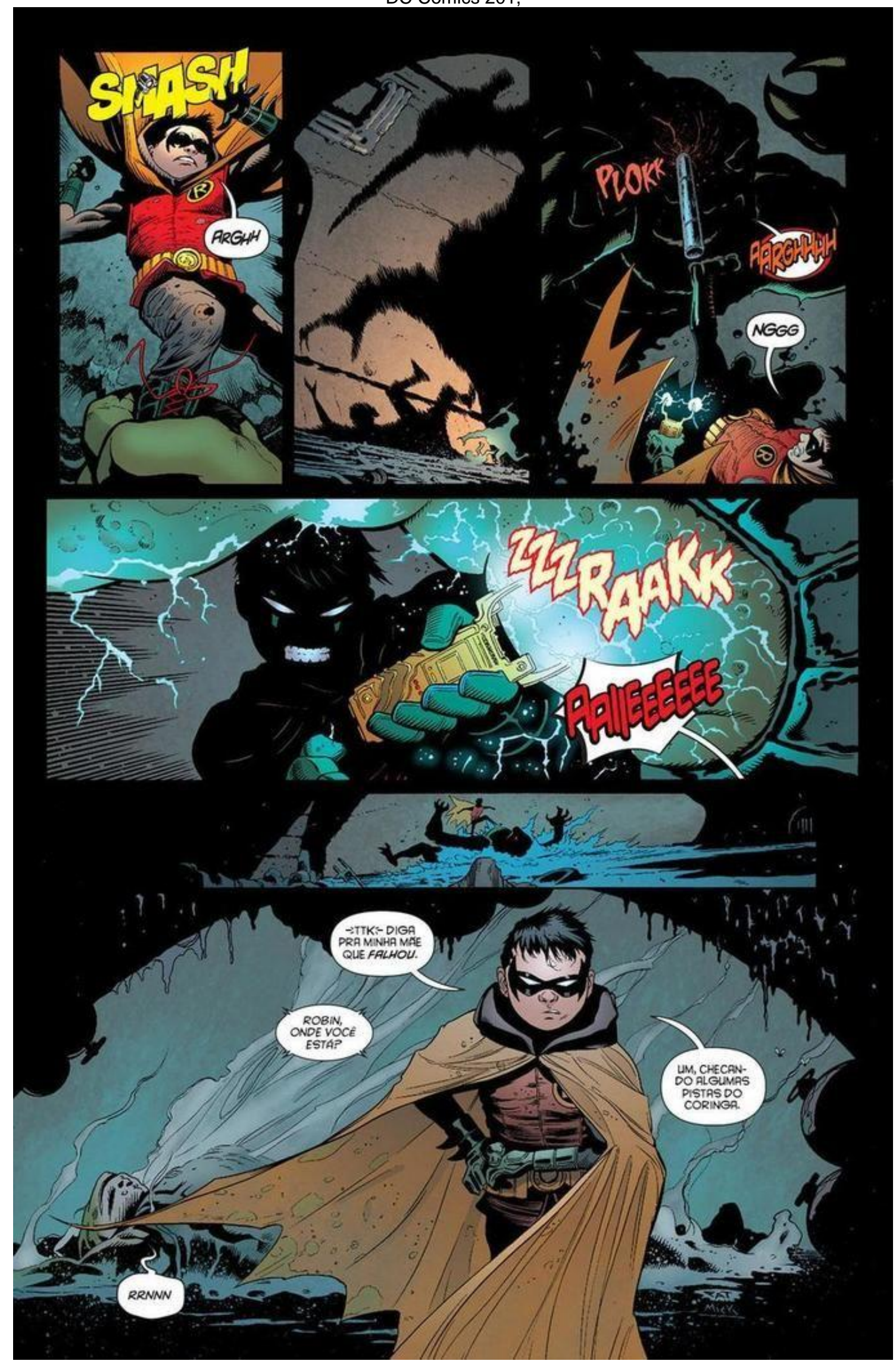


Anexo 7 - Utilizada para decalque a figura panorâmica fundo linha 1 mesclado com linha 2, revista Batman e Robin, no 3 página 9 DC Comics 2011.

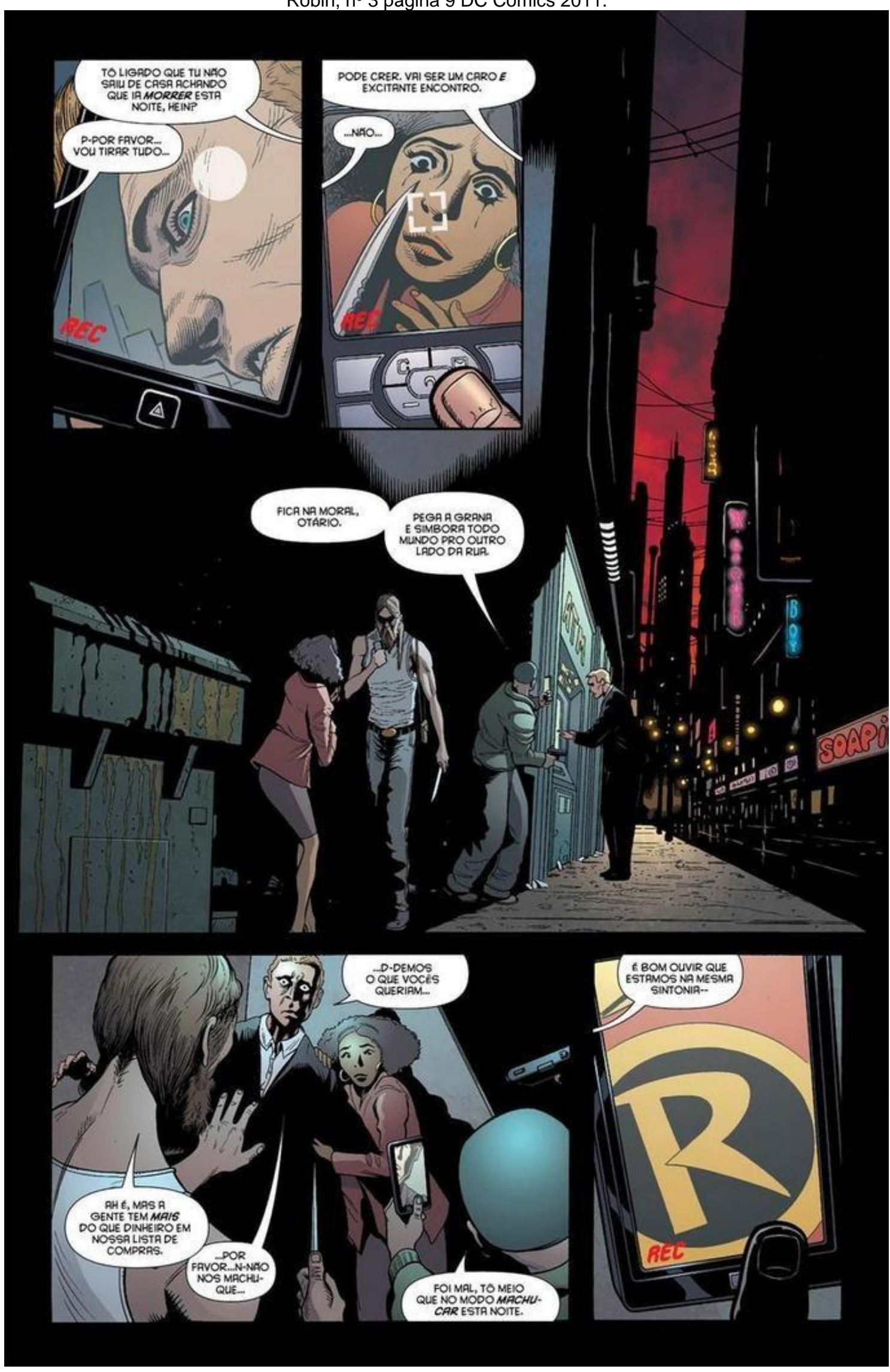


Anexo 8 - Utilizda para decalque a figura única da segunda linha da revista Batman e Robin, no 3 página 10, DC comics, 2011.

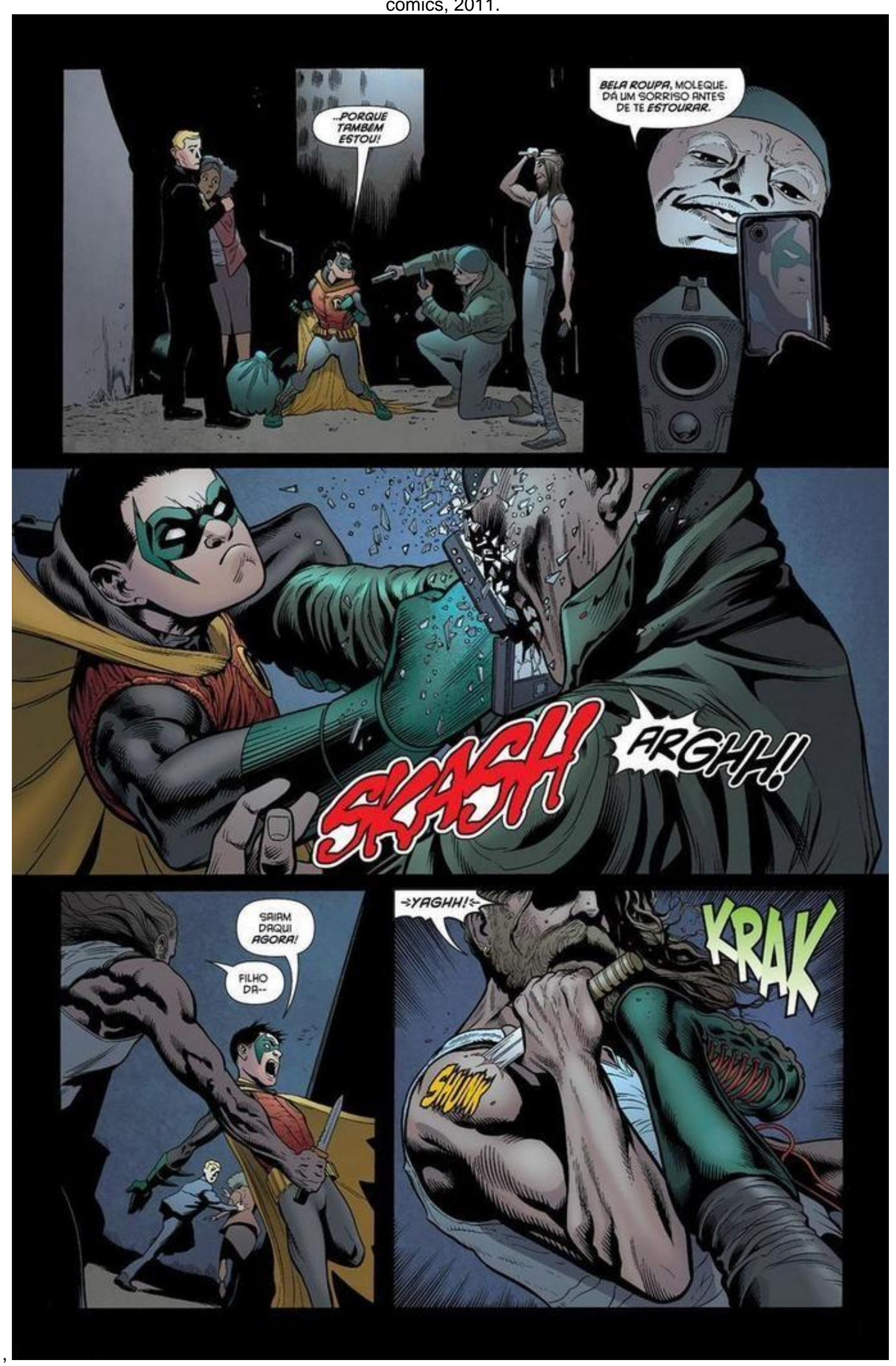


Anexo 9 - Utilizada para decalque a figura única da terceira linha da revista Batman e Robin, no 3 página 12 DC Comics 2011.

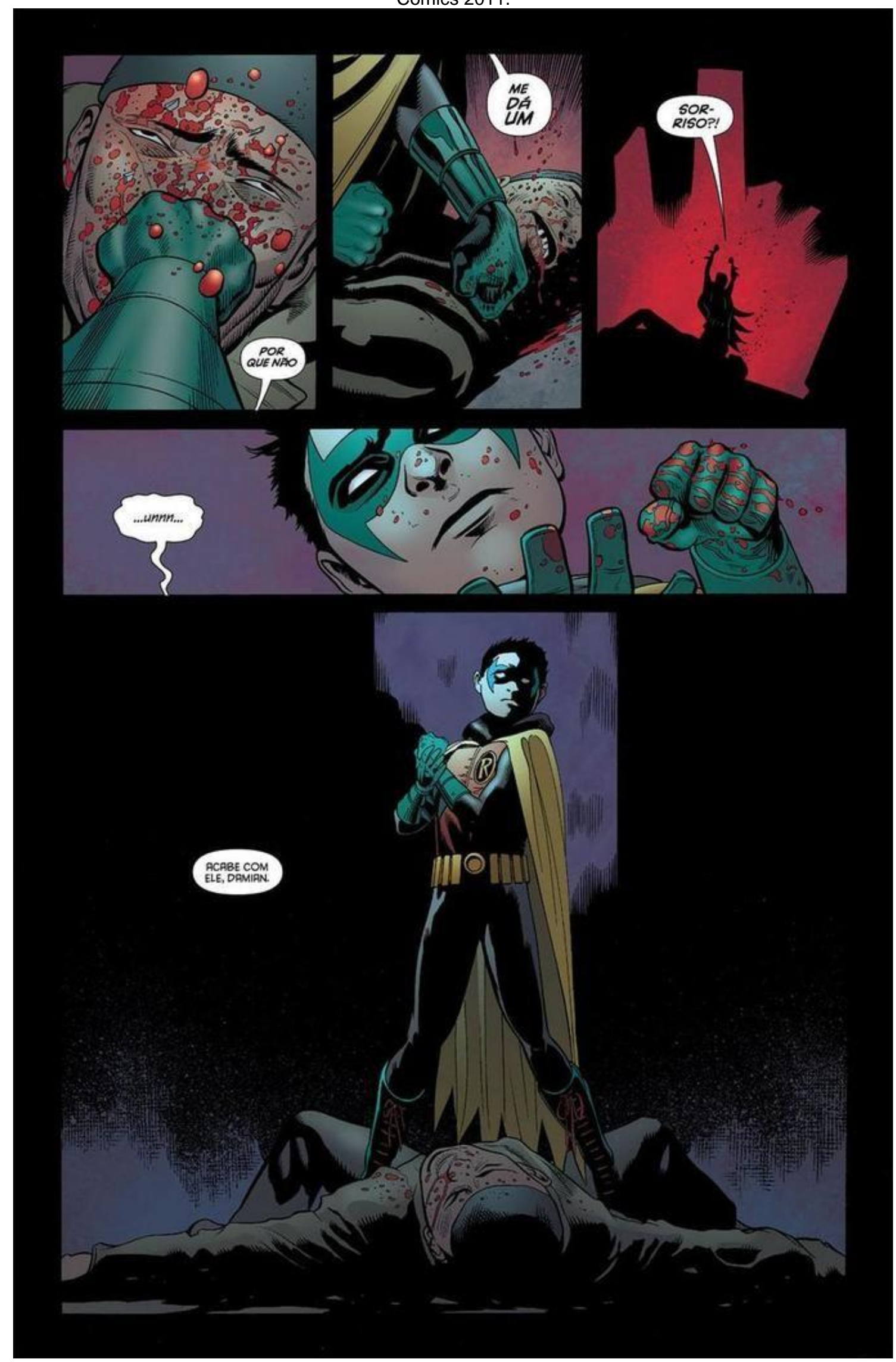




\section{FONTE COMPLETA DAS FIGURAS}

' Figura da carta de Conde Meurs, disponível em: https://www.lambiek.net/artists/image/artefacts/18001850/zutphen 1493 groot.jpg consultado em 01/07/2017.

ii Exemplo de Centsprent, De koopman en de knecht (O comerciante e o servo), entre 1889 e 1945, editora: Nachf de C. Burckardt disponível em: http://www.geheugenvannederland.nl/nl/geheugen/view/de\%20koopman\%20knecht?query=\&facets\% 5BcollectionStringNL\%5D\%5B\%5D=Centsprenten+van+de+Koninklijke+Bibliotheek\&maxperpage $=36$ \&coll=ngvn\&identifier=KONB14\%3ABorms0100 consultado em 15/01/2018.

iii Figuras da caverna de Lauscax - disponível em http://arthistoryworlds.org/ARTANDARCHITECTUREFOUNDATION.ORG/3LascauxHallofBulls.html consultado em 02/12/2017.

iv Tapeçaria Bayeux - disponível em: http://northumbriangunner.blogspot.com.br/2015/10/opnormandie-bayeux-tapestry.html consultado em 02/12/2017.

v Emakimono - "The Illustrated Sutra of Past and Present Karma" - artista desconhecido do final do século XIII - Metropolitan Museum of Art - Nova York, disponível em: https://www.metmuseum.org/toah/works-of-art/2012.249/ consultado em 19/12/2017.

vi Escrita dos ossos do oráculo - caracteres chineses da Dinastia Shang (XVI a XI a.C.), extraído do livro: HÖLLMANN, T. O. Chinese script: history, characters, calligraphy. Tradução: Donicht, Maximiliane. New York: Columbia University Press, 2017.

vii Evolução dos caracteres chineses - adaptação da autora do original de Thomas O. Höllmann extraído do livro: HÖLLMANN, T. O. Chinese script: history, characters, calligraphy. Tradução: Donicht, Maximiliane. New York: Columbia University Press, 2017.

viii Figuração e transformação do caractere chinês 女(mulher) extraído e formatado de Noriko K. Williams, do original disponível em: https://kanjiportraits.wordpress.com/tag/the-kanji-\%E5\%A5\%B3/ consultado em 19/01/2018.

ix transformação do caractere chinês 好 (gostar) extraído e formatado de Noriko K. Williams, do original disponível em: https://kanjiportraits.wordpress.com/tag/the-kanji-\%E5\%A5\%B3/ consultado em 19/01/2018.

$x$ Charge de William Hogarth - $1792 \quad$ - disponível em: https://www.princeton.edu/ graphicarts/prints/index12.html, consultada em 20/01/2018.

xi Três painéis de Mon livre d'heures de Frans Masereel - disponível em: https://en.wikipedia.org/wiki/Passionate Journey\#/media/File:Mon livre d\%27heures -

three panels.jpg consultado em 10/01/2018.

xii Otto Nübkel - Destiny - 1930 - Nova York- repúblicação por Dover Publications 2007, disponível em: https://books.google.com.br/books?id=SAeeM S1LuwC\&printsec=frontcover\&hl=pt-

BR\&source $=$ gbs ge summary $r \& c a d=0 \# v=0$ epage \& $q \& f=f a l s e$

xiii Le Cahrivari - disponível em: http://www.daumier.org/uploads/pics/charivari 2 header.jpg consultado em: 26/01/2018

xiv Daumier - Mais pis que j'vous dis qu'c'est des amis....(Mas deixe-me dizer-Ihe que são amigos...) litografia - publicada em Le Charivari em 08, 18, e 23 de agosto de 1845 copiado de IVES, C. F.; 
STUFFMANN, M.; SONNABEND, M. Daumier Drawings. New York: THE METROPOLITAN MUSEUM OF ART, 1992página 37

xv Daumier - Une discussion littéraire dans le deuxième balcon (uma discussão literária no Segundo balcão). Litografia - publicada em Le Charivari, Paris, 1864 copiado de MAYOR, A. H. Prints \& People - a social history of printed pictures. Nova York: The Metropolitan Museum of Art, 1972 página 426

xvi Charles-Joseph Traviès de Villers - Studio of La Caricture and Le Charivari 1834 - disponível em: https://media.artgallery.nsw.gov.au/collection images/4/491.1988\%23\%23S.jpg consultado em 25/01/2018.

xvii Daumier - Rue Transnonain - litografia - publicada em La Caricature - 1834 - L'Association Mensuelle, Paris copiado de MAYOR, A. H. Prints \& People - a social history of printed pictures. Nova York: The Metropolitan Museum of Art, 1972 página 424.

xviii Punch - The London Charivari - número 1 - 1841, diponível em: https://punch.photoshelter.com/img/pixel.gif consultado em 25/01/2018.

xix - Japan Punch - 1867 - copiado do livro: MCCARTHY, H. A Brief History of Manga: The Essential Pocket Guide to Japanese Pop Culture. Lewes, United Kingdom: Ilex - Octopus Publishing Group, 2014, página 11.

xx Páginas 30 e 31 de Monsieur Jabot do livro: TÖPFFER, R. Monsieur Jabot. Organização André Caramuru Albert: tradução Flavia Lago. São Paulo: SESI-SP editora, 2017.

xxi Gustave Doré - Chapeuzinho vermelho - 1861 - copiado do livro TATAR, M. Contos de Fadas edição comentada e ilustrada. Tradução de Maria Luiza Xavier de Almeida Borges. Rio de Janeiro: Zahar, 2013. Página 34.

xxii La Vie en Province, Histoire d'une invitation à la campagne (Vida na província, história de um convite ao interior) - Journal pour Rire - 1849 - copiado do livro: KUNZLE, D. Gustave Doré: twelve comic strips. Mississipi: University Press of Mississipi, 2015.

xxiii Winsor McCay - Little Sammy Sneeze - 1905 - Copiado do livro: SMOLDEREN, T. The Origins of Comics - from William Hogarth to Winsor McCay. Tradução de Bart Beaty e Nick Nguyen. Jackson: University Press of Mississipi, 2014 página 55.

xxiv Gustave Doré - Des-agréments d'un voyage d'agrément - 1851 - copiado do livro: SMOLDEREN, T. The Origins of Comics - from William Hogarth to Winsor McCay. Tradução de Bart Beaty e Nick Nguyen. Jackson: University Press of Mississipi, 2014 página 55.

${ }^{x x v}$ The Strange Adventures of Bachelor Butterfly - 1846 - Wilson \& Co. Versão integral do livro disponível em: https://archive.org/details/McGillLibrary-122951-2115, consultada em 23/01/2018.

xxvi As aventuras de Nhô-Quim Janeiro de 1869 - Jornal Vida Fluminense - copiado de AGOSTINI, A. As aventuras de Nhô-Quim \& Zé Caipora: os primeiros quadrinhos brasileiros 1869-1883/Angelo Agostini; pesquisa, organização e introdução Athos Eicher Cardoso. Brasília: Senado Federal, Conselho Editorial, 2002

xxvii Caricatura de Hermes da Fonseca por Rian (Nair de Teffé), disponível em http://concursobrasileirodeenredos.blogspot.com.br/2015/04/esboco-de-enredo-primeira-damasapeca.html, consultado em 09/05/2018.

xxviii Ally Sloper - 1874 - Marie Duval disponível em Wikimedia Commons: https://upload.wikimedia.org/wikipedia/commons/1/1d/Marie Duval\%2C Ally Sloper\%2C Recent Ev ents \%28Judy\%2C May 13\%2C 1874\%29.jpg, consultado em 09/05/2018. 
xxix Christophe (Georges Colomb), Un Arroseur Public, Le petit français illustré, 1889, copiado do livro: SMOLDEREN, T. The Origins of Comics - from William Hogarth to Winsor McCay. Tradução de Bart Beaty e Nick Nguyen. Jackson: University Press of Mississipi, 2014, página 117.

${ }^{x \times x}$ Richard F. Outcault, Hogan's Alley, New York World - 1896, copiado do livro: SMOLDEREN, T. The Origins of Comics - from William Hogarth to Winsor McCay. Tradução de Bart Beaty e Nick Nguyen. Jackson: University Press of Mississipi, 2014, página 107.

xxxi Revista Tico-Tico, № 1 - 11/10/1905 - extraído do site Efemérides Escoteiras, em seu tópico datando - nascimento da revista Tico-Tico que mais tarde divulgaria o escotismo brasileiro: https://3.bp.blogspot.com/-tE-UOphtxdg/WazDgG9y5pl/AAAAAAAAD-

Y/FpQP9MuNzWwAVi9paSzDKtO43Jf7WclogCLcBGAs/s1600/Tico-tico\%2B1.jpg consultado em 04/02/2018.

xxxii Propaganda dos Colletes de Mme. Garnier na Revista Tico-Tico no 15 de 17/01/1906, extraída do acervo digital da revista Tico-Tico da Hemeroteca Digital do Brasil, disponível em: http://bndigital.bn.br/acervo-digital/tico-tico/153079 consultada em 04/02/2018.

xxxiii October Idyll - Mstislav Dobuzhinsky - 1905 - extraída do acervo digital da WikiArt.org, disponível no site: https://www.wikiart.org/en/mstislav-dobuzhinsky/october-idyll-1905 consulta em 04/02/2018.

xxxiv Krazy Kat - George Herriman - 1916, copiado do livro: SMOLDEREN, T. The Origins of Comics from William Hogarth to Winsor McCay. Tradução de Bart Beaty e Nick Nguyen. Jackson: University Press of Mississipi, 2014, página 161.

xxxv The Funnies ํo 28 - Setembro - 1930 - Dell Publications - extraído do site da Wikipedia, disponível em: https://en.wikipedia.org/wiki/The Funnies\#/media/File:The-funnies.jpg consultada em 06/02/2018.

xxxvi Tintin no País dos Sovietes - 1929 - Le Petit Vingtième extraído do site "Por um punhado de imagens - Banda Desenhada, Cinema, outras imagens... e alguns textos, disponível em:

http://porumpunhadodeimagens.blogspot.com.br/2010/12/tintin-regressa-em-formato-reduzido.html consultado em 06/02/2018.

xxxvii Capitão América - o 1 - 1941 - extraído do site da Marvel Comics, disponível em: http://marvel.com/comics/issue/7849/captain america comics 19411 consultado em 11/02/2018.

xxxviii Revista Archie - no 1 - 1942, extraído do site Wikipedia, disponível em: https://en.wikipedia.org/wiki/Archie (comic book)\#/media/File:Archie 1942 issue 1.jpg consultado em 10/02/2018.

xxxix Walt Disney Comics - o 1 - 1940 - extraído do site: The Disney's wiki disponível em: http://disney.wikia.com/wiki/Walt Disney\%27s Comics and Stories consultado em 11/02/2018.

xl True Comics - no 1 - 1940 - extraído do site Comic Book Plus, distribuidor de conteúdo online de revistas de quadrinhos antigas gratuita e legalmente, disponível em: http://comicbookplus.com/?dlid=24813 consultado em 11/02/2018.

xii Detective Comics no 38 - 1940, extraído do site Comixology, responsável pelas vendas de quadrinhos online da DC Comics, disponível em: https://images-na.ssl-images-amazon.com/images/S/cmximages-prod/ltem/28860/ICO003761 1. SX360 QL80 TTD .jpg consultado em 13/02/2018.

xlii Comics Code Seal (selo do código de quadrinhos) extraído da wikipedia, disponível em: https://en.wikipedia.org/wiki/Comics Code Authority\#/media/File:Approved by the Comics Code A uthority.gif consultado em 13/02/2018.

xliii Bacio Sotto le Stelle - Walter Molino sob o pseudônimo de J. W. Symes, extraído do site da revista 
online Print, disponível em: http://www.printmag.com/illustration/italy-land-of-fumetti-in-a-sea-of-pulp/ consultado em 11/02/2018.

xliv Astro Boy no 1 - 1952 - Osamu Tesuka, extraído do site oficial de Osamu Tesuka, disponível em: http://tezukaosamu.net/jp/mushi/201301/intro.html, consultado em 13/02/2018.

xlv Ribon no Kishi (A Princesa e o Cavaleiro) - 1953 - Osamu Tesuka, extraído do site oficial de Osamu Tesuka, disponível em: http://tezukaosamu.net/jp/mushi/201112/intro.html, consultado em 13/02/2018.

xlvi Pôster original japonês do filme Branca de Neve e os Sete anões de Walt Disney - extraído do site Animation Studies, disponível em: https://blog.animationstudies.org/?p=2246, consultado em 13/02/2018.

xlvii Masahiko Matsumoto - The Man Next Door (Hinomaru bunko - 1957), extraído do site The Comics Journal disponível em: http://images.tcj.com/2014/09/matsumoto-man next dooroct1957.jpg, consultado em 13/02/2018.

xlviii Catecismos de Carlos Zéfiro,extraído do site ALMANAQUE CULTURAL BRASILEIRO, disponível em: http://almanaquenilomoraes.blogspot.com.br/2015/10/o-criador-das-revistas-de-sacanagem.html, consultado em 14/02/2018.

xlix Príncipe Shotoku - Kai Takizawa and Masami Fukushima - 1953, copiado do livro: MCCARTHY, H. A Brief History of Manga: The Essential Pocket Guide to Japanese Pop Culture. Lewes, United Kingdom: llex - Octopus Publishing Group, 2014, página 47.

' Harenchi Gakuen - Go Nagai - 1968, extraído do site "Go Nagai Wiki", disponível em: http://es.gonagai.wikia.com/wiki/Harenchi Gakuen (manga), consultado em 14/02/2018.

li Diabolik - Angela e Luciana Giussani - 1962, extraído do site Paul Gravett - Comics - Graphic Novels - Manga, disponível em: http://www.paulgravett.com/articles/article/diabolik the fumetti neri tradition, consultado em 12/02/2018.

lii Maus - Art Spiegelman - entre 1980 e 1991 na revista Raw, disponível em: https://images.livrariasaraiva.com.br/imagemnet/imagem.aspx/?pro id=177012\&qld=90\&l=430\&a=-1, consultado em 11/05/2018.

liii Mr. Natural - Robert Crumb - 1967, disponível em: https://www.budsartbooks.com/media/catalog/product/cache/1/image/1800x/040ec09b1e35df1394338 87a97daa66f/b/o/bomnh-book-mr-natural.jpg, consultado em 11-05-2018.

liv Poema de Augusto de Campos - 1965, imagem extraída do site da revista online Amarello, Disponível em: http://www.amarello.com.br/artigo/rever-de-augusto-de-campos/, consultada em 01/03/2018.

Iv A Traição das Imagens, 1928-9, óleo sobre tela, $60 \mathrm{~cm} \times 81 \mathrm{~cm}$, René Magrite, LACMA - Los Angeles County Museum of Art, Los Angeles, extraído do site do Lacma Museum, disponível em: http://www.lacma.org/sites/default/files/bpipe.jpg, consultado em 01/03/2018.

Ivi Stubbs em fotografia solo - extraído do blog Amazing Creatures, disponível em: http://1.bp.blogspot.com/-

VKFGMGizmMg/UAhKIUXhxYl/AAAAAAAAQaA/ycGCAGaBwlw/s1600/stubbs-the-cat-is-a-mayor-oftalkeetna-029.jpg, consultado em 01/03/2018.

vii Stubbs em fotografia com taça - extraído do site do The Daily Shepple, disponível em: http://www.thedailysheeple.com/the-great-statesman-and-beloved-mayor-of-alaskan-town-hasdied 072017, consultado em 01/03/2018.

Iviii Stubbs em pôster do West Rib Pub \& Grill em Talkeetna, extraído do perfil de facebook montado 
criado para o gato, disponível em: https://www.facebook.com/martinmcculloughcomedy/, consultado em 01/03/2018.

lix Katrin - Mensile di attualita varieta e fotoromanzi - no 46, 1978 - página 54 digitalizado da revista SANDREANI, E. A mezzanotte nel parco. Katrin, Roma, p. 5-62, Novembro 1978.

Ix Whamm! - Roy Lichtenstein de 1963, extraído do site Tate Gallery, disponível em: http://www.tate.org.uk/art/art-terms/c/comic-strip-art consultado em 26/02/2018.

Ixi Quadro único da 3a linha - página 11 de Star Jockey, DC - NATIONAL COMICS. Star Jockey. All American Men of War, Nova York, p. 11-23, Fevereiro 1962.

Ixii Zé Carioca - Rivane Neuenschwander, extraído do site printerest, disponível em: https://i.pinimg.com/564x/63/5d/bc/635dbc36abbb8fd33e5089c769dc70a7.jpg, consultado em 03/03/2018.

Ixiii Zé Carioca - Rivane Neuenschwander - intervenção dos visitantes, extraído do site VejaBH online, disponível em: http://vejabh.abril.com.br/images/vejabh/2015/03/10/1617/r4DIB/2404 rot expo01.jpeg?1426015075, consultado em 03/03/2018.

Ixiv Exposição Louvre no 9 - Mori Gallery - Tóquio - fotos de Keisuke Tanigawa, extraído do site TimeOut Tóquio, disponível em: https://www.timeout.com/tokyo/blog/japanese-manga-meets-francophonecomics-in-moris-louvre-no-9-080116, consultado em 01/03/2018.

Ixv Exposição Louvre no 9 - Mori Gallery - Tóquio - fotos de Keisuke Tanigawa, extraído do site TimeOut Tóquio, disponível em: https://www.timeout.com/tokyo/blog/japanese-manga-meets-francophonecomics-in-moris-louvre-no-9-080116, consultado em 01/03/2018.

Ixvi Exposição Louvre no 9 - Mori Gallery - Tóquio - fotos de Keisuke Tanigawa, extraído do site TimeOut Tóquio, disponível em: https://www.timeout.com/tokyo/blog/iapanese-manga-meets-francophonecomics-in-moris-louvre-no-9-080116, consultado em 01/03/2018.

Ixvii Exposição Louvre o 9 - Mori Gallery - Tóquio - fotos de Keisuke Tanigawa, extraído do site TimeOut Tóquio, disponível em: https://www.timeout.com/tokyo/blog/japanese-manga-meetsfrancophone-comics-in-moris-louvre-no-9-080116, consultado em 01/03/2018.

Ixviii Exposição Louvre no 9 - Mori Gallery - Tóquio - fotos de Keisuke Tanigawa, extraído do site TimeOut Tóquio, disponível em: https://www.timeout.com/tokyo/blog/iapanese-manga-meetsfrancophone-comics-in-moris-louvre-no-9-080116, consultado em 01/03/2018.

Ixix Cartum de Angeli - Jornal Folha de São Paulo - 25/09/2014 - Acervo online do jornal Folha de São Paulo, disponível

em:

https://acervo.folha.com.br/leitor.do?numero=19993\&anchor $=5962449 \&$ origem $=$ busca $\& p d=74122 c 39$ e344b35ccb8974ad40d21ad0, consultado em 27/02/2018.

Ixx Calvin and Hobbes - Bill Waterson, extraído do site GoComics, disponível em: http://www.gocomics.com/calvinandhobbes/1993/11/03, consultado em 03/03/2018.

Ixxi Nude Descending a Staircase, No. 2 - Marcel Duchamp - 1912 - extraído do site do Philadelphia Museum of Art, disponível em: https://www.philamuseum.org/collections/permanent/51449.html, consultado em 01/03/2018.

Ixxii The Rude descending a staircase (Rush-Hour at the Subway) - 1913 - extraído do site do Museu de arte moderna de Nova York - MOMA showstudio, disponível em: http://78.media.tumblr.com/da874e1cf10088a26ce6f5669ca8e7c4/tumblr o7v52ghVe11qahy1wo1 12 
80.png consultado em 02/03/2018.

Ixxiii Abstract Comics - Gary Panter - sem título - 2000, extraído do site Abstract Comics, disponível em: http://abstractcomics.blogspot.com.br/2012/12/abstract-comics-and-systems-theory-talk.html, consultado em 04/03/2018.

Ixxiv Abstract Comics - Benoit Joly - "Parcours" - 1987, extraído do site Abstract Comics, disponível em: http://abstractcomics.blogspot.com.br/2012/12/abstract-comics-and-systems-theory-talk.html, consulta em 04/03/2018.

Ixxv Abstract Comics - A.M. - A Vague Epic- 2006-2008, extraído do site Abstract Comics, disponível em: $\quad$ http://abstractcomics.blogspot.com.br/2012/12/abstract-comics-and-systems-theory-talk.html, consultado em 04/03/2018.

Ixxvi Abstract Comics - A.M. - A Vague Epic- 2006-2008, extraído do site Abstract Comics, disponível em: $\quad$ http://abstractcomics.blogspot.com.br/2012/12/abstract-comics-and-systems-theory-talk.html, consultado em 04/03/2018.

Ixxvii "Quino, Gente en su Sitio", ed. nueva imagen 1978, extraído do site Taringa, disponível em https://www.taringa.net/posts/humor/14955212/Quino-Gente-en-su-sitio-Humor-Grafico-114imagenes.html, consultado em 05/03/2018.

Ixxviii Laerte - "Striptiras", Circo Editorial Ltda., extraído do site do Departamento de Engenharia Civil da Escola de Engenharia da Universidade Presbiteriana Mackenzie. Disponível em: http://meusite.mackenzie.br/professor cucci/cartum24.jpg, consultado em 05/03/2018.

Ixxix Projeto de Bentham - Panóptico - desenho do arquiteto inglês Willey Reveley, 1791, extraído do acervo digital de imagens da wikipedia, disponível em: https://pt.wikipedia.org/wiki/Pan-\%C3\%B3ptico\#/media/File:Panopticon.jpg, consultado em 11/03/2018.

Ixxx The Annunciation to Saint Anne, 1505 - 1510 Bernhard Strigel - Museo Thyssen-Bornemisza, Madrid

Ixxxi Detalhe de: The Annunciation to Saint Anne, 1505 - 1510 - Bernhard Strigel - Museo ThyssenBornemisza, Madrid

Ixxxii Legenda em Gustave Doré, extraída do site Andy's Early Comics Archive, disponível em: http://konkykru.com/e.dore.trois.artistes.incompris.1.html, consultado em 11/03/2018.

Ixxxiii Sebastien Millon @2011-2017 sebreg, extraído do site Devinart, disponível em: https://sebreg.deviantart.com/art/From-Ear-to-Ear-208127789, consultado em 11/03/2018.

Ixxxiv Family Circus - Jeff Keane - extraída do site oficial do autor, disponível em: http://familycircus.com/comics/march-2-2018/, consultado em 11/03/2018.

Ixxxv Dark Side of the Horse de Samson, dispnível em: http://gocomics.typepad.com/.a/6a00d8341c5f3053ef01a3fd1f23e1970b-800wi, $\quad$ consultado em 19/05/2018.

Ixxxvi Gasoline Alley - Frank King - 24 de Agosto 1930, extraído do site Periodic Fable, disponível em: https://theperiodicfable.wordpress.com/comics-index-of-multi-panel-pans-by-decade/1930s-multipanel-pans/, consultado em 17/03/2018.

Ixxxvii Charge de Signe Wikinson, disponível em: http://www.gocomics.com/signewilkinson/2017/12/1, consultada em 24/03/2018.

Ixxxviii Charge de andy Marlette disponível em: http://www.commonsenseevaluation.com/wp- 
content/uploads/2013/06/The-Big-Bad-Wolf.jpg, consultado em 24/03/2018.

Ixxix Charge de Clayton Correa, disponível em: http://images.redetv.uol.com.br/public/jornalismo/redetvinoticias/201603311456474NfZK3NQQK.jpg, consultado em 24/03/2018.

xc Cartum de Mike Peters, 25-01-2014 http://www.cartoonistgroup.com/subject/The-Obesity-Comicsand-Cartoons-by-Mother+Goose+and+Grimm.php, consultado em 23/03/2018.

xci Pôster da peça Coups de feu rue Saint-roch, com acréscimo de tarja colocada pela diretora Jocelyn Fiorina, disponível em: https://g1.globo.com/pop-arte/noticia/facebook-lamenta-censura-a-nudez-datela-a-liberdade-guiando-o-povo.ghtml, consultado em 24/03/2018.

xcii Museu de História Natural de Viena, Vênus de Willendorf - disponível em: https://noticias.uol.com.br/ciencia/ultimas-noticias/redacao/2018/03/01/facebook-censura-foto-deestatua-esculpida-ha-quase-30-mil-anos-por-nudez.htm?cmpid=copiaecola, consultado em 24/03/2018.

xciii Charge de Ivan Cabral, original (esquerda) e adulterada (direita), disponível em: https://www.vice.com/pt br/article/xyq3yw/o-trampo-dos-cartunistas-esta-sendo-vandalizado-porgrupos-anti-e-pro-governo, consultada em 25/03/2015.

xciv Meme Batman bate em Robin, extraído da montagem disponível no site: http://3.bp.blogspot.com/DQW-3sxYSrY/UkWbGmf6hul/AAAAAAAAAwk/4ELOfwZ4was/s1600/exemplos meme.jpg, consultado em 25/03/2018.

xcv Meme Batman bate em Robin, extraído da montagem disponível no site: http://3.bp.blogspot.com/DQW-3sxYSrY/UkWbGmf6hul/AAAAAAAAAwk/4ELOfwZ4was/s1600/exemplos meme.jpg, consultado em 25/03/2018.

xcvi Meme Robin slaps Batman https://i.imgflip.com/t7b2a.jpg, consultado em 25/03/2018.

xcvii Meme Deadpool slaps disponível em: https://i.pinimg.com/736x/33/7c/18/337c18dfb64630f6da64eb2e2cd687a7--robin-meme-funnybatman.jpg, consultado em 25/03/2018.

xcviii Meme Batman slaps trump, disponível em:

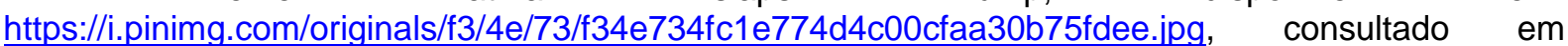
25/03/2018.

xcix Meme Batman bate em Robin - pano de prato, disponível em: http://www.casageek.com.br/7449thickbox leocame/pano-de-prato-batman-e-robin.jpg, consultado em 25/03/2018

c Sandman - os caçadores de sonhos, 2000 - Ed. Conrad, pg. 28 e 29

ci Sandman - The Dream Hunters - Ed. DC Comics 1999, pg. 28 e 29

ciiSoldado G.U.I. Lambert, B2nd Battalion Royal 22e Regiment, lendo uma revista em quadrinos, Coréia, 28 de maio de 1951, Royal 22nd Regiment. Fotográfo: Paul E. Tomelin Canada: Dept. of National Defence / Library and Archives Canada / Restrictions on use: NIL, disponível em: http://www.thememoryproject.com/stories/230:paul-tomelin/, consultado em 30/03/2018.

ciii Homestuck - Andrew Hussie - webcomic, disponível em: http://www.mspaintadventures.com/, consultado em 01/04/2018.

civ Corte de quadro da webtoon Yun T'aeho's P'ain, episódio 53, disponível em http://www.tcj.com/thewebtoon-a-new-form-for-graphic-narrative/\#comments, consultado em 07/04/2018 (a professora 
Heekyoung Cho informa que extraiu a imagem do site de hospedagem de webtoons coreanos: http://webtoon.daum.net/webtoon/viewer/30249 em coreano)

cv Tintim na África - Herge - Edição brasileira de 1970 - Editora Record, página 22, 1a e 2a linhas, extraído de: HERGÉ. Tintin na África. Tradução de Distribuidora Record de Serviços de Imprensa. Rio de Janeiro: Record, 1970.

cvi Minstrel - Black Face - Poster e Strobridge \& Co. Lith, de domínio público, disponível no site http://loc.gov/pictures/resource/var.1831/ consultado em 22/05/2018.

cvii Imagem "sem clareza" segundo o INEP em 1944, extraído de INEP. Revista Brasileira de Estudos Pedagógicos. Brasilia: Imprensa Nacional, 1944 v. 6, pág. 412.

cviii llustração de Ettore Bottini para a capa do livro "A guerra dos gibis" de Gonçalo Junior, 2004, extraído de GONÇALO JUNIOR. A guerra dos gibis: a formação do mercado editoria brasileiro e a censura aos quadrinhos, 1933-64. São Paulo: Companhia das Letras, 2004. ISBN 85-359-0582-0, capa.

cix All American Men of War - número 89 - jan-fev - 1962 - página 21, editora: DC - National Periodical Publications, Inc. Nova York

cx Milo Manara - ilustração para a coleção "Erotic Tarot" de 2006, versão reduzida disponível em: http://1.bp.blogspot.com/--XwEtzSMCIQ/T7PXm9 O Fl/AAAAAAAACjA/me-kXw6xGqk/s1600/milomanara.jpg, consultado em 24/04/2018.

cxi Milo Manara disponível em: http://bookpalace.com/acatalog/info ManaraClick13.html, consultado em 24/04/2018.

cxii Bianco, nero e grigio: I'unicità dello stile di Dino Battaglia, disponível em :

http://nedbajalica.blogspot.com.br/2012/09/dino-battaglia-racconti.html, consultado em 24/04/2018.

cxiii Ilustração de Dino Bataglia para "IL RACCONTO" de Italo Calvino, disponível em: http://dinobattaglia.blogspot.com.br/2013/11/alter-linus-003-1974.html, consultado em 24/04/2018. 


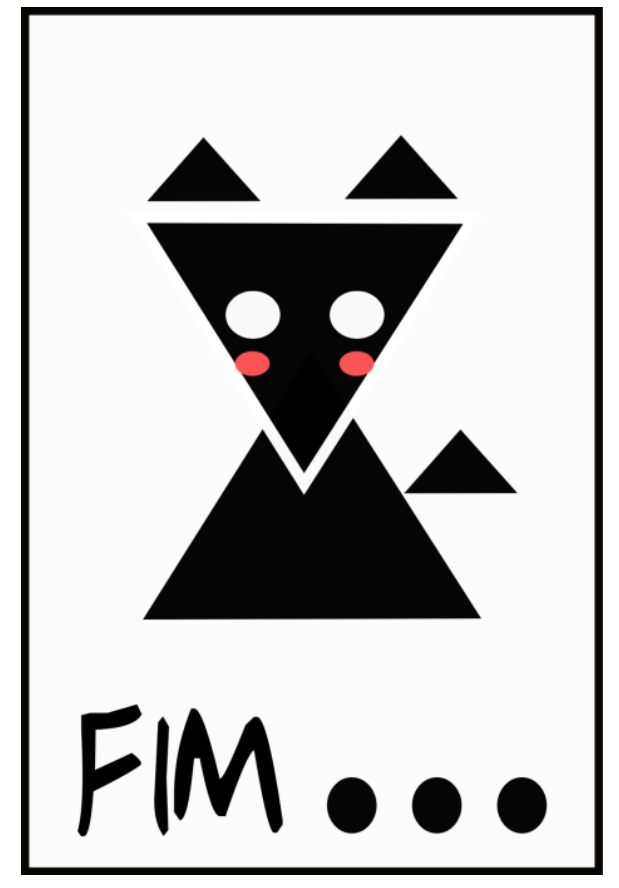

